
W.3.

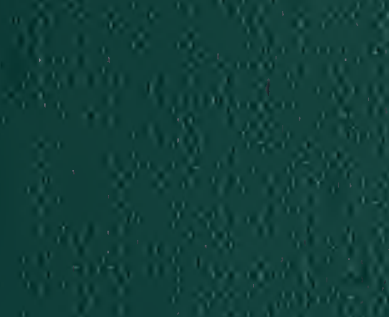
3.5. n$3=2,+2,8 \%$ 


,







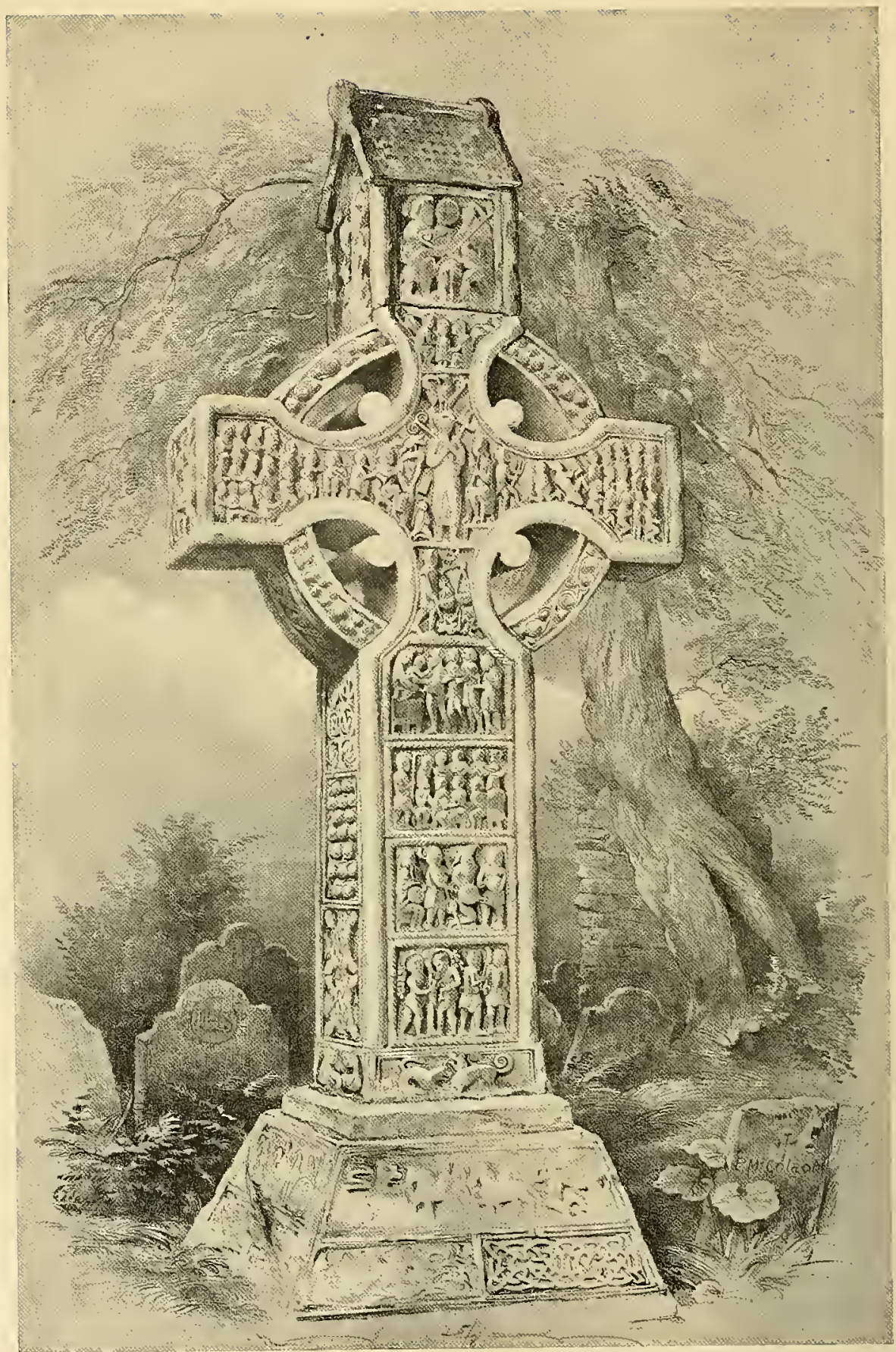

The Southeast Cross, Monasterboice. From O'Neill's Crosses of Ancient Treland. 


\title{
The Cross
}

\section{In Tradition, History, and ART}

\author{
BY THE
}

REV. WILLIAM WOOD SEYMOUR

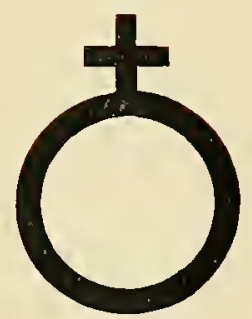

Stat Crux, dum volvitur orbis

MOTTO OF THE CARTHUSIANS

WITH ILLUSTRATIONS

G. P. PUTNAM'S SONS

NEW YORK AND LONDON

Tbe Tinickerbocker press

I 898 
Copyright, 1897

$\mathrm{BY}$

G. P. PUTNAM'S SONS

Entered at Stationers' Hall, London

Purchase

T. pieipent Morgan

1200 Fund

Toe Iiniekerbocker press, Hew Bork 


\section{PUBLISHERS' NOTE}

$\mathrm{O}^{\prime \prime 2}$

IVING to the death of the author, the Rev. IVilliam Wood Seymour, shortly after the completion of the first draft of the manuscript of his work, the text of this manuscript did not receive the advantage of the author's final revision.

The author's friend and literary executor, the Rev. Thomas S. Drowne, had kindly consented to give his personal supervision to the book while it was passing through the hands of the printers, but in connection with his own long illness (an illness which resulted in his death some time before the book was in type) it did not prove practicable for him to give attention even to the completion of the proof-reading. This work has been done with as much care as was practicable in the case of a book of so special a character which had been left without the notes or the final instructions of either author or editor.

It had seemed both to the literary executor and to the publishers that there would be no warrant for modifying in any way the author's conclusions or expressions of opinion. If the volume were to be brought before the public in accordance with the author's wish, it was thought essential that the author's own point of view and method of treatment should be adhered to without change.

It was further decided by those interested in the undertaking that it was better to take the risk of issuing the volume with certain inadequacies or imperfections rather than to permit to be thrown away the labor to which the author had devoted years of his life.

Fanuary 1,5898 . 



\section{CONTENTS.}

Bibliography $\cdot 0.000$

\section{PART I.}

CHAPTER

I.-The Cross before the Christian Era and in Prehistoric Times . . . . . . . . . I

Section I.-In Africa . . . . . . . . . 2

Section 2.-In Asia . . . . . . . . . . . 9

Section 3.-In Europe . . . . . . . . 22

Section 4.-In America . . . . . . . . 34

II.-Types of the Cross . . . . . . . . . 46

III.-The Early Form and Use of the Cross . . . 64

Section I.-The Cross of Punishment . . . . 64

Section 2.-Voluntary Crucifixion . . . . 79

Section 3-Crucifixion of Children by the Jews . . SI $_{1}$

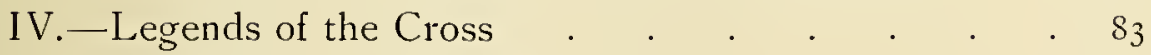

Section I. - Its Fabled Antiquity . . . . . . . 83

Section 2.-Traditions Respecting the Wood of the Cross . . . . . . . 93

Section 3.-Miraculous Appearances of the Cross . IO3

V.-The True Cross and its Traditionary History . . II4

Section I.-The Discovery of the Cross by S. Helena . 114

Section 2.-Traditionary Persons at the Cross . . 126

VI.-The Title of the Cross . . . . . . . 134

VII.--The Doctrinal Teaching of the Crucifixion · · 140 
CHAPTER

I.- The Cross in Early Christian Art . . . . 151

II.-The Crucifix in Early Christian Art . . . 167

III.-Monograms of Our Lord . . . . . . . 188

IV.-Rood Screens _ . . . . . . . . . . 193

V.-Altar and Reliquary Crosses . . . . . 205

VI.-Cruciform Ornaments . . . . . . 212

VII.-Processional Crosses . . . . . . . . . 226

VIII.- - The Crosier and the Pastoral Staff . . . . . 236

IX.-Pectoral and Absolution Crosses . . . . 250

X.-Consecration Crosses . . . . . . . 257

XI.-Spire and Gable Crosses . . . . . . . 261

XiI.-Standard Crosses . . . . . . . . . 264

XIII.-Memorial Crosses . . . . . . . . . 275

XIV.-Sanctuary Crosses . . . . . . . . . . 289

XV.-Preaching Crosses . . . : . . . . 293

XVI.-Market Crosses . . . . . . . . . . . 308

XVII.-Landmark Crosses . . . . . . . . . 321

XVIII.-Wayside, Street, and Weeping Crosses • • • 324

XIX.-Mortuary and Burial Crosses . . . . . $33 \mathbf{I}$

XX.-Churchyard Crosses . . . . . . .

\section{PART III.}

I.- - Varieties of the Cross . . . . . . . $\quad$. 353

II.-The Cross in Heraldry . . . . . . . 360

III.-The Cross on Coins . . . . . . . . . 375

IV.--The Banner of the Cross . . . . . . . 383

V.-The Color of the Cross in Art . . . . . 394

VI.-The Ordeal of the Cross . . . . . . . 396

VII.-The Adoration of the Cross . . . . . . 398

VIII.-Superstitions Concerning the Cross . . . . 404 


\section{Contents}

IX.-The Sign of the Cross . . . . . . . 415

Section 1.-Personal Use of the Sign . . . . 415

Section 2.-In Baptism . . . . . . . 422

Section 3.-In Confirmation . . . . . . 426

Section 4.-In the Holy Eucharist . . . . . 429

Section 5.-In Benediction. . . . . . 430

Section 6.-In Ordination . . . . . . . 431

Section 7.-In Prayer . . . . . . . 432

Section 8.-In Signatures . . . . . . 433

Section 9.-In Touching for the King's Evil . . 435

Section 10.--Power of the Sign over Devils . . 438

X.-Puritan Objections to the Cross . . . . . . 44I

XI.-The Southern Cross . . . . . . . $45 \mathrm{I}$

XII.-Miscellaneous Crosses . . . . . . . . 456

Section 1.--Noteworthy Crosses in History and Nature, 456

Section 2.-Ingenious Crosses . . . . . . 463

Section 3.-Cross and Pile . . . . . . . 466

Section 4--Good-Friday Cross Buns . . . . 467

Section 5.-The Crown of Thorns. . . . . 468

Index . . . . . . . . . . . . 475 



\section{ILLUSTRATIONS}

Inscription Showing Different Forms of the Tau Cross ' $\mathrm{Ra}^{2}$.

Amon-Ra ${ }^{2}$

Amon ${ }^{2}$

Soul, Bearing a Crux Ansata, Returning to the Body ${ }^{3}$

Cross upon Heart ${ }^{2}$

Cross on Cake ${ }^{2}$.

Egyptian Symbols for the Five Planets ${ }^{2}$. . . . . . 6

Buddha, with Cross on Breast and Hands ${ }^{4}$. . . . . IO

Different Forms of the Fylfot Cross ${ }^{5}$. . . . . . II

Hera, or the Assyrian Venus ${ }^{6}$. . . . . . . . 16

Assyrian Winged Globe ${ }^{6}$. . . . . . . . . Is

Sceptre Knob Found at Troy $^{7}$. . . . . . . . 2 I

Earthen Vessels Found at Castione ${ }^{8}$. . . . . . 23

Cylinder Found at Villanova ${ }^{8}$. . . . . . . . 24

Heads of Cylinders Found at Villanova ${ }^{8}$. . . . . 24

Accessory Vase Found at Golasecca ${ }^{\text {* . . . . . . . } 25}$

Ossuary found at Golasecca ${ }^{8}$. . . . . . . . 25

Engraved Gem " . . . . . . . . . . 27

Ancient Gaulish Coins ${ }^{\prime 0}$. . . . . . . . . 27

Cross, with the Bust of Neptune, Found near Paris ${ }^{10}$. . . 28

Cruciform Druidical Temple ${ }^{11}$. . . . . . . . 3 I

Sepulchral Monument at New Grange, near Drogheda" . . 33

Tablet with Cross, in Temple at Palenque, Mexico ${ }^{13}$. . . 35

'From Bosio's La Trionfante e Gloriosa Croce.

"From Haslam's The Cross and the Serpent.

"From Sharpe's The History of Egypt.

'From Lundy's Monumental Christianity.

${ }^{5}$ From Lee's Glossary of Liturgical Terms.

${ }^{6}$ From Layard's Nineveh.
7 From Schliemann's Troja.

From De Mortillet's La Signe de la Croix.

${ }^{9}$ From Walsh's Essay on Ancient Coins, Medals, and Ge'ms.

${ }^{10}$ From Gould's Curious Nyths.

"From Higgins's Celtic Druids.

${ }^{12}$ From Stephens's Central Anerica. 
Cross Found at Palenque ${ }^{3}$. . . . . . . . . ${ }_{3}^{6}$

Plan of Sepulchral Chamber at Mitlan ${ }^{2}$. . . . . . 38

Section of Sepulchral Chamber at Mitlan ${ }^{2}$. . . . . 38

Plan and Section of Sepulchral Chamber at Chila, Mexico ${ }^{2}$. . 38

Emblems Found in the Mounds in the Mississippi and Ohio Valleys ${ }^{3} . \quad 42$

Temple Mound, Lovedale, Kentucky ${ }^{2}$. . . . . . . 43

Temple Mound, Marietta, Ohio ${ }^{2}$. . . . . . . 44

Roman Mound near Banwell, Wiltshire, England * . . . 45

Isaac Carrying the Wood" . . . . . . . . 50

Sacrifice of Isaac $^{6}$. $. \quad . \quad . \quad . \quad . \quad . \quad . \quad . \quad 54$

The Brazen Serpent ${ }^{6}$. . . . . . . . . 54

The Crucifixion $^{\circ}$. $. \quad . \quad . \quad . \quad . \quad . \quad . \quad 54$

Window in Cathedral at Bourges ${ }^{\circ}$. . . . . . . 57

Crucifixion by Impaling ${ }^{7}$. . . . . . . . . 65

Crucifixion on Stauros ${ }^{7}$. . . . . . . . . . . 65

Crucifixion by One Hand and Foot ${ }^{8}$. . . . . . . 67

Crucifixion of S. Andrew ${ }^{7}$. . . . . . . . $7 \mathrm{r}$

Crucifixion by Tying ${ }^{7}$. $\quad$. . . . . . . . . . 72

The Crucified Exposed to Wild Beasts ${ }^{7}$. . . . . . 73

Crucifixion and Burning ${ }^{\top}$. . . . . . . . . . 73

Crucifixion Head Downwards $^{7}$. . . . . . . 75

Crucifixion with Arms and Legs Spread ${ }^{7}$. . . . . . 76

Self-Crucifixion of Matthew Lovat . . . . . . . 80

Adam Sends Seth to Paradise for Some of the Oil of Mercy ${ }^{3}$. $\quad 84$

The Archangel Michael Gives Seth Three Seeds of the Tree of

$$
\text { Life }^{3} \text {. . . . . . . . . . . } 85
$$

Seth Buries Adam and puts the Three Seeds of the Tree of Life under his Tongue $^{9}$. . . . . . . . . . . 86

The Three Seeds Spring Up ${ }^{\circ}$. . . . . . . . 86

The Crucifixion $^{9}$..$\quad$. . . . . . . . 87

The Jews Bury the Crosses ${ }^{9}$. . . . . . . . 88

1 From Wilson's Mexico.

${ }^{2}$ From Squier's Serpent Symbol in America.

${ }^{3}$ From Blake's The Cross, Ancient and Modern.

4 From Squier's Antiquities of New York and the West.

${ }^{5}$ From Jameson's History of Our Lord.
' From Twining's Symbols of Early and Mediaval Christian Art.

7 From Lipsius's De Cruce.

${ }^{8}$ From Bartholinus's De Cruce Christi.

${ }^{9}$ From Veldener's The Legendary Histony of the Cross, with Introduction by John Ashton. 
The Empress Helena Setting Forth from Constantinople in Search of the Cross ${ }^{1}$. . . . . . . . . . . . . . 89

The Empress Helena Receiving the Cross ${ }^{1}$. . . . . . . 89

The True Cross Restoring a Dead Maid to Life ${ }^{1}$. . . . . 9 I

A Part of the True Cross Placed in a Church by the Empress Helena ${ }^{1}$. 9 I

Passion Flower $^{2}$. . . . . . . . . IO2

The Vision of Constantine ${ }^{2}$. $. \quad . \quad . \quad . \quad . \quad . \quad$ IO4

The Labarum ${ }^{2}$. . . . . . . . . . . IO5

Medal of Constantine ${ }^{2}$. . . . . . . . . . 107

Medal of Constantius ${ }^{2}$. . . . . . . . . IO7

Coin of Ptolemy $^{3}$. . . . . . . . . . . . 108

S. Helena in Jerusalem ${ }^{4}$. . . . . . . . . . II4

Discovery of the Crosses ${ }^{4}$. . . . . . . . II5

Test of the True Cross ${ }^{4}$. . . . . . . . . I I5

S. Helena Deposits a Portion of the Cross in Jerusalem ${ }^{4}$. . II9

S. Veronica's Napkin at S. Peter's, Rome ${ }^{5}$. . . . . . . I 27

The Descent from the Cross $^{6}$. . . . . . . . . . I29

Early Representation of the Crucifixion with Thieves ${ }^{6}$. . . 131

The Title of the Cross ${ }^{2}$. . . . . . . . I 37

The Crucifixion (Ivory Work of the IXth Century) ${ }^{5}$. . . I4I

Sun and Moon at Crucifixion (Ancient Ivory) ${ }^{6}$. . . . 142

Angels Round Cross (Duccio, Siena) ${ }^{6}$. . . . . . . . I43

Angels Attending the Crucifixion (Pietro Cavallini, Assisi) ${ }^{6}$. . 143

Adoration of the Cross (S. Marco, Florence) ${ }^{6}$. . . . . I45

The Cross Imprinted on the Body ${ }^{3}$. . . . . . . I5I

Christ Represented as Orpheus $^{7}$. . . . . . . 152

Triple Cross Representing the Second Person of the Trinity ${ }^{7}$. 153

Representation of Pan Applied to Christ as the Good Shepherd ${ }^{8}$. I 53

Epitaph from the Catacombs ${ }^{8}$. . . . . . . . 155

Coin of Crispus ${ }^{3}$. . . . . . . . . . . 156

First Coin with Cross, Issued by Galla Placidia, Vth Century ${ }^{6}$. 157

${ }^{1}$ From Fisher's Antiquities at Stratford-onn ${ }^{5}$ From Harper's Magazine. Avon.

${ }^{6}$ From Jameson's History of Our Lord.

"From Bosio's La Trionfante e Gloriosa Croce. 'From Twining's Sy'mbols of Early and

${ }^{3}$ From Gretser's De Sancta Cruce. Mediceval Christian Art.

${ }^{4}$ From Veldener's The Legendary History of ${ }^{8}$ From Maitland's Church in the Catacombs. the Cross, with Introduction by John Ashton. 
Christ Holding a Gemmed Cross ${ }^{1}$. . . . . . . I 58

S. Pudentiana, from Fresco in the Church of S. Pudentiana ${ }^{2}$. I 58

Mosaic in the Church of S. Maria Maggiore, Rome ${ }^{2}$. . . . I60

Mosaic in the Church of S. Michael, Ravenna ${ }^{2}$. . . . I62

The Transfiguration $^{2}$. . . . . . . . . . $16_{4}$

Cross Surmounted by Crown ${ }^{2}$. . . . . . . . . 165

Angel Changing Crown of Thorns for Real Crown ${ }^{3}$. . . . I66

The Lamb as a Symbol of Christ. In the Basilica of S. Peter's,

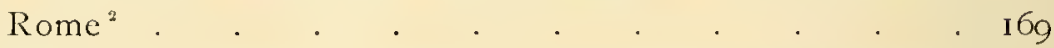

The Lamb as a Symbol of Christ. In the Church of SS. Cosma and Damiano $^{2}$. $\quad . \quad$. . . . . . . $\quad$ I $7 \mathbf{I}$

Early Form of Crucifix, from MS. of VIth Century ${ }^{3}$ • . . $\quad$ i72

Crucifix Found in the Catacomb of Pope Julius ${ }^{3}$. . . . . $\quad$ I73

Hohenlohe Siegmaringen Crucifix ${ }^{3}$. . . . . . . 174

Back of Hohenlohe Siegmaringen Crucifix ${ }^{3}$. . . . . 175

Early Pectoral Crucifix ${ }^{8}$. . . . . . . . . . 176

Cross of Lothario (IXth Century) ${ }^{3}$. . . . . . . I77

Adam at the Foot of the Cross ${ }^{3}$. . . . . . . 178

Mary at the Cross ${ }^{4}$. . . . . . . . . . I80

Anubis-Christos ${ }^{5}$. . . . . . . . . . IS I

Identity of Heathen and Christian Symbols ${ }^{\circ}$. . . . . I 88

The Labarum ${ }^{6}$. . . . . . . . . . . I88

Monograms of the Saviour ${ }^{6}$. . . . . . . . . Is\&

Monogram of the Three Emblems Carried in the Mysteries ${ }^{6}$. . I $\$ 8$

Various Crosses of the Greek Form ${ }^{\top}$. . . . . . . . I 89

Greek and Latin Crosses of Various Forms ${ }^{7}$. . . . . . . Is9

Monogram in the Lapidarian Gallery, Rome ${ }^{8}$. . . . I9I

Mystic Cross ${ }^{\top}$. . . . . . . . . . . . . I9I

A Cathedral Screen $^{\circ}$. . . . . . . . . . . 194

A Parochial Screen ${ }^{9}$. $. \quad . \quad . \quad . \quad . \quad . \quad . \quad . \quad$. 196

'From Bosio's La Trionfante e Gloriosa "From Didron's Christian Iconography; or Croce.

${ }^{2}$ From Ciampini's Vetera Monimenta.

${ }^{3}$ From Jameson's History of Our Lord.

4 From Jameson's Legends of the Madonna.

${ }^{5}$ From King's The Grostics. the History of Christian Art in the Middle Ages.

${ }^{8}$ From Maitland's Churct in the Catacombs.

${ }^{9}$ From Pugin's Treatise on Chancel Screens and Rood-Lofts.

${ }^{6}$ From Jennings's The Rosicrucians, Their Rites and Mysteries. 
Iconostasis at Tepekerman' . . . . . . . . . 197

Marble Screen in the Church of the Frairi, Venice ${ }^{2}$. . . Ig8

Screen and Rood-Loft, Hospital, Lubeck ${ }^{2}$. . . . . 200

Maximianus Velcoming Justinian ${ }^{3}$. . . . . . . 206

Reliquary of Orvieto, XIVth Century ${ }^{*}$. . . . . . 208

Bronze Crucifix, XIIth Century" . . . . . . . 210

Ciborium, Byzantine, End of XIVth Century ${ }^{5}$. . . . 2 I 3

Monstrance of Sedletz Castle, Bohemia, XVth Century ${ }^{5}$. . 214

Monstrance $^{6}$. . . . . . . . . . . 2 I5

Monstrance: German Example of the XVIth Century ${ }^{6}$. . . 2 I6

Sceptre Surmounted by the Cross ${ }^{\circ}$. . . . . . 216

Crown of Charlemagne $^{\circ}$. . . . . . . . . 2 I 7

English Crown . . . . . . . . . . . 2 I8

Crown of Austria " . . . . . . . . . 218

Crown of Reccesvinthus, VIIth Century ${ }^{5}$. . . . . . 219

Brooch of Silver Filagree Work (Date Uncertain) s. . . . 220

Crucifix Made from an Old Spanish Hilt. . . . • . 222

Sword Hilt, XVIIth Century ${ }^{4}$. . . . • • . . 223

Dr. Donne's Seal ${ }^{8}$. . . . . . . . . . 225

S. Augustine's Interview with Ethelbert * . . . . . 227

Processional Cross ${ }^{\circ}$. . . . . . . . . . 228

Processional Cross $^{3}$. . . . . . . . . . . 229

Processional Cross ${ }^{3}$. $. \quad . \quad . \quad . \quad . \quad . \quad . \quad \cdot 231$

Processional Crosses $^{3}$. . . . . . . . . . 233

Ancient Processional Cross, Circa I400 ${ }^{10}$. . . . . . 234

$\operatorname{Crosier}^{11}$. . . . . . . . . . . . 237

Crosier $^{6}$. . . . . . . . . . . . . . 238

Tau-Shaped Pastoral Staff of Carved Ivory, Limburg ${ }^{6}$. . . 239

Pastoral Staff ${ }^{\circ}$. . . . . . . . . . . 240

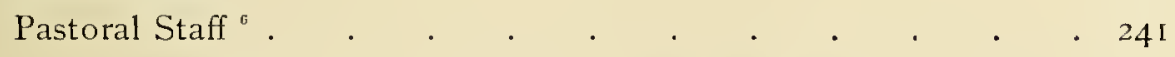

'From Neale's History of the Holy Eastem ${ }^{6}$ From Lee's Glossary of Liturgical and EcChurch. clesiastical Terms.

${ }^{2}$ From Pugin's Treatise on Chancel Screens ' From Rerry's Heraldric Encyclopedia. and Rood-Lofts. $\quad{ }^{8}$ From Walton's Complete Angler.

${ }^{3}$ From Ciampini's Vetera Monimenta. $\quad{ }^{9}$ From an old print.

"From Labarte's Flandbook of the Arts of the ${ }^{10}$ From Paley's Manual of Gothic Architecture. Middle Ages and Renaissance.

${ }^{5}$ From Wheatley's Art Work in Gold and Heraldry. Silver. 
Pastoral Staff with Knob ${ }^{1}$

Forms of Pateressa ${ }^{2}$. . . . . . . . . . 242

Pastoral Staff of S. Boniface ${ }^{3}$. . . . . . . . . 243

Cross Worn by One of the "Seven Chiefs against Thebes," Circa B.C. $1200^{4}$. . . . . . . . . . 250

Cross Worn by Samsi-Vul IV., King of Assyria, E.C 835. British Museum ${ }^{4}$. . . . . . . . . . 25 I

Mosaic in the Oratory of S. Venantius, Rome ${ }^{5}$. . . . $\quad 252$

Byzantine Pectoral Cross ${ }^{6}$. . . . . . . . 253

Queen Dagmar's Cross ${ }^{7}$. . . . . . . . . . 255

Cross of the Knights Templars . . . • • • . 256

Exterior Cross ${ }^{2}$. . . . . . . . . . . 258

Consecration Crosses ${ }^{*}$. . . . . . . . . . 259

Spire Cross $^{8}$. . . . . . . . . . . 26 I

Crosses on Gables ${ }^{9}$. . . . . . . . . . . . 262

Front of Stone at Aberlemmo, with Cross ${ }^{10}$. . . . . . 266

Crosses in Isle of Man Bearing Runic Inscriptions ${ }^{10}$. . . 268

The North Cross, Clonmacnoise " ${ }^{\prime \prime}$. $\quad$. . . . . . 269

The Southeast Cross, Monasterboice" . . . . . . 27 I

Drumcliff Cross $^{12}$. . . . . . . . . . . . 273

Geddington $\mathrm{Cross}^{13}$. . . . . . . . . . 280

The Queen's Cross, near Northampton ${ }^{13}$. . . . . . 282

Waltham Cross . . . . . . . . . . . 283

Waltham Cross ${ }^{13}$. . . . . . . . . . 284

Abingdon Cross . . . . . . . . . . 286

Charing Cross . . . . . . . . . . . . 286

Frithstool, Beverley Minster ${ }^{6}$. . . . = . . . 290

S. Paul's Pulpit Cross ${ }^{14}$. . . . . . . . . . 295

${ }^{1}$ From Rock's Church of Our Fathers. $\quad$ From Lee's Glossary of Liturgical and Ec-

${ }^{2}$ From Neale's History of the Holy Eastern clesiastical Terms. Church.

${ }^{9}$ From Parker's Companion to Glossary of

${ }^{3}$ From 'Twining's Symbols of Early and Me- Tirms Used in Gothic Architecture.
dicual Christian Art.

${ }^{4}$ From Brock's The Cross: Heathen and "II From O'Neill's Crosses of Ancient Ireland. Christian.

'From Ciampini's Vetera Monimenta.

${ }^{12}$ From O'Neill's Fine Arts of Ancient Irelind.

${ }^{6}$ From Labarte's Handbook of the Arts of the ${ }^{13}$ From Britton's Architectural Antiquities. Middle Ages and Renaissance.

it From Holland's Cruciana.

' From Stephens's Queen Dagmar's Cross. 


\section{Illustrations}

S. Paul's Cross ${ }^{1}$

PAGE

S. Paul's Cross, Time of Latimer' ${ }^{2}$. . . . . . . 299

Preaching at S. Paul's Cross ${ }^{1}$. . . . . . . . 303

Reredos in S. Paul's ${ }^{2}$. . . . . . . . . 304

Pulpit Cross at Iron-Acton, Gloucester . . . . . . 305

Blackfriar's Pulpit, near Hereford ' . . . . . . . 306

Gloucester High Cross ${ }^{3}$. . . . . . . . . . 309

Market Cross at Cheddar" . . . . . . . 3 IO

Cross at Chichester, Sussex ${ }^{4}$. . . . . . . . 3 II

Winchester Butter Cross . . . . . . . . . 312

Mercat (Market) Cross as Restored in $1885^{\circ}$. . . . . 313

Salisbury Market Cross . . . . . . . . 315

Cross of Stourhead ${ }^{4}$. . . . . . . . . . 316

Devizes Market Cross . . . . . . . . . 317

The High Cross, Formerly in the Market-Place at Wells ${ }^{\circ}$. . 318

Cross at Inverary $^{\top}$. . . . . . . . . . 325

Tottenham Cross . . . . . . . . . . 327

Wayside Cross in the Alps ${ }^{8}$. . . . . . . . 328

"Ampney Crucis," near Cirencester . . . . . . . 329

Stone Coffin of Llewellyn, Prince of Wales. In Llanrwst Church ${ }^{9} 335$

Stone Coffins with Cross on $\mathrm{Lid}^{10}$. $\quad . \quad$. $\quad . \quad$. 336

Stone Coffin-Lids ${ }^{\circ}$. $\quad$. . . . . . . . . . . . 337

Stone Coffin-Lids $^{9}$. . . . . . . . . . . 338

Headstone Cross in Iona . . . . . . . . . 339

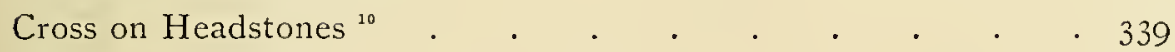

Grecian Headstones ${ }^{11}$. . . . . . . . . 340

Head and Base of a Monumental Brass Cross, Grainthorpe Church,

Lincolnshire $^{\prime 2}$. $\quad . \quad . \quad . \quad . \quad . \quad .341$

Brass Effigy of Thomas Cranley, Archbishop of Dublin and WVar-

den of New College Chapel, Oxford ${ }^{12}$. . . . . . 342

1 From an old print.

${ }^{2}$ From a photograph.

${ }^{3}$ From Pooley's Old Crosses of Gloucestershire. ${ }^{10}$ From Cutts's Manual for the Study of Se-

4 From Britton's Architectural Antiquities.

${ }^{5}$ From Arnold's History of the Cross of Edin- ${ }^{11}$ From Neale's History of the Holy Eastern burgh.

${ }^{6}$ From Pooley's Old Stone Crosses of Somerset. ${ }^{12}$ From Boutell's Monumental Brasses of "From Bishop's Pictorial Architecture. England.

\& From Holland's Cruciana.
${ }^{9}$ From Boutell's Christian Monuments in England and Wales.

pulchral Slabs and Crosses.

Church. 
Inscriptions in Catacombs ${ }^{2}$. . . . . . . . 345

Cemetery Cross at Saillans (XVIth Century) ${ }^{3}$. . . . 346

Cemetery Cross at Marcillac ${ }^{3}$. . . . . . . . 347

Cross at Georget $^{3}$. . . . . . . . . . . 348

Cross Quartered with the Four Gospels. From a Fresco in the Catacombs ${ }^{4}$. . . . . . . . . . 354

Christ, Armed with the Cross of Resurrection, Descending into Limbo * . . . . . . . . . . 355

Lorraine or Jerusalem Cross $^{4}$. . . . . . . . . 357

Greek Cross, with Double Cross Arms (XIth Century) ${ }^{4}$ • . . 357

Inhabited Cross, Florentine, I49I ${ }^{4} \cdot$. . . . . . 358

Cross of S. George s. . . . . . . . . . . 363

Cross Potent $^{5}$. . . . . . . . . . . . . 364

Jerusalem Crosses $^{5}$. . . . . . . . . . . 364

Tau Cross ${ }^{5}$. $. \quad . \quad . \quad . \quad . \quad . \quad . \quad . \quad .365$

Saltire Cross ${ }^{\circ}$. . . . . . . . . . . . . 365

Calvary Cross ${ }^{\circ}$. . . . . . . . . . . 365

Cross Botoné ${ }^{\circ}$. . . . . . . . . . . . . . . 366

Cross Patonce ${ }^{\circ}$. . . . . . . . . . . . . 366

Cross Fleury $^{5}$. . . . . . . . . . . . . . . 366

Patriarchal Cross ${ }^{5}$. . . . . . . . . . . . ${ }_{3} 67$

Cross of S. James ${ }^{5}$. . . . . . . . . . . . . 367

Cross Pommée ${ }^{6}$. . . . . . . . . . . . . . 367

Cross Avellane ${ }^{5}$. $. \quad . \quad . \quad . \quad . \quad . \quad . \quad .368$

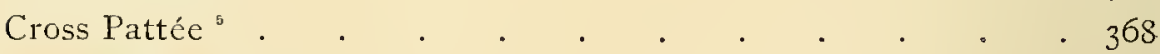

Maltese Cross ${ }^{6}$. . . . . . . . . . . . . 368

Cross Moline $^{5}$. $. \quad . \quad . \quad . \quad . \quad . \quad . \quad . \quad . \quad .369$

Cross Milrine". . . . . . . . . . . . . 369

Cross Ancrée ". . . . . . . . . . . . . . . 369

Cross Barbée ${ }^{5}$. . . . . . . . . . . . 370

Cross Ancettée $^{5}$. $. \quad . \quad . \quad . \quad . \quad . \quad . \quad .370$

Pall Cross $^{\circ}$. . . . . . . . . . . 370

${ }^{1}$ From Cutts's Manual for the Study of Se- ${ }^{3}$ From Drouyn's Croix de Procession, de Cipulchral Slabs and Crosses.

${ }^{2}$ From Kip's Catacombs of Rome. metieres et de Carrefours.

"From Didron's Christian Iconography".

${ }^{5}$ From Newton's Display of Heraldry. 


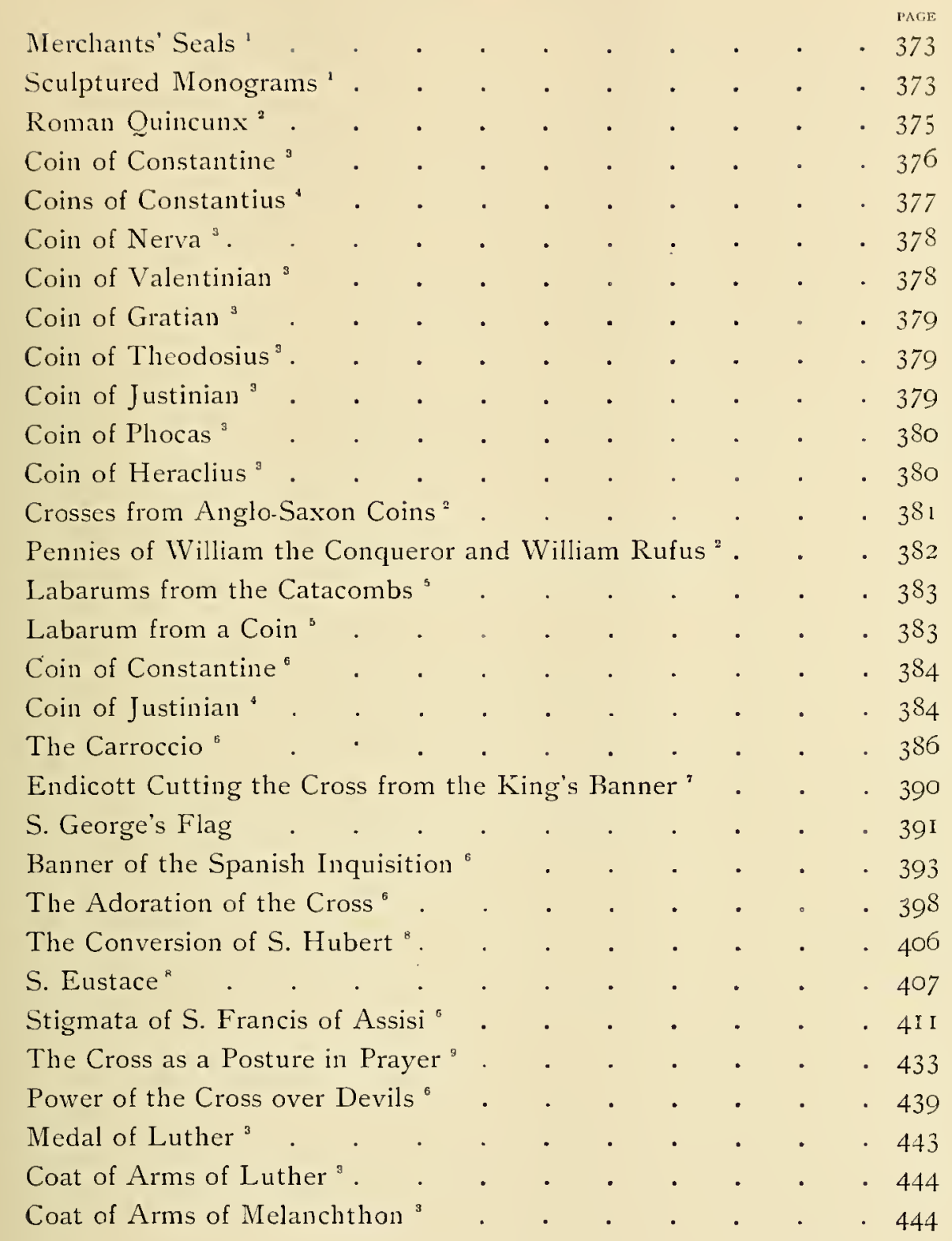

'From Newton's Display of Heraldry.

${ }^{2}$ From The Art Fournal.

${ }^{3}$ From Gretser's De Sancta Cruce.

'From Walsh's Essay on Ancient Coins, Medals, and Gents.
'From Lee's Glossary of Liturgical and Ecclesiastical Terms.

${ }^{s}$ From Holland's Cruciana.

7 From an old print.

${ }^{8}$ From Jameson's Sacred and Legendary Art.

- From Maitland's Church in the Catacombs. 
The Southern Cross ${ }^{1}$. . . . . . . . 45 I

Black Cross of Abingdon ${ }^{2}$. . . . . . . . . . 458

Magnified Scales of the Minnow ${ }^{3}$. . . . . . . 460

Cross- or Star-Spored Fungus ${ }^{3}$. . . . . . . . . 460

The Cross in Flowers ${ }^{3}$. . . . . . . . . $46 \mathrm{I}$

Snow Crystals ${ }^{1}$. . . . . . . . . . . . . 462

Crystallization of a Tear-Drop ${ }^{1}$. . . . . . . . . 463

Croce Angelica di S. Tomasa de Aquinæ " . . . . . . 463

Acrostic of Raban Maur ${ }^{5}$. . . . . . . . . 464

1 From Crowther's The Stary Cross. $\quad{ }^{3}$ From The Art Fournal.

'From Palmer and Crowquill's Wanderings 'From Holland's Cruciuna. of a Pen and Pencit. From Maur's De Laudibus Sancta Crucis. 
BIBLIOGRAPHY 



\section{BIBLIOGRAPHY}

A Kempis, Thomas. Serm: De Cruece quotidie tollenda in retig. asszempta. (Opp. t. i., ed. Sommal.)

- Concio seu meditatio de Cruce Fesu, quam pro zobis ipse portavit: item, Demerito dominice passionis et dignitate sancta Crucis. (Opp. t. ii.)

ALGER, IV. R. History of the Cross. Boston, 1858 .

Ambrosius, S. De Cracce, Serm., 55 et 56. (Opp. t. iii.) Basile, 1506.

Anderson, J. Scotland in Early Christian Times [Celtic Crosses]. 2 vols. Edinburgh, I881. Angela de Fulignio. Theologia Crucis. ("Die Theologie des Kreuzes J. Christi" in G. Terstegen, Azeserlesene Lebensbeschreibungen heiliger Seelen. Bd. St. 5.)

Passus Spiritzales, etc., c. 10. (Vita B. Angelæe, auct. Arnold.; A.A.SS. Boll., 4 Jan.)

Anselmi. (Pseudo-Anselmi) De Mensutratione Crucis.

ARndt, F. The Seven Words of Festes upon the Cross. $18+2$.

ARNDT, Jon, Iconographia : gründlicher und christlicher Bericht von Bildern, ihrem Ursprung, rechtem Gebrauch und Missbranch im A. n. N. Test. . . . Von den Ceremonien oder Zeichen des Creutzes, auch von der äusserlichen Reverentz und Ehrerbietung gegen den hochgelobten Namen Jesu Christi, unseres einigen Erlösers und Ehrenkönigs. 4to, 1596.

ARnold, Thomas. History of the Cross of Edinburgh Commonly Called the Mercat Cross. Edinburgh, I885.

Ashton, John. The Legendary History of the Cross, a series of sixty-four woodcuts, from a Dutch book published by Veldener, A.D. 1483. Preface by S. Baring-Gould. New York, I887.

Astle, Thomas. Observations on Stone Pillars, Crosses, and Crucifixes (Royal Soc. of Antiquaries). London, 1798.

Baldwin, J. D. Ancient America. [The Cross in Central Am. Ruins.] New York, I872.

Baring-Gould, S. Crerions Myths of the Midlle Ages. [The Legend of the Cross.] London, Oxford, and Cambridge, $\mathrm{r} 868$.

Bartholrnus, Thomas. De Cruce Christi, Hyponnemata IV. Hafn., i651. Amstel., i67o.

- De Latere Christi Aperto Dissertatio. Lugd, Bat., I6.46.

Baudis, AND. Crux Christi ex historiarum monzententis constructa. 4 to. Viteb. (Vienna), I669.

BeCKer, FERd. Das Spottcrucifix der römischen Kaiserpaläste aus dem Anf. des 3 Gahrhdts., erlärtert. Bresl., 1863 .

BERJEAU, J. P. History of the Holy Cross. London, I 863.

Berthold von Regensburg. Sermon: Von dem héren Kóriuze. (Pfeiffer, Berthold, etc.) 1862.

Betkius, Joachin. Mysterizm Crucis oder Erinnerung derer Geheimnissen und Fraffi des Crentzes Christi. Berlin, I637. Frankf., 1646 and 1647.

Birlinger, A. Die dentsche Sage, Sitte, u. Literatuer in Predigt und Legendenüuchern. (Austrian Vierteljahrschr. f. Kath. Theologie, Bd. xii., I873.) 
Blake, Wrllson W. The Cross, Ancient and Modern. New York, 1888.

Blight, J. T. Ancient Crosses and Other Antiquities in the West of Comwall. London, 1856. - Ancient Crosses and Other Antiquities in the East of Cormwall. London, $18_{5} 8$.

BoldetTi, M. A. Osservazioni sopra I Centeteri de Santé Martiri. [Seal Rings, Greek Cross, etc.] 2 vols., fol. Romæ, I720.

Bonaventura, Lignzem Vita. (Opp. t. v.) Venet., I754.

Borgia, Steph. De Cruce Vaticana. Romæ, 1779.

- De Cruce Veliterna. Romæ, 1780.

Bosio, Ant. Roma Sotteranea. [Gemmed and Floriated Cross, Cruciform Nimbus, etc.] 4 to. Romæ, 1637.

Bosius, JAC. Crux triumphans et gloriosa. Antverp., I6r7. Or, La Trionfante e Gloriosa Croce Trattato di Facono Bosio. Fol. In Roma, I6ro.

Boutell, C. Christian Monuments in England and Wales. London, I854.

- Heraldry, Historical and Popular [chap. vi., " Heraldry of the Cross"]. London, 1864.

Bracciolini, F. La Croce Racquistata. 3 toms. Venezia, 1838.

Brand, J. Observations on Popular Antiquities [The Cross, Good Friday, etc.]. 3 vols. London, $18+2$.

Brentius, JoH. Eitlich Tractetli (1528): Wie das Holz des Kreuzes behauen und am weichsten angegriffen werden soll, u. s. f. (in J. Hartmann, Joh. Brenz, Leben und ausgezvählte Schriften). (Other works of Brenz, Urban-Rhegins, etc., falling under this head, see chap. vi.)

Bridel, PH. The Seven Word's of Feszes zepon the Cross. Lausanne, I85I.

Brock, Mourant. The Cross, Heathen and Christian. A Fragmentary Notice of its Early Pagan Existence, and Subsequent Christian Adoption. London, I879.

Byneus, Anton. De morte F. Christi commentaritus amplissintus. Lib. iii. Amstel., I69II698. Also in German : Gekreutzigter Christus, etc. Cassel, I7or.

Calfhill, J. An Answere to the Treatise of the Crosse (John Martiall's). London, I565. Reprinted for the Parker Soc., Cambridge, 1846.

Calvinus, JoH. De Crucis tolerantia, que est pars abuegationis sui. (De souffrir patienment la croix, qui est une partie de renoncer à nous mesmes): Instit. Relig. Christ. Lib. iii., ed. 1559 sqq.

Carracroli, J. M. Dissert. de titulo Crucis e sacre et profance historice monumentis. Neapol., 1656 .

Chry sostomi, Joann. De Cruce et Latione homil. duo. (Opp. t. ii., ed. Montf.)

D De Cameteris et Cruce (Ib.).

Psevdochrysostomi Homitia in venerab. ac. vivificam crucem (Ib.).

Cracconius, A. Libellus de Signis sanctissime Crucis, i. e., de variis Crucis apparitionibus, priscis et novis. Romæ, I59I.

Ciampini, J. R. Vetera Monimenta [Pars Secunda, cap. 6, De Cruce Stationali Investigatio historica]. 3 toms, fol. Romæ, I69o.

Clement, C. E. A Handbook of Christian Symbols [The Cross]. Boston, I886.

Cooper, H. G. The Philosoplyy of the Cross, or Christ as Man. Grantham and London, I855. Copus, Alanus. De Cruce.

Cox, G. W. The Mythology of the Aryan Nations [The Stanros or Cross]. 2 vols. London, 1870 .

Crossing, W. The Ancient Crosses at Dartwnor, with a Description of their Surroundings. I 887.

Crowther, J. The Starry Cross. A Story of Dreamland. London.

Culmann, L. An Crux expediat vel noceat (in loc. Joh. xvi. 7 : expedit ut ego vadam). Norimb., I550.

Cummng, J. G. Runic and Other Monumental Remains of the Isle of Man: with Plates of Runic Crosses. 
Curtius, Cornel. De Chais Dominicis Libir. Autverp, 1634, 1670.

CuTrs, E. I. A Manual for the Stady of the Sipulehral Slabs and Crosses of the Miadli Ages. I.ondon, 1849 .

DALL.EUS, JoANn. Adversus Latinorum décultus religiosiobjecto, lib. v., cont. argumenta contra Latinam de religioso Crucium cultu traditionem propria. (Tom. ii.), ed. Genev., I665.

Dalton, II. The Sezen Last Words of Fisus upon the Cross. I871.

Daniell, Moktlock. Calvary, or the Cross of Christ. London, 1839.

Massovius, L. Signa Crucis gentis Ilibrac. Kil., 1695.

Decker, Conrad, De Staurolatria Romana. Lib, ii. IIanov., I6I7.

DE Fleury, M. R. Mimoire sur les Instrumens de la Passion de Notre Seigneur Fésus-Christ. Degen, Ph. Das Kreuz als Strafoverszeus unt Strafe der Altin. Aachen, 1873.

De Mortillet, G. Li Signe de la Croix avant le Christianisme. Paris, 1866.

DE Pressensé, E. The Mystery of Suffering. London, I869.

DE Rossi, J. B. Inscriptiones Christianit urbis Rome sept. saculo antiquiores. Romæ, I857 sqq.

- De Christianis titulis Carthaginiensibus. Paris, 1858.

De Christ. Monumentis IX $\Theta\urcorner N$ exhibentibus. Paris, 1855 .

De Venutos, Phil. De Cruce Cortonensi diss. Liburni, I73I.

De Voragine, Jac. Opus Aurezm, etc. [De Inventione Crucis, etc.], 1526. Legenda Aurea. Græesse, $18_{51}$.

Didron, A. N. Manuel d'Iconographie Chrétienne. Paris, 18+5. Translated into English, Christian Iconography, or the History of Christian Art in the Middle Ages. London, vol. i., 1851 ; vol. ii., 1886.

- Anmales archéologiques. Paris, 1844 sqq.

Don Anthonio De Gunnara. The Mount of Caluarie: wherein is handled all the mysteries of the Mount of Caluarie, from the time that Christ was condemned by Pilat, until he was put into the sepulchre by Foseph and Nichodemus. London, 1595 and I 597.

DRAXONIs, ThOMAS (Drake of Warwick). Synopsis, consolatoria, s. spiritualia et selectissima Consitia, remedia, et lenimenta adversus Crucem. Francol., I618.

Drelincourt, C. Le Triomphe de l'Eglise sous la Croix. Genève, 1630.

Drouyn, Lîo. Croix de Procession, de Cimetieres ct de Carrefours. Fol. Bordeaux, 1858 .

Durandus, G. Rationale Divirzorum Officiorum. [De Inventione Sanctæ Crucis, De Exalta. tione S. C., Crux Christi, etc.]. Fol., Ven., I 482 . 4to, Nürnberge, 1494. I 2mo, Lugduni, I584. First book translated into English, The Symbolism of Churches and Church Ornaments. [Introductory Essay, chap. vii., $\$$ iii. The Atonement, etc.]. Leeds, 1843.

Durer, A. Passio Christi. Nurenbergensi effigiata cum varij generis carminibus Fratris Benedicti Chelidonij Musophili. Edited by Henry Cole. London, I87o.

Du Sommerard, M. Album des Arts au Mojen Age.

Eales, S. J. Via Crucis: Fourteen Sermons on the Passion of our Lord and Saviour Jesus Christ. London, I 886.

Ecclesiologist (Camb. Camden Soc.). [Churchyard Crosses, Monumental Crosses, Memorial Crosses, Ancient Crosses.] 9 vols. Cambridge and London, 1843-49.

- (New York). [Cross before Christian Era.] New York, 1847-

EIsfngrein, M. Von dem Zeichen des heil. Kreuzes, diss es ein recht christlicher, uralter apostolischer, und in Gottes Wort gegriundeter Gebrauch, auch nütz und gut sei. Ingolstadt, 1572 .

Farel, Guil. Du vray usage de la Croix de Fésus Christ, et de l'abus et de l'idolatrie commise autour d'icelle. Genève, I560. Nouv. éd. Genève, 1865.

FAvine, A. The Theater of Honour and Knighthood. [The Crosse of the Order of the Knights of the Holy Sepulcher of Jerusalem, of Malta, of the Temple, etc.] Fol. I623. 
Fergusson, J. Rude Stone Mlonuments [Crosses]. London, I872.

Fivizanus, Aug. Libri $I I I$, de more summo Pontifici Crucem praferendi. Romæ, I592.

Fontanus, Nic. Responsum ad Propositam sibi questionem, An manus, clavis transfixa, parcs ferendo corpori, inde pendulo. (in op. Thom. Bartholini De Cruce Christi). Hafn., I65I. Amstel., 1670. Lugd. Batav., 1695.

Fosbroke, T. D. Encyclopiedia of Antiquities and Elements of Archaology [Cross, etc.]. 2 vols. 4to. London, 1825 .

Frane, J. The Song of the Cross. An Exposition of Psalm xxii. London, 1872.

FrEYBE, A. De Karfreitag in der deutschen Dichtung. (A companion volume to Morris's Legends of the Holy Rood.) Gütersloh, 1877.

Friedler, J. IH. Archäologie der Leidensseschichte. Bonn, I843.

FrIEDRICH, C. Kritischer Rückblick auf die Literatur über die Geschichte und Archäologie des Krentzes. Bonn. Theol. Lit., Nos. I7-I9, I875.

Fulda, J. Jul. Chr. De Crucis signaculo, Christianorum precum comite destirato. Lips., I 759 .

Fulke, W. A Rejoinder to Fohn Martiall's Reply against the Answer of Master Calfhill to the Blasphemous Treatise of the Cross. London, I580. Reprinted for the Parker Soc., Cambridge, 1848 .

GaRrucci. Il crocifisso graffito in casa dei Cesari. Romæ, 1857.

Geistliche Kranken-Apothek, d. i. christliche Unterweisung, wie Kranke und Sterbende ihr Kreuz geduldig tragen Können. Stuttgart, I 703 .

Gibson, W. Observations on the Remains of a Stone Cross or Pillar at Hemsby, Norfolk, with Conjectures on its Ancient Designation and Use. (Royal Soc. of Antiquaries.) London, I Sor.

Grorgi (Georgius) Dom. De monogrammate Christi Domini. Romæ, I738.

Glossary of Terms in British Heraldry. [Crosier, Cross.] Oxford, I847.

Grandis, L. Les perfections de Dien connues par la Croix. Paris, I642.

Greswell, D. Colloquia Crucis. London, 1871 .

GRETSER, JAC. De Cruce Christi rebusque ad eam pertinentibus. Libri iv. 4to. Ingolstadii, I598. Tom. ii., ibid., I600. Tom. iii., ibid., I605.

- De Cruce Christi, t. i., nunc tertia editione multis partibus anctus, ut ferme novum opus videri possit. 4to. Ingolst., 1608.

De Crzze. Tom. iii., lib. i.: De numismat. crucigeris; lib. ii. De inscriptionibus crucigeris.

- Hortus S. Crucis. Ingolst., I610, I630, etc.

- Signa Crucis, d. i., ein lustiger und nutzlicher Tractat vom dem Zeichen des heil. Creutzes, aus dem Lat. verdentscht durch Carolum Stengelium. Ingolst., I6I2.

- Opera Ominia de Sancta Cruce, nunc accurate recognita, multis partibus ocupletata, etc. Fol. Ingolst., .16 6 .

Greyfenberg, A. Die Lehre vom Creutz der Christen in 4 Haubtartikel geteilet und zu Wittenberg in fünf Predigten ausgelegt. Wittenberg, 1567.

Grierson, J. Voices from the Cross: or, The Words uttered by our Lord during the Hours of His Crucifixion. Edinburgh, I855.

Gron, M. The Abbé. The Practical Science of the Cross. London, $187 \mathrm{I}$.

Guenebault, L. J. Dictionnaire Iconographique des Monzments de I'Antiquité Chretienne et du Moyen Age. [Croix de J. C.; Croix dites Gemmées, Historiées, Pectorales, Grecque et Latine. Crosses, Crucifix, etc.] 2 toms. Paris, I 845.

HablChHorst, AND. DAN. De Cracifixione Christi satisfactoria in medio malefactorum facta, ex ratione. Is. liii., Ps, xxii., etc. 4to. Gryphiswald, I68I.

Handbook of English Ecilesiology. [Pinnacle and Churchyard Crosses, etc.] London, 1847. 
HARenberg, J. CH. Excritatio de Crucis signo, symbolo salutis frontibus Isractitarum imponendo, ad Ezech. ix., 4. (In the Bibl. Brem. hist. philol. theol., Class vi., fasc. 6.)

HAsLam, IV. The Cross and the Serpent: being a brief History of the Triumph of the Cross throngh a long series of $\Lambda$ ges, in prophecy, types, and fulfilment. Oxford, 18.9 .

IIAUSEN, CH. A. Thologia paracletica gencralis et specialis, oder gründliche Erklärung von der Christen Kreuz und Trost in Predigten. 2 vols. Dresden, 1706, 1723.

Heftenus, Ben. Schola Cracis. Antverp., 1629.

- Tia regia Crucis. Antverp., 1654.

Heales, A. The Archaology of the Christian Altar in Wistern Europe. [The Cross.] London, ISSI.

llemmann, Johr. Crux Christi, oder die schmerzreiche Natirwoche unseres lIeilands, i6r8. New edn. Ruppin, IS6r.

- IIplalogus Christi, oder die sieben Worte am Kreuz, I6I9. lierlin, I856.

Hemans, C. I. A History of Ancient Christianity and Sacred Am in Italy. [Discovery of the Cross, Croziers, Crucifix.] Jlorence and Rome, I\$66.

A History of Medicual Christianity and Sacred Art in Italy. [The Crucifixion as treated in Art, Crusades, etc.] 2 vols. Florence and Rome, 1869.

Hemmng, Jor. Fesu Christi meditatio sacra de passione Christi simulque de Crucis ligno et signo ciusque usu ct abusu. Han., 1657 .

Henneberg, J. V. Philol-histor. u. Krit. Commentar üb. d. Geschichte der Leiden und des Todes Fesu. Leipz., I822.

Higgins, G. The Celtic Druids. [The Cross common to Greeks, Egyptians, and Indians; Crosses and Globes, etc.] London, I829.

- Anacalypsis. [The Meaning of the Cross; Monograms of Christ, etc.] 2 vols. 4 to. London, 1836 . New edn. begun in parts, 1875 .

Holland, J. Cruciana. Illustrations of the most striking aspects under which the Cross of Christ, and Symbols derived from it, have been contemplated by Piety, Superstition, Imagination, and Taste. Liverpool, I835.

Holy Crosse: A Briefe Treatise of the Vertue of the Crosse, and the true manner how to hononr it. Translated out of French into English, I599.

Hook, W. F. The Cross of Christ; or, Meditations on the Death and Passion of our Blessed Lord and Saviour. London, I84t; New York, $18+4$.

Husenbeth, F. C. Emblems of Saints by which they are Distinguished in Works of Art. [Cross, Crucifix.] London, I850, 1854.

Huzard. "Observations sur l'origine et la siguification du symbole appelé la croix ansée." Mémoires de l'Acad. des Inscriptions et Belles-Lettres. Tom. xvii.

JAmeson, A. Legends of the Madonna. [Part iii., Lo. Spasimo; The Procession to CalvaryThe Crucifixion-The Descent from the Cross-The Deposition.] London, 1857.

- and LADY EASTLAKE. The History of our Lord as exemplificd in IVorks of Art. 2 vols. London, I864.

Jennings, H. The Rosicrucians, their Rites and Mysteries. London, I87o. $3 \mathrm{~d}$ ed., 2 vols., 1887.

Jewett, Llewellynn. The Cross, in Nature and Art. Series of eight papers. London Art Fournal, i 874 .

- The Cross Tan, as an Emblem, and in Art. Ib., I875.

The Fylfot Cross; or, Thorr's Hammer. $I b ., 1875$.

Ancient Irish Art; the Shrine of St. Manchán. Ib., I875.

Art in the Belfry. Ib., IS72.

KeAne, M. The Towers and Temples of Ancient Iroland. [Ancient Irish Crosses and Primeval Tradition.] Dublin, 1867.

KegeL, PHiL. Geistliche Kampfschul, welcher massen ein Christl. Ritter die Mühseligkeit dieses Lebens erdulden soll, etc. Leipzig, I616. 
Kemble, J. M. Elene: or. The Recovery of the Cross; The Holy Rood, a Dream. (The Codex Vercellensis, with an English translation, printed for the Ælfric Soc.) London, I 856 .

Kesson, J. The Cross and the Dragon. London, 1954.

KING, C. W. Early Christian Numismatics. London, 1873.

- The Gnostics and their Remains. [Crnx Ansata.] Ib., I864.

KIP, W. J. The Catacombs of Rome as illustrating the Church of the First Three Centuries. [Monograms of Christ, etc.] New York, 1854.

KipPING, H. Lib. de Cruce et cruciariis, in Exercitatt xxxv. Brem., I679.

Knox-Little, W. J. The Three Hours' Agony of Our Blessed Redeemer. Manchester, 1877.

The Mystery of the Passion of our Most Holy Redeemer. Manchester and New York, I $88 \mathrm{I}$.

Krummacher, F. W. Der Leidende Christus. Ein Passionsbuch. Bielefeld, I854. Also in English: The Suffering Saviour.

La Croix de Notre-Seigneur Fésus-Christ on Refléxions sur Fésus-Christ Crucifé. Amsterdam, 1727.

Langbein, B. A. Das Wort vom hrezeze. Sermons. 4 vols. Leipzig, 1857-1860.

Langen, Jos. Die letzten Lebenstage Fesw. Freiburg in Br., 1864.

LANGER, F. IV. The Seven Word's of Fesus upon the Cross. 1842.

LaVATER, Lud. De Crucis tolerantia. I586.

Lecrolx, P. Military and Religious Life of the Middle Ages. [Absolution Cross-Reliquary Cross-Monograms of Christ-Crown of Thorns, etc.] London, 1877 .

Leo, Magn. De Passione Domini. XIX. Serm. (In Migne's Patrologia.)

Letronne, M. “Examen archéologique de ces deux questions: I. La croix ansée Égyptienne a-t-elle été employée par les Chrétiens d'Égypte pour exprimer le monogramme du Christ? 2. Retrouve-t-on ce symbole sur des monuments antiques étrangers à l'Égypte?" $M l e-$ moires de l'Acad. des Kinscriptions et Belles-Lettres. 4to. Paris, I 846.

Lindsay, LoRD. Sketches of the History of Christian Art. 3 vols. London, 1847.

Lipsius, J. De Crzece, libri tres, ad sacram profanamque historiam atiles. Antverp., I594. Ib., I 595. Ib., I597. Ib., I 599. Ib., I606. Amstel., I670. Vesal, I675. Antverp., 1694. Lugd. Batav., 1695.

LoнE, W. The Seven Words of Fesus upon the Cross. 1859.

Lowe, J. B. The History of the Cross Practically Considered. London, 1849.

Lüвke, W. Ecclesiastical Art in Germany during the AFiddle Ages. [Crosses and Reliquaries.] Edinburgh, 1877 .

Lundy, J. P. Nonumental Christianity, or the Art and Symbolism of the Primitive Church [Jesus Christ as Sufferer]. New York, I876.

Luther, M. Feine christl. Gedanken der alten hcil. Väter und Lehrer der Kirche, dass ein Christ das Kreuz, so ihm von Gott aufgelegt ist, mit Geduld tragen solle. 1530.

- Sermonen von Kreze und Leiden.

- Predigten am Kreazer findungstage und am Kreuzerhebungstage.

M'Cheyne, Edgar R. The Philosophy of the Cross. London, 1874 .

MacGeorge, A. Flags, Some Account of their History and Uses. [Standard of Constantine, S. George's Cross, etc.] London, Glasgow, and Edinburgh, I88I.

MACKAY, A. B. The Glory of the Cross. London, 1877.

Macintrire, J. J. The Cross and the Crescent as Standards in War. London, 1854 .

Maitland, C. The Charch in the Catacombs. [Earliest Forms of the Cross.] London, i846.

Malan, C. The True Cross. Loudon, 1838, 1872.

Martiall, J. Treatise of the Crosse cuthred ovt of the Scriptures, Councelles, and auncient Fathers of the primitive Church. Antwerp, 1564 .

- A Reply to MIr. Calfhill's Blasphemous Answer against the Treatise of the Cross. Lovan., 1566. 


\section{Bibliography}

MARTYR, P. De Cruce et affictionibus perferendis. Basil., I580.

Maurus, Rabanus. De laudibus $S$. Cracis. Fol. Baden, 1503, 1607, i847.

Mclane, W. W. The Cross in the Light of To-Day. Philadelphia, 1883.

Melanchthon, Ph. Loc. de calamitatibus et de Cruce, et de reris consolationibus.

Menckenö. Diatribe de Monogrammate Christi. Lips., I 734.

MENKEN, GoTTFR. Ucber die cherne Schlange und das symbol. Verhälniss derselben zur Person und Gischichte Fe'su Christi. IS12. Bremen, 1858.

Merillus, Emundus. Nota philologica in passionem Christi. Roterod., I693.

Mermannus, A. De Veneratione ss. Reliquiartm. De Rogationibus. Lovan., I566.

Montfaucon, B. Amtiquity Explained and Represented in Sculptures. Translated by David Humphreys. [The Cross the most Common Punishment used by the Ancients, etc] 5 vols. London, 1722 .

Morris, R. Legends of the Holy Rood, Symbols of the Passion, and Cross : Poems in Old English of the Eleventh, Fourteenth, and Fifteenth Centuries. London, I871.

MUellek, H. Creutz, Buss, und Betschule, vorgestellet von David im 143 Psalm und der Gemeine Christi zu St. Maricn in Rostock in zwijährigen Bett-Stunden geïfnet. Rostock, I661, 1665, 1671, 1674. Frankf., 1668, I671, 1674, I687, and frequently since.

Muflter, L. Ueber Sterne, Krezze, und Kreise als religiöse Symbole de alten Cultervölker. Copenhagen, IS64.

Muenter, F. Sinnbilder und Kunstvorstellungen der alten Christen. Altona, I825.

Muenz, P. J. Archäol. Bemerkungen über das Kreaz, das Monogramm Christi, die Altchristlichen Symbole, das Cruifix. Frankft-a/N., I 867.

MÛ̉Ller, H. Historia passionis, crucifixionis et sepultura Domini nostri $\mathcal{F}$. Christi, notis theologico-historico-criticis illustrata. Rostoch., 1661.

Muratori, L. Ant. Diss. 2I, Di Cruce Nolana (Antiqu. Ital., tom. ii.).

Mussafia, A. Sulla leginda del legno della Croce. Vienna, 1870 .

Mystere de la Croix affligeante et consolante, mortifiante et vivifante, humiliante at triomphante, de Fésuts-Christ et de ses Membres. Par un disciple de la Croix de Jésus. 1732. Nouv. édit. Lausanne, 1791. Londres, 1859: German: Das Geheimniss des Kreuzes Fesu Christi und seiner Glieder. Leipzig, I 782.

Newton, W. A Display of Heraldry [chap. xxii., Various Forms of Crosses]. London, 1846.

Nicete, Paphlag. Orat. in exaltat. ven-Crucis. (In Combefis, Auctar. Bibl. patrum.novissim.) Par., 1672.

NicQuetus. Titulus Sancta Crucis, seu historia et mysterizm tituli Sancte Crucis. Par., 1648. Antverp., I670. Vesaliæ, 1675. Lugd. Bat., I695.

Nińusius, B. De Cruce, epistola ad Thom, Bartholinum. Colon., I647.

Nisbet, A. A System of Heraldry, Speculative and Practical: with the true Art of Blazon, according to the most approved Heralds in Europe [chap. xv., Of the Cross, and its accidental and proper Forms]. Edinburgh, I 722.

Olearius, ЈоH. Christliche Geduldschule sammt heracrquickendem Troste. Halle, i668.

O'Neili, H. Illustrations of the Most Interesting of the Sculptured Crosses of Ancient Ireland. Large fol. London, 1857.

- The Fine Arts and Civilization of Ancient Ireland. [Ancient Crosses.] London and Dublin, I 863.

Owen, E. Old Stone Crosses of the Vale of Clwyd and Neighboring Parishes. London, $\mathrm{n}$. d. 1886 .

PACIANDI, P. De veteri Christi crucifixi signo et antiquis crucibus, qua Ravenne sunt. dissert. (Gori : Symbola Literaria, tom. iii.) I 7.48 .

Paget, F. E. Tract upon Tomb-Stones. [Crosses.] London, $18+7$.

PAlmer, W. An Introduction to Early Christian Symbolism. London, 1859. Fol., 1885. 
Parker, J. H. A Glossary of Architecture [Cross, Rood, etc.]. 3 vols. Oxford, 1836, 1850. Companion vol., $18+1$.

Perrot, A. M. Collection Historique des Ordres de Chevalerie Civils et Militaires existant chez les differents perples du Monde. Paris, I 846.

Petrie, G. The Ecclesiastical Architecture of Ireland, anterior to the Anglo-Norman Invasion. [Stone Crosses.] Dublin, I845.

Pettigrew, T. J. Chronicles of the Tombs. [Ancient Saxon, Irish, and early Latin epitaphs.] London, 1857 .

Piper, F. Der Baum des Lebens. (Evangel. Kalend.) Jahrg., 1863.

Pooney, C. An Historical and Descriptive Account of the Old Stone Crosses of Somerset. London, I 877 .

Notes on the Old Crosses of Gloucestershire. London, I 868.

Prime, W. C. Holy Cross: a History of the Invention, Preservation, and Disappearance of the Wood known as the True Cross. New York and London, I877, 1886.

Proceedings of the Archeological Institute [Salisbury, Marliet Crosses, etc.] London, I85I.

Pugin, A. W. Glossary of Ecclesiastical Ornament and Costume. [Cross, Crosier, Crucifix, etc.] London, r. 4 to., 1844, I $846,1868$.

QuIRSFELD, J. Gistliches Myrrhengärtlin, versetzt mit 50 traurigen Cypressen, worunter die geängstigte Seele in allerlei Crentz und Widerwärtigkeiten mit Christo ihr tröstliches Gespräch hält. Leipzig, I696.

RAOUl-RochetTe. "De la croix ansée, on d'un signe qui lui ressemble considerée principalement dans ses rapports avec le symbole égyptien sur des monuments étrusques et asiatiques." Mémoires de l'Acad. des Inscriptions et Belles-Letires. 4to. Paris, I 846.

RAPP, ED. "Das Labarum und der Sonnencultus." In Falurbb. des Vereins von Alterthumsfreunden im Rheinlande. Bonn, I 866.

Ribadeneira, P. Flos Sanctorum. [Invention of the Cross, etc.] Fol., I665.

RICCI, BART. Triumphus Fesu Christi crucifixi, cum iconobus martyrum (anct. A. Collaert). Antverp., I6I4.

Richter, Ch. Godofr. (G. H. Zeibich). Dissertatio de signo Crucis e templis nostris eliminando. 4to. Viteb., I735.

Rimmer, Alfred. Ancient Stone Crosses of England. London, 1875.

Rock, Daniel. The Church of Our Fathers. [Pectoral, Papal, Patriarchal and Archiepiscopal Crosses, etc.] 3 vols., 8vo. London, 1849.

- Hierurgia: or, the Holy Sacrifice of the Mass. [Chap. ix., On the Cross.]. 2 vols. London, 1833 ; 1 vol., I 85 I.

Roos, FrIEdr. Kreuzschule, oder Anweisung zu einem christlichen Verhalten unter dem Leiden. Tubingen, I779; Stuttg., I857. 7th ed., I875.

RUED, J. J. Seelen-Apoteck, oder Labsal und Erquickung in allerhand Creutz und Trübsalen, Nïrnberg, I653.

Salmasivs, Ciaud. Epistola de Cruce.

- Altera Epistola ad Thom. Bartholinizm.

De Hyssop et Cruce, Tertia Epistola.

- Lugd. Bat. 1646 .

Savonarola, Hieron. Il trionfo della Croce. I497. Triumphus Crucis sive de veritate fidei, lib. iv., recens in lucem, edit. Lugd. Bat., I633.

Scheele, E. Das Kreuz F. Christi. Passions und Osterpredigten. Halle, I857.

Schlichter, Chr. Lud. De Cruce apud Fudaos, Christianos, et Gentiles signo Salutis. 4to, Halæ, 1733.

Schliemann, H. Troja, Results of the Latest Researches and Discoveries on the Site of Homer's Troy [Stanros or Cross]. New York, I884.

Schmid, J. A. De Crucis dominica per Helenam, Constantiui, matrem, inventione. Helmstad, 1714. 


\section{Bibliography}

Schroeder, E. Van dem holte dis hilligen Creuzis. (Middle Low-Germ. Poem, with Introd. Notes and Glossary). Erlang., I 869.

SCrIver, Cur. Siclenschatz, oder von der menschlichen Secle hoher Wiurde, tiefem und klïglichem Sïndenfolle, Busse nud Eruu'rung durch Christum, göttlichem heiligen Lebcn, vielfaltigem Kreuse und Trost $i m K^{2}$ rens, etc. Magdeburg, I681, I692. Magd. and Leipzig, 1737, and often since.

Scultetus, M. Warer Christen Creatz. In diesen Kümnerlichen Zeiten allen hochbetrübten und vilgeplagten Creutzträgern zu Unterricht und Trost beschrieben. Zerbst, I 592.

Shaw, 1I. Dresses and Decorations of the MIiddle Ages. [The Cross from Mt. Athos. Processional and Reliquary Crosses.] 2 vols. London, 1858.

Shuttleworti, H. C. The Last Words of Our Saviour. Oxford and London, I878.

Simeonis, Franc. Gymnasium Crucis. Greutzschule, gerichtet auf die sonntägliche Evan. gelia. Hamburg, I67o.

Smith, WM. A Dictionary of Christian Antiquitics. [Cross. Adoration of the Cross. Finding of the Cross. Sign of the Cross. Crucifix.] 2 vols. London and Boston, 1875 .

Spanheim, E. Discours sur la Croix de notre Seigneur. Genève, I655.

Spener, Ph. Gottl. Das Kreuz. (In Evangelischer Glaubenstrost aus den göttlichen Wohlthaten.) Frankfurt, I694.

Stephens, G. Qneen Dagmar's Cross. Facsimile in Gold and Colors of the Enameled Jewel. London and Cheapinghaven, 1863.

Stockbauer, J. Kzunstgeschichte des Kreuzes. Die bildi. Darstellung des Erlösungstodes Christi im Monogramm. Kreuz, u. Crucifix. Schaffhausen, 1870.

Stoeckel, Luck. Creutzschule der glüubigen Kinder Gottes. Oppenheim, I6I I.

Stokes, M. Early Christian Art in Ireland. London and New York, 1888.

STroud, WM. Treatise on the Physical Cause of the Diath of Christ. London, 1847.

The Cross-Bearer. A Vision. Boston, I86I.

Theremin, Franz. Das Krenz Christi. 4 vols. Berlin, 1828-184I.

Tilandri, Thом. Schola Crucis et Lucis in etlichen Predigten. 4to. Rostock, 16I6.

Twining, L. Symbols and Emblems of Early and Medicual Art. [Second Person of the Trinity represented by the Monogram and by the Cross.] London, 4 to, 1852 ; New ed. $8 \mathrm{vo}, \mathbf{1} 885$.

TympiUs, M. Creutz-Fähnlein. 4to. Minster, I6I9.

Typotius, JAc. Symbola Divina et Humana, Pontificum, Imperatorum, Regum [Symbola S. Crucis]. Fol. Pragæ, I60I.

Tyrwhit, R. St. Christian Art and Symbalism. London, 1872.

Variorum orationes encomiastice de inventione $S$. Crucis item de exaltatione et de adoratione $S$. Crucis. (Alexand. monarch., Georg. Hamartolos, Sophron. Flierosol., Andreas Cretens., Joseph. Thessalonicens, etc.) In Gretseri de Cruece, tom. ii. Ingolst, I6I6.

Vaughan, C. J. The Seven Words of Fesus from the Cross. London, 1875.

Lessons of the Cross and Passion, etc. London, 1886.

VAUX, J. EDward. Christ on the Cross. London, 1873.

VELDENER, J. Gescliedenis van het heylighe Cruys: or History of the Holy Cross, reproduced in facsimile from the original edition of $\mathrm{I}_{4} \mathrm{~S}_{3}$. Text and engravings by J. Ph. Berjeau. London, I863.

Vischer, Christ. Trostschrift, wie sich ein Christ in Allerlei Creutz trösten solle. Schmalkalden, I57\%.

VON BUNSEN, ERnst. Das Symbol des Krenzes bei allen Nationen, und die Entstehung des Kreuz-Symbols der Chr. Kirche. Berlin, 1876 .

Von Meyer, J. F. "Das Kreuz Christi." Blätter f. höh. Wahrheit, Bd. vii.

WaIte, A. E. The Real History of the Rosicrucians. London, 1887.

Wakeman, W. F. Handbook of Irish Antiquities, Pagan and Christian [chap. iv., Crosses, etc.]. Dublin, 1858 . 
Walch, Jo. E. Iмm. "De antiqua cruce stationali æria inaurata diss." Miscell. Lips. nov. z'ol. $i x$. Lips., 1752.

Walcott, Mackenzie E. C. Sacred Archaology. [Cross, Crucifix, etc.] London, 1868.

WalsH, R. An Essay on Ancient Coins, Medals, and Gems, as illustrating the Progress of Christianity in the Early Ages. London, 1830.

WALTHER; ANT. BALT. Furistisch-historische Betrachungen über das Leiden und Sterben Fesu Christi, etc. Bresl. and Leipzig, $173^{8}$.

Warburton, E. The Crescent and the Cross. London, 1844. New York, 1845.

WARD, II. DANA. History of the Cross: the Pagan Origin, and Idolatrous Adoption and Worship of the Image. London and Philadelphia, I87 I, 1872.

WeErth, E. Aus'm. Das Siegeskreuz der byzantinischen Kaiser Constantin VII., Porphyro. genitus $u$. Romanus 11 , etc., erläutert. Fol. Bonn, I866.

Weidner, Joh. Gläubiger Kinder Gottes Kreusschule. Augsburg, I73I.

Westcott, B. F. The Victory of the Cross. Sermons in Hereford Cathedral. London and Cambridge, 1888.

Wichelhaus, JоH. Versuch eines ausfïhrlichen Commentars zu d. Geschichte des Leidens $\mathcal{F}$. Christi nach den vier Evr. Halle, 1855.

Wildvogel, Chr. De Venerabili signo Crucis. 4to. Jenæ, I6go.

Wudrian, V. Schola Crucis, Creuzschul. Stralsund, I64I, Bremen, 1641, and often elsewhere. Also Latin : Schola Crucis et tessera Christianismi. Lüneburg, $\mathbf{1 6 6 6 .}$

Zestermann, A. CH. A. Die bildliche Darstellung des Kreuzes $u$. der Kreuzigung Christi. (Zwei Programme der Thomasschnle.) 4to. Leipz., I867, 1868.

ZOECKLER, OTTO. The Cross of Christ: Studies in the IHistory of Religion and the Inner Life of the Church. Trans. by M. J. Evans. 8 vo. London, 1877 . 
PART I. 



\section{THE CROSS}

\section{IN TRADITION, HISTORY, AND ART}

\section{CHAPTER I}

THE CROSS BEFORE THE CHRISTIAN ERA, AND IN PRE-HISTORIC TIMES

Section I.-In Africa. Section 2.-In Asia. Scetion 3.-In Europe. Section 4.-In Ameriea

" $\mathbf{T}$ HAT is now called the Christian religion has existed among the ancients, and was not absent from the beginning of the human race until Christ came in the flesh, from which time The True, i.e., the the true religion, which existed already, began to be called Christian, ReligChristian.".

These words of S. Augustine are the keynote of this chapter. Its intention is to show that among other traces of the true religion, preserved in traditions, rites, and symbols, God has handed down through all ages a prophetic type of the cardinal truth which was indissolubly connected with, and not only revealed in, the Atoning Sacrifice.

It is well known that the leading truths of the primeval religion imparted to man by his Creator, in Paradise, may be traced through the principal pagan mythologies; and that a symbol of the fundamental article of the Christian creed and hope has been recognized as sacred in the very earliest records of antiquity, acknowledged as holy by nations who lived long before the Sacrifice of Calvary, and were far removed from the "chosen people," to whom were committed " the oracles of God "; reverenced in all ages, and by nations in every stage 
of civilization from the lowest to the highest; in a word, that God nezer left Himself without a witness among men, that many "shall come from the east and from the west, from the north and from the south,

The Leading Point, "Atone- and shall sit down with Abraham and Isaac and Jacob in ment," Universal. the kingdom of God." " This fact has been almost unnoted.

And yet it is universal. In every kind of relic which time has spared, it is clearly to be read. It is graven on rocks and monoliths, painted upon the walls of temples and tombs, enamelled upon vases and sepulchral urns, stamped upon coins and medals, moulded in ornaments and amulets, used as a talisman upon the humble hearth, and traced in the plans of the dwelling-places of the Deity, whether subterranean or super-

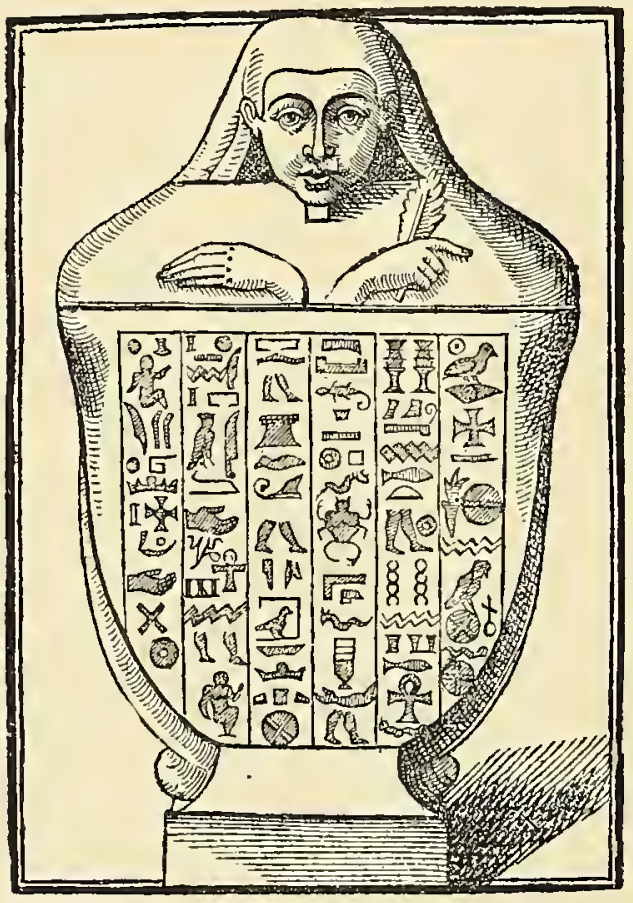

Inscription showing different forms of the Tau Cross.

From Bosio's La Trionfante e Gloriosa Croce. terrancan, whether formed in the earliest mounds and rudest caverns of the rock, or in the ornate and grand cathedrals and minsters which the piety and skill of the Middle Ages have bequeathed to our times.

Section I. In Africa.-Let us examine first the testimony of Egypt, the mother of art and of civilization, a land which Cross in Egypt traced its paternity directly to Menes or Mizraim, the son of Ham, the son of Noah. Here, unchanged for thousands of years, we find among her most sacred hieroglyphics the cross in various forms. The simplest, with four arms of equal length placed erect, + , or like an $X$; but the one known specially as the "Cross of Egypt," or the Tau cross, is shaped like the letter $\mathrm{T}$, often with a circle or ovoid above it. Yet this mystical symbol was not peculiar to this country, but was 
reverenced as "the hidden wisdom" among the Chaldeans, Phonicians, Mexicans, and every ancient people in both hemispheres.

In Egyptian hieroglyphics the cross has been variously interpreted. When with four equal arms, sometimes formed of serpents, it has been assumed to be an emblem of the four elements. When composed of two or four sceptres with a circle at the point Its Interpretation. of intersection it is said to indicate "divine potentiality." The simple cross has been interpreted as meaning " support," or "Saviour," some times " avenger," " and "protective power " "; but when the circle, the emblem of eternity, is placed upon it, forming the crux ansata, its signification, which also is implied often in the sim-

The Crux Ansata. pler forms of the cross, is "Life to come." To this interpretation the early Christian historians bear witness, and their statement has been confirmed by modern sav-

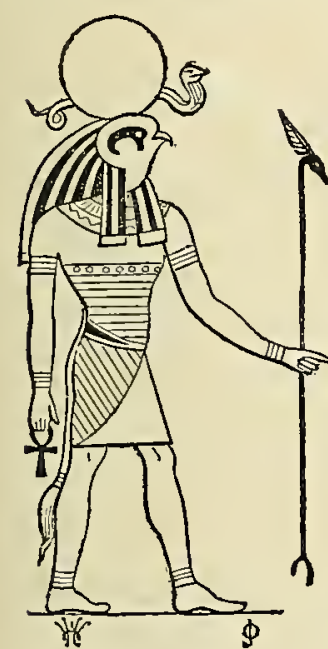

Ra.

From Haslam's The Cross and the Serpent. ants. ${ }^{3}$ The crux ansata, therefore, is the inseparable accompaniment of the chief triad of the Egyptian deities, Ra, Amon-Ra, and Amon, who are represented as holding in one hand the crook, or crosier-like staff, the symbol of power, peace, and purity, and in the other the "sacred Tau." " It is very significant that the second person, Amon-Ra, is generally represented as seated up- From Haslam's The Cross and on a throne, wearing the

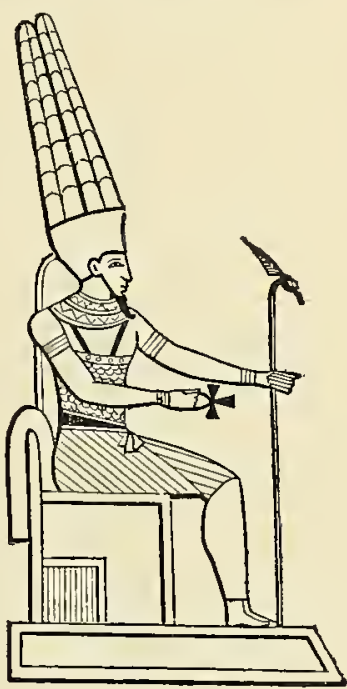

Amon-Ra. The Serpent.

Pharaoh crown, with outstretched arms offering to his worshipper the cross and the crosier, i. c., eternal life and peace. The ancient Egyptians believed that he had two

1 Champollion, Précis du Systime Hierog., tom. ii., nos. 277, 348, I9т.

2 Sup. Encyclop. Brit., vol. iv., p. 66, no. I08.

${ }^{3}$ Rufinus, lib. ii., cap. 39 ; Sozomen, lib. iii., cap. I5, etc. ; Young, Recent Discoveries in Hieroglyphics, P. I56; Champollion; Précis, etc., 277 ; Layard, Nineveh, vol. ii., p. 213. For another interpretation, considering the circle as the apple, see infra note, p. 8.

${ }^{4}$ Wilkinson, Ancient Egyptians, vol. ii., p. 283 . 
natures, divine and human, that he was their defender against evil, and also the inspirer of counsel and wisdom. Nor is the crux ansata con-

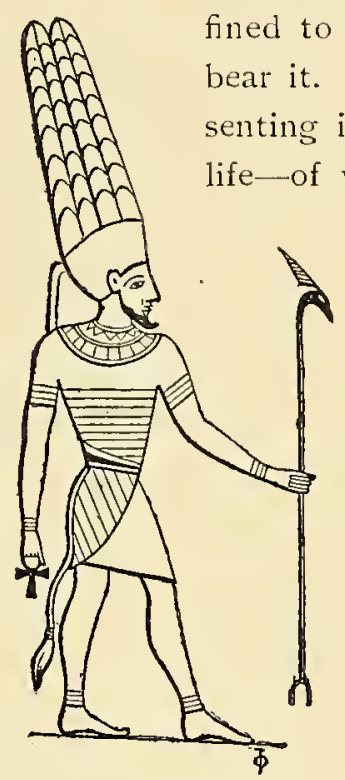

Amon.

From Haslam's The Cross and the Serpent.

The crux ansata is placed, to indicate the everliving spirit, on tombs and sarcophagi. Sometimes it is in the talons of a conventional figure, representing the soul, bearing a human head and the body of a bird, hovering over, and protecting the body of the departed. The deities are frequently depicted holding the sacred Tau in their mouths, ${ }^{1}$ or presenting or receiving it from the lips of a dying man, ${ }^{2}$ who is often lying on a lionshaped couch. ${ }^{3}$

A most decisive proof of the meaning attached to this hierogram was given at the destruction of the Serapeum at Alexandria, the shrine of the gigantic emerald, or glass, statue of Serapis, the god of healing, which crux Ansata in had been brought, by the Temple of Serapis. order of Ptolemy Soter, from Sinope on the southern shore of the Black Sea (B.C. 293), and reerected within the labyrinth on the banks of Lake Moeris. Upon this idol, and upon the walls of the temple, was engraved the crux ansata. Theodosius destroyed it (A.D. 389), despite the earnest prayers of the Egyptian priests for its preservation, because it was the

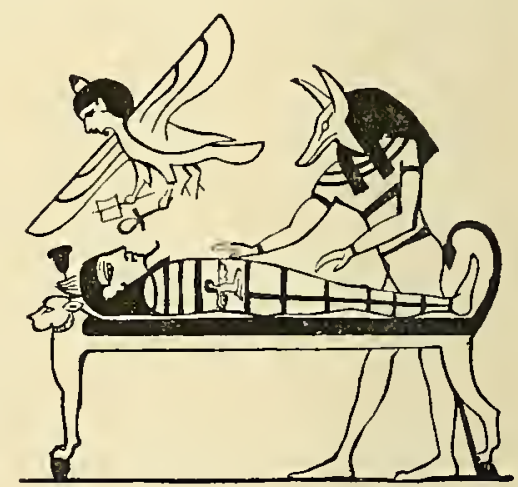

Soul, bearing a Crux Ansata, returning to the body.

${ }^{1}$ As a passport for the soul. That the soul was exhaled from the mouth of the dying, is a superstition retained from the time of the ancients to the present day. It was believed among the common people in the last century that the soul could be seen, in semblance of a light-blue smoke, passing from the lips. Hogarth, it will be remembered, in his last painting, represents Time prone on his back exhaling a puff of breath that curls from his mouth bearing the word Finis.

? Sir R. Ker Porter, Trazels, vol, ii., p. 45.

${ }^{3}$ Sharpe, Vocabulary of Egyptian Hierogliphs, no. $\$_{33}$. 
symbol of their god, and of "Life to come." Some Christians who understood the Egyptian hieroglyphics confirmed the interpretation, and this, together with a tradition that when this figure of the cross should appear their religion would come to an end, induced many of the pagans to embrace Christianity.' Not only the priests, who were intelligent, were converted, but we are told that from every house the bust of Serapis was removed and the cross substituted. ${ }^{2}$

The Christians not only accepted the crux ansata as the symbol of their faith, but used it and the Tau in place of the Latin and Greek crosses in their churches and elsewhere. Besides, in a Christian inscription at Phile may be seen both the Maltese $\begin{gathered}\text { The Crux Ansata } \\ \text { Adopted by }\end{gathered}$ and Egyptian crosses. In the church of the cemetery of Christıans. El-Khargeh in the Great Oasis are other examples. ${ }^{3}$ Even in the desert to the east of the Nile is a church with the following inscription:

\section{KAOOศAIKH+EKKAH\&CIA.}

At Edfou also, the cross is painted upon the walls, with an inscription, perhaps, of later date, "The Cross of the Christians." "

As among many other nations, the cross was worn as an amulet by the Egyptians. Sometimes the chief ornament of the necklace was a little image of Amon-Ra with a Tau cross upon the back; sometimes the emblem was tattooed or painted upon the arms and thighs, as represented in the paintings found by

Cross Worn apparently as an Amulet. Belzoni in the tombs of Thebes.

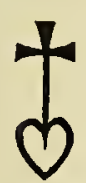

A significant symbol is the long cross surmounting a heart. It means " good," or " goodness." Upon the front of many of the houses in Thebes and Memphis it is depicted, intimating, "This is the abode of the

\section{Cross Surmount-} ing a Heart. Cross upon good." Pharisaism, it seems, existed long before the advent
Heart. of Him whose type we are considering.

1 Socrates, Hist. Eccles., lib. v., cap. I7 ; Sozomen, lib. viii., cap. I6 ; Rufinus, lib. ii., cap. 29.

2 Fleury, Eccles. Hist., xix., 29.

${ }^{3}$ S. Baring-Gould, Curious Nyths of the Middle Ages, vol. ii., p. 93 ; Hoskin, lisit to the Great Oasis, plate xii. See Wilkinson's Ancient Egyptians, vol. ii., pp, 283-284, for use of Tau cross in Christian monuments.

4 Bradford, Amcrican Antiquities, p. 392. 
The sacred bulls and reptiles were fed upon a cake composed of flour, honey, and milk, or oil. All symbolical materials, upon which was imCross on Cake. pressed a cross pattéc; and on the higher festivals the priests and worshippers partook of it." This crossed cake was the hieroglyph for " civilized land," but in that rude character there was a deeper mystical reference to Paradise. ${ }^{2}$

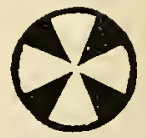

Cross on Cake. From Haslam's The Cross and

The invention of the astronomical signs is generally the Serpent. attributed to Egypt, but those used by the ancient Greeks, BabylonAstronomical ians, Druids, the natives of India and of America, so closely Signs. resemble them that they indicate a common origin. Five of these characters are plainly composed of the circle, or parts of it, and the cross:

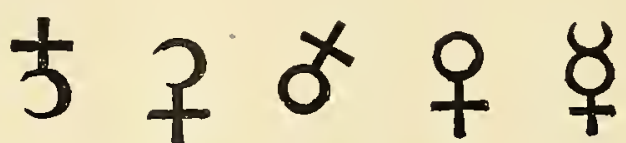

Egyptian Symbols for the Five Planets. From Haslam's The Cross and the Serpent.

while that of the earth, the circle filled with the cross, is significant. In these hieratic monograms the position of the cross varies, sometimes being placed above, at others below or at the side of the disc, hence it has been supposed that the position not only " distinguished one sphere from another, but also indicated the degree of happiness in each." s The signs of Jupiter, Venus, and Mercury are sometimes placed in the hands of the corresponding Egyptian deities, Ra, or Osiris, Isis, and Hermes. The monogram of the last is a variation of the caduceus or mystic wand of Mercury, and, according to Kircher, was originally the sacred Tau, to which was added the cross and crescent, modified afterwards by Thoth, the Egyptian Mercury, into serpents and wings, sym-

1 An evident type of the Eucharist. Similar types were found in Asia and in America, both on the North and South continents. See ch. ii.

The tradition of the four rivers of Paradise flowing towards the cardinal points, thus dividing the land cruciformly has been handed down in many mythologies. In the Sinéru of the Buddhist, grows the four-limbed Damba-tree, or tree of life, and from its roots gush forth four sacred streams northward, southward, eastward, and westward; from the four sides of the golden Mount Meru in the Slävratta, or "celestial earth" of the Hiudoo, proceed the four primeval rivers. The Tien-C"han, or "celestial mountain land" of the Chinese and Tartars, is divided by the four overflowing streams of Tychin, or Immortality, and through Asgard, the abode of happiness of the Scandinavians, flowed four rivers of milk.

${ }^{3}$ Edinburgh Rev., vol. cxxxi., p. 23 S. 
bolizing the power of the cross over the devil." Hence $\not$, called the Tautic emblem, ${ }^{2}$ is the sign of power, and Mercury always bears the caduceus when conducting a soul to Hades, for by its touch the god could release the spirit of the dying or recall the dead to life; like the cross, also, it had power over enmity. By its influence, enemies found their hatred changed to love.

How to account for the peculiar shape of the crux ansata passes our power. Its universality-it is found in every quarter of the earthattests the reverence in which it was held by the primeval nations, but as Baring-Gould confesses, " no one knows,

Crux Ansata. and probably no one ever will know, what originated this sign and gave it such significance." ' It has been suggested that the $T$ represents a table or an altar, and the ovoid symbolizes a vase, ${ }^{4}$ or an egg ${ }^{5}$ upon that altar, others suppose it to be a mere handle, because it is often so used, but not always. On a Babylonian cylinder the god holds the sacred emblem by the long arm, whilst a priest offers him a gazelle. ${ }^{6}$ On a stele from Khorsabad the two parts are disjoined, - an eagle-headed man holds the circle in his right and the Tau in his left hand. " This was affixed to the end of the pole of a war chariot, doubtless as a talisman.

An able writer suggests that in the first instance the crux ansata was intended to denote the solar and terrestrial spheres respectively, and, subsequently, when princes and conquerors had conceived the exalted idea of ruling by divine right, or of pretending a divine origin, each

${ }^{1}$ Kircher, Hierog., lib. iv., 20, quoted in Deane's Serpent Worship, p. 133. "The caduceus in its present form represents a modification of the universal Ophite hierogram, emblematic of the Trinity; the circle for light, the serpents for wisdom, and the wings for life; signs corresponding to the title Trismegistus, or thrice great Hermes." Haslam, Cross and Serpent, p. 173 .

${ }^{2}$ The monogram of the Egyptian Tau is formed of three Tans thus, $\vdash^{\top} \dashv$, similar to the Masonic jewel of the Royal Arch. Maurice, Indian Antiquities, vol. vi., p. 68. Three Taus also compose the symbol of the Scandinavian Teutates.

${ }^{3}$ Curious Myths, vol. ii., p. 94.

+ Ungarelli, Interpretat. Obeliscorum Urbis, p. 5.

${ }^{5}$ Dognée, Les Symboles Antiques-L' Euf. The " Mundane egg" is often represented with a horizontal line passing through the middle dividing it into two cones. The space ontside and around the figure symbolizes heaven, boundless as is the universe; "the space within the upper cone, above the line which represents the earth's surface was the rot $0_{0}$ or coelus, the hollow vault, "the fertile womb of all teeming nature' . . . and the space below the line and within the lower cone was the region of fire, the abode of the mysterious spirits." Haslam, Cross and Serpent, p. 72 .

${ }^{6}$ Curious Myths, vol. ii., p. 96.

'Botta, Mon. de Ninive, vol. ii., pl. I58. 
adopted the circle, and, associating with it the equally expressive cross, the two conjoined thus became emblematical of dominion; and this symbol of royalty has been perpetuated to our day by every Christian potentate in Europe, whose coronation orb surmounted by a pectoral cross is nothing more than the embodiment of the crur. ansata. ${ }^{2}$

Kircher mentions a curious tradition that Thoth received the sign from which he formed the crux ansata from the patriarchs. "It was Tradition of its Transmission from Angeis. received by Moses from Shem, who received it from Noah, who received it from Enoch, who received it from Seth, who received it from Adam, who received it from the angel Raziel," who gave it to our first father as a talisman of great power against demons, etc. (Abenepli)."

McCulloch, quoting the above, inquires: "Who is 'Abeneph'? If a Jew or a Mahometan, and his name would give color to that opinion, then his testimony would be of great value as to the mysterious signification of the cross in very ancient times. It is not likely that a follower of Judaism, or Islam, would invent a tradition honoring a Christian symbol.",

From Egypt the reverence for the cross doubtless spread throughout the other parts of Africa, but, owing to the low state of civilization, we must not look for monumental evidence, but to traditionary usages preserved to the present day, for traces of the ancient use of the hierogram. Nor do we look in vain; although the degraded people have forgotten the meaning of the symbol, yet they have religiously preserved it because it has been transmitted from their ancestors.

1 Edinburgh Rev., vol. cxxxi., p. 232. For obvious reasons the phallic theory is not discussed. Sir Gardner Willinson declares that there is no gromnd in its favor ; true the Egyptian word signifying " life" bears a resemblance to the Yoni 1 ingam of the Hindoos, but in Egypt the Tau was the symbol of purity, the greatest gift of God to man. Ancient Esyptians, vol. ii., p. 283. S. Baring-Gould pronounces the theory "Monstrous and devoid of evidencc." Curious Myths, vol. ii., p. 93 and App. A. On the Rosetta stone it is used to translate the title $\alpha i \omega v^{\prime} \beta \imath o s$ given to Ptolemy Epiphanins. Ibid., p. 92. For the contrary opinion consult Cox, Aryan Mythology, App. C. Nor is the Tau the Nile key; that is of a different shape, and Nilus is of all the gods the least often represented with it in his hand.-Wilkinson, vol. iv., p. $34 \mathrm{r}$,

${ }^{2}$ Raziel, according to the Rabbins, was the angel who instructed Adam in the Cabbala, or oral law, or traditions of the Jews. S. Baring-Gould says, it was related by the Arabian Philosopher, Ibn-ephi, that the circle signifies the apple, and thus the Carthusian emblem which bears the motto, "Stat crux dum volvitur or bis" is in reality the mystic symbol of Adam-a mound and cross - the crux ansata or life out of death. - Legends of the Old Testament, p. 54.

' Michulloch, Researches among the American Aborigines, p. 335. 
At Susa, in Abyssinia, among other religious rites, the natives plunge a cross in the River Gitche. This is the custom among all the Galla tribes, but for which they can assign no other reason than that it had been handed down from their forefathers.'

The Kabyle women, although Mlohammedans, tattoo a cross between their eyes. No devout Arab, although professing the same faith, will marry one of them until the sign is obliterated by a corrosive liquid. ${ }^{2}$

In Wanyamwizi, or the Land of the Moon, the inhabitants decorate their walls with crosses and serpent-like ornamentations painted with ashes and red and black clay. The Moslem companions of Burton declared them to be idolatrous, but the natives asAfrica. serted that they paid them no worship, yet were unable to tell the origin of the custom. ${ }^{3}$

"At a period far remote, before the foundations of Carthage were laid, a Berber nation, now called the Yuaricks, overspread the desert, and conquered the oases and mines. This terrible people are yct the scourge of the peaceful farmer and the passing caravan. They camp in leather tents; they are armed with lance and sword, and with shields, on which is painted the image of a cross. . . . They established a line of kingdoms from the Niger to the Nile, in the border land between the Sahara and the parallel $10^{\circ}$ N. Timbuctoo, Haoussa, Bornow, Baghirmi, Waday, Dorfur, and Kordofan were the names of these kingdoms; in all of them Islam is now the religion of the state." "

Section 2. In Asia.-Leaving Africa, and proceeding to Asia, we find, in India, the cross bearing the same meaning as in Egypt. When with four equal arms it signifies the four elements, which the Hindoos consider as eternal, and the component parts of all things. The gods, the soul of man, and the life of animated nature they suppose to be generated from them. Hence their doctrine that nothing will be annihilated, but only changed-souls by transmigration, matter by transmutation; and therefore Siva, the Destroyer, also the Preserver, the deity who presides over the elements, is represented

1 Harris, Highlands of Ethiopia, vol. iii., p. 79.

2Perry, Carthage and Tumis, p. 274. There is a tradition in this tribe that when r 200 years have passed since the flight of Nahomet the religion of Side Aissa (Jesus Christ) will be restored.-C. E. Oakley at British Soc. Evang. of the East, April, i 864.

${ }^{3}$ R. F. Burton, Lake Region of Central A frica, pp. 222, 297.

4 Winwood Reade, Martyritom of Man, p. $2 S_{5}$. 
with a cross upon his breast. The cross is also found in the hands of Siva, Brahma, Vishnu, and Tvashtri. IVhen with a wheel in the centre

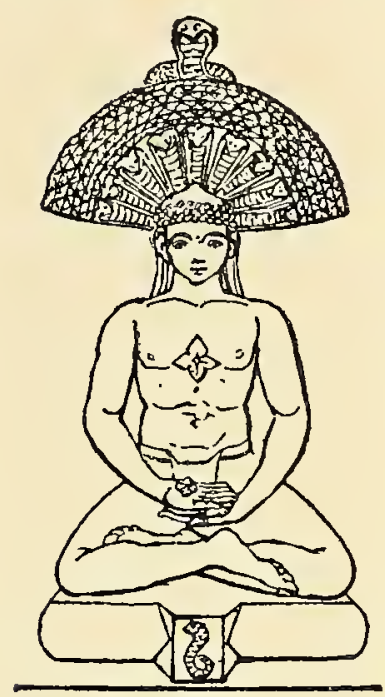

Buddha, with Cross on breast and hands.

From Lundy's Domumental Christianity. it is called Kiakra, or Tschakra, "and is said to be the oldest ensign of majesty in India." " When held by Vishnu, the world-sustaining principle, it signifies his power to penetrate heaven and earth and bring to naught the powers of evil. It symbolizes his eternal and ever-vigilant government of the world. Hence, probably, its use as a sceptre by the ancient kings of India.

An Indian painting represents Brahma " crowned with clouds, with lilies for eyes, with four hands; one holding the necklace of creaIndia Acknow- tion, another the Veda, a third ledging the Cross. the chalice of life, the fourth the fiery cross. Another painting represents Krishna in the centre of the world as its sustaining principle, with six arms, three of which hold the cross, one holds a sceptre of dominion, another a flute, a third a sword. Another gives Jama, the judge of the nether world, with spear, sword, scales, torch, and cross. Another gives Brawani, the female earth principle, holding a lily, a flame, a sword, and a cross."

To this day, in Northern India, the cross is used to mark the jars of

Cross now in sacred water taken from the Indus and Ganges, as in the North India. northeastern parts of Africa the women impress this sign as a mark of possession upon their vessels of grain, etc.

In South India.

In Southern India the cross is used as an emblem of disembodied Jaina saints.

The worshippers of Brahma and Buddha outnumber ${ }^{3}$ those of Christ;

More Followers and the symbol, identified as that of our Master, was of Brahma than revered by the East Indians-their Lao Tse, centuries of Christ.

before our Lord appeared upon earth.

1 Edin. Rev., vol. cxxxi., p. 232.

${ }^{2}$ Müller, Glauben, Wissen, und Kunst, der Alten Hindus, Tab. i., fig. 2 ; Tab. i., fig. 78 ; Tab. ii, fig. 6I ; Tab. ii., fig. I 4 o. Quoted in Gould's Curious Myths of the Middle Ages, vol. ii., p. IIo.

${ }^{3}$ Berghaus, in his Phy'sical Atlas, places the Buddhists and Brahmins at 44.6 per cent. of the human race, while Christians are 30.7. Max Müller, Chips from a German Workshop, vol. i., p. 214. 
Frequently we mect in India with a peculiar form of the cross, which in its universality and interest yields only to the Tau of Egypt. More than three thousand years ago was the strange cruciform symbol, known as the Fylfot cross, reverenced in India.' It is a sacred symbol in the tombs of Egypt and in the catacombs of Rome. It is graven on the temples of the pre-historic nations of both the Eastern and Western Hemispheres. The heraldry of the Middle Ages blazoned it on their shields. To-day it is used as a mystic symbol
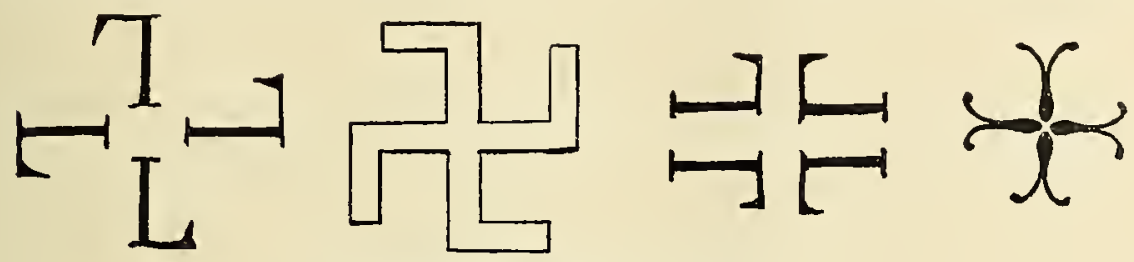

Different forms of the Fylfot Cross.

From Lee's Glossary of Liturgical Terms.

among the secret societies who ape the form, but have lost the soul, which animated the brotherhoods of those ages, now known, in the spirit of sarcasm, as dark. Modern heralds term it gammodion, and crux gammata, considering it as composed of a fourfold repetition of the Greek gamma. Edmondson defines it as the cross potent rebated, or cross componic. The Buddhists call it the Sawastilia, or, in the Pali form, Suti, meaning, "It is well " or " So be it," and it is the symbol of resignation. The Jainas consider it the emblem of the seventh deified teacher of the present era, Supraswa, or Suparswaneth. Its use extended from the earliest day to the present. It is found on early Hindoo coins and seals, and is used to-day by the women as a charm against evil.

Among the most ancient, interesting, and valuable relics, from our point of view, are two rude crosses of stone recently discovered in Central India, just within the Vindhyazone, in a region which must at some remote period have been cultivated, for there cros:es in 1ndia. are remains of terraces and walls; but for many miles the country, for centuries and centuries, has been uninhabited and overgrown with dense forests. The population was driven away " not improbably three thou-

${ }^{1}$ Mowe, Hindoo Pantheon, pl. ii., figs. $7 \mathrm{I}, 72,8_{4}$. The last page is apparently the ground plan of a temple in the shape of a Fylfot. 
sand years before the advent of our Saviour." They are monoliths resembling the Cornish crosses (especially that of St. Buryan), the one about ten feet nine inches and the smaller, eight feet six inches above ground, and are similar to others near Rajunkolloor in the Deccan, and are probably the work of the same people. "Here, then, amongst these now fragmentary peoples, from the débris of a widely spread primeval race, we find the symbol of the cross, not only expressing the same mystery as in all other parts of the world, but its erection, doubtless, dating from one of the very earliest migrations of our species. It is $\mathrm{im}$ possible to adduce any clcarer or stronger proof of its antiquity than this." "

The glory of the East is her temples, and the plan of many of these exhibits her faith in the saving symbol. Tavernier describes the magCruciform nificent pagoda of Bindh Madhu at Benares. The body of Temples. the edifice was an immense cross, with a lofty dome in the centre, above which a pyramidal structure arose to a great height. At each extremity of the cross was likewise a pyramid, so that the form of the cross was visible at a vast distance. Tavernier visited this in the end of the seventeenth century, not many years before it was destroyed by Aurungzebe, who afterwards built a mosque on its site. ${ }^{2}$ Temples. of a similar form are found at Mahratta, on the Jumna, and elsewhere. Even when the buildings are rectangular, their pyramidal towers are placed crosswise.

At the temple of Chillambrum on the Coromandel coast, there are seven lofty walls, one within another, round the quadrangle, and as many pyramidal gateways in the middle of each side, which form the limbs of a vast cross, consisting of twenty-eight pyramids, extending more than a mile in one continuous line. ${ }^{3}$

The cave temples are even more wonderful than the superterraneous structures, and are perhaps older." Among the most celebrated is that called Elephanta by the Europeans, Gharipuri by the
natives. It is situated on a small island in the harbor of Bombay. The cave is nearly in the form of a Greek cross, its dimen-

${ }^{1}$ Edin, Rev, vol. cxxxi., p. 253.

2 Tavernier, Foyages, tom. iv., p. I49; Maurice, Indian Antiq., vol. iii., p. 47.

${ }^{3}$ Haslam, Cross and Serpent, p. Ioo.

${ }^{4}$ The Brahmins say they are six thousand years o]d. Talboy's Oxford Tables of Chronology places them two thousand B.C. Fergusson thinks they may have been constructed since theChristian era. At all events the religion of which they are symbols antedates Christianity. 
sions being longitudinally one hundred and thirty-three feet, transversely one hundred and twenty-three, height about seventeen feet. At the extremity is the Hindoo triad; the crux ansata is conspicuously placed in one arm, and the walls are covered with gigantic figures, in low relicf, allusive to Siva. Bishop Heber considered this temple specially dedicated to that god in his character as Supporter or Destroyer.' Similar cave temples are found at Salsette and Ellora.

Java received her civilization and art directly from India. Her temples may date since the Christian era, but her religion,-in a part of the island,-Buddhism, was antecedent. Of the Chándi Sewu, or thousand temples, Sir Stamford Raffles writes: Cross in Java. "In the whole course of my life I have never met with such stupendous and finished specimens of human labor and of the science and taste of ages long since forgot, crowded together in so small a compass as in this little spot, which, to use a military phrase, I deem to have been the head-quarters of Hinduism in Java." Of course the sacred symbol is prominent. The Chándi Sewu is a vast parallelogram of two hundred and ninety-six small temples with pyramidal roofs composed of five or six steps, of which the lower three are in the figure of a cross. ${ }^{2}$ The ground plan of the larger temples, as the Chándi Loro, Jongrang, and the Chándi Káli Bening, are cruciform. In the vicinity of the temples are found small silver coins bearing the impression of a cross and of some unintelligible characters.

We follow Buddhism and its kindred religion into China. Here the Lao-tseu, as the cross is called, is acknowledged to be one of the most ancient devices, known long anterior to the Sakya-Buddlia era, long before the expiatory Cross was erected upon

Cross in China. Calvary. It is portrayed upon the walls of their pagodas, it is painted upon the lanterns used to illuminate the most sacred recesses of their temples. It symbolizes heaven. Also, as in Africa and in other parts of Asia, the pottery of China often bears the Fylfot, probably with the same secondary meaning employed by the people, the sacred right of possession. ${ }^{3}$

${ }^{1}$ Dudley, Naology, p. 333 ; Asiatic Researches, vol. iv., no. $3 \mathrm{I}$.

${ }^{2}$ Raffles, Hist. of Faza, vol. ii., pp. I5-IS, 65.

${ }^{3}$ It has been said that an iron cross bearing a date corresponding to A.D. 239, was found in the province of Kiang-see. Kesson, Cross and Dragon, p. 1o. If so, it may have been a Christian relic, presuming the tradition to he true that $S$. Thomas preached the gospel in China; 
From China we pass to Japan, and find the Fylfot cross the distinctive badge of the ancient sect of Xaca Japonicus, or first 'Cross in Japan. reforming Buddaka. The divinity, now worshipped as supreme, wears the Fylfot on his breast.'

This curious symbol (the Fylfot) seems a bond among nations of a certain zone. In Thibet it has pre-eminence among the royal regalia, on Cross in Thibet the crowns and sceptres of the Bonpa deities, whose and Tartary. theology claims to be the most ancient of all others. The gommodion is graven on the Artec, or musical bell, borne by Balgovind, the herald of peace.

Among the Tartars, the name of both priest and deity, Lama, signifies a cross, and the symbol is used in their worship. ${ }^{2}$

Even in the extreme bounds of Asia, in Kamchatka, Humboldt

but there is a gennine relic, which, although of late date, it may not be out of place to notice here. In 1625 , in digging a foundation in the city of See-gan-foo, capital of the province of Shen-se, a monument was discovered on which was sculptured a cross resembling that npon the traditionary tomb of $\mathrm{S}$. Thomas at Maliapore. The termination of the arms resembling the cross bottone, its base is surrounded with clonds. The inscription gives the date of its erection, recording the name of the bishop, emperor, etc. "In the margin is written in Syriac: "In the days of the Father of Fathers, Mar Ananjesus, the Patriarch.' Below are these words, also in Syriac: 'In the Greek year Iog2, Mar Jezedbuzd, a Presbyter and Chorepiscopus of the royal city of Chumdan, the son of Millesius of happy memory, a Presbyter of Balkh in Tochuristan, erected this tablet of stone, in which are described the precepts of our Savion r, and the preaching of our fathers to the Emperor of the Chinese.' These notices fix the date of the monument to A.D. $78 \mathrm{I}$. The Patriarch Ananjesus died about 778 , but it is highly probable that the intelligence of his death had not yet reached the far-distant regions of China." Layard, Nineveh, vol. i., p. 206, Am. ed. The inscription further contains a profession of Christian faith, an exposition of Church ceremonies and observances, according to the Nestorians, and a general description of the introduction and progress of Christianity in the empire. Then follows a list of missionaries since A.D. 636. The names are in Syrian, Persian (or Pehlevi,) and Chinese. Voltaire and others have sneered at the genuineness of this interesting monument, but Milman in his note to Gibbon's Decline and Fall, chap. xivii., cites the evidence of its anthenticity. A full translation of the inscription is given in Kesson's Cross and Dragon, chap. ii. ; see also Layard as above.

'Edin. Rev., vol. cxxxi., p. 23 S.

2Cardinal IViseman, Science and Revealed Religion, vol. ii., p. 256; Voyage de la Chine, par Avril, p. I9f. The cross was S. Andrew's or the Saltire. Higgins says it represents perfection, indicated by the fingers of both hands. The Mexicans nsed the same character in their secular calendars. The Tartars derive the word Lama from the Scythian lamh, a hand. The Irish luam means a head of a church, an obbol, etc. Higgins, Celtic Druids, p. 312 ; Bradford, Am. Antiq., 392. The double pyramid, or hand, of the Egyptians, signifying fire and water, formed of two triangles 8 was the famous Hexalpha, or Solomon's seal, or Wizard's Foot. According to Eastern allegory, it was placed (as that of S. Michael) upon the rebelious spirits in their abyss or prison. Hargrave Jennings, The Rosicrucians, p. I66. The original meaning of décussés was the number ten, the Roman numerical sign for which, $\mathrm{X}$, is made of two Vs joined. See Sir Thomas Browne's Garden of Cy'rus. 
found the cross and rude remains of hicroglyphics, similar to those of Egypt, but, unfortunately, to the degenerated natives, the mystic signs, though revered because lianded down from their forefathers, were as dead letters, ${ }^{3}$ all tradition even of their origin having been lost.

Returning southward, Persia is still more satisfactory. The cross is noted among the sacred symbols, and appears conspicuously upon an ancient tomb to which homage is still paid, as that of the prophet Daniel. It is at Susa, known in the days of the captivity as Shushan. Sir Robert Ker Porter describes it as of green granite, one side covered with hieroglyphic Tomb of Daniel. figures in low relief. The first now contains the sun, moon, and a star; the second, animals, hare, dog, etc.; the third, a figure with the head and lower extremities of a tiger, the arms of a man, and the tail of a goat. Three symbolic figures separate this monster from another, also half-man, half-brute, holding a staff; the fourth now presents an antelope, a serpent, and a scorpion; the fifth, a trident, two birds, and a cross with four equal arms. ${ }^{2}$

The gems and "stones wrought by man's device," also bear invaluable testimony. Dr. King records an intaglio, the bust of a Persian, upon a sard. "In the field of the design was engraved a Cross in Antique ram's head, a double cross, precisely as on the coins of Sala- Gems. mis in Cyprus, thus indubitably marking the portrait as that of a Persian satrap of that island, at some period before the age of Alexander (died B.C. 323), after whose time the Persian dominion over the Greek islands had entirely ceased. ${ }^{3}$

The treasures of art and religion in Assyria have lately been opened to us. The cross is everywhere dominant. In the early Christian centuries, Europe adopted the custom of prefixing the sign of the cross to signatures and inscriptions of a specially sacred Cross in Assyria. nature; but the reverential practice had been anticipated thousands of

'Haslam, Cross and Serpent, p. IOI.

${ }^{2}$ Porter, Trazels in Georgia, Persia, and Armenia, vol. ii., p. 4I3. This traveller gives the same interpretation as later archæologists. "The cross indeed (in wonderful coincidence) is generally understood to be symbolical of the divinity, or eternal life." Vol. ii., p. +15 . Prideaux refers to the tradition of Daniel's death and monument at Susa "even to this day." Connections, pt. i., b. iii. The Persians adored the sun, the moon, and the elements. Hence the cross. Merodotus, quoted by Layard, vol. ii., p. 335. See also Layard, Croix Ansée, pp. 25-32.

${ }^{3}$ C. IV. King, Antique Gems, p. I 46. 
years before, for Layard tells us that when the cruciform characters are Cross before the placed crosswise before a word, "there is every reason to Name of a believe that they precede the name of a divinity." ,
Divinity.

The sculptures of Khorsabad and the ivories from Nimroud exhibit nearly every variety of the cross. The cross pattc is supposed primarily to have typified the elysium of the four great gods of the Assyrians,--Ra and the first triad, Ana, Belus, and Hea; when inserted in a roundlet, it is emblematic of Sansi, or the sun, dominat-

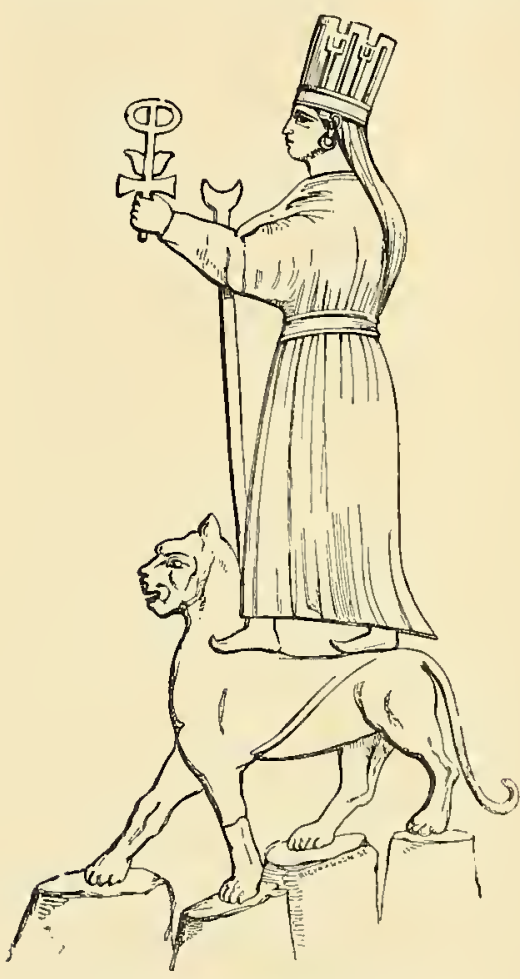

Hera, or the Assyrian Venus.

From Layard's Nineveh. ing the earth as well as the heavens. ${ }^{2}$ It certainly appears to have been used as the symbol of government, or royalty, and part of the paraphernalia in regal religious ceremonies, for it is figured on the breast, or placed in the hands of the monarchs on the Assyrian marbles now in the British Museum. A large cross pattéc thus ornaments the breast of Tiglath Pileser in a tablet from Nimroud. Another king from Nineveh bears a Maltese cross, and another, from the hall of Nisroch, wears an emblematical necklace consisting of the sun surrounded by a circle, the moon, a Maltese cross within a circle, a three-horned cap, and a symbol like two horns.

The Assyrian Venus, Hera, also bears in her hand the crux ansata. ${ }^{3}$

The frequency of the cross graven upon the cylinders, or seals, should be noticed. Many of these are found among the ruins in Assyria, verifying the assertion of Herodotus that every man carcross on Signet. ried a signet of his own. These cylinders are from one

${ }^{1}$ Layard, Nineveh, vol. ii, p. 153. See infra, part iii., chap. ix., sec. 8 .

${ }^{2}$ Edinb. Rev., vol. cxxxi., p. 237. This writer thinks " that the multiplication of small dots, minor orbs, and other adjuncts about the end of the arms, and in the angles of intersection, are undoubtedly emblematic of celestial as well as terrestrial sovereignty, denoting the number of superior deities, and their peculiar attributes."

${ }^{3}$ Layard, Nineveh, vol, ii., p. 346. 
to two inches in length, and about half these dimensions in thickness, perforated lengthwise, and worn like a bracelet on the wrist. When signets are mentioned in the early part of the Old Testament, they are spoken of as worn on the hand, rarely, if ever, upon the finger. Hence most of them must have been of this type, although rings of very ancient date have been found.' Pharaol took off his signet ring from his hand to bestow it upon Joseph (Gen. xli., 42). The Amalekite brought unto David the crown and bracelet, i. $\iota$., the signet of Saul (2 Sam. i., Io). The Lord declared of Coniah, "Though he wore the signet upon my right hand," etc. (Jer. xxii., 24) ; and of Zorobabel, "Even he was as a signet on the right hand" (Ecclesiasticus xlix., I I). The impression of the seal was taken by rolling it over a lump of tempered clay. Hence the comparison used by the Almighty to Job, the heavens are "turned as clay to the seal " (Job xxxviii., I4).

Layard divides the cylinders into four classes: the early and lower Assyrian, the purely Babylonian, and the Persian. The first class ends with Shalmaneser in the eighth century B.C. ${ }^{2}$ Among examples of this class, given by King, we find the crux Division of Seals. ansata. Among the next class is an instance of a woman holding a Tau cross, apparently in the act of worship to the moon, Astarte, one of whose symbols, it will be remembered, was the cross. Upon a cylinder in the Paris Cabinet of Antiquities, published by Münter, are four figures, the first winged, the second armed with thunderbolts. Beside the latter is the crux ansata, with a hawk perched on the oval handle. The cross here is not a subordinate figure, but half the height of the deity. The other figures are those of a woman and child. In the same collection are other cylinders bearing the sacred symbol. Upon one, a monarch, or deity, is seated, on either side is the crux ansata, behind the throned figure a servant holds up a cross, and still behind him is a Maltese cross. Upon another specimen a god is represented extending the cross to a priest, who offers him a gazelle. ${ }^{3}$ These cylinders were disused after the Macedonian conquest."

1 The signet ring of Cheops is preserved in the Abbott Collection of Egyptian Antiquities, in the Historical Society, New York.

${ }^{2}$ A cylinder was discovered at Konyunjik, supposed by Layard possibly to be the signet ring of Sennacherib, eighth century, B. C. The King is worshipping before the sacred oak. Above is the emblematic representation of the divine presence in the form of a winged cross passing through a circle (the emblem of eternity), surmounted by three heads, the symbol of a triune god. Lysons, Our British Ancestors, p. 220. See also King's Antique Gems, pp. 129r32. $\quad{ }^{3}$ Gould, Curious Nyths, vol, ii, , p. 95. $\quad{ }^{4}$ King, Antique Gems, p. I30. 
Although worn among the ornaments, even by the women in their earrings, yet, probably, the cross was held sacred as an amulet, for the

Cross as an Amulet or Ornament. captives were not deprived of it. Usually it is pendant from a necklace, or attached to the collar of the dress, as was customary among the Shari, an Assyrian tribe, and also among the Rot-n-no, supposed to be Lydians, and likewise among the Rebo, a Northern Asiatic tribe resembling the Parthians. Sir Gardner Wilkinson adduces these instances to show that " the cross was already in use as early as the fifteenth century before Christ." "

The winged globe is common to Egypt, Persia, and other Eastern
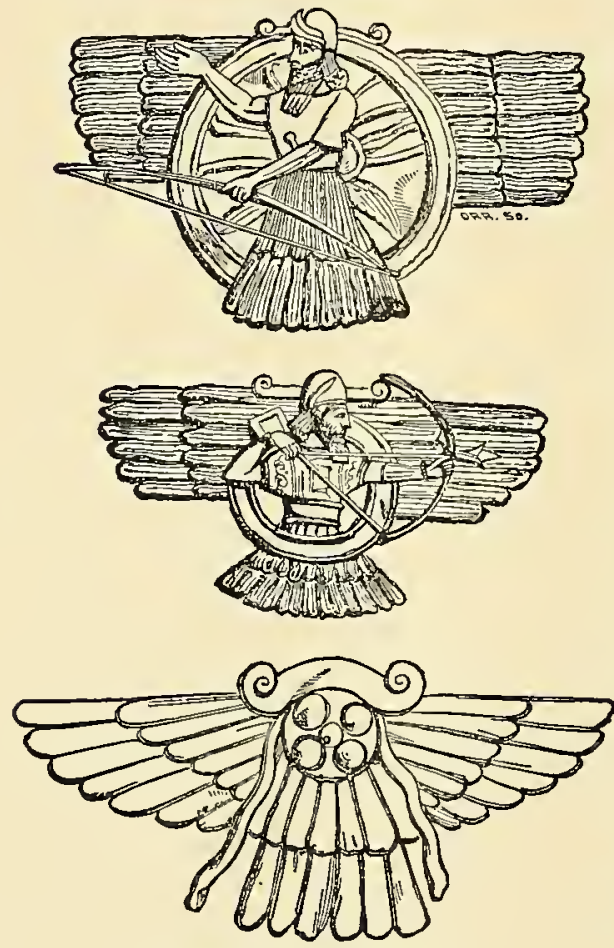

Assyrian Winged Globe.

From Layard's Nineveh. nations. But the Feroher, as it is called, is most fully developed Winged Globe, in Assyria. In Ninor Feroher. eveh we find within the circle the figure of a deity armed with a bow; the wings and figure forming a Tau cross. As. the Psalmist says, "He hath bent his bow and made it ready " (Ps. vii., I2). If the scene be that of a battle, the deity who hovers above in his cruciform nimbus holds the bow drawn; if a triumph is represented, the bow is unbent; if he presides over an act of worship, the right hand is raised in benediction. This symbol is never represented except over a king, as his protecting spirit or guardian, or else as receiving his royal homage and worship." Some have interpreted the Feroher as a symbol of a triune god, and translate the circle as Traces of a Belief symbolizing eternity; the wings, omnipresence, and the in a Trinity. human figure, wisdom or intelligence. ${ }^{3}$

1 Wilkinson, Ancient Egyptians, vol, i., p. 376.

${ }^{2}$ Layard, Nineveh, vol. ii., p. 339. M. Layard conjectures that the circle denotes eternity, surrounding the image of Baal with the wings and tail of a dove to show the association of Mylitta or the Assyrian Venus, and the whole is a symbol of the triad. Observations sur la Croix Anséc.

${ }^{3}$ Rawlinson, Five Great Monarchies, vol. ii., 230. 
From the mines of Wadi Malihara, or "Valley of the caves," near Feiran in Arabia, the nations bordering on the Red Sea procured their copper. The caves show the extent of their excavations, and the many inscriptions on the rocks give evidence of the

Cross in Arabia, long ages during which the work was carried on. Among these inscriptions are the cartouches of Cheops, of the fifth Egyptian dynasty, the builder of the Great Pyramid at Gizeh; and Rameses of the eighteenth dynasty, the great-grandson of the Pharaoh who pursued the Israelites in their passage through the Red Sea. According to Wilkinson, between these reigns 1500 years elapsed. Prominently among these ancient writings in the rock appear the Tau cross, and that surmounting an orb. ${ }^{1}$

Mesopotamia was connected with Arabia in patriarchal ages. Relics of ancient date are few. In post-Christian times, although still in antiChristian countries, we find a cross carved on early Cufic gems, the legends being arranged so as to form a Tau, or a Mesopotamia. cross. The Cufic characters were disused after the thirteenth century, so we have a clue to the antiquity of the signets. ${ }^{2}$

We approach the Holy Land with reverence, for we remember by whom every tittle of the ceremonial law was ordained as typical of higher things. Universal tradition asserts that the blood of the Paschal lamb was sprinkled upon the lintels and doorposts, on the eve of the Passover in Egypt, in the form of

Cross in Palestine, "Under the Law." a cross. ${ }^{3}$ According to the Talmud, Jarchi, and Maimonides, when the officiating priest sprinkled the blood of a victim in sacrifice upon the

1 Various theories concerning these inscriptions have been put forth. Some consider them the work of the Chaldeans, others that of the Israelites during their sojourn in the wilderness, others that of the early Christians, and still others that of a tribe of ancient Arabians before the Arabic language was known in the desert. Robinson, Biblical Researches, vol. i., pp. 92, 95. II3, etc.

${ }^{2}$ King, Antique Gens, p. I53. The Cufic, or square Arabic character, was one of the modifications of the Pehlevi. It took the name from the fact of its having been adopted by the transcribers of the Koran at Cufa in Mesopotamia. Ibid., p. 477.

${ }^{3}$ It is done so to this day in some countries. In Patras and Corfu, "we observed the doors of the Jews marked on the door-posts and Jintels with the blood of the Paschal Lamb; and the mark was alway made in the shape of the Cross," . . . and so "seems a witness against themselves. It is Christ's death lying at their doors. It is a mute echo of the awful, prophetic, self-invoked curse, "His blood be on us and on our children." F. W. Faber, Sights and Thoughts in Foreign Churches, etc., p. 399. At Corfu the cross was inscribed with a lock of the lamb's wool dipped in its blood. Tuckerman, The Greeks of To-day, p. 309. In India, blood is still painted on the door-posts by the natives as a charm against cholera. Fournal of Sacred Lit., 1863, p. 504. During the plague in London, it will be remembered, the red cross was so used. 
consecrated bread and hallowed utensils, it was in the form of a cross, and the same sign was traced in consecrated oil upon the heads of the priests when annointed.' Even whenever occasion required the moving of the victims, or the waving of the branches of palm, the motion was made to indicate the figure of a cross. ${ }^{2}$

Especially should this be noted in the solemn heave and wave offerings, called by the Jews, Tompha. Dr. Adam Clarke says, "As the Cross Figured in wave offering was agitated to and fro, and the heave offerHeave and Wave ing up and down, some have conceived that this twofold Offerings. action represented the figure of the cross, on which the great peace offering between God and man was offered in the personal sacrifice of our blessed Redecmer. Had we authority for this conjecture, it would certainly cast much light on the meaning and intention of these offerings, and when the intelligent reader is informed that one of the most judicious critics in the whole republic of letters is the author of this conjecture, viz., Houbigant, he will treat it with respect. I shall give his own words on this verse. "The heave and wave offerings, as two ceremonies in the same oblation, are here distinguished. The wave offering implies that the victim was moved hither and thither, to the right hand and to the left; the heave offering was lifted up and down, and this was done several times. In this way the Jews explain these things, and teach the Christians that by these acts the cross was adumbrated, upon which that Peace offering of the human race was lifted up which was prefigured by all the ancient victims.' "' s Most significant, also, it is that the heave offering was a peace offering (Lev. vii., 32), and the wave offering was part of the " consecration of sweet savour " (Lev. viii., 28, 29) of Aaron and his sons as High Priest and priests. Yet these ceremonial and prefigurative sacrifices were instituted i 528 years before the Lamb of God, both priest and sacrifice, was offered, the Peace Offering and Redeemer, upon Calvary.

Between Phœnicia and Judea there was frequent intercourse, but we have sad evidence that the pagan country had the weightier influence in religion. Therefore we cannot suppose that Tyre and Sidon derived

${ }^{1}$ It is thus prescribed in the "Office of the Coronation of the Sovereigns of Great Britain." Sir Thomas Browne thinks the oil was poured in a circle on the heads of Jewish kings, but decussatively on the heads of priests. - Works, vol. iii., p. 390.

${ }^{2}$ Maimon, De I'accâ Rufá, p. 495.-quoted in Faber's Hora Mosaica, vol. ii., p. I88.

${ }^{3}$ Clarke, Commentary, Ex. xxix., 27. 
their adoration for the cross from Israel. Yet they held it as a sacred symbol. Astarte, the moon, the goddess of the waters, was a fit tutelary divinity for a commercial nation, and she is represented on the coins of Byblus and other cities as standing on the Phonicia, Asia prow of a vessel holding a long cross. Solomon, in the Minor, etc. apostasy of his old age, worshipped at her shrine a thousand years before Christ. In sin and ignorance the wisest man knelt before an idol. But that image bore in its hand the symbol of light and truth to future ages.

Phonicia extended her colonies throughout the Mediterranean. So we find in Gozzo, an island near Malta, a cruciform temple of Astarte. At Citium, in Cyprus, colonized by the Phœnicians more than eight hundred years B.C., a medal has been found bearing on one face a lamb, on the other a circle of beads resembling a rosary, and a cross. The crux ansata is stamped upon the coins of this island, and also on those of Cilicia in Asia Minor, with Phonician legends. Upon one coin the cross fills the whole face; upon another it is placed below the throne of Baal of Tarsus; others bear the sacred bull accompanied with the cross, or a lion's or ram's head on the obverse and the cross and circle on the reverse. A superb medal of Cilicia with a Phonician inscription, struck under the Persian subjugation, three to five hundred years B.C., has upon one face Astarte with the cmux ansata by her side. The last example we shall cite of Phœnician work is an exquisite intaglio of chalcedony, given in the Némoircs de l'Acad́mie royalc des Inscriptions ct Belles Lettres. ${ }^{1}$ Between two stars a figure of a deity stands, above his head is the triangle, or symbol of the trinity, beneath are cruces ansata."

Before leaving Asia we pause to notice the cross upon the tomb of Midas, king of Phrygia, B.C. 7is, and the Fylfot cross upon the coins of Cross in Phrygia Chalcedon. A gold-headed staff or scep- and Chalcedon. tre knob, ornamented with an engraved cross, has been lately found on the site of Homer's Troy, among other discoveries of curious jewels in gold, silver, copper, and bronze. ${ }^{3}$

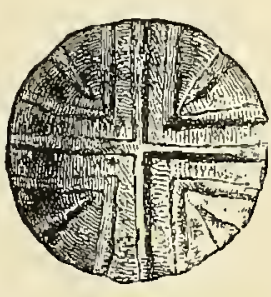

Sceptre Knob, found at Troy. From Schliemann's Troja.

1 See vol. xvi.

${ }^{2}$ Clarke, Travels, vol. iv., p. 77 ; McCulloch, Researches, p. 332 ; Humboldt, Nouveau Continent, tom. ii., p. 355 ; Gould, Curious Myths, vol. ii., p. 96.

3 Henry Schliemann, Troja, p. I07. 
Section 3. In Europe.-Leaving the land of Shem and passing to the tents of Japhet, we are welcomed at the very cradle of European art and civilization by the cross. It may have been brought Cross in Greece. with other traditions by those who wandered into Greece after the dispersion of Babel, or it may have been transmitted from Egypt, or Phœnicia, but the same promise of "future life" was symbolized. ${ }^{1}$ It was used also as a sign of mercy in extending temporal existence, for when a criminal was condemned to death, his name was marked on the judicial tablets with a Thcta, the initial of $\theta \dot{\alpha} v \tilde{\alpha} \tau o s$, death; but when acquitted, with a $T$, the Tau cross, as a sign of life. The Romans borrowed these symbols for the same purpose. ${ }^{2}$ It has been conjectured that this use of the cross was derived from that marked with the blood of the Paschal lamb on the door-posts of the children of Israel on the night of the Passover in Egypt. ${ }^{3}$

It is plain that a sacred symbolic meaning was connected with the cross in Greece. Four hundred years before Christ, Plato, in his Epistle to Dionysius of Syracuse, intimated his belief in a trinity, and elsewhere " expressed an opinion that the form [symbol ?] of the second person was stamped upon the universe in the form of a cross." "

An inscription in Thessaly, EPMA $\Omega X \Theta O N I O Y$, is accompanied by a Calvary cross. ${ }^{5}$ Numerous examples of the Fylfot cross are found on Greek cross in Greece. pottery, circa B.C. 600, and on the coins of Corinth and also those of Gnossos, or Cnassos, a city of Crete, B.C. 500-450.

Northern Italy was inhabited by a people so many ages ago that history has forgotten them. Research has discovered that they dwelt in villages built on platforms over lakes, that they were cross in Italy. ignorant of the arts of civilization, but they knew enough to believe in the cross as a religious symbol, " and that they trusted in the cross to guard, and it may be to revive, the loved ones whom they committed to the dust." "

'Caylus, Recuit d'Antiq.; Fosbroke, Encyc. Antiq., p. I59.

${ }^{2}$ Raoul Rochette, Sur la Croix Ansée, note 7 ; Persius Sat., iv. 13.

${ }^{3}$ It " is, in fact, a symbol of acquittal : God having acquitted or justified them, they therefore were to be spared. From this original emblem of divine protection, the Greeks derived the notion of marking the names of the acquittcd with a $T$ without knowing its real signification." Deane, Serpent Worship, p. I43; Godwin, Roman Antiq., p. 24I.

${ }^{4} \mathrm{~S}$. Augustine acknowledged his indebtedness to Plato in enabling him to understand the doctrine of the Trinity.-Lysons, Our British Ancestors, p. 215.

${ }^{5}$ Gould, Curious MIyths, vol. ii., p. 95 .

${ }^{6}$ Ibid., p. 99. 
There are vast remains of these people, consisting of cinders, bones

animals, grain, querns, moulds for metals, portions of their houses, pottery, mainly in fragments; a few weapons, some articles of the toilet, even hair-pins and combs, and such other matters as would accumulate around habitations. Owing to the geological changes, the shores and beds of lakes have become dry ground, and the deposits, being rich in phosphates, have been dug into by the farmers for fertilizing purposes; hence these discoveries.

The remains belong to three distinct ages. In the first, the pottery is rude, not made upon the wheel, nor fire-baked; both of these evidences of the advances of civilization are found in the re- Different Ages of mains of the second age; also, iron is met with, although the Terramares. the metal in these terramares, as these depositories are termed, is mainly bronze. In the third period, rarely distinguished, the beginnings of ornamentation are discovered in the rude representations of animals and human beings on the pottery. Among the remains of this last age, some shapeless pieces of bronze occur, which some antiquarians have supposed to be the first trace of money. Etruria flourished twelve centuries before the Christian era, ${ }^{1}$ yet these nations must have lived and disappeared many ages before Etruscan art and civilization were born.

\section{At Castione,} near the station of Borgo San Donino, between Parma and Piacenza, there is
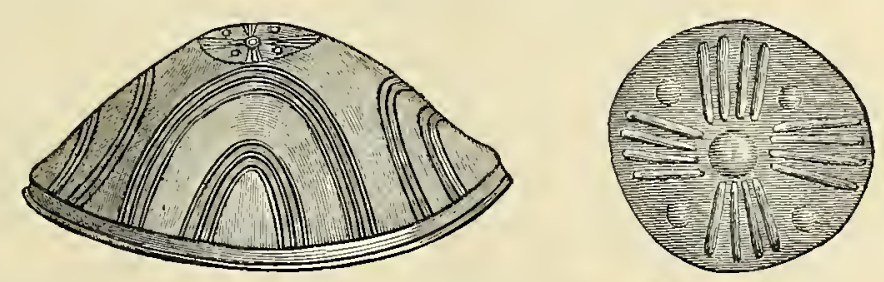
a mound upon which is a convent. Originally that mound was the bed of a lake which was filled with relics of this ancient people;

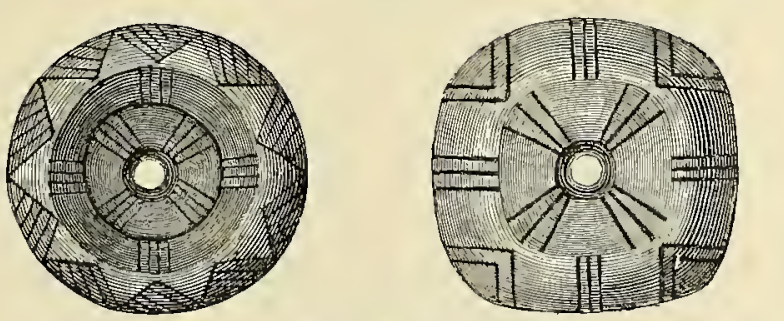

Earthen vessels found at Castione.

From De Mortillet's Le Signe de la. Croix. among them are earthen vessels, and upon the bottoms of some were rudely engraved crosses, as represented in the accompanying engravings.

${ }^{1}$ M. Des Vergers calculated that Etruscan civilization was developed B.c. I 330. 
At Villanova, near Bologna, one of their burial-places has been discovered. More than one hundred and thirty tombs have been examined. cemeteriesat They are carefully and symmetrically constructed of villanova. boulders, over which the earth has accumulated. Within each sepulchre was a cinerary urn containing calcined human remains,

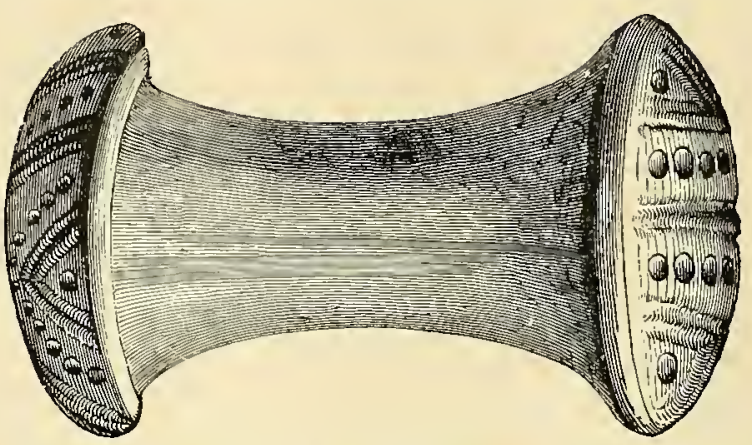

Cylinder found at Villanova. From De Mortillet's Le Signe de la Croix.
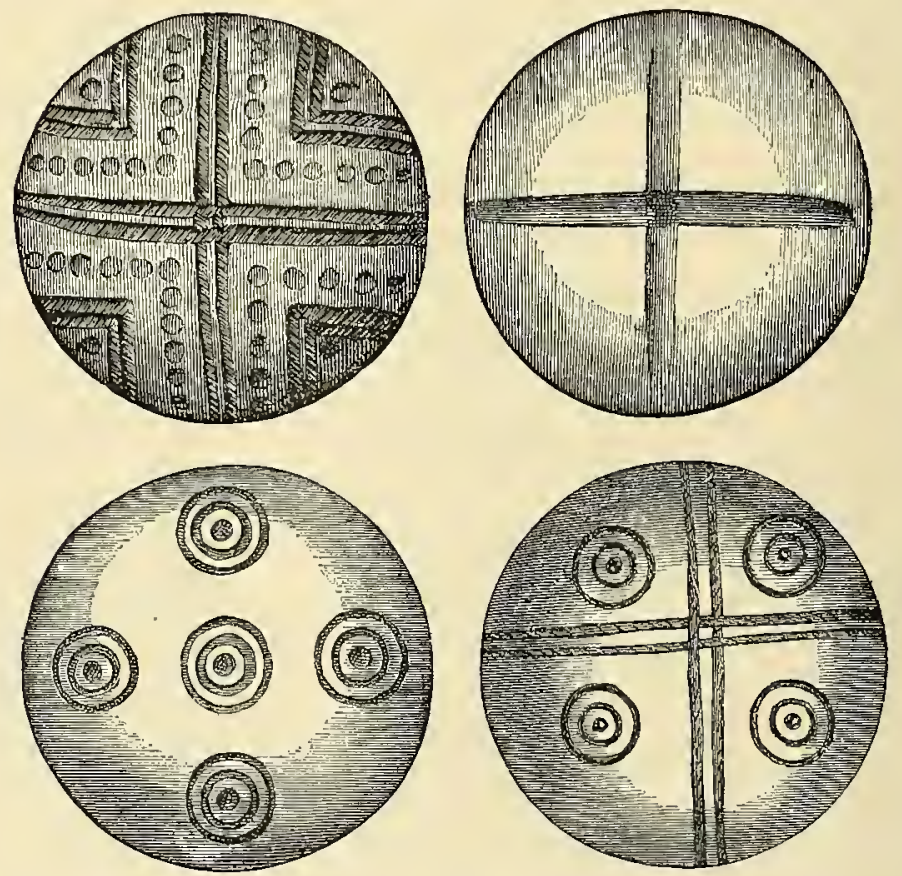

Heads of Cylinders found at Villanova. From De Mortillet's Le Signe de la Croix.

and sometimes half-melted ornaments. The urns were shaped like two inverted cones joined together, the mouth being closed with a little 
saucer. Near the remains of the dead were found solid double cones with rounded ends on which crosses were elaborately engraved. In the vases of double cones around their partition was a line of circles containing crosses.

There is another cemetery at Golasecca near the extremity of Lago Maggiore. A number of tombs have been opened; they belong to the same age as those of Villanova, that of the lacustrine habitations.

" That which characterizes the sepulchres of Golasecca, and gives them their highest interest," says M. de Mortillet, who investigated them, " is this, - first,

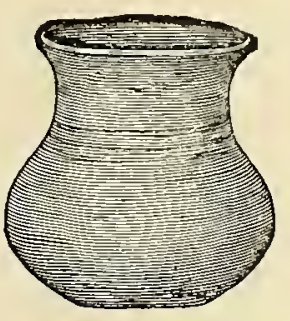

Accessory Vase found at Golasecca.

From De Mortillet's $L e$ Signe de la Croix.

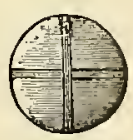

Bottom of Vase. the entire absence of all organic representation; we found only three, and they were exceptional, in tombs not belonging to the plateau;secondly, the almost invariable presence of the cross under the vases
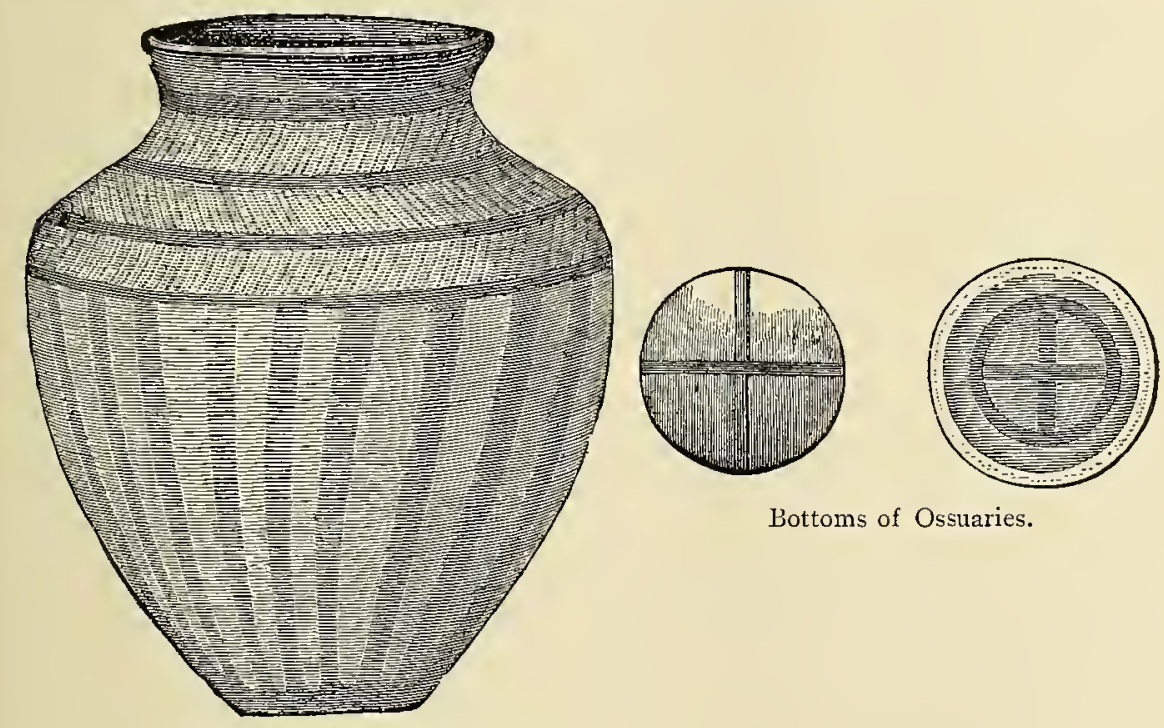

Bottoms of Ossuaries.

Ossuary found at Golasecca.

From De Mortillet's Le Signe de la Croix.

in the tombs. When one reverses the ossuaries, the saucer lids, or the accessory vases, one saw almost always, if in good preservation, a cross traced thereon. . . . The examination of the tombs of Gola- 
secca proves in a most convincing, positive, and precise manner, that which the terramares of Emilia had only indicated, but which had been confirmed by the cemetery of Villanova,-- that above a thousand years before Christ, the cross was already a religious emblem of frequent employment." '

In ISI7, at Montecucco near Rome, vases bearing the Fylfot cross were dug up from underneath the volcanic tufa, of such an age that they At Montecucco. are pronounced to have been manufactured by a people who inhabited the country before Ascanius founded Alba Longa, that is, before I I 6 B.C. ${ }^{2}$

Among the ancient Latins the Fylfot cross was the emblem of Libertina, or Persephone, the Queen of the Shades, the arbiter

Fylfot used by

Latins, and adopted by the

Fossors. Christian of mortal fate; and this, or the practice of concealing the symbols of their belief under the guise of pagan emblems, may have led the early Christian Fossors, or tomb-diggers in the catacombs, to adopt it as it appears on their garments.

So much space has been given to the unwritten page of the history of Italy, that only a brief reference can be made to other examples.

In the mausoleum of Lars Porsenna, circa 500 B.C., in Etruria, thrice was the cross repeated. ${ }^{3}$ The coins of Vibius Pansa, consul of Rome, cross in Etruria. 46 B.C., bear on the reverse Jupiter crowned with oak, or in Rome. olive, holding in his right hand a patcra, in his left a long sceptre terminating in a cross. The staff of the Roman augurs was sometimes surmounted with this symbol, and the vestal virgins suspended the Fylfot cross from their necks, doubtless with more reverential feeling than many women at the present day bear the jewelled emblem of salvation among the trinkets which adorn their bosoms.

Gems also give their testimony. Among other examples may be mentioned a chalcedony exhibiting Jupiter holding in one hand an image of Victory, in the other a double cross. The thunderbolt and eagle are on either side. Upon the reverse is an inscription arranged to represent a serpent coiled. ${ }^{4}$

${ }^{1}$ De Mortillet, Ies signe de la Croix avant le Christianisme, Paris, I866, chap. iii., pp. 98127 ; Gould, Myths, vol. ii., pp. 103-105.

"Hobhouse, Illustrations of the IVth Canto of Childe Harold, stanza clxxiv.

3 According to Pliny, who borrowed his account from M. Terentius Varro. Edin. Rev., vol. cxxxi., p. 250.

4 On account of the symbols, Walsh considers this a Gnostic gem, of the sect that followed Simon Magus, who was sometimes represented as Jupiter. Waish, Gems, p. 62. It may be so, but we have very similar coins that were ante-Christian. 
Many of the coins of Syracuse bear the impress of the Fylfot. A medal of Camarima

Cross in Sicily. bears a swan and an altar; beneath the latter are the cross and ring.

The most ancient coins of the Gauls were circular, with a cross in the middle. That these were not representa-

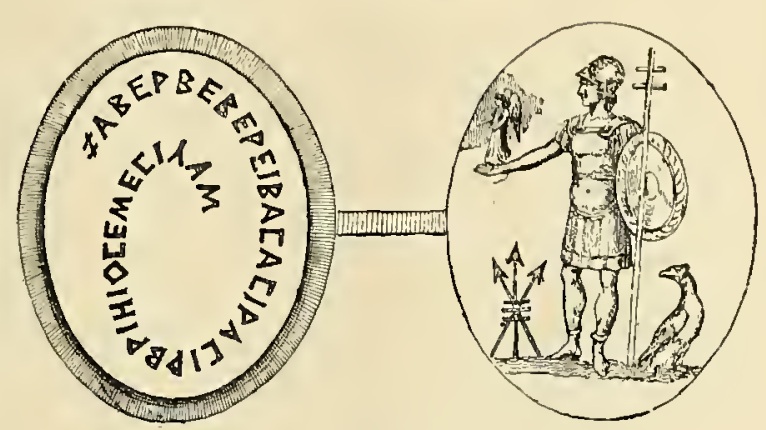

From Walsh's Ancient Coins, Medals, and G'ths. tions of wheels, as has been supposed, is evident from there being but four spokes, placed at right angles; and this symbol continued when coins of the Greek type took their place. The Cross in France. coins of the Volcre Tectosages, who inhabited the region now known as Languedoc, were stamped with crosses, the angles of which were filled

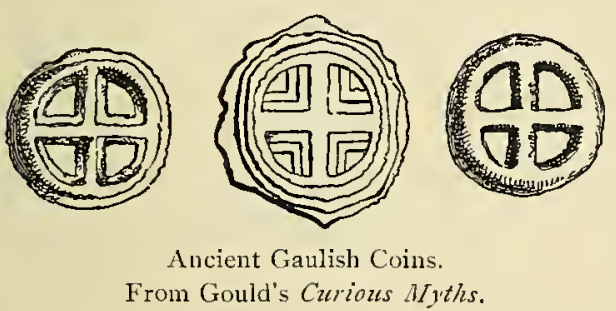
with pellets. The Leuci, who lived in the country of modern Toul, used similar devices. A coin figured in the Reruc des Numismatiques, I835, bears a circle containing a cross, whose angles are occupied by chevrous. Some of the crosses are surrounded by a ring of bezants, or pearls. Near Paris, at Choisy-le-Roy, was found a Gaulish coin, the obverse bearing a head, the reverse a serpent coiled around the circumference, enclosing two birds; between them is a cross with pellets at the end of each limb, and pellets occupying the angles. Similar coins have been discovered in Loiret and elsewhere. About two hundred coins were discovered, in I835, at Cremiat-sur-Yen, near Quimper, in an earthen urn with ashes, in a tomb, showing that the cross was used in Armorica, in the age of cremation.

In I 850 , S. Baring Gould exhumed at Pont d'Oli, near Pau, the ruins of an extensive palace, paved with mosaic. The principal ornamentations were crosses of different varieties. The pavement of the principal room was bordered by an exquisite running pattern of vines with grapes springing from drinking vessels in the centre 
of the sides. Within were circles composed of conventional roses, in the middle a vast cross, measuring nineteen feet eight inches by thirteen

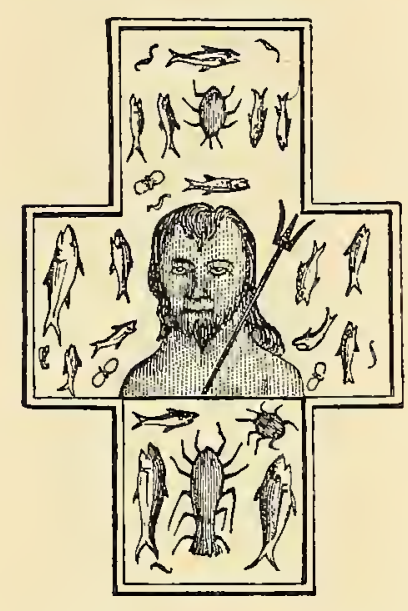

Cross, with bust of Neptune, found near Paris.

From Gould's Curious Myths.

feet. The ground work of white was filled with shell and other fish, and in the centre was a bust of Neptune with his trident. The laborers exclaimed, "C'est le bon Dieu, c'est $̛$ fésus." It may have been of post-Christian times, but, from the examples already given, Mr. Gould believes the cross to have been a sign well known to the ancient Gauls, and that this was their work. ${ }^{1}$

Among the more northern nations of Europe Cross in North- who derived their mythology from ern Europe. Scandinavia, the Fylfot cross appears as a symbol of worship under the name of Thor's hammer.

In 1835 , in a field in Bornholm, an island in the Baltic, near Sweden, ornaments and coins of gold were discovered bearing this figure. Some of the coins were impressed with a horned beast bearing a human head as a In Sweden. rider, upon whose forehead was Thor's hammer. Four of the specimens have also the name of the god in Runic characters. ${ }^{2}$

Among the flint weapons found in Denmark are stone cruciform hammers, which are supposed to have been used in sacrificing victims to Thor. It was with his hammer, Mjölner, that Thor crushed 1n Denmark. the head of the Mitgard serpent, destroyed the giants, restored to life the dead goats which drew his car, and consecrated the pyre of Baldur. This hammer was a cross. ${ }^{3}$

In the old Scandinavian records we read that when Odin was near his death, he caused himself to be marked with the point of a spear, saying that he was going to Godheim, to prepare a welcome for all brave warriors who should be dedicated to him, and the Swedes believed that he had gone to the ancient Asgard to live eternally. He was marked with

${ }^{1}$ Gould, Myths, vol, ii., pp. 76-86. An able writer in the Edinburgh Review thinks that Gould has been misled by the tresul, or trident, and that the figure is that of Proteus, not Neptune. Vol. cxxxi., p. 335 .

${ }^{2}$ Transactions of the Society of Northern Antiquatians for 1836 .

${ }^{3}$ Gould, Myths, vol. ii., p. 86. 
the sign of the head of a spear, that is, with the sign of the cross; for, "The sign of Thor's hammer, or the head of a battle-axe, or halberd," says Laing, "was used as the sign of the cross after the introduction of Christianity as a kind of consecration by a holy symbol." 1

Of King Hacon, we are told that he was a Christian, and wished his people to be " baptized, and believe in one God, and in Christ, the son of Mary, and to refrain from all sacrifices to heathen gods. They refused, and insisted upon the King's offering sacrifice at the harvest festival. The King sat on his throne. Now when the first full goblet was filled, Earl Sigurd spoke some words over it, blessed it in Odin's name, and drank to the King out of the horn; and the King took it and made the sign of the Cross over it. Then said Kaare of Gryting, 'What does the King mean by doing so ? Will he not sacrifice?' Earl Sigurd replied, "The King is doing what all of you do who trust to your power and strength. He is blessing the full goblet in the name of Thor, by making the sign of his hammer over it.' On this there was quietness for the evening, for his followers called themselves the children of Thor, and expected to be saved in the last day by Thor's hammer," ${ }^{2} i$. e., the cross.

Longfellow refers to the Scandinavian symbol and the cross when describing King Olaf keeping Yule-tide at Drontheim:

"O'er his drinking horn the sign

He made of the Cross divine,

As he drank, and muttered his prayers ;

But the Berserks evermore

Made the sign of the hammer of Thor

Over theirs."

In reality both were the same-

"And in foaming cups of ale

The Berserks drank washæl

To the Lord."

Even to this day, Thor's hammer, or the Fylfot cross, is used in the magical rites still practised in Iceland by the witches, who claim thereby to rule the elements.

Cross in Iceland.

" I came not to bring peace, but a sword," was the sad prophecy of

${ }^{1}$ Laing, Chronicles of the Kings of Norway', vol. i., p. 224.

2 Ibid., p. 330. 
the Prince of Peace, and even his symbol was misused to fulfil his word. One custom, probably derived from the Scandinavians, descended to a late date: the summons among the north-western nations The Fiery Cross. i.e., a cross the ends of which had been scorched. Scott's graphic description, of the preparation and hurrying on of

$$
\text { "- the fell cross of blood and brand," }
$$

is not exaggerated. In the island of Lewes, one of the Hebrides, when the Danes became oppressive, a fiery cross was circulated among the Gaels with the brief announcement: "Every one shall slay his guest." The strangers, being unwarned and dispersed, were murdered singly. ${ }^{3}$ Even as late as June 9, I685, the fiery cross was sent, by order of government, through the west of Fife and Kinross, that all between sixteen and sixty might rise and oppose Argyle." It is said also to have been circulated in some parts of Scotland in I745, but without effect.

The cross was held in high reverence in the religious rites of the Druids. In the consecration of their holy oaks, the trees were made cross among cruciform either by being lopped in the desired shape, or the Druids. by the insertion of other branches. At the intersection of the arms the word Thau, or God, was inscribed, on the right Hesus, on the left Belenus, and in the middle of the trunk Tharnis, the names of the Druidical triad." In Charnwood Forest, Leicestershire, England, is

${ }^{1}$ Herbert, Tceland Poetry, pt. i.

2 Lady of the Lake, canto iii., stanzas viii-xxi.

${ }^{3}$ Worsaae, Danes and Norwegians in Englant, p. 293.

4 " Diary of Lord Fountainhall, I680 to 1701, " Forsyth, Antiquarian Portfolio, vol. i., p. 35 I.

${ }^{5}$ Borlase, Antiquities of Cornwall, p. I08; Manrice, Indian Antiquities, vol. vi., p. 49. The cutting of the mistletoe is too significant to be passed without notice. The fête was on the sixth day of the moon." (Christ suffered on the sixth day, at the sixth hour, and that number has always been considered symbolical of suffering, hence even the chalice to hold the mystical blood represents the number in the form of its foot.) The mistletoe was sought for npon an oak of about thirty years growth. (Christ was about thirty when $\mathrm{He}$ bore His cross.) When the oak was found, a triangzular altar was raised. In the procession the Eubagi marched first, conducting two white bulls which had never borne the yoke, then followed the bards chanting hymns. to God. Next came the novices, students, and disciples, accompanied by a herald clothed in white. These were followed by the most ancient pontiffs, one carrying the bread which was to be offered; the second two bearing two vessels filled with wine and water; the third a wand terminating in a hand of ivory representing Justice and Power. Next came the clergy, preceded by the supreme pontiff, in a white robe, and a girdle of gold, and the procession was closed by nobles and people. Having arrived at the oak, prayers were offered, and a burnt offering of some of the bread, wine, and water. The remainder of these elements was distributed among 
an oak, known as the Copt, or copped oak, the outer shell of which was in cxistence about fifty years ago, and was evidently one of the Druidic Thaus; it is probably more than two thousand years old.'

Some of the remains of what are presumed to

the priests. The celebrant then ascended the iree and cut off, with a golden sickle, the mistletoe, one of the principal priests receiving it with great reverence. The supreme pontiff, aided by olhers, immolated the two bulls, and the ceremony concluded by the prayer that God's benediction would rest upon the gift to be distributed among the people, then prostrate upon the ground. The inferior order of Druids then distributed portions of the sacred mistletoe, some of which were sent to the temples, and some were worn as amulets against sickness, evil spurits, thunder, etc. Manet, Notes and Queries, 3d ser., iv., p. $4^{5} 5$.

The Druidical name of the mistletoe, "All Heal," is significant. Its British name, Gui, signifying spirit, life, the spirit of healing and divination. There seems to be an mnderlying tradition of the prophetic value of a branch which was to have healing powers, as Zechariah foretells: "Behold I will bring forth my servant the branch." Zech. iij., 8. It was a branch which sweetened the waters of Mara. Even the golden branch of Virgil, and other mythological traditions, may point to the "religious branch" foretold by the prophets, as springing from the "stem of Jesse." Again, the mistletoe was of a different nature from the oak on which it grew. A mystical representation of the expected Saviour, the "All Heal" taking another nature than that which belonged to him by prior generation, i.e., the grafting of the human upon the divine nature. The oak itself was sacred to God, the name in Hebrew, Aleh, having the same root as divinily itself. Lysons, Our British Ancestors, p. I99, 201.

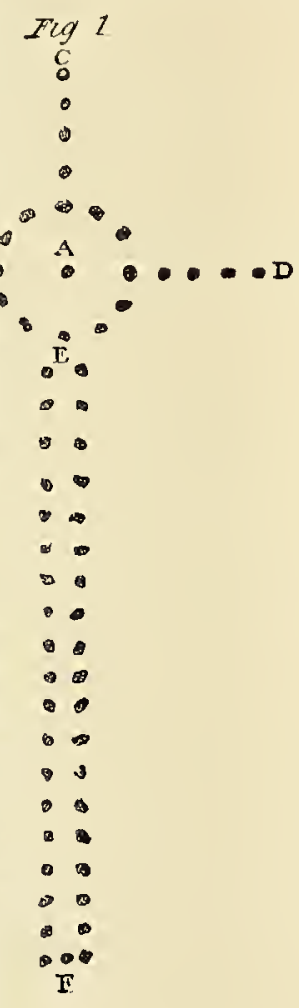

Fra. 2

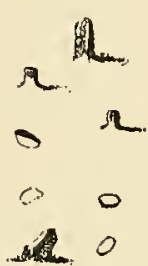

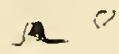

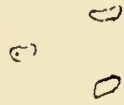

n

$\Omega$

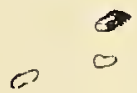

2.

is

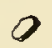

0

(P)

网。

厚

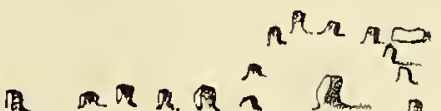

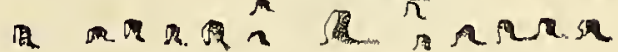

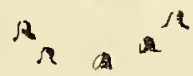

${ }^{3}$ Dudley, Naology', p. 136.

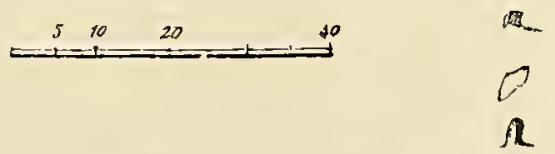

Cruciform Druidical Temple. From HIggins's Celtic Druids. 
have been their temples are cruciform. An example is found near Classernis, in the island of Lewes. Thirty-nine massive stones form the longer Cruciform limb of the cross, thirteen the circle, in all fifty-two; twelve Temples. compose the head and arms. The stones are from four to seven feet in height, except the centre one, which is thirteen. The diameter of the circle is sixty-three feet; the length of the cross at present is five hundred and eighty-five feet, formerly it was seven hundred; the length of the arms is two hundred and four feet.'

The Druids considered that the long arm of the cross symbolized the way of life; the short arms the three conditions of the Symbolism. spirit world, equivalent to Heaven, Purgatory, and Hell.

According to enthusiastic Irish antiquarians, their cave, or rather subterranean mound, temples are more ancient than any other ecclesiastical remains in Great Britain. One of the best Cross in Ireland. known is that of New Grange, near Drogheda, in the county of Meath. It is formed of vast stones covered with earth. The New Grange. ground plan is cruciform, about eighty feet in length by twenty-one in the transverse. The height of the gallery, at the entrance about two feet, gradually increases until it becomes nine. The temple appears to have been dedicated to Thor, Odin, and Friga. ${ }^{3}$ Vallancy considered the inscriptions, in Ogham and symbolic characters, the most ancient in Ireland. He translated that on the right of the long arm of the cross, "The Supreme Being," or " Active Principle." On the same side, thrice repeated, are characters of a somewhat like import, signifying "The Great Eternal Spirit." On the " covering stone" of the east transept is, "To the great Mother Ops," or "Nature." In front of the head of the cross is "Chance, Fate, or Providence." On the north stone of the west transept is, " The sepulchre of the Hero," on a stone on the left of the gallery are " men, oxen, and swine, probably signifying the several species of victims sacrificed at this temple in honor of universal Nature, Providence, and the names of the hero interred within." Vallency supposes that this tumulus was erected towards the close of the second century." If not pre-Christian, it is at least the work of men who knew nothing of Christianity.

\footnotetext{
1 Toland, Hist. of the Druids, p. 136.

2 Gould, Myths, vol. ii., p. 86.

3 Wright, Louthiana, p. 15.

${ }^{4}$ Vallancy, "Col. Rel. Hib.," vol. ii., p. 2 I , quoted in Higgins, Celtic Druids, p. xliii.

${ }^{5}$ For full description see Fergusson's Rude Stone Monuments.
} 


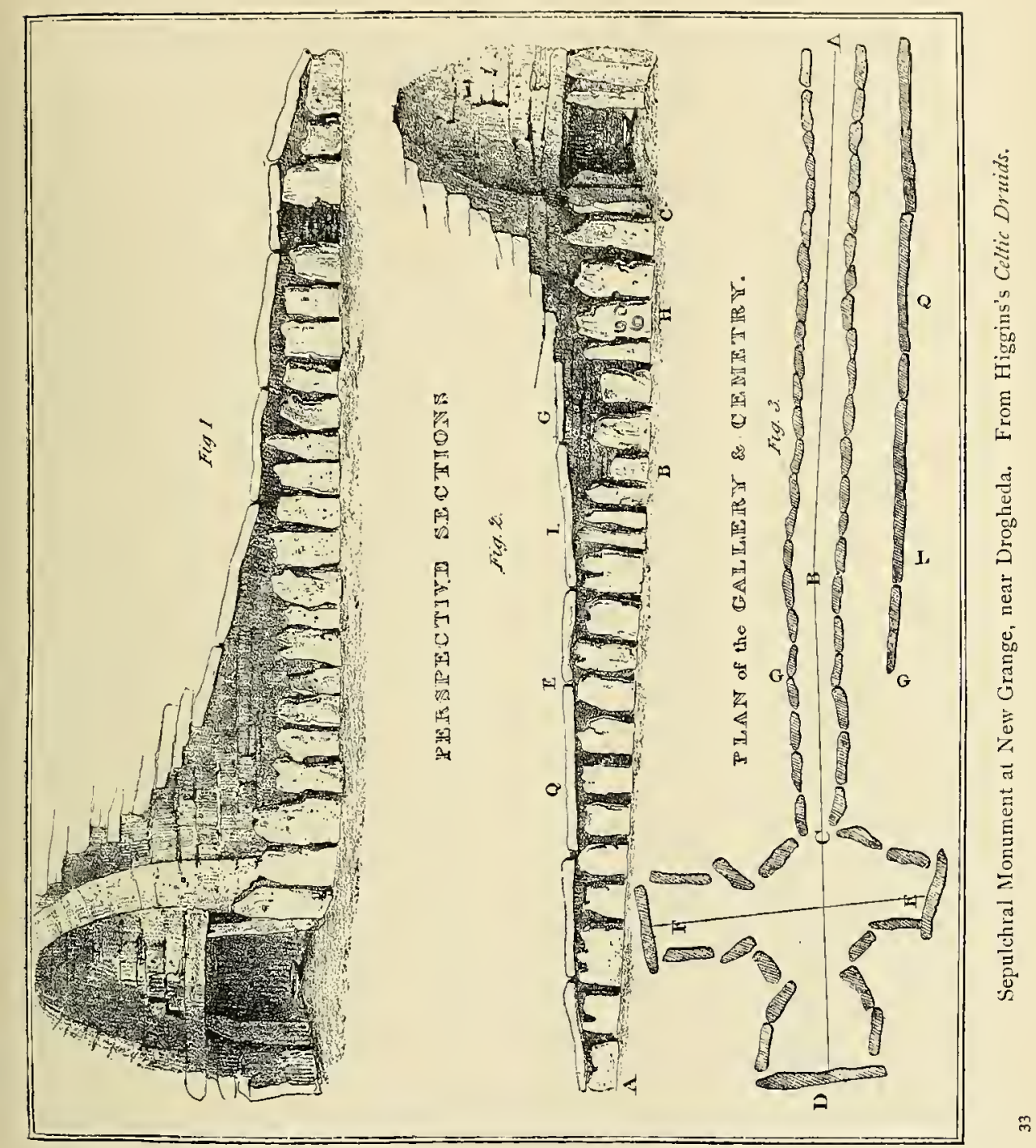


In the neighborhood of New Grange are two other mounds, known as the Hills of Nowth and Dowth. The latter was explored in IS47. It Nowth and Dowth. resembled New Grange, and within its chamber is a quadcross is conspicuous."

The Tau cross, according to McCulloch, was known among the ancient Irish as the symbol of WVisdom.

Section 4. In America.-IVe might slightly alter Bishop Berkeley's Cross in America. famous prophecy, adapting it as a fact, that

"Westward the "Cross' of empire takes its way "-

for, in passing from the Old to the New World, we find that the cross rules almost from Behring's Straits to Cape Horn. It has been found from Oregon to Patagonia.

When the Spaniards first landed in Mexico and Central America “ They could not suppress their wonder," says Prescott, " as they bein Mexico and held the cross, the sacred emblem of their own faith, raised Central America, as an object of worship in the temples of Anahuac." 2 Even among the relics of nations whose existence had been forgotten by those who then inhabited their lands, the cross had been adored. Palenque is supposed to have been founded by Votan in the ninth century before the Christian era. One of the principal buildings in that city is a palace, or temple, two hundred and eighty-eight feet long by one hundred and eighty feet in width, and forty feet high. At the back of one of its altars, sculptured on a slab of gypsum, is a cross ten feet high, richly decorated with symbolic figures. On the lower limb is a fish, reminding us of that Christian symbol in the Catacombs of Rome; above the cross sits a bird, which Stephens thinks is the Zuitsitizilian, or humming-bird of the Mexicans, which corresponds, in their traditions of the deluge, to the dove of Noah; but Gould considers it the eagle, Nisroch, or rain cloud, already noticed on the cylinders of Babylon. On each side of the cross is a human figure, one of which holds up a child to the cross. The garments of the three are profusely decorated with crosses. ${ }^{3}$

\footnotetext{
1 Wakeman, Handbook of Irish Antiquties, chaps. iii., iv.

${ }^{2}$ Prescott, Conquest of Mixico, vol., iii., pp. $3^{s} 3,3^{8} 4$.

${ }^{3}$ Stephens, Central America, vol. ii., p. $35 \mathrm{I}$.
} 


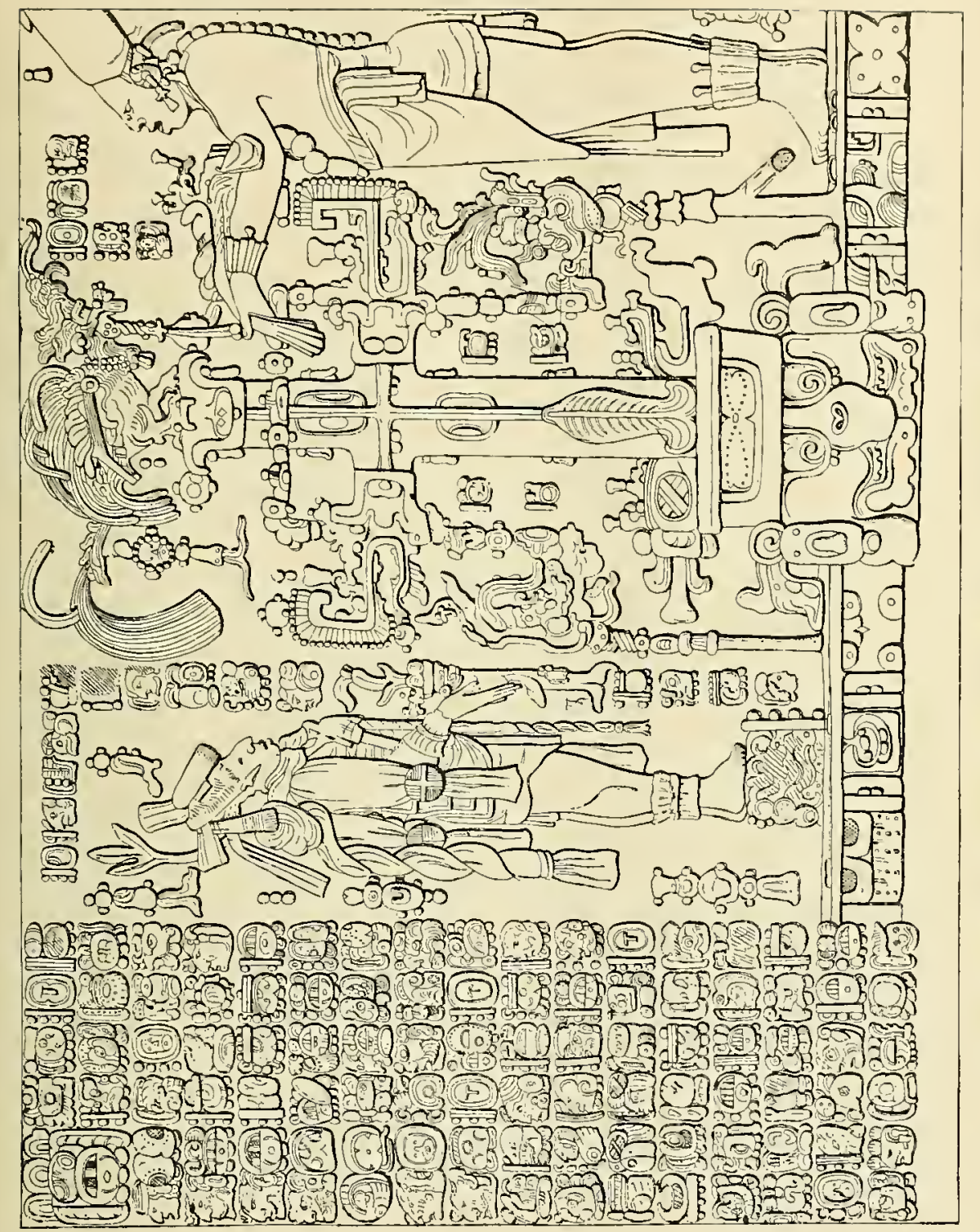


"The same cross is represented on old pre-Mexican MSS., as in the Dresden Codcx, and that in possession of Herr Fejérváry, at the end of which is a colossal cross, upon which is represented a bleeding deity, and figures stand around a Tau cross upon which is perched the sacred bird.' '

The Spaniards also found Tau crosses of metal, ${ }^{2}$ but whether used as ornaments, or amulets, they appear to be ignorant. The Tau is figured upon the breasts of bronze statuettes of unknown antiquity which have recently been disinterred in the cemetery of Juygalpa, in Nicaragua. ${ }^{2}$

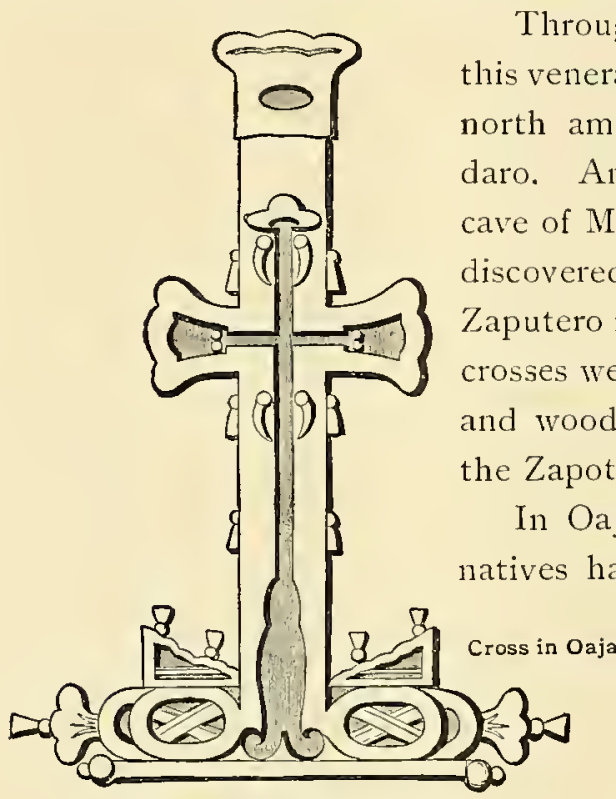

Cross found at Palenque.

From Wilson's Mexico.

Throughout the whole of Mexico we find this veneration of the cross. It occurs in the north among the Mixtecas and in Queredaro. An Incian cross was found in the cave of Mixteca Baja, and similar ones were discovered among the ruins on the island of Zaputero in Lake Nicaragua. White marble crosses were found on the island of S. Ulloa, and wooden ones in Aquatolco and among he Zapotecas. ${ }^{4}$

In Oajaca, there was a cross which the from time immemorial. By order of the Bishop of Cervantes, it was placed in a sumptuous chapel in the cathedral, and information concerning its discovery, together with a cup cut from its wood, was sent to Paul V. at Rome, who received it upon his knces, singing the hymn Tcxilla Regis."

In Cholula there is a temple which its discoverers presumed to be dedicated to the worship of the cross, ${ }^{6}$ and in the "Casas de Piedras in

1 Gould, Myths, vol. ii., p. го6.

' Kingsborough, Alexico, vol. vi., p. 420.

${ }^{3}$ Boyle, Ride Across a Continent, vol. i., p. r6r.

+ Gould, Myths, vol. ii., p. ro7.

${ }^{5}$ Calderan, Life in Mexico, Letter 37 . The cross of Cozumel might also be instanced. Stephens thinks it of Spanish origin, Yucatan, vol. ii., chap. 20; but Prescott considers it native, Mexico, vol. iii., p. 334.

${ }^{6}$ Kingsborough, Mexico, vol. vi., p. 418. 
Chiapa some of the windows are in the form of the Greek cross, and on the wall of one of the apartments is a tablet of sculptured stone, exhibiting the figure of a large and richly ornamented cross placed upon an altar or pedestal." I Kingsborough gives

In Cholula. a curious example of a cross with a skull at the foot similar to the medireval crucifixes in the Eastern Hemisphere. ${ }^{2}$

Nor are cave temples wanting to complete the resemblance to the Eastern Hemisphere. One at Mitla, " the city of the moon," has been hewn out of the solid rock, its limbs being one hundred and twenty-three feet in length, and about twenty-five in width.

Cruciform Cave Temples. Upon the walls the figure of a perfect Maltese (Greek?) cross is carved. ${ }^{3}$

Upon certain high festivals, the Mexicans made crosses out of Indian corn and the blood of their sacrificial victims. These were first worshipped, and afterwards broken and distributed among the worshippers, who ate them as a symbol of union and brother-

Cruciform Cake. hood. Such close resemblance to the Sacrament of the holy Eucliarist probably led the Spaniards to think that S. Thomas and his disciples had found the way from India to these countries." But not only the type of one sacrament was practised by the natives previous to the arrival of the Spaniards, but also even a rite of baptism.

The sepulchres of the ancient inhabitants of Mexico and Central America were generally cruciform. ${ }^{\circ}$ Du Paix gives a number of in-

1 Bradford, American Antiquities, p. $8 \mathrm{r}$.

${ }^{2}$ Kingsborough, Mexico, vol. ii., pl. 37.

3 Ibid., vol. vi., p. 429.

${ }^{4}$ Prescott, Mexico, vol. i., p. 60 ; vol. ii., p. 5 ; vol. iii., pp. $3 s_{3}-386$. The last syllable of Quetzacoatl signifies a twin. By some confusion of ideas, probably, the Spanish writers supposed this intimated Didymus, $i$. $e_{\text {. }}$, Thomas.

5.'Their surprise was heightened, when they witnessed a religious rite which reminded them of the Christian Communion. On these occasions, an image of the tutelary deity of the Aztecs was made of the flour of maize mixed with blood, and, after consecration by the priests, was distributed among the people, who, as they ate it, showed signs of humiliation and sorrow, declaring it was the flesh of the deity. How could the Roman Catholic fail to recognize the awful ceremony of the Eucharist? With the same feelings they witnessed another ceremony, that of the Aztec haptism, in which, after a solemn invocation, the head and lips of the infant were touched with water and a name given to it, while the goddess Civacoatl, who presided over child-birth, was implored that the sin which was given to us before the beginning of the world, might not visit the child, but that, cleansed by these waters, it might live and he born anew." "The Spaniards were not aware," continues Prescott, " that the cross was the symbol of worship of the highest antiquity in Egypt and Syria, and that rites resembling those of Communion and Baptism were practised by pagan nations on whom the light of Christianity had never shone." Prescott, Mrexico, vol. iii., pp. 383-387.

"Squier, Serpent Symbol in America, pp. 95-Ioo. 
stances. From Mitlan, or " the palace of the dead," from the structure upon the commencement of the Mijian Mountains, from the town of

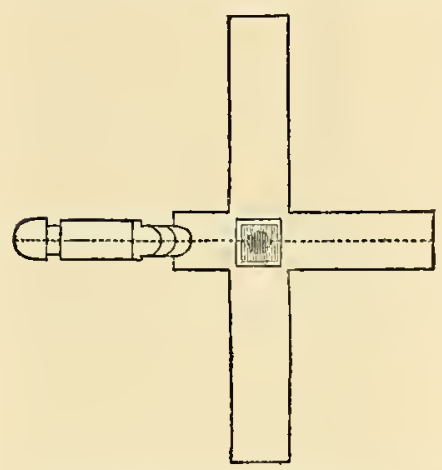

Plan of Sepulchral Chamber at Mitlan. From Squier's Serpent Symbol.
Chila on the summit of the Cruciform
Sepulchres. mountain called Tortuga, and elsewhere, do not these witnesses intimate a belief in the Resurrection by means of the truth hidden in the sacred symbol? And is not this confirmed by the ancient Mexican names for the cross? The "Tree of Nutriment," the "Tree of our Flesh," the "Tree of Life" "' And that this symbol was placed on their tombs and temples shows that the significance was not limited to this life only:

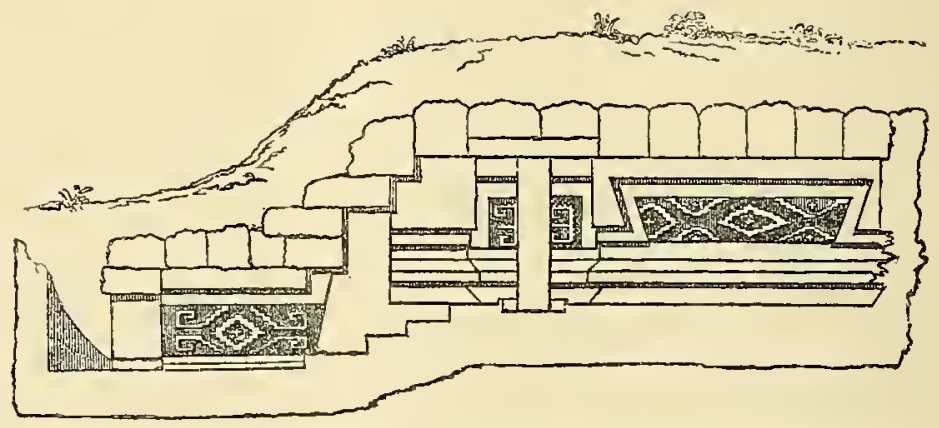

Section of Sepulchral Chamber at Mitlan. From Squier's Serpent Symbol.
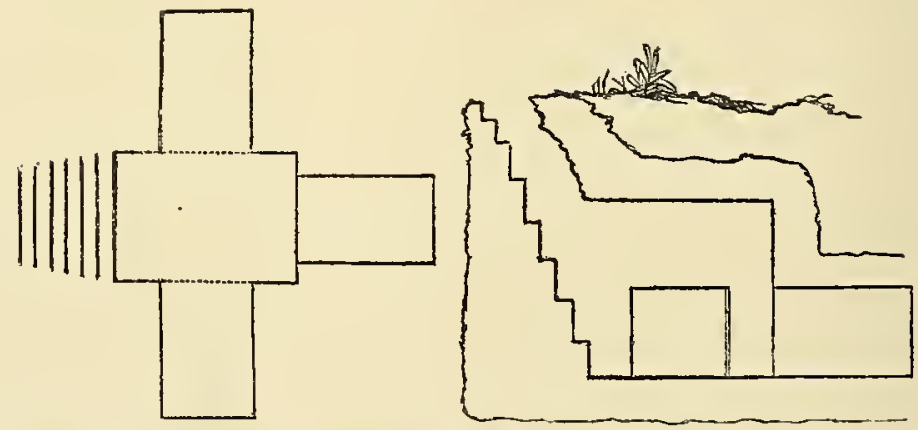

Plan and Section of Sepulchral Chamber at Chila, Mexico. From Squier's Serpent Symbol.

A tradition appears to have been common throughout Mexico and Central America, that a nation, bearded and white, bearing the cross,

${ }^{1}$ Brinton, Nyths of the Nery Horld, pp. 95. 96. 
should come from a distint land; hence in many places the Spaniards were welcomed as expected guests, the priests informing them that ancient prophecies had foretold the coming of a nation bearing the sacred sign, and that their own religion would disappear Strangers bringbefore it.' In Y'ucatan, the early Roman Catholic missioning the Cross. aries have preserved some of the hymns of the natives in which these ancient traditions have been embodied. Admitting all due allowance for the religious bias of the missionarics in their translation of the native chants, yet the substratum of truth is acknowledged by early historians. We quote a translation, said to be literal, of one hymn as an example:

"At the close of the thirteenth Age of the world, While the cities of Itza and Tancah still flourish, The sign of the Lord of the Sky will appear, The light of the dawn will illumine the land, And the Cross will be seen by the nations of men. A father to you will He be, Itzalanos, A brother to you, ye nations of Tancah, Receive well the bearded guests who are coming, Bringing the sign of the Lord from the daybreak, Of the Lord of the Sky, so clement yet powerful."

This is said to have been composed about 1450 , therefore before the arrival of the Europeans, and was used throughout Yucatan. ${ }^{2}$

Although the ancient official annals of Mexico were destroyed by the Spanish invaders, yet tradition and early histories have preserved the outlines. Successively the country has been occupied by the Chichimecs, the Colhuas, the Toltecs or Nahuas, and Antiquity of Mexican the Aztecs, who had been the inhabitants for more than Customs. two centuries before they were conquered by Cortez. Advanced as they were in civilization, still, in some respects, they were behind their predecessors. In architecture, they were surpassed by the Toltecs and Colhuas. The former of these occupied the land more than a thousand years before the Christian era. ${ }^{3}$ How much more ancient were their pre-

${ }^{1}$ Stephens, Yucratan, vol. ii., p. 377. Kingsborough, Mexico, vol. vi., pp. 4I8-420.

${ }^{2}$ Lizana, Hist. de N'uestra Señora de Itzamal, lib. ii., cap. I ; Brasseur, Hist. du Mexique, ii., p. 605, quoted in Brinton's $M_{j} t / h s$, p. 222.

"Brasseur de Bourbourg says: "In the histories written in the Nahualt language, the oldest certain date is 955 years before Christ." It is quoted from the Codex Chimalpopoca, and refers to a division of land, and it shows that they bad been settlers in the land long before the civil war made this necessary. Quoted in Baldwin's Ancient America, p. 204. Baldwin examines the subject of Antiquity more fully than these pages will allow. 
decessors, the Colhuas, we have not the means at hand for ascertaining. Concerning their edifices, Eubank writes: "I am not aware that there has been even a conjecture as to the date of these ruins. The concentric circles of some trees growing upon them mark 973 years, but how many centuries had elapsed from the ruin and desolation of the city, and for the accumulation of the soil over it ere this tree took root, can only be conjectured. ${ }^{1}$ Waldeck counted i 609 rings of annual growth upon a tree which he felled." 2

Enough for our purpose that they were pre-Christian, and that the cross as an honored symbol appears frequently upon them. Among the later Mexicans the cross was adored as the emblem of Quiateot, the god of rain. An old chronicler, when describing a temple, saith:

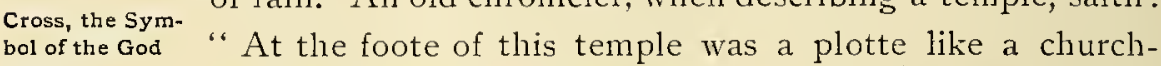
of Rain.

yard, well walled and garnished, in the midst whereof stoode a crosse of ten foote long, the which they adored for the god of Rayne, for at all times when they wanted rayne, they would go thither in procession devoutly, and offer to the crosse quayles sacrificed, for to appease the wrath that god seemed to have against them, and none was so acceptable a sacrifice as the blood of that little birde. They used to burn certain sweete gume, to perfume that god withall, and to besprinkle it with water, and this done, they believed assuredly to have rayne." s Even to our day traces of this superstitition are preserved among the Mexican Indians. Lieutenant Whipple, in his exploration for the route of the Pacific Railroad found boards erected bearing the Tau cross, consecrated, as he was told, to the god of rain. ${ }^{4}$

Among the ancient Mexicans, the showery month, Quiahuilt, received its name from the weeping god, Quiateot, their Nisroch. Water, as the generator, was honored under the symbol of the cross in Cibola. In Cozumel, in time of drought, sacrifices of quails and incense were offered to the cross, which was taken from its shrine in the temple and borne in procession, as in the ancient Christian litanies. The Aztecs

${ }^{1}$ Eubank, Hydraulics, p. I64.

${ }^{2}$ North Am. Rev., vol. li., p. 428.

3 The pleasant Historie of the conquest of West India, now called New Spain. Translated out of the Spanish tongue by $T . N ., 2678$. It is curious to note the similarity of a custom in Borera, one of the Hebrides. A stone cross was placed opposite the Church of S. Mary called the water cross. When the islanders wanted rain it was erected, when they had enough, it was laid down. Martin, Western Isles, p. 59 ; Brand, Antiquities, vol. iii., p. 169.

4 Whipple, Rep. for Exploration of the Pacific Railroad, vol. iii., p. 40. 
offered a more bloody sacrifice, crucifying young men and maidens, but, with cruel mercy, did not suffer them to die upon the cross, but put them to death with arrows. The Aztec goddess of rain bore a cross in her hand, and the Toltecs claimed that their deity, Quetzalcoatl, taught them the sign and ritual of the cross, hence his staff, or sceptre of power, resembled a crosier, and his mantle was covered with red crosses. ${ }^{1}$

The actual cross was also used as an instrument of punishment in Mexico, and, at times, with a refinement of cruelty unknown in the Eastern Hemisphere. The Itzæxes, a tribe in Yucatan, enclosed the criminal in a metallic cross, which was heated

The Cross as an Instrument of till the poor wretch expired. ${ }^{2}$ Among the Mexicans, judgPunishment. ing from their pictures and MSS., it would appear that the usual form of the cross of death was the S. Andrew's, or Saltire. ${ }^{3}$

South America probably was indebted for her religion to the same race who populated Mexico, for we find the Mexican cross in Popoyan and Cundinamarco, in New Granada.' Among the Muyscas in Cumana it was adored, and mothers placed their newCross in South America. born children under its protection against evil spirits." When the Muyscas sacrificed to the deity of water, they stretched cords across a lake, forming a cross, and at the intersection threw in offerings of gold, emeralds, and precious oils. ${ }^{\circ}$

In an ancient huaco, or catacomb, there was found a syrinx, or pandean pipes, cut out of a mass of lapis ollaris, the sides were decorated with Maltese (Greek ?) crosses and other symbols resembling Egyptian. The Incas reverenced a cross made out of a

In Peru. simple piece of jasper which had been bequeatled to them by an earlier people. ${ }^{8}$ Upon the side of one of the little hills which skirt Pisco Bay is an immense cross, about one hundred feet high, formed of stones inlaid in the rock. According to the native priests, it was miraculously made by an angel to warn Pizarro from his wicked tyranny. Doubtless, the tradition is much younger than the cross; and the Peruvians had learned enough from their conquerors from the old Christian world to

\footnotetext{
${ }^{1}$ Gould, Myths, vol. ii., p. Ios ; Brinton, Mytths, etc., pp. 95, 96.

2 Waldeck, p. 24, quoted in Bradford's Am. Antiqs., p. 293.

${ }^{3}$ Kingsborough, Mfexico, vol. ii., p. 37 ; iii., pp. I, 43, 66.

- Brinton, Myths, etc., p. 95. TTrans. Royal Soc., Edin., vol. xx., p. I2I.

${ }^{5}$ Gould, Myths, vol. ii., p. I07. $\quad{ }^{8}$ Gould, Nyths, vol, ii., p. 107.

${ }^{6}$ Brinton, Myths, p. 96 ,

${ }^{9}$ Schoolcraft, Indian Tribes, part v., p. 659.
} 
invent a story fitting for the time to a marvel. A cross also once adorned the Temple of the Sun at Cuzco, and a massive one of marble was found within a shrine in that city. Vega testifies that " although the cross was not worshipped, yet it was held in great veneration." Crosses of copper, probably worn as amulets, were common.

Still farther south, Martin Dobrizhoffer writes of a nation in Paraguay: "I saw not only a cross marked on the foreheads of the Abipones cross in but likewise black crosses woven in the red woollen garParaguay. ments of many. It is a surprising circumstance that they did this before they were acquainted with the religion of Christ, when
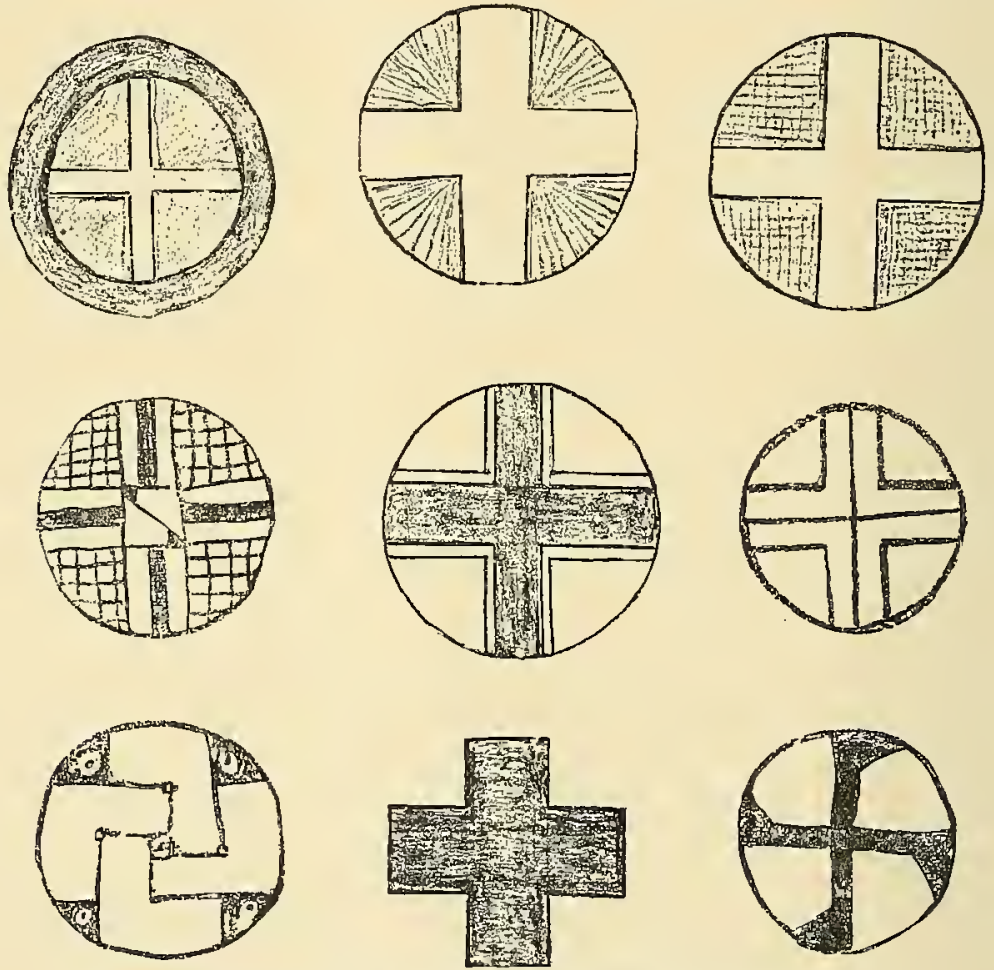

Emblems Found in the Mounds in the Mississippi and Ohio Valleys. From Blake's The Cross, Anciont and Alodern.

the signification and merits of the cross were unknown to them. This custom was handed down from their ancestors." "

Even in the extreme bounds of the continent the Patagonians tat-

${ }^{2}$ From vol, i., p. 65 ; vol. ii., pp. $467,468$.

2 Dobrizhoffer, Account of the Albipones, vol. ii., p. 20. 
tooed the holy sign upon their foreheads, hecause it was a custom transnitted from their forefathers " not derived from Spaniards."

Among the ruder nations of the Northern Continent are found aboriginal relics of the cross. The Mississippi Valley is rich in Indian remains. Curiously shaped pieces of galena, which at first crossamong were presumed to be money, but by modern archæologists the Ruder are pronounced to be either ornaments or mcdals, have America. been found marked with the crux ansata, and a vase containing, among other relics, a coin or medal bearing a cross crosslet, was dug up in I 844 , near Natchez."

The mounds in the Ohio and Mississippi valleys are of various shapes. Some resemble the human figure, some animals, some serpents; for instance, an elevation in Adams County, Ohio, repre- Mounds. sents a serpent seven hundred feet long swallowing an $\mathrm{egg}^{3}$; others are circular, and many are cruciform. The circular mounds

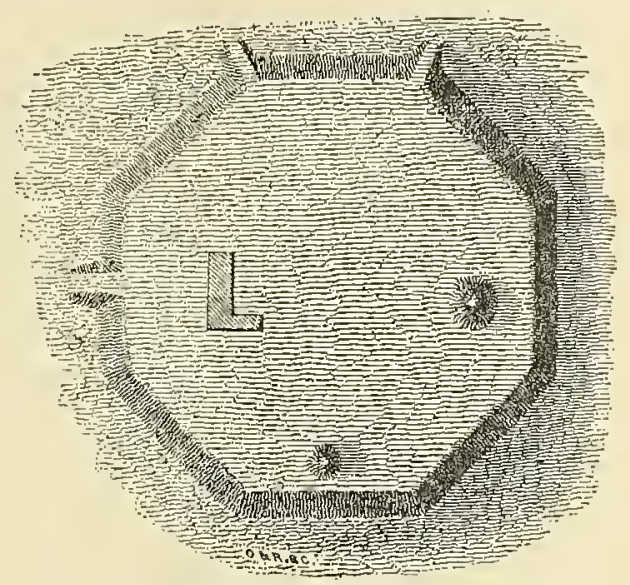

Temple Mound, Lovedale, Kentucky. From Squier's Serpent Symbol in America. may have been used as forts or habitations, and the forms of the others indicate their object. The cruciform mounds, ill adapted for fortification or habitation, must have been erected for some other purpose. Is it not likely that they were erected for sacrificial or religious intent? Mounds of a similar shape are not confined to this country, and civilization has, doubtless, obliterated many in the Eastern Continent. But the great resemblance between those of widely separated countries should be noted.

As to the antiquity of these it is impossible even to conjccture, as they are the work of nations who lived so long before the race of Indians who inhabited this country when visited by Europeans, that even all tradition of them had been lost. The mound- Their Antiquity. builders were far more advanced in civilization than their successors.

1 King and Fitzroy, Narrative of Ten I'ear's' I'oyage, vol. i., p, 90.

'Dickeson, Am. Numismatic Manual, pl. iv., figs. I, I, p. 43. Dr. Anthon, in the Nunismatic and _4 rchaological Fournal, I869, decides against their being coins.

${ }^{3}$ Squier, Ancient Monuments in the Mississippi Valley, p. 98. 
Many centuries must have elapsed before their once cultivated fields, villages, and mounds were covered with the immense forests through which the later red man roved and hunted when the white man first visited him. General Harrison has shown that the great diversity of species of trees plainly indicates that the forests which still cover many of these sites are of second growth, as the primitive forests are more generally of one or of a few species. Yet there are patriarchs, for Sir Charles Lyell mentions that eight hundred rings were counted in the trunk of a tree growing on a mound at Marietta.

Again, the skeletons of the mound-builders show, by their extreme

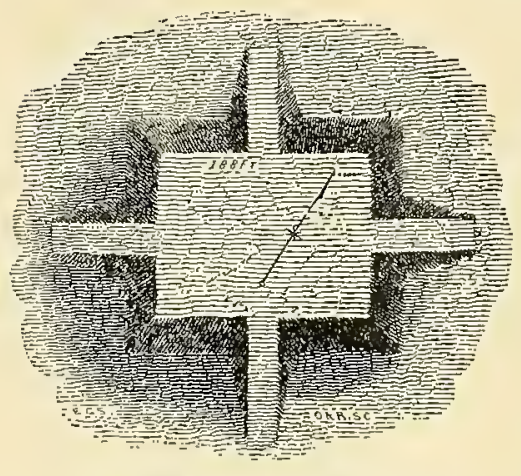

Temple Mound, Marietta, Olio. From Squier's Serpent Symbol in America. decay, immense age. Human remains found near the surface are supposed to be those of later Indians. The original dwellers in the land are interred always within the mounds, or near the bottom, and these are so decayed as to crumble to pieces on removal. Indeed, only one skull of a mound-builder has been preserved.' Yet we know that human skeletons, sound and well preserved, and known to be nearly two thousand years old, have been found in England, and other parts of Europe, although that damp soil has been less fitted for preservation than the dry, compact earth of the mounds.

Other proofs of antiquity might be adduced, such as the changes marked by the water-courses, and the evidence of the copper mines which show that they had been worked for a long period before their desertion, and yet, perhaps a still longer one has passed since then, as evinced by the immense forest growth; but it is needless to multiply proof. We have only room to instance a few examples. ${ }^{2}$

In Tarleton, Ohio, is a mound in the form of a Greek cross. Its arms, ninety feet in length by three in height, are turned toward the cardinal points of the compass. ${ }^{3} \quad$ It resembles an earthwork in the village

I At a meeting of the American Association held at Dubuque, August 26, 1872, reported in the Tribune, several other skulls were shown, but it seems doubtful if they were of the original mound-builders. Their successors huried their dead in the mounds, but nearer the surface. $-N$. Y. Tribune, August 27, $1872 . \quad{ }^{2}$ Baldwin, Ancient America, chaps. i., ii., ii.

${ }^{3}$ Squier, Ancient Mlonuments in Mississippi Valley, p. 98. 
of Banwell, England. Another proof of the universality of the cross even in such monuments as these. Similar mounds are found in Wisconsin and Oregon, some with the transverse placed ob-

liquely. Doubtless other examples will be discovered west Mounds in ohio. of the Mississippi, when the archeologist, as well as the surveyor and miner, explore that region.

The later tribes who inhabited the Atlantic States used the figure of the cross in their religious rites. The Lenni Lenape, once one of the most numerous and widely spread tribes on the Atlantic coast, in their sacrifices for rain placed upon a figure of a cross some red stuff, a gourd, and some tobacco. The Creeks, at their festival of the Busk, a feast celebrated to the four winds, formed a cross out of four logs, pointing

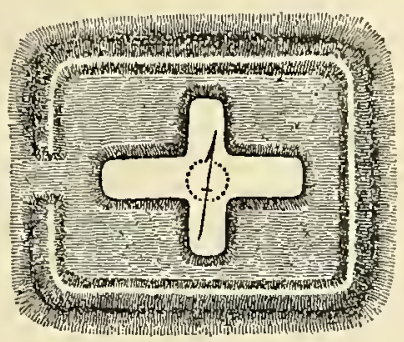

Roman Mound near Banwell, Wiltshire, England.

From Squier's Antiquitic's of New York and the West. to the cardinal points, and at the intersection built a fire."

That not a link may be wanting in the chain which binds all nations, Jew, Gentile, and Pagan, even the islands between the Western and Eastern Continents are hallowed by the " shadow of the Cross." The inhabitants of the Gambier Islands tattooed themselves with this emblem, and the discoverers of the

Cross in 1slands between the Continents. Mulgrave Islands were welcomed by natives decorated with necklaces from which crosses were suspended. ${ }^{2}$ So also in the isles of Tonga, Viti, and Easter. Two colossal statues from the last, bearing the Tau upon their backs, are now in the British Museum. Thus we have completed the circuit of the globe, and find this holy symbol with a sacred signification in ages far apart and among nations widely separated, and, for the most part, utterly ignorant of each other's existence. ${ }^{3}$ And yet all embodying, in a greater or less degree, according to their advance in civilization, the primal truth of all religions adumbrating the great truth of Christianity,-Redemption by sacrifice,-symbolized by the Cross.

${ }^{I}$ Brinton, $M Y y t h s$, etc., p. 98 .

${ }^{2}$ Mavor, Vogages, vol x., p. 159; Beechey, Narrative, etc., p. 126.

${ }^{3}$ Edin. Rez., vol. cxxxi., p. 231 . 


\section{CHAPTER II}

TYPES OF THE CROSS

"THE Law was a shadow of good to come. This good was Christ;

1 the law was a shadow; when the sun is behind, the shadow is before, when the sun is before, the shadow is behind: so was it in Christ to them of old; this Sun was behind, and therefore the Law or shadow was before: to us under grace the Sun is before: and so now the shadow or ceremonies of the Law are behind. . . . And those that went before, and they that followed after, they all sang, Hosama to the Son of God." "

In the present chapter the magnitude of the " stumbling block" which the Cross was to the Jews and Gentiles is explained, but the greatness of the scandal did not in one whit deter the early teachers of Christianity from preaching Christ, the promised Messiah crucified, not only literally upon Calvary, the abhorred place of execution for the vilest of criminals, but also in type and shadow in the lives of the patriarchs, and in the Law and the Prophets. Even Justin Martyr, although he knew that he stirred to its depths the prejudice of his adversary Trypho, the Jew, especially urges the manner of the Sacrifice foreshadowed by the types. True, in their desire to show that all the particulars of Christ's death were symbolically set forth in the O1d Testament, the Fathers resorted to, what appears to us, strained and far-fetched images, yet the knowledge of these is necessary to understand the expression of the love for Christ which is exhibited in the literature and art of the mediaval ages.

The types of the Cross deduced from the IIoly Scriptures by the early Christian writers may be classified as: Those which refer to the material Classification of the Cross; Those which symbolize its form; and, Those of Types. which shadow forth its triumph." The last class falls not within our province. To quote a tithe of the references by the Fathers

\footnotetext{
${ }^{1}$ Sutton, Learn to Tive, chap. i., sec. It.
}

${ }^{2}$ Haslam, Cross and Serpent, p. I87. 
relative to the others would require a folio; therefore only a few pertinent extracts will be given.

Of the first class, the most prominent in point of time and in importance, is the Tree of Life. "The Tree of Life, which was planted by God in Paradisc, prefigures the precious Cross," writes Damascenus, " for after that death was by the means of a Tree of Life. Tree, it was needful that by a Tree should be given Life, and the Resurrection." " Like the Tau cross, representations of a sacred tree, as the symbolical source of life, long preceded Christianity. The palm (Phanix dactylifcra) was thus employed by the Egypt-

The Palm. ians, and by them transmitted to other nations. On a stele, preserved in the Berlin Museum, found by Dr. Lepsius in the village of Abousir, near the Great Pyramid, the palm is thus delineated: From its stem proceed two arms, one administers fruit or the bread of life to a kneeling person, the other pours from a vase the water of life into the mouth of the recipient. The date of the stele is at least fifteen hundred years before Christ. The sacred symbolism of the palm was recognized under both dispensations in the Holy Scriptures. Solomon adorned the Temple with its representations, and to S. John in Patmos was revealed " the Tree of Life which bare twelve manner of fruits, and yielded her fruit every month, and the leaves of the tree were for the healing of the nations" (Rev. xxii., 2). So of the palm it was believed that it put forth a shoot every month, and, as its leaves were used for writing purposes, the words of the Gospel may have been inscribed upon them.

The early and mediæval Christian artists frequently represented the Tree of Life as a palm. There is an example in the mosaic in the apse of S. John Lateran at Rome. The tree is guarded by an angel. Upon a branch is perched a phœenix (the symbol of immortality), an aureole surrounding its head; and the first two persons of the Holy Trinity stand on either side.

As the Cross was sometimes more than a symbol, being used as synonymous with Christ, so also was the palm-tree. In an Evangelium of the ninth century, in the British Museum, a miniature represents the four Evangelists gazing up to a palm on the top

Palm Synonymous with the Cross. of which is placed the cross, with the $A$ and $\Omega$ suspended from its arms. ${ }^{2}$

'S. John Damascenus, Orthodox Fidei, lib. iv., c. I 2 .

${ }^{2}$ See Dr. Barlow's able article in The Builder, Oct. 30, 1858. In the Assyrian sculptures the winged figures personifying principles of the Deity are placed on each side of a palm-tree, 
Noah's ark is a favorite type of the cross among the Fathers. Justin Martyr says: "For Christ, though he was the first begotten of every creature, was also again made the author of a new race, who are regener-

Noah's Ark a Type of the Cross. ated through him by water and faith, and wood, which was a type of the cross, even as Noe was saved by wood, sailing on the water with his family. IVherefore when the prophet says, 'In the time of Noe have I saved thee,' as I said before, he speaks to a people that were faithful to God, and had these types." "

The next type is derived from the history of Isaac. " A clearer type can scarcely be conceived of the Saviour of the world, in whom all The wood of nations of earth were to be blessed, than Isaac was. . . . Isaac's Sacrifice. Therefore Isaac bearing the wood, did signify Christ bearing the Cross," says Bishop Pearson, adding, " this is not only the observation of the Christians, but the Jews themselves have referred to this type unto that custom; for upon Gen. xxii., 6- And Abraham took the wood of the burnt offering and laid it upon Isaac his son '- the lesser Bereshith hath this note, 'as a man carries his cross upon his shoulders.' " 2 Isaac in this prefigured the Saviour's sacerdotal capacity, for it was part of the priest's office to carry the wood to the altar. ${ }^{3}$

It may be objected that the symbolism is not perfect from the fact that Isaac was not slain, but in truth the figure is the more closely fulDeath, the work filled. Isaac fell not by his father's hand, because God in of the Devil, the Scriptures clearly points out that death is not His work,
not of God.

but that of the adversary, the devil. "For God made not death, neither hath He pleasure in the destruction of the living." (Wisdom of Solomon i., I3.) "God created man to be immortal, and made him to be an image of his own eternity. Nevertheless, through envy of the devil came death into the world." $(I b ., \text { ii., 23, 24. })^{4}$ S. Gregory also assigns as a reason, "In this sacrifice for us, He died as to His humanity, but His immortality remained from His divinity." '

holding in their hands a pine cone, as the Egyptian deities do the crux ansata. The cones point towards the tree, significant of a connection with it, as the source from which divine life is derived.

'Justin Martyr, Dialog. with Trypho, \$ cxxxviii. The words quoted probably refer to Isa. Iiv., 8,9 . There is a mystery in the very name of the vessel appointed by God for the salvation of his chosen race. On the symbolical meaning of the name $A r k$, see the note at the end of this chapter.

2 Pearson on the Creed, art. iv., note, P. 303, London ed., I839.

3 Origen in Gen., Hom., 8.

4 Of course the Apocrypha is not cited as positive proof, yet the Church selects, at times, lessons from it, and the interpretation given above is not strained.

${ }^{5} \mathrm{~S}$. Gregory in Ezek., lib. i., Hom. 6. 
The gist of patristic interpretation may be summed up in the words of S. Ephraim: "Isaac ascended the mountain bearing the wood that he might be immolated like an innocent lamb, and the Saviour went up Mount Calvary that He might be offered as a lamb

S. Ephraim. for us. When thou contemplatest the sword (Abraham's knife), consider the lance. When thou lookest upon the wood, let thy mind dwell upon the Cross. When thou seest the fire, embrace in thy thoughts the love and desire; and when thou beholdest the ram caught by the horns in the plant Sabec, behold the Lamb of God, see Him with pierced hands hanging from the Cross. The plant called Sabec is, by interpretation, remission, or liberation. The old man dismissed, and liberated, his son from slaughter, designating the Cross which remitted sins to the world and ministered life to it. The ram suspended in the shrub Sabec alone mystically liberated Isaac, but the Lamb of God suspended upon the cross liberated the world from death and hell." '

The change of type from Isaac to the ram presents no difficulty. " Both Isaac who was not slain, and the ram which was slain, were types of Christ crucified. The first represented him in his divine nature, which died not, and in his sacerdotal office, or capacity, as he exercised it upon the cross; the second exhibited him purely in his human nature, and only so far as he was a sacrifice.",

S. Augustine supposes that the thicket was of briars, prefiguring the crown of thorns, and S. Basil finds in it the type of the nails. ${ }^{3}$

In mediæval art Isaac is frequently represented as bearing the wood arranged as a cross, as may be seen in the sculptures in the west porch of Notre-Dame in Rheims; in a window in the north aisle of Notre-Dame in Chartres; and also in a window in the Isaac in Art. Cathedral of Bourges, from which our illustration is taken. Date, thirteenth century. ${ }^{4}$

IS. Ephraim, Serm. de Abraham.

${ }^{q}$ Origen, in loc., Hom. 8. S. Ambrose, De Abraham, lib. i, c. $8, \$ 77$. S. Aug., Ps. 5 I, \$ 5. S. Chrysost., in loc., Hom. 47, etc. Paulinus considers the lamb to have been a prelude to the Paschal lamb which was in itself a type of Christ crucified. Ep. 10, ad Sever. S. Ambrose thinks the ram was chosen as best representing the Prince, or Leader of the Flock. $D e$ Abraham, lib. i, c. 8, \& 77. Parker, Bibliothera Biblica, Gen. xxii., 13.

${ }^{3}$ S. Aug., De Civ. Dei., lib. xvi, c. 31 (chap. 32 in Eng. Trans., I6ro). S. Basil, Seleuc. Orat., 7, p. 43. S. Prosper traces the analogy of the types, and literal Sacrifice, and concludes that this was the Day of Christ which "Abraham saw, and was glad." S. John viii., 56. De Prom. et Pradict. Dei., par. I, c. I 7. S. Ambrose, lib. i., c. $8, \$ 77,78$. S. Chrysos., in v. 12, 13, Hom., 47. Parker, Biblio. Bib., Gen. xxii, 13.

${ }^{4}$ Didron, Christ. Icont, vol. i., p. 370 and note. 
The ladder in Jacob's dream, is, strictly speaking, rather a type of Him through whose intercession the angelic powers are " ministers to the heirs of salvation " (Heb. i. 14), than of the instrument Jacob's Ladder.

of $\mathrm{His}$ sacrifice, yet the early Christian writers, as well as the artists, often use the Cross as synonymous with the Crucified, and frequently refer to this figure.

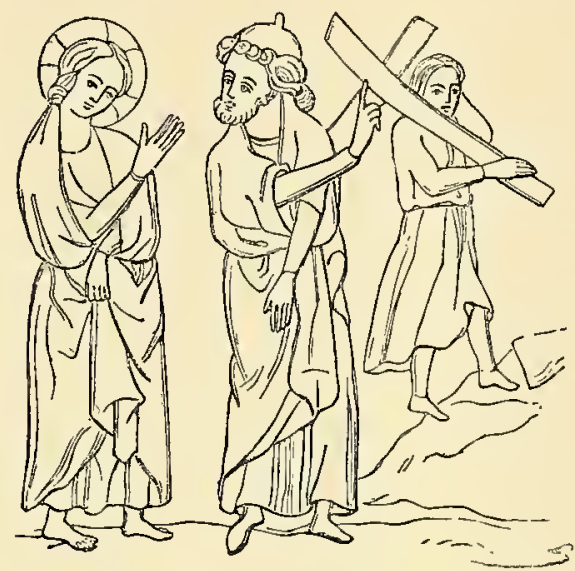

Isaac Carrying the Wood.

From Janieson's History of our Lord.

S. Jerome considers the descending angels as typical of the Jews, the ascending, of the Gentiles. ${ }^{\text {I }}$ Bosio symbolizes the height, width, length, and depth of the Cross, as love, good works, discipline, and faith; the four steps in the ladder of the Christian's Cross. ${ }^{2}$

Concerning the rod of Moses," the Fathers are voluminous in their The Rod of comments on it as a Moses. type of the Cross. Origen concisely gives the pith. On the swallowing up of the magicians' serpent-changed rods (Ex. vii., I 2), he says, " The serpent is used in Scriptures as a symbol of wisdom and knowledge (S. Matt. x., I6; Gen. iii., I), and Moses' rod being changed, devoured those of the magicians. Thus the Cross of Christ, the preaching of which seemed foolishness, and which is typically lodged in the writings of Moses, according to our Lord's saying, 'For he wrote of me' (S. John v., 46), this Cross, I say, being cast on the ground, that is, after it once reached the faith and belief of the world, was turned into wisdom, and into such marvellous and mighty wisdom as devoured all the wisdom of Egypt, that is, of this

1 S. Jerome, Ps. 9 r.

${ }^{2}$ Bosio, La Trionfante e Gloriosa Croce, lib. iii., cap. 5 .

${ }^{3}$ In the Traditionary Hist. of the Cross it is shown that Moses" rod was made of a part of the Tree of Life in Paradise. It was handed down by the patriarchs to Joseph. After his death it was seized by Pharaoh. Jethro being friendly to the Israelites, secretly conveyed it away and planted it in his garden. When Moses took refuge with Jethro, and was beloved by Zipporah, she prevailed upon her father to consent to the marriage on condition that Moses could pluck from the ground the rod (zaphir), which none of her other suitors could move. Noses perceived that upon it was written the sacred Tetragrammaton which he only could pronounce. Hence he was able to perform the miracle. Modie's What is Your Nane?, p. I67. See also Sale's Koran, vol. ii., p. 183, note. 
world. The rod of Moses is (in figure) the Cross of Christ, by which the world is conquered and its princes trimmphed over." 1

S. Augustine says, " The Cross which is believed to be foolishness to the infidels, is turned against the serpent, that is, wisdom, and in sacred knowledge it devoured all the wisdom of the world." 2 Severianus supposes that when Moses struck the rock, he did so, as did the Jews with the blood of the Paschal lamb, "in the shape of the cross, that even nature and inanimate things might venerate the Cross, for the king being absent, we venerate the image of the king. The sign is sufficient." s S. Augustine further writes, Moses did nothing without "the wood of the sacrament. God despised not the aid of the rod, but ennobled it, that we might know the mystery of the wood to come, a shadow of the sacrament figured in the rod." " If the Red Sea was to be divided, Moses was commanded to lift up his rod, and the sea, recognizing the figure of the wood to come, opened a safe path to the people." If he came to the bitter waters of Marah, unless it received the wood within itself, it was not sweetened. Which thing was a sign, through the use of the Cross, the bitterness of nations was to be turned to sweetness. If the people have not water to drink, the rock is struck by the wood, and a virtue imparted which it had not by nature. If the cruel host of Amalek is to be slain, Joshua, the son of $\mathrm{Nun}$, is commanded to hold the rod in his hands, and Moses stretches his arms in the shape of the Cross, and thus by means of the figure of the Cross the invincible enemies are overcome." "

" God was pleased," says S. Antony, “to make choice of Moses' shepherd staff, or crook, which was always in his hand, to give him the

'Origen in Ex., c. 7, Hom. 4., compare S. Aug., De Tempore, ser. 86, 87. The rod was a symbol of power. "The rod of Moses in his hand and antecedently to the change of it, implied the state of the Hebrews in Egypt as long as Joseph flourished and ruled there, swaying, as it were, the very sceptre of that kingdom. This rod cast on the ground, signified the servile and abject condition of the Hebrews after Joseph's death, when they were tied down to continnal hard labor in clay and brick; and being turned into a serpent it was very obviously a representation of this people as abhorred, and worried by the Egyptians. . . . The rod restored to itself again, expressed that happy change when they were delivered from their slavery, and obtained not only liberty, but power and rule." Lyr. Tost. Perer. Parker, Biblio. Bib. Ex. iv., 3. Serpent, the symtiol of wisdon; see also Bunsen's Keys of S. Peter.

2. Ang., De Temp., ser. 86, 87.

${ }^{3}$ Sever., Orat. 4 In Cruce, etc. Orat. 3 De Imagine.

4 There is a tradition among the Jews, that the sea was divided into twelve openings for the separate reception and safety of each tribe. Parker, Biblio. Bib., Ex. iv., 21.

${ }^{5}$ S. Aug., De Temp., ser. Ior, 90, Hom. 27, 50. 
sign, or test, of a miracle, to keep him mindful of his sometime obscure condition. The opening of the Red Sea was not done by the column of fire, or the Shechinah, but by Moses' rod." The rod is

Moses' Rod.

the special ensign of power. Moses had his, and Aaron, Pharaoh, and Nebuchadnezzar theirs, saith S. Hilary." " This rod of Moses by which Egpyt was subdued is in a figure the Cross of Christ, by which the world is conquered," saith Origen." "Death came by the serpent, if so, wood in the serpent showed Christ crucified," writes S. Augustine. ${ }^{3}$ Again the rod turning into a serpent, and being returned into a rod, showed the Resurrection, argues S. Cyril. ${ }^{4}$ And also the rod and the serpent were emblems of power and wisdom. As S. Ambrose says, the serpent was a symbol of the divine wisdom in the decree and economy of Christ crucified. ${ }^{5}$

The Jews admitted that the brazen serpent had a symbolic meaning the mystery of which they could not understand. So confessed one of the Jews present at the discussion of Justin Martyr with Brazen Serpent. Trypho. ${ }^{6}$ The true significance is recognized by the author of the Wisdom of Solomon, who terms the brazen serpent " a sign of salvation. . . For he that turned himself toward it was not saved by the thing that he saw, but by thee, that art the Saviour of all." (Wisdom xxi., 6, 7.) Our Blessed Saviour himself quoted the figure, applying it personally. (S. John iii., 14.) "The lifting up of the serpent is the death of Christ," saith S. Augustine, " the cause, by a certain mode of construction, being put for the effect. . . . Our Lord, however, did not transfer $\sin , i$. $c$, the poison of the serpent, to his flesh, but death, in order that, in the likeness of sinful flesh, there might be punishment without sin, by virtue of which sinful flesh might be delivered both from punishment and from sin." " "Christ is therefore the serpent," says Nicetas, "like as in the similitude of sin $\mathrm{He}$ was made man." And again, " The brazen serpent was not verily a serpent, but the figure of one, it had no venom. In the same manner, Christ, who had not the venom of sin, was not one of us, who bear the form of a ser-

${ }^{1} \mathrm{~S} . \mathrm{Hilary}$ in Ps. 134, Col. 405.

${ }^{2}$ Origen in Exodus, c. 7, Hom. 4, p. 42.

${ }^{3} \mathrm{~S}$. Aug. in Ps. $73, \$ 5$.

${ }^{4}$ S. Cyril, Catech., 18. Parker, Biblio. Bib., Ex. iv., 3, 4.

${ }^{5}$ S. Ambrose, Ps. I08, ser. 6, § 8 . Parker, Biblio. Bib., Num. xxi., 8.

${ }^{6}$ Justin Martyr, Dialog. with 7 \% 1 pho, \$ 94.

"S. Aug., quoted in Catena Aurea, S. John iii., I4. 
pent." " That is, have the poison of wickedness. "Sce then the aptness of the figure," exclaims Theophylact, " the figure of the serpent has the appearance of the beast, but not its poison; in the same way Christ came in the likeness of sinful flesh, being free from sin." a

That the early Church fully understood the type, S. Augustine shows when he writes, " To prefigure His Cross, Moses, by the merciful command of God raised aloft upon a pole the image of a serpent in the desert, that the likeness of sinful flesh, which must be crucified in Christ, might be prefigured." s

Another witnesses: "If any one feigneth not to see that the image of the brazen serpent, after the manner of one hanging, signified a type of the Cross of the Lord which was to deliver us from serpents, that is, from the angels of the Devil, while it hanged up the Devil, that is, the serpent which had been slain by its means (or whatever other interpretation of that figure hath been revealed to more worthy men), so long as the apostle declareth that all things happence at that time to the people in a figurc (I Cor. x., II). I am content that the same God who in the Law forbade any likeness to be made, should by a special mandate have interposed His command that the likeness of a serpent should be made. If thou obeyest the same God, thou hast His law. Thou shall not make the likeness of any thing, if thou regardest also the command touching the likeness made afterwards, do thou also follow Moses' example, and not make any image contrary to the law, unless God command thee likewise. " 4

Yet another says, "It may seem unaccountable that they should be commanded to look up to a serpent in order to their safety. Why not rather to Heaven, or to the Tabernacle, or to the holy things reposited therein, to the ark, or the mercy seat, or the cherubim, or the altar, or the candlestick, or the veil? Why not any of these rather than an image, whether graven or cast, which Moses had but so little time before forbidden absolutely to be made. What then can we make of this but that it was a type of our Saviour's crucifixion as himself hath told us ? But still it may be asked why the figure of a serpent should be chosen

1 Nicetas in notes ad 2 Orat. in Pascha. Greg. Razianzen.

2 Theophylact, in loc., Catena Aurea, S. John iii., I4.

${ }^{3}$ S. Aug., Ps. cxix., v. 123., vol. v., p. 430, Oxf. Trans. S. Aug. on S. John, Hom. xii., also S. Aug., City of God, b. x, c. 8.

Tertullian on Idolatry, vii., 6 . 
. for a type of Christ? I answer that this serpent was a symbol, or emblem, of wisdom, of the divine wisdom in the decree and economy of Christ crucified. And as this brazen serpent had nothing of poison in

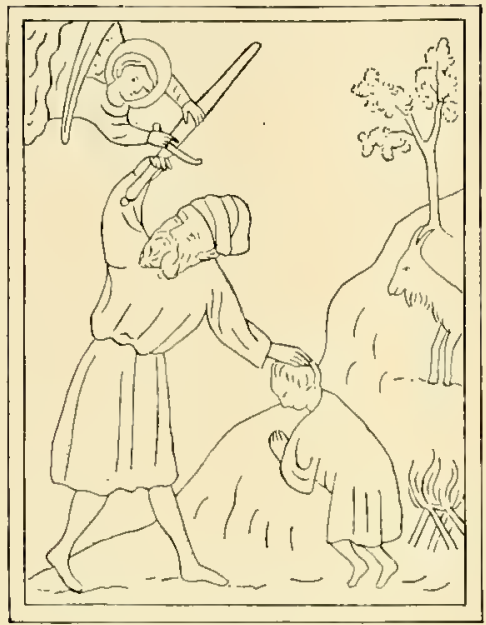

Sacrifice of Isaac.

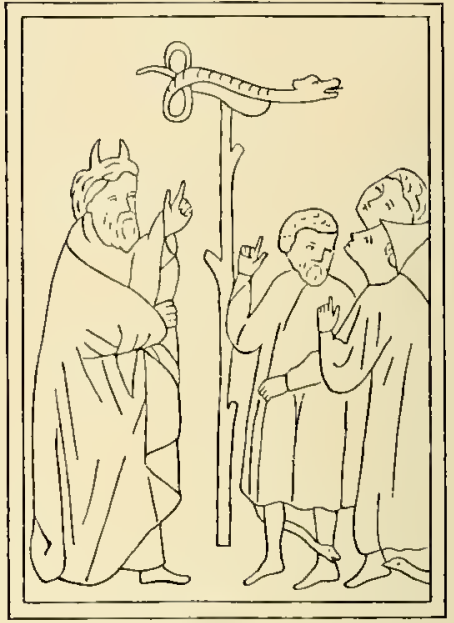

The Brazen Serpent.

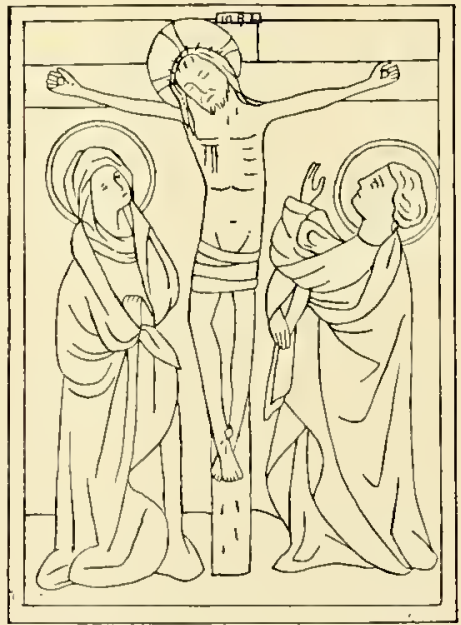

The Crucifixion.

From Twining's Symbols of Early and Mediaval Christian Art.

it, so the blessed antitype was sent in the likeness of sinful flesh (Rom. viii., 3), yet without $\sin$ (Isa. liii., 9)."

The illustration is from a book of the fifteenth century, in the British

${ }^{1}$ Severian., quoted in Parker's Biblio. Bib., Nnm. xxi., 8. 
Museum. The Venerable Bede gives us early authority for the use of the type in art in England. In A.D. 677, the monasteries of S. Peter at Wearmouth, and S. Paul's at Jarrow were founded by S. Bennet who " adorned it with many pictures disposed in such a manner as to represent the harmony between the Old and New Testaments, and the conformity of the figures, the one with the reality of the other; thus Isaac carrying the wood which was to make the sacrifice of himself, was explained by Christ carrying the Cross on which he was to finish his sacrifice, and the brazen serpent was illustrated by our Lord's crucifixion."

Another type is the wood cast into the water at Marah. S. Ambrose interprets it: " By the bitter water is designated the Law of Moses, but by the wood the Passion of Christ, which was completed by the wood of the Cross. The people who came out of Egypt found bitter water because they received the law which

Wood Cast in the Pool of Marah. they were not able to fulfil, but to the Gentiles coming to the faith of Christ the bitterness of the law is changed through the Passion and Resurrection of Christ into sweetness." "2 Others of the Fathers considered the calamities of life figured by the bitter waters which are sweetened by the grace of the Cross, the sign of which we receive in holy Baptism, by which also we are revivified, even as those dying of thirst in the wilderness are refreshed by living water. ${ }^{3}$

Concerning the cluster of grapes borne by the spies of Israel as an earnest from the Promised Land, S. Augustine writes, " For even the Divine Word may be understood by the grape; for the Lord even has been called a cluster of grapes, which they The Cluster of Grapes. that were sent before by the people of Israel brought from the land of promise hanging on a staff crucified as it were." " "Jesus Christ is the cluster," says S. Gregory, " exhibiting himself on the wood that bore Him up, whose blood is joyfully drank by the saints in order to their salvation in the Kingdom of Heaven." "The two bearers are sometimes taken for the Old and New Testaments. S. Ephraim considers them as typical of the "Prophets and Apostles." "Perhaps the interpretation

1 Twining, Symbols of Early and Medicual Christian Art, p. 88.

${ }^{2}$ S. Ambrose, Super. Apocal., c. 6.

3 S. Ang., in loc., Tertul. ad Fudeos, c. I3.

4 S. Ang., Ps. 8.

${ }^{5}$ S. Greg., Nyssen, in Cant. Cor., Hom. 3.

${ }^{6} \mathrm{~S}$. Ephraim, Rhythum, xviii., note K., Oxf. Trans. 
of S. Ambrose is better: "The one who preceded was the Jewish Church, heralding by type and prophecy the coming Messiah, yet saw Him not, and despised Him; the bearer who followed was the Gentile which had Him constantly before his eyes." .

The vine and grapes naturally commended themselves to art. In a window of Lullingstone Church, Kent, England, Christ is represented nailed to a vine in the form of a $\mathrm{Y}$ or Pall cross rising from Use in Art. the middle of a cistern, from one side of which water is flowing. People of all ranks approach and some are filling vessels. A monk is digging a channel to let the water flow freely. Above is the text, "If ani man thirst, come to me and drink" (S. John vii., 37). The date of the glass is about $1520 .^{2}$

A type more familiar in art than in the writings of the Fathers is, the action of the Widow of Sarepta when, gathering two sticks to dress food The Two Sticks for herself and son, she is met by Elijah. S. Augustine Gathered by the explains the woman as typifying the Church, and the sticks,
widow of Sarepta. not only in material but number, the Cross. ${ }^{3}$

The mediæval artists seized the tradition that the Widow held the wood in the form of a cross, and perpetuated it, as in the windows of Notre-Dame in Chartres, and on the sculptures at Rheims." The cross is generally represented as a Saltire. The illustration is from a window in the cathedral of Bourges and is of the thirteenth century. The cross is of a green color, as is frequently the case when the symbolic, and not the actual tree is represented.

S. Augustine also draws a simile from the staff of Elisha when laid upon the dead child of the Shunamite woman. "The staff without Elisha avails naught, because the Cross without Christ is Staff of Elisha.

powerless. Therefore the blessed Elisha ascends into the chamber, as Christ ascends upon the Cross, Elisha bows himself that the child may be resuscitated, so Christ humbled himself that he might raise up the world lying in sin. See how this man of perfect age contracts himself that he may agree with this little dead child. What Elisha prefigured in the boy, Christ filled up in the whole human race." s

I S. Ambrose, ser. 72 De Natale. S. Cyprian. See also S. Isidore, Num. xi., and others.

${ }^{2}$ Archrological Foumal, 1856 . The blessed Virgin is sometimes compared to the Promised Land which produced the grapes.

${ }^{3}$ S. Augustine, in lib. 1. Homitiarum, Hom. 18, et Hon. Contra Faustum, lib. xii, c. 34.

"Didron, Christ. Icon., vol, i., p. 37 and note. $\quad{ }^{5}$ S. Aug., De Tempore, ser. 206. 
These are only a part of the types in which the warmth of carly Christian love delighted to trace the mystery of the Cross. The club of Cain, Aaron's rod that budded, Rahab's scarlet cord, the nail of the tent used by Jael, Gideon's oak, David's staff and his judgment seat, the axe rescued by Elisha, etc., were pressed into the service. ${ }^{1}$ And although these typical and allegorical representations may appear strained and far-fetched to us, they were " used in compliance with the custom of those times, and liad their use amongst those who had been familiarized to that sort of argument." 2

The types of the Cross in the New Testament are few yet significant. Prominent is that of the bier of the

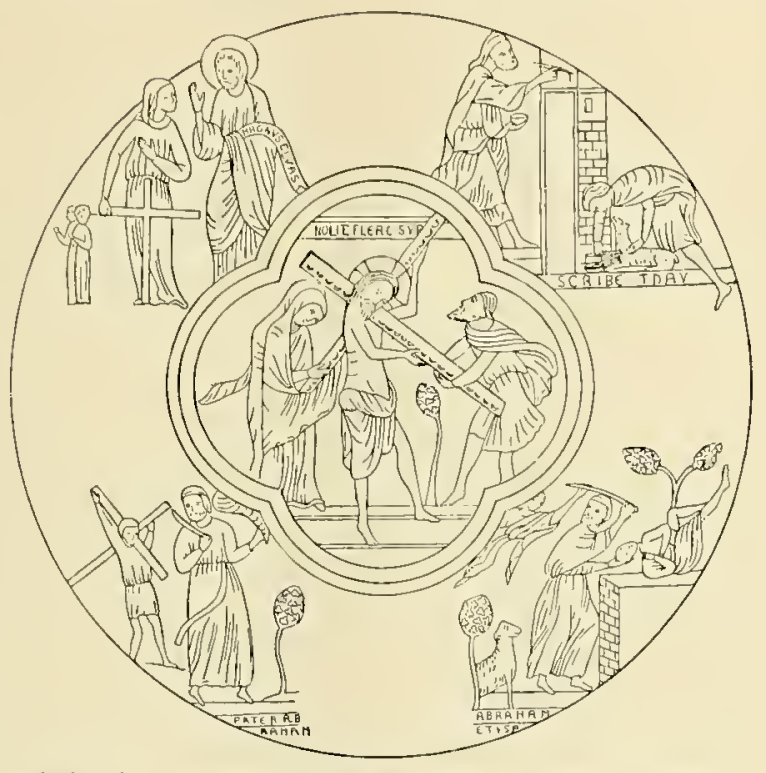

Window in Cathedral at Bourges, From Twining's Symbols. son of the Widow of Nain. S. Ambrose says, " There was hope of his rising again, because he was borne on wood, which though before it did not benefit us, yet after Christ had touched cross in the New it began to profit unto life, that it might be a sign that salvation was to be extended to the people by the wood of the Cross." 3 As a later writer remarks: "Here it is not Testament. Son of the the dead that He touches, but the bier; like the staff of Elisha, laid on the dead child, He touches us but through the wood of his Cross; His communication of Himself to us is through the dead, and dead-bearing but life-giving wood." ‘

A happy similitude is that of the ship tossed upon the waves of the Lake of Genneseret. "It is necessary that we should be in the ship,"

1 For a fuller account of these types see Bosio, La Trionfante Croce, lib. iii.

${ }^{2}$ Prelim. Diss. to Brown's Trans. of Fustin Martyr, p. ii., ed. I846.

$3 \mathrm{~S}$. Ambrose, in Lucan, cap. 7.

'Isaac Williams, Our Lord's Ministry, Second Year, p. 103. 
saith S. Augustine, " but this wood in which our infirmities are carried, is the Cross of Christ, in which we are signed and saved from the Ship on Lake of drowning of the world." " "The wood of the Cross is the Genneseret. Ship of our safety," '2 saith S. Ambrose.

Frequent reference is made by the Fathers to the light which was to be placed not under a bushel, but upon a candlestick. S. Hilary deThe Candlestick clares, "The lamp, $i$. $c_{\text {. }}$. Christ Himself, is set upon its on which the stand when suspended on the Cross in His Passion, to give Lamp is Placed. light forever to those that dwell in the Church; to all that are in the house." s S. Augustine, commenting on the Passion, says, " The Lord commended that very cross by bearing it upon His shoulders; and for that candle which was to be lighted and not to be put under a bushel, the Lord bore the candlestick." 4

There are other types made use of by the Fathers, but they are farfetched, and want of space compels their omission. ${ }^{5}$

The second class of types refer to the form of the Cross. A striking one is adduced by Tertullian, interpreting the action of Jacob when second Class of blessing the sons of Joseph. " His hands being laid upon Types Referring their heads and interchanged, and turned indeed crosswise, to Form.

the one over the other, so that, representing Christ in a figure they might even then foreshow the blessing to be accomplished in Christ." 5 S. Augustine beautifully alludes to this type when apostrophizing divine wisdom. "O Thou Light . . which Jacob saw, when blind through great age, with illumined heart, in the persons of his sons, shed light on the different races of the future people, in them foresignified; and laid his hands mystically crossed, upon his grandclildren by Joseph, not as their father by his outward eye corrected them, but as himself inwardly discerned." "

The Jews, as has already been stated, marked the posts and lintels Blood of the of their doors with the blood of the Paschal lamb in the form Paschal Lamb. of the Tau cross." "And the lamb concerning which this precept is given," says Justin Martyr, " should be roasted whole, a

I S. Augustine, De Diversis, ser. 22. $\quad{ }^{2}$ S. Ambrose, De Spiritu Sanctu, lib. i., cap. 8.

3 S. Hilary, quoted in Catena Aurea, S. Matt. v., I5.

4 S. Augustine on S. John, Hom. cxvii., \$ 3.

${ }^{5}$ See Bosio, La Trionfante Croce, lib. iii, cap. 28 , and Gretser, De Cruce, lib. i., cap. 47.

${ }^{6}$ Tertullian on Bapt., viii; Tertul. also applies the action, crossed hands, to Confirmation.

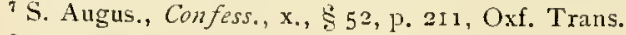

${ }^{8}$ See chap. i., also Didron, Christ. Iconog., vol. i., p. 370. 
type of that punishment of the Cross which Christ was to undergo. For a lamb when it is roasting is like the figure of a cross; for one spit is run straight through from the lower parts to the head, and another is run through the back, on which the shoulders of the lamb do hang." ' Bishop Pearson, quoting the above, considers it no "far-fetched figure of the Cross." 2

S. Cyprian, exhorting martyrs to patience, instances Moses passing the whole day in prayer and elevation of his hands. "Which example of perseverance," he declares is written, " because Moses to overcome Amalek, who in figure is the devil, elevated his hands in the sign and sacrament of the Cross. Neither was he able to overcome his adversaries but by stability in

The Posture of Moses' Hands when Israel Overcame Amalek. the sign, therefore he persevered in the elevation of his hands." ' S. Augustine also often employs this type, $c x . g r .$, Moses, " the friend of God, who overcame the enemy, extended his hands to Heaven, even then exhibiting the figure of the Cross of Christ." "4

Among the ancient Jews was preserved, unconsciously, another type. The unspeakable Name was written with three jots within a circle and beneath the sacred Tau. Many of the coins of Samaria are so inscribed, and it is said that this was graven on the plate Tetragrammaton. of gold worn on the forehead of the High Priest. Bede and others, referring to the figure and its position, consider it as a type of the Cross, and adopt the words of S. Paul, " God forbid that I should glory save in the cross of our Lord Jesus Christ " (Gal. vi., I4). ' It may have been some lingering recollection of this sign which assisted in prompting the literal figuring of the cross on the brow by some early Christians. ${ }^{6}$

The form of the Cross was likewise typified in the number three hundred which was the numerical value of Tau. S. Barnabas thus speaks of it: "Understand, therefore, children, these things more

fully, that Abraham, who was the first that brought in cir- The Number 300. cumcision looking forward in the spirit of Jesus circumcised, having re-

'Justin Martyr, Dialog. zeith Trypho., sec. I, xl.; see also S. Ephraim, Rhythum, xviii., $\S 3$, p. 168 and note, Oxf. Trans.

${ }^{2}$ Pearson on the Creed, art. iv. $\quad$ s. Cyprian, De Exort. Martyrum.

${ }^{4} \mathrm{~S}$. Aug., De quinque Haresities; see also Justin Martyr, \$\$ 90, II I, and note in translation.

${ }^{5}$ Bede, De Tabernaculo, lib. ii., c. 2 I.

${ }^{6}$ Bede speaking of Pharaoh's signet ring which he gave to Joseph, refers to the Cross which the Christian wears as a seal on his forehead and in his heart. Baptism, is called by the Fathers " The Lord's Signet," “" The Church's Seal," etc. 
ceived the mystery of three letters. For Scripture says, that Abraham circumcised three hundred and eighteen men of his house. But what was therefore the mystery that was made known unto him ? Mark, first, the eighteen and next the three hundred. For the numerical letters of ten and eight are I. H., and these denote Jesus, and because the Cross was that by which we were to find grace, therefore he adds three hundred, the note of which is $T$, the figure of His Cross. He who has put the engrafted gift of His doctrine within us, knows that I never taught to any one a more certain truth; but I trust that ye are worthy of it." '.

'Three hundred and eighteen was the number of Abraham's servants when, having conquered the four kings, he met Melchizedec, and did Number of Abra- homage to him as the typical Great High Priest to whom ham's Servants Levi should pay tithes.

Three hundred, the number Tau, were the chosen men of Gideon, who destroyed Midian, ${ }^{2}$ of whom Paulinus remarks, not the number or And of Gideon's valor of the legion, but the sacrament of the Cross, exmen. $\quad$ pressed in the numeral for three hundred, Tau, overcame their enemies." "By the three hundred, comprised in the letter Tau (which bears a resemblance to the cross), it is expressed that the sword of the enemy is overcome by the wood of the Cross." 4

Bosio reminds us that the very form of anointing the

The Anointing of the High Priest. High Priest was typical. While the unction of kings was somewhat like a crown, in the shape of the letter caph, that of the IIigh Priest was in the form of a Saltire cross. ${ }^{5}$

The early Christians loved to trace the type of the symbol of salvation in everything in nature. " See ye to it," exclaims Justin Martyr, " if there be aught in this world which without this form

Type of the Cross in Every- hath its orderings, or can minister to intercourse between thing in Nature. single gem only we give in conclusion: " And if the little bird drew in

${ }^{1}$ S. Barnabas, Catholic Epistle, Wake's Trans., $\$ 9$.

2 It is noteworthy that Gideon himself was typified by the barley cake of which he dreamed. (Jud. viii., 13), and the barley cake was the sacrificial cake which we have seen (chap. i.) was marked with a cross.

${ }^{3}$ Paulinus, Epist., I.

4S. Gregory, Morals on Fob, b. xxx., c. 74. Clemens Alexand, applies this type to the dimensions of the ark. Stromatum, lib. 6., c. 4; also S. Chrysostom on S. Mark, Hom. iv.; see Bosio, La Trionfante Croce, lib. iii., cap. 2.

${ }^{5}$ Abarbanel, quoted by Bosio, lib. iii., cap. Io. The unction in coronation in the present. day is in the above form.

${ }^{6}$ Justin Martyr, Apol. 2. 
its wings, and refused to use the silly mystery of the Cross, the air would then refuse her, and not bear her up; but her wings praise the Rood. And if a ship spreadeth her sails for the sea, in the mystery of the Rood and from the yoke of wood, she maketh a bosom for the wind; when she hath spread forth the Rood, then is the course spread clearly out for her voyage. And if the ship was that of the Jew, the Cross rebuked him by his deed, since though not intending it, in the ship himself with his own hands, he hath spread and displayed the mystery of the Rood. The sca by the Rood was subjected to the unbelievers; but unless the crucifiers had made wood into the form of a cross, and upon it had hung the Body as a sail, the voyage would have halted. "1

" I believe," writes one of the worthiest scholars of this century, " that a spiritualized eye, seeing all the human race shut up in the person of our Lord, having before it always the figure in which it pleased Almighty God to place him before us on the Cross, might expect to find a similar figure-the figure of the Cross--placed here and there all over the work of creation, as a religious spirit in better days than the present erected that Cross on high, wherever a human foot might be arrested by it; and as the ancient Fathers detected it in the most hidden allusions of Scripture-Moses stretching out his hands to the Amalekites, his rod, the branch which he threw into the bitter waters, the wood of the ark, the tree of life-in every animal and material nature he would expect to discern the figure of a cross; and he would not be surprised to find all mathematical figures were reducible to this element, or, as modern anatomists have suggested, that the whole animal world is framed upon this type-a central column with lateral processes. It is one of the grand speculations of zoölogical science."

\section{APPENDIX}

\section{NOTE ON THE SYMBOLICAL IIEANING OF THE WORD ARK}

" Altwo' nothing indeed can be more ridiculous and absurd than the childish play which some people make with names and words, it is nevertheless certain that some names and words there are which are naturally expressive of those things they are imposed upon, and that there are certain powers of the

${ }^{1}$ S. Ephraim, Rhythum, xviii. See also Tertullian, Apology, chap. xx., xxx.; Gretser, De Cruce, lỉ. i., cap. 52 ; Lipsius, De Cruce, lib. i., cap. x.; Bosio, La Trionfante Croce, lib. iii.

'Sewell, Christian Morals, p. 323. 
letters, and combinations of those powers, which bear some sort of signature of the things expressed, so that both letters and words are sometimes purely symbolical, and in some sense sacramental; whereof instances, both in the Old and New Testament, are obvious enough. Of this nature is the name, THEBAH, which God was pleased to give to that structure which he commanded Noah to make, and that with all exactness, according to the pattern of it which was shewn him. Now this name is not originated from any other Hebrew word so far as we can find, but is in itself an original, and therefore also triliteral, as the original words in that tongue generally are. Notwithstanding which, since it is a sacred name, and God himself imposed it, though the origination of it may not be so plain to every vulgar eye, yet we may safely conclude that there could not but be some very good reason for the choice thereof. Something of which we may be able perhaps to glance at. But the deep ground of the imposition of this, or indeed of any other name given by God, we must not expect ever fully to penetrate into. It consists, then, of these three letters, Than, Beth, and $H e$; all of which are here symbolical.

" $\mathrm{n}$, Than, is the symbol of man and of the human nature which is the perfection and end of all the creatures, says Chøedamus. And Christ, who is from the Greek alphabet called Alpha and Omega, is, according to the Hebrew, called Aleph and Thau, the first and the last, or God and man; ThaU being the perfection of the creation; and the abbreviation of Thummim. Whence the Syriac has translated it, I am Urim and Thummim. This Tha is also made a note of repentance [Theshubah], and of the preservation which is consequent of it. And therefore, in the vision of Ezekiel, God is represented as commanding his angel to set a THAU upon the foreheads of the men that sigh, and lament the publick sins and abominations. And this Thau, the mark of the angel of penitence, and of the soul's Theshubah, or return to God, several of the fathers make to be the sign of the Cross; how truly I determine not.

“ =, Bcth, signifies a house after the manner of which was built the Ark; and it denotes the superior wisdom, or the house of wisdom wherein (say the Hebrew doctors) all things were $a b$ origine disposed in their archetypes, before they were yet brought forth into their proper form, or species; and by which Wisdom all things that are created, were created, and produced, according to the Psalmist. In zuisdom hast thou made all things, that is, in the SoN, which is the beginning of all things as well as the ending, Gen. i. and John i., or the first and the last in the alphabet of nature; as filling indeed the whole book of nature. This is the second symbol or literal characteristick of the ark, impressed by divine science in the very name of it; And the third is

" $\pi$, $\bar{H} e$, which is the letter that was afterwards given by God to Abraham, as here to Noah; concerning which the learned Jews observe that it is doubled in the great name of Gon, because in the first He, God, formed and produced the world in his mind, and in the second he unfolded things into their several kinds and proper specifick forms, but with this provision: that the beings explicated or manifested in the second production or creation, should in 


\section{Types of the Cross}

similitude and consonance imitate and emulate the first, or the heavenly originals themselves.

"And this is the radical interpretation of the name, THEBAH, as it was given by the wisdom of God to the ark or vessel of Noah, namely, "That it was to represent to him, and to his posterity, the perfection of the human nature such as it is in Christ, and the preservation thereof through the waters, even the waters of Baptism and Regeneration.'

The comment of our learned commentator is rich in lore. It is with regret a line is omitted, especially as the work is very rare. Room must be made for one more observation: "That the one and the same word being read from the right to the left is TheвaH, and from the left to the right is HA-BEтn, $i . c$, The House, which is as much as Beth-Ha-Kadesh, the Sanctuary, or the Church. Conformable to which was that constant primitive application, as we find in the holy fathers, of the Ark to the Church."-Bibliotheca Biblica, amnotation xiv. (to Genesis vii.). 


\title{
CHAPTER III
}

\author{
THE EARLY FORM AND USE OF THE CROSS
}

Section I.-The Cross of Punishment. Section 2.- Voluntary Crucifixion. Section 3.-Crucifixion of Children by the Fca's

$\mathrm{T}$ HE cross was at first a simple stake upon which the sufferer was impaled, or to which he was fastened; in time it became a gibbet of various shapes. The original signification is preserved in the Greek

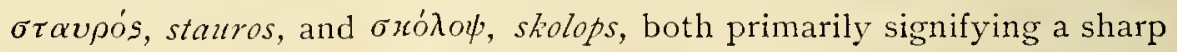
stake set in the ground. The development of the instrument of death is shown in the Latin names, crux, patibulum, and furca. The cross was Original Cross. not recognized in the Mosaic law, hence the Jews had no word to express it, but used a double term expressing conjunction, the warp and woof.

Section I. The Cross of Punishment.-The cross was used in ancient times as a punishment for flagrant crimes in Egypt, Assyria, Persia, Inventor of Palestine, Carthage, Greece, and Rome; the explorers found the Cross. it in Mexico, and modern travellers in China, Japan, and Madagascar. Tradition ascribes the invention of the punishment of the cross to a woman, the Queen Semiramis, by whom, or by her husband Ninus, Farno, King of Media, with his wife and seven sons, were crucified. ${ }^{2}$ As it is uncertain when the celebrated Assyrian Queen lived,

'Pearson on the Creed, art. iv. ; yet Lysons, tracing the origin of the word, says, "Chrosh קוgnifies boards or pieces of timber fastened together, as we should say, crosswise ; the word is so used in Exodus xxvii, 6. This seems a very natural and probable etymon for the term. but it may also allude more to the agony suffered on such an erection, and then its origin perhaps may be traced to 'p broken in pieces like clay in the hands of a potter. Chrotshi in Chaldee, we are told by Parkhurst, means accusations, charges, revilings, reproach,"-all of them terms applied to our Lord in his sufferings. "Crux ponitur pro omni angore, strictius pro morte in ligno." Pliny shows that the punishment of the cross among the Romans was as old as Tarquinius Priscus; how much older, it is perhaps difficult to say.

${ }^{2}$ Diodorus Siculus, Antiq., lib. ii., c. I. 
it may be doubted whether she is entitled to the unenviable credit of devising the most agonizing death possible. Josephus says ${ }^{1}$ that Pharaoh's chief baker was crucified not hanged, as our English translation reads, and l'haraoh may have preceded Semiramis.

Among notable instances of crucifixion, are those of the Queen of Scythia by Cyrus in the sixth century B.C. Alexander the Great is said

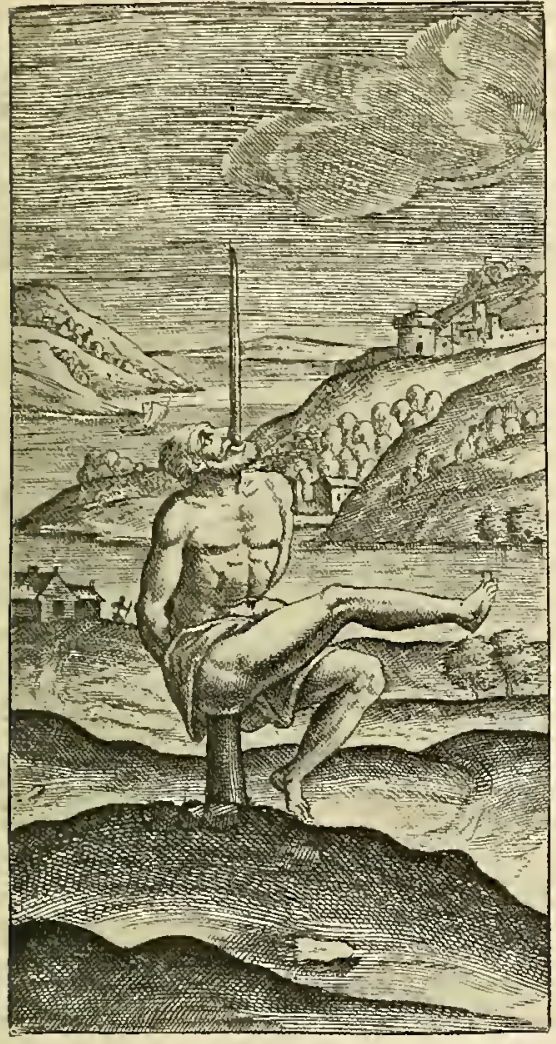

Crucifixion by Impaling. From Lipsius' De Cruce.

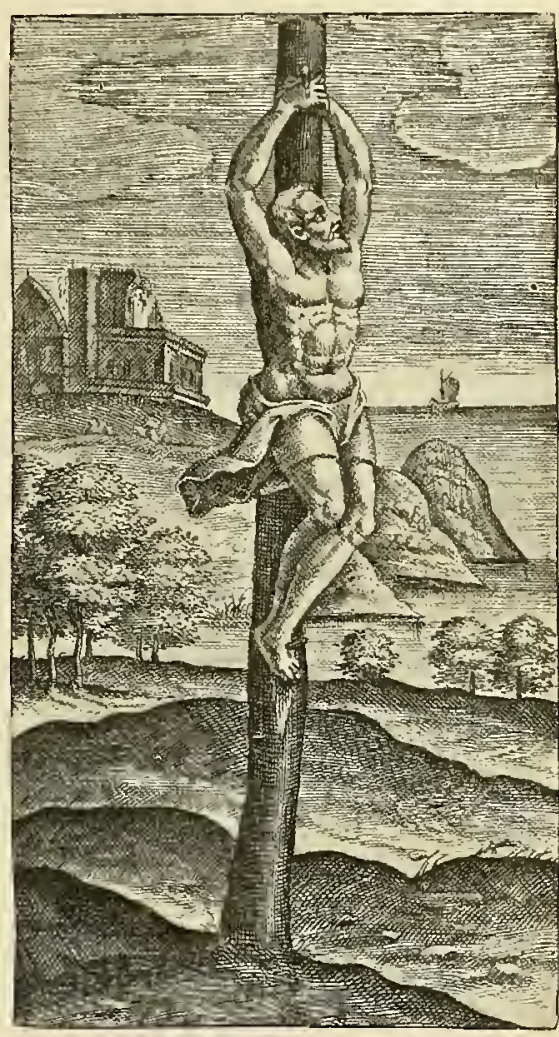

Crucifixion on Stauros. From Lipsius' De Crace.

to have crucified two thousand Tyrians. By the cross perished Polycrates, King of Samos. This monarch had been uniformly fortunate, never in any of his plans or wishes having been even disappointed. Becoming alarmed at his uninterrupted happiness, he resolved to sacrifice his most highly prized treasure, to avert unknown

${ }^{1}$ Josephus, Antiq., b. ii., c. 5. Semiramis by some historians is supposed to have lived B.C. 2000 ; by others, B.C. I250. Pharaoh cir. в.C. 1720. 
future ills. Accordingly he threw into the sea his signet ring which he valued above all else; it was swallowed by a fish which was caught soon after and the ring restored to him. His evil fate came at last. He was conquered by Orcetes, a commander of Darius, and crucified. Leonidas, after death, was hung upon the cross by Xerxes, B.c. 480. Ariarathes, King of Cappadocia, in his eighty-first year, was flayed alive, and then crucified, together with his officers, by order of Perdiccas, B.C. 322. So, also, was Regulus at Carthage, B.C. 255. Eight hundred Jews were thus put to death, and the throats of their wives and children cut by command, and in the presence of Alexander Jannæus, while he and his wives partook of dinner heightened by this zest.

As early as the time of Tarquin B.C. 600, the Romans singled out this punishment as one of peculiar disgrace, by exposing upon the cross

Bodies of Suithe corpses of those who had committed suicide to escape cides Exposed imposed labor. The Carthaginians, Egyptians, and Persians on the Cross. treated in like manner the dead bodies of those they held specially dishonored.'

The Jews deny the crucifixion of persons alive, because their law required that executions should be accomplished, and the bodies buried Crucifixion by that same day. ${ }^{2}$ Yet Maimonides describes their gibbet as the Jews. Similar to a cross, and Lipsius supposes that thus suffered the "Heads of the people" for the idolatry of Baalpeor, ${ }^{3}$ the King of $\mathrm{Ai}^{4}{ }^{4}$ the five kings, and the sons of Rizpah. ${ }^{5}$ But no nation has suffered more severely by this mode of execution than the Jews, when the measure they had meted out was returned unto them. "His blood be upon us, and upon our children," was their imprecation, and it was fulfilled. Varus at one time crucified two thousand of them for sedition. At the siege of Jerusalem, the Romans " caught every day five hundred Jeivs, nay sometimes they caught more . . . and nailed them one after one way, and another after another, to the crosses, by way of jest, when their multitude was so great that room was wanting for the crosses, and crosses wanting for the bodies." " "So that they which had nothing but 'crucify' in their mouths, were therewith paid home in their own bodies, early suffering the reward of their imprecations, and properly in the same kind." ?

\footnotetext{
${ }^{1}$ Lipsius, $D e$ Cruce, lib. iii., cap. г $2 . \quad{ }^{2}$ Deut. xxi., 22, $23 . \quad{ }^{3}$ Num. xxv., 4.

${ }^{4}$ Josh. viii., 29. ${ }^{5}$ Josh. x., 26; 2 Sam. xxi., 9. ${ }^{6}$ Josephus, Antiq., b. xvii., c. Io.

${ }^{7}$ Browne, Iulgar and Common Errors, b. v., c. $2 I$.
} 
Deatl by the cross was the most ignominious that could be inflicted. The Roman citizen was exempt from it ; to the Jew, "cursed " was, "everyone that hangeth upon a tree" "; the Greek re- Ignominy of garded with mingled contempt and pity the preacher who the cross. proclaimed " The unknown God " to be one who had submitted to such a disgraceful death. One unacquainted with the tone of feeling among Jews and Gentiles at the time of our Saviour's crucifixion can form no conception of the " scandal of the cross." The great obstacle to the building up of the Christian Church was, that the "Headstone of the corner" was " a stone of stumbling and a rock of offence." " The force of the Apostle's expression can be very imperfectly estimated by those who have not read the early Christian documents. ${ }^{3}$

Among the Jews there was some chance of mercy and escape from death offered to the accused Ac- Chance of Obto the accused. Ac- taining Witness
to Innocence. cording to the Mish-

na, before any one was punished for a capital crime, proclamation was made before the prisoner by the public crier, that if any one

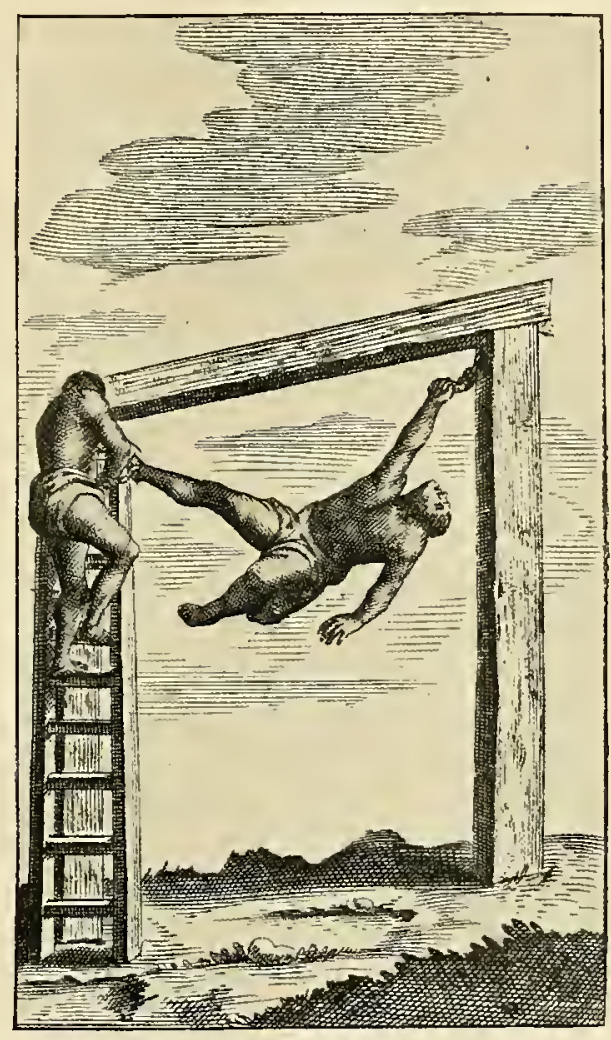

Crucifixion by One Hand and Foot. From Bartholinus' De Cruce Christi. knew aught of his innocence, he should appear before the judge and declare it. And the Gemara of Babylon says, that, "before the death of Jesus this proclamation was made for forty days, but no defence could be found." "

1 Gal. iii., 13.

${ }^{2}$ I Pet. ii., 7, 8.

${ }^{3}$ Blunt, Hist. of the Christian Church, First Three Centuries, p. 135. "From this circumstance the Heathen are fully convinced of our madness, for giving the second place after the immutalule and eternal God, and Father of all, to a person who was crucified." Justin Martyr, Apology 2 ; see also Minutius Felix, pp. 57, 147, ed. Davis, Cantab, r712.

${ }^{4}$ Lowth on Isaiah liii., 8. On the passage from the Gemara above mentioned, Lardner observes, "It is truly surprising to see such falsities, contrary to well-known facts." Testi- 
Now it is plain, from the history of the four Evangelists, that in the trial and condemnation of Jesus no such law was observed (though, Denied to our according to the account of the Mishna, it must have been Lord. in practice at that time): no proclamation was made for any person to bear witness to the innocence and character of Jesus, nor did any one voluntarily step forth to give his attestation to it. And our Saviour seems to refer to such a custom, and to claim the benefit of it, by his answer to the High Priest, when he asked him of his disciples and of his doctrine: "I spake openly to the world; I ever taught in the synagogue and in the temple, whither the Jews always resort; and in secret have I said nothing. Why askest thou me? ask them which heard me, what I have said unto them; behold, they know what I said " (John xviii. 2O, 2I). This, therefore, was one remarkable instance of hardship and injustice, among others, predicted by the prophet, which our Saviour underwent in his trial and sufferings.'

Previous to the execution, the sufferer was stripped of his clothing; nor is it probable that our Lord was spared this indignity. Jeremy Preliminaries to Taylor says, "For as soon as Adam was clothed he quitted Execution. Paradise; Jesus was made naked that he might bring us in again." = In this state of nudity the scourging was inflicted. This was either with rods, or with whips of cords or leather, to which small bones were sometimes fastened to increase the severity. By the Jewish law the stripes were limited to forty, and to lean to the side of mercy in case of a miscount, only thirty-nine were inflicted, thirteen blows being given with a scourge having three thongs. There was no limit in the Roman law, only a freeman could not be punished with a whip. This exemption was not extended to our Saviour; he received the chastisement of a slave. $^{3}$ Such was the severity of the flagellation, that death frequently

monie's, vol. i., p. I98. Lowth proceeds: "The report is certainly false, but this false report is founded on the supposition that there was such a custom, and so far confirms the account above given from the Mishna." The Mishma was composed in the middle of the second century, according to Prideaux. Lardner ascribes it to the year of Christ, iso.

${ }^{1}$ Lowth, Ibid.: "S. Paul likewise in similar circumstances, standing before the judgment seat of Festus, seems to complain of the same unjust treatment : that no one was called, or would appear to vindicate his character. "My manner of life from my youth, which was at the first among mine own nation at Jerusalem, know all the Jews; which knew me from the beginning, if they would testify, that after the most straitest sect of our religion I lived a Pharisee." -Acts xxvi., 4, 5 .

${ }^{2}$ Jeremy Taylor, Life of Christ, part iii., sec. I5.

${ }^{3}$ Some Romish writers have imagined an enormous number of stripes inflicted upon our Lord. S. Brigitta, in her Revelations, says five thousand, others more; 
anticipated the intended torture of the cross. Sometimes the victim was gagged, or his tongue cut out, lest in his agony he might reveal unplcasant secrets, or revile his judge. The additional insults: the ironical crowning with thorns, the purple robe, and mocking homage to which our Lord was subjected, were founded on no customary or legal usage, but were merely the exhibition of malicious cruelty, or they may be otherwise accounted for. It has been conjectured that Pilate, moved either by the warnings of his wife, " more afraid ," God," sought to pacify the Jews by scourging Jesus; and exhibiting Him, thus disgraced, to ridicule, and so to purchase for our Lord immunity from further torture. But if such feelings moved the stern Roman governor, they were crushed by the change of attack by the Jews. Abandoning their first charge of blasphemy, they accused our blessed Lord of sedition and treason (for which crucifixion was the special punishment), and excited Pilate's fears. "If thou let this man go, thou art not Cæsar's friend: whosoever maketh himself a king speaketh against Cæsar" (S. John xix. I 2).

It was part of the condemnation for the sufferer to bear his cross to the place of execution. This deprived him of the right of sanctuary, and added, if possible, to the disgrace. The lowest term of reproach that a Roman could apply to another was "crucifer," the Victim. "cross bearer." "Sin laughed to see the king of heaven and earth, and the great lover of souls, instead of the sceptre of his hingdom, to bear a tree of cursing and shame; but Piety wept tears of joy, when she should behold that Cross, which loaded the shoulders of her Lord, afterward sit upon sceptres, and be engraved and signed upon the forelread of kings."

It has been supposed that Jesus bore only the transverse beam, while Simon the Cyrenian, carried the rest of the cross, but it is generally presumed that our Lord sustained the whole, ${ }^{2}$ until he sank under its weight; as Isaac, his type, carried the wood of the mystical sacrifice. No Jew or Roman could touch the in-

Portion of the Cross Borne by our Lord. strument of shame without defilement, so a passer-by is pressed into the service, betokening the gathering in of the Gentiles. The meaning of the names are significant. Cyrenian signifying "obedient," and Simon,

${ }^{1}$ Jeremy Taylor, Life of Christ, part iii., sec. I5. Discourse xx.; see also S. Aug. on S. John xix., 17 .

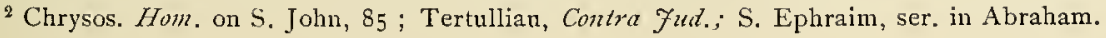


"an heir." "It was not a Jew," says S. Ambrose, "who carried the cross, but a foreigner and wayfarer; neither did he precede, but follow, according to the Scripture, - take up thy cross and follow me. " 1

Sometimes a tablet studded with sharp nails was fastened to the border of the garment of the condemned, and S. Cyprian affirms, " that Heels Goaded Christ did stich to the wood that he carried, being galled with Nails. with the iron at his heels, and nailed even before his crucifixion." 2

The place of execution was usually by the roadside, or on an elevation without the city, ${ }^{3}$ that passers-by might take warning. Wine medistupeyfying cated with myrrh was given to the victim, to blunt the Potion. Sensibility by partial stupefaction. This our Lord refused, in order that His mind might be unclouded. This benumbing potion must not be confounded with the draught offered to Jesus when upon the cross; that was a mixture of sour wine and water called Posca, a common beverage among the Roman soldiers.

The cross rarely exceeded ten feet in height, although there is a tradition that our Saviour's was fifteen feet high, and the transverse eight Height of Cross.

feet long." The sufferers were not always fastened to the cross with nails, but were sometimes bound with cords. In this manner, according to tradition, S. Andrew was crucified, hence his agony was protracted for several days "; and the thieves are generally represented in art as at least with their feet tied. Probably in the instance of our Lord, the prophecy of the Psalmist, " They pierced my hands and my feet," was literally fulfilled, yet some conjecture that his feet were only bound to the Cross." Additional agony was sometimes

${ }^{1}$ S. Ambrose, lib. x. in Lucan.

${ }^{2}$ S. Cyprian, De passione; Taylor, Life of Christ, part iii., sec. xv. Discourse xx. ; Lipsius, De Cruce, lib. ii., cap. Iт.

3 "Wherefore Jesus. also, that he might sanctify the people with his own blood, suffered without the gate." Heb. xiii., 12.

${ }^{4}$ Gretser, De Cruce, lib. i., cap. 7. Perhaps palms, not feet, are meant. A palm is 8.7 inches. The height of the cross is generally much exaggerated by painters. In the mystery attributed to S. Gregory Nazienzen a more correct idea is given, for the body of our Lord is not raised above the reach of his Virgin Mother.

"Per hos tuos sacros pedes, quos osculor

Materno amore, te nunc, misereat mei."

${ }^{5}$ This tradition is very ancient. On the old seal of the city of Rochester, England, probably taken from that of a convent established cir. A.D. 600 , the saint is thus represented. Yet $\mathrm{S}$. Peter Chrysologos says he was crucified on a tree, and other writers specify it as a palm-tree.

${ }^{6}$ Dr. Pallus, followed by Rosenmuiller, Kuehnoel, and Frische. It is admitted that binding was common both as to the hands and feet when the former were nailed; hence probably also 
inflicted by exposing the crucified to the attacks of wild beasts, or, by building a fire at the foot of the cross, the sufferer expericnced the torture of burning and suffocation, as in the case of Pionius, a presbyter of Carthage.

The bodies of the victims were generally left upon the cross until they decayed or were devoured by wild beasts and birds. On great occasions, such as birthdays, ctc., the Roman govennors gave permission that they might be taken down, but out of respect to the law, already alluded to, the Jews were allowed to hasten the death of the crucified, so that by burial " that same day, the land be not defiled." Hence the legs of the fellow-sufferers with Jesus were broken; yet so carefully did God preserve his prophecies, that not only not even a bone of our Lord's body was broken, either by the lance that pierced $H$ is side, or the nails which wounded His hands and feet, but as the Romans were the executioners, not even a hair of His head perished, although by the Jewish law that of malefactors was shorn. ${ }^{1}$

The cross was generally erected previous to the execution, that more effect might be given to When the Victim to the warning punish- was Fastened ment. Thus in the war

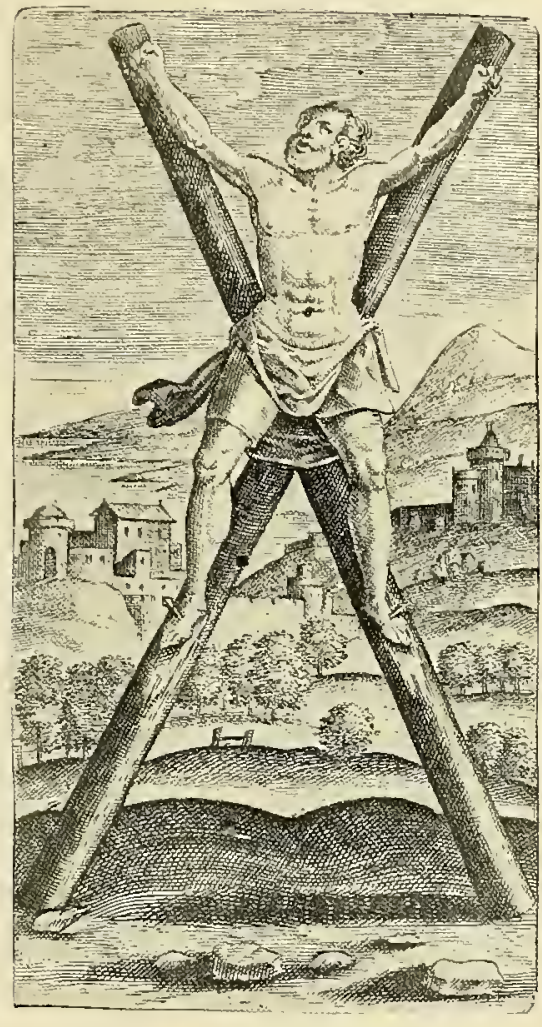

Crucifixion of S. Andrew.

From Lipsius' De Cruce. of the Romans against the Jews, Lucilius Bassos having taken captive Eleazar the chief of the young Israelites, "set up a cross as if he were just going to hang Eleazar upon it immediately . . . in order to prevail with them to surrender the city for the preservation of that man." 2 were the latter. Oldshausen on Luke xxiii., 27-34. According to a writer in Gentlemen's Mag., April, I738, binding was peculiar to the Romans. On the Irish standard crosses, the feet are represented as bound. $\quad{ }^{1}$ Browne, Hydriotaphia or Urn-Burial, chap. i.

${ }^{2}$ Josephus, Fewish IVar, b. ii., chap. vi. 
Sometimes the victim was nailed to the cross while it was prostrate, as in the instance of the martyr Pionius." The risk of the body's being torn from the nails, by its swaying, while the cross was being lifted up and settled in its place, was guarded against by the binding, and the projection in the upright post, which passing between the thighs supported the

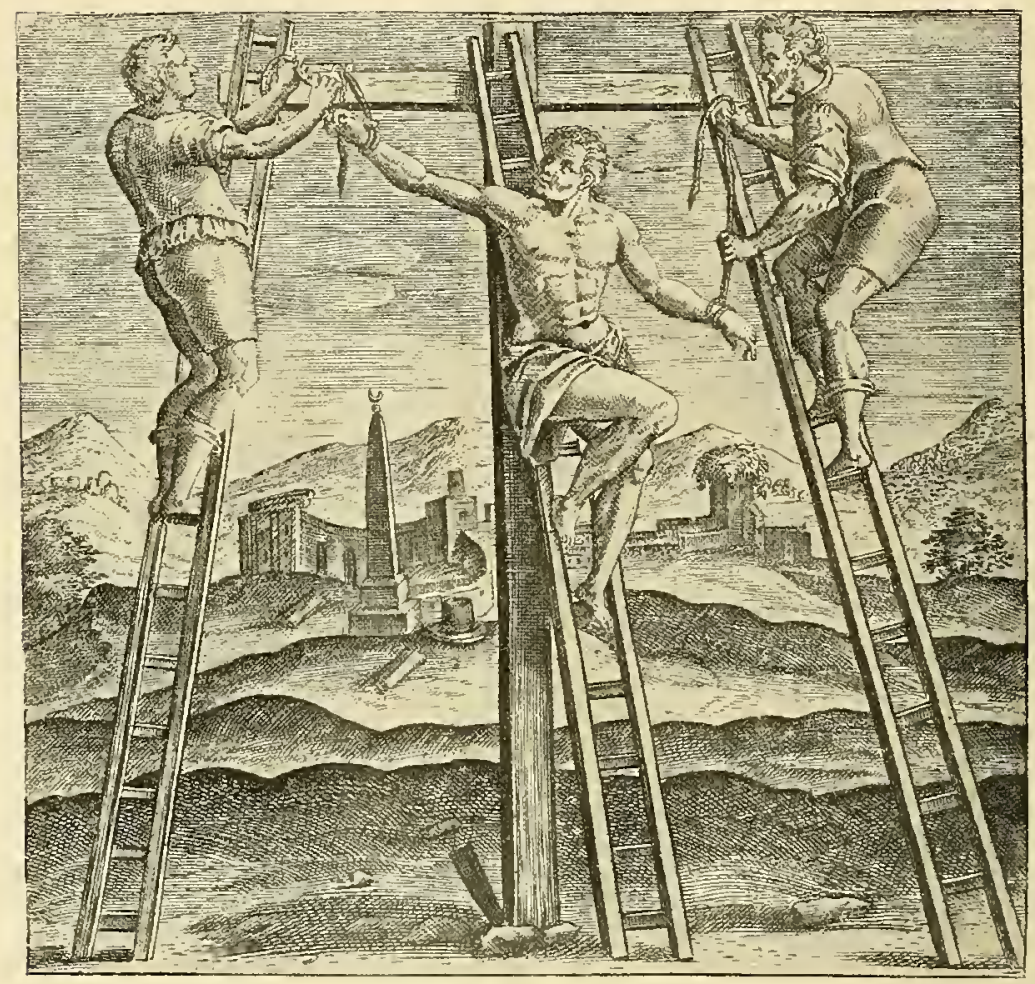

Crucifixion by Tying. From Lipsius' De Crute.

body. Irenæus thus describes the cross: "The structure of the cross has five ends, or summits, two in length, two in breadth, and one in the middle on which the crucified person rests." a Justin Martyr says, " that which is fixed in the middle, to which they who are crucified are fastened, stands up like a horn." 3 Tertullian's description is very clear. "A part, and indeed the principal part of the cross, is any post which is fixed in an upright position; but to us the entire cross is imputed including its transverse beam, and the projecting bar which serves as

${ }^{1}$ Lipsius, De Crece, lib. ii., cap. 7.

"Ireneus, Opera, p. I66.

${ }^{9}$ Justin Martyr, Dialog. with Trypho, § g1. 
a seat." Hence such phrases as frequently occur in old writers, " to rest upon the sharp cross," etc. ${ }^{2}$ The modern Japanese and inhabitants of Madagascar and the Soudan are said to construct their crosses after this manncr. In art this portion of the cross is ignored, and the suppedancum, or support beneath the feet, is substituted.

Neither from the simple narative of the Evangelists, nor from tradi-

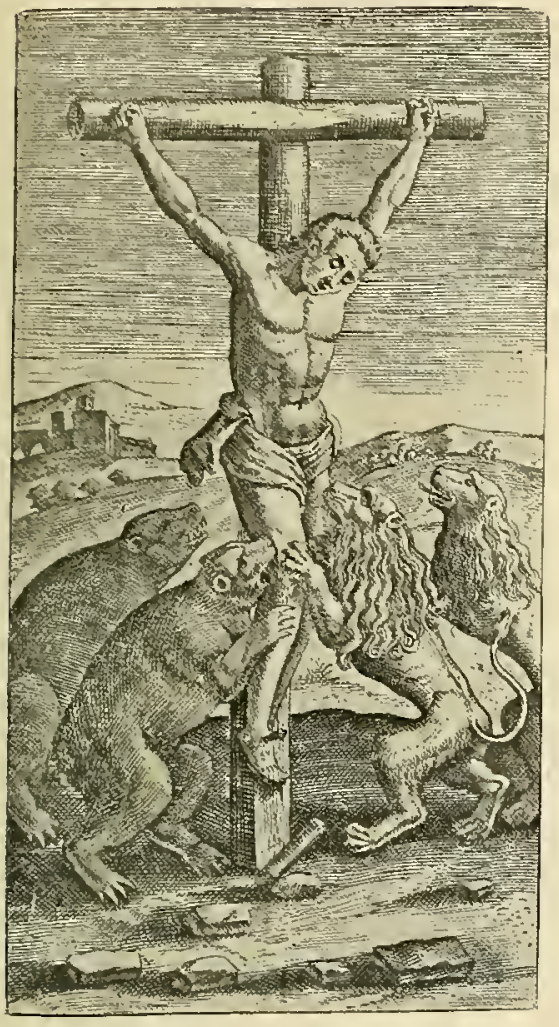

The Crucified Exposed to Wild Beasts.

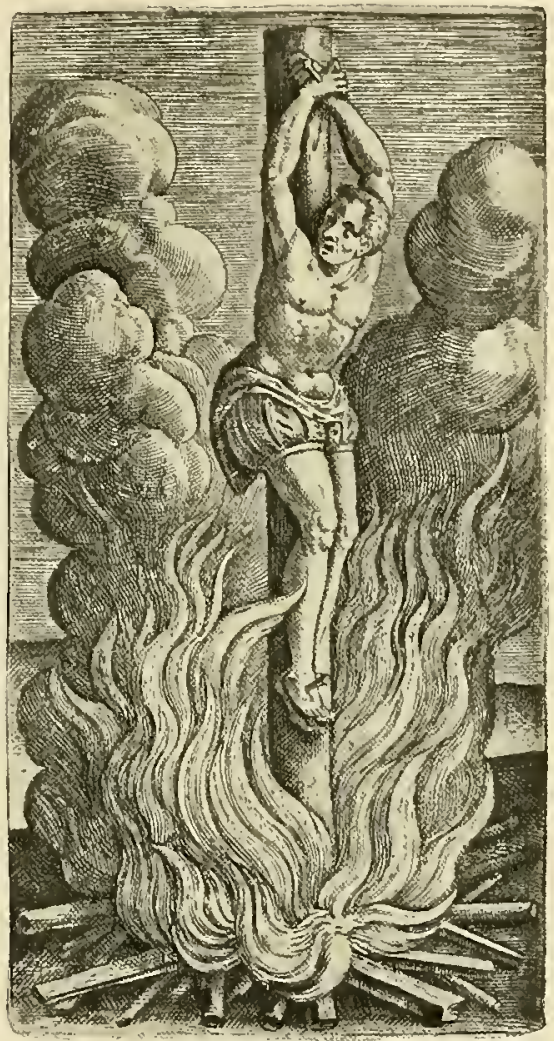

Crucifixion and Burning.

From Lipsius' De Cruce.

tion, can we learn exactly how our Saviour was fastened to the Cross, except that the evidence demanded by, and offered to, the sceptical S. Thomas (S. John xxi, 27) shows that at least those holy hands-which had healed the leper, blessed the babes, given food to thousands-were riveted to the cross. Guevara, Bishop of Mondonedo, chaplain to Charles V. of Spain, gives a very curiously fanciful, supposititious account of the

\footnotetext{
${ }^{\prime}$ Tertullian, Ad Nationes, lib. ii.
}

${ }^{2}$ Cicero against Verres, v., 66. 
Crucifixion. He presumes that as Adam used his hand in plucking the forbidden fruit, so Christ first extended his hand to be nailed, the left, supposititious the hand of the heart, " because the heart of Christ should Accounts of pay for that which the heart of Adam did offend, and the
Christ's Crucifixion. hand of Christ should pay for that which the hand of Adam did steal." Then the cross was raised and rudely settled in the ground while the feet swung roughly against the cruel tree, lastly the feet, the left being placed over the other, were fastened.' In Romish legends we read that to $\mathrm{S}$. Bonaventure it was revealed that Jesus ascended a ladder to be affixed to the cross. Fra Angelico. Raphael, and others, have adopted this method. S. Brigitta, in her visions, witnessed both modes; hence some few painters have represented our Lord as supine on the cross before its erection.

According to tradition our Lord's back was turned towards Jerusalem, which was in the east, and his face toward the west. ${ }^{2}$ This may have

Position of Christ on the Cross.

been a refinement of cruelty on the part of the executioners. Jesus' back was placed toward the capital of the nation of whom the Roman governor had written he was " King," and his face turned to the setting sun, not only to remind him of his departing glory, as his enemies fondly deemed, but that no torture, however petty, yet agonizing, as the blaze of the sun would be, might be spared. Yet Damascenus spiritualizes even this. "Jesus' eyes," he says, "were turned toward the West, toward the Roman Church, whither the chief of the apostles, SS. Peter and Paul, were to go." s " Our Saviour was crucified with his face to the West," says Bishop Hall, "which, however spitefully meant of the Jews, as not allowing him worthy to look on the holy city and temple, yet was not without a mystery. His eyes look to the Gentiles, saith the Psalmist; as Christ therefore on his crass looked toward us sinners of the Gentiles, so let us look towards him." "

${ }^{1}$ Mount of Calvarie, pt. I., chap. 3I-33.

${ }^{3}$ Damascenus, lib. iv., cap. 13.

${ }^{4}$ Bishop Hall's Sermon xxxy. The position of Jesus, averted from his city, may have been intentional on the part of the Roman centurion. When Verres seized Gavius in Sicily, about to embark for Rome, he stripped and scourged him in the market-place. The poor wretch uttered no cry but the oft repeated words "Civis Romanus sum," "as if," says Cicero, "those magic words had power to save him." But in vain. Verres ordered a cross to be erected on a headland that commanded a view of Italy across the strait, saying in savage mockery that as Gavius called himself a Roman citizen, he might have the opportunity of looking toward his native land, and there he was crucified. 
The position of the crucificd was not invariably the same. S. Peter, at his request, according to tradition, was executed with his head downwards, considering it too high an honor for one who had denied his master to suffer in the same manner that he did. Crucified. The apostle was not alone in his mode of martyrdom. Many saints, especially in Egypt, were put to death in the same manner:' others

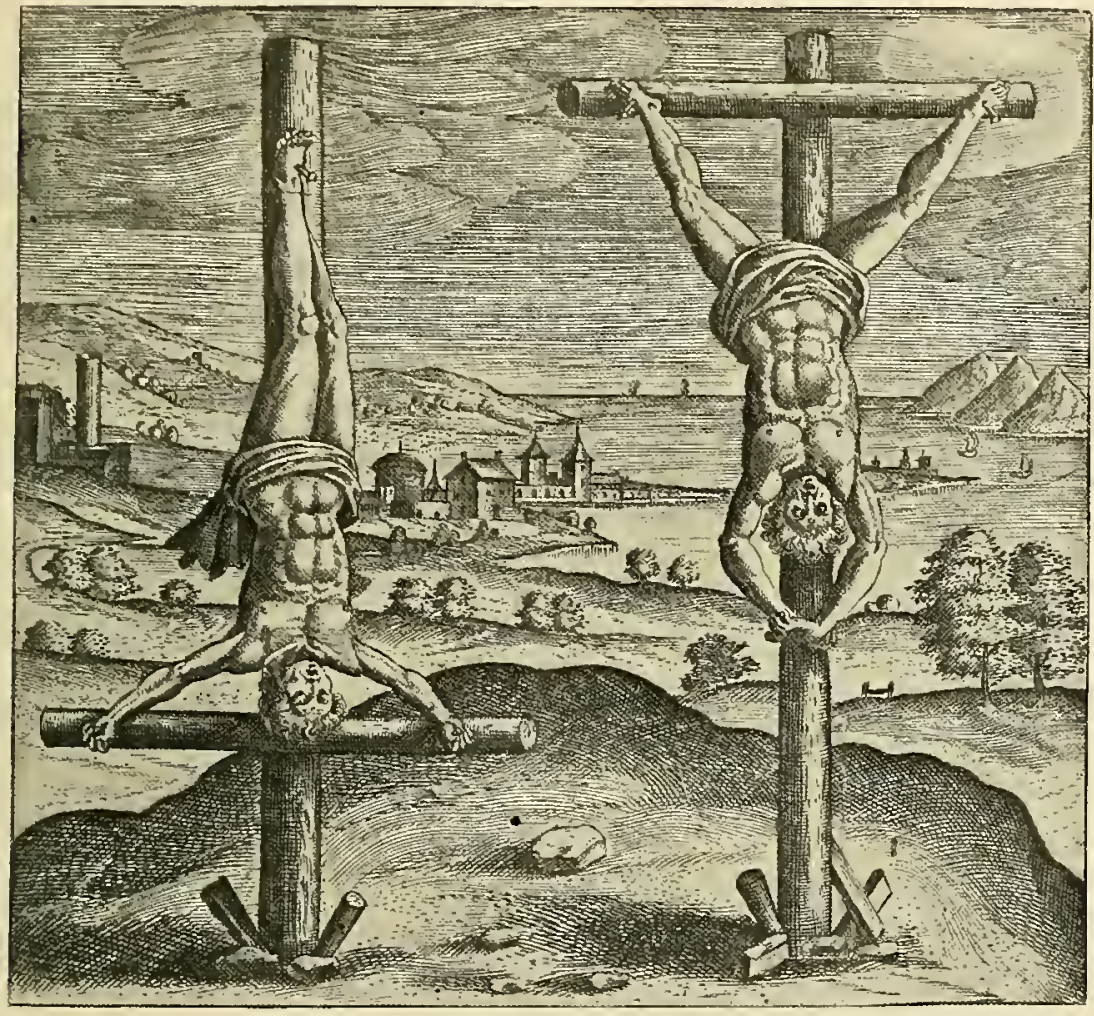

Crucifixion Head Downwards. From I,ipsitus' De Cruce.

suffered, like S. Andrew, upon the cross since known as the Saltire cross, or the cross with one arm and the foot resting upon the ground. ${ }^{2}$ In short, the cross was turned any way that infernal art could suggest to add to the torment. In spite of the fearful agony on the cross, men sometimes lingered a long time. Doubtless some instances are exaggerated, yet others are too well authenticated to

'Forsyth, Life of Cicero, vol. i., p. 58.

${ }^{2}$ Eusebius, Eccles. Hist., b. viii., c. 8; Lipsius, De Cruce, lib. iii., cap. 8. Hemans says this is a Parthian, not a Roman mode. The Builder, March I6, 1872, p. 210. 
be doubted. From Bosio we learn that the Apostle S. Andrew lived two days on the cross, preaching to the people. Victor, Bishop of Amaterna, crucified with his head downwards, also lived two days, which was the usual time that crucified persons lived. Timotheus and Maura, a married pair, are said to have lived nine days and nights, and expired on the tenth day. This story is probably an exaggeration. The Reverend

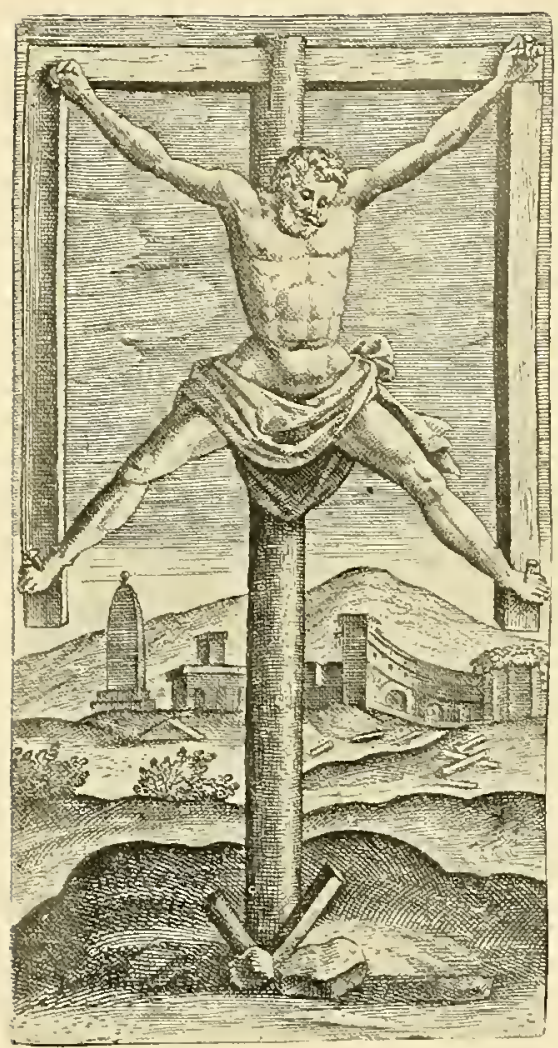

Crucifixion with Arms and Legs Spread. From Lipsius' De Crace.

Alban Butler relates, that Marceus and Marcellainus, " twin brothers, of an illustrious family of Rome, were condemned to be bound to two pillars with their feet nailed to the same. In this posture they remained a day and a night, and on the following day were stabbed with lances." In the year 297, by order of Emperor Maximian, seven Christians at Samosata were crucified. Hipparchus, an old man, died in a short time; James, Romanus, and Lollianus expired the next day, being stabbed by the soldiers; Philotheus, Habibus, and Paragrus were taken down still living; Calliopius, a youth of Pamphylia, was executed after suffering the most cruel tortures, being scourged, broken on the wheel, and partially burnt; he was crucified with his head downward on the fifth day of Passion week, and expired on the following, or preparation, day at the same hour.

The fortitude displayed under crucifixion by Bomilcar is thus described by the pagan historian Justin: After a severe defcat of the Carthaginian army by Agathocles, King of Sicily, this African chief had shown a disposition to desert to the enemy,- " for which offence," says Justin, "he was nailed by the Carthaginians to a gibbet in the middle of the forum, that the same place which had been the scene of his honor 
might now witness his punishment. But Bomilcar bore the cruelty of the citizens with magnanimity, and from the height of the cross, as from a tribunal, declained agrainst the crimes, etc. Having thus spoken with a loud voice anid an immense concourse of the people, he expired."

Besides the law already refered to, requiring the bodies to be buried before sundown, there was also a superstition among the Juws, that if the corpse was left upon the cross, the departed soul knew no peace, but wandered in unrest until the interment of its former tenement. The Jews did not pray, at least publicly in their synagogues, for those who were crucified, nor would

No Rest in the Grave unless Buried. Victims not Prayed for. they allow their bodies to be placed in the family tombs, until the flesh had decayed in the public cemeteries. Hence we can understand why special mention is made that Joseph of Arimathea, moved by the Holy Ghost, " begged the body of Jesus" to place it in his own sepulchre. The act was so contrary to that customary in his own nation, that it was noted by the Evangelists and thus not only was the prophecy fulfilled - " He made His grave with the rich" (Isa. liii., 9)--but the identity of the body, and the reality of his Resurrection, were established beyond a doubt.

After the death of the victim, the cross was buried with him. Adam Clarke says in his commentary on Isa. xiv., I9: " But thou art cast out of thy grave like an abominable branch, and as the rainent of those that are slain, thrust through with a sword, that go

Cross Buried with the Sufferer. down to the stones of the pit; as a carcase trodden under feet." That is, as an object of abomination and detestation; such as the tree is, on which a malefactor has been hanged. " "It is written," saith S. Paul (Gal. iii., I3), " Cursed is every one that hangeth on a tree ", (from Deut. xxi., 23). The Jews, therefore, held also as accursed and polluted the tree itself on which a malefactor had been executed, or on which he had been hanged after having been put to death by stoning. And Dr. Clarke quotes from Maimonides and Kalinski: "The Jews never hang any malefactor upon a tree that is growing in the earth, but upon a post fixed in the ground, that it might never be said, "that is the tree on which such an one was hanged;' for custom required that the tree should be buried with the malefactor. In like manner, the stone by which a criminal was stoned to death, or the sword by which he was beheaded, or the napkin or handkerchief by which he was strangled, should 
be buried with him in the same grave. For as the hanged man was considered the greatest abomination, so the very post or wood on which he was hanged was deemed a most abominable thing, and thcrefore buried under the earth." I The value of these testimonies to the disposal of the instruments of death, will be seen when we come to examine the evidence for the discovery of the true Cross.

The sufferings endured by a person, on whom this punishment is inflicted, are narrated by Georg Gottlob Richter, a German physician, in a Disscrtation on the Saviour's Crucifixion: ${ }^{2}$

"I. The position of the body is unnatural, the arms being extended back and almost immovable. In case of the least motion an extremely painful sensation is experienced in the hands and fcet, which are pierced with nails, and in the back, which is laccrated with stripes.

" II. The nails, being driven through the parts of the hands and feet, which abound in nerves and tendons, create the most exquisite anguish.

"III. The exposure of so many wounds to the open air brings on an inflammation, which every moment increases the poignancy of the suffering.

"IV. In those parts of the body which are distended or pressed, more blood flows through the arteries than can be carried back in the veins. The consequence is, that a greater quantity of blood finds its way from the aorta into the head and stomach than would be carried there by a natural and undisturbed circulation. The blood-vessels of the head become pressed and swollen, which of course causes pain and a redness of the face. The circumstance of the blood being impelled in more than ordinary quantities into the stomach is an unfavorable one also, because it is that part of the system which not only adimits of the blood being stationary but is peculiarly exposed to mortification. The aorta, not being at liberty to empty in the free and undisturbed way, as formerly, the blood which it receives from the left ventricle of the heart, is unable to receive its usual quantity. The blood of the lungs, therefore, is unable to find a free circulation. This general obstruction extends its effects likewise to the right ventricle, and the consequence is an internal

1 Hone gives a curious account of the execution of a Jew in London in I82 I. The executioner, at the request of his friends, did not touch his body, not even his toes. The Jews took down the corpse and buried it, the rope with which his hands were tied, and everything they could obtain, used al his execution (as it seems from the narrative), and this according to their law, before sundown, - Year Book, p. $13 s_{3}$.

${ }^{2}$ See work, p. 36 et seq. 
excitement, and cxcrtion, and anxicty which are more intolerable than the anguish of death itsclf. All the large vessels about the heart, and all the veins and arteries in that part of the system, on account of the accumulation and pressurc of blood, are the source of inexpressible misery.

"V. The degree of anguish is gradual in its increase, and the person crucified is able to live under it, commonly till the third, and sometimes till the seventh day."

As we would be glad to relieve God's once chosen people from any of the crime and shame of rejecting their Saviour, so we catch at even such a straw as the following tradition given by Southey:

" When Toledo was recovered from the Moors by Alonzo VI., the Jews assured him that they were descendants from All of the Jews not Guilty of the Death of our Lord. part of the ten tribes sent by Nebuchadnezzar into Spain, and that when Caiaphas the High Priest wrote to their ancestors, they objected to the death of Jesus of Nazareth, asserting that the prophecies appeared to be fulfilled in that just person. This answer is said to be preserved in the archives of Toledo."'

Section 2. Voluntary Crucifixion.--Instances have occurred of persons, who, being influenced by fanatical enthusiasm, have voluntarily undergone the fearful torture of crucifixion.

In 1756 , at Paris, two girls, pupils in a Roman Catholic sisterhood, suffered crucifixion for the profane purpose of exhibiting a lively image of the Saviour's Passion. Each was nailed to a cross, through the hands and feet, and continued in that position for more than three hours. After the nails were drawn, and the wounds dressed, the sisters sat down to a repast, pretending that the operation had been attended with no pain, and that on the contrary they had experienced exquisite pleasure. They had indeed, by wonderful self-command, suppressed all audible indications of anguish; but their agony, specially at the drawing of the nails, was shown by writhing, and other unequivocal demonstrations.

\footnotetext{
1 Southey also quotes a Jewish authority, who states that there are three different races of Jews. "One, who took counsel for the death of Jesus of Nazareth: these are in continual motion. The second, who urged on his sufferings: these never can look any man in the face and with difficulty can raise their eyes to Heaven. The third were the descendants of David, who strove to prevent the death of Christ, and shut themselves in the temple that they might not witness it: these are affable, good men, who love their neighbors and can look anywhere."Dow Roderick, p. I8I, ed. I8I6.
} 
In a second exhibition by the sisterhood, two of their number, Fanny and Mary, were the insane victims. Fanny suffered with the greatest heroism. She remained upon the cross for three hours, and was shifted during that time in a great variety of positions. But Mary, who was lacking in faith, or fortitude, shuddered at the fastening of the nails, and in less than an hour shouted for relief. She was accordingly taken from the cross and carried out of the chamber in a state of insensibility.

These instances may have been among the followers of the Abbé Paris, commonly known as Conzulsionaries. These fanatics afford other examples. One of them, Sister Felicite, declared that she had been crucified twenty-one times! Probably an exaggeration. Five others of the same sect are mentioned, one of whom suffered twice, another three times. They remained upon the crosses for different periods, varying

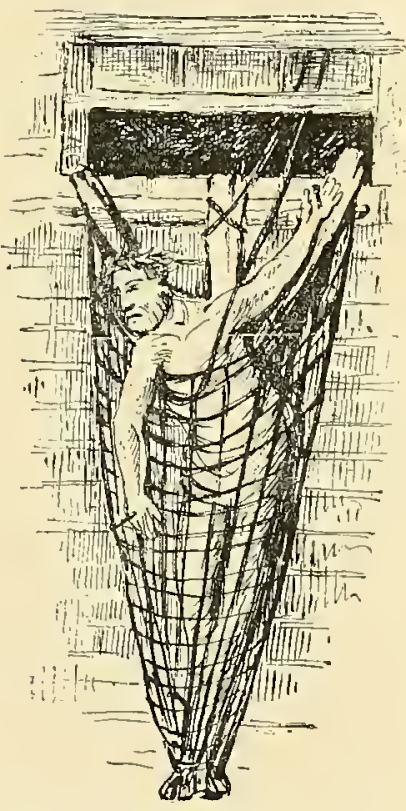

Self-Crucifixion of Matthew Lovat. from half an hour to nearly four hours, yet they uttered no cries, lost but little blood, and all speedily recovered.

As late as $I 797$, a girl was crucified in the parish church of Fareins, near Trévoux, in the diocese of Lyons. As may be conjectured, Good Friday was the day profaned by this exhibition.

There is also a very curious instance of a self-inflicted crucifixion. Matthew Lovat Self-Crucifixion. Was a shoemaker in Venice. Matthew Lovat. On September 2 I, I SO3, having made a cross of the wood of his bedstead, he attempted to fasten himself to it in the strect called the Cross of Biri, but was prevented as he was about to drive the nail into his left foot. Three years after this, he made a second attempt which was more successful.

Having prepared a cross, he stripped himself naked except for a girdle about his loins. Fearing that he would not be able to attach himself securely to the cross, he covered the lower part with a net, extending from the suppedaneum to the transverse. Having introduced himself

${ }^{1}$ Neale, Hist. of the Fansenists, p. 58. 
into this, he next drove a nail through the palm of his right hand by striking it on the floor until the point appeared on the outside. He then drove a nail through both feet, fastening them to the wood. Tying himself around the waist to the cross, he next wounded himself in the side with a knife. He was yet in the room: to show himself to the people required the exercise of much fortitude and resolution. The foot of the cross having been placed upon the window-sill, he drew himself forward by means of his fingers pressing on the floor, until the lower end, overbalancing the rest, the cross fell outside of the house and hung by ropes previously fixed to sustain it. He then fastened the right hand, already pierced by the nail, to its proper place, but after driving the nail through the left hand he was unable to affix it. This took place at eight o'clock in the morning. As soon as he was seen he was taken down and carried to the hospital where his wounds were completely cured.'

Section 3. Crucifixion of Children by the Jews.-The Jews have been accused of crucifying young children upon Good Friday, in derision of the solemn event then commemorated, and in revenge for the loss of their prosperity. The names of some of their victims have been preserved in the Hagiology of the Roman Church: SS. William of Norwich, said to have suffered in I I37; Richard of Pontoise, in I 82 ; Hugh of Lincoln, in 1255, ' for whose death eighteen Jews were hanged; Simon of Trent, in I472. A child in Norwich, in 1235, was stolen by the Israelites, circumcised, and his crucifixion attempted; but the offenders were discovered and compelled to pay a fine of fifty thousand marks. ${ }^{3}$ Another child was crucified in Northampton, for whom fifty Jews were drawn at horses' tails and hanged.

S. Hugh of Lincoln is the most celebrated of these youthful martyrs. Matthew Paris gives a detailed account of the tortures inflicted on this saint. He was fed ten days with milk, then, the Jews being assembled, each individual stabbed him with a knife; he Hugh of Lincoln. was forced to drink esel, was mocked as Jesus, the false prophet, crucified, and, finally, pierced in the side with a lance. The body was thrown

1 For a full account, see Cesare Ruggiere, M.D., Namative of the Crucifixion of Matthew Lovat, Pamphleteer, vol. iii., pp. 361-376; IVinslow, Anatomy of Suicide, pp. 329-337; Stroud, Physical Causes of the Death of Christ, pp. 372-375.

${ }^{2}$ About 1254, Alexander IV. being Pope, seventy-one Jews were imprisoned on charge of crucifying a boy, of which fact twenty-five knights made oath.-Oxford Tables of Chronology.

${ }^{3}$ F. C. H., Notes and Queries, 2 d ser., vol. viii., p. 26 I. 
into a well where it was found by a miracle. One of the Jews being arrested, confessed that his nation did so every year. ${ }^{1}$

A statue of freestone, twenty inches high, of $\mathrm{S}$. Hugh existed until I779. This had been removed from his tomb and was found behind the high altar of the Cathedral of Lincoln." Chaucer immortalizes him in the Prioress's tale.

" $\mathrm{O}$, yonge Hew of Lincoln slain also

With cursed Jews, as it is notable,

For it is but a litel while ago,

Pray eke for us, we sinful folk unstable,

That of his mercy God so merciable,

On us his grete mercie multiplie,

For reverence of his moder Marie."

In art S. Hugh is represented as a child about three years old, nailed upon a cross, or standing with a palm in one hand and a cross in the other. S. Simon of Trent, as a child with a cross by his side, or crucified, with a man cutting his breast; or, as in a picture attributed to Agostino Caracci, holding a palm in one hand, in the other the long bodkin with which his side was pierced. S. William of Norwich, as a child crucified, or crowned with thorns, holding two nails, a knife in his left side; or as a child bound to two posts, but one foot nailed, the Jews mocking him and one stabbing his left side and catching the blood in a bowl; or three nails in his hand and a hammer in his left; or with the cross in his right hand and three nails in his left, the wounds in his hands and feet bleeding. These instances of martyrdom have been generally believed to have occurred, but Mrs. Jameson speaks of them as " real or imaginary," and Southey strongly protests against their being authentic."

${ }^{\prime}$ Matthew Paris, pp. 912-913; Gent. Magr., I 795, p. 372. 2 'Archcologia, vol. i., p. 26.

${ }^{3}$ Jameson, Legends of Monastic Orders, $2 \mathrm{~d}$ ed., p. I37. Southey says : "During those ages when the Jews were objects of popular hatred throughout Christendom, and when the slightest excitement sufficed for setting the rabble loose to butcher them and sack their houses, a common prelext for such atrocities was to assert that they had crncified a Christian child, or insulted a crucifix, or profaned a consecrated wafer, and that the murder, or the sacrilege, had been discovered by a miracle. A confession of the imputed crime was forced from the parties by torture, after which they were put to the cruellest death that exasperated bigotry could devise. The supposed victim was then made a popular saint. . . . Such instances . . I believe have occurred in every country where the papal power has been acknowledged, to the reproach of all. . . . Regardless alike of probability and humanity, the local ecclesiastical authorities entertained these charges, inconsistent as they were, contented with such proof as could be wrung from flesh and blood by the extremity of torture."-Letters to Chas. Butler, vindicating the Church of England, p. 4I4. 


\section{CHAPTER IV}

THE LEGENDS OF THE CROSS

Section 1.-Its Fabled Antiquity. Section 2.-Traditions Respecting the Wood of the Cross. Section 3.-The Miraculous Appearances of the Cross

THE germ of the so-called Legend of the Cross is found in the Apocryphal gospel of Nicodemus, but it has been developed so that, while the different versions agree in the main ideas, it is difficult to dovetail these details so that a connected story can be presented.' Omitting some minor particulars, it is as follows:

Section I. Its Fabled Antiquity.-Adam was weary of life, and longed to die. Calling his son Seth, he bade him "Go to the gates of Eden and ask S. Michael, who guards the Tree of Life, to send me some of the oil of mercy which God promised me when he thrust me out of Paradise." Seth replied,

Mission of Seth for the Oil of Mercy. "Father, I am ready, but I know not the way."- - Go," commanded Adam, "by that valley which lieth Eastward; there is a green path along which you will find blackened footprints, for where my feet and those of your mother trod in leaving the garden no grass has since grown."

When Seth approached the gates of Eden he found them guarded by

1 The principal authorities are the Aurea Legenda of Jacobus de Voragine, and a curious Dutch block-Look, Geschiedenis van het heylighe Cruys, printed by J. Veldener in $\mathrm{I}_{4} 8_{3}$. Of the latter only three copies are known to exist ; one in the Royal Library at Brussels, one in the collection of Mr. Schinkel at The Hagne, and another in the library of Lord Spencer. M. Berjeau has translated and reproduced in fac-simile the last, with additions from a French MS. of the thirteenth century which is in the British Museum. The legend is also found in the I'ita Christa, printed at Troyes in 1577 , and in the Catalogzes Sanctorum of Peter de Notalibus. It has been condensed and given in a modern dress in Lord Lindsay's Christian. Art, Mrs. Jameson and Lady Eastlake's History of Our Lord, and S. Baring-Gould's Curious Myths of the Middle Ascs. 
an angel in whose hands was a sword of living fire, but he was permitted a glimpse of the Paradise lost by his father's transgression. Seth beheld a crystal fountain whose sands were of silver, through which the water rolled in four mighty rivers. Before the fountain was a gigantic tree, but bare of fruit and foliage; around its trunk a terrible serpent had writhed himself and had burned the bark and devoured the leaves. Be-

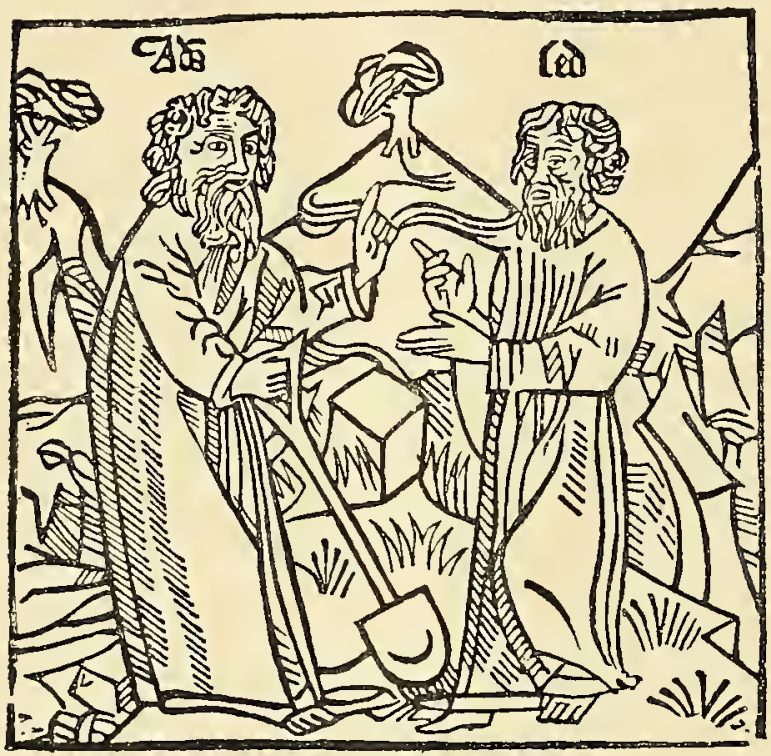

Adam Sends Seth to Paradise for Some of the Oil of Mercy.

From Veldener's The Legendary History of the Cross.

neath the tree was an awful precipice, for its roots reached to the depths of Hell. The only human inhabitant there was Cain, who strove to climb the tree to re-enter Paradise, but the roots, as if instinct with life, twined around and entangled the murderer, even penetrating his flesh. Appalled, Seth raised his eyes to implore mercy, and gazed at the top of the tree. Its head reached unto Heaven, and its branches were covered with foliage, flowers, and fruit, and what was most beautiful of all, a little babe was listening to the songs of seven white doves circling around him, and a woman more glorious and lovely than the moon bore the child in her arms. ${ }^{2}$

1 The above passage is given from S. Baring-Gould's NIyths. It is not to be found in the authorities to which the writer has access :

"In an Apocryphal MS. entitled The Book of the Prophet Moses, in the possession of the Hon. Robert Curzon, is recorded the following conversation between God and Adam after the Fall: "Then I called him, saying, Oh Adam ! thou hast transgressed my command; lift up thine eyes. Then I said unto him, What seest thou? He said, I see a tree standing above my head.

" Then I answered him, and said unto him Thou hast spoken truth.

" 'He said, Oh Lord! this tree above my head is like a cross.' "-Jameson, Hist. of Our Lord, vol. i., p. 108.

In an ancient commentary on S. Nlatthew, the star which appeared to the Wise Men had the form of a radiant child bearing a cross.-Jameson, Legends of the Madonna, p. 2 II. 
The angel at the gate refused to give Seth the oil of mercy, telling him that it could not be bestowed upon man until five thousand five hundred years had elapsed, but, in token of future pardon, he gave him three seeds from the Tree of Life, ${ }^{1}$ and commanded him to bury them with his father. So Seth returned. When Adam heard the message of the angel he became merry, and laughed for the first time since his transgression, and said :

"O God, I have lived long enough. Take my soul from me." Adam died the third day after Seth's return, and his sons buried him in the Valley of Hebron."

The three seeds produced three saplings, which mar - Product of vellously be- the Seeds. came one, yet preserved their distinct natures. This sapling Moses found, and plucked it as his $\operatorname{rod}^{3}$; it was this that sweetened the bitter waters of Marah, and

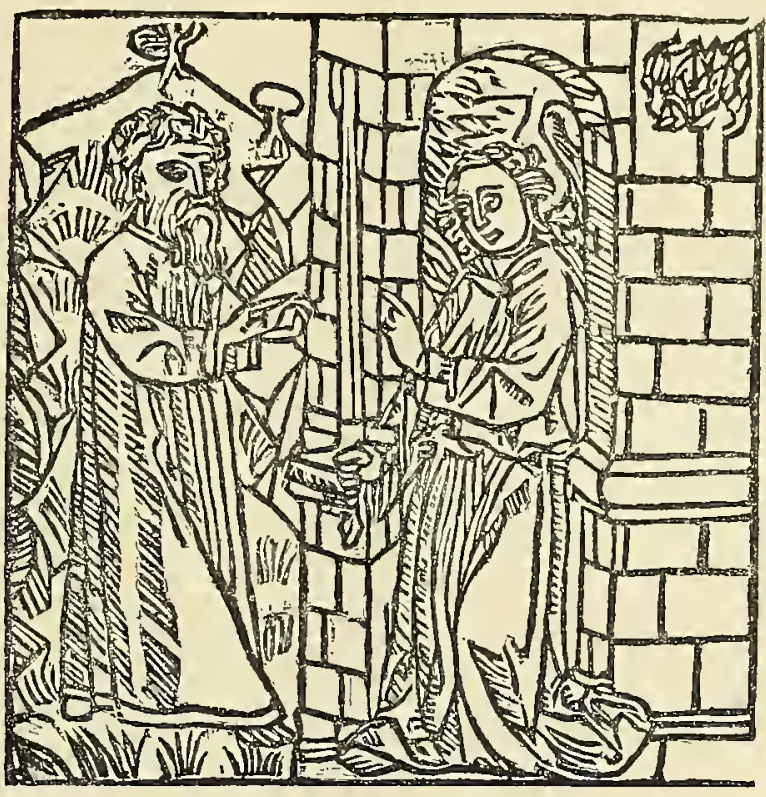

The Archangel Michael Gives Seth Three Seeds of the Tree of Life. From Veldener's The Legendary History of the Cross.

drew forth water from the rock in the wilderness. As the Prophet was punished for his presumption in not calling upon God when he smote

1 The usual reading is the Tree of Knowledge. "But the Aungelle seyd to him that he myghte not have of the Oyle of mercy. But he toke him three greynes of the same Tree that his fadre ete the appulle off, and bad him, als sone as his fadre was ded, that he sholde putte theise three Greynes undre his tonge, and grave him so: and he dide."-Voiage and Travaile of Sir Fohn Manndeville, p. I3. The angel gave Seth a branch of the tree whereof Adam had eaten, bidding him plant it on Mount Lebanon, and that when it bore fruit his father should be healed. -Legenda Aurea.

${ }_{2}^{2}$ The tree, with the bones of Adam, was preserved in the ark by Noah, who divided the relics among his sons. The skuil fell to the share of Shem, who buried it in a mount of Judea called from this circumstance Calvary and Golgotha. The tree Noah himself planted on Mount Lebanon. It was at once palm, cypress, and cedar.-Tentzelius' Numial Treatise, quoted in Southey's Omniana, vol. i., p. 25r. The woods here are evidently typical of Victory, Death, and Eternity.

${ }^{3}$ See chap. ii., "Types of the Cross," for a somewhat different story of Moses' rod. 
the rock the second time, he was not permitted to carry the rod into the

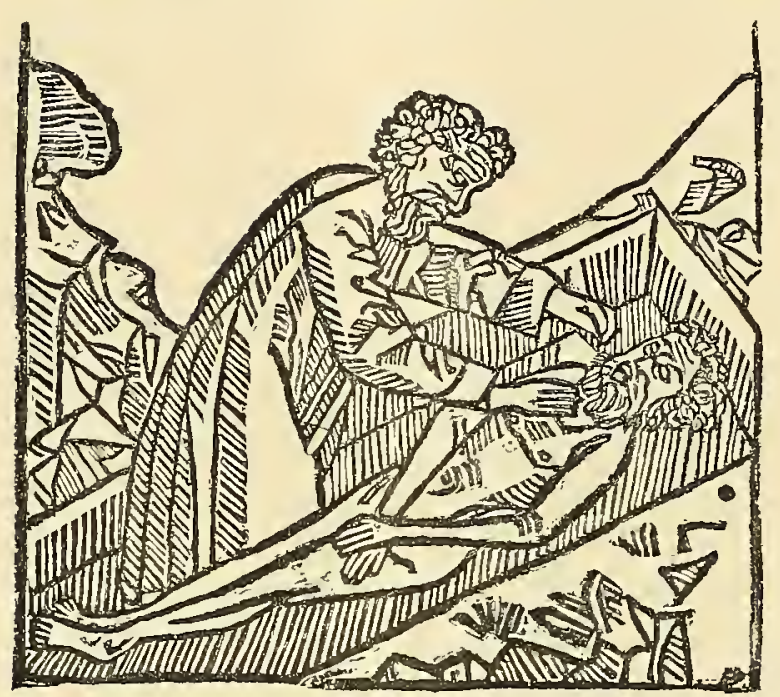

Seth Buries Adam and Puts the Three Seeds of the Tree of Life under his Tongue.

From Veldener's The Legendary Iristory of the Cross.

Promised Land, so he planted it in Moab. David, being moved by an angelic vision to transplant it to Jerusalem, sought it for thrce days before he found David Finds it. On his the Tree. way to the Holy City divers miracles were wrought ; the sick were healed, a leper cleansed, and three black men made white by its touch. The monarch planted it in that part of his garden to which he resorted for private devotion, and under it bewailed his grievous sins; he also begirt it with thirty rings of sapphire, and built a wall around it.

In time, the tree became gigantic, and Solomon Uses it. Solom on desired to use it as a column in the Temple; but, cut it as they might, the workmen found that the beam miraculously became either too long or too short for their purpose. In anger it was thrown aside. A woman, named Sibylla,

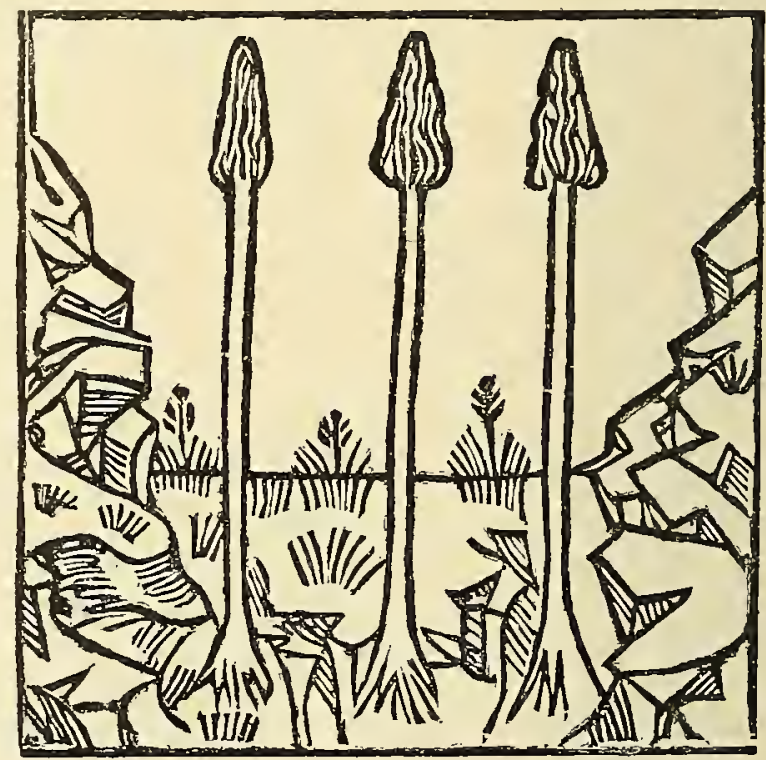

The Three Seeds Spring $\mathrm{U}_{\mathrm{p}}$.

From Veldener's The Legendary History of the Cross. 
sat upon it to rest; suddenly her clothes took fire, and she prophesied that Christ should hang upon that beam, whereupon the Jews beat her to death, and then threw the beam as a foot-bridge across a stream that it might be trampled under foot. When Balkis, the Queen of Sheba 1 visited King Solomon, she prophetically dis- Visitand of Sheba, visited King Solomon, she, prophetically dis- Prophecy of cerning its future destination, refused to walk over it, but, worshipping it, took off her sandals and forded the stream. And she declared to Solomon that upon that holy wood the Saviour of Adam and his posterity would suffer. Thereupon the King commanded that the beam should be overlaid with silver, gold, and jewels, and placed it over the door of the Temple, which faced the rising sun. His grandson, Abijah, coveting the treasure, stripped the adorn- Abijah Robs and ments from Conceais the the wood, and, to conceal the theft, buried the beam in the ground. A spring welled forth from the place, which in after times was known as the Pool of Bethesda, and the angel, to whom was committed the care of the sacred wood, at times

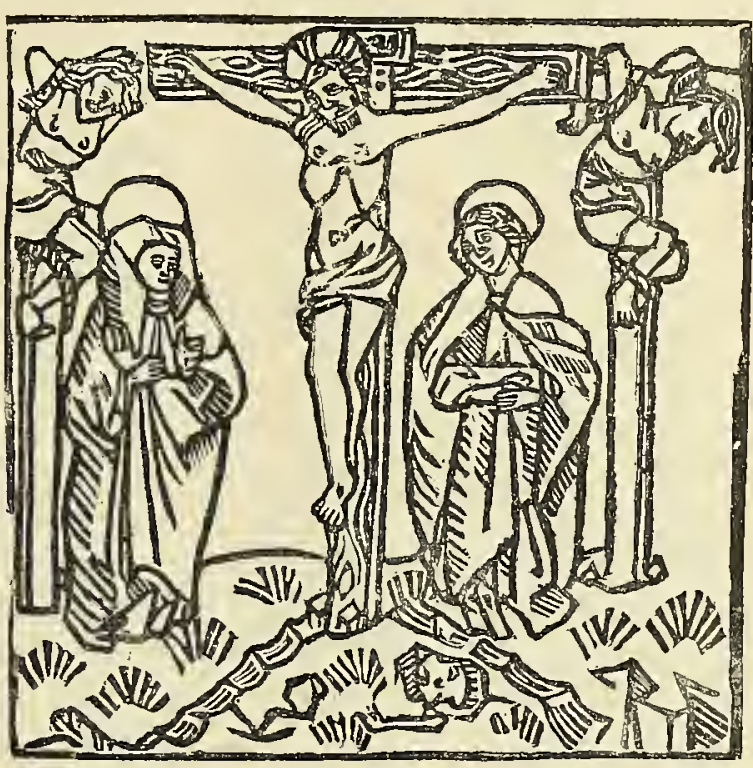

The Crucifixion.

From Veldener's The Legendary History of the Cross.

" troubled the water," and the tree, giving forth its virtue, healed the sick.

At the time of the crucifixion of our Lord, the rood floated to the surface, and from it the Cross was formed in which were it Reveals itself four species of wood, yet made of one tree: the palm, $\begin{array}{r}\text { when Nueded } \\ \text { for Christ's }\end{array}$ cypress, cedar, and olive.

Sacrifice.

When S. Helena, the mother of Constantine, visited Jerusalem, the Spirit having infused into her the wish to discover the Cross of our Lord,

1 Bruce calls her Maqueda. The kings of Abyssinia have always claimed to be the lineal descendants of Solomon and the Queen of Sheba.-Sale, Koran, vol. ii., P. I74, note; Bruce, T'ravels, vol. ii., p. 165. 
she called togetler the wise men, and elders of the Jews, who, much fearing, sought anxiously among themselves what this assembling could s. Helena's mean. One of them, named Judas, said: "I know that she Mission. wishes to learn where is the wood of the Cross upon which Jesus was crucified, but beware lest ye reveal it, for as soon as that Cross shall be found, our Law will be done away. I have learned this from my forefathers, one of whom, Zaccheus, was the father of Stephen." That was the protomartyr. But the Jews declared that they had never heard these things before, and agreed on no account to reveal where was the wood of the Cross. But when they were brought to the Empress, they

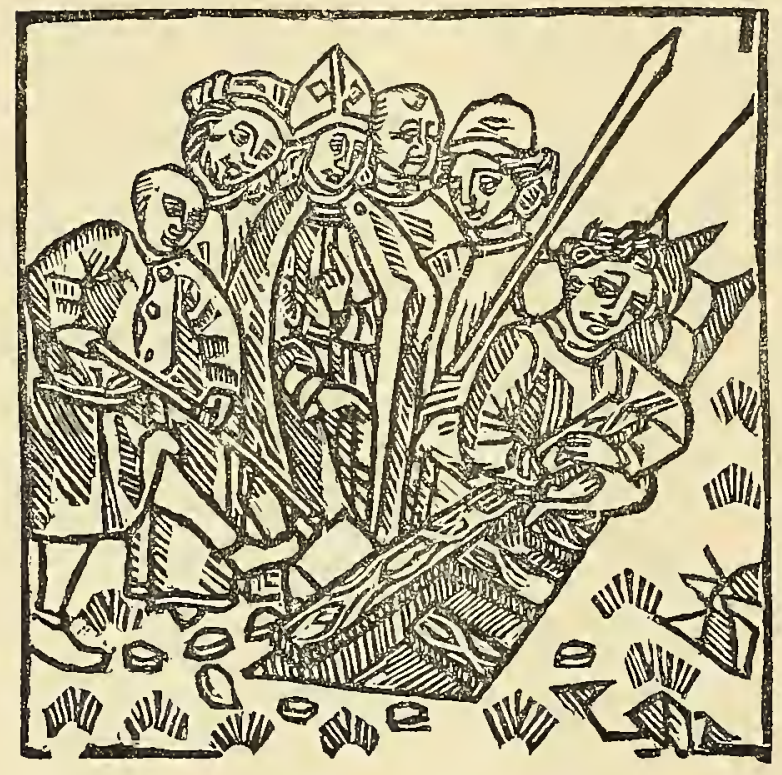

The Jews Bury the Crosses.

From Veldener's The Legendary History of the Cross. were terrified by her threats of death by fire, and pointed out Judas as a just man, and the son of a prophet, who was skilled in their law and traditions. The old man being obdurate, S. Helena commanded him to be cast into a pit to starve until he disclosed the truth. He endured the agonies of hunger for six days; on the seventh day he yielded, and led the Empress to Calvary. Upon the sacred mount was a temple of Venus, which Satan had subtilely caused Hadrian to build in order that when the Christians came to that spot to worship they might be charged with adoring the Paphian goddess. Judas having prayed, the earth trembled, and a fragrant odor was diffused. S. Helena commanded the pagan temple to be demolished and its foundation ploughed up.

Then Judas began to dig vigorously, and at the depth of twenty feet he found three crosses. But a new difficulty arose, for they could not distinguish the Cross of Christ from that of the thieves. And about the 


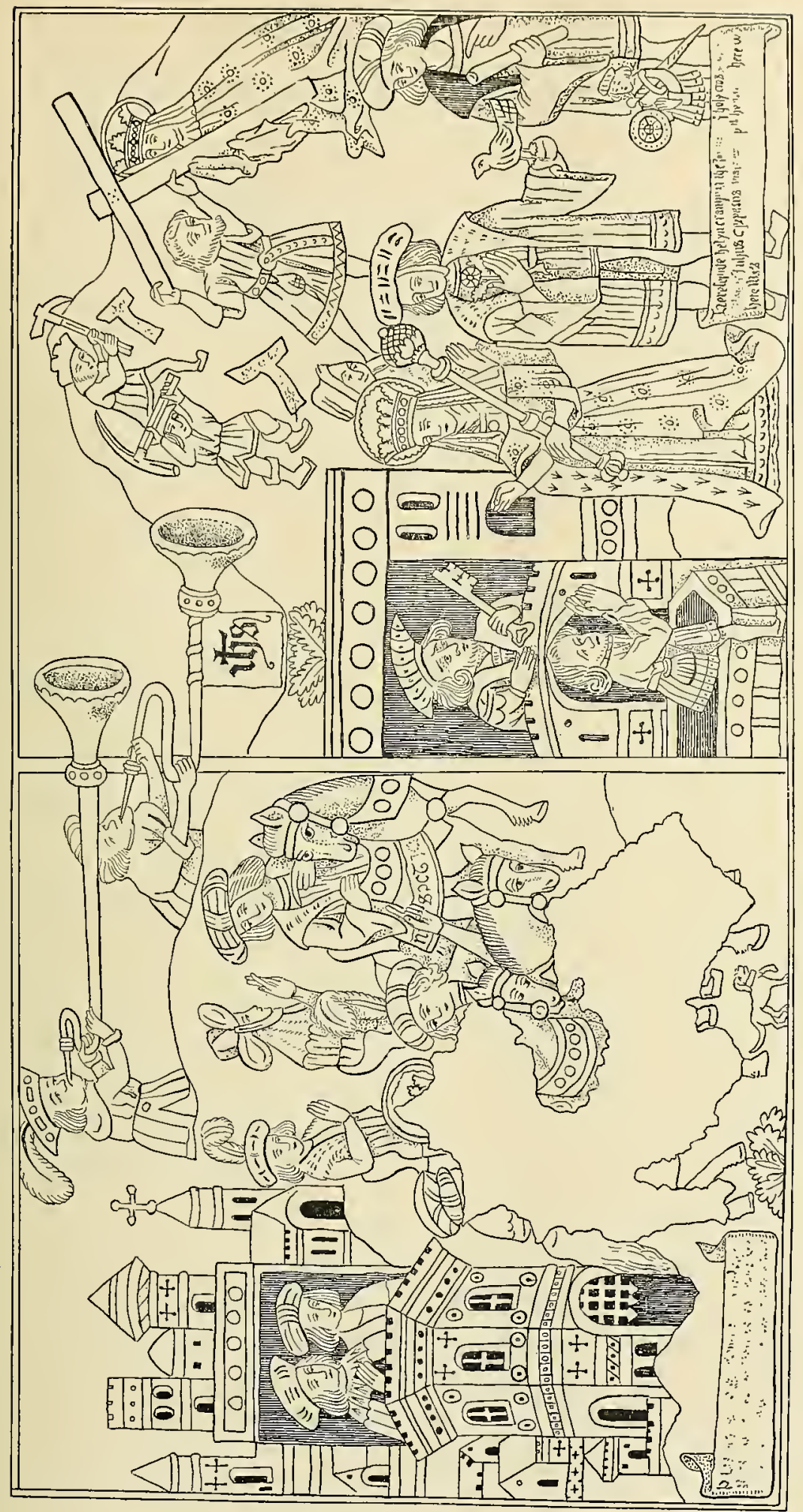


ninth hour a certain dead man was carried by, and Judas stopped the bier and laid the first and the second cross upon the dead man, but he moved not. Then they laid the third Cross upon him, and imDiscovery of the
Cross and Subse- mediately he came to life. A certain woman also, of the quent Miracles. first rank in the city, was lying half dead, to whom Macarius, the Bishop of Jerusalem, applied the first and second crosses, but they profited nothing; but the third being laid upon her, she rose up whole. But the devil was vexed, and cried in anguish, "By the first Judas I gained many souls, but by the second Judas I have lost all that I gained "; he also threatened him with torments and persecution, which came to pass under the reign of Julian the Apostate. For Judas was converted by these miracles, and was baptized, his name being changed to Quiriacus, and, after the death of Macarius, he became Bishop of Jerusalem.

S. Helena desired also the nails by which our Lord was fastened to the Cross, and Bishop Quiriacus having prayed, the nails immediately Discovery of appeared upon the ground, glittering like gold; being dethe Nails. livered to the Empress, she reverently adored them, and caused one to be placed in the crown, or helmet, of her son Constantine; another was forged as a bit, or placed upon the bridle of his war-horse, in verification of the prophet's words, "In that day shall be upon the bells [margin bridles] of the horses, Holiness to the Lord "' (Zech. xiv., 20); and the third she reserved for herself; but, being in a dangerous storm on the Adriatic, she threw it into the sea, which until that time had been a whirlpool. Some say there was a fourth nail, which was placed in the statue of Constantine which overlooked the city of Rome. The Cross of the Lord she divided; part she sent to her son, and the rest she enclosed in a silver shrine and left at Jerusalem. And she appointed the Feast of the Invention of the Holy Cross to be solemnly celebrated every year.

And in the course of many seasons, as time flowed on, the Lord permitting his people to be scourged for their sins, Chosroes, King of the Cross in Posses- Persians, subdued all the kingdoms of the East to his sion of Chosroes. dominion. But, coming to Jerusalem, he fled terrified from the sepulchre of the Lord, yet carried away the portion of the Lord's Cross left there by S. Helena. Wishing to be adored as a god, he caused to be constructed a tower of gold, silver, and precious stones, 


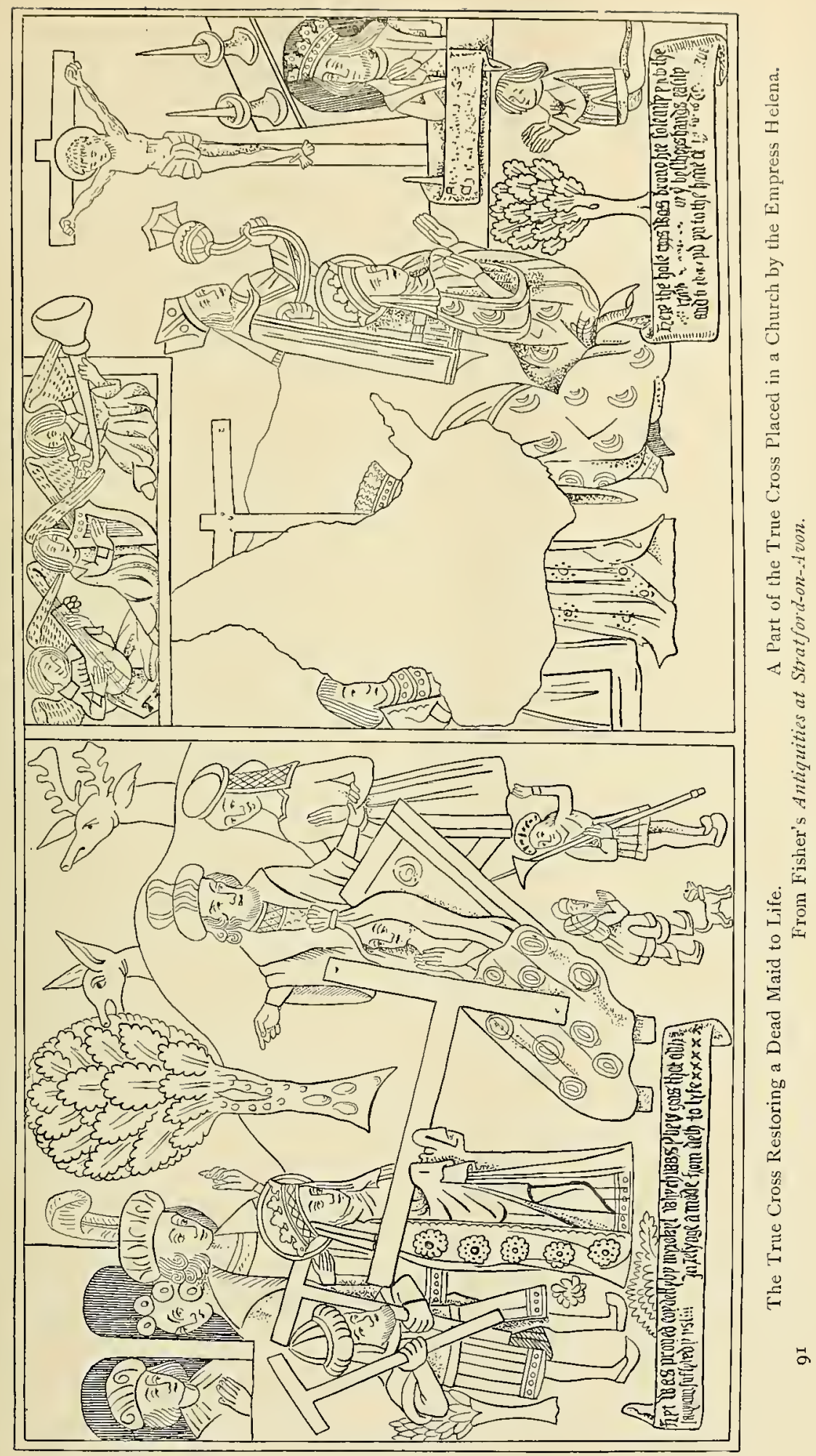


and placed therein images of the sun, moon, and stars. By slender conduits artificial rain fell, and chariots drawn with a great noise in a subterranean passage shook the tower and imitated thunder. And giving up the lingdom to his son Chosroes, he enthroned himself in the tower as the Father, and put the Cross upon his right in place of the Son, and a cock for the Holy Spirit.'

Then the Emperor Heraclius, being roused from his natural indolence by this blasphemous impiety, came with a mighty army against the Rescue of the Heraclius. son of Chosroes to recover the holy Cross. And they met by the river Danube, and the two princes agreed to fight in single combat upon the bridge, and that he who should remain victor should dispose of the army of the other. Heraclius, commending himself to God and the holy Cross, after a severe conflict, overcame his antagonist, who, refusing to be baptized, was slain. "And immediately the whole army of the Persians, as if by divine impulse, yielded itself to the Christian faith and received holy Baptism."

Heraclius offered to Chosroes, as he had revered the Cross after his fashion, that his life and kingdom should be preserved. " And that infidel not acquiescing, Heraclius straightway beheaded him. But because he had been a king, and had after a manner honored the Cross of Christ, he ordered him to be buried." The tower was destroyed, the silver given to the soldiers, but the gold and precious stones the Emperor reserved to repair the churches which the tyrant had destroyed.

The rest of the legend is given in the quaint language of Caxton's version :

Heraclius " thenne tooke the Holy Crosse and brought it agayne to Jerusalem. And as he descended fro the Mount of Olyuete and wolde liaue entred by the gate, by whiche our Sauyour wente to his Passyon, on horsbacke adurned as a kyng, sodainly the stones of the gates de-

1 "After reading this history, some conception may be formed of the important place held by the cross in Christian Iconography. The cross, as has been said, is not merely the instrument of the punishment of Jesus Christ, but is also the figure and symbol of the Saviour. Jesus, to an Iconologist, is present in the cross as well as in the lamb, or the lion. Chosroes flattered himself that in possessing the cross, he possessed the Son of God, and he had it enthroned on his riglit hand, just as the Son is enthroned by God the Father, so also the earliest Christian artists, when making a representation of the Trinity, placed a cross beside the Father and the Holy Spirit; a cross only, without onr crucified Lord. The cross did not only recall Christ to mind, but actually showed him. In Christian Iconography, Christ is actually present under the form and semblance of the cross. The cross is our crucified Lord in person: "Where the cross is, there is the martyr,' says S. Paulinus."-Didron, Christ. Icon., vol. i., p. 369. 
scended and ioyned them togyder in the gate like a walle, and all the people were greatly abasshed. And thenne the angel of our Lorde appyered vpon the gate holdyng the syne of the Crosse in his honde \& sayd, Whan the Kyng of Heuen wente to hys Passyon by this gate, he was not arrayed lyke a kyng, or on horse-

Return of the Cross to Jerusalem. backe, but came humbly vppon an asse in shewynge the example of humylyte, which he lefte to theym that honour hym. And whan that was sayd he departed \& vanysshed awaye. Thenne the Emperour tooke of his hosen and shone hymself in wepynge, and despoyled hym of all his clothes in to his sherte, and then tooke the Crosse of our Lorde and bare it moche humbly vnto the gate. And anone the hardenesse of the stones sette the celestyal commandement, and remeued anone and opened and gaaf entre vnto all theym that entred. And thus was the precious tree of the Crosse restablyshed in his place, and the ancient miracles renewed." A dead man was raised, four paralytics were cured, ten affected with leprosy cleansed, divers devils were cast out and diseases healed, and as a proof of the divine blessing the sweet odor, that had departed from the day when the Cross had been removed from the tower of Chosroes, returned, and refreshed them all with its sweetness. "Thenne the Emperour dyde repayre the chirches and gaft to them grete gyftes and after retourned home to his Empyre."

This Exaltation of the Cross really took place on September I4, about A.D. 620. The festival has greater antiquity, having been instituted when.S. Helena placed the Cross on the summit of an altar, September 24, A.D. 326.

Section 2. Traditions Respecting the Wood of the Cross.-To various trees is assigned the mournful honor of furnishing the material of the holy Cross. Perhaps the most general tradition ascribes it to the aspen, ${ }^{2}$ because the leaves ever tremble, as if

The Cross Made of the Aspen.

${ }^{1}$ Other traditions cluster around the aspen-ex,gr.: All the trees drooped their leaves at the time of their Creator's sacrifice, but the aspen haughtily asked, "What are thy suffering; to us? the plants need no atonement, we are not fallen." The Angel of Death breathed upon the boaster, and it has trembled ever since. Mrs. Jameson also relates a legend of the journey of the infant Jesus and the blessed Virgin and S. Joseph, when flying from Judea to Egypt. As they passed through a forest of trees, they would have lost their way, but for the guidance of an angel. As they entered the forest all the trees bowed themselves in reverence to the infant God, only the aspen in her exceeding pride refused to acknowledge $\mathrm{Him}$, and stood upright. Then the infant Christ pronounced a curse against her for her arrogance, and her leaves have trembled ever since.-Legends of the Madonna, p. 234. 
shuddering at the remembrance of the awful use in which it had been once employed.

Anciently, it was a widespread belief that the Cross of our Lord was made of the mistletoe which formerly was a large tree, but the curse

Mistletoe the Material of the Cross. which He bore who hung thereon, being in part transferred to the tree itself, it dwindled away and became the parasite it is now. The ceremonies of the Druids in gathering the mistletoe, or " All Heal," as they called it, were peculiarly symbolical of the offices of the Cross. In Scandinavian mythology, the mistletoe furnishes the wood from which is made the arrow with which Hädur, at the instigation of Loki, kills Baldur. Formerly, small pieces of mistlet oe were worn as amulets to protect pious souls from the temptations of Loki.

In some parts of Great Britain the elder is respected as the wood which bore the Lord of Life in death, and some persons religiously abstain Cross Made from using it as fuel. In this instance the legends respectof Elder. ing the tree of our Saviour and that of his betrayer have become interchanged. Sir John Mandeville says: "Fast by the Pool of Siloam, is still the elder tree on which Judas hanged himself in despair when he sold and betrayed our Lord."' That this tradition was acknowledged in England as late as the golden age of Elizabeth is seen from the frequent references by authors in her time and previously. Shakespeare thus plays with the word in Love's Labonr's Lost.

"Holifernes: Begin, Sir. You are my elder.

Biron: Well followed; Judas was hanged on an elder."

Ben Jonson says also in Every Man in His Humour

"He shall be your Judas, and you Shall be his elder tree to hang on."

Nixon, in his Strange Footpost, writes, " Our gardens when they have in them not one of those elders whereupon so many covetous Judases hang themselves."

Richard Flecknoe also refers to the same tree whose

${ }^{1}$ Mandeville, Travels, p. I75. Bohn's ed. In Germany and Scandinavia the elder was supposed to be the abode of the goddess Huldah and her servants the elves. Every Sat. (Vienna), June 7,1873, p. 638 . 
"Virtue oft from Judas came

Who hanged "himself "pon that same."

Diarum.

In the epilogue to Lilly's Alcrander and Campaspe, the elder is referred to as a mark of shame. "You may make doves of vultures, roses of nettles, laurel for a garland, or elder for a disgrace."

Shakespeare makes it also an emblem of grief:

"Grow patience

And let the stinking elder grief intwine

His perishing root with the increasing vine."

Cymbeline, Act iv., Sc. 2.

There is a curious tradition that the Cross was made of an apple-tree, derived from a far-fetched gloss on Canticles viii., 5. "I raised thee up under the apple-tree; there thy mother brought thee The cross Made forth: there she brought thee forth that bare thee." ${ }^{2}$ In of an Appte-Tree. the Vulgate the verse reads: "Ibi corrupta est matcr tua, ibi violata est gcnctrix tua." An ancient MS. in the possession of Dr. Adam Clarke, formerly belonging to the youngest son of Edward III., reads, " There defouled is she that got thee."

The oak also has been supposed to be the tree which contributed the

1 But even as to the death of Judas some differ. The doubt arises from the word $\alpha \pi \eta \forall \xi \alpha \tau o$ which may refer to suffocation withont specifying the manner. Some say he was bung on a fig tree, others on a sycamore. See Fuller's Pisgaln Fiew of Palestine, b. iii, c. I3. Eutbymius and Ecumenius say that the hanging did not kill him, but the rope broke and he cast himself headlong. See Browne, Relig. Med., sec. xxii., p. 52; and Inquiry into Vulgar and Common Errors, b. vii., cap. II. The Minssulmans reverence all places consecrated to the memory of Christ and the blessed Virgin, except the tomb of the Holy Sepulchre, the sanctity of which they do not acknowledge, for they believe that Jesus ascended into Heaven, leaving the likeness of his face to Judas, who was crucified and buried in place of his Master. Curzon, Monasteries of the levant, p. 162. There is a curions tradition which is occasionally met with in art. Judas, knowing that his Master wonld descend into Hades and liberate the souls confined there, and conduct them to Paradise, hastened, after his treachery, to hang himself, in order that he might precede our Lord into Hades, and thus he saved. But the Devil bent down the tree on which the traitor was suspended, so that his feet touched the earth, and retained it in that position until Christ had passed through Hades, and then permitted the wretched soul " to go to his own place." Ciampini, Vetcra Monimenta, tom. iii,, tab. ix., fig. 31, gives an example from the brass doors of the Archiepiscopal Church at Beneventano.

There was a tree formerly called after the traitor, and hated accordingly. Pulci in Morgante Maggiore makes the traitor Ganelon plan the ambush against Charlemagne in the pass of Roncesvalles, under the shade of a Judas tree.

${ }^{2}$ Have we not here the origin of the common tradition that the apple was the forbidden fruit? Refer to Clarke on text. Also Gill on Canticles for some other traditions more curious than valuahle. 
material for the altar of the sacrifice, not only because it was a common tree in Palestine, and well fitted by its strength for the purpose, but also cross Made of because the fragments which bear the greatest probathe Oak. bility of genuineness appear to be of that wood.' The oak, also, as Gretser observes, has been sanctified by many divine mysteries and manifestations. It was under an oak that God covenanted with Abraham at Mamre for the salvation of his seed. Under an oak the angels avaited Abraham's hospitality, and repaid it by foretelling the birth of Isaac. Under an oak Deborah, Rebekah's nurse, was buried, and the name of it was called Allon-bachuth (Gen. xxxv., 8). Under an oak Jacob buried his idols; the angel appeared to Gideon under an oak; and other examples could be cited. Ciaccon, commenting on Isa. vi., I2, I3, says: " And the Lord has removed men far away, and there shall be a great forsaking in the midst of the land. But yet it shall be a tenth, and it shall return . . . as an oak whose substance is in them when they cast their leaves; so the holy seed shall be in the substance thereof." And, continues the commentator, "so the Jews, ravished and decimated by the Romans, yet the remainder of them, saved by the oaken Cross, preserved the seed of blessing and the salvation of the human race." 2

Such is the Legend of the Cross. One of the most imaginative and fantastic, yet one of the most popular myths of the Middle Ages, and ever a favorite subject for artists both in glass and fresco. It appears at Troyes, in the windows of the churches of S. Martin ès-vignes, of S. Pantaléon, of S. Madeleine, and of S. Nizier. It is frescoed on the walls of the choir of S. Croce in Florence by Agnolo Gaddi, and Pietro della Francesca has celebrated it in a series of paintings in the chapel of the Bacci, in the Church of S. Francesco at Arezzo.

Perhaps the most interesting example is the fresco on the walls of the chapel of the Guild of the Holy Cross in the Church of the Trinity at Stratford-upon-Avon. The Guild dates at least from the year I 296 , when it was authorized to build a hospital and this chapel. Shakespeare doubtless drank inspiration from these paintings, but the same spirit of vandalism which coated his bust with whitewash in like manner covered these inestimable works, so that their very existence was forgotten; and

${ }^{1}$ Lipsius, De Cruce, lib. iii., cap. I3.

${ }^{3}$ Gretser, De Cruce, lib. i., cap. 6. 
Horace Walpole declared that no specimen of this art (fresco painting) existed in England. But, in ISO4, they were discovered and restored to light.

It is not necessary to say that the lcgend must be read with a view to its allegorical interpretation. Born in the time of early Christian literature, when every page and text of Holy Scripture was read in the light of symbolism, it attained its full growth in of the Legend. the Middle Ages, which, as Warton says, were those " of vision and mystery: every work was believed to contain a double meaning. Nothing escaped this eccentric spirit of refinement and abstraction; and together with the Bible . . . the whole general history of ancient times was explained allegorically." "

Studying the story in the right spirit, there are many beautiful teachings hidden in the fantastic language of the legend. For instance, David begirt the tree with thirty rings of sapphire. It is not necessary to dwell on the number, for its symbolism is apparent, but note that in the language of heraldry, sapphire represents Azure, which symbolizes justice, humility, loyalty, and perseverance. Colombière says, "Azure represents the heaven, which is the highest of all things created, the tribunal of God and the everlasting mansions of the blessed." In sacred archæology, blue symbolizes piety, sincerity, divine contemplation, godliness etc. Reading the story thus, understandingly, we can perceive why David is represented as thus adorning the tree, and placing it in the part of his garden consecrated by private devotion and penitence for his grievous sins.

The Cross was spoken of as made of three species of wood, and these were varied according to the lesson desired. The words of Isaiah were sometimes cited by the Fathers. "The glory of Lebanon The Three Varieshall come unto thee; the fir tree, the pine tree, and the ties of wood. box together, to beautify the place of my sanctuary; and I will make the place of my feet glorious" (Isa. 1X., 13). S. Chrysostom so applies the text. In the Vulgate the words are cypress, pine, and cedar. Often the transverse is spoken of as made of palm, for the Bridegroom in Canticles says, "I will go up to the palm tree, I will take hold of the boughs thereof" (Cant. vii., 8), alluding to the stretching out of our Lord's hands upon the Cross. Hence we are told the Cross was made

\footnotetext{
1 Warton, Introduction, Diss, Early English Poetry.
} 
of the palm of victory, the cedar of incorruption, and the olives of royal and priestly benediction, ${ }^{2}$

But in later legends the number of the trees is increased. The simple symbolism of the Trinity gives place to a more complex idea, and yet Four Species. one concentrating and gathering together the various symbols of the second person of the Trinity, His office and His Church. Hence the Cross is said to have been composed of four kinds of wood. Four is the number which speaks of stability and the material universe, and the Church is made up from the elect from the four quarters of the earth, for Abraham was bidden, "Lift up now thine eyes . . . northward, and southward, and eastward, and westward " (Gen. xiii., I4). " Thus was the throne on the four quarters extended." The four quarters were watered by the rivers of Paradise, four streams yet proceeding from one head. The altar of incense was ordained to be four-square, with its four horns sprinkled with the blood of the sacrifice by which the offering was rendered acceptable. The sun was created on the fourth day, and in Revelation it is stricken out under the fourth trumpet; and the sun is a well-known symbol of the Lord himself in the Incarnation. ${ }^{2}$ The symbolism might be carried out further, but enough has been adduced to show its applicability, and that the coincidences are not merely accidental.

In the Legcnda Aurca, we read that the upright was of cedar, the transverse of cypress, the title of olive, and the suppcidancum, or footInterpretation of rest, of palm. And thus we would venture to interpret it.

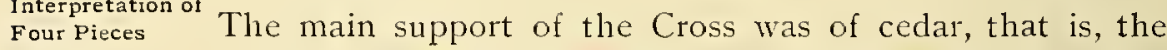
of Wood. altar upon which the sacrifice was offered was of the wood consecrated, not only by being employed in Solomon's temple, but by

1 Nicquetus quotes several authors in favor of the supposition that the Cross was made of only three kinds of wood, viz., cypress, pine, and cedar. Hist. de Tituli S. Cruces, lib. i., cap. 3. A gloss on $\mathrm{S}$. Clement places cedar in the root, palm in the upright, and cypress in the transverse; an ancient hymn locates cedar in the foot, cypress in the upright, palm sustains the hands, while the olive "rejoices" in the title. Gretser, De Cruce, lib. i., cap. 5. The Venerable Bede says the Cross was made of cypress, cedar, pine, and box, "But the box was not in the Cross unless in the title." The upright was of cypress as far as the transverse, which was of cedar and the top of pine. Bede in Collect.

${ }^{2}$ The four living creatures which stood round the throne will occur to every one. This term, living creature, is sometimes of $\operatorname{good}(y \omega \nu)$ and sometimes of evil ( Williams say's, "as four is of evil and also of good, it may be of the animal nature of man sanctified in the New Mlan." Isaac Williams on the Apocalypse, pp. 65, 7o. For a fuller development of the symbolism of this number see also Williams, pp. 84, I 23, I49, 168, 27 I.

${ }^{3}$ Legenda Aurea, De Inventione S. Crucis. 
having been previously appointed by Moses as one of the symbolical ingredients in the offering for leprosy and defilement consequent upon contact with death. ${ }^{\prime}$ The cypress sustaining the outstretched arms, the tree of mourning, yet ever green, as was the love everlasting, which, while it wept over sinners, extended its arms to embrace the whole world in its sacrifice. The olive, on which was the title, the universal pledge of peace, proclaimed that the Prince of Peace died to restore peace between God and man. The palm, the crown of earthly glory and symbol of martyrdom, is trampled under foot.

It was an early tradition that Clirist was crucified in the same place where Adam was buried. S. Chrysostom alludes to it. "Some say that Adam died there, and there lieth, and that Jesus, in that place where death had reigned, there also set up the troply. For He went forth bearing the Cross as a trophy

The Place of Adam's and Christ's Death the Same. over the tyranny of death, and as conquerors do, so bare He upon his shoulders the symbol of victory." 2 Even locally, thus the words are reconciled "As in Adam all die, even so in Christ shall all be made alive " (I Cor. xv., 22). " An apt connection," saith S. Jerome, "smooth to the ear, but not true." Another text was also adopted. "Awake thou that sleepest and arise from the dead, and Christ shall give thee light." In early art Adam is frequently represented as rising at the very foot of the Cross, holding a chalice to catch the precious blood, which, having fallen upon his grave, had recalled him to life. Sometimes the story is varied, and we are told that in one and the same place where the sacrifice was offered for that sin which " the blood of

${ }^{1}$ Leprosy was in a certain seluse the sacrament of death, " The outward and visible sign" of an inward corruption and sin which none but priests as vicegerents of God could remove. Lev. xiii. Hence our blessed Saviour appealed to his curing that disease as proof of His Divinity. S. Matt, xi., 5 .

${ }^{2}$ S. Chrysostom on S. John ; Hon. 85, p. 756, Oxf. Trans. This belief was common in the early Church. Origen speaks of it as well known in his time. Tract. xxxv. in Matt.; also S. Ambrose, Epis., lxxi. ; S. Athanasius, Ser. de Passione Opera, tom. ii., p. 9o, Benedict ed. S. Augustine writes, "The ancients hold that because Adam was the first man, and was buried there, it was called Calvary, becanse it holds the head of the human race." De Civitate Dei, cap. 32. S. Jerome adds Isaac to the list of those sleeping there. Tom. i., p. 937, Paris ed., I6IS. Molano, Hist. Imag. Sacra., lib. iv., cap. II. S. Basil says, "Probably Noah was not ignorant of the sepulchre of our forefather and that of the first born of all mortals, and in that place, Calvary, the Lord suffered, the origin of death there being destroyed." Isa. cap. 5. It was also held by some, S. Jerome says, that Jerusalem was the centre, or, as it was frequently expressed, the navel of the earth. Gretser, lib. i., cap I7. Tertullian and S. Cyril are more minute, and say that Calvary was the centre. Tertul., Contra. Mar., lib. ii.; S. Cyril Collect. Lect. xiii.

${ }^{3}$ History of our Lord, vol. ii., p. 207. 
bulls and goats could not take away," there was the offering of Cain and Abel, the sacrifice of Noah when he came out of the ark, there also Abraham offered Isaac, there was the threshing floor of Araunah which David bought to sacrifice therein when the plague, which his pride had brought upon Israel, had been stayed. In the same place, also, once dwelt Melchizedek, and Solomon built his temple.'

Donne, in his Hym to God my God in my sickness, has thus beautifully handed down to us an old-time tradition:

"We think that Paradise and Calvarie,

Christ's Cross and Adam's tree stood in one place;

Look Lord, and find both Adams met in me ;

As the first Adam's sweat surrounds my face,

May the last dam's blood my soul embrace."

As the tree of the Cross was planted in the terrestrial paradise, so it was believed that it would be transferred to the celestial, to reappear in heaven at the end of time borne in the arms of Christ, or of his angels, when the Lord descends to judge the world at the last day. ${ }^{2}$ Yet The Appearance the sign is already known there, according to an apocryof the Penitent phal gospel which relates that while Enoch and Elias Thief in Hades. were communing respecting the descent into Hades by the Saviour, "The penitent thief entered Paradise bearing upon his shoulder a cross as a token given by his Redeemer to attest, to the guardian angel of the gates, his right to admission." 3 Perhaps this legend was in the mind of quaint old Quarles, and found utterance in his expressive words, "The Cross of Christ is the key of Paradise."

But the legends clustering around the Cross are not always fraught Legend of the only with anguish; there are some simple and beautiful Redbreast. stories intertwined with the hearth-lore of many nations. For instance, that of the robin-redbreast.

"Bearing His cross, while Christ passed by forlorn, His Godlike forehead by the mock crown torn, A little bird took from that crown one thorn To soothe the dear Redeemer's throbbing head.

\footnotetext{
1 Adam, Happiness of the Church, p. 32. $\quad 2$ Didron, Christ. Icon., vol. i., p. 369.
}

${ }^{3}$ Gospel of Nicodemus, chap. xx. Some of the Fathers allude to the belief that the penitent thief was admitted into Paradise, as S. Chrysostom says, "before Abraham, before the whole human race." De Cruce et Latr., ii., §2. S. Cyril also says, "The faithful Abraham had not yet entered; but the robber enters! Moses and the Prophets had not yet entered, and the lawless robber enters." Catec. Lect. xiii., \$3I. 
That bird did what she could; His blood, 't is said, Down-dropping, dyed her tender bosom red.

Since then no wanton boy disturbs her nest; Weasel, nor wild cat, will her young molest, All sacred deem that bird of ruddy breast.'

Whittier has embalmed in one of his exquisite poems an old Swedish tradition that the robin-redbreast brings daily a drop of water to cool the tongues of those parched with thirst in Hell. His red breast is the effect of the scorching fires that the bird braves in his act of mercy.

Of the cross-bill we are told, he tricd to minister to his Maker in his agony. Longfellow gives us a translation from the German of Julius Mosen. The Lord and Creator of the universe Cross-bill. being forsaken of all his creatures save this little bird, who, striving at the nail,

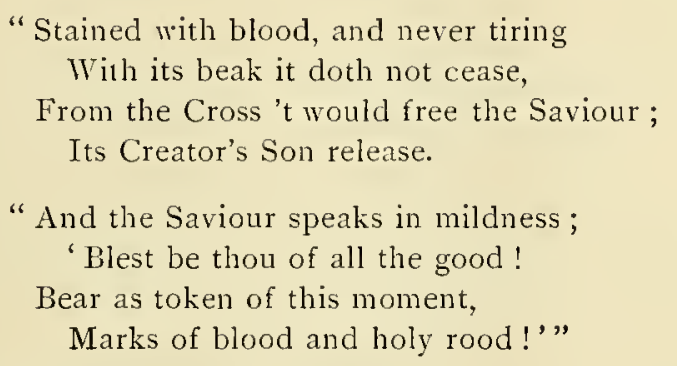

Mrs. Hemans reminds us of the arum,

"Beneath the cross it grew ;

And in the vase-like hollow of its leaf, Catching from that dread shower of agony

A few mysterious drops, transmitted thus Unto the groves and hills, their healing stains :

A heritage for storm or vernal wind Never to waft away!"

\section{Wood Walk.}

The granadilla, or passion-flower, seemed such a miracle of nature, when descriptions and drawings of it were first received in Spain and Italy, that Bosio hesitated about taxing the credulity of his readers, and fortified his description by reference to " persons of quality and gravity" who had travelled in the New IVorld. The pious author of the Triumph of the Cross avows his conviction, " that it

'Author unknown, Notes and Queries, fth ser., vol. iv., p. 390. 
seemed as if the great Creator of the Universe had been pleased to imprint on it the evident image and clear signification of the instrument of the Passion of his only begotten Son in order that in after times they might aid in the conversion of the idolatrous people." His description

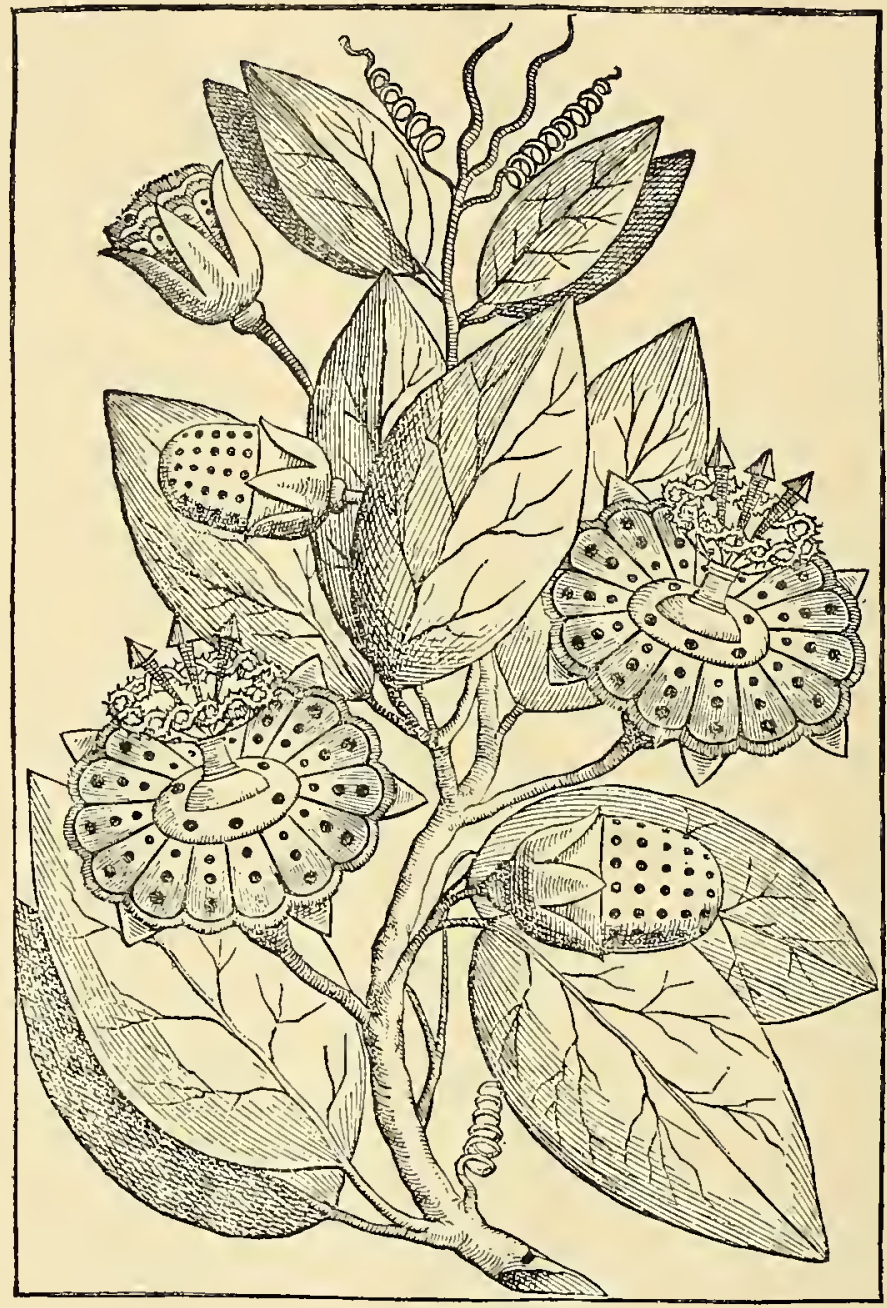

Passion Flower.

From Bosio's La Trionfante e Gloriosa Croce.

of the flower is such as might be expected from his simple yet fervid devotion. The upper petals are tawny in Peru, but white, tinted with rose color, in New Spain. The fringe of filaments above, resembling the scourge with which our Lord was beaten, are the color of blood. In the 
middle of the flower rises a stem, like the pillar to which Jesus was bound; above this are three triangular little branches like the nails, surmounting is the crown of thorns surrounded by a veil of threads seventytwo in number, corresponding to the traditionary number of thorns in our Saviour's crown, colored like a peacock-feather. In the centre and surrounding the column are leaves like a lily, each spotted with five drops of deep blood color " which resemble the five wounds Christ received on the Cross," hence the Spaniards call it the flower of the five wounds (flor de las cinco llagos). The leaves of the plant resemble the head of the lance with which the side of Jesus was pierced. If any part of the flower or vine is broken, blood-like sap drops from it. The flower is generally partly closed, as if carefully guarding its wonderful mysteries; Bosio, therefore, gives a representation of it open, that the pious reader may contemplate it with spiritual profit, and he devoutly suggests that it would seem that Infinite Wisdom had concealed these mysteries of the Cross and Passion until the time the Most High had preordained to fulfil S. Paul's words: "The mystery which hath been hid from ages and from generations, but now is made manifest to his saints: To whom God would make known what is the riches of the glory of this mystery among the Gentiles"' (Col. i., 26, 27).

But time and space would fail us to gather together a tithe of the holy memories which have been embodied in thought and word by the devout worshippers of the Cross. We cannot do better than end this part of our subject with the following words from Mrs. Hemans's Wood Walk :

$$
\text { "Many a sign }
$$

Of the great sacrifice which won us Heaven The woodman and the mountaineer can trace On rock, on herb, and flower. And be it so! They do not wisely that, with hurried hand, Would pluck these salutary fancies forth From the strong soil within the peasant's breast, And scatter them-far, far too fast !-away As worthless weeds. Oh ! little do we know When they have soothed, when saved!"

Section 3. The Miraculous Appearances of the Cross.-It was on the 26 th of October, according to Gibbon, the 7 th of November, according to other historians, A.D. 3I2, the eve of the battle between Max- 
entius and Constantine, about midday, some say; when the sun began to decline towards its setting, say others; when to the Roman Emperor Appearance of the Cross to Constantine. and his army there appeared in the heavens a cross of light above that of the sun, with the inscription, in a constellation of stars, according to some authorities, EN TOTT $\Omega$ $N I K A$, " "In this Conquer." Amazed, the pagan augurs presaged that the sign of the Cross, which they "believed to be deadly, not joyful, to

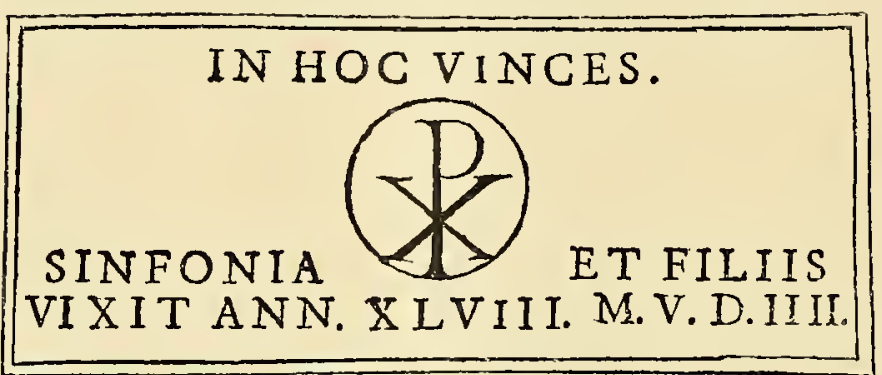

From Bosio's La Trionfante e Gloriosa Croce. men," portended the destruction of the whole army. ${ }^{2}$ Eusebius tells us that at sight of this apparition, Constantine, who was wavering between paganism and Christianity, was in doubt as to what it portended, and retired to rest, anxious and thoughtful. During the night Christ apHis Vision peared to him, together with the sign before seen in the at Night. heavens, and bade him use it as a standard for protection against his enemies. As soon as it was day, he related the vision to his friends, and then assembling the workers of gold and precious stones he ordered them to imitate with their materials his description. ${ }^{\mathrm{s}}$ The historian gives a minute account of this standard, which was called the Labarum. A long spear, plated with gold, with a transverse bar, formed a cross. From the bar was suspended a square banner of purple, interwoven with The gold and precious stones. Above this were golden porLabarum. traits of the Emperor and his sons, and the whole was surmounted by a.golden crown, brilliant with gems, within which was placed the Greek letter $X$, intersected by the letter $P$. It is said to have been preserved in the palace at Constantinople until the nintl century.

Nicephorus and Zonaras say that the inscription was in Latin, IN HOC VINCE. Eusebius implies it was in Greek. The commander Leo affirmed the same. Brentius thinks the appearance was that of the monogram $\mathbb{X}$. Gretser, De Cruca, lib. ii., cap. 37 : see also Cath. Orth., ii., I9, p. 168, and Mosheim, ii., iv., I, note 29, 30. Neander says, "Undoubtedly in the native language of the Roman soldiers: "In Hoc Tince." Eccles. Hist., vol. ii. p. 7, note. $\quad{ }^{2}$ Baronius, Annals., 312 ; Gretser, De Cruce, lib. ii., cap. 36.

${ }^{3}$ Eusebius, Life of Constantine, book i., c. 22-31.

"Hemans, Ancient Christianity' and Sacred Art, p. 90. 
Such a magnificent standard would seem more fitting for a procession than for a battle-field. To guard it, therefore, fifty chosen men (called Draconarii, from one of the pagan Roman standards) were appointed, who carried it by turns, and when any part of the army was hard pressed in battle, thither it was borne, and by the confidence it inspired, the army was invincible. And, according to the legend, the bearers never were wolinded, for the missiles aimed at them struck the staff. The device of the monogram was also engraved by Constantine upon his shield and coins.

The account of the vision was given by the Emperor to History of Eusebius, and the Story. solemnly confirmed with an oath. For thirteen hundred years no one questioned the story. Godefroi, a French

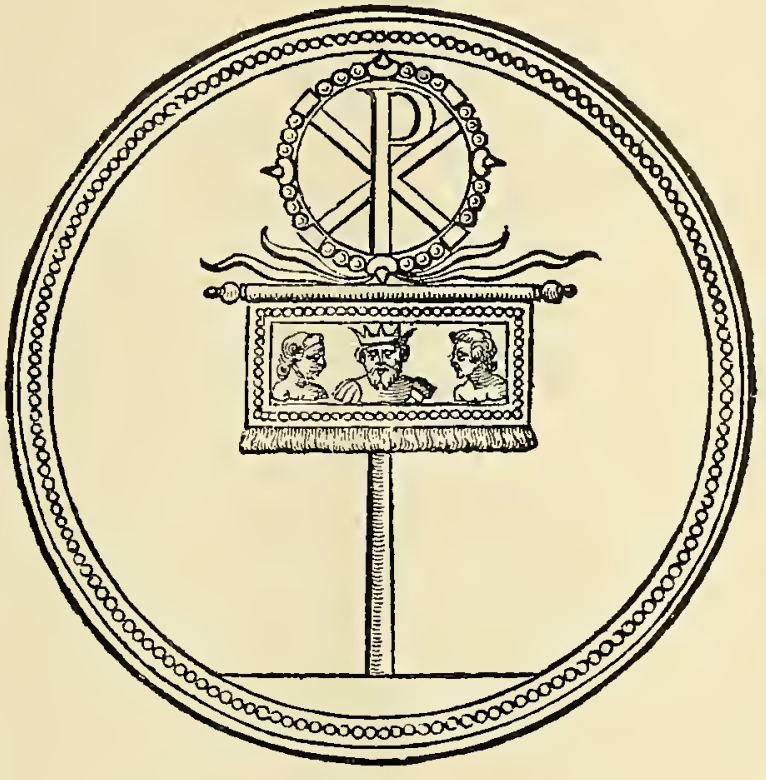

The labarum.

From Bosio's La Trionfante e Gloriosa Croce. writer of the seventeenth century, was the first who impugned the veracity of the historian, or of Constantine; and, of course, the infidel Gibbon expresses his opinion that Protestant and philosophic readers of the present age will incline to believe " that, in the account of his own conversion, Constantine attested a wilful falsehood, by a solemn and deliberate perjury." " But Constantine declared that the whole army witnessed the miracle. He was in his thirty-eighth year when it happened, and there must have been many in that army younger than himself, and who were alive ${ }^{2}$ when Eusebius published his account, and yet there is no evidence of its having been contradicted. Nor do we

' Gibbon, Decline and Fall, chap. xx.

2 The Acts of Artemius are extant. He was in Constantine's army and was afterwards deprived of his commission, on account of his Christian faith, by Julian the Apostate. Artemius testifies that he saw the sign and read the letters, and that many witnesses could be produced 
read of any disturbance when the Labarum was presented to the army as their standard. Would the rugged Roman soldiers have accepted, The Change of without the most weighty reason, the change of their the Roman Eagle beloved Eagles, which for so many centuries had flown for the cross. before them to victory, for an image hated and accursed, and only telling of shame and ignominy? The army at that time was, doubtless, mainly composed of heathen, and it ruled Rome. It was the army which had called Constantine from Britain to Rome, and placed him over four competitors, as the successful candidate for the imperial purple. Would Constantine have dared to risk his popularity and power without sufficient cause? In modern times, could Washington have led the American troops from Valley Forge to Yorktown under the standard of a gallows? or Napoleon have returned from Elba to Paris carrying the insignia of a guillotine? Yet these symbols would not have been less abhorrent to Americans, or to Frenchmen, than was the cross to Romans.'

There is also pagan testimony as to the miracle. In a panegyric delivered immediately after the victory, the heathen orator asks, " What god, what divine presence encouraged thee, that when nearly all thy companions in arms and commanders not only had secret misgivings, but had open fears of the omen, yet against the warnings of the diviners, thou didst thyself perceive that the time of delivering the city was come?" " Hence we know that something miraculous must have happened. No other miracle save that of the Cross has ever been suggested.

About the year A.D. 3 I4 or 315, Constantine erected a triumphal arch at Rome, with an inscription testifying that he had gained the victory, "instinctu divinitatis, mentis magnitudine." Also, as soon as he entered Rome he caused to be made a statue of himself holding a cross in his hand, and with an inscription to the effect that "with the life-giving sign" he had delivered the city from the "dominion of a tyrant."

from the army. Vita Acta. S. Artemii afud sur, tom. v., cited by Gretser, De Cruce, lib. ii., cap. 36. Burton, however, thinks that the anthenticity of this document may be dousted. Eccles. Hist., chap. xxx., p. 64t, note.

${ }^{1}$ Cicero says, "That the very name of the cross was not only far removed from the body of a Roman citizen, but even from his thoughts, eyes, and ears... as an indignity to a Roman and a freeman."-Cicero pro Rabir., cited by Gretser, De Cruce, lib. ii., cap. 36.

"Eusebius, Eccles. Hist., book ix., chap. 9. 
Bosio also describes and gives a representation of a medal. The obverse bears the head of Constantius, the son of Constantine, the reverse, a soldier holding a labarum, behind him is a figure of Victory crowning him with laurel, and the inscription is Hoc SIGNO VICTOR ERIS. Thus we have the testimony of history,
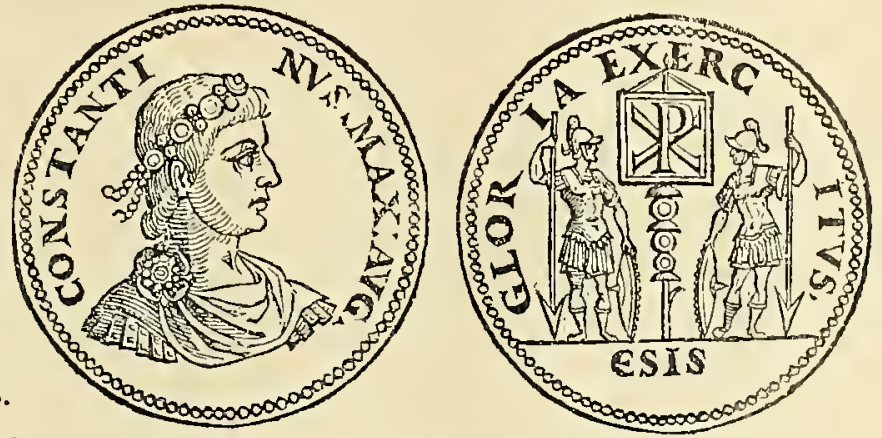

Medal of Constantine. From Bosio's La Trionfante Croce. statues, and medals, which are generally considered tolerable proof. ${ }^{1}$

It has been supposed by some that the sentence was not actually formed in the sky, but only some emblem, such as a crown signifying

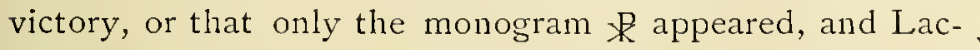
tantius is quoted as testifying to the latter. Before the Vision? 3 I4 he published his De Mortibus Persecutorum, in which he says: "Constantine was admonished in sleep to matk the heavenly sign
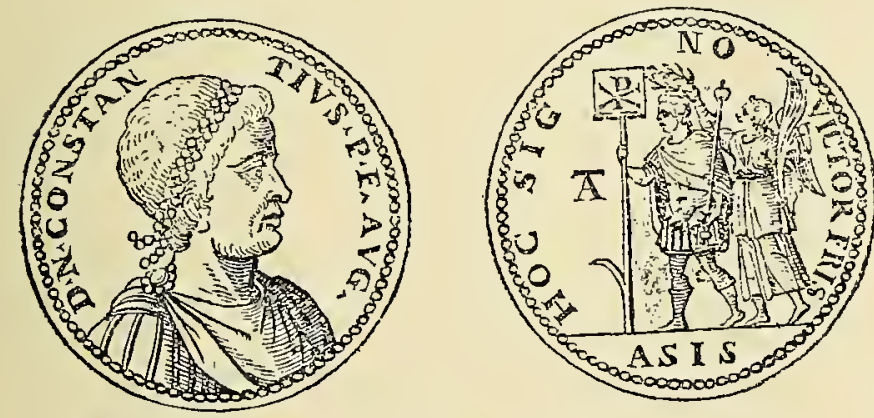

Medal of Constantius. From Bosio's La Trionfante Croce. of God on the shields, and so to engage the enemy. He did as he was bidden and marks the name of Christ on the shields by the letter $\chi$ drawn across them with the top circumflexed. Armed with this sign, his troops take up arms," etc. "Here is no mention, in so many words, of a cross, but it may be asked, does Lac'tantius refer only to the monogram when he speaks of a "hecicnly sign " ? The monogram was already known to the heathen. It appears, for ex-

${ }^{1}$ For the contrary see Lardner, Credibility of the Gospel, chap. Ixxx. ; Neander, vol. ii., p. Ir ; Mosheim (Murdock's ed.), ii., iv., r, notes; see also in favor, Dr. Good's Studies of Nature.

${ }^{2}$ Lactantius, De Nort. Persecutorum, p. 44. 
ample, on a coin of one of the Ptolemies, in the third century B.C., and has been supposed to be a contraction for Ippotós, signifying " good, benign, gracious." ' At all events, Lactantius, in common with others,
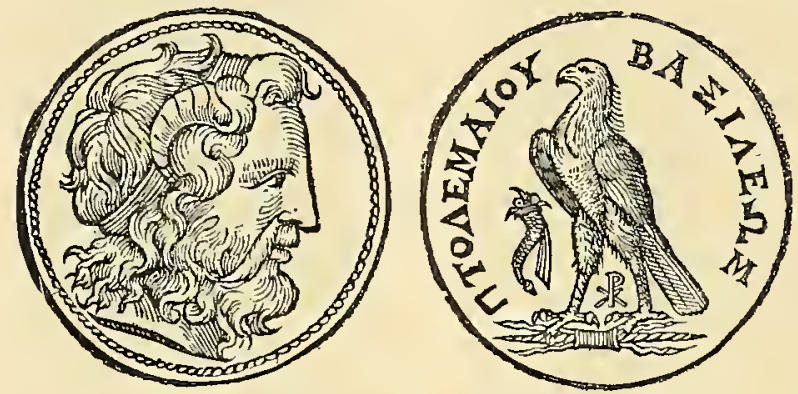

Coin of Ptolemy. From Gretser's De Sancta Cruce. testifies that something wonderful had occurred. It matters little in what way, or by what symbol, our Lord did address Constantine; that he should do so intelligibly is enough, and that the Emperor understood the sign is plain, not only because of his declaring himself from that time forth on the side of Christianity, but also because of his erecting monuments to that fact, one of which is standing to this day.

We would call attention to another point. When God would overthrow the Babylonish empire, the symbol of paganism, and reassert the Condemnation of legitimacy of his own people, he wrote upon the wall of

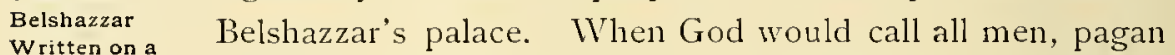
Perishable Wall. as well as those of Promise, unto redemption, he inscribed, not the sentence of condemnation upon a material wall which shall perish, but the words of salvation upon that firmament into which the Saviour had ascended. If the first story be true, and no Christian doubts it, may not the last be also ? ${ }^{2}$

Although the appearance of the Cross to Constantine is perhaps the only one generally considered as miraculous, there have been many others recorded in history and tradition, which may have been caused by natural means, yet, at the time of their appearance, were considered supernatural.

${ }^{1}$ Gretser, De Cruce, lib. ii., cap. 38. It might be supposed that the Christians adopted this monogram only with its pagan signification, but Tertullian bids them remember that they

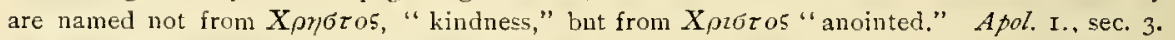
Perhaps the earliest use of the monogram, as used by Christians, that is extant, is in the epitaphs of Alexander and Marius, in the Catacombs. They were martyrs during the time of Adrian and of Antonine in the early part of the second century.

"The contrast might be carried out. "Mine, Mene, Tckil Upharsin," was inscribed upon a wall, symbolical of that "wall" between the Jew and the Gentile, which, the apostle says, shall be broken down. "In this Conquer," was written beneath the floor of " the house of many mansions." 
S. Cyril gives onc instance. " During the holy days of Pentecost, in the third hour of the day in the second year of the episcopate (May 7 , $35 \mathrm{I})$, there appeared a luminous cross of enormous dimensions over holy Golgotha, extending even to the Mount of Olives; it was extremely brilliant, surpassing the light of the sun; and was seen not only by one or two individuals, but by the whole city. It was a passing phenomenon, but continued visible for scveral hours. The effect on the believers was to inspire them with fear mingled with joy; the churches were thronged, not only by Christian worshippers, but by Jewish and heathen candidates for the sacrament of initiation, convinced of the truth of the Church's faith by this symbol of their salvation in the heavens." 1

In the Anglo-Saxon Chronicle for the year 773 it is recorded, "In this year a fiery crucifix appeared in the heavens after sunset," In 773. and again in 806 , "This year, the second before the nones of June, a cross appeared in the moon." =

During the reign of Henry II. of England, on the vigil of S. Laurence, in the village of Dunstable, about the ninth hour of the day, the heavens opened and a cross of wonderful mag-

In Time of nitude appeared, upon which our Lord was affixed, and the blood was seen flowing from the wounds in his hands, feet, and side. ${ }^{3}$

Upon the death of Baldwin, King of Jerusalem, A.D. I I44, very early upon the Festival of the Resurrection of our Lord, the heavens near the meridian were opened, and the moon, which was brilliantly at Jerusalem. shining, was " wiped out" by the effulgence of light, and a cross as of gold and gems appeared.

On the day of the coronation of Rudolph "of Hapsburg, A.D. I264, a cross appeared in the sky."

In 1264.

An interesting legend is interwoven with the early history of Portugal. Alphonsus, King of Lusitania, was about to meet in the battle of Ourique, with a small force, the united armies of five in Portugal. kings. He had pitched his tent near the hut of a hermit. Vast numbers of Moors surrounded the army, and " devoured hope." The Christian chiefs, hoping against hope, endeavored to animate their soldiers for the morrow, which was the Festival of $\mathrm{S}$. James, the patron

\footnotetext{
'S. Cyril, Opera, p. 247, Paris ed., I640.

${ }^{2}$ Anglo-Saxon Chronicle, pp. 339, 345, Bohn's ed.

${ }^{3}$ Gretser, De Cruce, lib. iii., cap. 7.

4 Ibid.

5 Ibid. The pious and credulous author gives many other instances, interesting, but too numerous to quote.
} 
saint of Spain. At evening the anchorite visited Alphonsus, and bade him watch for the tolling of the bell at night, for then Christ would appear to him. Joyful, yet anxious, Alphonsus kept the vigil. At dawn the wished-for sound rang through the air, and the vision of the crucified Lord appeared. Excited beyond the bounds of reason, Alphonsus exclaimed: " Why, O Saviour of the world, dost thou appear unto me who believe in thee, and worship thee most fervently! To these infidels who are thy enemies and mine, and are ignorant of thy divinity, it were better to appear, that they may know the mystery of thy Cross, and cease to be insane." Christ commanded the army to be set in array, and at a given signal the trumpets to sound in concert. Miraculous effect seemed added to the clangor. To the Moors it seemed as if the heavens were falling and the earth trembling. A bloody battle followed. One hundred and sixty thousand Moslems were slain. Three days after the victory, Alphonsus was engaged in distributing the spoils, and to each soldier was given a white shield, on which, in the language of heraldry, the story of the victory was told. First, because Christ had revealed Himself on the Cross, there was a blue cross on a silver shield; then, because five kings were conquered, five shields were inlaid upon the cross, upon every one of which were thirty pieces of silver, because the Saviour was sold for so many. In after years this was changed for convenience; two decussated crosses of five coins placed in the middle and one at the top, so that the thirty pieces might be computed. ${ }^{1}$

In I 30 I, a fiery cross appeared over the Palazzo Publico in Florence before the city fell by the treachery of Charles de Valois, " so that all At Florence. those who saw it, as I myself saw it clearly," says Dino Compagni, "saw that God was grievously angry with the city.",

Evelyn gives an account of a somewhat similar prodigy, in his diary for March I0, I643. Being at Hatingfordberry, he beheld " a shining In England cloud in the air, in shape resembling a sword, the point Appearance of reaching to the north; it was as briglit as the moon, the a Sword. rest of the sky being very serene. It began about eleven at night, and vanished not till about one, being seen by all the South of England."' It will occur to the reader's memory that a sword was seen suspended over Jerusalem before its destruction.

1 Gretser, De Cruce, lib. iii., cap. 8; Müller, Lectures on Language, 2 d series, p. 577.

${ }^{2}$ Dino Campagni, book ii., p. 42, quoted by Trollope, Hist of Florence, vol. i., p. 274.

${ }^{3}$ Notes and Qucries, April I8, $185 \mathrm{I}$. 
In 1838 , a dark cross was observed for many successive nights in the hearens at Jerusalem, as if that part were devoid of stars. Still later we have two instances of this phenomenon. "The Reverend At Jerusalem, Alfred Gatty, of Ecclesfield, England, published an account of an appearance in the clouds, "of our Saviour upon the Cross. The head was concealed in light, but the arms were outstretched, In England. and the body was quite distinct."' The other story is in Poland. The police of Warsaw reported that a fiery cross was seen over one of the houses in that city, and a crowd was collected, which was dispersed by the ciril authority.

The writer himself was witness to such a natural arrangement of the clouds in the heavens. In the autumn of 1854 , while sailing upon Lake Champlain, he saw, about sunset, a short distance above the sun, two delicate white clouds upon a trapezoidal opening clouds over Lake of the sky. The sides of the blue opening in the clouds Champlain. and that of the cross were bent in the very position which a banner would assume. As the rest of the sky was overshadowed with dense black clouds, one could easily imagine that in an earlier age this appearance would have been considered miraculous. ${ }^{3}$

There is a curious instance in the life of Colonel James Gardiner which would be unnoticed as a mere dream or idle fantasy but for the high standing of the Colonel and the character of his pious biographer, Dr. Doddridge, on whose authority this account is given. Colonel Gardiner in early life was irreligious and profligate. One evening while impatiently waiting for the hour when he had an appointment with a lady, to pass away the time, he carelessly took up a book entitled The Christian Soldicr, or Heaven Taken by Storm. He may have fallen asleep while reading, but he always asserted that he was fully awake, and firmly believed that what he saw was not a vision of the imagination, but a reality. An unusual effulgence of light falling upon the book that he was reading, he raised his eyes to see if an accident had happened to the candle, when he beheld, suspended in the air, a visible representation of our Lord upon the Cross surrounded with glory, and either heard an audible voice or was impressed as if a voice had spoken, saying in effect,

1 London Times, May 23, 1863.

2 Two others witnessed this beautifuI phenomenon, the Rev. James R. Davenport of New York, and Robert Lowry of New Jersey. 
" O sinner, did I suffer this for thee, and are these the returns ?" He sank in a swoon, to recover, a sincere and lifelong penitent. ${ }^{1}$

Appearance of the Cross, the "Sign of the Son of Man" at the Day of Fudgment

" The wood of the Cross was born with the world, in the terrestrial paradise; it will reappear in heaven at the end of time, borne in the arms of Christ or of his angels, when the Lord descends to judge the world at the last day.", "And if the sign of the Cross had such an effect, in the first ages of a stronger faith, to work miracles, overcoming thereby the powers of nature, and the use of which has always been accompanied in the Church with the giving of supernatural grace, as in baptism and the like, we may well suppose that this sign visibly displayed in the heavens should, from its exceeding virtue, eclipse the sun and the stars, whether these expressions be taken literally or figuratively." 3 The belief of the early Church in the appearance of the Cross as the sign of the coming of the Son of Man in the Day of Doom, was almost, if not quite, universal. The Ethiopian Church embodied it in her creed. " What, indeed, "asks March.

a modern divine, " can be more honorable to our Lord and Saviour, or more full of terror to His enemies, than that the Cross of Christ, which they accounted foolishness, and more than so, esteemed the greatest reproach of the Christian faith, should at that day be made the herald to proclaim $\mathrm{His}$ coming, and to call all nations of the world before Him ?" " (I Cor. i., 2I-26; Wisdom v., I-7.)

" The salutary Trophy of Jesus," saith S. Cyril, “ . . . shall appear again with Jesus from heaven, for the trophy shall precede the s. Cyril.

King; that seeing Him whom the picred, and by the Cross knowing Him who was dishonored, the Jews may repent and mourn; (but they shall mourn tribe by tribe when their season of repentance shall be no more); and that we may glory, boasting of the Cross, worshipping the Lord who was sent and crucified for us, and worshipping also God His Father who sent Him, with the Holy Ghost. To whom be glory for ever and ever. Amen." And again S. Cyril says: “But Christ's own true sign is the Cross; a sign of a luminous Cross shall go before the King, plainly declaring Him who was formerly cruci-

1 British Cyclopadia, Art. "Gardiner."

2 Didron, Christ. Icon., vol, i., p. 369 .
${ }^{3}$ Williams, Holy Week, p. 288.

* March, Ser. on S. Matt. xxiv., 30. 
fied; that the Jews, who before picrecd Him and plotted against $11 \mathrm{im}$, when they see it may mourn tribe by tribe, saying, 'This is He who was smitten, this is He whose face they spat on, this is He on whom they put chains. This is He whom of old they crucified, and set at naught; whither, they will say, shall we flee from the face of His wrath ? But the Angel of hosts shall encompass them, so that they shall not be able to flee anywhere. The sign of the Cross shall be a terror to Ilis foes; but joy to His friends who have believed in Him, or preached Him, or suffered for His sake. Who, then, is that blessed man, who shall be found the friend of Christ? That King, so great and glorious, attended by trains of angels, the fellow of the Father's throne will not despise His own servants. For lest His Elect be confused with His foes, He shall send His Angels with a great sound of a trumpet, and they shall gather together His clect from the four winds. He despised not one, even Lot; how, then, shall He despise many righteous? Come ye blessed of My Father, will He say to them who shall then ride on chariots of clouds, and be collected by angels.' ,' '

This, also, was the belief of Origen, Chrysostom, S. Jerome, Theophylact, Augustine, Bede, and others. Even the Sibyl sang

O lignum felix, in quo deus ipse perpendit;

$\mathrm{Nec}$ te terra capit, sed coli tecta videhis,

Cum renowata Dei faces ignita micabis.

${ }^{1}$ S. Cyril, Catech. lect., xiii., 4 I ; xv., 22. 


\section{CHAPTER V}

THE TRUE CROSS AND ITS TRADITIONARY HISTORY

Section 1.-The Disconery of the Cross by' S. Hclcna. Section 2.-Traditionary Persons at the Cross

W

HATEVER doubt may exist in the minds of archaologists of these times as to the discovery of the very cross upon which our Saviour suffered, there was none in the faith with which the historians of the fourth and fifth centuries recorded the disinterment of a cross by the venerable Empress Helena, which was then everywhere received as the veritable instrument of the Passion of our Lord.

Section I. The Discovery of the Cross by S. Helena. S. Helena,

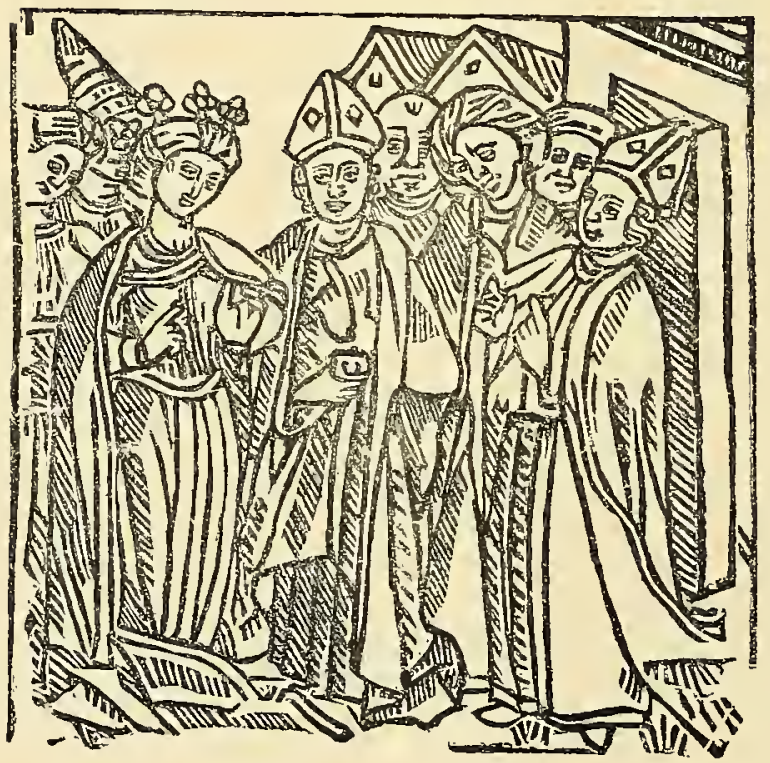

S. Helena in Jerusalem.

From Veldener's The Legendary History of the Cross.

a short time before her death, which occurred Journey of at the ads. Helena. vanced age of eighty years, journeyed to Jerusalem in the year 326 , impelled, perhaps we may say, by a divinely inspired desire to visit the spot sanctified by the sacrifice of the Lamb of God. When she arrived at Mount Calvary, she found it polluted by a temple of Venus, erected by Hadrian, as if for the express purpose of 
desecrating, or concealing from Christians, the spot to them the most sacred in the world. But the very effort of the Roman Emperor to cover it with oblivion served to keep alive the remembrance, as the very decree of the Ephesian Senate dooming to forgetfulness the incendiary of their temple, perpetuated his memory.

By the order of $\mathrm{S}$. Helena, the idolatrous temple was destroyed, and its material, together with the sur-

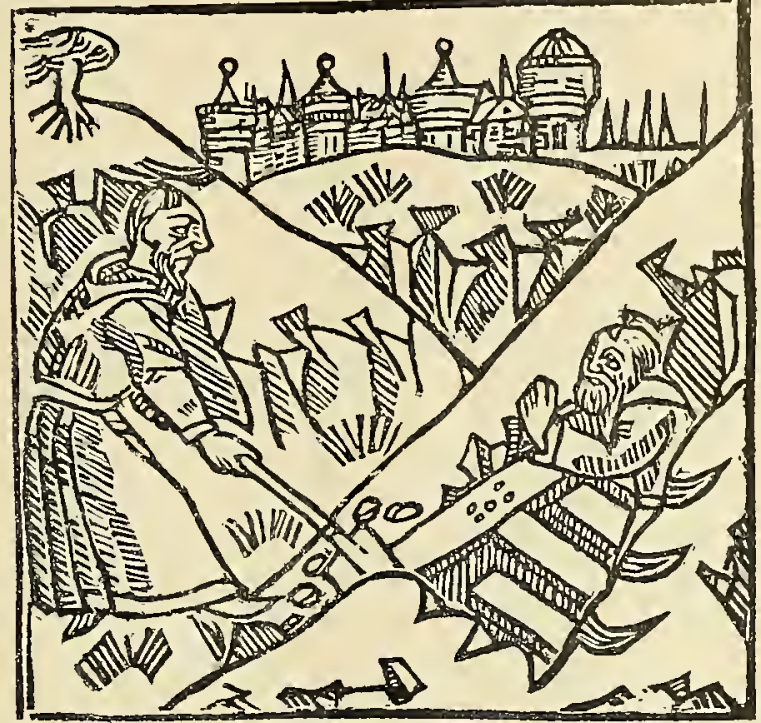

Discovery of the Crosses.

From Veldener's The Legendary History of the Cross. rounding soil, was removed. In doing this, the Holy Sepulchle was

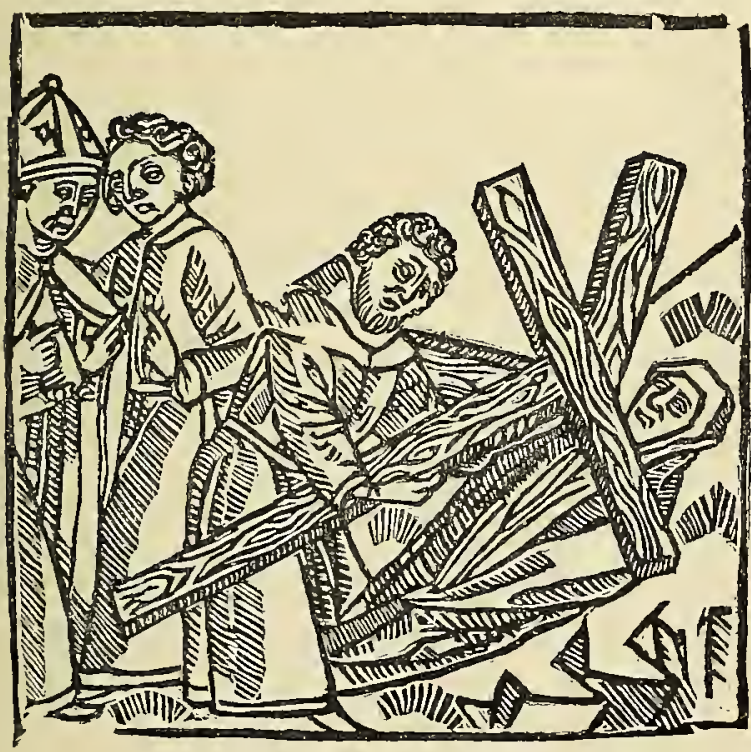

Test of the True Cross.

From Veldener's The Legendary History of the Cross. disclosed, and not far from it the crosses of our blessed LORD and of those crucified with him were discovered. There is some variation in the accounts of the mannes in which the cross of Oul SAVIOUR was distinguished, but not more than might be expected from varipus authors far removed from each other, and from the scene itself. S. Ambrose and S. Chrysostom assert that our LORD's cross was identified by the title which Pontius Pilate caused to 
be affixed to it. Rufinus, Socrates, Sozomen, and Theodoret relate, as the test, the restoration of a sick woman who was placed upon each of Testimony of the crosses with the earnest prayers of Macarius, Bishop Early Historians. of Jerusalem, that God would manifest by a miracle the very wood upon which His Son suffered. Paulinus and Sulpicius speak of the woman as being already dead, but that she was restored to life by contact with the holy Cross. In this case is it not allowable to use the same argument that is employed to establish the truth of the Gospels, viz., that the diversity of the narratives only confirms the fact of the discovery? If there had been any collusion, the stories would have been alike.

The simple facts that the discovery of three crosses, one of which was decided to be that of our LORD; the locality of the Holy Sepulchre, and the place of Crucifixion are spoken of by the historians of the fourth and fifth centuries as well known, about which there was no dispute or doubt in their days, would seem conclusive to all who are willing to confess with Bishop Horsley that they " have an unfashionable partiality for the opinions of antiquity." " But Dr. Robinson, with the cool Dr. Robinson's scepticism of a savant of the nineteenth century, says: objections. "The alleged discovery of them [i.c., Golgotha and the Tomb] by the aged and credulous Helena, like the discovery of the Cross, may not, improbably, have been the work of fraud. It would perhaps, not be doing injustice to Bishop Macarius and his clergy, if we regard the whole as a well laid and successful plan for restoring to Jerusalem its former consideration, and elevating his See to a higher degree of influence and dignity." ${ }_{2}$ Elsewhere, in his Rescarches, the Doctor acknowledges that " notwithstanding the silence of Eusebius, there would seem to be hardly any part of history better accredited than the alleged discovery of the true Cross." 3

It has been urged that Eusebius, who lived in those times, would not have been silent about so important a discovery. It is true that the hisTestimony of torian does not in so many precise words speak of the disEusebius and covery of the Cross, but both he and Theodoret have Theodoret.

recorded the Emperor Constantine's letter to the Bishop

Macarius, on the occasion of the building of the Church of the Resurrec-

${ }^{1}$ Horsley, Biblical Criticism, vol. ii., p. IsI.

${ }^{2}$ Robinson, Biblical Reserthes, vol. ii., p. So.

${ }^{3}{ }_{\text {Ibid., vol. ii., pp. } 15,16,76 .}$ 
tion, and in that he refers to " the Token of the Sariour's most Holy Passion, buried beneath the earth of many years." .

We know that it was customary among the Jews to bury the instrument of death, whatever it might have been, with the sufferer, ${ }^{2}$ but JEsus was removed in haste, for the Sabbath was nigh, to the sepulchre of Josepl of Arimathea, which was a tomb the Cross. hewn in the rock, not allowing space for the cross, even if desired. Again, although these pious souls perhaps hardly recognized the full divinity of our blessed Lord, yet they did not look upon Him as a criminal, and at that moment they could have viewed the cross witl no other feeling than that of abhorrence, hence the most probable disposition of the " unhappy tree" must have been in the pit that contained those of his fellow-sufferers. That this was the belief of S. Chrysostom, who, most likely, represented that of the Church in lis day, we learn from his own words: "For since the wood of the cross was buried, because no one was careful to take it up, inasmuch as fear was pressing, and the believers were hurrying to other urgent matters; and since it was in after times to be sought for, and it was likely that the three crosses would lie together, in order that the LoRD's might not be unknown, it was manifest to all, first by its lying in the middle, and then by the title, for those of the thieves had no titles." "

S. Cyril, Bishop of Jerusalem, delivered his Catchetical Lectures about A.D. 347 , in the very " Church of the Resurrection" erected by Constantine. In these lectures he refers to the Cross as

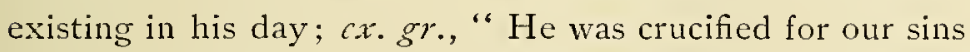

S. Cyril's Testimony. truly. Shouldest thou be disposed to deny it, the very place which all can see refutes thee, even this blessed Golgotha, in which, on account of Him who was crucified on it, we are now assembled, and, further, the whole world, is filled with the portions of the wood of the Cross." + Again he says, " Many, my beloved, are the true testimonies concening Christ," and among them he enumerates, " The holy wood of the Cross is His witness, which is seen among us to this day, and by means of those who have in faith taken thereof, has, from this place, now almost

${ }^{1}$ Fusebius, Life of Constantine, b. iii., c. 50: Theodoret, Eccles. Hist., b. i., c. I 7.

${ }^{2}$ Gretser, De Cruce, lib. i., cap. 37. Smith. McClintock, and Strong, in their Encyclopedias say the cross was burned, and refer to Otho's Lex. Rab. as authority, but we have preferred the opinion of the Fathers, that it was buried.

${ }^{3}$ S. Chrysostom on S. John, Hom., Ixxxv.

${ }^{4}$ S. Cyril, Catech. Lect., iv., Io. 
filled the whole world." ' Again, speaking against the Docetæ, who denied the reality of Christ's Passion, he says, "Jesus then really suffered for all men; for the Cross was no illusion . . . for, though I should now deny it, this Golgotha confutes me, near which we are now assembled; the wood of the Cross confutes me, which has from thence been distributed piecemeal to all the world." "

It is not marvellous that wood should remain underground for the space of three hundred years without decay. Many instances could be The Preservation adduced of wood being preserved for as long a time, cx. gr., of the Cross the coffin of Bishop Coverdale, who died in I 569 (or I 580 , under Ground not Necessarily according to some accounts), has been disinterred within the a Miracle. last few years, having remained undecayed in the ground for about as many years as did the crosses; and this in the damp soil of England, so that in the drier earth of Palestine the mere preservation of a beam of oak involves no miracle. ${ }^{3}$

That a cross, or rather that three crosses were found, is settled beyond reasonable dispute. The question is, was one of them that on summary of which our blessed Lord suffered? We have the following Proof as to summary of testimony. The instrument of torture and
Finding the Three Crosses. death was, among the Jews, usually buried with the sufferer. Crosses were found where it was well known that Christ and the two crucified with Him were executed. As to the miracle identifying the true Cross, that may be exaggerated. Wonderful events, told by distant historians, naturally became distorted. But the historians who record the discovery of the Cross agree in the main fact, and their testimony is received as truthful and credible in other matters. Have we a right to doubt, then, in this? It must be concluded that the cross, claimed as the true Cross, was that upon which our Saviour died, or that a gross fraud was perpetrated by Bishop Macarius and his clergy. Dr. Robinson insinuates the latter, although professing to wish " no injustice done

1. S. Cyril, Catech. Lect., x., I9.

"Ibid., xiii., 4. The authenticity of the Jetter of S. Cyril to Constantine has been doubted. There is proof enough withont it, yet as a matter of interest the passage in which the discovery of the Cross is referred to is quoted. "In the time of thy father, the divinely favored Constantine of blessed memory, the salutary wood of the Cross was found in Jerusalem. Divine grace granting the discovery of the hidden holy places to one who laudably pursued religious objects."

${ }^{3}$ A spring lock which apparently had belonged to the Crusaders was dug up a few years ago at Jerusalem, still in working order, although it had been under ground four or five hundred years. Williams, IIoly City. 
to them." But their characters have ever stood above suspicion. Besides, which is the more probable: a well-sustained, successful fraud, or the simple discovery of a relic, in the very place pointed out by tradition, which was only three hundred years old ?

The opinion of the Church that the pious search of S. Helena should at least be commemorated is shown by the appointment The Festival of of the Fes- the "Invention tival of the of the Cross" Invention the Church. of the Cross (May 3d) by the Greek, Roman, and Anglican branches, and the latter also retained the festival at the time of the reformation of the calendar, when she struck out many holy days as savoring of superstition.

The Cross was divided into three prin-

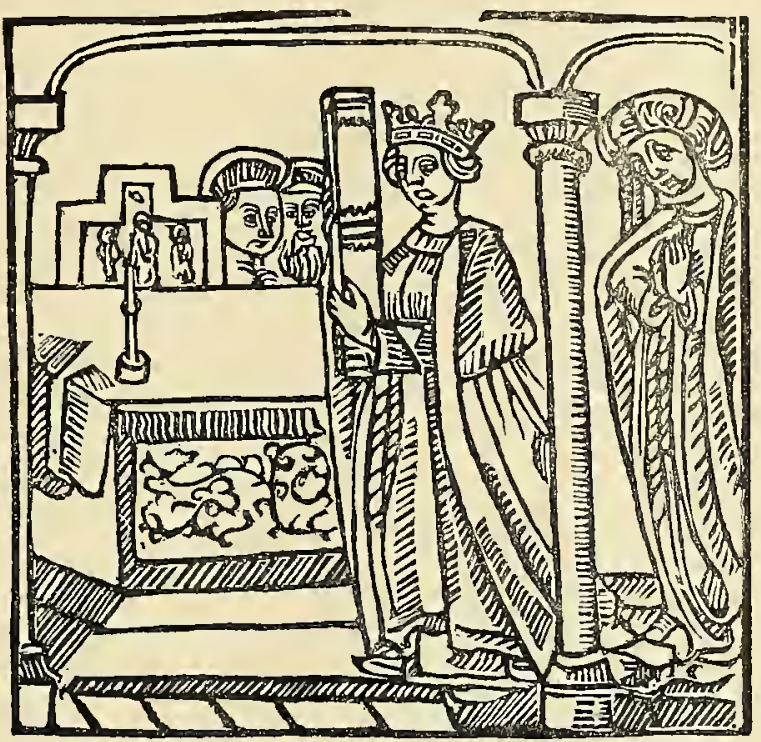

S. Helena Deposits a Portion of the Cross in Jerusalem. From Veldener's The Legendary History of the Cross.

cipal parts, of which one, enclosed in a case of silver, was committed to the care of the Bishop of Jerusalem ${ }^{2}$; another part was sent to Rome, where it is preserved under the dome of S. Peter's. This must not be confounded with the title which is at S. Croce the Cross. in Gerusalemme at Rome. The third fragment was sent to Constantinople.

'As Bishop Odenheimer asks, "Is there no Puritan tradition which jealously embalms the memory of Plymouth Rock . . . and preserves to this day the site where the so-called Pilgrim Fathers landed ?". Ferusalen and its Sacred Loalities, p. 206. "For my own part," said Bishop Wainwright when visiting these sacred localities, "since faith is a higher principle than doubt, I look upon the believer even in the impossible with greater reverence, than upon the unhappy universal skeptic." Pathways of Our Lord, p. rof. For a full examination of sacred localities, see VVilliams, Holy City. For a defence of the discovery of the Cross, Newman's Introduction to the portion translated of Fleury's Ecclesiastical History'.

${ }^{2}$ A guardian was appointed uver this fragment of the Cross, as we learn from the mention of Porphyrius, who was ordained Bishop of Gaza about A.D. 395, that he had been the Stantrophalox, or custodian, of the holy Cross. Fleury., Eccles. Hist., b. xxi., 8. Lord Mahon, while 
The Jerusalem fragment often appears in the pages of history. In A.D. 6I4, Jerusalem was invaded by Chosroes, King of Persia, who deJerusalem stroyed the clurches erected by S. Helena, and carried to Fragment. his own country the portion of the holy Cross. The Patriarch of Jerusalem, Zacharias, accompanied by the sacred relic, and the wife of Chosroes, who was a Christian, carefully preserved it from desecration. For fourteen years it remained in the keeping of the Persians, when they were conquered by the Emperor Heraclius, who carried the holy relic to Constantinople. The next year it was restored to Jerusalem, and on the fourteenth of September, a day commemorated in the calendars of the Church as that of the " Exaltation of the Cross,"

Festival of Exaltation of the Cross.
Heraclius, having disrobed himself of his royal apparel and put on mean garments, entered the holy city with bared head and feet, carrying upon bis shoulder a portion of that burden which he believed was once borne by our SAviour Himself. In A.D. 635 or 636 , Heraclius was driven from Jerusalem, and reconveyed the sacred treasure to Constantinople. Either it soon found its way back; or a portion of it must have been preserved in the holy city, for it is often mentioned in history. But little of note occurred until the battle of Tiberias, July 3 and 4, I 87 , when the Cross was placed on a hill as a rallying-point for the broken squadrons. Long and bitter was the contest, for the Christians fought for the altar of their Sacrifice, but the heathen were victorious, and " what was most lamented," saith Matthew Paris, "the Cross which freed men from the captivity of their sins was taken by Saladin.," 1

Frederick Barbarossa endeavored to obtain its restitution, but the wily conqueror, aware of the value set upon it by the Christians, demanded, as its ransom, the cities of Tyre, Antioch, and Tripoli, then in the possession of the Crusaders; promising also that if these were given up, he would restore the sacred wood, and permit pilgrims to visit Jerusalem. These conditions probably were not accepted, for, in 1218 , we find the Sultan, Malik-el-Camel, proposing, in order to save Damietta the key of his kingdom, to deliver up Jerusalem, to advance money to

apparently doubting the genuineness of the relic, admits its preservation: "From this period, however, the history of this fragment of wood may be clearly and accurately traced during the twelve succeeding centuries." Essay read before the Royal Society of Antiquarians, Feb. Io, I881. Bagley, Graphic Illustrator, p. 263.

${ }^{1}$ Fuller, Holy $\mathrm{War}$, book ii., chap. 45 ; Vertot, Hist. of the Knights of Malta, vol. i., p. 177. 
rebuild its walls, and to give up the true Cross. Two years later, the Christians being conquered by the Saracens, were obliged to quit Damietta, and to deliver to their foes their slaves and prisoners at Acre and Tyre. The Saracens on their part agreed to give up their captives of Cairo and Damascus, to conduct the army to a place of safety, and to restore the true Cross. " Everything was executed on both sides," says Vertot, " except the restitution of the true Cross, which the infideis in all probability had lost." ' Yet it has been claimed that it was restored and placed in the hands of the Knights Templar, and preserved by them until their dissolution by Philip the Fair. In the Manual of York, I 509 , however, there is a prayer which would intimate that it had not been rescued from the paynim. "We shall make special prayer . . . for the holy Crosse that God was done upon, that God for His merci bringe it out of the hethen mennes handes into Cristen mennes kepynge."

The fragment of the Cross sent to Constantinople is said to have been that which was transferred to S. Louis of France in A.D. I24I by Baldwin the Second; ostensibly for fear lest it should fall into the hands of the Saracens, but more probably as a pledge Fragmentsent for means to carry on the Crusade. Its arrival in Paris is to Paris. commemorated on the seventh of August, as the Feast of the " Susception of the Cross." S. Louis deposited the sacred relic, which he met with due reverence, in the Church of $S$. Stephen at Sens until a chapel could be erected and consecrated by the Pope's legate in Paris. The King, having fasted three days, imitated the example of Heraclius, and with bare feet and head, his garments ungirt and of mean material, bore the precious wood to its shrine. This same fragment, or a portion of it, S. Louis caused to be set in gold, and he himself showed it publicly at solemn festivals and holy days to the people. ${ }^{2}$ This custom was continued by his successors.

1 Vertot, Hist. Knights of Malta, vol. i., pp. 267, 269. In the treaty of Acre the Saracens had promised to return the true Cross, and gave hostages for the fulfilment of this agreement. After some delay, the condition not having been performed, Richard I. threatened to cut off the heads of the pagans in his hands. Saladin anticipated him by sacrificing the Christians in his possession. The King kept his word, the captives were beheaded in the sight of Saladin's ariny. The bodies were disembowelled, and it is added that much silver and gold were found in the entrails. The gall obtained from the victims was used for medical purposes. Riley's Hozeden, ii., p. 220. However, there is a piece of the Cross still preserved at Jerusalem. Curzon, Monasteries of the Levant, chap. xiii.

${ }^{2}$ According to Favine, S. Louis, on Good Friday, I24I, caused the portion of the Cross to be brought into the Abbatial church of "S. Anthonee des camps lez Paris, at the entrance 
A curious historical incident connected with this appears in the Acts of the English Parliament in I423, whereby the Duke of Bedford, Regent of France, for his nephew, Henry VI. of England (challenging his title to France), and "representing his person; shall show on Good Friday, the true Cross to the people, as the kings of France used the same day to do." " During the French Revolution a pious person concealed the relic and, when the storm of licentious infidelity had subsided, restored it to its former shrine.

A part of the Cross sent by the Empress Helena to Rome is enshrined in the place of honor under the dome of S. Peter's. The history of the

Roman more important part, the greater portion of that claimed to

Fragment. be the identical title placed by Pontius Pilate over our Lord, will be given in the succeeding chapter. Sixtus V. enclosed a fragment in the cross which surmounts the obelisk in the Piazza of S. Peter's.

From the numerous fragments of which we read, it would seem as if S. Cyril's words were to be taken literally, and " that the world was filled with pieces of the Cross." Some, true or false, have become famous, owing to association, and we will note a few of the most celebrated.

The Palatine cross is so called because it was bequeathed by the Princess Palatine, Anna Gonzaga, to the monks of S. Germain in Paris. The Patatine Cross. Princess had received it from John Casimir, King of Poland, in which country it had been preserved for many years, and was believed to be genuine. It had been a gift from one of the Greek emperors. The story is told that its sanctity was tested by having been preserved intact in a fire so intense that the glass and gold setting were melted.

When the tomb of Charlemagne was opened, the Emperor was dis-

whereof was prepared a theatre, whereon the King, the Queens, Blanche his mother, and Margaret of Provence his wife, and his three brethren monnted; the Archbishops, Bishops, Prelates, Princes and great lords, and an infinite number of the people assisted in the ceremonie." From thence the Cross was carried to Notre-Dame by the King; one of his brothers bearing the crown of thorns, which had been previously pledged by Baldwin. This same piece of the Cross had been pawned by the sons of John De Brenne to the Venetians for one hundred and fifty pounds of silver. Charles VII. exhibited the relic on Wednesday, Nov. 13, 1457. Theatre of Honour, vol. i., p. I5I. The relic is now preserved in the Sainte Chapelle; some say it was secretly sold by Henry III. to the Venetians, yet Lord Mahon considers this false, but says the Paris fragment disappeared on the 2oth of May, 1575. Mahon, Essay on the True Cross, read at the Royal Society of Antiquaries, Fcbruary, 1834 .

' Favine, Theatre of Honour', vol. i., p. 153. 
covered sitting on a golden throne, and vested in his imperial robes. 'The double crown of France and Germany was on his fleshless brow; his pilgrim's wallet was by his side, and his good sword foycusc, with which, according to the monks of S. Denis, the mighty from the Tomb asunder a knioht clad in complete of Charlemagne. monarch once clove asunder a knight clad in complete armor. His feet rested upon the buckler of gold given him by Pope Leo III., and from his neck was suspended by a massive chain of gold the talisman winch he believed rendered him victorious, a part of the true Cross, the gift of the Empress Irene, enclosed in an emerald. In $181 \mathrm{I}$, this invaluable relic was presented by the burghers of Aix-laChapelle to Napoleon; he wore it upon his breast in the battles of Austerlitz and Vagram, after the example of his illustrious predecessor, who for nine years never entered into battle without it. Bonaparte afterwards gave it to Queen Hortense, from whose bosom it was never absent.'

In the Cathedral of Seville a piece of the Cross is preserved. Its genuineness was tested by Archbishop Alonzo de Fonseca, who placed it on a brazier of burning coals where it remained during the performance of mass; it filled the church with fragrance,

Piece in Spain. and was unscathed. The pious prelate records the fact, but forgets to mention the nature of the wood. ${ }^{2}$

Great Britain very early received portions of the sacred relic. In the Anglo-Saxon Chronicle it is recorded that in A.D. 883 . Alfred the Great received a fragment from the Pope, Martin II., of Rome. After the time of the Crusades frequent mention is made in

In Great Britain the wills of the devout, of pieces left as pious legacies to churches or friends. Henry VII. thus solemnly bequeaths a portion which he says was brought from Greece. Malmesbury Abbey for a long time treasured a fragment which it received from Athelstan, to whom it was presented by Hugh of France.

Capgrave thus details the history of the Cross at Bromshold. "S. Helena having found the Crosse, did divide it in nine parts according to the nine orders of angels; of one part thereof which was most sprinkled with Christ's blood, his hands and feet being thereto nailed, she made a little crosse, which she enclosed in a box of gold beset with precious

1 Barrera, Gems and Fezuels, p. 272.

${ }^{2}$ Alonzo Morgado, Historia de Sevilla, I587, p. ro2. 
stones and gave it to her sonne Constantine. It went successively from one Emperor to another until it came to Baldwin. . . . So long as hee carried this crosse with him to bataile hee had ever upper hand of his enemies, but fogetting it, hee was forthwith slain: upon which his chaplaine Hugh stole secretly away with the said boxe and Crosse, and came to this monastery of Bromholm. . . . By the virtue of this holy crosse, co-operante Domino, thirty and nine persons were raised from death to life, and nineteen which were blind received their sight; besides many other miracles which it wrought, if you believe my author." I

Ireland is enriched with several fragments of the true Cross. Paschal II. presented one to Murtogh, one of the Kings of Ireland, in I I IO. In

In Ireland.

honor of the gift, the grateful sovereign built the Cistercian Abbey of Holy Cross near Thurles, Barry Oge gave another piece to the abbey belonging to the same Order in Tracton, in I 3 So. A third is preserved near Dublin, and in the contest between the competitors for the priory of Kelmainham in $\mathbf{I} 482$, it is related that one party had been deprived of its privileges by the grand Master of the Order for pawning a piece of the true Cross. ${ }^{2}$

Very soon the demand for portions of the precious relic increased beyond the natural ability of the Cross to supply it. Supernatural Multiplication of power was attributed to it. "The crosse," writes Ribathe Fragments. deneira, ${ }^{3}$ who fathers, probably unjustly, his words upon Paulinus, " being a piece of wood without sense or feeling, yet seemeth to have in it a living and everlasting virtue; and from that time to this, it permitted itself to be parted and divided to comply with innumerable persons, and yet suffereth no loss or detriment." Marvellous indeed must have been the increase to supply the centuries of demand, but no less marvellous than the miracle that many of the fragments are of different species of wood, yet that may be in part accounted for by admitting that the Cross was composed of divers kinds. Two hundred years ago, Erasmus declared that " if the fragments of the Cross were collected, enough would be found for the building of a ship, and yet our Lord carried the whole in his Cross." " Voltaire also sneers in similar language; Swift, too, whose wit was never sacrificed to his reverence, says that

\footnotetext{
${ }^{1}$ Capgrave, Life of King Edmund, quoted in Weaver's Funeral Monuments. Piers Plowman says, "But wenten to Walsingham, and my wife Alis and byd the Roode of Bronholme bring me out of dette,"

${ }^{3}$ Flos Sanctorum, p. 317.

"Nant, Hist. of the Church in Ireland, vol. i., p. 70. . ${ }^{4}$ Dialogue on Pilgrimages.
} 
Lord Peter " was telling of an old Sign Post that belonged to his Father, with nails and timber enough on it to build sixteen large men of war." '

Calvin admits that it is considered as a certain fact that S. Helena did discover the true Cross, yet he thinks the search was one of foolish curiosity, and, as to the innumerable relics now claimed to be parts of it, he says, "the Gospel testifies that the Cross could be borne by one single individual; low glaring, then, is the audacity now to pretend to display more relics of wood than three hundred men could carry " ! " To such statements Dr. Rock answers: " Large crosses of wood, upon which short thread-like chips from the true Cross were glued, have been at times mistaken by the heedless traveller, or shamelessly passed off by exaggerating and boastful sacristans, for so many portions of the true Cross itself." Hence the above slur, but " the thin, almost indiscernible parings from the true Cross itself, all, if brought together and put into a scale, would not weigh many ounces." s

Fuller thus quaintly writes on this subject: " And though some know no more than Asop's cock how to prize these pearls, let them learn the true value of them from the Roman jewellers. . . . As for the common exception against the Crosse, that so many several pieces thereof are shown, which put together would break the back of Simon Cyrene to bear them, it is answered, Distraluitur, non diminuitur, and, like the loaves in the Gospel, it is miraculously multiplied in the dividing. If all these fail, Baronius hath a razour shaveth all scruple clear away: For, saith he, Quicquid sit fides purgat facinus; so he that worshipeth the false relics of a true saint, God taketh his good intention in good worth, though he adore the hand of Esau, for the hand of Jacob." 4

Before dismissing this part of our subject, it is well to quote the opinion of one of the most pleasant and learned, yet irreverent, of archæologists. Speaking of the relics shown as of the true Cross, he says: "Of the three principal pieces, one is now, or lately was, at Etchmiazin in Armenia, the monks of which aru accused of having stolen it from the Latins of Jerusalem when they were imprisoned by Sultan Suleiman. The second piece is still at Jerusalem, in the hands of the

1 Tale of a Tub, sec. iv.

${ }^{2}$ Calvin, Treatise on Relics, p. 233.

${ }^{3}$ Rock, Church of Our Fathers, vol. ii., pp. I 79, 280 , note.

"Fuller, Historie of the Holy Warre, book iii., chap. I2. 
Greeks; and the third was sent by the Empress Helena herself to the Church of Santa Croce in Gerusalemme at Rome. There is indeed little reason to doubt that the piece of wood exhibited at Rome is the same that the Empress sent there in the year 326. . . . I may remark that all the very ancient specimens of the relics of the true Cross are of the same wood, which has a very peculiar half petrified appearance." 1

Those who have investigated the subject most fully in our day, all unite in one testimony, that but little is to be found at present throughout Christendom claiming to be the original wood. Dr. William C. Prime, in his interesting monograph on this subject, ${ }^{2}$ emplatically states that " there are very few fragments anywhere which profess to be relics of the holy Cross. The common idea that enough wood is shown in various places as relics of the true Cross to build a dozen crosses is a very foolish error, invented by some one who imagined that when a church claimed to possess a piece of the true Cross, it must be a piece of at least some feet in length and solid contents. Generally speaking, that very rare and highly prized relic, 'a piece of the true Cross,' whether possessed by a church, a crowned head, or a private individual, is a minute speck of wood, scarcely visible to the naked eye, set sometimes on an ivory tablet, always enclosed in a costly reliquaire. No other fragment is known so large as the Santa Croce tablet, which is not ten inches long by seven wide. There are but very few fragments known which are large enough to be called pieces of wood. Leaving out the Santa Croce tablet, all the relics of the holy Cross, claimed to be such, that I have been able to hear of in all the world, if gathered into one piece; would not make another block of wood as large as the Santa Croce tablet. This tablet is not generally spoken of as a part of the Cross itself."

Section 2. Traditionary Persons at the Cross.-The traditionary history of the Cross and Crucifixion would be incomplete without mention of the persons whom love and faith, although beclouded, have grouped around the altar of Calvary. A brief account will suffice, as they are so well known by their representations in art.

1 Curzon, Monasteries of the Levant, chap. xiii.

Holy Cross, a History of the Invention, Preservation, and Disapparance of the Wood Known as the True Cross, pp. 59, 60. 
S. Veronica may claim precedence, as being honored by a shrine at the right hand of the high altar of S. Peter's at Rome. There are various versions of this legend. According to one, our Saviour was passing her door, bearing His Cross, when, S. Veronica. touched with compassion, she wiped the drops of agony from His face, and the features of our Lord were imprinted upon the cloth or sudarium. Hence the name vora icon, or true image, which in time was transferred to the woman herself. Some say, however, that she was Bernice, or Veronica, the niece of Herod, being daughter of Salome, his sister, who was suddenly converted at the sight of the suffering Saviour. Being sent for by Tiberius to heal him of his sickness, she went to Rome, too late, howcver, to save the Emperor, and finally suffered martyrdom under Nero. According to another account she came to Europe with Lazarus and Mary Magdalene, and sealed her faith with her blood in Provence or Acquitaine. Veronica is rarely absent from early pic-

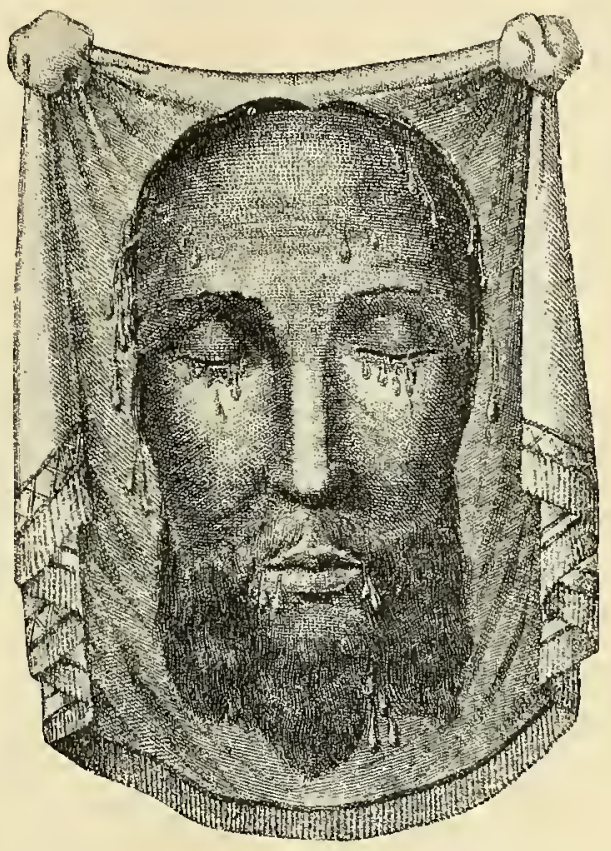

S. Veronica's Napkin, at S. Peter's, Rome. From Harper's Magazine. tures of the Crucifixion. She also appears in the Coventry Mysteries.

Veronica. A! ze synful pepyl, why fare thus? ffor swet and blod he may not se! Allas! holy prophete, Cryst Jhesus! Careful is myn hert for the !

And she whypyth his face with her kerchy.

Fhesus. Veronica, the whipyng doth me ese!

My face is clene that was blak to se:

I xal them kepe from alle mysese, That token on thi kerchy and remembyr me!"

1 There is another version which removes Veronica from the scene of the Crucifixion. She was the woman that was healed by touching Christ's robe. Desiring a portrait of Him, S. Luke 
Longinus was the centurion who, at the command of Pilate, pierced the side of our Lord with a lance, and, moved by the eclipse of the sun and the earthquake, believed in Christ. Through disease S. Longinus. or age he was purblind, but the blood of Christ streaming from the spear accidently touched his eyes and his sight was restored. Renouncing his profession, he was taught by the Apostles and dwelt in Cæsarea twenty-eight years, converting many by his words and example. Then the governor commanded him to sacrifice to idols, and on his refusal ordered his teeth to be drawn and his tongue to be cut out. But Longinus did not lose the power of speech, and seizing an axe he dashed in pieces the idols, saying, "Behold if these are God." Then the demons, coming out of the idols, entered into the governor and his friends, who, becoming insane, fell headlong at the feet of the saint. Longinus demanded of the devils why they dwelt in the idols. They answered, "Wherever Christ is not named, or his sign placed, there is our abode." Then Longinus said unto the governor, on whom blindness had now fallen, "It is impossible that thou shouldst be healed unless thou first slay me, when I will pray and thou shalt receive health of mind and body." Then the governor ordered that he should be beheaded, but immediately after cast himself upon the body, weeping tears of penitence. And instantly his health of mind and body were restored, and he ended his life in good works. ${ }^{1}$

Such is the story of the Golden Legend, and that which is received in the Romish Church. But there is a sad confusion of the soldier who pierced our Saviour's side after his death, with the centurion, who, at sight of the miracles when Jesus " gave up the ghost," confessed, " Truly this was the Son of God," and, therefore, since then has been honored as the "first fruits of the Gentiles."

Like Veronica's, the altar of S. Longinus is one of the four under the dome of S. Peter's, and, like his name, has evidently been made to suit

thrice painted it. Bnt all were unlike. Then Christ said unto her, “Unless I aid yon, Luke's art is in vain, for my face is only known to Him who sent me." Afterwards being at her house He asked for water to wash $\mathrm{His}$ face, and returned her the napkin with the portrait, which works miracles. At length the Roman Emperor sends for it. Some say it was Tiberius afflicted with worms in his head; others that it was Vespasian with a wasp's nest in his nose. At the sight of the sudarium the Emperor is healed. In gratitude, and to revenge the death of Jesus, Jerusalem is destroyed by the Romans; who finding the four soldiers who divided the robe of our Lord, cut them in four pieces, and the others who took part in His death were sold for thirty pence.-Hist. of Our Lord, vol. i., p. 4I.

${ }^{1}$ Aurea Legenda. 
the event, being derived from longhe $\left(\lambda \circ \gamma^{\prime} \chi^{\prime}\right)$, a spear. It appears in a Syriac MS. of the eleventh century, although the legend is much more ancient.

Stephaton, or Calpurmut, presented the sponge, sometimes changed for a cup, to our l.ord. In early form, Stephaton carries a vessel of vinegar. As Lady Eastlake says, " his history has been in no way preserved or imagined," which is rather strange

Stephaton. considering his frequent presence in painting and illuminations.

Nicodemus we regard with more interest than his represented companions, as having a more real identity. To him is usually, and ahways in Greek art, assigned the task of drawing the nails which fastened our Lord to the cross, while $S$. John conceals these that the mother may be spared the sight of the instruments of torture and death. In Italian art he often supports the body of Christ in the descent from the cross; with Joseph of Arimathea he bears it to the tomb and afterwards prepares spices for embalmment.

Joseph of Arimathea usually assists Nicodemus Joseph of in drawing Arimathea. the nails from the hands, and in sus-

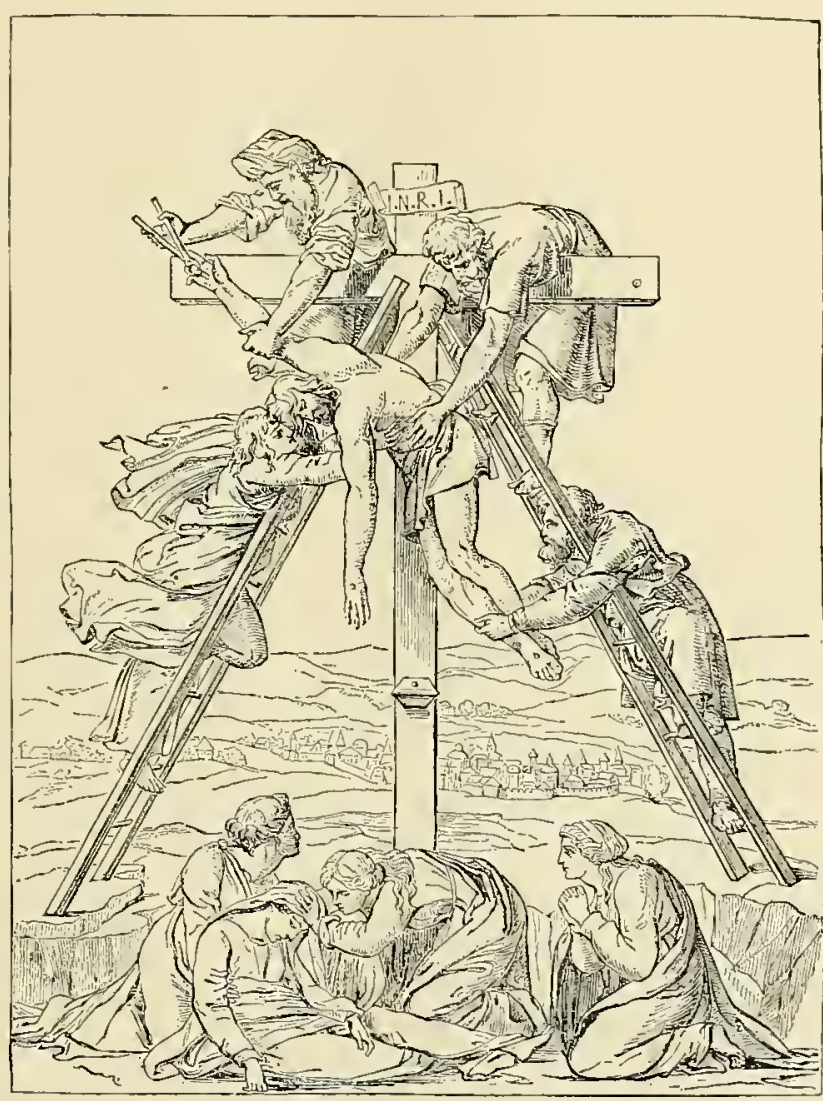

The Descent from the Cross. From Jameson's Fistory of Our Lord. taining the upper part of the body both in its descent from the Cross and in bearing it to the sepulchre. The position of honor was probably 
given to him because he had the courage to beg the body of Jesus from Pilate.

All these characters, except Stephaton, are given by name in the Coventry Mysterics.

Lastly, appears Ahasuerus, who, according to the legend, drove away our Lord from his door-post as He leaned against it for support on His wandering Jew. Way to Calvary. Matthew Paris says that, in I228, an Armenian archbishop visited the monastery of S. Albans, England, and asserted that he had known the man. That he had been Pilate's door-keeper, by name Cartaphilus, who, when they were dragging Jesus from the Judgment Hall, struck Him, bidding him "Go faster." Upon which Jesus replied, " I indeed am going, but thou shalt tarry till I come." Soon after, being converted, he was baptized by the name of Joseph. At the end of every hundred years he falls into a fit or ecstasy, out of which he recovers and returns to the same age, thirty years, that he was when Jesus suffered. He is a very devout person, remembers all the circumstances of Christ's death and resurrection, the composing of the Creed by the Apostles, etc. " It is idle to follow his history; he is only referred to because that " inspired Dutchman," as Mrs. Jameson calls Rembrandt, has seen fit to introduce him into one of his etchings.

Nothing can be added to the simple majesty of faith and despair, recorded in the narrative of the Evangelists, of the penitent and the imThe Two penitent thief. Early art has represented not only the face Thieves. $\quad$ of the one, beaming with love and trust turned towards the Saviour, and that of the other distorted with hate and malignity and averted from him, but has also depicted holy and evil angels receiving the souls of each.

According to an old legend, the good thief rescued the Holy Family, which had fallen in with a band of robbers, on the way to Egypt. "When the Lady S. Mary saw the kindness which the robber did show them, she said unto him, "The Lord God will receive thee to his right hand and grant thee pardon of thy sins.' Then the Lord Jesus answered and said to his mother, "When thirty years are expired, O Mother, the Jews will crucify me at Jerusalem; and these two thieves shall be with me at the same time upon the cross. Titus on my right hand, and 
Dumachas on my left, and from that time Titus shall go before me into Paradise.' "'

The spot where the Holy Family met the robbers is still pointed out, near Ramla, and in the time of the Crusades was visited as a pious act of pilgrimage. In the Academy of Florence there is a fresco representing the scene.

These men are known by other names than those just given. S. Xavier, in his History of Christ, calls one Vieimus, and the other Justinus. The Roman martyrology, and late tradition, following the Gospel of Nicodemus, calls the good thief (Sanctus Latro) Dismas, and the other, Gestas. ${ }^{3}$ According to that apocryphal legend, the penitent robber presents himself " a miserable figure, carrying the sign of the Cross upon his shoulders" at the gate of Paradise, and the guardian angels admitted him first into the regions of the blessed. ${ }^{4}$ The even hand of justice! Paradise on earth, was lost through a thief, a like criminal must first enter the Heavenly. ${ }^{5} \quad$ S. Jerome awards the penitent the palm of martyrdom, and S. Bonaventura, rightly defining a martyr as dependent upon two conditions - " a right will and a right cause "declares the first was wanting in the Innocents, the second in the good thief, but that Christ supplied the deficiency in each. ${ }^{6}$

Lady Eastlake says that " there is some reason to believe that the crucifixion of the thieves preceded, in art, the crucifixion of our Lord," and gives an example of Jesus standing, apparently free, between the robbers bound to posts; but by the eleventh century, probably much earlier, could dates be determined, the three crosses appear. In a Syriac MS. in the Laurentian Library at Florence the thieves are nailed From Jameson's History of to their crosses, but, usually, they are represented

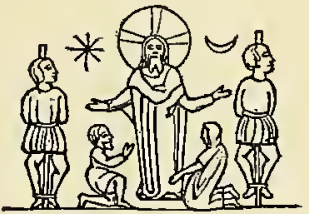

Early Representation of the as only tied, not nailed to the cross. The same authoress also quotes the

${ }^{1}$ Gospel of the In faucy', chap. viii.

${ }^{2}$ Legends of the Madonna, p. 234.

${ }^{3}$ Favine gives a charm which being written upon parchment, and bruised with wine in'a mortar, will make criminals condemned to death insensible to pain. He adds, "I never knew any who made proof of it."

\section{"Imparibus meritis pendent trio corpora ramis Dismas et Gestas, in medio sedit ima potestas Gestas damnatus, Dismas ad astra levatur."}

${ }^{4}$ Gospel of Nicodemus, chap. xx.

${ }^{5}$ S. Cyril, Catic. Lect., xiii., 3.
-Theatre of Honour, vol. ii., p. 247.

${ }^{6}$ History of Our Lord, vol. ii., p. I66. 
- traditions, that the conversion of Dismas was owing to the shadow of our Lord falling upon him, and that he was baptized by the water which flowed from our Saviour's side when pierced.' This presumes that the good thief was placed upon the right side, as is usually represented in art, but some would place him on the left because Jacob so crossed his hands when he blessed the children of Joseph." S. Anselm, by a figure which does not seem clear, says, the right thief figured those who suffered for justice, the left, those who were pseudo-martyrs, who suffered for charity. ${ }^{3}$

A cross, said to be that upon which the good thief expiated his crimes, is preserved in the city of Nicosia in the island of Cyprus; some authorities state that a part is in the Church of S. Croce in Gerusalemme at Rome.

There is a curious incident connected with this part of our subject. In the sixteenth century there lived in Sienna a man named Brandano. Brandano the Being chosen to perform the part.of the penitent thief in "Fool of Christ." the miracle play in the Easter celebration, while suspended on the cross, the remembrance of his past life. which had been bad, moved him to repentance. He underwent a severe penance for several years, at the end of which he began to preach to the inhabitants of Sienna, prophesying and denouncing in the streets the Siennese and the Florentines. Hence he was called the "Fool of Christ." Among other vaticinations he foretold the taking of Rome by Charles V. The papal courts being wearied with his denunciations, Clement VII. ordered him to be tied in a sack and thrown into the Tiber. Disengaging himself he met the Pope, who was visiting some of the churches. Clement was affrighted at the apparition of one whom he supposed either dead, or miraculously delivered, and was still more terrified at his prophecy, "You have put me in a sack, and God will sack you." s When the sacking of Rome did occur, the words of this madman were remembered. On the same night on which Pope Clement died in Rome, Brandano ran about the streets of Sienna proclaiming the fact; the next day his prophetic ravings were confirmed. ${ }^{\circ}$

${ }^{1}$ For fuller accounts see Mrs. Jameson's Legends of the Mladonna; and Hist. of Our Lord. vol. ii., p. 166.

"Molanus, Hist. Images Sacra, lib. iv., cap 4.

${ }^{3} \mathrm{rbid}$.

"Suidas says that Constantine buried part of that cross in the Forum. Gretser, De Cracce, lib. i., cap 99 . 5 "Voi avete messo nel sacco me, e Dio mettara in sacca voi."

${ }^{6}$ This man's real name was Carosi. His life was published at Tivoli, printed by Indovidono, in 4 to, entitled Vita e Profezie del Brandano Sanese Volgarmente detto il Pazzo di Christo. Redding, Yesterday and To-day, vol. iii., p. 290. 
INSTRUALNTS OF THE PASSION OF CHRIST

I. The Cross. 2. The nails (four is the number to be preferred as the most correct, three being used only after the time of Cimabuc). 3. The thirty pieces of silver. 4. The sudarium, or Veronica. 5. The pillar (which is better given in the ancient form, like that preserved in the Church of S. Praxede in Rome, that of the ordinary, architecturally correct proportions). 6. The scourges. 7. The hammer. 8. The spear. 9. The reed and sponge. IO. The cock. II. The lantern. I2. The sword with which S. Peter smote off the ear of Malchus. I3. The bowl in which our Saviour washed his Apostles' feet. 14. Christ's robe and the dice. I5. The rope with which Christ was bound to the pillar.

Besides these, the sindone, or cloth, in which our Lord was wrapped. If this last is to be enumerated, as it sometimes is, among the instruments of the Passion, there surely can be no reason why the panniculum should not be also. This was the headcloth of the blessed Virgin, which she wrapped around the loins of her Son. Hans Holbein, the father, gives a representation of this scene. What more touching picture of the exercise of a mother's last privilege! ${ }^{1}$

${ }^{1}$ Hist. of Our Lord, vol. ii., p. I26. 


\section{CHAPTER VI}

THE TITLE OF THE CROSS

“ ND Pilate wrote a title and put it on the Cross. And it was written

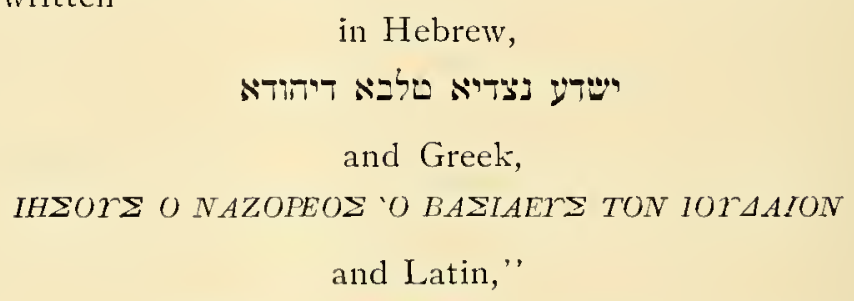

and Greek, IHSOR O NAZOPEOS O BASIAET

and Latin,"

IEHSUS NAZARENUS REX IUDAORUM

-John xix., Ig, 20.

The crime of the sufferer was either proclaimed by a crier, or inscribed upon a label affixed to the upper limb of the cross. ${ }^{1}$ This custom still exists in the case of crucifixion in China, and in all execucrimes of the tions in Turkey. As this label was not of perishable

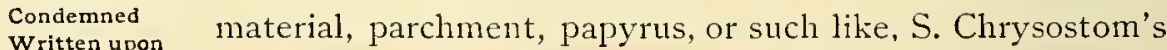
Written upon account seems the more probable, that the true Cross was
a Label. discovered by the title being fastened to it. ${ }^{2}$ The Syriac, Arabic, and

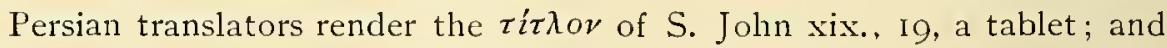
Bishop Pearson considers it the correct interpretation. ${ }^{3}$

The Evangelists differ as to the order of the languages in the superscription. Probably that given by S. John, the eye-witness, is correct. Order of The Hebrew was written first; it was the language of the inscription. country. The Greek was next, as being familiar to most of the lookers-on. The Latin was necessarily used, because the sentence

${ }^{1}$ Gretser, De Cruce, lib. i., cap. 31. Lipsius, De Cruce, lib. ii., cap. II.

2. Chrysostom on S. John xix., I9.

${ }^{3}$ Pearson on the Creed, art. iv., note, p. 3 II, ed. I839; Lardner, Credibility of the Gospel, vol. i., book i., chap. vii., \& Io. 
must be written in the tongue in which it was pronounced by the Roman ruler, and it was last, that being the place of honor. That the Hebrew was first, being the least esteemed, we infer from an accidental observation of S. Chrysostom that " the Hebrew tongue" is " a language despised by all, especially the Italians." '

Early commentators give a simple reason for the triple inscription: That it might be read by all of the bystanders, and also to show that our Saviour by his sacrifice turned the work of the devil, the causer of the confusion of tongues, against himself. BeLanguages. sides, they call our attention to the choice of these languages. That of the Romans was taken because they were the most powerful nation of the world; of the Greeks, because they were the wisest and most subtile; while the Hebrews were the most pious and religious."

No tittle, however minute, of matters pertaining to our Lord is passed over by His early followers, and therefore they bid us mark that the gospel was preached, after Christ's death, in the same order in which His kingship was proclaimed from Preached. His throne, the Cross; first to the Jews, then to the Greeks, lastly to the Romans. ${ }^{3}$

Another thing to be noted is the means by which the title was fastened to the Cross. One mode of cancelling a bill, or sentence, among the Jews was by driving a nail through the document. Christ then, when fulfilling the prophecy, may in truth be said literally to have nailed our sins to His Cross."

' Chrysostom, 2 Tim., Hom. iv.

2 "These three tongues were eminent before all others: the Hebrew, because of the Jews who gloried in God's laws; the Greek, because the wise men of the Gentiles; the Latin, because of the Romans, at that time bearing rule over many, and indeed over almost all nations." $-S$. Aug. on S. John, Hom. xvii., 4. "And these are written, because $\mathrm{He}$ is the author of all sanctity and purity, which flourished among the Hebrews, to whom was given the divine law; also because $\mathrm{He}$ is the author of all truth and wisdom, which flourished among the Greeks; also in figure because $\mathrm{He}$ is the author of all virtue and power, which fourished among the Latins ; for He is made for us wisdom, justice, redemption, and sanctification." - S. Bonaventura, Collat., 84 on John. "The Lord is king of Philosophy, practical and natural, and of Theology. The practical is figured by the Roman characters, for the sovereignty of the Romans was especially strong and powerful in warlike matters ; by the Greek, natural Philosophy; and what was wanting to the Greeks, by the Hebrew, Theology, for the knowledge of divine things is gathered up in the Jews."-Theophylact on S. John chap. xix.

${ }^{3}$ The meaning of the name Jesus is well known, but few think of the full meaning of His title "Jesus of Nazareth." Nazareth from iy, natzar, signifies he watched over, as a shepherd his flock; he obeyed the law of the Lord; he protected, defended, as a vinedresser a vineyard; he restrained, as lips are from evil; he cultivated, as one would a vine. As a noun natzar means a branch, a prince, an offspring.

${ }^{4}$ Pearson on the Creed. 
When what was presumed to be the true Cross was discovered, what became of the title?

In the lonely, almost unpeopled waste of the Esquiline Hill in Rome, where the traveller crushes under his foot the dust of what was once the

Where the

Palatine wealth of the city, wending his way through quiet Presumed Title lanes of vineyards and olive gardens, marvelling that he is is now.

within the walls of a city, at last he reaches a little mound, all that remains of the palace dedicated to the voluptuous orgies of the boy Emperor, Heliogabalus. Here, in a chariot of gold studded with gems, drawn sometimes by abandoned women harnessed instead of horses, or banqueting on silver couches, the air perfumed with incense, amid a mimic rain of roses and violets, the sensual fool gave his weak might towards corrupting Rome. In place of circuses, now see vineyards. Instead of palaces, now behold a half-ruined church, founded by Constantine, A.D. 330, at an expense of one hundred and forty-three thousand gold scudi.

As S. Helena found Mount Calvary polluted by a temple of Venus, so her son would redeem this canker-spot of Rome, for this is the shrine of the Title of the Cross, and though fifteen hundred years of war, desolation, and corruption have swept over it, it has been preserved (is it too much to say through Divine Providence ?) and is still reverenced as Santa Croce in Gerusalemme.

About A.D. 720, the basilica became roofless, and was repaired by Gregory II. Two hundred years later the adjoining monastery was rebuilt; but by the twelfth century it again became a ruin. The monks were removed to the Baths of Diocletian, and three thousand florins were expended in building what is probably the greater part of the present structure. In 1492, during some repairs under the direction of the Cardinal Mendoza, a.niche was discovered near the top of the apse, closed Discovery of by a brick front, on which was inscribed "Titulus Crucis." the Title. Within, a lead coffer was found, fastened with three seals, containing a piece of wood about two inches thick, twelve and a half inches in length, and eight inches in breadth. On this, in imperfect letters, was the inscription in Hebrew, Greek, and Latin-JESUS NAZA-

${ }^{1}$ Moroni, Dictionary of Erudition; Gerbet, in his Esquisse de Rome Chrétienne, states that on the seals were the words "Gerard, Cardinal of S. Croce." If true the relic was immured in the twelfth century by a Cardinal titular of this church, who became Pope as Lucius II.Hemans, Catholic Italy, vol. i., p. 206. 


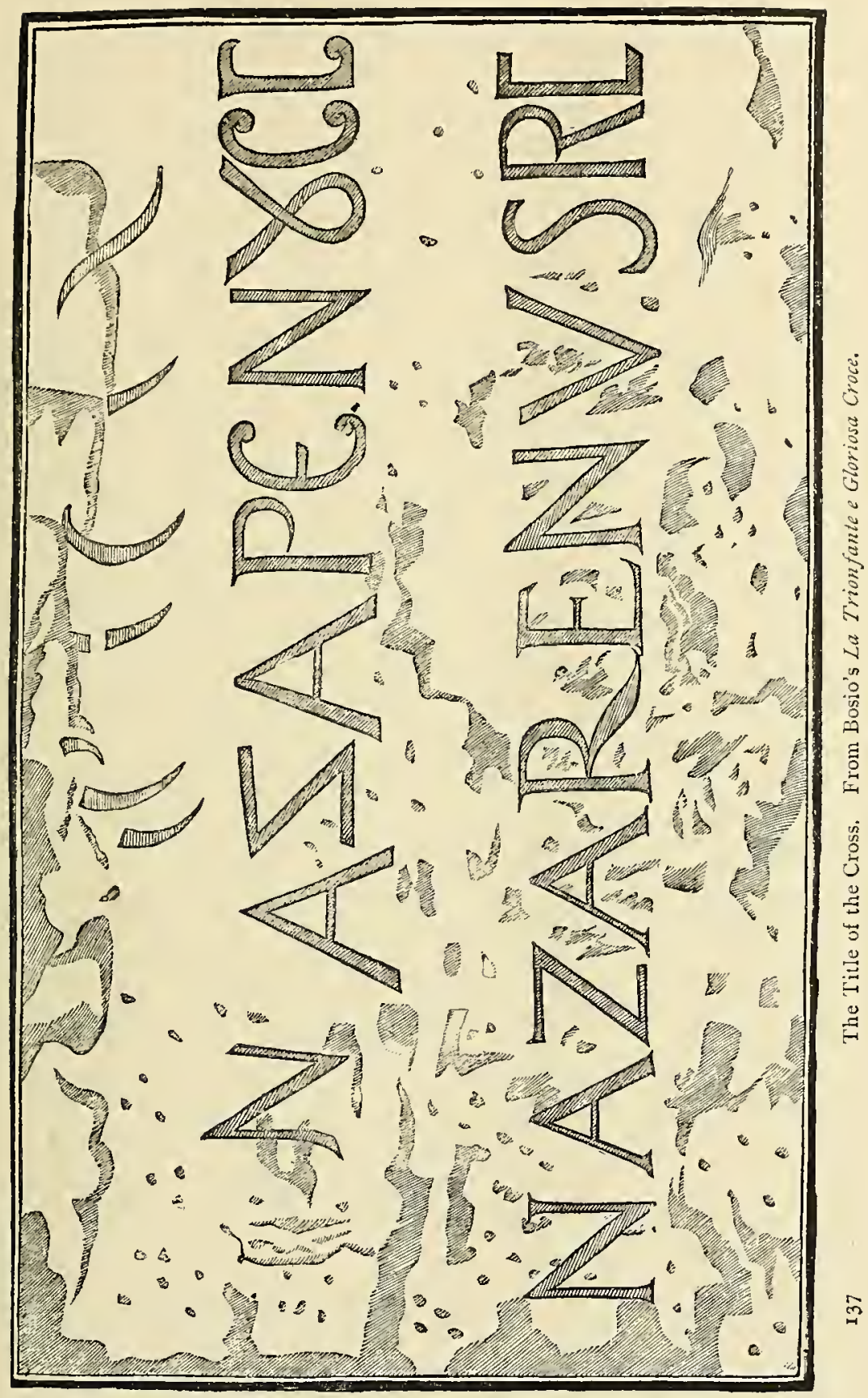


RExE KING. Of the Hebrew, only mutilated parts of the characters rcmained, enough, however, for a Rabbi to decipher " Nazarene King of "- not in the ancient Hebrew letters, but in the Syriac, which was the vernacular language of Judea when our Saviour suffered. Since that time the upper portion of the title has become more effaced. Of the Greek $\beta \alpha \sigma i \lambda \varepsilon v 5$, only the initials remain; while of the Latin Rex, the initial is wanting. The table was white, the letters red; for all Roman judicial sentences were thus inscribed, and enough traces were visible to determine the original colors.

This relic is claimed by the Roman Church as being the veritable Title of the True Cross, which was placed for safe keeping in the niche where it was found by the Emperor Valentinian III. in the fifth century. The custom of immuring highly prized relics, Paulinus mentions as being common in his day, a century earlier.

As to the genuineness of the holy relic, of course it is as impossible to decide as upon that of an intaglio purporting to be of the age of Genuineness of Alexander. As in the case of the gem, so in that of this the Relic. bit of wood, we can at least say it bears evident marks of great antiquity. Curzon and Lord Mahon ${ }^{2}$ both think it the same as that brought by S. Helena from Jerusalem. Strong proofs of its being what it is represented are the marks of carelessness, showing evident haste in its preparation, such, for instance, as giving the Latin instead of the Greek desinence in " Nazarene," the inversion of the letter $Z$ in the same word, and the writing of all the inscriptions from right to left. Of the Hebrew, too little remains to form any judgment, but the Greek is the work of another hand than that which formed the Latin characters, or else one unused to the language.

But the history of the church itself is so interesting that it must be completed. In 1744 , the façade was erected, mainly from the ruins of the adjacent temple of Venus. The columns are of granite, Concluding
History of History of
the Church. and a rare marble, bigio lumachcllato, but of the original twelve only eight are now visible, the others having been built into the heavy piers which divide the nave and aisles. The antique pavement is a beautiful specimen of the mosaic known as the Opus Alexandrinum. On the vault of the apse is an exquisite fresco of the discovery

' Curzon, Monasterics of the Levant. Mahon, Hist. of the Holy Cross. Essay read before the Royal Soc. of Antiquaries, Feb. 10, 1831 . 
of the Cross; the work is attributed by some to Perugino, by others to Pinturricchio. On one side of the tribune is a silver lamp burning before the chapel, within which is enshrined the sacred relic; the floor beneath is formed of earth brought by S. Helena from Mount Calvary. Over this shrine is the inscription forbidding women to enter except upon the festival of the venerable founder.

In the last century the French Republicans desired to search the chapel. After resisting as long as he dared, the Superior gave up some of the keys, but one was wanting, being lost or mislaid. The French prefect, perhaps moved by some lingering feeling of reverence, would not force the doors, and the chapel and its sacred contents were undisturbed.

There are two facts connected with Santa Croce which are interesting. One is, that in this church the Golden Rose ${ }^{1}$ is consecrated, and the other is, that within the precincts of S. Croce was anciently a basilica, probably the only one in the imperial city in which the cause of a slave could be pleaded. What place more fitting for the sanctuary of the title of Him in whom all are free? And is the place of this shrine a mere accident?

1 The Golden Rose dates perhaps from the end of the eleventh century. It is an ornament of gold, musk, and balsam, symbolical of the Divinity, body and soul of Christ. It was consecrated by the Pope on the fourth Sunday in Lent. In the ceremony allusion is made to the fruit of good works, the flower of the field, and to the rose and lily as emblematic of the Virgin. After mass it is carried away by the Pope, and if the intended recipient is in Rome, it is presented to him by his Holiness himself. In I446, Engenius sent one to Henry VI. Henry VIII. was the favored recipient of this gracious gift from both Julius II. and Leo X. Charles IX. of France received the Rose from Pius V. after the massacre of S. Bartholomew. The latest instance of the extension of this distinguished courtesy was to Isabella, Queen of Spain, by his Holiness Pius IX.

A beautiful specimen of a branch of a rose-bush literally blooming in gold is preserved in the Hotel de Cluny.-Walcott, Sacred Archzology; Ciampini, Vet. Mon., tom. iii., cap. 7. 


\section{CHAPTER VII}

\section{THE DOCTRINAL TEACHING OF THE CRUCIFIXION}

$W^{\mathrm{E}}$

E should never forget when studying the works of artists, especially of the earlier masters, that we are not looking upon a mere work of art designed only to please the eye. They were meant to teach the heart, for the " handmaid of Religion," as art has been called, Symbolism of was compelled to do her office even when the artificers Early Painters. in their own individual lives, were " of the carth earthy." Everything had its teaching; the adjuncts of the solemn scene represented, all imparted this lesson to those whose only knowledge of that which pertained to salvation came from the oral teaching of their preachers; the not less forcible, though mute teachers which hung on the walls of their simple parish churches, or, graven in stone, made the walls of their magnificent cathedrals eloquent. The sun and moon, the presence of the beloved disciple and grief-stricken mother, the skull of the father of the human race, the penitent Magdalene, all told the story of the world lost and saved; enforced the doctrine of death for sin, and life in the redemption then being paid. Hence the ministry of angels, "All ministers to the heirs of salvation," was represented not only attendant upon their and our dying Lord, but upon the two thieves, as types of the two classes of the saved and lost in the human race.

In the accompanying illustration we have the youthful, unbearded image of the Saviour, crowned with the crown of glory by the Father, represented by the hand giving the Latin benediction, Cross of Ancient
Ivory, Ninth assisted by angels. On either side are the Sun and Moon,
Century. Century. each with the hand to the cheek, an ancient form of expressing grief. On the right hand of our Lord is the Church, represented by a female figure holding a triumphal banner; on the left, the 


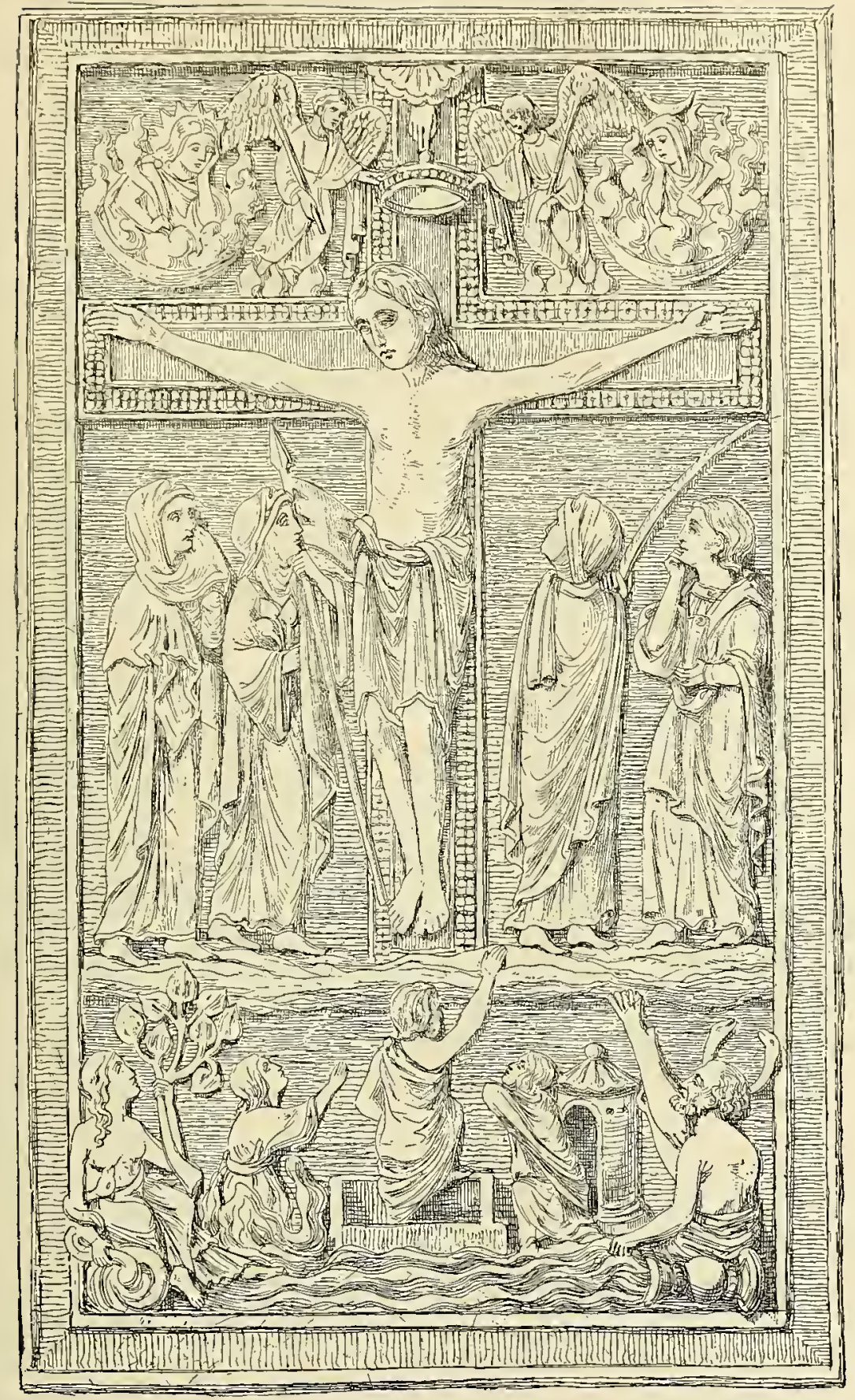

The Crucifixion (Ivory Work of the IXth Century). From Jameson's History of Our Lord. 
Synagogue with averted face, holding, probably, a palm-branch in allusion to the day when the Jews saluted him King.

The blessed Mother and S. John stand on either side, each with the hand to the cheek; that of the Virgin is covered by her drapery, an early Oriental sign of respect, still preserved in Italy, where the ecclesiastics cover their hands in divers acts of reverence towards the Pope; such, for example, as receiving the cardinal's hat. The Apostle holds a scroll in his hand, his being the only Gospel recording the presence of himself and the Virgin Mother at the final scenes. Below, are the old classical figures of Ocean, pouring water from his urn, and Earth bearing a tree and giving suck to a serpent, while the three intermediate figures are supposed to be typical of the resurrection from earth and sea (an explanation not satisfactory to us).

In place of the serpent, sometimes Earth, as mother of all, nourishes young children; at others she holds a small human figure which represents darkness over the earth. Again, between the figurcs of Earth and Water is a female figure with banner and globe, or simply draped with uplifted veil, like Tellus in the Catacombs, which represents the Heavens, for " heaven and earth are full of thy glory." Sometimes on

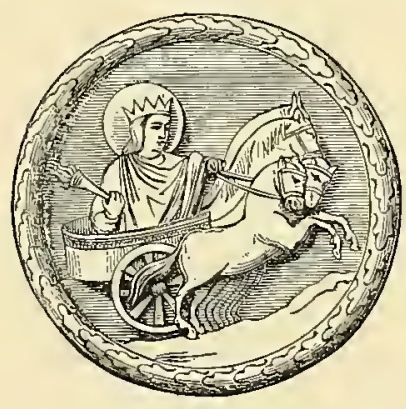

Sun and Moon at Crucifixion (Ancient Ivory). From Jameson s History of Our- Lord.

the same level with

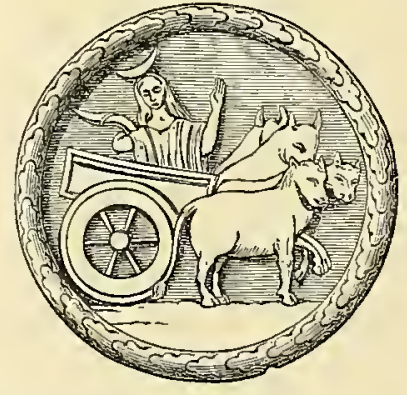

the Church and

Synagogue, on the left hand, sits a female crowned with towers, who is supposed to be the emblem of Jerusalem, while coiled around the foot of the Cross is "the

old serpent," either lifeless, his head having already been crushed by the heel of the seed of the woman, or else helplessly gazing upward upon the second Adam, as on the fall he looked triumphantly down upon the first.

The figures of Sol and Luna are differently represented. In some instances they are in chariots, the first drawn by horses, the latter by

${ }^{1}$ Hist. of Our Lord, vol. ii., p. 146 . Some of this explanation is unsatisfactory. The symbols will be better interpreted, we trust, by future archæologists. 
oxen; in others they are symbolized by full-length figures with reversed torches, etc.

By the eleventh century all these mystic personifications vanish, and

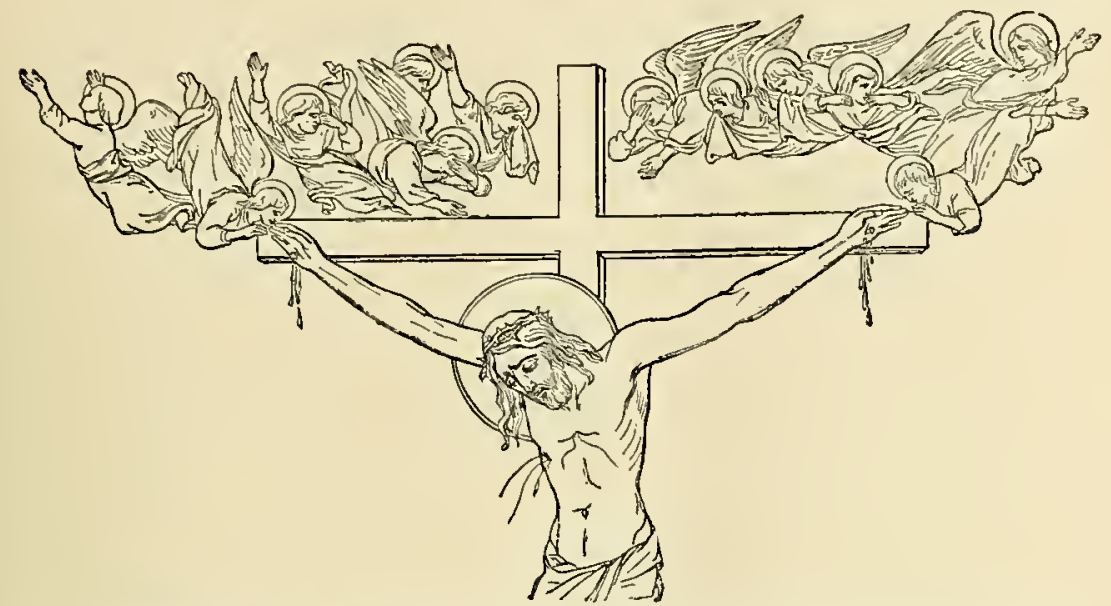

Angels Round Cross (Duccio, Siena). From Jameson's History of Our Lord.

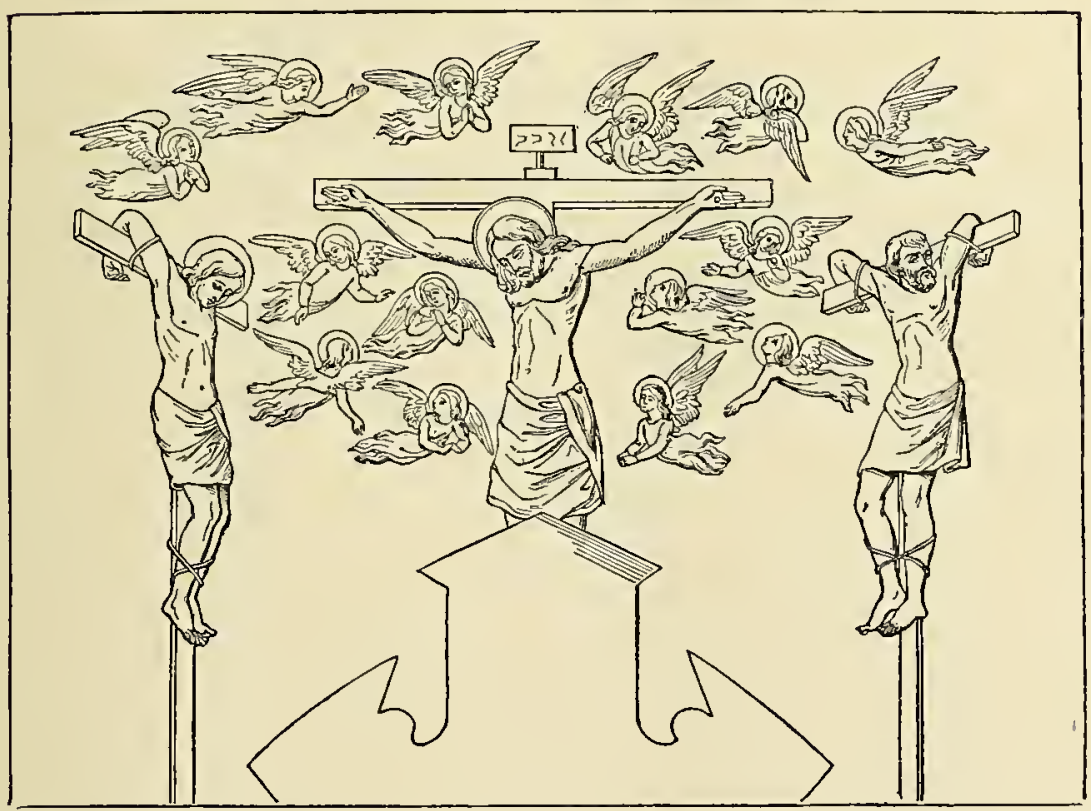

Angels Attending the Crucifixion (Pietro Cavallini, Assisi). From Jameson's History of Our Lord. give place to groups of passionate angels and other figures betokening, if not a more earnest faith, a more realistic one. The serpent lingers the longest, being found even in modern art. 
The skull of Adam also retains its place. In early MSS. Adam himself starts from his sepulchre and receives the blood in a Eucharistic chalice. Sacrificial types are varied. The pelican, emblem of the Eucharist, is placed either above or below the Cross; the wolf suckling Romulus and Remus, in allusion to ancient Rome, or an altar on which a red heifer is being sacrificed, is below the Cross. ${ }^{1}$ The figure of the Divine sufferer changes as has been noted.

Lady Eastlake, in her History of Our Lord, has divided the subject of the Crucifixion into various heads: Symbolical, Doctrinal, Historical, Legendary, Allegorical, and Realistic, with their subdivisions. To her work we refer the reader for the full treatment of the subject under these divers heads, only condensing from her admirable book the three following descriptions.

First, the Doctrinal Crucifixion.

The great scene of the Atonement, not literally with the few truehearted believers, the Jews and the Romans, but illuminated by "the Doctrinal light of fulfilled prophecy . . . adored by saints." As Crucifixion. an instance, this distinguished authoress gives the great Crucifixion by Fra Angelico da Fiesole, which she justly calls " the highest example of the mystery of our Redemption that the pencil of man has produced for the edification of his fellow creatures. It is in the Convent of S. Marco at Florence . . . It knits together in one unexampled whole the grand Christian idea, from the earliest glimmerings of truth permitted to the patriarchs of the old law to the joyous confessions of faith delivered by the latest preachers of the painter's own brotherhood."

The figure of Christ is represented, not hanging from the Cross, but with arms extended as properly carrying out the idea of the universal embracing of the merits of the sacrifice. The repentant thief, in "holy peace," turns to Him who has promised that he shall be the "first fellow heir in Paradise." The impenitent, with a "wail of pain," averts his head from the " only Physician." " Below, on the extreme right, are the three patron saints of the house of Medici," that family having presented the convent to the Order of the Dominicans. S. Lawrence, with his symbol, the gridiron, at his side; S. Cosmo, clasping his hands tightly, and S. Damian turning away in a burst of grief. The special 


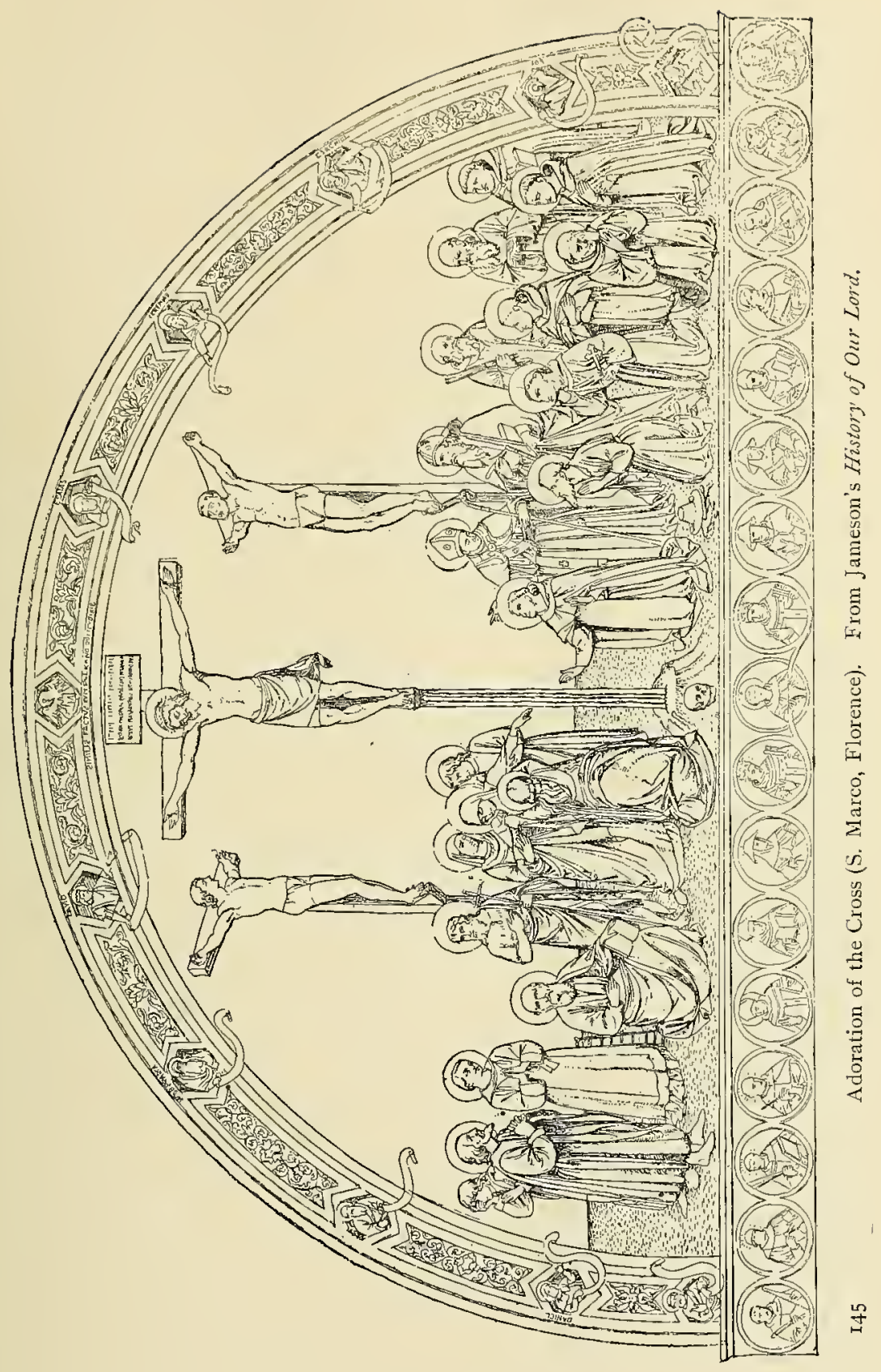


patron saint of the Convent of S. Marco kneels with open Gospel in hand; next stands the precursor, S. Joln the Baptist; next is the group of the Maries and the beloved disciple.

On the left of the Cross kneels the founder of the Order, S. Dominic himself. Near him bows S. Jerome, his cardinal's hat cast upon the ground. Above, in full Episcopal robes, is S. Ambrose, an allusion to his noble exercise of official power when righteously rebuking the Emperor. Near him is S. Augustine; his pen and book refer to his Rules, which the Dominicians had adopted. S. Francis, honored with the stigmata, is near S. Jerome. Behind, S. Bernard is clasping the Rules of his Order to his heart as if offering his work to his Lord. S. Benedict, who by self-inflicted flagellation strove to suffer like his scourged Master, stands holding his rod. S. Romualdus is next. The kneeling Franciscan turning away from the Cross " as not worthy of it" is supposed to be either S. Gualbertus, or, perhaps, the painter himself. S. Peter Martyr and S. Thomas Aquinas complete the group.

In the centre of the semicircular framework is the typical pelican, with the inscription, "Simitis factus sum pclicano solitudinis,"- "I am like a pelican of the wilderness"' (Ps. cii., 6). On either side are halflength figures of the prophets bearing scrolls inscribed with the appropriate prophecies.

On the left, David presents, " In siti mea potacerunt me aceto," - " In my thirst they gave me vinegar to drink" (Ps. lxix., 21 ).

Jacob: "Ad predam fili mi ascondisti; requiescens accubuisti ut leo," - "From the prey, my son, thou art gone up; he stooped down, he couched as a lion" (Gen. xlix., 9).

Zechariah: "His plagatus sum," _ " I am beaten by them."

Daniel : "Post hebdomades vii. et lxii. occidet Chst,"-- " After seven and three score- and two weeks Messiah shall be cut off" (Dan. ix., 25,26 ).

Dionysius the Areopagite: "Deus nature patitur." This person is alluded to in Acts xvii., 34. It is related that being in Heliopolis at the time of the Crucifixion, he noted the eclipse of the sun which occurred at the death of Jesus, and, knowing that it was supernatural, he exclaimed, "The God of Nature suffers." It is also stated that in consequence of this phenomenon, the Athenians erected the altar "To the Unknown God." 
Isaiah: "Vere languores nostros, idcm tulit et dolores nostros,""Surcly he hath borne our griefs and carried our sorrows" (Isa. liii., 4).

Jeremial1: "O Vos omnes qui transitis por viam attcnditc et videte si est dolor sicut dolor meus," - " All ye that pass by, behold and sce if there be any sorrow like unto my sorrow" (Lam. i., 12).

Ezekiel: "Exaltavi lignum hile" (humile),_ " I bare it upon my shoulder" (Ezel. xii., 7).

Job: "Qui det de canibus ei ut saturem." (Not found).

Erythrean Sibyl: "Morte morictur: Tribus diebus somno subscepto ct tunc ab inferis regressus ad lucem venict primus." These words are considered as a paraphrase on the articles of the descent into Hades and ascent to Heaven in the Nicene Creed.

In the centre of the base is S. Dominic, from whose hands proceeds a sort of genealogical tree presenting the most eminent brethren of his Order. On S. Dominic's right is: I. Pope Innocent V. 2. Cardinal Hugo, who performed the funeral services to S. Dominic in I22I. 3. Paulus, Patriarcha Gradensis, in Florence. 4. Antoninus, Archbishop of Florence; he was alive at the time of the execution of the work. 5. Jordanus of Germany, the second General of the Order. 6. Nicolas, Provinciales Portugalesis. 7. Remigius of Florence. S. Buonianus, saint and martyr.

On the left of S. Dominic: I. Pope Benedict II. 2. Cardinal Giovanni of Florence. 3. Pietro della Pallude of France, Patriarch of Jerusalem. 4. Albertus Magnus. 5. Raimond of Catalonia, of Pegnaforte, the third General of the Order, elected 1237. 6. Chiaro da Sesto of Florence, "Provincialis Romanus." 7. S. Vincent of Valencia, "Predicator." 8. Bernard, saint and martyr. "The marvellous completeness of this work," says Lady Eastlake, " proceeding, as it does, in equal proportions from the Churchman, the Christian, the Monk, and the Man, will excuse the length of this description. No other Crucifixion is like it except in the mere fact of the devotional as opposed to the historical character; and in some respects, such as the attitude of the Virgin, it forms an exception to this class." 

PART II. 



\section{CHAPTER I}

\section{THE CROSS IN EARLY CHRISTIAN ART}

THE sign of the cross was used in the age immediately succeeding 1 the Apostolic, perhaps even in that time, but at what precise period it became an actual, visible, or

Antiquity of the Cross. tangible form we are ignorant.

Tertullian, in the second century, ridicules the accusation of their enemies, that the Christians worshipped the Cross as an idol; thus if not admitting its common use, yet affording ground for presuming that it was known in their worship.'

At a very early period, some zealots, taking the words of S. Paul literally, "Hence- cross Imprinted forth let no man on the Body. trouble me; for I bear in my body the marks of the Lord Jesus ", (Gal. vi., I 7), imprinted upon their foreheads, and other parts of their bodies the Cross, and, in some instances, probably, the monogram of Christ. The heretical Jacobites, who rejected water, substi-

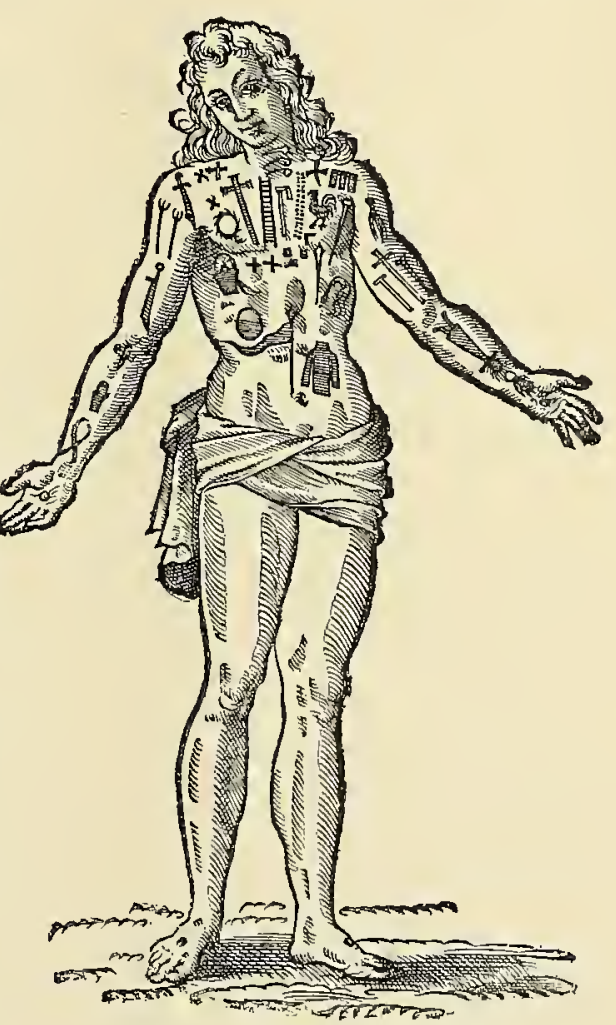

The Cross Imprinted on the Body. From Gretser's De Sancta Crace. tuted a baptism of fire, branding with a red-hot iron a cross upon the

I Tertullian, Apology, xvi. 
cheeks or foreheads of their proselytes. ${ }^{1}$ This was no new invention. Among the ancient Syrians, Greeks, and other nations indelible marks were made on the face, or elsewhere, denoting the standing of the bearer.

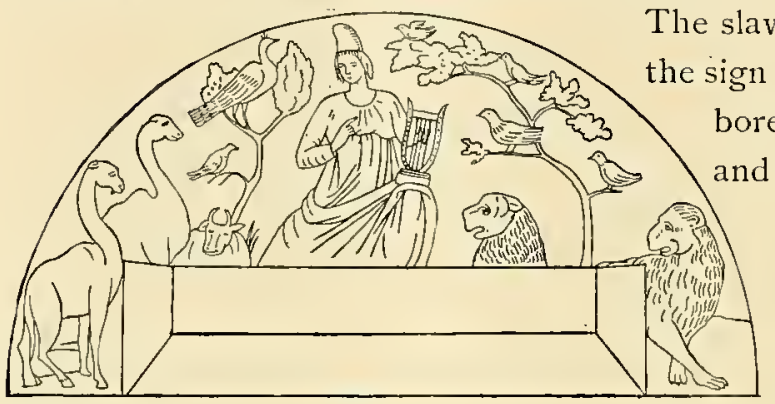

The slave was thus marked with he sign of his master, the soldier bore that of his commander, and the idolater that of his favorite god. ${ }^{2}$

But persecution, and the severe canons of the Church against those who necdlessly threw
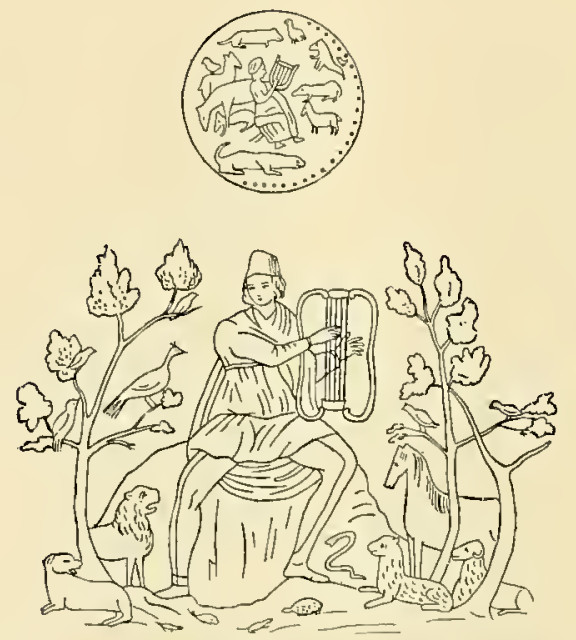

Christ Represented as Orpheus. From Twining's Symbols of Early and Mediaval Christian Art. away their lives through vainglory, or inordinate zeal for martyrdom, soon taught the believers to add the wisdom of the serpent to the harmlessness of the dove; and the sacred symbol was carefully concealed, with other mysteries, ${ }^{3}$ till in the fulness of time, the faith in Christ crucified, which its upholders declared had long "filled the hovel and the palace" could be openly proclaimed. Hence, even in

the holes and dens of the earth, the Catacombs, where the highest officer in the Court and the lowliest slave knelt side by side to celebrate the sacrifice of their common Lord, for centuries the Cross was only timidly shown. iii., I I.

1 Perverting the text, "He shall baptize you with the Holy Ghost and with fire." Matt.

' Procopius says, "Many marked their wrists, or their arms, with the sign of the Cross.' See Rev, xx., 4. Spencer, De Leg. Heb., lib. ii., cap. 20. Lowth on Isaiah xliv., 5. Compare Rev. xiii., I6 ; xiv., 9. Julian the Apostate, reviling the Christians, says, "Ye worship the wood of the Cross, painting figures thereof on the forehead and before doors." Tertul., Oxford Trans., p. 57, note c. Ptolemy Philopator enslaved the Jews, and marked upon their foreheads the ensign of Bacchus, an ivy leaf. Hammond, Annot. Rev., xx., 4.

${ }^{3}$ De Quincey gives a graphic account of the secrecy which the early Christians were obliged to practice, in his essay on the Essenes.-Hist. and Critical Essays. 
The pious believers were contented to adopt as a type of Christ, the representation of Orpheus, surrounded by wild beasts entranced by the melody of his lyre, or the Good Shepherd "carrying his lost sheep" upon his shoul- Pagan and other shristianized. der, ${ }^{1}$ or leaning upon his staff (the symbol of the Christian hierarchy according to S. Augustine), or they read the sacrifice of the Lamb of God in the typical slaying of Abel and the offering up of Isaac. Clearer tokens the early Christians required not, so they consecrated pagan emblems with a holier significance, and adopted the Fylfot and Tau crosses

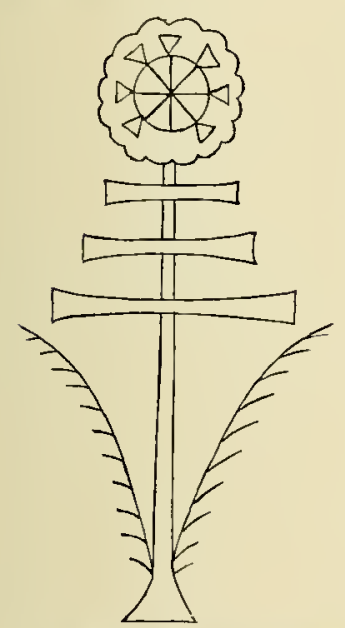
instead of the literal figure, be- Representation of Pan Applied to Christ as cause they were familiar, to their

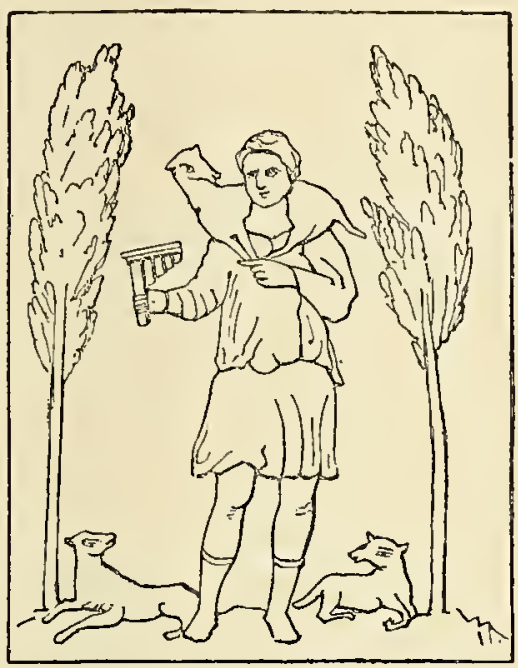
enemies, and could give no information to their persecutors.

From this scrupulous guarding of the sacred symbol it has been erroneously concluded that the use of the actual cross, or even that of its represented figure, was un-

Early Use of known in the early Church until a comparatively late period.

An authoress of the highest authority in art has

Triple Cross, Representing been thus misled. After quoting the well-known the Second Person of the Trinity. From Twining's Sy'mbols. words of S. Chrysostom that the Cross was everywhere "held in honor, in Lady Eastlake on Early Use of the highway, on mountains, in forests, on hills, on the sea, in the Cross. ships, on islands, on our beds and on our clothes, on our arms, in our

${ }^{1}$ Lord Lindsay states that this symbol was adopted from the Greeks. A statue of Mercury carrying a goat at Tanagra is mentioned by Pausanias. According to this theory it is not the lost sheep, but the scape-goat of the wilderness that our Saviour rescues. Lindsay, Christian Art., vol. i., p. 41. Dr. King thinks the emblem represents a Gnostic Anubis with the double head, one human and the other that of a jackal. Iring, Gnostics, p. 2or. 
chambers, in our banquets, on gold and silver vessels, on gems, in the paintings of our walls, on the bodies of diseased beasts, on human beings possessed by devils, in war and peace, by day, by night, in the dances of the feasting, and the meetings of the fasting and praying," she goes on to say, " that this was true in some sense, there can be no question," but that ancient objects of art, as far as known, show no corrobation of the use of the Cross in the simple form familiar to us at any period preceding or closely succeeding the words of S. Chrysostom. There is no doubt, however, that the " so-called monogram of Christ" was much used and venerated as representing to the eye of faith the sign of the Cross.

In early Christian art our Lord is represented as free from bonds, divested of all circumstances of suffering, with no sign of the " accursed tree." Faith needed to be strengthened by depicting the signs of Christ's love and power as shown in healing the sick and raising the dead rather than by representing the ignominy and horror of His sufferings as man. In assuming this natural repugnance on the part of Christians to use the Cross, we must also remember that the Romans looked upon the form of this instrument of punishment with horror. According to Cicero, "the very name of the Cross was banished from the thoughts, eyes, and ears of a Roman citizen." It required the abolition of the punishment of crucifixion and the lapse of generations Arbor Infelix. before the " old ideas connected with the Arbor Infelix gave way before its new and glorious meaning, and the pure form of the Cross emerged to sight, no longer the sign of a horrible death, but of the Divine Triumph over all Death. Returning, therefore, to the evidence of that form of art which exists in greatest abundance, namely, coins, we find the first appearance of the simple cross in the dignified form [i.e., the llasta, or long cross held erect] on a coin issued by Galla Placidia, who died A.D. 45 I." 1

In clearing up the above error, it will be briefly shown by a few examples that the Cross was used and honored even in Apostolic days, "and those of the Church of the first three centuries.

Pompeii was overwhelmed with ashes A.D. 79. In one of the passcross in ages of a ruin in that city, known as the house of Pansa, Pompeii. is placed, so as to be visible to the passers-by, a cross in bas-relief upon a panel of white stones. Opposite, visible only to the 
indwellers, is represented one of the guardian serpents, the Dci Custodes. Mazois explains the whole, that probably at that time the Cross was a symbol understood by the Christians who placed it among the symbols of paganism, to inform the faithful that here the truth had found an asylum under the safeguard of all the popular superstitions. ${ }^{1}$

S. Cadvan preached the Gospel to the Britons in the third century. His monument bears four crosses. The inscription is in Latin, partly in British characters of the above date. ${ }^{2}$

Early Cross in Britain.

Maitland gives the following epitaph from the Catacombs:

In the inscription, the lower arm of the Cross interferes with a letter, compelling the sculptor to change its shape, thus showing that the Cross was not an after-thought, but contemporaneous with the lettering. The epitaph reads: "Lannus, the Martyr of Christ rests here. He suffered

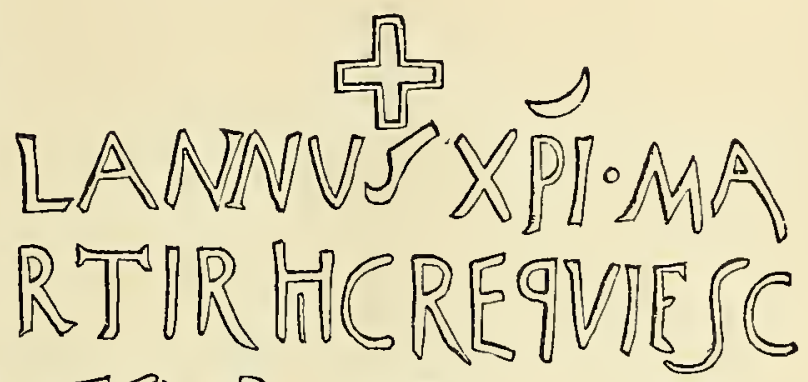
under Diocletian. The sepulchre is also ITSU⿴囗十品

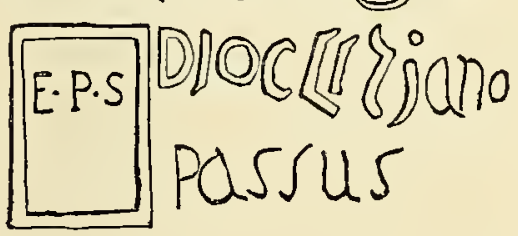
for his successors."

The letters, E. P. S., according to Boldetti, stand for et posteris suis. ${ }^{3}$

Diocletian reigned from A.D. 284-305, nearly one hundred years before the time of S. Chrysostom. The baths at Rome of that Emperor were built about the year 302, one year before the persecution began. Forty thousand Christians, it is stated,

In the Baths of Diocletian. were employed in that work. Upon some of the bricks have been found the sign of the Cross, supposed to have been placed there by the workmen."

1 Mazois, Les Ruines de Pompeii, part ii., p. 34, qnoted in Dyer's Pompeii, p. 32I. A cross, nnfinished, covered with insulting inscriptions and caricatures has lately been discovered in that city. Nezo York Tribune, March I5, I866. Perhaps what is supposed to be the work of an enemy is that of a Gnostic heretic, like the Graffito crucifix discovered in Rome, but in either case it shows that the cross was a well-known symbol.

${ }^{2}$ (Eng.) Ecclesiologist, vol. v., N. S., p. 224.

${ }^{3}$ Maitland, Church in the Catacombs, p. I27.

${ }^{4}$ Murray, Handbook of Rome, p. 5 s. 
Eusebius also says that Constantine erected crosses in the principal streets of Rome and of Constantinople, and in his palace. LactanErected by tius seemingly asserts that the last was, in fact, a cruciConstantine. fix. ${ }^{1}$

The appeal to coins is still more unfortunate for Lady Eastlake. The illustration given in the margin is of a coin of Crispus, son of Constantine and his wife Fausta, who was created Cesar A.D. 315, cross on Coins. and was slain nine years after. The reverse bears a figure of our blessed Lord holding a plain Cross, " in the dignified form," between two persons, probably Constantine and Crispus. Another

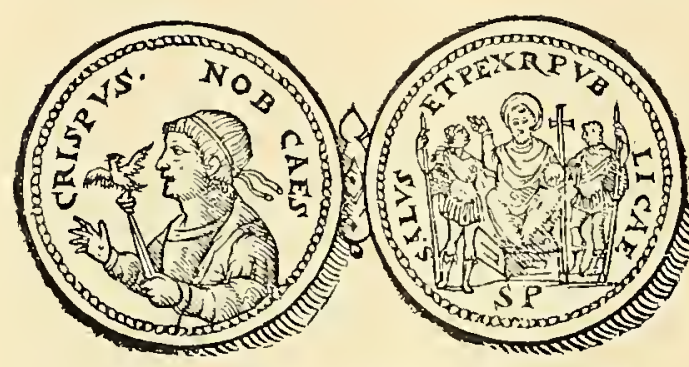

Coin of Crispus. From Gretser's De Sancta Crace. instance can be found in a medal issued just after the death of Constantine in A.D. 337. The Cross is plainly depicted above the Labarum. Other examples are found on the coins of Jovian, A.D. 363 ; Valentinian, A.D. 364; Gratianus and Valentinianus,

A.D. 378 . In the last instance the Emperor treads a serpent under his feet, while he holds a long cross in his hand. ${ }^{2}$

It has been a disputed point who was the originator of the symbol, or mound, surmounted by the Cross, a type of the conquest of Christ Author of the over the world. Ducange gives the honor to Valentinian. Mound.

Gretser presents a coin of that Emperor confirming that claim. Others trace the emblem to Jovian; it appears on the coins of Theodosius, A.D. 375-395; other coins of this reign exhibit the Cross borne as a sceptre by the Emperor or held by the figure of Victory. ${ }^{3}$

More examples might be given, but sufficient evidence has been adduced antedating Galla Placidia, who died A.D. 45I, by the better part of a century. Yet, that about her time the world more freely reverenced the holy sign may be seen from the fact that the Cross appears "for the first time, distinct and isolated, beside an epitaph, in A.D. $438 . ", 4$

${ }^{1}$ (Eng.) Ecclesiologist, vol, v., N. S., p. 226 . Lactantius died A.D. 330.

${ }^{2}$ Gretser, De Crutce, tom. iii., lib. i., caps. 8-I4.

${ }^{3}$ Ibid.

${ }^{4}$ Hemans, Anient Christianity and Sacred Art, p. 580. 
It is sufficient glory to that empress of uncqual fame, 'that to her we ate indebted for the "first instance that can be authenticated " of the Cross occupying a prominent position " on large monuments of art." " Her sepulchral chapel is in the clurch of SS. Nazario e Celso, built in A.D. 440, at Ravenna: the dome is azure with golden stars, in the midst of which shines a golden cross. Fourteen hundred years have passed since that dome was finished; but the cross, uninjured, save by the ravages of time, still protects the only tomb of the Casars which has not been violated. The mausoleum of Augustus is now a circus; the tomb of Hadrian, a fortress; but the ashes of Galla Placidia, Honorius, and Valentinianus III. rest beneath the shadow of the first representation of the Cross thus exalted, to hallow not only a sepulchre, but also a temple to Him who is the Resurrection and the Life.

The Cross suffered its mutations, in honor and dishonor. Rufinus says that every house in Alexandria had its door-posts, entrances, windows, and walls painted with

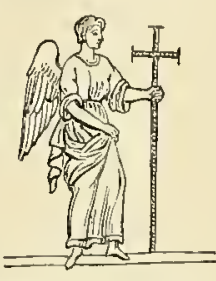

First Coin with Cross, Issued by Galla Placidia, Vth Century.

From Jameson's History of Our Lord. the holy sign. The Emperors Valens and Theodosius, A.D. 427, required that every sign of our Saviour, whether engraved or depicted, should be effaced-a bit of pre-Puritan spite. Four years later, the second Council at Ephesus required every private house to possess a Cross. Still further reverence was shown to the Cross by the Council of Constantinople (" in Trullo"), which forbade its being inlaid in the pavement of a church, in order that the symbol of our salvation should not be trampled under foot.

The natural feelings of love and veneration soon led the primitive Christians to adorn with precious gems and jewels the symbol, which to the world told only of shame, ignominy, and death, but to the believers spoke of redemption and salvation.

Gemmed or Jewelled Crosses.

Bosio asserts that the idea of thus ornamenting the Cross was derived from the salutation which (so says tradition) S. Andrew uttered when

1 Alternately exalted and degraded, she lived to be a Gothic Queen, a Roman Empress, twice a captive of Barbarian armies. Once she was clriven twelve miles on foot amidst the common herd before the car of the usurper, her first husband's murderer. Literally, her ashes are here preserved, for, in 1577 , some children thrusting a taper through an aperture in her toml, set fire to the vestments clothing the royal corpse, and all was consumed. Hemans, Ancient Christianily and $4 r t$, pp. 356-7.

${ }^{2}$ Hist. of Our Lord, vol. ii., p. 3 I8. 
he first beheld the instrument of his martyrdom. When yet a long way off he beheld it, and, falling upon his knees, exclaimed, " Hail! Cross

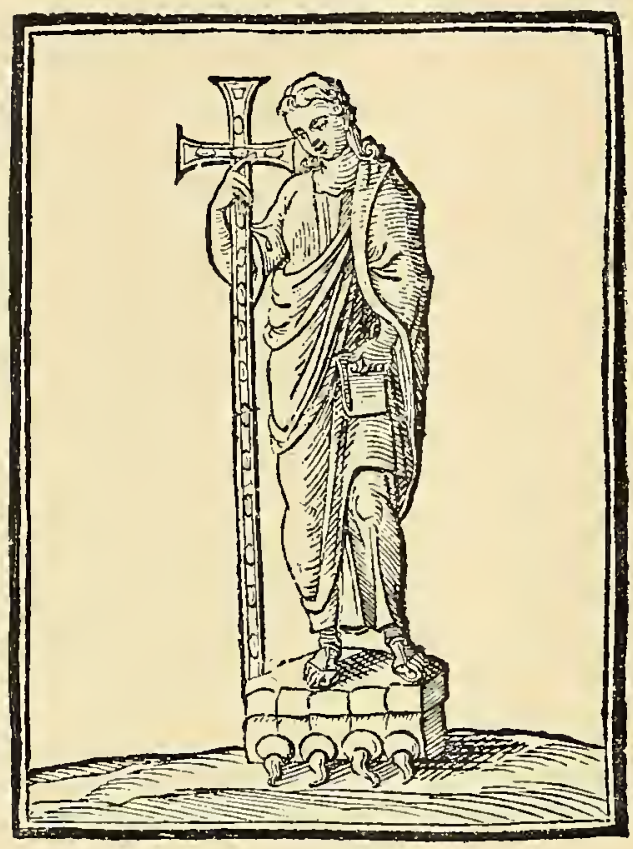

Christ Holding a Gemmed Cross.

From Bosio's La Trionfante e Gloriosa Croce. which was consecrated by the body of Christ, and adorned as with pearls by his members."

No early gemmed crosses have been preserved, but representations of them and of the jewelled monogram are frequent in the Catacombs and on sarcophagi. Eusebius also informs us that Constantine " set up the symbol of the Saving Passion, formed of precious stones." 2 But such valuable treasures have long since been despoiled. The engraving given is from the Cat. acombs. It was carved on the sarcophagus of Sextus Petronius Probus, a Christian officer in the time of Valentinian (the latter part of the third century), and was formerly in the ancient Church of S. Peter. The figure (Christ ?), holding a gemmed cross, stands upon a structure of stones (i.c., perhaps the Church), in number, ten, probably signifying infinity; from this base flow the four mystical rivers of Paradise. ${ }^{3}$

Excepting the examples in the Catacombs and on

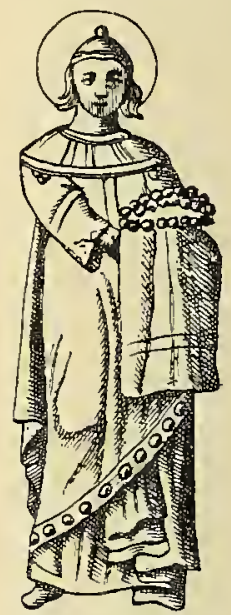

S. Pudentiana, from Fresco in the Church of S. Pndentiana.

From Ciampini's Vetera Monimenta. the tombs, the earliest representations of jewelled crosses that have been preserved are the mosaics and frescos which adorn many of the Italian

1" Salve Coux, qux in corpore Christi dedicata es, et ex membrorum eitus margaritis ornata. Antequam ascenderet Dominus, timorem terrenum habuisti, molo vero anorem calestem obtines, pro voto susciperis. Sciris enim à Credentibus, quanta in te gaudia haheas, quanta munera preparata." Bosio, Trionfante Croce, lib. vi., cap. r2. The scene is represented by Guido in a fresco in S. Andrew's Chapel, Church of $\$$. Gregorio, Rome.

'Life of Constantine, lib. iii., cap. 40.

${ }^{3}$ Bosio, lib. vi., cap. I2. 
churches. The fresco on the roof of the apse of S. Pudentiana, formerly assigned to the time of Adrian I., but by Crowe and Cavalcaselle to the fourth century, is pronounced the first in merit among Christian mosaics. Seated in the centre is the Saviour with one arm extended, in the other is an open book inscribed Conscrator Ecclesiac Pudcntiance. SS. Praxedis

Mosaics in Churches. In $\mathrm{S}$. Pudentiana. and Pudentiana, with leafy crowns in their hands, are at a lower level. In front are S. Peter and S. Paul, with eight other figures; in the background, beyond a portico with arcades, are seen various stately buildings, " one a rotunda, another a parallelogram with gable-headed front, recognizable as a bapistry and basilica, here, we may believe, in authentic copy from the earliest types of the period of the first Christian Emperors. Above the group, and hovering in air, a large cross, studded with gems, surmounts the head of our Saviour, between the four symbols of the Erangelists." '

In the Church of S. Maria Maggiore, at Rome, decorated with mosaics by Sixtus III., A.D. $432-440$, above the arch of triumph, over the tribune, surrounded by scenes from the Old and New Testaments, is a medallion on which is represented the throne Maggiore. of God, richly ornamented with gems. At the back is a jewelled cross resting upon another, surmounted by a crown, from which flows a veil, shrouding, as it were, the lower cross. Upon the seat is placed the Book of Life with seven seals. Here the Cross stands for Him who suffered upon it. Another example, in which it has the same direct symbolism, is in S. Maria Cosmedin in the same city. The date of the mosaics is of about the year A.D. 553. The Cosmedin. gemmed Cross is placed upon a royal throne, blazing with jewels. S. Paul and S. Peter stand on either side, covering their hands with their robes in reverence (a custom observed in some ceremonies of the Latin Church to this day), the one holding a roll, the other the keys. It is significant that to $\mathrm{S}$. Paul is assigned the right hand, the place of honor, while S. Peter occupies the left. This disposition of the Apostles was the most common until about the year 800 , when the claims of S. Peter to the supremacy were exalted. ${ }^{2}$

'Hemans, Ancient Christianity and Sacred Art, p. 495.

${ }^{2}$ Bosio attempts to explain this testimony of S. Panl's supremacy in honor. He says the mosaic is according to the Greek custom, which regarded the right as yon "enter" the choir, facing the altar, as the place of honor, whereas the Latin Church held the right as you "go 


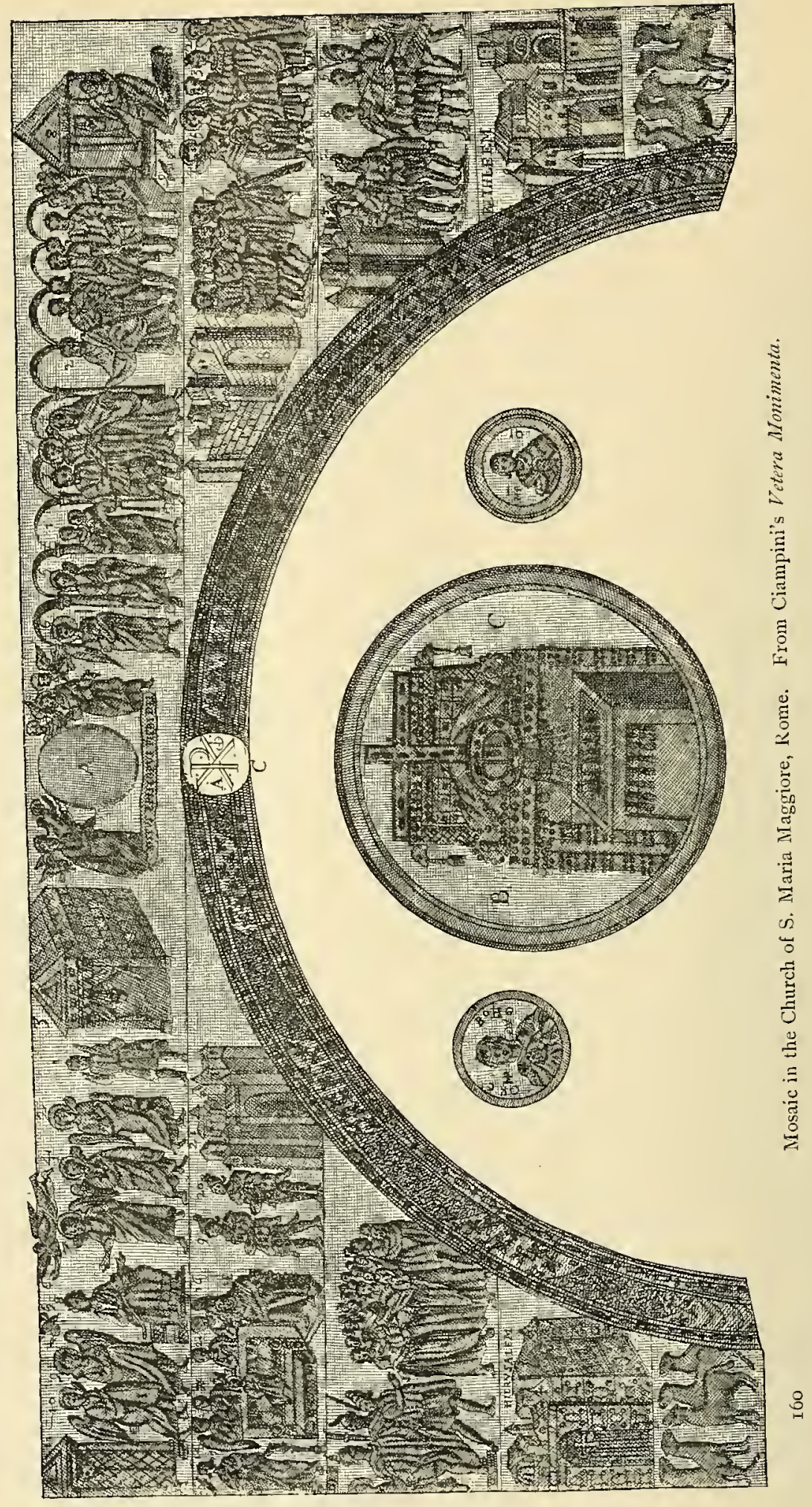


There is also a very fine mosaic in the Church of S. Michael the Archangel, at Ravenna, A.D. 545, in which Christ stands erect holding it magnificent Latin cross. Bosio gives an illustration formerly in the old S. Peter's, Rome, in which the wounded

S. Michael, Ravenna. Lamb stands at the foot of the Cross, streams of blood old s. Peter's, flowing from his breast and feet.' One of the latest instances before the change to a crucifix is in the Church of John Lateran. S. John Lateran at Rome, rebuilt by Nicholas IV., A.D. 1288-94. Part of the church was burned in I309, but the mosaics were preserved. Above the gemmed cross is the dove, the symbol of the Holy Ghost diffusing its divine influence; believers, typified by hearts and lambs, are partaking of the life-giving streams of Paradise ${ }^{2}$; below is the holy Jerusalem, the city of God, its gate guarded by an angel; from within rises the palm of victory, upon which is perched the phonix of immortality. About the same date is the exquisite mosaic crucifix over the tribune of S. Clemente.

out " the more exalted. In other words, as on the stage. or in a picture, the right hand of the scene of art is the spectator's left. Trionfante Croce, lib. vi., cap. I2. To make this and another point clearer we quote from Marriott: "An enumeration of all known monuments antecedent to the year 800 A.D., in which the two Apostles are represented together, would show that in a very large majority of cases, the place of our Lord's right hand is assigned to S. Paul. . . If the rule were invariable that S. Paul occupied the one place, S. Peter the other, there would be some show of probability for the assertion, that in these early times the place of honor was not what it now is; that the spectator's right, not the right hand of the principal personage, indicated the place of precedence.-Testimony of the Catacombs, p. $7^{6}$.

1 The development of the lamb as a symbol of Christ is instructive. In the Catacombs, and on ancient sepulchres it stands on a hill amid the four rivers of Paradise. It sometimes bears on its shoulders a crook and milk-pail. According to Northcote, it then typifies the Eucharist. But Walcott says it then represents the Good Shepherd. In the fourth century, its head is crowned with the Cross and monogram. In the fifth century the nimbus appears. In the sixth it bears a spear, ending with a cross, the emblem of Wisdom according to WValcott, or else bleeding from five wounds, one gushing into a chalice. Still later, it is girded with a golden zone of Power and Justice (Is. xi., 5), and bears the banner Cross of the Resurrection, or treads upon a serpent (Rev. xviii., I 4). In the eighth and ninth centuries it rests on a throne amid saints and angels as in the Apocalyptic vision. -Walcott, Sacred Archaology", "Lamb" ; see also Didron, Christ. Icon.

" "In that day there shall be a fountain opened to the house of David and to the inhabitants of Jerusalem, for sin and for uncleanness" (Zech. xiii.). Mystically signifying, according to S. Ambrose, Prudence. Temperance, Fortitude, and Justice. De Paradiso ex Gen., 43. According to S. Bernard, the river of Mercy, the river of $\mathrm{W}$ isdom, the river of Grace, and the river of Charity. In the fountain of Mercy, we have the water of remission to wash away $\sin ;$ in that of Wisdom, we have the water of discretion to quench our thirst; in that of Grace, the water of devotion to water the fruit of our good worlis; while that of Charity supplies fervent zeal. "Nodern Roman archæologists represent the mound 'as a mountain not a rock, and to it and the four streams they give various interpretations. Mt. Zion and the four streams which flow therefrom'; 'the four rivers of Paradise flowing from II 


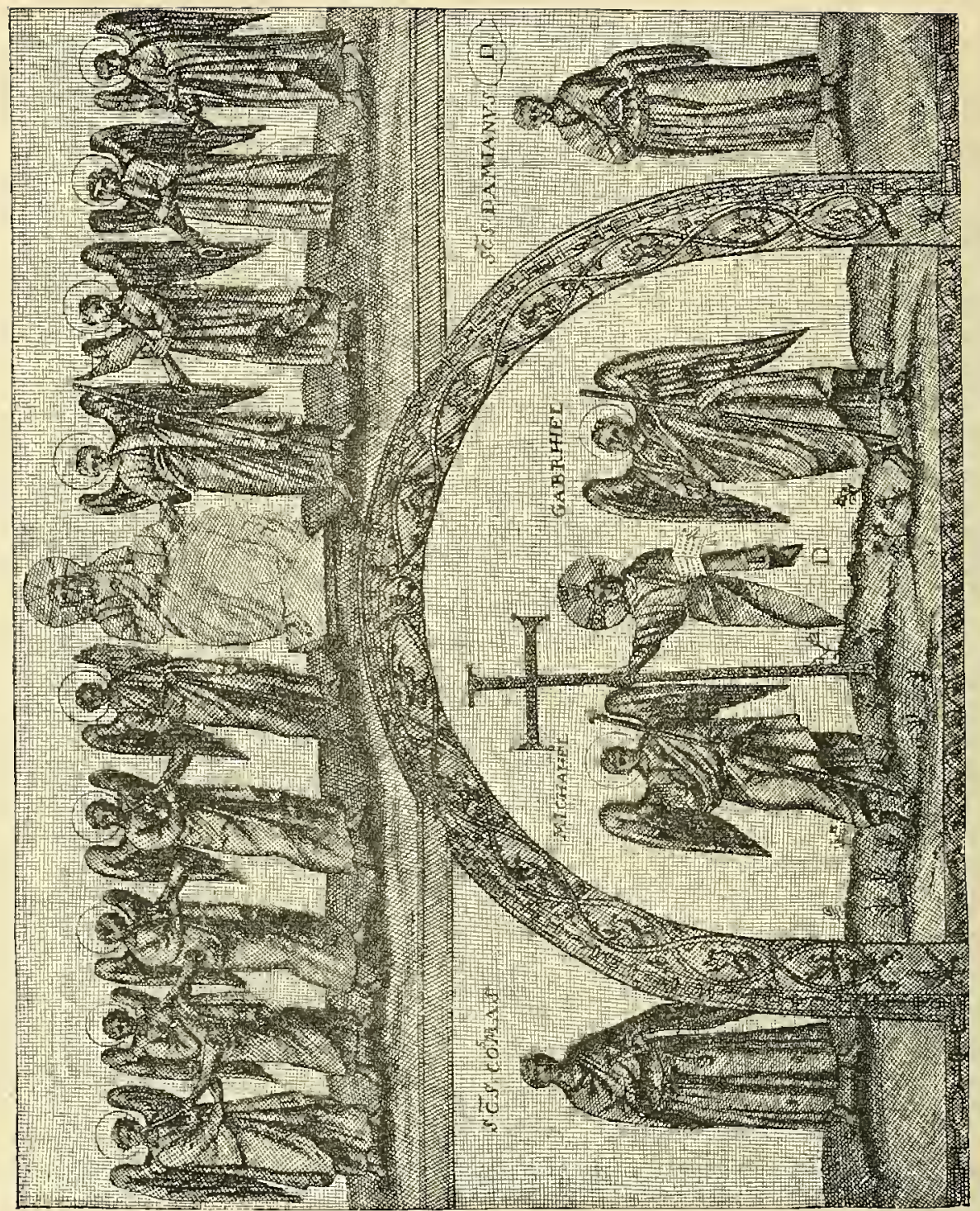


Over the tribune in S. Apollinare in Classe, at Ravenna, is a gemmed cross placed in a medallion of stars. Here the Cross " is Christ under the figure of the gibbet on which He suffered," as pointed out by the inscription $L \times \Theta Y z$, salus mundi and the $A$ and

S. Apollinare in Classe.

Q. On either side of the medallion are Moses and Elias, showing that the scene intended to be represented is that of the Transfiguration. The number of the stars is ninety-nine, and M. Lacrois, the clorc-national and historical correspondent at Rome, thinks that the number may be intended to refer to the number of " just persons, in relation to whom there is less joy in Paradise than at the conversion of a single sinner." '

The next ornamentation was the crown: although this is connected generally with the crucifix rather than the naked cross, yet it is more in place to treat of it here. God claimed the crown as an ornament of honor to be used in His service, commanding crowned eross. that the mitre of the High Priest should be decorated with this insignia of power (Ex. xxxix., 3O, 3I). ${ }^{2}$ One of the earliest, if not the earliest mention of a crown was that of Rabbah, King of the Am- Earliest Mention monites - which David took from his head and placed upon of a crown. his own (I Chron. xx., 2). Among pagan nations it was at first a sacred emblem. Pliny says that the ancients had no crown except that given to the gods. ${ }^{3}$ Saturn was first thus honored; then Jupiter, after conquering

the mountain which designates the Church,'- 'the four streams which issue from that one head of waters, over which Peter presides,' etc. Paulinus of Nola gives in his epistola XII aut Severum a different interpretation, and one in accordance with the Fathers of his day (fourth century). In describing the mosaic vauled roof of a church which he has built, he says :

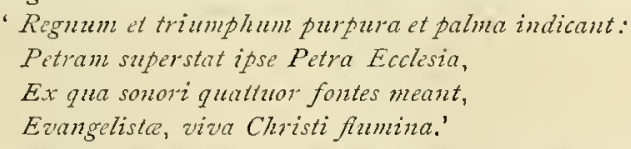

'The purple and the palm are signs of royal estate and of trimph. Standing upon a rock is He who is Himself the Rock of the Church; and from this go forth four voiceful streams, Evangelists, the living Rivers of Christ." - Marriott, Testimony of the Catacombs, p. 82.

One of the latest writers on Christian Art and Symbolism, Rev. R. St. Tyrwhitt (who is endorsed by Ruskin) regards the four streams as the rivers of Baptism; the lambs represent the Christian flock, while the stags are the outer Gentiles desiring baptism. Christian Art and Symbolism, p. 123 .

${ }^{1}$ Didron, Christian Iconography, vol. i., p. 397. "It is to this cross surrounded with stars that the exclamation of the Emperor Heraclius might apply: "O Crux Splendidior cunctis Astris!" "This personification of Christ is repeated till the seventh century." Tyrwhitt, Christian Art and Symbolism, p. 125.

"The Ark of the Covenant, Ex. xxv., II ; The Table of Shew Bread, Ex. xxv., '24; The Altar of Incense, Ex. xxx., 3, were commanded to have a crown of pure gold, probably a raised ornamental border.

${ }^{3}$ Pliny, lib. xvi., cap. 4. 


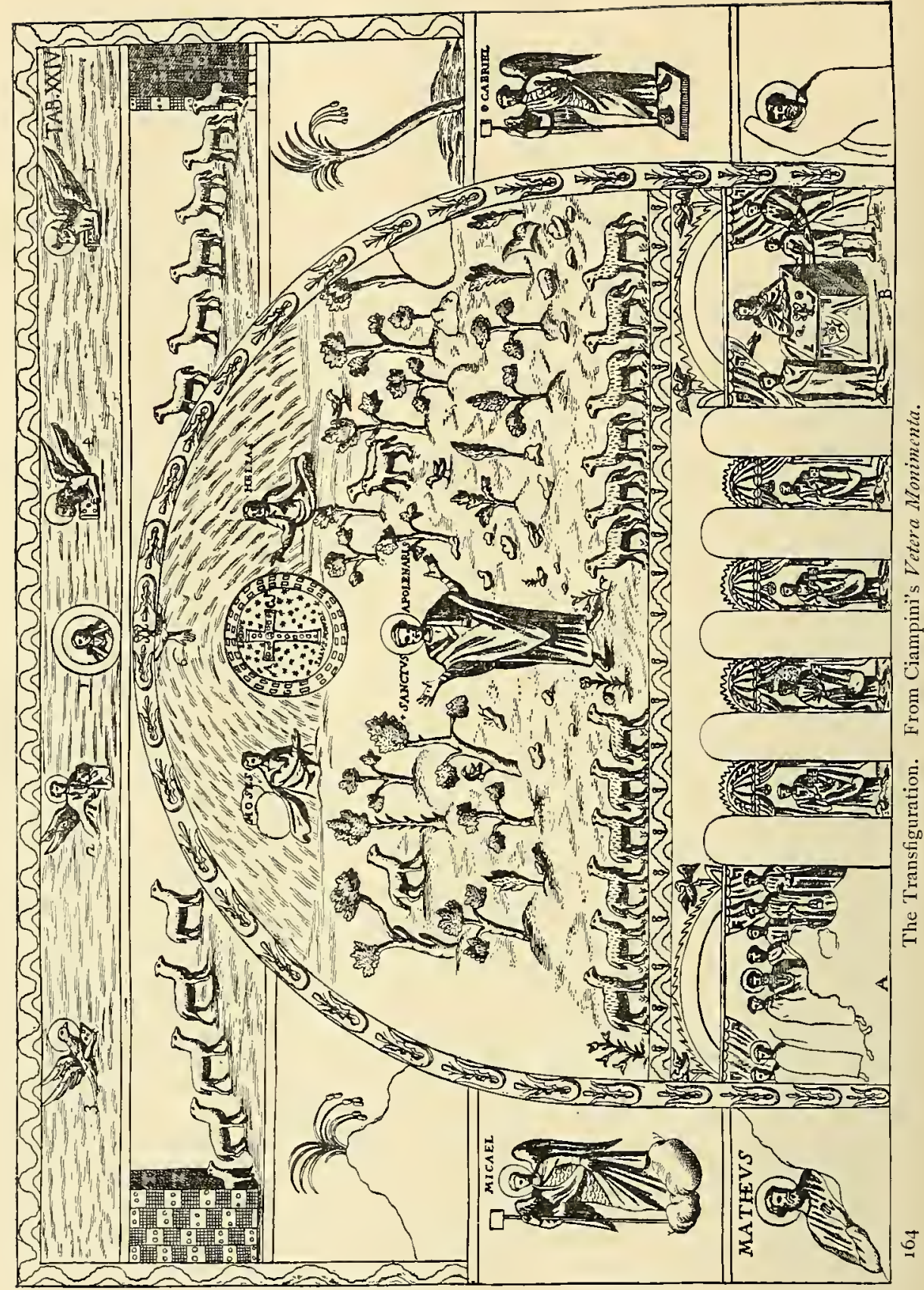


the Titans; Juno wore a vine branch ; Heracles sometimes was garlanded with poplar, sometimes with wild olive, sometimes with parsley; Apollo's coronet was laurel, and that of Bacchus, ivy ': hence some early Christ-

ians were scrupulous about the use of the crown, when even a chaplet of herbs or flowers might be perverted; but the words of S. Paul, "But we see Jesus who was made a little lower than the angels crowned with glory and honor; that he by the grace of God should taste death for every man" (Heb. ii., 9), were soon applied literally to the beloved symbol of our Lord.

There are three forms under which the crowned cross is given. The first seems inappropriately Crowned Cross. classed here, The First. but it is done so by Gretser and by Bosio; it is simply a cross surrounded by a nimbus. This, according to tradition, was the celebrated miracu-

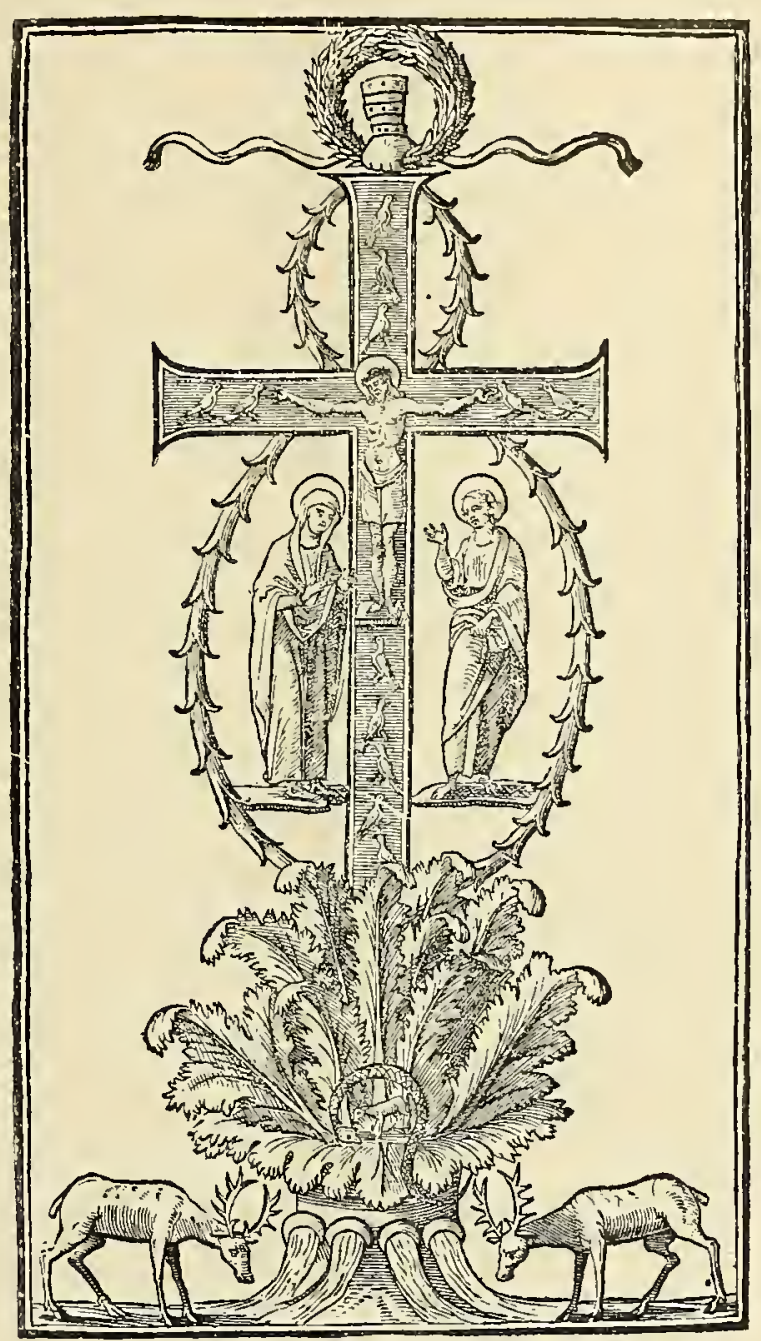

Cross Surmounted by Crown.

From Bosio's La Trionfante e Gloriosa Croce. lous cross of S. Thomas in Malabar, which is spoken of elsewhere. ${ }^{2}$ It is said that when Julian the Apostate was once inspecting the viscera of animals for divination, the Cross thus surrounded appeared. The Em-

1 Tertullian, De Corona, vii.

${ }^{2}$ For account of its miraculous change of color and dropping blood, see part iii., chap. viii. 
peror's terror was assuaged by the augurs, who declared that the nimbus was not a crown of glory, but a sign that the Christian religion was bound and circumscribed. ${ }^{2}$

The second form also belongs to the crucifix. In this, the crown is

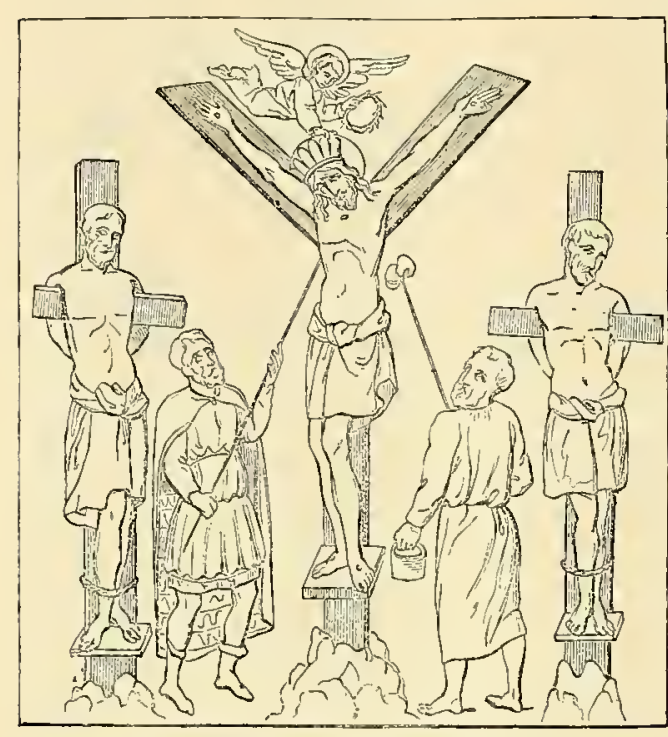

Angel Changing Crown of Thorns for Real Crown. From Jameson's History of Our Lord. placed above the cross, often The second held by a hand, Form. $\quad i . \epsilon$, the first person of the Holy Trinity-as in the exquisite mosaic in the tribune of San Clemente, at Rome. Doubtless this mode of representation arose from the custom of the triumphs in Rome. Then the attendant held the laurel crownabove the head of the victorious general, but the wreath was not permitted to rest on his brow.

The third form, like the former, appertains to the crucifix. It is the substitution of a crown of gold and gems in place of that of thorns. The symbol of The Third liumiliation and suffering ${ }^{2}$ exchanged for that of power and Form. royalty. This is one of the earliest variations. Even in the Catacombs are instances of the crown of thorns exchanged for one of flowers.

IS. Gregory Naz., Contra Fulian; Gretser, De Cruce, lib. ii., cap. Ir.

a Gretser, De Crace, lib. ii., cap. II ; Bosio, Trionfante Croce, lib. vi., cap. II. 


\section{CHAPTER II}

THE CRUCIFIX IN EARLY CIIRISTIAN ART

ROM what we have learned respecting the concealment of the
Cross in the primitive Church, we are not surprised at the absence of the crucifix in the early ages. There were reasons for this omission. Doubtless, one was the influence of the Why the CruciJewish converts, who retained their abhorrence of images, in Early Ages. fearing idolatry in representative art." Therefore, the Gentiles yielded to their objections, and so vigorously was the rule enforced, that if a convert had been previously an artist, and continued in his handicraft after his profession of faith, he was considered an apostate, and was denied baptism. Again, the same reason which induced the early Christians to veil the Cross under such symbols as the Fylfot and Tau, because they were already familiar to the pagans, influenced them to represent the sacrifice of our Lord under the guise of some well-known type from the Old Testament. Another reason, perhaps the most powerful, was the spirit of the primitive Church-the spirit of charity. This charity was shown even towards the persecutors. The early believers were men " of whom it may be truly said, "the world was not worthy'; amid mockings and scourgings, bonds and imprisonments, destitute, afflicted, tormented, tempted, slain with the sword, stoned, sawn assunder, not a thought of bitterness, or revenge has expressed itself in sculpture or painting during three centuries-not a single instance has been recorded of the tortures and martyrdoms which have furnished such endless subjects for the pencil in later ages. Even the

1 "AIl makers of images were turned from their (the Jews) commonwealth; for not a painter or statuary was admitted, their laws wholly forbidding them, lest any occasion should be given to dull men, or that their mind should be turned from the worship of God to earthly things by these temptations." Orisen contra Celsus, p. I8I, ed. I638, quoted in Jeremy Taylor's Dissuasive from Popery, book ii., sec. 6. 
sufferings of Christ are alluded to merely by the Cross borne lightly in his hand, as a sceptre of power rather than a rod of affliction; the agony, the crown of thorns, the nails, the spear, seem all forgotten in the fulness of joy brought by His Resurrection. This is the theme, Christ's Resurrection, and that of the Church in His person, on which, in their peculiar language, the artists of the Catacombs seem never weary of expatiating. Death swallowed up in victory, and the victor crowned with the amaranth wreath of immortality, is the vision ever before their eyes, with a vividness of anticipation which we who have been born to this belief can but feebly realize." I The Crucified One prayed "Father, forgive them," hence his followers, cherishing the memory of the instrument of his Passion as a symbol reminding them of the altar on which the sacrifice for the sins of the whole world had been offered, were unwilling, by too literal a representation of that sacrifice, to foster any feeling that savored of bitterness.

It was acknowledged by the early Church that some representation was needed for the teaching of truths through the eye as well as through the ear. Therefore a symbolic one was chosen, and, naturally, it was the one so often dwelt upon in the Scriptures-the Lamb. It was the type hallowed in the first recorded sacrifice; ordained the Paschai symbol of the Saviour in Egypt; foreseen-" dumb before his shearers," and " led to the slaughter" "-by Isaiah; recognized by S. John Baptist; accepted by our Blessed Lord Himself, and revealed, as standing before the throne in the Day of Judgment, in the apocalyptic vision of $S$. John.

It cannot be determined how early ths symbol was used. Paulinus, Bishop of Nola, circa A.D. 400, says, "Beneath the bloody Cross

Symbol of the Lamb and the Cross. stands Christ in the form of a snow-white Lamb consigned to unmerited death." In the apse of the old basilica of S. Peter's at Rome, founded by Constantine, A.D. 324, the lamb stood at the foot of the Cross, a chalice at its breast, into which probably the blood was flowing, although it is not so represented in the rude engraving of Ciampini. ${ }^{2}$ An early example, still in existence, is in the Church of SS. Cosma and Damiano, at Rome, A.D. 530. Here the lamb is reposing at the foot of the Cross. ${ }^{3}$

${ }^{1}$ Lindsay, Christian Art, vol. i., p. 50.

${ }^{2}$ Ciampini, Vet. Moni., tom. iii,, tab. xiii.

${ }^{3}$ Ibid., tom. ii., tab. xv. 


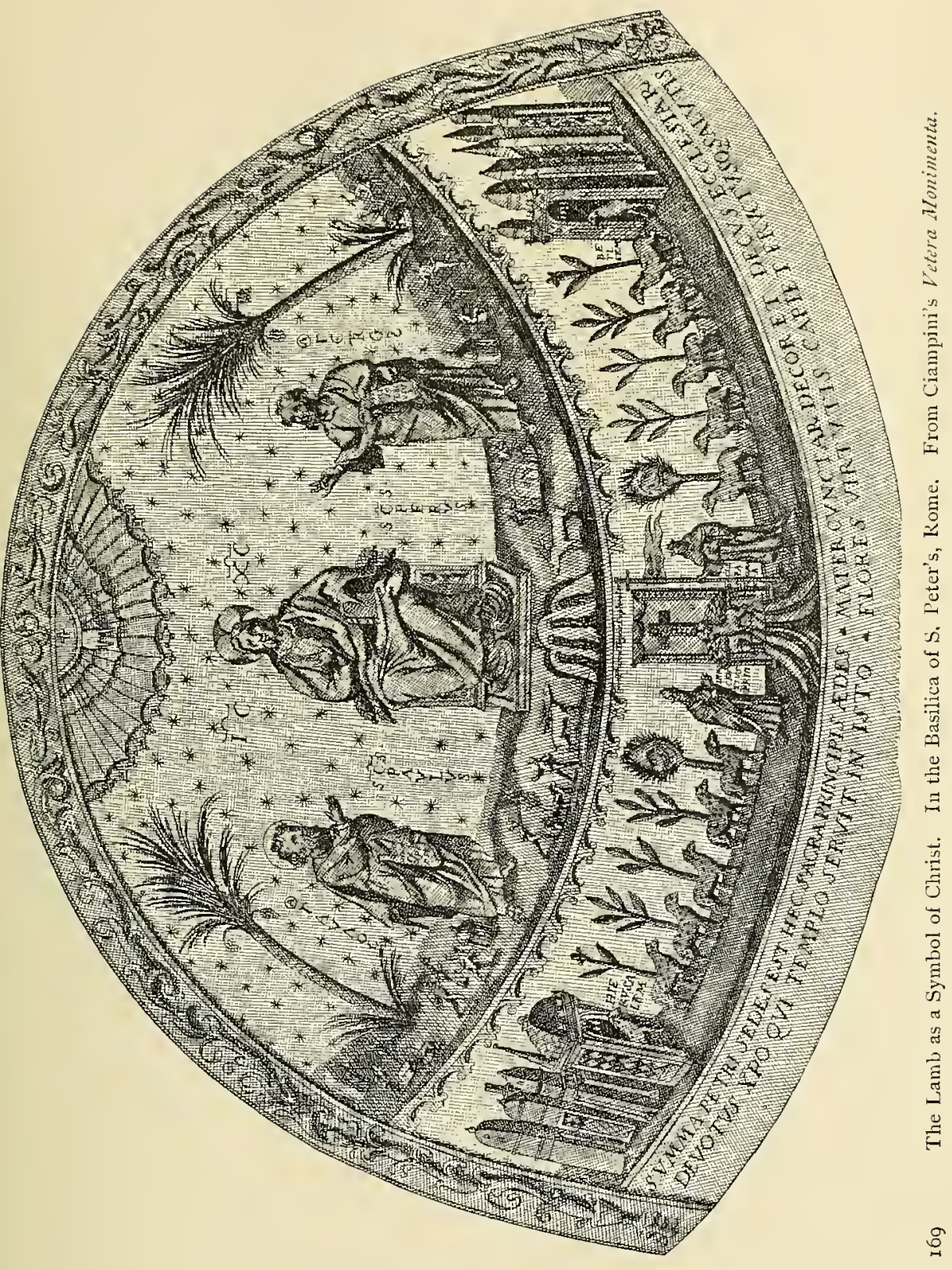


The Church, however, fearing lest in the simple type men would not sufficiently honor the antitype, decreed in the Quinsextan Council, generally known as that "in Trullo," A.D. 69I: " That the representation in human form of Christ our God, who takes away the sin of the world, be henceforth set up and painted in place of the ancient lamb." ' The lamb was sometimes retained and added to the reverse of the actual crucifix, as on the stational cross of Velletri. In the Cross of Mayence, the lamb is on one side of the tree, the crucified form on the other. But the crucifix, in sculpture or painting, was known before this time. We are told that the palace of Constantine was adorned with representations of sacred subjects, including one of the Crucifixion. ${ }^{2}$ Pelagitus I. (A.D. 555-559), being charged with having been accessory to the exile of his piredecessor Vigilius, took a disculpatory oath, holding over his head a crucifix and the Gospels." Venantius Fortunatus, about A.D. 560, alludes to a representation in relief, probably metallic:

\section{"Crux benedicter nitet Dominus qua carne prepondit." .}

A little later occurs what has been considered the first authentic mention of a crucifix, by Gregory of Tours (Bishop A.D. 575-595), at Earliest mention Narbonne. This was on painted cloth, but, as we shall of Crucifix Gen- show, there were still earlier examples. The earliest painterally Received. ing extant is in a Syriac Eiangcliarium, date A.D. 586, Eariest Extant. written at Zagba in Mesopotamia, purchased nine centuries later by the Medici for their library at Florence, where it is still preserved as one of the choicest jewels. The figure of our Lord is robed in a purple tunic reaching to the ankles, and sleeveless. Among other proofs of its antiquity, note that the soldiers are not drawing lots, or casting dice, for the seamless robe, but playing at Mora with the fingers for it. This. game is familiar in Italy at the present day. On the cruets of Monza, the gifts of Gregory the Great in the sixth century, are exhibited the head of Christ with a cruciform nimbus, and a cross flowering. In another representation of this time Christ appears with extended arms, the cross being wanting, while the thieves are bound to

1 Canon 82

2 Milman, Hist. of Chrisianily, vol. iii., p. 575.

${ }^{3}$ Anos, Biblioth., no. 62, quoted in Lea's Suferstition and Force, p. 2I. In the poem $D e$ Passione Domini, attributed to Lactantius (third and fourth centuries) a crucifix is described, but owing to its doubtful authenticity it is not cited.

${ }^{4}$ Carm., lib. ii., 3 . 


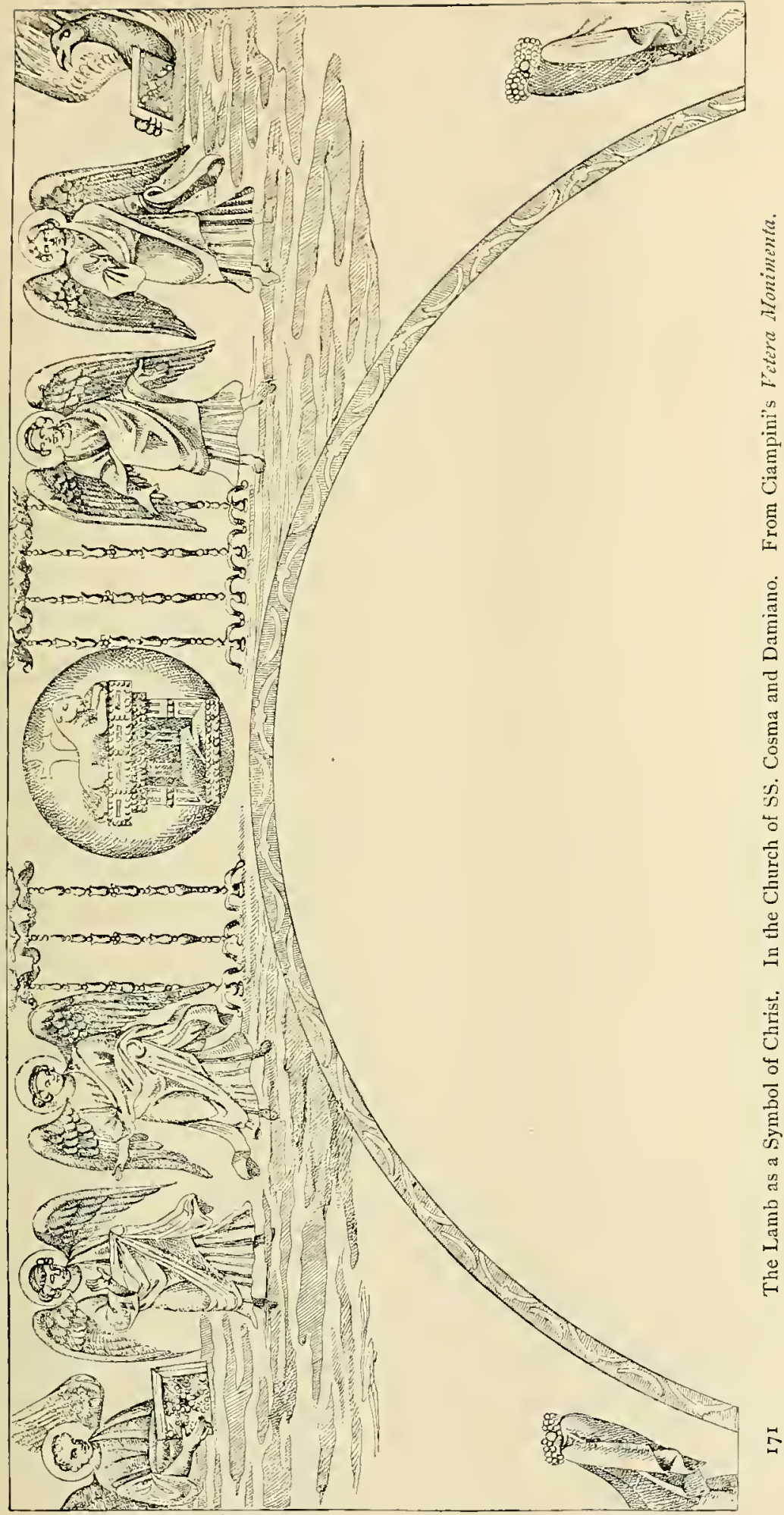


stakes. ${ }^{1}$ On the pectoral Cross of Monza, of the same period, the actual cross is given in enamel. At first, the crucifix was simply sketched in

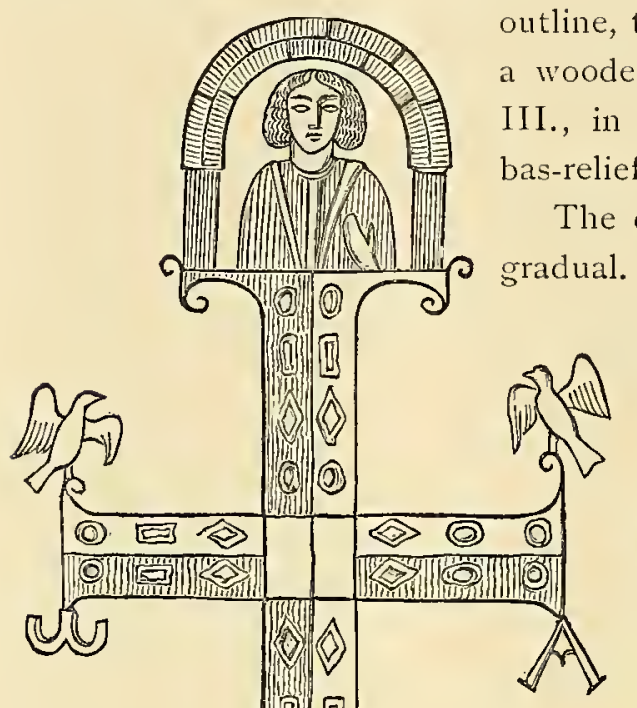
outline, then the figure was painted upon wooden cross; but in the time of Leo III., in the ninth century, it became a -relief.

The development of the crucifix was was placed upon the top of the Development of Cross, as it appears the Crucifix. in an Evangeliarium of the sixth century, in the Library of Munich." A similar one is represented in the Church of S. Stefano at Rome, which was probably part of the great market built by Nero, consecrated as a church A.D. 467. Ciampini assigns A.D. 645 as the date of the mosaics. ${ }^{3}$

It is probable that the canon of the Council " in Trullo" was almost immediateCrucifix in the ly obeyed, for Raoul Rochette Catacombs. assigns the close of the seventh century as the time of the earliest appearance of the crucifix." The sole example found in the Catacomb of S. Julius is generally attributed to this time, although Lady Eastlake says it is by some considered From Jameson's History of Our Lord. to belong to the eleventh century. At first, the figure of our Lord was

1 Hist. of Our Lord, vol, ii., p. I67.

"Ibid, vol. ii., p. 320. Lady Eastlake gives the following account of a pectoral cross, "which, according to an ancient inscription on it, was presented by the Emperor Justin (elected emperor A.D. 519) to the Pope of that period, Gregory II. Here the Agnus Dei, the Lamb slain from the foundation of the world, stands in the centre, with the bust-length figure of our Lord in the act of benediction occupying the upper end. Below is a figure believed to be John the Baptist, while, with a profane presumption which only the abject exaltation of the Eastern emperors can account for, the figures of Justin and his wife Flavia Eufemia, are placed at the transverse ends." Ibill., p. 32I. There is some mistake here, as Gregory II. was not consecrated until A.D. 7 I5.

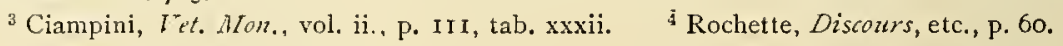


rested in a sleeveless tunic extending from the neck to the feet; but this was not always the case, as in an exquisite crucifix, once in possession of the Hohenlohe Siegmaringen 'family, the tunic has sleeves. In this instance the Saviour is very young; there are no wounds, no nails, no suffedancum, nothing to suggest suffering; the placid face, "fairer than the children of men," and the outstretched arms only speak of the all-embracing love which prompted thesacrifice; its awful reality is only intimated by the instrument of the Passion, upon which the Lord rests. ${ }^{2}$

In the eighth and ninth centuries the feet are fastened with nails, the hands outstretched as in the act of benediction or prayer, yet generally free. At times this is reversed, the hands are fastened, and the feet, woundless, are supported on the suppodancum. The faith$\mathrm{ful}$ attendants, the blessed Virgin and S. John, exhibit fortitude and submission which

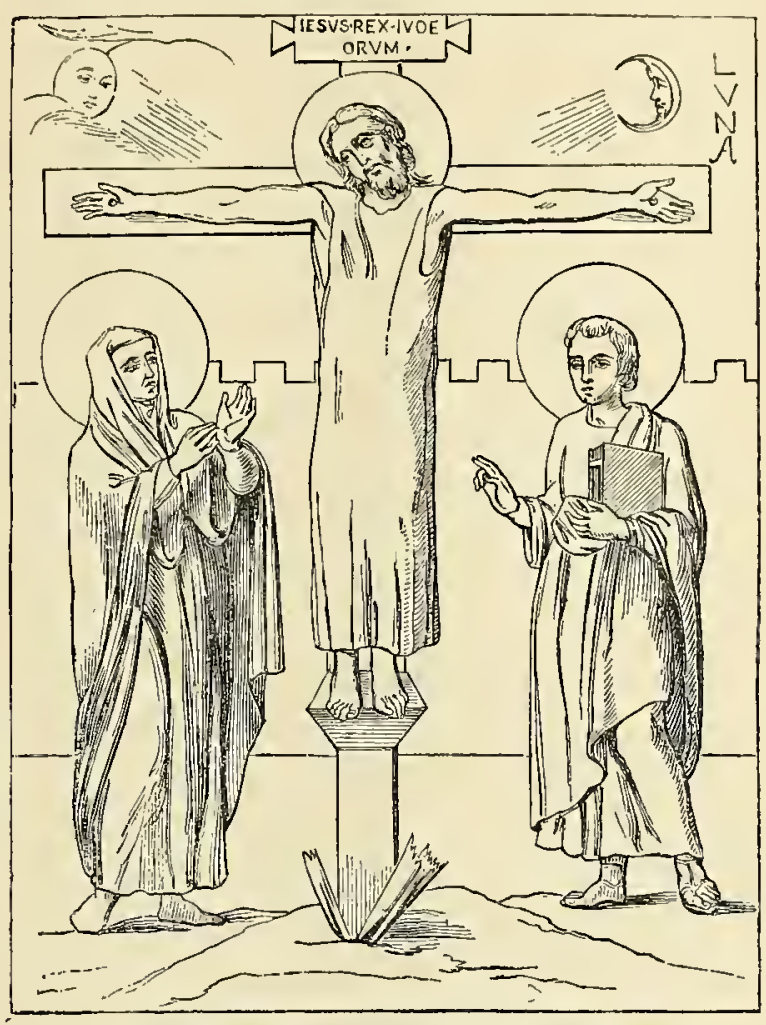

Crucifix Found in the Catacomb of Pope Julius. From Jameson's History of Our Lord.

mark the symbolic character of early art, so different from the literal rendering of grief and despair delineated in later ages; the sun and moon, which often heretofore have been personified driving their chariots, the one drawn with horses, the other with oxen, now appear little more than a radiated orb and a crescent, their names frequently written perpendicularly according to Greek art. On some of the carved ivories

1 Hist. of Our Lord, vol, ii,, p. I53; Notes and Queries, 3d ser., p. 392

2 Hist. of Our Lord, vol. ii., p. 330. 
the Evangelists are represented on the ends of the Cross with their winged symbols whispering the inspired record to them. ${ }^{1}$ On paintings, their symbols only are often given, a practice which came into

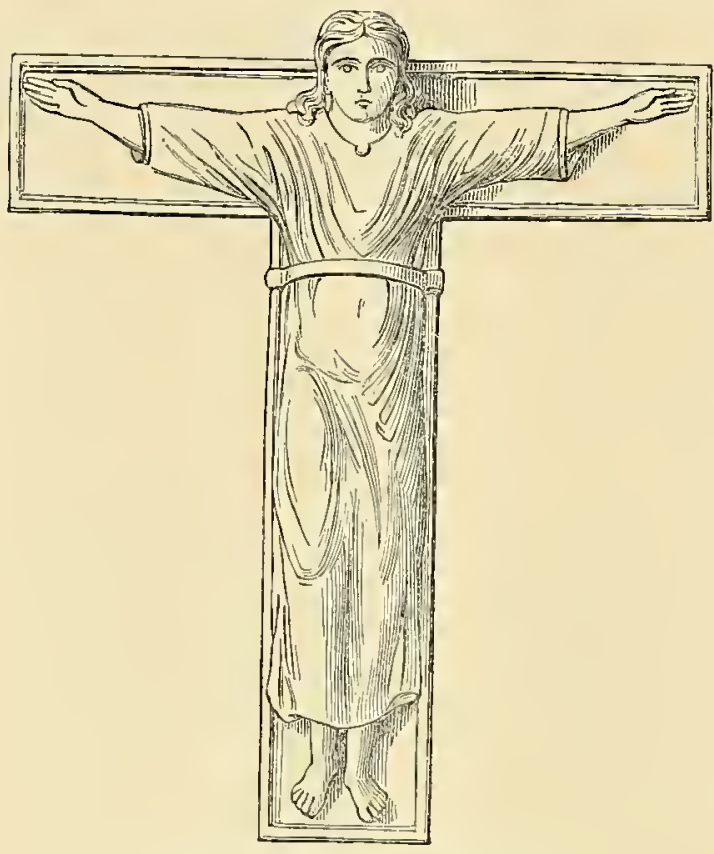

Hohenlohe Siegmaringen Crucifix.

From Jameson's History of Our Lord. use about the sixth century. The wound appears in the ninth or tenth century ${ }^{2}$; sometimes an opening made in the robe showing it. Invariably it is on the right side, for two reasons; first, because that is the place of power and dignity; sccond, because of the typical allusion to the Church. In art, Eve is always represented as drawn from the right side of Adam, allegorically teaching that the Church receives her life "from the wounded side of her Saviour, thereafter

to be espoused to him and become the mother of all living." s

Until the eleventh century Christ was almost always portrayed as living, and there are instances, generally in work of Byzantine origin,

I Hemans, describing the ivory diptych presented by Agiltruda to the monastery of Rambano, A.D. 888 and now preserved in the Vatican, explains the sun and noon as signifying the divine and human nature of Christ, the one radiant through its own, the other by reflected, light. Ancient Christianity and Art, p. 534. Under this Cross are represented Romulus and Remus suckled by the wolf. An extraordinary association, which our readers can interpret as may best. please them. Hemans thinks it an allusion to the victory of Christ over the empire represented in its traditional origin.

2 The crncifix in Aix-la-Chapelle, called that of Lothario, the son of Charlemagne (died A.D. 855) represents Christ as dead, with the wound in his side. The short loin cloth, drooping body, etc., would appear evidence of a later date. But its age is presmmed to be certain. Hist. of Our Lord, vol. ii., p. 329.

${ }^{3}$ Lindsay, Christian Art, vol. i., p. 85. I think that Heywood, somewhere in his Hierarchy of Ansels, refers to a tradition that Eve was taken from the left side of Adam, hence in the marriage service they stand "the man on the right hand, and the woman on the left." In the service of the holy Eucharist in the Greek Church, the priest "stabs" the "holy bread" on the right side, thus recognizing the commonly received tradition. Neale, Eastern Church, Introduction, p. 322. See also engraving in King's Greek Chureh in Russia. 
as late as the twelfth century. The earliest example in painting, that is extant, of Christ as dead, occurs in a fresco in S. Urbino above the valley of Egeria, dateA.D. IOI I.' There are still earlier instances of crucifixes, among

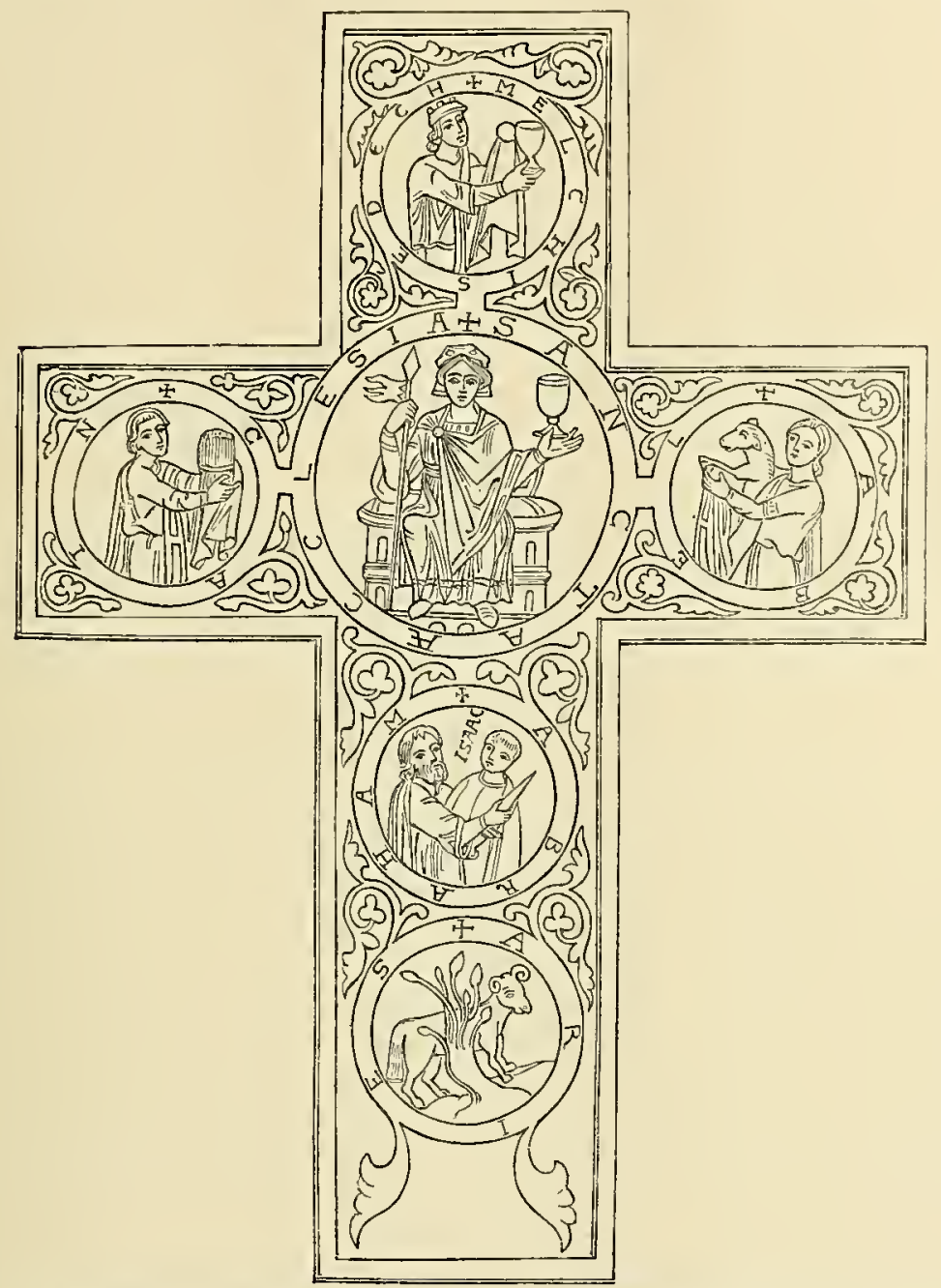

Back of Hohenlohe Siegmaringen Crucifix. From Jameson's History of Our Lord.

which are two celebrated ones, one a pectoral cross described by Cardinal Borgia, another the cross of Lothario, claimed to be of the ninth century."

The skull at the foot of the image appears about this time; sometimes it represents that of Adam, in accordance with the tradition that

${ }^{1}$ Hemans places it about A.D. 1059, and believes " that it is the most ancient crucifix, as a scene, in painting, in any Italian church.

2 Hist. of Our Lord, vol. ii., p. 328. 
the Cross was placed over the resting-place of our first father, and the blood of the Saviour raised him to the second life. In some early work Adam rises and receives the blood in a chalice.' The cup alone

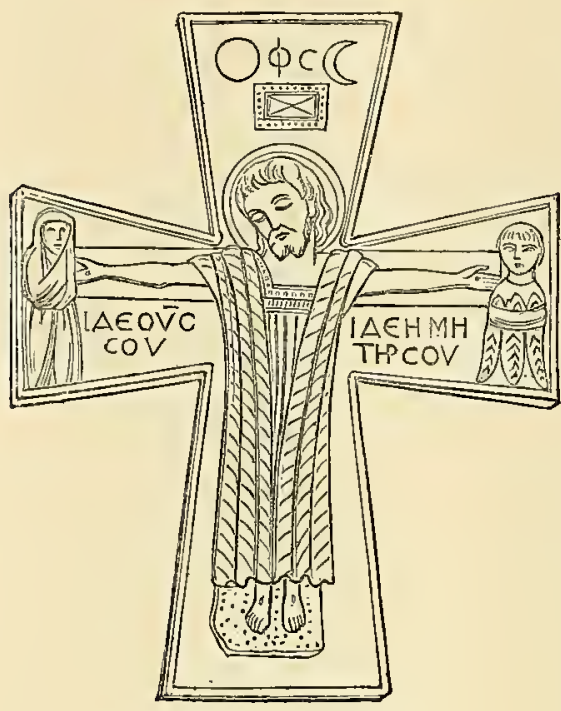

Early Pectoral Crucifix.

From Jameson's History of Our Lord. appears in the thirteenth century. The Skull at Foot At other times, the skull of the cross. stands not for the father of all living, but simply denotes Golgotha, "the place of a skull," the Syriac for Calvary, " the place of the beheaded."

At first the feet of Christ upon the Cross were represented as free, The Nails. then bound, and then fastened severally with a nail. ${ }^{2}$ This was in accordance with the tradition that S. Helena discovered with the Cross, four nails; which is the number mentioned by S. Cyprian, S. Gregory of Tours, and Innocent III. At Florence, in the thirteenth and fourteen th centuries, Cimabue and Margaritone depicted the feet crossed and pierced with a single nail. Jacobus de Voragine also records this change, which Ayala, Bishop of Galicia, denounced as introduced by the Albigenses, and therefore heretical. ${ }^{3}$ But to return to the robe.

In the eleventh and twelfth centuries the robe becomes shorter, being merely a tunic extending from the navel to the linees; in the thirteenth

Crucifix in XIth and XIIth only a roll of linen, the perizonimm, enfolding the loins, a Centuries.

${ }^{1}$ An example of the fourteenth century given in Hist. of Our Lord, vol. ii., p. 2oS. Didron gives another example: In the Lady Chapel of Beauvais, in a window of the thirteenth century, Adam is depicted rising from the tomb at the foot of the Cross; a green mantle is thrown over his head and around his loins. His left hand upholds the clip receiving the bloor. Christ. Icon., vol, i., p. 27r. The color green, is symbolical of hope, charity, and regeneration.

2 In his attack on relics, Calvin reckons up some sixteen or seventeen nails exhibited as genuine; to this has been answered, that the Cross was composed of several pieces, and doubtless many nails were used, some of which have been preserved. But of the four which fastened the sufferer, one was thrown by S. Helena into the Adriatic, and the other three, according to Curtius, are preserved at Rome, Milan, and Treves. $-D_{\varepsilon}$ Clavis Dominicis., cap. 7 .

${ }^{3}$ Besides this alteration, the Albigenses are said to have painted the blessed Virgin with one eye, in derision. Lncas, Contra Albigcnses, quoted by Jeremy Taylor, rol. i., p. 327. 


\section{The Crucifix in Early Christian Art}

Some artists have gone still further and exhibited the revolting spectacle of the image of the Crucified One without a robc.' Christ, entirely Crucifix with nude, is placed opposite to Eleazar the High Priest, who is Nude Figure. sacrificing a red cow without the camp of the Hebrews in expiation of the sins of the people. The man Jesus of Nazareth may

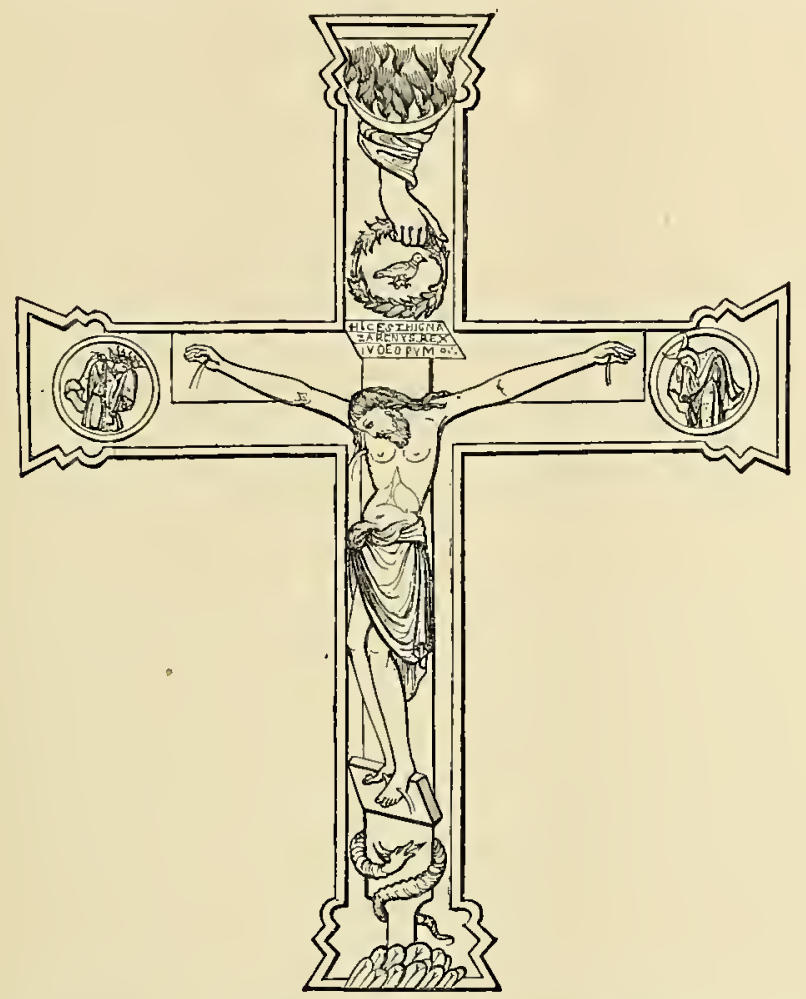

Cross of Lothario. (IXth Century.) From Jameson's History of Our Lord.

have had brown hair as is generally represented, but in this, as in other instances of a symbolic character, owing to the implied association

'Didron, Christian Iconography, vol. i., p. 259. The Hon. Rohert Curzon asserts that previous to the eleventh century the figure was always cjothed with a robe. But there are exceptions: ex. gr. the Cross of Lothario, that in the lower church of San Clemente at Rome, and others, which are only partially vested. It has been suggested that draped figures are always of Byzantine origin, and that the difficulty of correctly rendering the nude body, in the rude days of Christian art, was the reason for its being robed. Molanus records the legendary reason why the Greek Church draped the body. In a vision the Lord appeared to an artist, and said, "All ye are clothed with various raiment, and me ye show naked. Go forthwith and cover me with clothing." Not understanding the vision, the priest disregarded it. Whereupon, the third day, Christ visited him again, and having scuurged him, said, "Have I not told you to cover me? Go now and cover with clothing the picture in which I appear crucified." Molanus, Hist. Imag. Sac., p. 420. Lord Lindsay notices as peculiar to Greek art that the waist-band is always arranged in broad folds like an apron. Christian Art, vol. i., p. 9I. 
between the two sacrifices, the hair and beard of Christ are red. This example may be unique. ${ }^{3}$

As the thirteenth century approaches, the crucifix becomes more degraded. There is not a shadow of the truth symbolized when, in

\section{Crucifix in} purer ages, art represented Christ as triumphant, even in his xillth Century. humiliation, as a monarch, although throned upon a cross. No longer is prescnted the living sacrifice with outstretched arms eager to embrace the world in His Atonement; the God who said, "I lave power to lay down my life, and I have power to take it again," but we have a portraiture of a dead man, Jesus, hanging by the hands, the face haggard with anguish, the frame emaciated by austerities, attenuated till every rib can be numbered, every nerve racked with agony, an attempt to embody the words of the Psalmist, " They pierced my hands

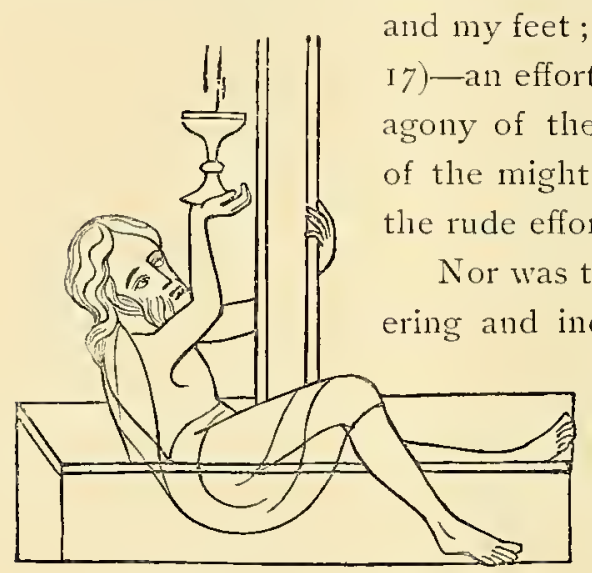

Adam at Foot of the Cross.

From Jameson's History of Our Lord.
Cross in Heaven. the " cruel anguish is even brought to sadden heaven.", Regardless of the second commandment, artists no longer timidly represented God the Father under the reverent symbol of the all-creating, all-protecting hand,

but as an old man, even when throned in glory in heaven, holding in his hands the Cross bearing the distorted body of the Son.

${ }^{1}$ Heures du Duc d'Anjou, p. I62. Bibliothèque Royale, Paris. Didron thinks that he has seen a second example in Biblia Sacra, No. 6829. Christian Iconog., vol. i., p. 260. The "Red Cow" brings to mind a Mlohammedan legend. According to it, the animals admitted into Paradise are, the prophet Saleb's camel (which was born of a rock. Sale, Koran, vol. i., p. 345, note E); the ram which Abraham sacrificed in place of Isaac; Moses' red cow zohose ashes he mingled with the waters of purification (here we have a reason for the above tradition alluded to in the MS.); Solomon's ant (which, when all creatures in token of their obedience to him, bronght him presents, dragged before him a locust, and therefore was preferred before all others, becanse it had bronght a creature so much bigger than itself); the Queen of Sheba's parrot, who carried messages between her and Solomon; Ezra's (Balaam's?) ass; Jonah's whale ; Katmir, the dog of the Seven Sleepers; and Nlahomet's camel. Thevenot, quoted in Sonthey's Ommianu, vol. i., p. I58.

${ }^{2}$ Didron, Christ. Icon., vol. i., p. 258. 
In the thirteenth and fourteenth centuries the mystic representations in crucifixions, of the sun and moon, earth and ocean, church and synagogue, give place to groups of angels indulging in passionate grief unworthy of thase blessed beings, who may be Ancient Art. supposed, if not to understand, yet to have some insight into the mystery of God which they were then beholding. In some Crucifixions angels are receiving in chalices the blood from the wounds. A little later and the symbolism of ancient art was put aside, and a female figure personifying the Church receives from the side the sacred stream, water and blood, typical of the two sacraments.

The treatment of the crucifix and Crucifixion in later times is so well known that further description is needless. The realistic ${ }^{1}$ has been sought for by the modern artist, forgetful that perhaps in doing so he was defeating the holy teaching of art. The ages which brought forth saints and martyrs, were taught of their Lord's sufferings by no such exhibition of mere anatomical knowledge of an outstretched, pendent body as painters and sculptors now present. There are some things beyond mere digital shill, even when genius mixes the colors or guides the chisel. As well might the artist attempt to portray the words "Eloi, Eloi, lama sabachthani!" as to embody the Sacrifice on Calvary. The eyes of this generation have not seen it. Men must be content to suggest, as did the workmen of old, and let faith and love fill up the outlint. We must go back a little to take up the thread of our history.

In the earliest authentic representations of the Crucifixion, the blessed Virgin and S. John are present. The former, usually upon the right side $^{2}$ (which was turned to the north), yet in the early example in the Church of Monza, already alluded to in The Virgin Mary example in the Church of Mohn at
the Cross. which the thieves are fastened to stakes while Jesus stands with arms uplifted, yet without a cross, the Virgin Mother is upon the left. Gretser also refers to a picture, said to have been in the possession

In the attempt to obtain an actual representation of agony, Guido equalled Prometheus. Having bound his model to a cross, in his ecstasy he stabled the poor wretch, and transferred his death-throes to the canvas. Afraid of the consequences, he fled. After some days the studio was necessarily broken open, and the half-decomposed corpse and the painting were found. Of course the artist was pardoned. What was the the life of a miserable model compared with the fame of the painter?

${ }^{2}$ In the Revelations of the Anchoress of Norwich, Juliana, 1373, she says: "Our Good Lord looked down on the right side and brought to my mind where our Lady stood in the time of his Passion." Revelations of Divine Loz'e, etc., p. 5s. Rock, Church of our-Fathers, vol. iii., pt. i. 
of Sophronius, Bishop of Jerusalem, in the seventh century, in which she is so placed. It has been questioned whether the Virgin and S. John ought not both to stand on the left of the Cross, to accord with Ps. cxlii., 4: "I looked on my right hand, and beheld, but there was no man that would know me."

According to Mrs. Jameson, when S. Mary stands alone on the right of the Cross, "She is the idealized Alatcr Dolorosa, the daughter of Jerusalem, the personified Church mourning for the great Sacrifice." 1

Modem art, treating the Crucifixion as a literal, dramatic scene, represents the blessed Virgin as prostrate upon the ground, overcome with grief, a mere human mother; but such a position is unworthy of her who was to be an example of faith and fortitude to the kindred of future martyrs. The words of S. John are: "When Jesus therefore saw his mother and the disciple standing by," etc. In this position is the "Blessed among women" represented in the sublime hymn

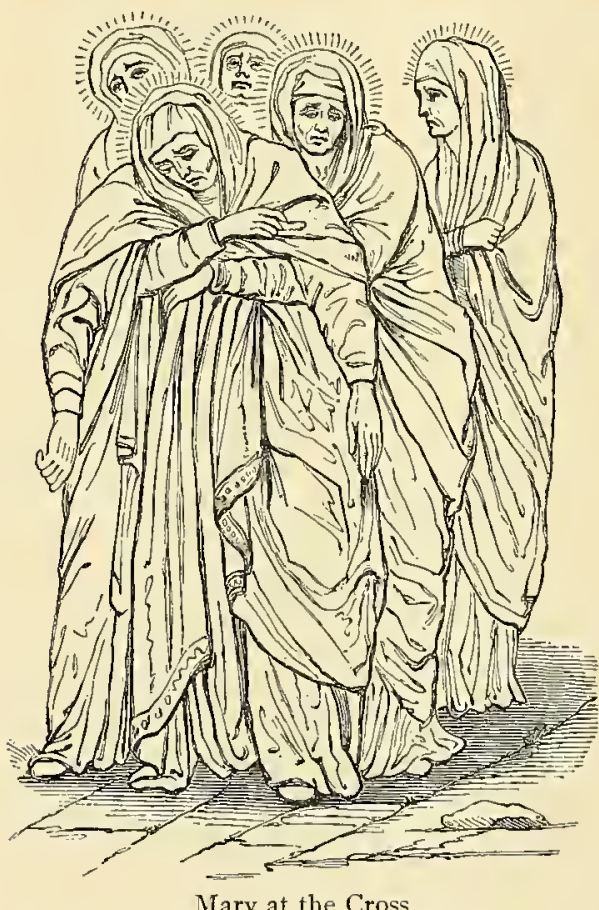

From Jameson's Leyends of the Madonna.

\section{Stabat Mater dolorosa, Juxta crucem lacrymosa, Dum pendebat filius.}

and by the early masters S. Mary is invariably depicted standing, if not erect, yet supported by the other Marys as given by Mantegna. ${ }^{2}$

In the Italian Church, as devotion was gradually drawn from the Son to the mother, the attention of the actors in the pictures, and the interest of the spectators, are directed more especially to her. Yet while the intention is to exalt her as divine, the weakness of her humanity is presented; for the blessed mother, unmindful of the prophetic warnings that a sword would pass through her own breast, forgetful of the celestial power which she

\footnotetext{
${ }^{1}$ Legends of the Madonna, p. 285.
}

${ }^{2}$ In the Louvre, Ibid., p. 286. 
had scen exhibited, sinks fainting, ovcrcome with maternal anguish, a human mother, at the foot of the Cross of her Son.

Earlier artists represent, conventionally, the blessed Virgin and S. John, at the ends of the transverse of the Cross. Giotto's crucifix, over the main entrance of S. Marco's in Florence, is an example. It was this work, it is said, which drew all Florence to see it. Dante alludes to it in his Purgatory.' We will note briefly a few remarkable crucifixions and crucifixes.

A few years ago upon the wall of a cell underneath the palace of the Caesars on the Palatine $\mathrm{Hill}$ in Rome, was discovered the rude slietch given in the engraving. The portion of the plaster was carefully removed to the museum of the Collegio Romano, and the drawing was at first pronounced to be a blasphemous caricature, the old story that the Jews worshipped an ass, and the inscription $A A E K$ ¿AMENOऽ TEBETE TON $\Theta E O N$, “Alexander

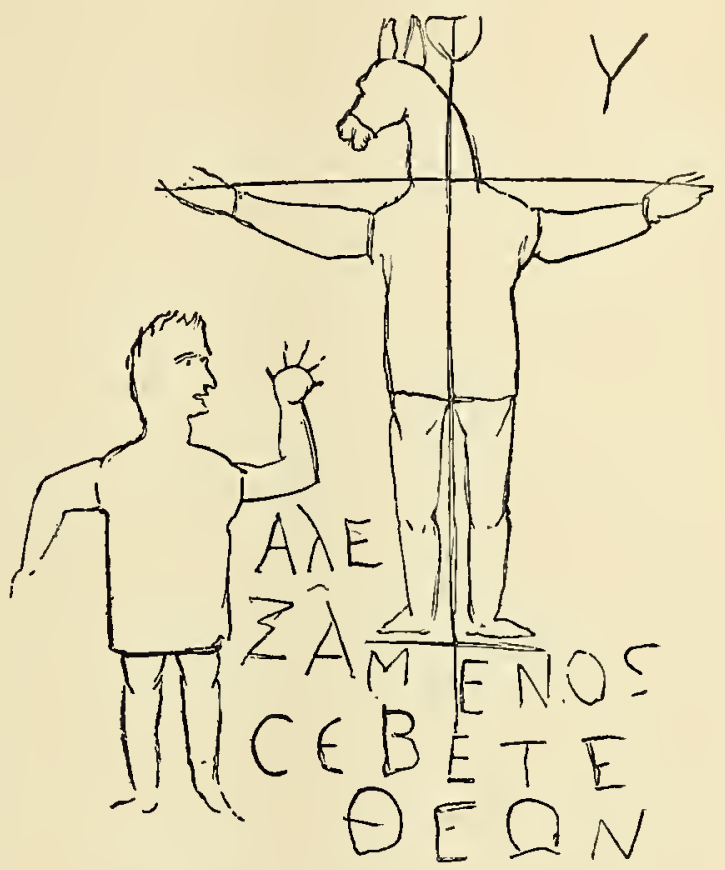

Anubis-Christos. From King's The Gnostics. worships his god," was supposed to be in ridicule. Mr. King, however, claims that it is the work of some deluded, yet pious gnostic, in the time of Septimus Severus, or perhaps earlier, for the bricks are of the time of Hadrian. The gems then worn as talismans and signets, show that Egyptian mythology was mingled with the doctrines of the heretical sects in the early ages of Christianity. A frequent symbol on the intaglios is the jackal-headed god Anubis, often bearing the caduceus of Hermes (which, it will be remembered, was formed from the Egyptian cross, or Tau) to designate his office of conducting departed souls to 
their final rest in the Pleroma; at other times holding the palm of victory for the triumphing faithful, or again presiding over the Psychostasia, or weighing of the soul, thus symbolizing Christ in his deliverance of souls in Hades, and the final judgment. Nor is the first office merely intimated, but on some Greek gems, Hermes, armed with the caduceus, assists the souls in Hades, as Christ with his Cross is represented by mediæval artists delivering souls from Limbus.

The jackal's head might easily be mistaken for that of an ass, and we find it believed by some of the heathen, that the new sect- " which they heard everywhere spoken against," - did worship such a deity. Tertullian writes: "For some of you have dreamed of an ass's head being our God; a suspicion of this sort Cornelius Tacitus hath introduced - . but now a new report of our God hath been lately set forth in this City [Rome] since a certain wretch hired to cheat the wild beasts, put forth a picture with some such title as this, ' The God of the Christians conceived of an ass.' This was a creature with ass's ears, with a hoof on one foot, 'carrying a book and wearing a gown." " The Christians transferred the charge against the whole body, to the Gnostics. Epiphanius, in the fourth century, asserts that the Gnostic Sabaoth ${ }^{\text {}}$ had, according to some, the face of an ass, according to others, that of a hog, on which account it was forbidden to eat swine's flesh. But in

1 The Empusa, or midday Hecate, had one ass's foot.

${ }^{2}$ Tertullian, Apology', xvi. Selden conjectures that this notion arose among the Gentiles from the law enjoining the redemption, with a lamb, of the firstlings of an ass, quoted by Bishop Patrick.-Com. on Ex., xiii., I3.

' "Now Sabaoth being held by all these sectaries as the national god of the Jews, it is very probable that in the same confusion of two beasts, originated that belief so prevalent amongst the Ancients and quoted by lacitus (Hist., v., 4), that the secret object of worship so jealously guarded within the sanctuary* at Jerusalem was the image of this animal (the wild ass), by the guidance of which they had relieved their thirst and distress. Moses having, by the observation of a troop of them, found out the springs that saved the congregation from perishing in the wilderness. Again in the spurious gospel, The Genealogy of Mary, + the cause assigned for the death of Zacharius, the son of Barachias is, that going into the Temple, he beheld standing within the sanctuary a man with the face of an ass; and when he was rushing out to cry unto the people, 'Woe unto you! whom do ye worship?' he was struck dumb by the apparition. But afterwards when he had recovered his speech and revealed the vision to the Jews, they slew him as a blasphemer. And they assign as the reason why the High Priest had bells fastened around the hem of his garment, in order that this monstrons deity might, by their tinkling, be warned of his approach, and so have time to conceal himself."-King, Gnostics, p. 9I.

* This story is connected with the belief that Bocchus was the real god of the Jews, for the ass was sacred to Bacchus. For this reason Pliny (cxxxvi.) assigns a curious reason, that "the ass was fond of fennel, a poison to all other beasts, but a plant sacred to the god of wine."

+ "This quotation is preserved by Epiphanius, for the work itself is entirely lost. It was ascribed to $S$. Mathew and was taken for their authority by the Collyridians, so-called from their sacrificing cakes to the Virgin Mary. . . The Birth of Mary', still extant, is of a totally different character." 
whatever spirit this rude graffito was made, it is a valuable testimony to the belicf of the Church in the second and third century in the Divinity of Christ. Even if, as at first supposed, it is the work of a heathen, in contempt of Christianity, yet it is an evidence that Christians acknowledged and worshipped Christ as God. And when the heathen traditions are read, they testify that the Christ whom the Jews crucified was identical with their God who was worshipped in the temple, of whom the heathen blasphemously reported he had the head of an ass.

One of the earliest, perhaps the earliest, representations of the Crucifixion extant, is that discovered, in I $\$ 6_{3}$, in the old Church of San Clemente at Rome underneatl the more modern building, which itself is ancient, having been erected in the ninth century. The Reverend Dr. Mullooly, the Prior of the

Irish Dominicans, to whose zeal we owe the excavation of the lower church, considers the frescos as the work of the sixth century, 5 I6 A.D.

The Saviour is represented as alive, unfastened by nails, no wound in his side; the arms are extended at right angles from the body; the head, surrounded by a cruciform nimbus, droops to the right; the beard is short and fine, and the countenance expresses no suffering. The tablet for the Title is affixed to the Cross, but there is no trace of an inscription, probably it has been obliterated by time. The tunic is short, reaching from the loins to the knees, a marked exception to the crucifixes of a little later period. The blessed Virgin stands with her hands extended towards her son, and S. John holds the roll ${ }^{1}$ of his Gospel in his left hand, while he points with the other to his Divine master.

The earliest Crucifixion in mosaic, on record, unfortunately it is no longer in existence, was that constructed by order of Pope John VII., A.D. 706. Curtius " thus describes it: "Until lately," he says, " it was to be seen in the old Basilica of S. Peter, in the Chapel in which is preserved the Veronica." Our Lord is represented as alive, the arms extended, but the liands drooping as if in the act of benediction, no sign of suffering, no wound in the side. A sleeveless tunic drapes the form to the ankle, like the crucifix found in the Catacomb of Pope Julian. In the engraving given in Ciampini, ${ }^{3}$ an

1 The distinction between the roll as a symbol of a prophet, and a book, that of an apostle, is not always marked in early art.

2 Curtius, De Clavis Dominicis, p. 56.

${ }^{3}$ Ciampini, Fet. Mon., tom. iii., p. 75, tab. xxiii. 
angel appears assisting those saints who arose from their graves (here placed near the Cross) at Christ's Resurrection (S. Matt. xxvii., 52-53).

One of the oldest crucifixes which has been handed down to us, is the celebrated Volto Santo at Lucca.' According to tradition, it was The Volto Santo carved out of cedar wood by Nicodemus, who received at Lucca. angelic assistance in finishing the face. Hence the name, "Volto Santo di Lucca" ; in mediæval Latin, "Vultum dc Luca," and therefore it is classed among those likenesses of Christ which, being considered miraculous, were called Achicropioctes, " made without hands," like the Veronica, the portrait of Jesus sent by him to Abgarus, and those attributed in part to S. Luke." History preserves the solemn oath of William Rufus, "Per rultem de Luca," which has been by some wrongfully translated " by the face of S. Luke." "

This crucifix is apparently of Byzantine origin, but, according to its legend, it was miraculously brought to its present shrine in A.D. 782 . It is preserved in a temple of costly marbles, erected by Matteo Civitali in I 484 , within the Duomo at Lucca, and is exhibited thrice a year for public devotion. Before the door of the temple is suspended a lamp of gold, weighing twenty-four pounds, a votive offering of the Lucchese in I 836 , to avert a visitation of the cholera. Dante alludes to this crucifix, when in the eighth circle of Malebolge the public defaulters are punished.

\section{"Qui non ha luogo il santo volto."}

From Curtius, who firmly believed in the genuineness and authenticity of this crucifix, we condense the following account: "Who," says the worthy friar, "will dare to doubt that Nicodemus represented truly the Crucifixion? He who drew out and received the nails in his own hands, can he have erred who was so often embraced with a sincere kiss? Who lavished his silver in procuring the myrrh and alocs for the embalming of Jesus? And the Lucchese declare that they have received this image from their remote ancestry, as the work of the secret, yet true believer." Describing the image, Curtius says, "that the Saviour

${ }^{1}$ Curtius, De Clavis Dominicis, p. 35 , Bosio, p. 685 .

'Sabinus, King of Bulgaria, provoked a rebellion by an attempt to abolish images. In consequence of the Iconoclastic movement numbers of artists fied from Greece to Italy. Gregory II. opened asylums for them, and in the ninth century, under l'aschal 1., the Eastern school produced the pictures of the Madonna, now dark with age, which in many instances are ascribed to S. Luke. The Volto Santo is supposed to be the work of one of these artists. - Walcott. Sacrea Archiology, p. 323.

${ }^{3}$ Divine Comedy', Inf., canto xxi. 
appears alive, not endued with the pallor of death; that his hair and beard were of a hazel color. The tunic is of the blackwool of China, embroidered with the Phrygian needle, which also added bcauty and value to the girdle. The crown is of pure gold [doubtful at present] worthy a king, and the sandals encrusted with plates of the same pure metal. Concerning these sandals, the following rare thing is written. There was a certain poor man who, driven to extremity by hunger, implored the aid of the Volto Santo. To his prayer, the image, or rather Christ in the image, inclined Himself, and threw to the beggar his shoe as an alleviation to his great misery. The poor wretch was about to depart from the church with his treasure, but the keepers of the temple in admiration of the miracle redeemed the shoe with an equivalent of gold, but they were unable to return the sandal to the foot of the image, hence it is supported by the chalice." '

As there are many pictures ascribed to S. Luke, so there are divers crucifixes attributed to Nicodemus. One is preserved in the Duomo of Palermo. Another was formerly at Berytus (Beyroot), Syria

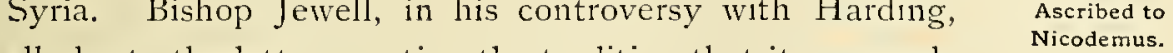
alludes to the latter, quoting the tradition that it was made by Nicodemus, and at his death given to Gamaliel, the teacher of S. Paul, and bequeathed in succession to James, Simon, and Zaccheus. Having been preserved a long time in Jerusalem, it was carried to Berytus, where, being discovered by the Jews, they crowned it with thorns, made it drink " esel and gall," and "sticke it to the heart with a speare," whence " issueth blood in great quantity; the powers of heaven are shaken; the sun is darkened, the moon loseth her light," etc. ${ }^{2}$

Perhaps this may be the very image mentioned in the second Council of Nice, A.D. 787. In the course of the iconoclastic controversy a similar miracle is narrated." Somewhere also in Spain the Capuchins exhibit a rival crucifix as the only one made by Nicodemus."

The genuineness of another curious crucifix is vouched for by Frate Curtius. He says it was sent by the Bishop of Jerusalem to Leo the

${ }^{1}$ Curtius, De Clavis Dominicis, cap. 5 .

${ }^{2}$ Jewell, Works, p. 372, ed. I6I I.

${ }^{3}$ Landon, Manual of Councils. 2d Nicea.

'Stirling, Amnals of the Artists of Spain, vol. i., p. 24 ; see also infra, part iii., chap. viii., for other miracles. 
Great about A.D. 450. It was neglected till Sergius I., 690, " honored it and exalted it for the adoration of the Roman people and that of the crucifix sent to whole world." The Cross is covered with plates of the purest Leo the Great. gold. Below the title I. S. X. S. are the "three human figures representing the most holy Trinity. On the right of the crucifix are S. Paul, S. Mary Cleophas, and the blessed Virgin. On the left are S. Peter, S. Mary Magdalene, and S. John; at the foot of the Cross is the skull of death upon Calvary which Christ conquered by dying. Below are the two Greek Fathers, SS. Basil and Chrysostom, who overthrew, in royal and golden letters, the heretics who opposed the most holy Trinity." ' It is needless to observe, that the figure of Christ is apparently of late work. As to the three figures claimed to personify the Trinity, the absence of the nimbus would disprove the claims; besides, the First Person was indicated by the symbol of the hand until the thirteenth or fourteenth century, when by degrees first the face, then the bust, and at length the entire person was displayed. ${ }^{2}$

In the Church of S. Patriarcale, once one of the principal churches in Venice, but now almost deserted, the tombs of the many early patriarchs of the Queen of the Adriatic within its walls Black Crucifix. forgotten, is also a curious crucifix. The figure is draped, but the face, which is visible, is black. ${ }^{3}$ The effect is unpleasant, yet it involuntarily recalls to one's recollection Fuller's quaint definition of a negro-." The image of God cut in ebony." "

At Melrose there was another crucifix of black marble, which was celebrated for its sanctity. Sir Walter Scott mentions it in his Eve of Black Rood S. Fohn. The lady meets the spirit of her lover, who apof Meirose. pears as when he lived, - not knowing that he had been slain by her husband,-and urges an interview on the following night:

'Cnrtius, De Clavis Dominicis, p. 50.

${ }^{2}$ Didron, Christ. Icon., vol. i., p. 210. Lady Eastlake thinks the first representation of the Father under a human form occurs in a MS. of S. Dunstan, who died A.D. 90S.-Hist. of Our Lord, vol. ii., p. $3+0$.

${ }^{3}$ Webb, Continental Ecclesiology. Hargrave Jennings speaks of the embodiment of Deity under darkness, and instances the Virgin and Child in black images in the chapels of S. Peter and S. Maria Maggiore at Rome, S. Francisco at Pisa, and S. Stephen in Genoa. The Rosicracians, p. I65. I do not remember a single one of them. Perhaps Mr. Jennings may have seen some of the dark pictures ascribed to S. Lnke, of which there is one at Scala Santa at Rome, and many elsewhere on the Continent.

4 The King of the Hervey Islands, part of Cook's Archipelago in the Pacific Ocean, has a crucifix painted black, the gift of a missionary in 1857 . His majesty has probably the same opinion as that of some of the African tribes, who represent the devil as white. 
"And I 'll chain the bloodhound, and the warder shall not sound, And rushes shall be strewed on the stair;

So by the black rood stone, and by holy S. John, I conjure thee, my love, to be there!"

The potency of the adjuration is shown by her ghostly lover's confessing when he appears in her apartment,-

"But I had not had power to come to thy bower, Had'st thou not conjured me so." "

In Florence are two rival crucifixes, whose histories are so well known that repetition seems almost needless. One, now in the Church of Santa Croce, is by Donatello. The artist in the pride of his heart exhibited it to his intimate friend Brunelleschi, who told him that he had "placed a peasant upon the Cross." Donatello angrily bade the critic to excel the work, if possible. Some time after, Brunelleschi invited his friend to dine, but begged him to go to the market and purchase some viands, while he awaited him at the studio. Donatello, having accomplished his errand, hastened to the studio, and opened the door. Brunelleschi had accepted the challenge, and the work stood before him. Poor Donatello let fall his apron filled with eggs and cheese for their dinner, and magnanimously exclaimed, "To you is given the power of carving Christs, to me that of peasants." : The latter crucifix is in the Church of S. Maria Novella, but the very means taken for its preservation-it is under glass-prevents it from being seen satisfactorily.

1 Minstrelsy of the Scottish Border. The superstition that some evil spirits cannot cross the threshold of a house unless aided by human power, is referred to by Coleridge, when Christabel brings in Geraldine :

"The lady sank, belike through pain, And Christabel with might and main Lifted her up, a weary weight, Over the threshold of the gate;

Then the lady arose again,

And moved, as she were not in pain."

${ }^{2}$ Vasari, Life of Donatello. 


\section{CHAPTER III}

\section{MONOGRAMS OF OUR LORD}

THE monogram of our blessed Lord was venerated by the early 1 Church equally with the sign of the Cross, and, like that sign, was held as a sacred symbol among the pagan nations long before it was consecrated by Christian adoption. The monograms of Osiris and Jupiter Ammon are similar to

Value and Antiquity of the Monogram. those of Christ. ' Sometimes the Rho is reversed, or a circle is placed in

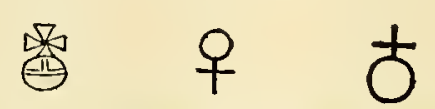

Identity of Heathen and Christian Symbols. From Jennings's The Rosicracians.

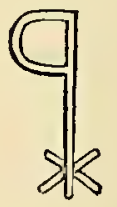

From Jennings's The Rosicrucians.

one of the angles of the cross. In a coin of one of the Ptolemies, as previously stated, the figure is supposed by Gretser to be a contraction

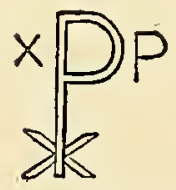

The Labarum.

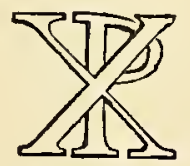

Monogram of the Saviour.

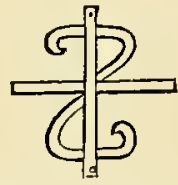

Monogram of the Three Emblems Carried in the Mysteries.

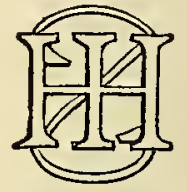

Monogram of the Saviour.

From Jennings's The Rosicrucians.

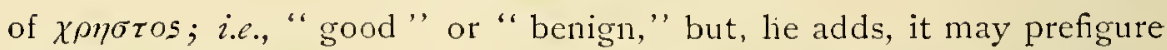
the Cross of Christ." In fact, the character may be translated as a contraction of various meanings; other instances of pre-Christian use

1 Higgins, Celtic Druids, p. I27.

${ }^{2}$ Gretser, De Cruce, lib, ii, cap. 38. The pagans, either from ignorance, or else unconsciously giving evidence of their kindness, often called the Christians, Chreestians, - Tertullian, Apol., c. iii. 
might be given; those in the illustration from Jennings ${ }^{1}$ might be supposed to stand for Christ Soter. The use of the monogram was widely extended, for we find it in ancient Runic inscriptions in Zealand and on the coins of the Eastern caliphs. "It is not infrequently met with in ancient Greek inscriptions, and is to be seen on some of the coins of Herod the Great." "

For the principal varieties of the monogram we must search the

Varieties of the Monogram. treasuries of early Christian art, the Catacombs,

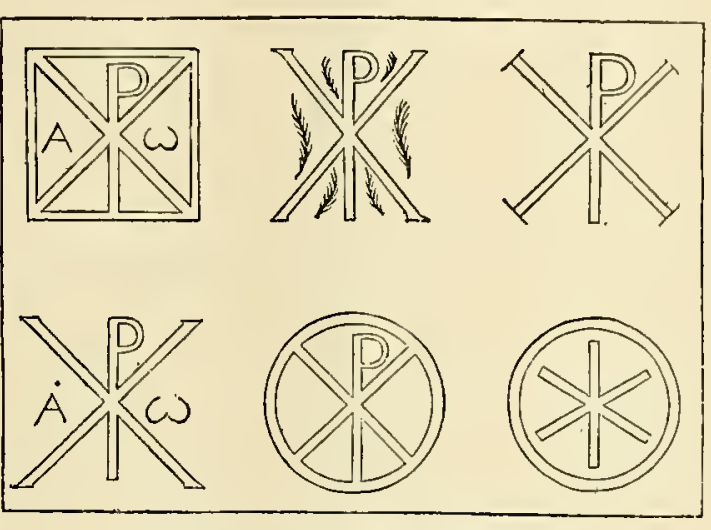

Various Crosses of the Greek Form. From Didron's Christian Iconography. and the first Italian churches. The most noted, that of Constantine's Labarm, appears on the shields of the soldiers of Justinian and Theodora in the mosaics in the Church of S. Apollinare Nuovo at Ravenna. As

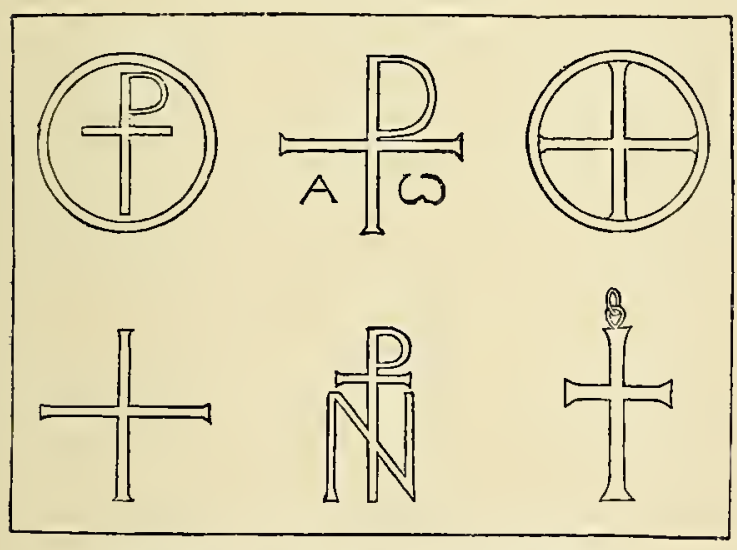

Greek and Latin Crosses of Various Forms. From Didron's Christian Iconography. in the early Cross, early Christian writers recognized in it the mystical seal alluded to by the Prophet and the Apostie (Ezek. ix., 4, 6; Rev. vii., 2, xiv., I). Tertullian and S. Clement of Alexandria, both allude to it ; Epiphanius and Origen explain it as symbolical of Christ's twofold nature.

Among the earliest instances existing since the time of Christ, are those found in the villa and baths of Chedworth, England. The monoInstances. gram and the word Arivi indicate that the structure was erected under

${ }^{1}$ Jennings, The Rosicrucians, pp. I47, I80, 248.

2 Northcote and Brownlow, Roma Sotterranea, p. 23 I. 
King Arviragus, who lived from the time of Claudius to that of Domitian. The expedition of the former to Britain took place A.D. 43 ; the latter began to reign A.D. $81^{1}$ Even the persecutor of the Christians, Decius, A.D. 249, places upon his coins the legend $B A$ R $A T O{ }^{2}$

As it was one of the earliest, it was also one of the most universal of Christian symbols, being engraved upon their tombs, seals, lamps, chalUniversality ices, etc.; both those for sacred and for familiar use, a sign, of Use.

the true meaning of which was unknown to their persecutors, yet speaking of love and mercy to the initiated. They accepted it as a literal illustration of the text,_- "I saw another angel ascending from the east, having the seal of the living God "' (Rev. vii., 2), to mark the elect.

One of the earliest instances yet found of its use, in the Catacombs, is in the following epitaph:

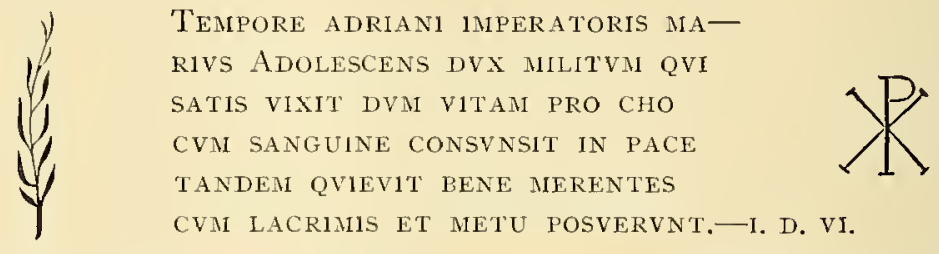

"In Christ. In the time of the Emperor Adrian, Marius a young military officer, who had lived long enough, when with his blood he gave up his life for Christ. At length he rested in peace. The well-deserving set this up with tears and in fear. On the 6th Ides of December." The last words and the palm branch attest his martyrdom. Hadrian reigned from A.D. II $5-13$.

Tyrwhitt says ${ }^{3}$ that " the monogram $\mathbb{R}$, or S. Andrew's cross is exchanged into the upright $P$ in the majority of inscriptions, about the was the cross end of the third century." He supposes from his researches Derived from that "this is the origin of the Christian use of the Cross as a the Monogram. symbol." The $\mathrm{P}$ " marks the transition from the lettermonogram of the Lord's name to the symbol which represented alike Ifis Person, His Life, and His Death, as the mind desired to contem-

${ }^{1}$ Lysons, Our British Ancestors, p. 225. In the Catacombs there is one inscription dated in the third year of Vespasian, A.D. 7I. Some may be still older. Northcote, Roman Catacombs, p. I9.

${ }^{2}$ The same word is found on the staves of Isis and Osiris. Higgins, p. I27.

${ }^{3}$ Tyrwhitt, Christian Art and Symbolism, p. 124. 
plate them." This theory may be true, but with all due deference to so distinguished an archeologist, we think, unless deceived by the authoritics we have followed, that proof has been given showing that the origin of the Christian use of the Cross as a symbol was quite as early as the use of the monogram, if not earlier, and independent of it.

In the library of the Vatican is an exquisite fragment of the piety of the early ages. The monogram is enclosed by a garland of flowers, and upon it sits the dove, symbol of the peace with God purchased by the Redeemer's death. Such representations were common about the fourth or fifth century. Paulinus, Bishop of Nola, who wrote inscriptions for the different parts of his basilica, placed beneath the crowned cross the words, "Bear the eross, you who wish

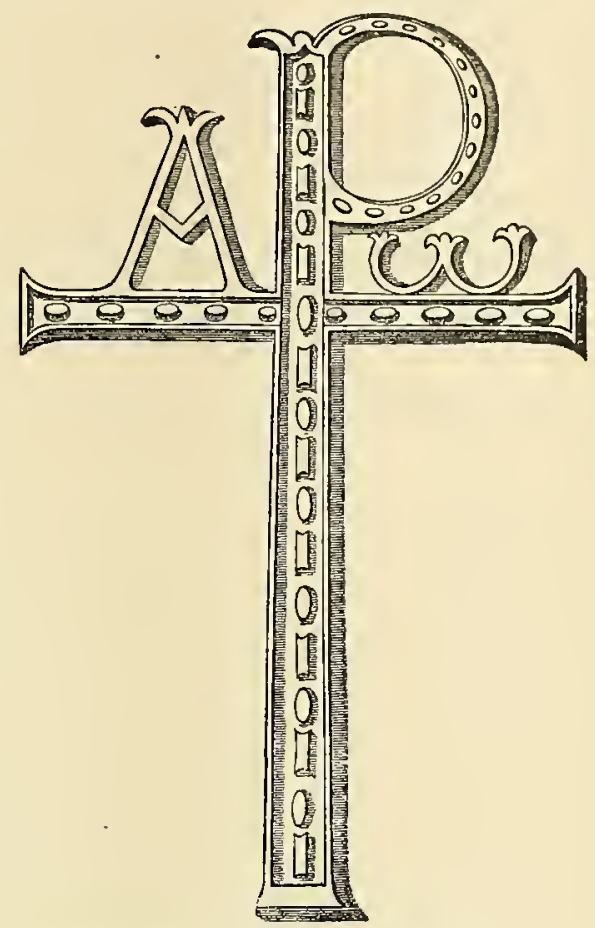

Monogram in the Lapidarian Gallery, Rome. From Maitland's Church in the Catacombs. to receive the crown." Elsewhere he says, in allusion to the same:

"The labor and reward of the saints justly go together

The arduous cross and the crown its noble recompense."

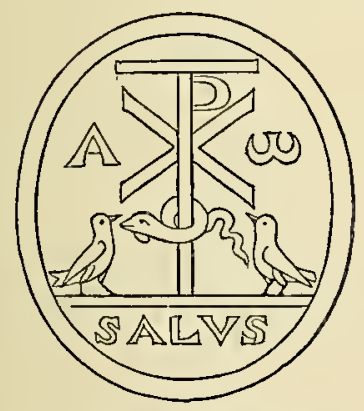

Mystic Cross. From Didron's Christian Iconography.

In the Lapidarian Gallery in Rome there is an exquisite specimen. The jewels which adorned the ancient crosses are represented in marble.

A reproduction of an early Christian intaglio is here given. A Tau cross forms part of the sacred monogram. Didron thus explains it: "Christ, the Son of God, is the commencement and end of all; the $A$ and $\Omega$, the beginning and end of intellectual signs, and by extension, of intelligence itself, and lastly, of the human soul, accompany the cross, on the right hand and on the left. The Cross has 
crushed Satan the old serpent, a serpent, therefore, unrolls and entwines himself around the foot of the cross." The soul, represented as a dove, " although menaced by the serpent, looks steadfastly at the Cross, whence she derives her strength, and by which she is rendered safe from the poison of Satan. The word SALUs, written below the ground on which the cross and doves are standing, is the song of triumph poured forth by faithful Christians in honor of Jesus and the Cross." 1

I Didron, Christ. Icon., vol. i., p. 395. 


\title{
CHAPTER IV
}

\author{
ROOD-SCREENS
}

$\mathrm{R}$

OOD-SCREENS are almost coeval with church architecture. The propriety of the separation of the choir or chancel from the nave, both for symbolical and practical reasons, was evident to the builders of our first churches. Perhaps they

Antiquity of Rood-Screens. derived their idea from recollections of the Temple, the original plan of which was from the Creator of all that is "fit and beautiful" ; and if so, then these sacred places are the more worthy of reverence and imitation. Doubtless they wished to tell the people of the veil between the Church Militant and the Church Triumphant, and remind them of the barrier impassable save through the sacrifice of Him whose Passion was represented above. ${ }^{1}$

Whatever may have been the cause or reason for the erection of a partition between the chancel and the nave, it was acted upon as soon as Christianity had liberty to develop; accordingly we find that in the time of Constantine, the choir of the Church of the Apostles, erected by the emperor at Constantinople, was enclosed by a screen ${ }^{2}$ or trelliswork. This was not an innovation or exception, for we find the same historian recording a similar screen in a church in Tyre, built and consecrated by Paulinus. ${ }^{3}$ The second Council of Tours, A.D. 557, ordered that laics should not enter the chancel, separated by a screen from the church, except to receive the sacrament of the Lord's Supper.

${ }^{1}$ Eusebius, Life of Constantine, book iv., 59.

IIn the symbolism of the Church the nave represents the Church Militant, the chancel the Church Triumphant; the screen the division, (i.e. death), above which the Doom or Last Judgment was formerly painted.

${ }^{3}$ Eusebius, Eccles. Hist., book x., chap. iv. "And that this (the holy altar) might be inaccessibie to the multitude he enclosed it with a frame of lattice work, accurately wrought with ingenious sculpture."

13 


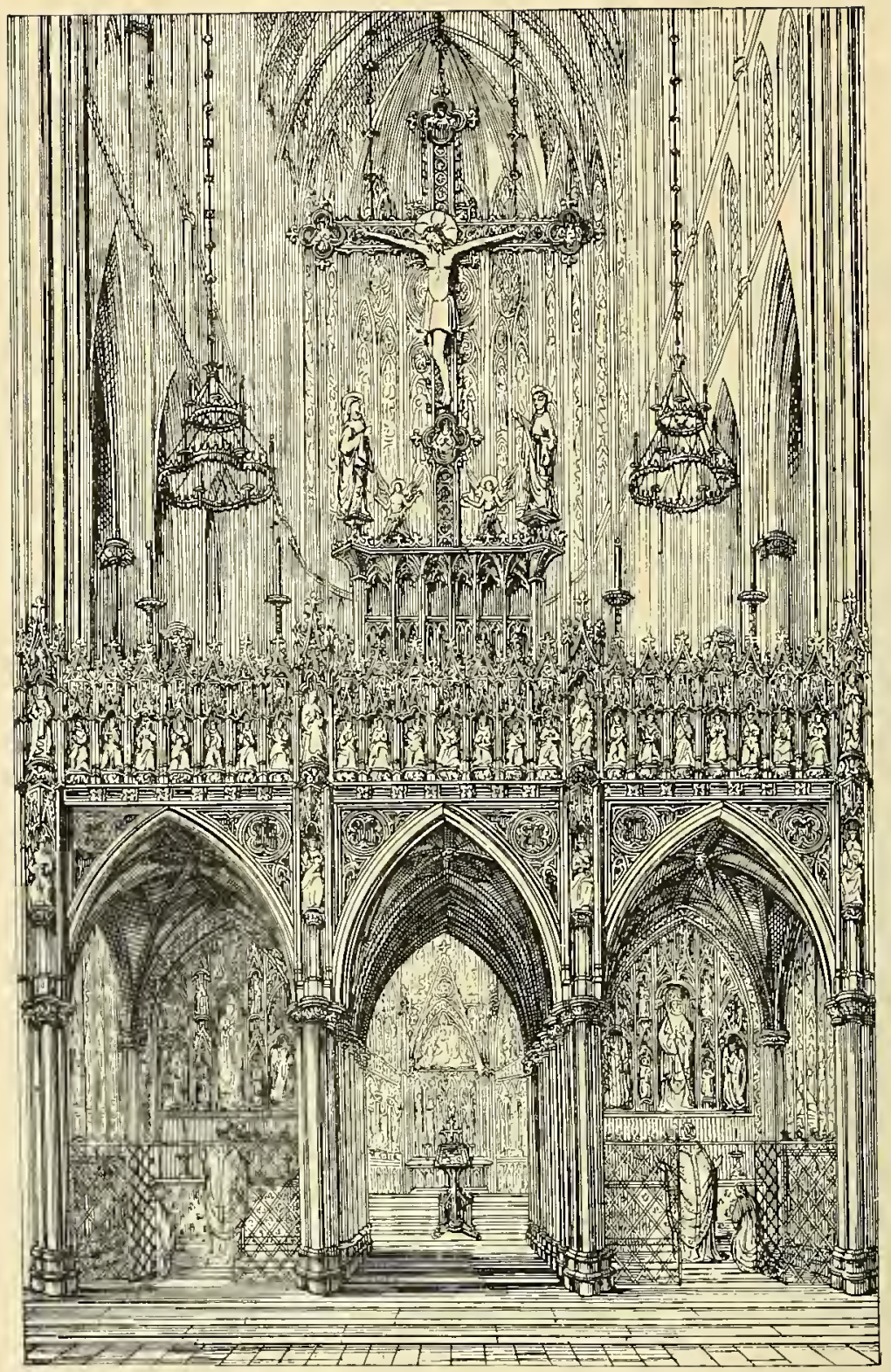

A Cathedral Screen. From Pugin's Treatise on Chancel Screens and Rood-Lofts. 
This reverent practice of antiquity has received the sanction of pious builders and prelates until very late times. Even in England, Archbishop Parker (1559) demands, " Whether a partition be made and kept between the chancel and the church according to the advertisements?" Nearly a hundred years later, Bishop Montague (I64I) asks, "Is your chancel divided from the nave or body of your church with a partition of stone, boards, wainscot, grates, or otherwise ${ }^{1}$ wherein is there a decent strong door to open and shut (as occasion serveth) with lock and key, to keep out boys, girls, or irreverent men and women ?" " Hooker defends the use. The Puritans objecting to these divisions of the church, " as being framed according to the pattern

Hooker's Defence. of the Jewish Temple," Hooker observes that it is "A fault no less grievous, if so be it were true, than if some king should build his mansion-house by the model of Solomon's palace. So far forth as our churches and their temple have one end, what should let but that they may lawfully have one form ? The temple was for sacrifice, and therefore had rooms to that purpose, such as ours have none. Our churches are places provided, that the people might there assemble themselves, in due and decent manner, according to their several degrees and order. Which thing being common unto us with Jeivs, we have in this respect our churches divided by certain partitions, although not so many in number as theirs. . . . There being in ours for local distinction between the clergy and the rest (which yet we do not with any great strictness or curiosity observe neither) but one partition, the cause whereof at the first (as it seemeth) was, that as many as were capable of the holy mysteries, might there assemble themselves and no other creep in amongst them." s

These screens were made of metal, stone, or wood. In Germany, Flanders, and the North of Europe metal was the usual material. In England and France, stone and wood; and in Italy and the South, they were usually composed partly of marble and

Material. partly of metal. ${ }^{4}$

The Eastern Church employed a screen called iconostasis, from the

1 Quoted in Handbook of English Ecclesiology p. 73. See also Perry's Lazuful Church Orzaments, p. 525 .

2 Montague, "Visitation Articles," Camb. ed., p. 43 , quoted in Hienergia Anglicana, p. 76.

${ }^{3}$ Hooker, Eccl. Polity", book v., $\S$ I 4 . See notes on same section.

${ }^{4}$ Pugin, Treatise on Chancel Screens, etc., p. II. 


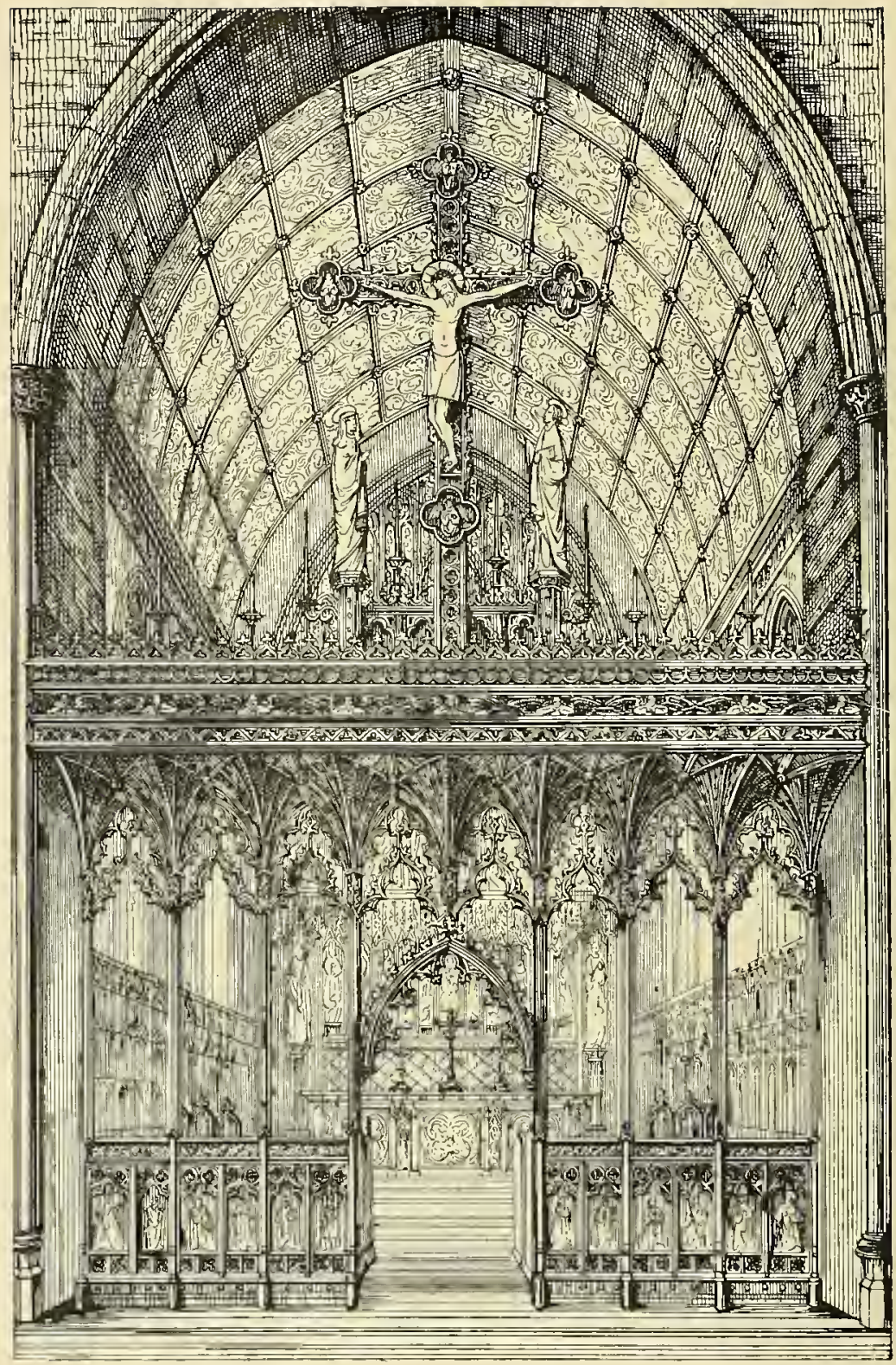

A Parochial Screen. From Pugin's Treatise on Chancel Screens and Rood-Lofts. 
icons depicted upon it. This does not occupy the same place as the rood-screen in the Western Churcl, but corresponds in place to our altar rails, separating the choir from the sanctuary, or bema.

It was made either of metal, marble, or wood. The one

iconostases. already referred to as built by Constantine was of copper-gilt. That of S. Catharine at Mt. Sinai is of ivory, tortoise-shell, and silver. ${ }^{1}$ S. Sophia's is of silver. The lower stage was wrought in arabesques or flowers; the second was composed of twelve columns (on each of the holy doors), entwined two and two, supporting a rich crest-work of chased metal, and filled in between with panels bearing, in oval medallions, icons of our blessed Lord and His mother, the prophets and apostles, and the monogram of Justinian and Theodora.

The ancient iconostascs, like the early rood-screens, were of open work. When they were made solid, it is difficult now to ascertain. The earliest example which Neale mentions is that in the Arian crypt of the Church of Tepekerman, in the Crimea, about

Tepekerman. A.D. 350, which appears to be nearly open. ${ }^{2}$

In the Western Church, the thirteenth century is the earliest date to which the use of solid screens can be assigned. Their object appears to have been the protection of the ecclesiastics from the cold after the multiplication of the offices consequent on the great frequency of Obits, $i$. c., funeral offices, the institution of the office of the blessed Virgin at the Council of Clermont, and other innovations. ${ }^{3}$

In the early Church, the

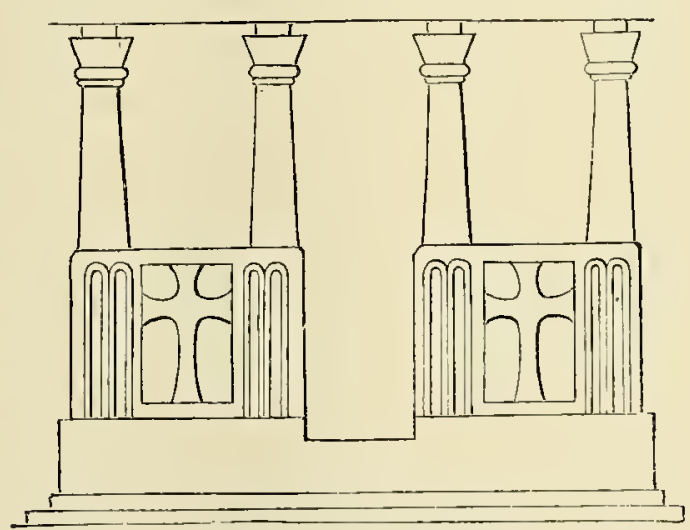

Iconostasis at Tepekerman.

From Neale's History of the Holy' Eastern Church.

Epistle and Gospel were read or sung from two stone pulpits, termed ambones, or analogia, placed at the lower end of the chancel. The lessons

1 Neale, Hist. Eastern Charch, Introduction, p. I93; also fully described in the Ecclesiologist, vol. xi. (N. S.), p. 9 .

" Neale, Hist. Eastern Church, Introduction, pp. I93, I94.

${ }^{3}$ Father Thiers, Diss. de la Clôture des Chaurs des Eglises, quoted in the Ecclesiologist, vol. ii., p. 92. 


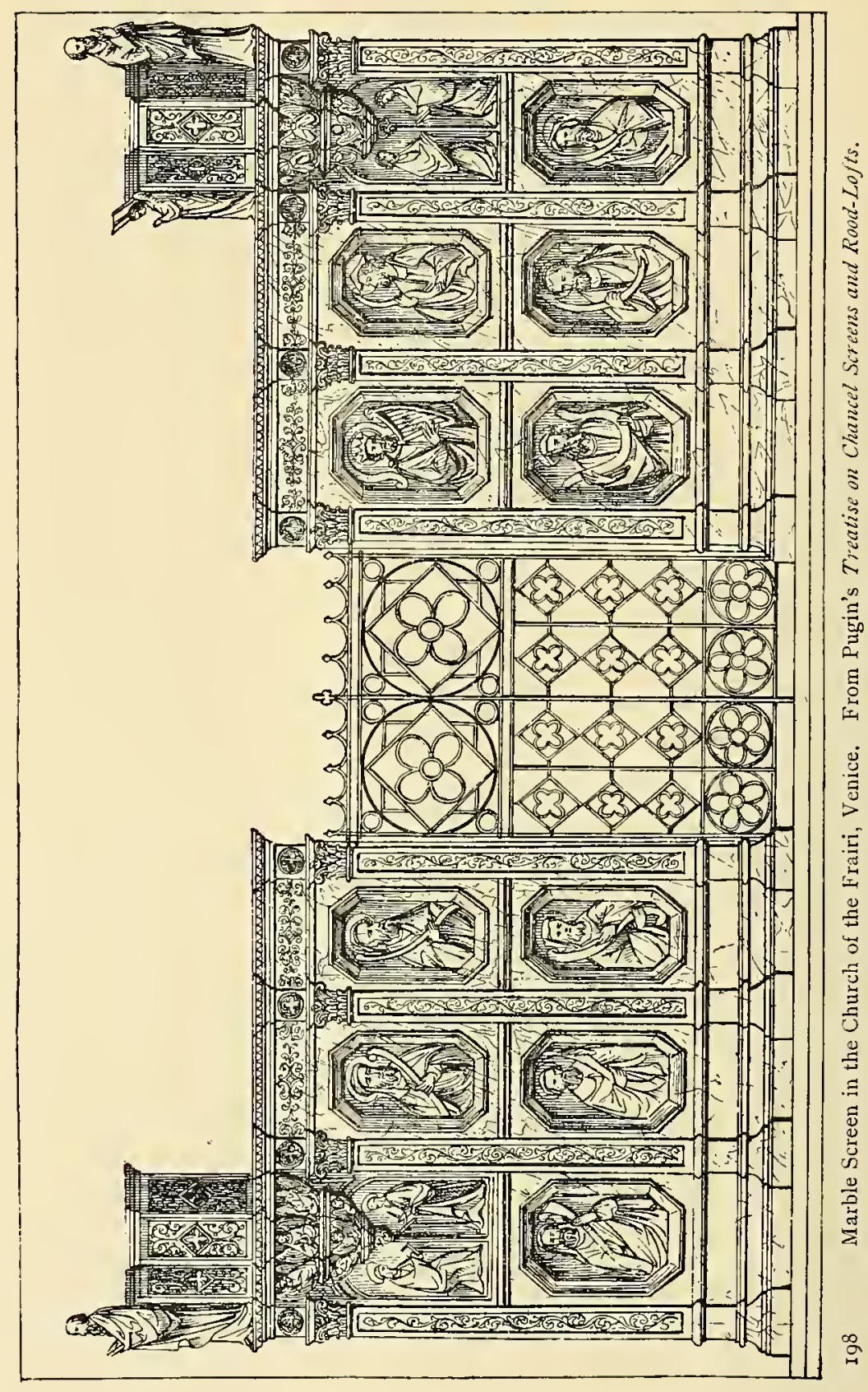


were also read from them, and as the reader, before commencing, asked a blessing, beginning with Fube Dominc boncdicore, they were commonly called $\mathscr{f} u b i s$, which name ${ }^{1}$ they retained when the pulpits were placed in the rood-loft, or gallery above the screen.

In the Eastern Church, the rood-loft, or, speaking more properly, the analogium, is very ancient, having been used long before it was introduced into the Western. In England, rood-lofts do not appear to have been common before the fourteenth cen-

Early Uses. tury, ${ }^{2}$ although one was erected at St. Albans in the twelfth century, and another in the thirteenth at Bury St. Edmunds; the cathedrals and monastery churches gradually adopting this feature in their architecture, for the purpose of giving warmth and seclusion to the canons or monks. In the course of time the rood-loft became the usual place for important public ceremonies, the reading of the pastorals of the Bishops, the proclamation of treaties, and the acts of Councils. From it, penitents were absolved, elect abbots presented to the people, and the Episcopal benediction was pronounced, and at a later date the organ and singers were placed in these lofts. Bishops often preached from them.

In general, rood-screens were accordingly of ample size, as in that of S. Sophia, Constantinople. Emperors were sometimes crowned in these places, which ceremony required considerable space for its due performance. Several of the kings of France

Size. ascended the rood-loft of Rheims Cathedral at their coronation; and as it was demolished previous to the accession of Charles X., a temporary loft was erected for the occasion.

Pre-eminently in the centre, over the holy doors, stood the great cross or rood. This was usually framed of timber richly carved, gilded, or painted. In the extremities were placed the four Evangelists, and usually under the form of the well-known symbols; the Rood-loft. more rarely, as sitting figures in the act of writing. On the reverse were frequently the four doctors, SS. Jerome, Ambrose, Augustine, and Gregory. The extremities of the Cross were generally floriated, and its sides crocketed or floriated.

1 The Ambones in the Eastern Church, it will be recollected, were placed between the choir and the sanctuary, as in San Clemente at Rome, not as was the rood-loft in the Western, between the choir and the nave.

${ }^{2}$ Glossary" of Architecture, " Rood-beam, Rood-loft." 


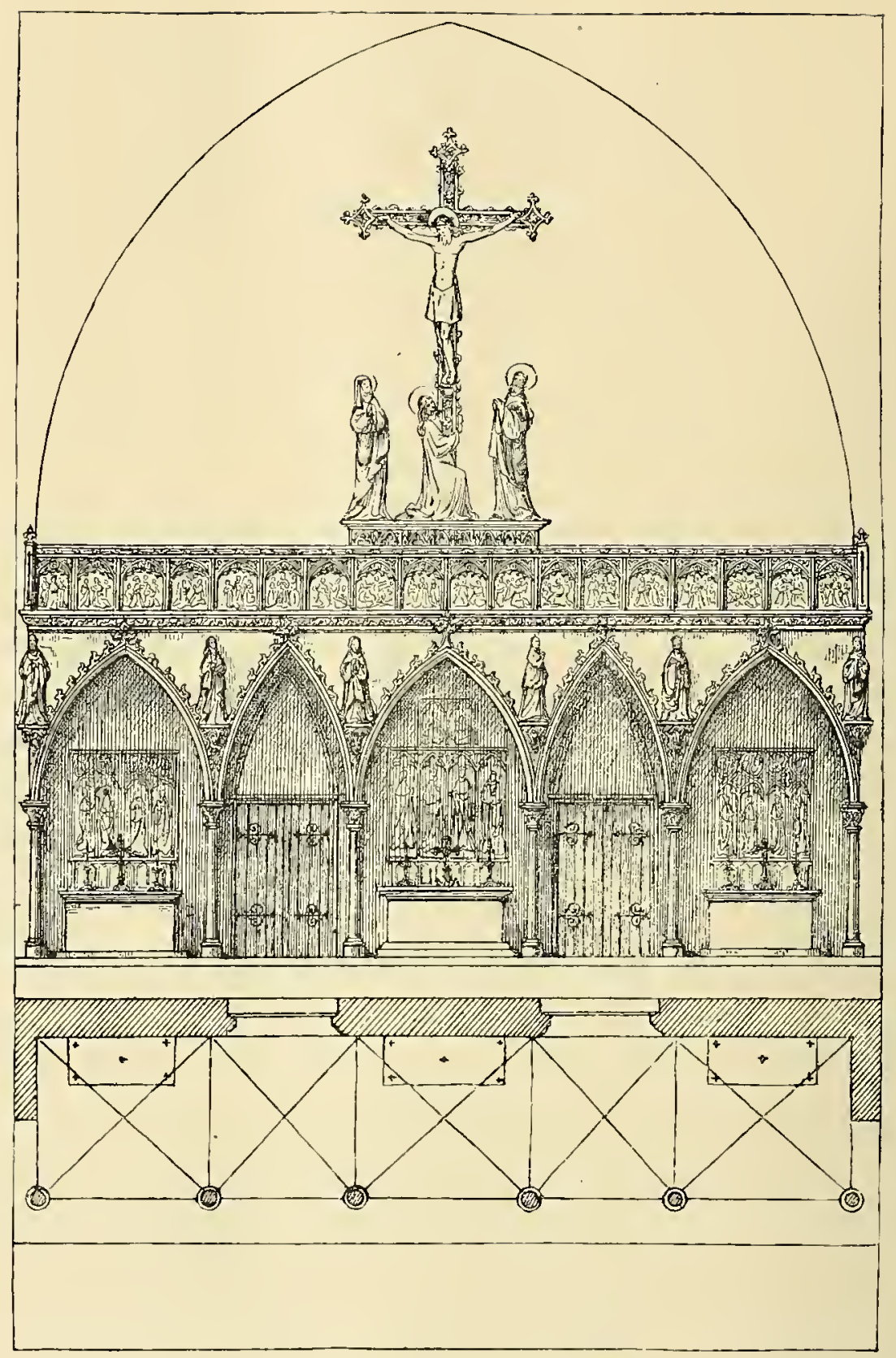

Screen and Rood-Loft, Hospital, Lubeck.

From Pugin's Treatise on Chancel Screens and Raod-Lofts. 
Occasionally, altars were erected in the loft under the foot of the Cross, as was the case in the Church of S. Maurice, at Vienna, where the parochial altar was in the centre of the rood-loft, and the elements of the Eucharist were also there reserved, sub titulo crucis. ${ }^{3}$

The blessed Virgin and S. John were placed at the foot of the Cross, but probably not at a very early period, and cherubim were occasionally added. The rood itself sometimes rose to a great height, examples being found extending sixty feet from the floor; in the hence, owing to the great weight, it was sometimes sup- Screen. ported by chains, often composed of long ornamented links, united by gilded balls. In many churches in the Low Countries, staples for these still remain. In the lofts were also placed the lecterns for the Epistle and Gospel. The lessons and great antiphones were also chanted from them, and in the Greek Church, the deacon read the diptychs from them, and also formally warned the catechumens and penitents to depart before the celebration of the holy Eucharist. The lecterns were either movable brass or metal stands, or stone desks built in and forming part of the masonry.

Coronas of silver or other metal were suspended from the rood-loft, and filled with lights on the great festivals, and also decorated with branches of trees and flowers.

Coronas.

Generally in wooden screens the brest-summer, or main front beam of the screen, is the foundation in which the rood is fixed, but there are exceptions, in which the rood-beam is placed at some distance above the screen. ${ }^{2}$ At Antwerp Cathedral, unless the writer is mistaken, a rood is suspended from the roof Rood Suspended. instead of a screen.

In Romanesque and early pointed work the chancel arches were so narrow that the walls on each side served as a sort of screen. The arch, therefore, was furnished only with gates and a rood-beam; and it hanges of and it has been questioned if the rood were not sometimes, Screen in Differin these cases, fixed in a kind of square niche over the chanent Periods. cel arch, where the Doom at a later period was usually painted. As the chancel arch increased in width, so the rood-screen increased in size and splendor, until it reached its height of magnificence in the Tudor age.

1 Pugin, Treatise on Chancel Screens, etc., p. I7.

2 Ibid., pp. I9, 20. 
The ascent to the loft was by means of the rood-staircase. Of these there were sometimes two, as in the case of S. Etienne-du-Mont at Paris.

Two spiral staircases of exquisite beauty wound around the Rood-Staircase. opposite piers of the screen. ' Occasionally they were concealed in a pier, or in the chancel wall, or, when accompanied by a central tower, formed a part of the main staircase to the belfry. Often they were also carried up in a rood-turret, many of the Norfoll churches having two turrets, ${ }^{2}$ which furnished at the same time a convenient passageway to the leads.

From the staircase, the entrance to the rood-loft was by the rooddoor. When the staircase was in the north or south wall of the aisle, Rood-Door. as in many of the churches in Somersetshire, a wooden passage was thrown across to the chancel arch. At S. Peter's, in Ropsley, Lincolnshire, the staircase is in the north wall of the north aisle, and a stone bridge is carried across, partly blocking the east window of the aisle. ${ }^{3}$

After the time of Edward VI., rood-lofts in England were mostly destroyed, and against them were directed the special fulminations of the Puritans, although their senseless rage should have been allayed by those lines which were often inscribed underneath the rood:

" Effigiem Christi dum transis, semper honora, Inscription on Non tumen effigiem, sed Quem designat, adora. the Rood-Screen. Nam Deus est, Quod imago docet, sed non Deus ipse, Hune videas, et mente colas, quod cernis in illa." 4

“ The effigy of Christ, when thou passest under, ever honor, but yet not the effigy, but whom it represents, adore; for what the image teaches is God, but itself is not God. Look then upon it, and in thy mind worship what thou seest in it."

Post-Reformation rood-screens are not uncommon. The Handbook of English Ecclcsiology instances several, and remarks that it is very curi-

Post-Reformation RoodScreens. ous that of all Sir Christopher Wren's churches, only one is destitute of some approximation to a rood-screen, so strong even then was ancient tradition. St. Paul's Cathedral retained its rood-screen until I 547. Stow declared: " the I 7 th of Novem.

${ }^{1}$ Galignani, Paris, p. 46.

2 Durandus, p. 2 ×7.

${ }^{3}$ Handbook of Encrlish Ecclesiology, " Rood-Screens." -

${ }^{4}$ Weaver, Ancient Funcral Monuments in Great Britain, p. II7. 
ber was begun to be pulled down the Roode in Paul's church, with Mary and John and all other images in the church; and then the like was done in all the churches in England, and texts of Scripture were written upon the walls of those churches against images." " Many remained even in the time of Elizabeth.

The translators of Durandus thus explain the symbolism of the chancel arch and rood-screen: " these, as separating the Choir from the Nave, denote literally the separation of the Clergy from the Laity; but symbolically the division between the Militant and Triumphant Churches, that is to say, the Death of the Faithful. The first great symbol which sets this forth is the Triumphal Cross, the Image of Him who by His Death hath overcome Death, and hath gone before His people through the valley of its shadow. The images of Saints and Martyrs appear in the lower panelling, as examples of faith and patience to us. The colours of the rood-screen itself represent their Passion and Victory: the crimson sets forth the one, the gold the other. The curious tracery of network typifies the obscure manner in which heavenly things are set forth, while we look at them from the Church Militant.

"And for as much as the Blessed Martyrs passed from this world to the next through sore torments, the mouldings of the Chancel Arch represent the various kinds of sufferings through which they went. Faith was their support, and must be ours: and Faith is set forth either in the abstract, by the limpet moulding on the Chancel Arch ; or on the screen, as in Bishop's Hull, Somersetshire, by the Creed in raised gilt letters, or is represented by some notable action of which it was the source: so in Cleeve, Somersetshire, the destruction of a Dragon runs along, not only the Rood-screen, but the North Parclose also. But in that the power of evil spirits may be exercised against us till we have left this world, but not after, horrible forms are sometimes sculptured in the West side of the Chancel Arch.

"The foregoing remarks may perhaps explain what has been felt by some Ecclesiologists as a difficulty: how it happens, since the Chancel is more highly ornamented than the Nave, that it is the Western, or Nave side, not the Eastern or Chancel side, of the Chancel Arch which invariably receives the greatest share of ornament. The straitness of the entrance to the Kingdom of Heaven is set forth by the excessive nar- 
rowness of Norman Chancel Arches. And the final separation of the Church Triumphant from everything that defileth was almost invariably represented by the Great Doom painted in fresco over the Rood-screen; of which there are still several examples, as the celebrated one in Trinity Church, Coventry; and many more might be found if the whitewash in that place were scraped off. And not only is the judgment of the world, but that of individuals here set forth: on the South side of the Chancel wall of Preston Church, Sussex, is a fresco of S. Michael weighing the souls; the Devil stands by, eager to secure his prize, but by the intervention of the Blessed Virgin, the scale preponderates in favour of the sinner." 1

Another mystical meaning is attributed by ecclesiologists to the rood-screen: the doors always open inwards. And the great rood above is "The Tree of Life in the midst of the garden "; and therefore stands in the midst of the church.

1 Introduction to Durandus, p. IO2. 


\section{CHAPTER V}

\section{ALTAR AND RELIQUARY CROSSES}

$\mathrm{E}$ USEBIUS, in his life of Constantine, in a passage which has been already quoted, says "that the symbol of the Saving Passion was set up, formed of precious stones." ' And from this it has been supposed that the Cross was placed upon the altar, The Altar Cross. as the most fitting place, in the time of that Emperor. But it is strange, if that be the fact, that the historian, in his minute description of churches, does not make more specific mention of the Cross as one of the ornaments of the altar. Perhaps it was so common that he did not think it necessary.

Bingham is of the opinion that the altar cross was introduced after the year 340. It is reasonable to suppose that, in the same century in which occurred the victory of Constantine over Maxentius, ascribed to the Roman Emperor's being cheered on to triUsed. umph by the miraculous vision of the Cross, and the presumed discovery of the sacred wood by S. Helena, the custom may have originated of placing " the symbol of the Saving Passion"' in the most sacred part of the temple.

Sozomen, in the fifth century, speaks of material crosses lying upon the altar ${ }^{2}$; and at the Council of Ephesus, A.D. 43 I, Acacius of Mitylene, incidentally alluded to the Cross being honored together with altars of Christ, ${ }^{3}$ indicating that it was part of the furniture of the sanctuary at that time.

In the second Council of Tours, A.D. 567, it was decreed that the elements of the Eucharist should not be kept in the armarium, but under the figure of the Cross upon the altar." The same Council also

${ }^{1}$ Life of Constantine, lib. iii., cap. 40.

${ }^{2}$ Sozomen, lib. i., cap. 3 .
${ }^{3}$ Fleury, Eccles. Hist., xxv., 34.

${ }^{4}$ Bingham, Antiq., b. viii., sec. 19. 


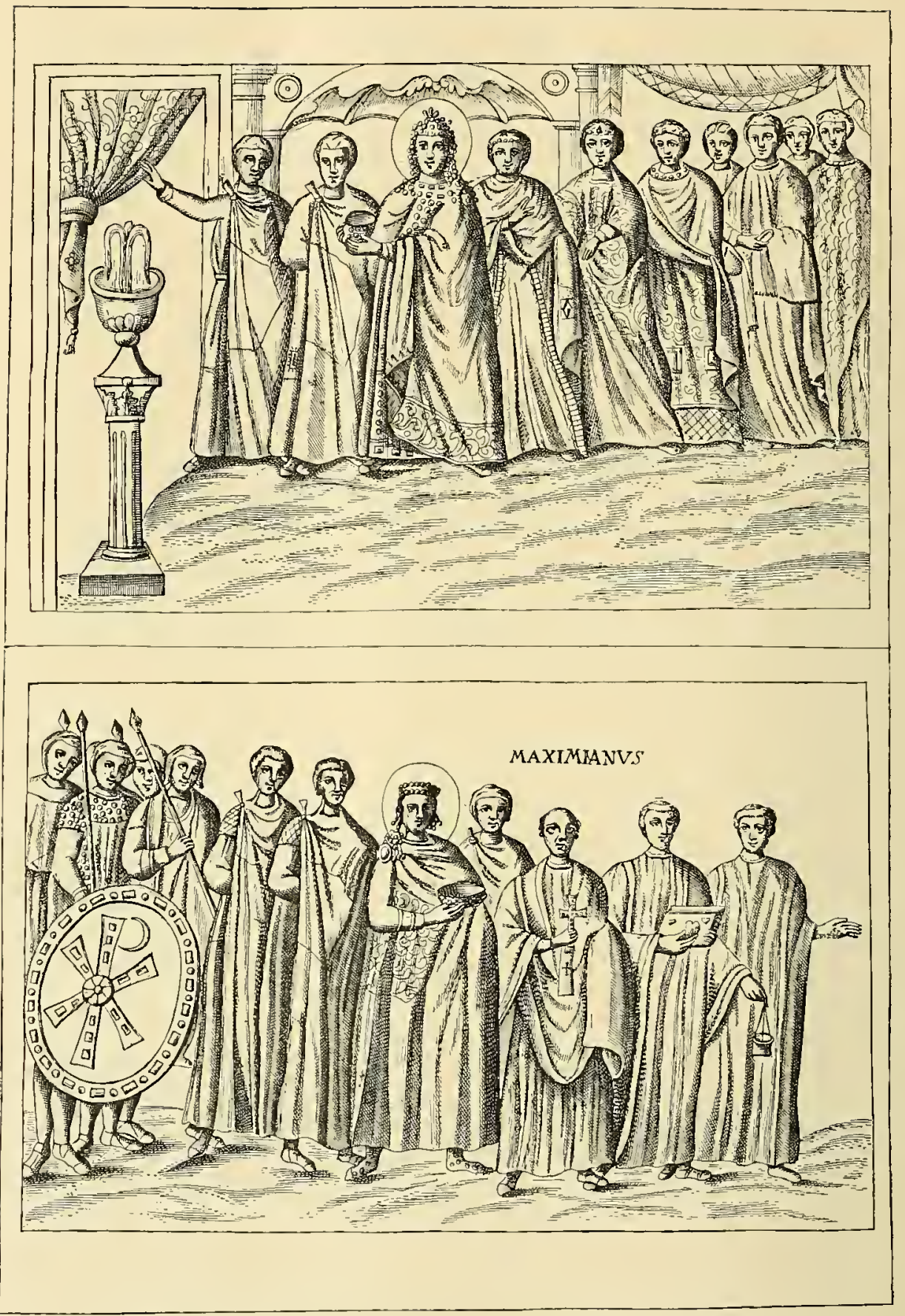

Maximianus Welcoming Justinian. From Ciampini's Vetera Monimenta. 
forbade the celebration of the Lord's Supper without the presence of a cross upon the holy table. Evagrius records that Chosroes gave silver crosses to a church in Constantinople to be fixed upon the altar.' In a fresco of the same century (the sixth), in the century. Church of S. Vitale at Ravenna, representing Maximianus welcoming the Emperor Justinian, the Bishop holds what seems to be an altar cross in his hands. ${ }^{2}$

In those days gifts were not uncommon of gold crosses richly adorned with costly gems, containing the still greater wealth of a fragment of the true Cross. Pope Symmachus ${ }^{3}$ (A.D. 498-5I5) presented such an one to the Vatican, and it can hardly be supposed but that these were placed in the most hallowed part of the

Cross Given to the Vatican by Pope Symmachus. sanctuary. Nevertheless, altars, till a late period, judging from the representations which have been handed down to us, were severely simple in their furniture. Leo IV., A.D. 347, ordered that the Altars Unadorned only ornaments should be the capsa or reliquary, the Gos- in Early Ages. pels and the pyx. In a fresco of the ninth century, in the Church of $S$. Ambrogio at Milan, S. Ambrose is represented as celebrating mass at a small cylindrical altar, the only ornament upon which is a plain cross. In a painting of the Italian school of the eleventh century, given by D'Agincourt, the altar at celebration supports only two tapers and a small cross. And that for one or two centuries these were used or omitted, indifferently, seems probable; for in the thirteenth century we find altars without cross, tapers, or adornments, as in the shrine by Giovanni da Pisa, Arezzo Cathedral, A.D. 1286; or with the Cross alone, as in a painting by Cimabue in the Uffizi, Florence. In the fourteenth century the altar still appears unadorned even in so high a solemnity as a coronation, as represented on the tomb of Guido Tarlati in Arezzo

1 Evag., Eccles. Hist., lib. vi., cap. $2 \mathbf{1}$.

${ }^{2}$ Ciampini, Fetera Aonimenta, tom. ii., tab. 22.

${ }^{3}$ To those utilitarians who object that money is zusted in the adornment, which might be given to other laudable objects, this Bishop of Rome should be cited. During a pontificate of sixteen years, when Kome was depressed owing to the Gothic and Vandal wars, besides building at least four churches, and enlarging many others, presenting six silver altars, and images of silver of the Saviour and his apostles (altogether weighing one hundred and twenty pounds), to the Ostian Basilica, he erected baths for the monks (and probably Pilgrims), established hospices for the poor near the basilicas within the city, and near S. Peter's, S. Paul's, and S. Laurence's without the walls, and expended large sums in the redemption of citizens sold into slavery, and in the maintenance of the African bishops driven into exile in Sardinia by the Vandals. Objectors to such liberality may find comfort in thinking that no bishop in the present day has the means, let alone the will, to emulate that Bishop of Rome. 
Cathedral, A.D. I 320-I330; or with only the Cross, as in Giotto's illustrations of the life of S. Francis, and in the frescos by Fra Angelico depicting the celebration of mass in the Chapel of $\mathrm{S}$. Laurence in the

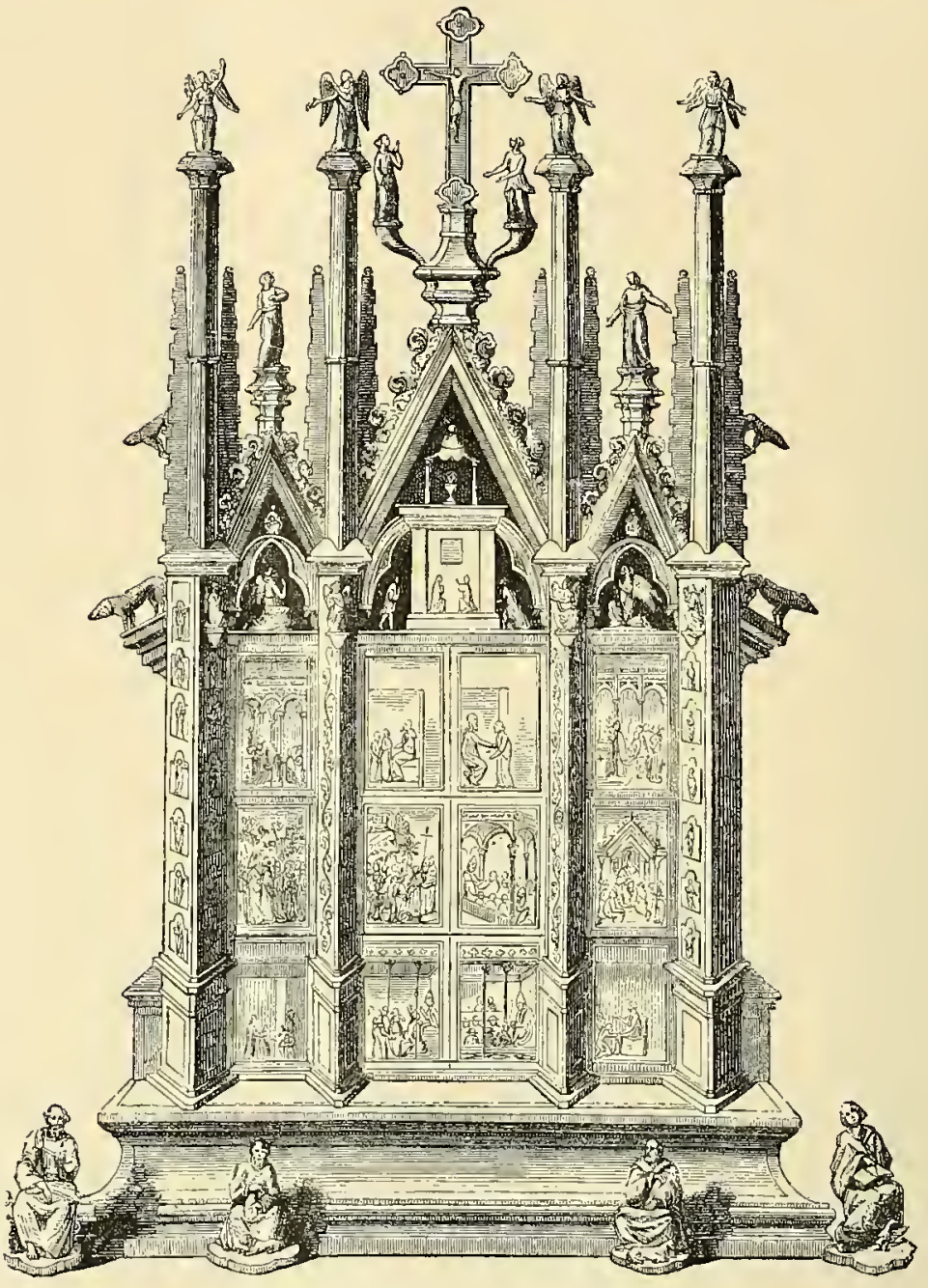

Reliquary of Orvieto. XIVth Century.

From Labarte's Handbook of the Arts of the Middle Ages and Renaissance.

Vatican. Even in the paintings of Raphael and of Andrea del Sarto the decoration of the altar is simple compared with the profusion now exhibited in modern Italian churches. ${ }^{1}$

It would seem, therefore, that in spite of the canon of the Council of

${ }^{1}$ Hemans, Ancicut Christianity and Sacred Art, pp. 558, 562. 
Tours as to the usage of the Cross, that it was not generally placed upon the altar until the ninth century, and even then, that there was no strict custom for several hundred years. It has been stated that " before the fourteenth century no candles or crosses were permitted to be permanently set on the altars, but were invariably brought in by two acolytes when mass was to be said." ' Prior to the sixteenth century altars exhibited little else than the “ emblem of the Saving Passion," and that as a simple cross

Crucifix when Ordered. much more frequently than as a crucifix. The latter was not an indispensable accessory until ordered by Benedict XIV., A.D. I754.

Many altar crosses were used as reliquaries, and contained a fragment of the true Cross, and were ornamented with precious stones. Beryls and pearls especially were chosen ; the color of the first, green, symbolizing Regeneration, Hope, and Charity; the pure white the Cross. of the other reminding the worshipper of Light, Innocence, and Purity.

Few ancient altar crosses are in existence. One of the most venerable is in the Baptistery at Ravenna; it is nearly of the pattic form, and is dated A.D. 6SS. A comparatively modern one, yet interesting on account of its donor, is preserved in York Minster. at Ravenna. It stands on six bases, having angels on their pinnacles; two of the celestials hold in their hands the relics of the chasuble of S. Peter; images of the thieves and others connected with the Crucifixion are at the foot, and it is adorned with rubies, sapphires, and other gems. It was the gift of King Richard the III.

Multitudes of examples might be given, but one is selected of the twelfth century. It is of copper and gilt. The feet are not crossed or nailed, but the third nail is shown in the suppedancum. " At the foot of the Cross are three archangels, who with Century. outstretched wings encircle the tree of redemption. Each of them holds a medallion, upon which is inscribed his name in Hebrew, with the Latin translation, recalling his office with the Most High:

\section{" Michacl quis ut Deus. Gabricl fortitudo Dei. Raphael medicina Dei."}

The sun and moon are represented by the conventional figures. Upon the tunic is an inscription on a sliding door, Lignum Domini, showing 
that within was a portion of the true Cross. "The messengers of the Eternal, seated at the foot of the Cross, are placed there to attest that the Crucified has not ceased to be the Lord of the universe, whose immutable decrees they are ready to execute."

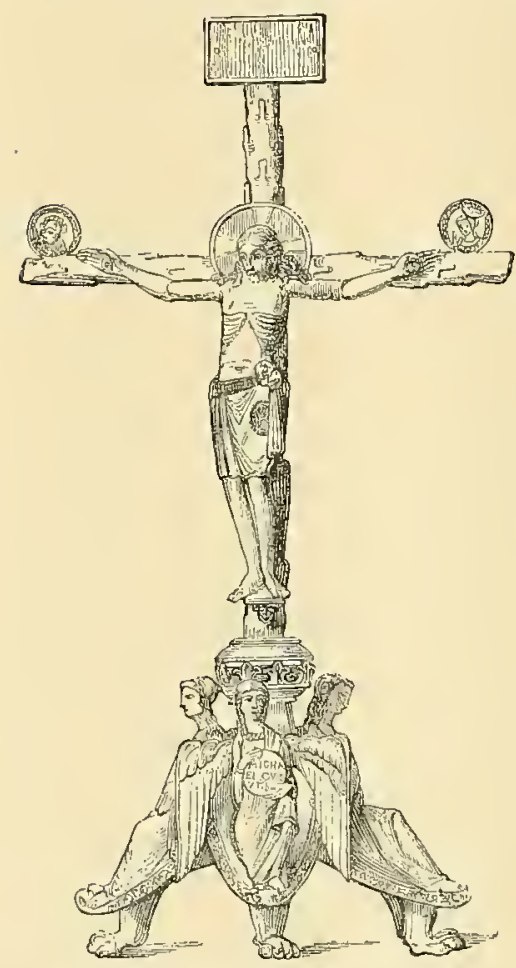

Bronze Crucifix. XIIth Century.

From Labarte's Handbook of the Arts of the Middle Ages and Renaissance.

All Protestants have not rejected the use of the altar Cross, or crucifix.

Use of Altar

The United Lutheran and Cross in Europe. reformed sects in Prussia still retain the crucifix upon their Communion tables. " At the coronation of the "'White King," Charles I., there was a crucifix upon the altar. Even when England was sunk in Erastianism, Bishop Butler placed a white marble cross on the altar of the Cathedral of Bristol, where it remained until destroyed by the mob in IS $3 I^{3}$ Nor should we forget in this place the Cross used upon the altar, which Queen Elizabeth refused to have removed.

The Nestorians, while venerating the Cross, will not tolerate the crucifix. cross Among When Roman Catholic misthe Nestoriars. sionaries have left the crucifix among them, they have broken the image from the Cross. They consider the Cross as sacramental," distinctly declaring that its efficacy is derived from Him who was crucified. Hence on Holy Cross day (September I 3 th) in their services they appeal to the " Cross " that " has saved us," "the Cross has made us triumphant," " the Cross has renerred us," " the Cross has made us at peace," "the

${ }^{1}$ Labarte, Handbook of Arts of the Middle Ages, p. xviii., fig I4.

2 Pusey, Letter to the Bishop of Landon, P. II 5 .

${ }^{3}$ Fitzgerald, Life of Bishop Butler, prefixed to his Analogy, p. lviii.

4 "'The earliest Christian artists when making a representation of the Trinity, placed a Cross beside the Father and the Holy Spirit; a Cross only, without our crucified Lord. The Cross did not only recall Christ to mind, but actually showed Him. In Christian Iconography, Christ is actually present under the form and semblance. of the Cross." Didron's Christ. Icon., vol. i., p. 367 . 


\section{Altar and Reliquary Crosses}

living Cross went out to seek after us, and saved our life that was lost." They trace the origin of the worship to the tradition that when Christ, just previous to his ascension, led his disciples to Mount Olivet. He stretched out $H$ is hands in the form of a cross, in order to bring to their recollection, that from the shame of the cross, on which they had seen him. He had derived that glory in which they beheld his ascension, according to the words of S. Paul: "He humbled himself and became obedient unto death, even the death of the Cross, wherefore God also hath highly exalted him " (Phil. ii., 8-9). So when the disciples saw their Lord exhibiting the figure of the Cross, they prostrated themselves to the ground. Hence the Nestorians say that the worship of the Cross began in the " upper chamber," and afterwards was recognized in Antioch; and yet guarding against idolatry, they affirm, "we offer fervent and Eucharistic worship, not to the fashioned matter of the Cross, but to Him whom we figure on it.",

${ }^{1}$ Badger, Nestorians, and their Rituals, vol. ii., Pp. I30-I36. 


\section{CHAPTER VI}

\section{CRUCIFORM ORNAMENTS}

$\triangle$ PROPER description of ecclesiastical and secular articles and 1 furniture in which the Cross is used would fill volumes, but much information may be easily found in other works; hence a reference to a few articles not at the present time in general use in the Anglican and American branches of the Church, by way of illustration, is all that is needed.

Every appurtenance of the altar was adorned with this sacred symbol, wrought, engraved, or surmounting it in due place. Prominent ciborium. among these is the ciborium. Sometimes it is merely a covered chalice or pyx, but it appears formerly to have been a small dome-shaped temple, or rather canopy, resting upon pillars, surmounted by a cross, while within it was suspended a dove, or cup of gold or silver, containing the reserved Host. It is of ancient use, being mentioned by $\mathrm{S}$. Chrysostom.

The monstrance is of mediaval times. Although in the eleventh century the Eucharist was sometimes carried in processions, yet the The Monstrance Council of Cologne, in 1452, first mentions that the Host was carried visibly in a monstrance, showing that, previously, the wafer had been borne in a closed ciborium. There are various forms of the monstrance. Sometimes it is, a little jewelled tower with glazed apertures, a figure of a saint, or the holy lamb, or a cross. A crystal tube mounted on a pedestal of gold or silver, covered with a canopy belongs to the fifteenth century, and a sun with rays, to the seventeenth century. At Conques there is preserved one of silver-gilt with a large disc, and a double or patriarchal cross above it; the lower portion is of the fourteenth century, the rest of later work. Other articles sanctified by the Cross are too familiar to need mention. 


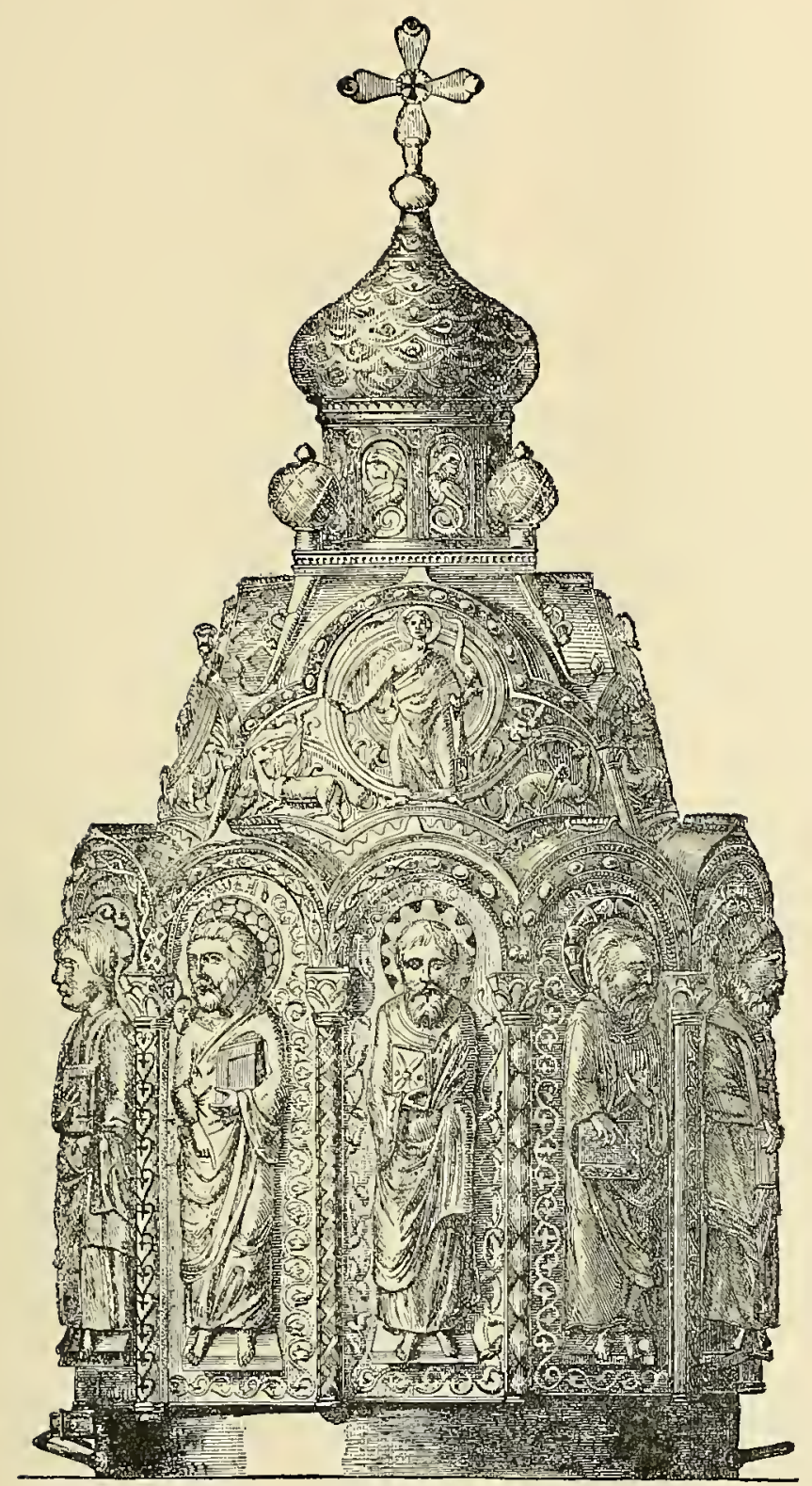

Ciborium. Byzantine, end of XIVth Century.

From Wheatley's Art Work in Gold and Silver. 


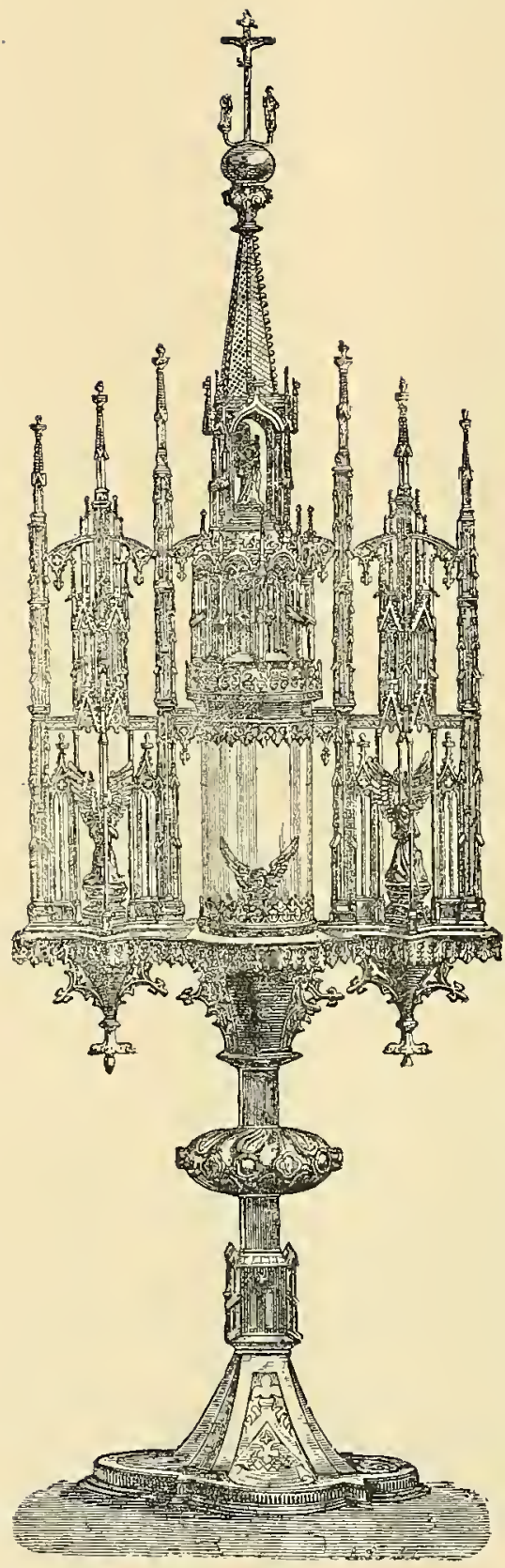

Monstrance of Sedletz Castle, Bohemia, XVth Century. From Wheatley's Art IFork in Gold and Silucr.
The sacerdotal vestments are now too well known to require description. Yet among the variations of the Cross is one worthy of notice. It was exhibited at the Archæological Institute, London, in 186I. A crimson velvet chasuble of the sixteenth century bore an embroidered crucifix, in which Christ Cross Repre- was represented as sussented as a Tree. pended, not from a cross, but from a veritable tree, leafless and lopped of its branches.

Probably the last instance of inno. vation is that of Pope Benedict XIII., Stations. in 1730 , who ordered a cross to be placed over every picture denoting a station in the Roman Catholic churches.

As has been already mentioned, Theodosius, about the end of the fourth century, introduced the royal symbol, Mound and Orb. the mound or orb, representing the world surmounted by the Cross. ${ }^{1}$ The Roman Senate still hankered after their pagan emblems, and requested permission to erect an altar to the goddess of Victory, which had been removed. The Emperor forbade it, and about the same time abolished the worship of Serapis and other heathen divinities of Egypt, decreeing that no one in the Roman dominions should presume to worship an idol by sacrifice. It was on that occasion that he crowned the orb with the Cross, as it is used in this day.

${ }^{1}$ See pp. S, I56, and Walsh, Ancient Coins, p. I2I. 
The interpretation of its symbolism is given in the Coronation Service of Great Britain:

"Receive this imperial robe, and orb, and the Lord your God endue you with knowledge and wisdom, with majesty and with power from on high, the Lord clothe you with the robe

\section{Prayer Used at Delivery of Cross and Orb.} of righteousness, and with the garments of salvation. And when you see this orb set under the Cross remember that the whole world is subject to the power and empire of Christ our Redeemer: for $\mathrm{He}$ is the Prince of Kings of the earth, King of Kings, and Lord of Lords. So that no man can reign happily who derives not his authority from Him, and directs all his actions according to His laws."

The ancient sceptre among the Greeks was a wand called $N \dot{\alpha} \rho \theta \eta s$, because made of a plant of that name, known by the Romans as Fcrula; hence the emperors were called Narthccophoroi. The only place in which this herb grows in abundance is in the island named Oxia, in the Sea of Marmora, where the Greek emperors made their summer residence.

Judging from the coins described by Gretser, Flavius Phocas, elevated to the

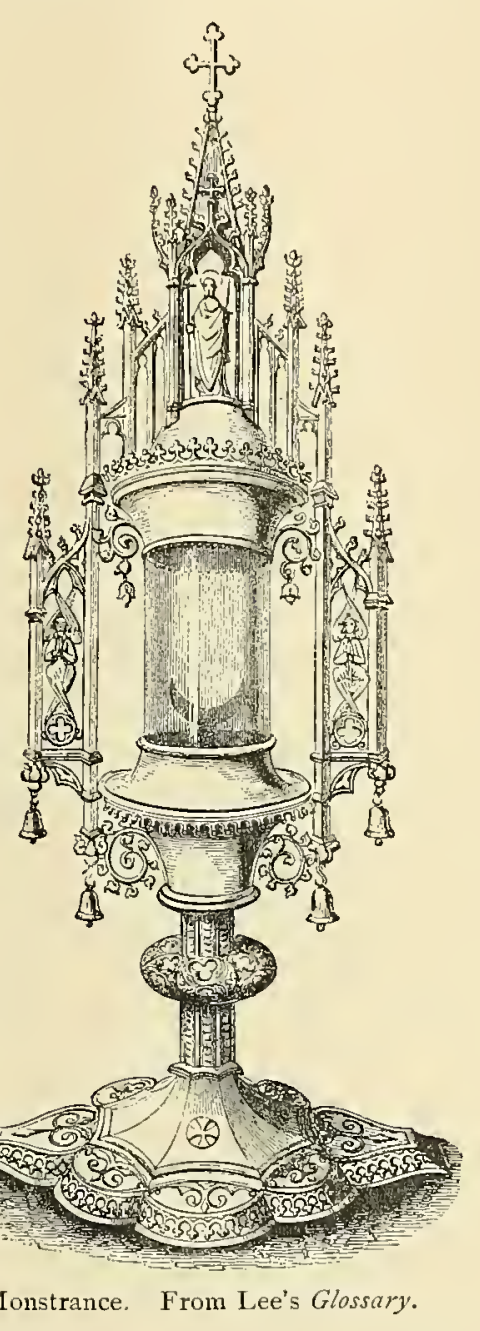
throne by the army in the year 602, was the first who adorned the sceptre with the Cross. He was a bitter, cruel, bad man, but fond of parading his piety. With what questionable motives Surmounted by originated those symbols of supreme power, the crowned the Cross. orb, the sceptre and cross-bearing crown, which have become the accredited badges of the great Christian sovereigns of Europe:

One of the most notable among ancient crowns is that of Charle- 
magne. This crown is still preserved in the Imperial Treasury at Vienna. It weighs fourteen pounds, and is composed

Crown of of eight plates of gold, four large and four charlemagne. small, connected by hinges. The first compartment contains twelve jewels, unpolished. The second, on the right hand, a figure of our Saviour sitting between two cherubs, each with four wings, and below, the motto $P e r$ mo reges regnant. The third, fifth, and seventh compartments contain only gold and gems. In the fourth is the figure of King Hezekiah, sitting, and by his side the prophet Isaiah, with a scroll, on which is written Ecce, adjiccan supor dics tuos $\mathrm{XT}$. annos. The sixth has the effigy of $\mathrm{King}$ David crowned; on the scroll in his hand is Honor regis judicium diligit. The eighth contains another figure, Solomon; on the scroll is Timete Dominium, Regem amate. On the top of the crown is a cross, with seventeen jewels in

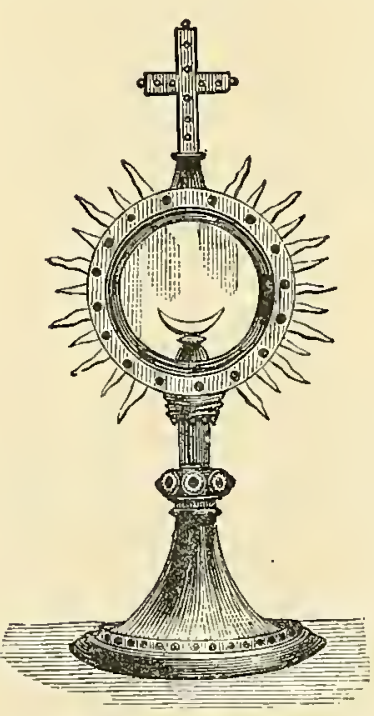

Monstrance: German Example of the XVIth Century.

From Lee's Glossary' of Liturgical and Ecclesiastical Terms. the forepart, and on the top of the Cross I. H. S. Rcx Fudaorm. In the arch or semicircle, which was added by the Emperor Conrad, are the following words: Chouonradus Dei gratia Romanorum Impcrator Aug. "The costume of the figures resembles that of the Emperors of the Lower Empire, and although the inscriptions are in Latin, the whole bears the impress of Greek workmanship. The ground of the figures is formed by the metal itself, which has been hollowed out to receive the enamel ; but the details of the design are traced out with fine fillets of gold. The flesh tints are in rose-colored enamel; the

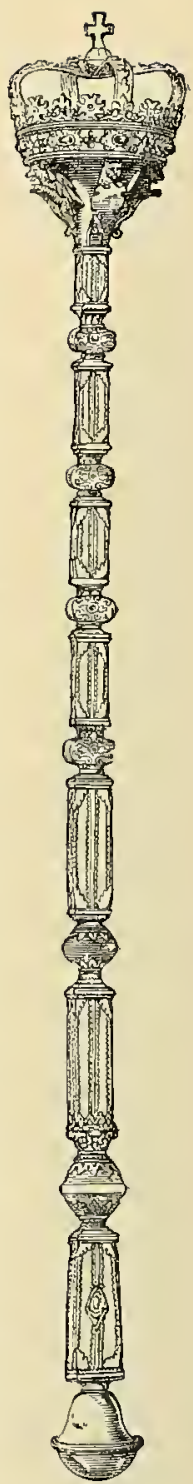

Sceptre Surmounted by the Cross. From Wheatley's Art Work in Gold and Silver. colors employed in the draperies and accessories are deep and light blue, red, and white. This crown has unquestionably been retouched at vari- 
ous periods, but yet there is nothing to invalidate the tradition which assigns the more ancient portions to the time of Charlemagne. The enamels must belong to the same early period." '

Every crown from the days of Charlemagne downward bears the sacred symbol, teaching the lesson of the apostle, " the powers that be, are of God."

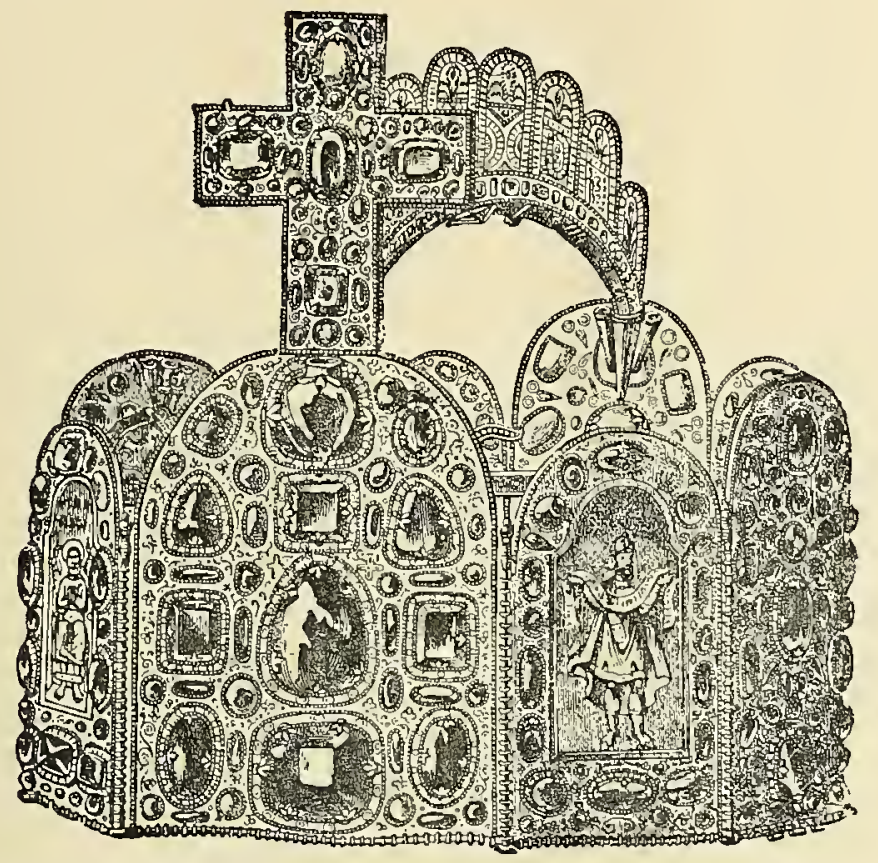

Crown of Charlemagne. From Wheatley's Art ITork in Gold and Silver.

The English crown royal is ornamented with crosses pattée and fleursde-lis, symbolizing the protecting power of the Cross and humility, or as some read it, emblematic of our blessed Lord and the Virgin. The royal crown of $\mathrm{S}$. Edward, of the same fashion English Crowns. as that of Edward the Confessor, was kept in Westminster Abbey until the time of the Great Rebellion, when it was stolen and sold in I642. It was formed of four crosses patonce and four fleurs-de-lis of gold. Four circular bars meeting at the top in the form of a cross rose from the crosses. At the intersection was a mound of gold studded with

${ }^{1}$ Labarte, Hlandbook of Fine Arts of the Afiddle Ages, p. I13; Millington, Heraldry in History', Poetry, and Romance, p. 255. This author says that this crown has been borne by several English kings who held the office of Archtreasurer to the Roman Empire. Lacroix, Arts of the Middle Ages, p. 127. 
precious stones, surmounted by a cross of gold and gems, with three large oval pearls, one of them fixed at the top, the other two pendent from the arms of the cross. The ancient fashion is preserved in the Queen Consort's crown in memory of Queen Editha, consort of Edward the Confessor.'

The coronet of the Prince of Wales resembles the crown royal, with the omission of one of the arches. That of the Princess Royal is composed of four fleurs-de-lis, two crosses, one of which is in the centre, and two strawberry leaves.

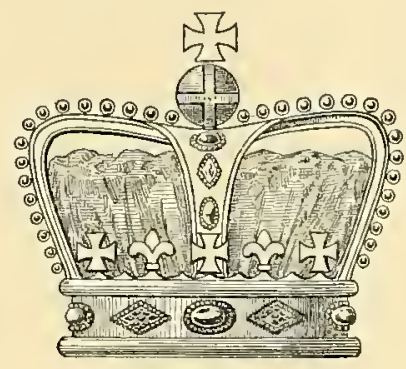

English Crown.

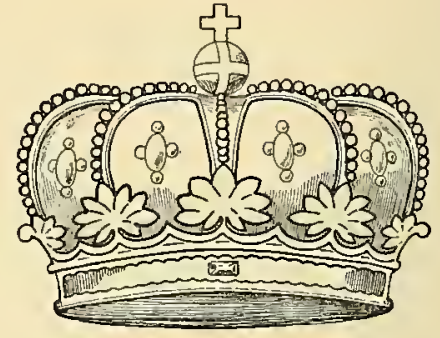

Crown of Austria.

From Berry's Heraldric Encyclopedia.

The crown of Austria is one of the most beautiful of European diadems. It is garnished with costly gems; from the cap, bordered with fleurs-de-lis, Crown of rises an arched fillet, enriched with pearls and surmounted Austria. by a mound whereon is a cross, gemmed also with pearls.

Another ancient crown is that of Hungary. "This most venerable relic of Byzantine art is formed of a broad, flat circlet of fine gold, from Crown of which spring four arches supporting a cross. It was sent Hungary. A.D. 1072, by Michael Ducas, Emperor of Constantinople, to the Duke of Hungary, or, as he is styled in his enamel portrait placed above the circlet, Geabitras, King of the Turks. Next comes a portrait of Constantinus Porphyrogenitus; then one of Ducas himself; the fourth and largest enamel represents Christ seated, exactly as he appears on the bezants of the period. These four portraits are placed at the springing of the arches that close the top of the crown; on the front of the circlet itself are fixed four smaller enamels of Michael, Gabriel, S. George, and S. Demetrius.

"Above the medallion of Christ is a large heart-shaped amethyst, below it is a huge, rough sapphire; four large sapphires are also set equi-

${ }^{1}$ Millington, Heraldry in History, Poetry, and Romance, p. 254. 
distant on the circlet, all but one of them being unpolished. The edges of the circlet are closely studded with pearls, set touching each other in a row. The large sapphire at the back is surrounded by four green stones, cut in an oblong form, but their precise nature cannot be ascertained. In the deed by which Queen Elizabeth of Hungary pledged this crown to the Emperor Frederick IV., the stones are enumerated as fifty-three sapphires, fifty rubies, one emerald, and three hundred . and twenty pearls. Here is another proof of the early existence of the emerald in Europe, and the correctness of the opinion as to the real nature of the hyacinthus, for what other gem, to judge from Claudian's account of the robes and armor of Theodosius, should we expect to see so lavishly employed as this in decorations of the Byzantine age?" "

“ In clearing away a deserted cemetery at Fuente di Guerrazzar, two leagues from Toledo," was discovered the cross of King crown of King Reccesvin- Reccesvinthus. thus, A.D. 653. It is a circle of fine gold. one foot in diameter, set with thirty huge rubies and thirty-five pearls, alternating with sapphires. The circle is edged by two borders, adorned with a runing pattern of Greek crosses made of pieces of carnelian-cloissonnés in gold. From twenty. four little chains hang these letters of gold, incrusted with carnelian, like the border:

+ RECCESVINTHUS REX OFFERET.

"From the letters again hang twenty-

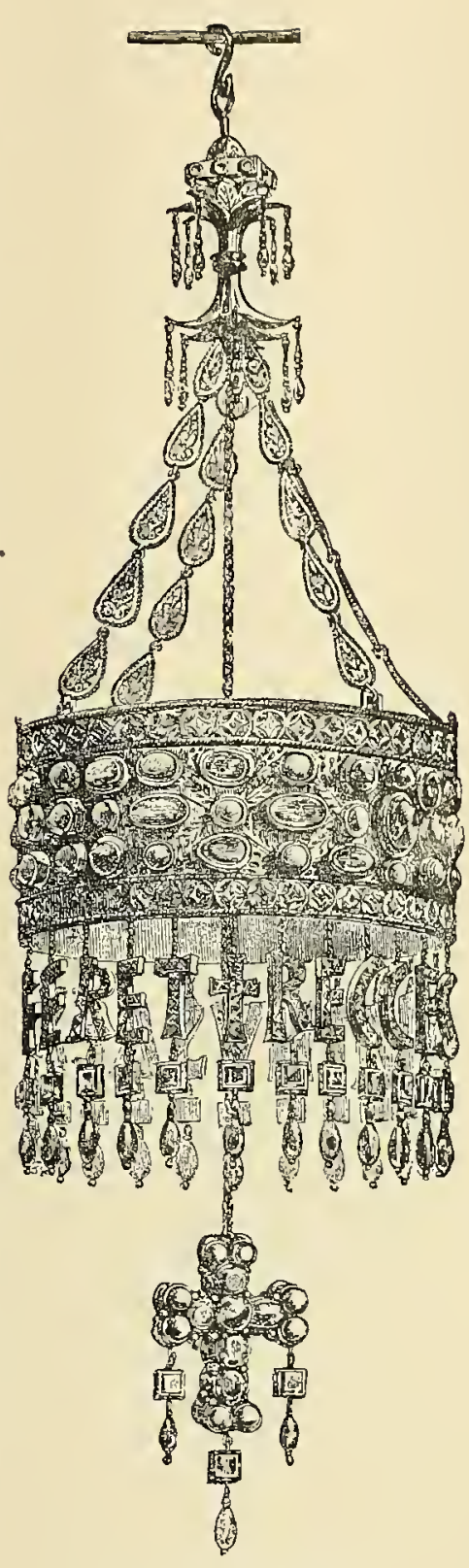

Crown of Reccesvinthus. VIIth Century.

From Wheatley's Art Work in Gold and Silver.

\footnotetext{
1 King, Antique Gems, p. 309.
} 
four pear-shaped pink rubies, forming a fringe all round the crown. Lowest of all hangs a magnificent cross, of elegant form, set with very large gems, and having three pendants from the arms and foot.

"The second crown, supposed to be the Queen's, is set with rubies, sapphires, emeralds, opals, and large pearls, and has a fringe of rubies and a pendant cross, but is altogether of a plainer make than the first." '

"This cross, itself indubitably a work of the Carlovingian period, but mounted upon a silver-gilt foot of very elegant design in the taste of the fifteenth century, is preserved in the treasury of the Cathedral of Aix-laChapelle. The surface of the gold is ornamented with arabesque tracery, and studded thickly with gems, set close together in plain raised collets. These consist of pearls, rubies, sapphires, amethysts (one an intaglio of the Three Graces), and emeralds. At the intersection of the arms of the cross is placed a magnificent cameo on onyx, about three inches high and two and a half wide, representing the laureated bust of Augustus,

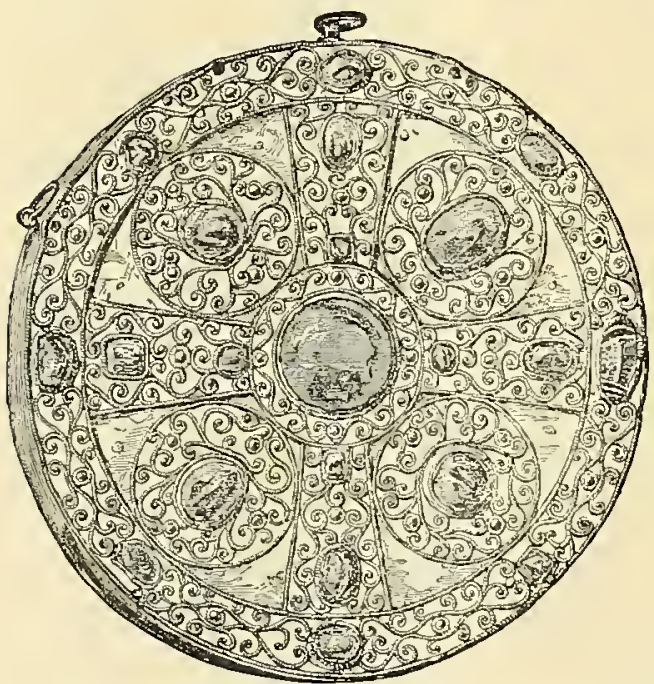

Brooch of Silver Filagree Work (Date Uncertain). From Wheatley's Art Wrork in Gold and Silver. holding an eagle-topped sceptre, a work of the highest merit. But the most interesting feature that presents itself to our notice in this early relic of the first dawn of mediæval art, is the signet of Lotharius himself, set in the lower part of the stem of the cross, immediately beneath the cameo of Augustus. It is engraved on a large oval piece of rock crystal, about one and three quarter inches high by one and a half wide, and represents the bust of the King, his head covered with a close fitting helmet with a slightly projecting frontlet, like those of the latest Roman period. Around the bust runs this legend, in well-formed Roman letters:

\section{+ XPE ADIVVA HLOTHARIVH REG}

"Christe adjua Hlotharium Regem," O Christ, defend King Lothaire. 'King, Antique Gems, p. 308 ; Lacroix, Arts of the MIiddle Ages, p. 125. 
"The execution of the engraving is very tolerable, far better than could have been expected at that date, A.D. S23, especially when we consider the rudeness of the coinage of the same period. It is not the work of the Byzantine school, for the characters of the legend bear no resemblance to those employed by its artists, but are precisely the same as those seen on the Frankish stone and metal work of the time of this monarch. This is by far the latest intaglio of ascertained date of which I have been able to find any trace; and its existence supports the opinion previously expressed, that the art of engraving gems lingered in Europe to a much later period than is generally supposed.

" This most splendid specimen of ancient jeweller's work is admirably figured in the magnificent Mélanges d'Archaologie, vol. i., by MM. Cahier et Martin."'

There was one article that none but a gentleman dare wear, and hence, on account of its symbolism and use, it deserves a place in this chapter as well as the crown. It is the sword, Cross-hilted, as became a soldier of the Lord.

The whole equipment of a knight in days of chivalry was symbolical. "The spear, on account of its straightness, was the emblem of truth, and the iron head, of the strength truth ought to possess. The helmet, of shamefastness; the spurs, of diligence. Knight's Armor. The gorget was the sign of obedience; for as the gorget went about the neck, protecting it from wounds, so the virtue of obedience kept a knight within the commands of his sovereign and the order of chivalry. The shield showed the office of a knight; for, as the knight placed his barrier between the king and the people; and as the stroke of a sword fell upon the shield, and saved the knight, so it behoved the knight to present his body before his lord when he was in danger." ' Most sacred of all was the sword whose hilt was fashioned like a cross, to remind the wearer of his duty to Him who died thereon. Consecrated upon the altar, it was prized as the knight's dearest possession,

and to many a name was given, so that the trusty weapon

Cross-hilted Swords. was invested as it were with a personality. King Arthur named his Excalibar; Sir Bevis of Hampton, Morglay; Charlemagne

Names of called his Fusberta Joyosa. The most celebrated sword Famous swords. of the Cid Ruy Diaz of Bivar was Tizona; he owned another scarcely

\footnotetext{
' King, Antique Gems, p. 305.
}

${ }^{2}$ Millington, Heraldry, p. 7I. 
less celebrated, Colada. Orlando rejoiced in the possession of Durindana. Launcelot of the Lake named his Aroundight; Siegfried's was called Balmung in the Nicbolungen-Lied. It was made by the divine

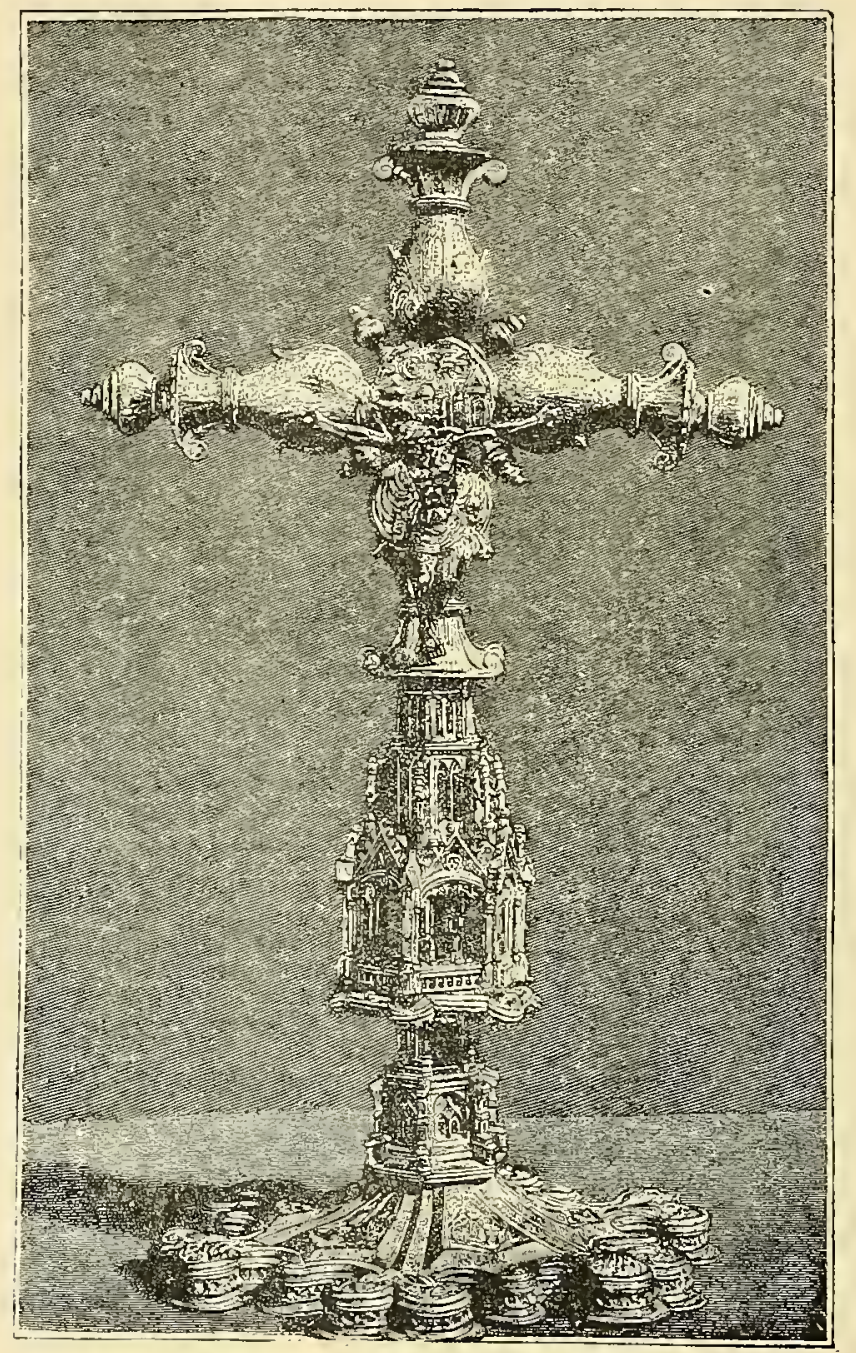

Crucifix Made from an Old Spanish Hilt.

blacksmith, Wieland. Mimung was another weapon lent him by Witticl. Edward the Confessor's was called Curtana, the cutter, a name now used for the pointless sword of mercy borne before the sovereigns. of England at their coronation. 


\section{Cruciform Ornaments}

The romance of Arthur relates the marvellous recommitment to supernatural hands of the famous Excalibar, or Caliburn, or Excalberd, at Arthur's Sword. the King's death. His soul could not depart until that was accomplished, and Arthur sends Sir Lukyn to throw it in the river, but the knight covets it-

"For all of coleyne was the blade;

And all the hilte of precious stone:

And ever alacke! then sayd the knighte,

Must such a sword awaye be throwne!"

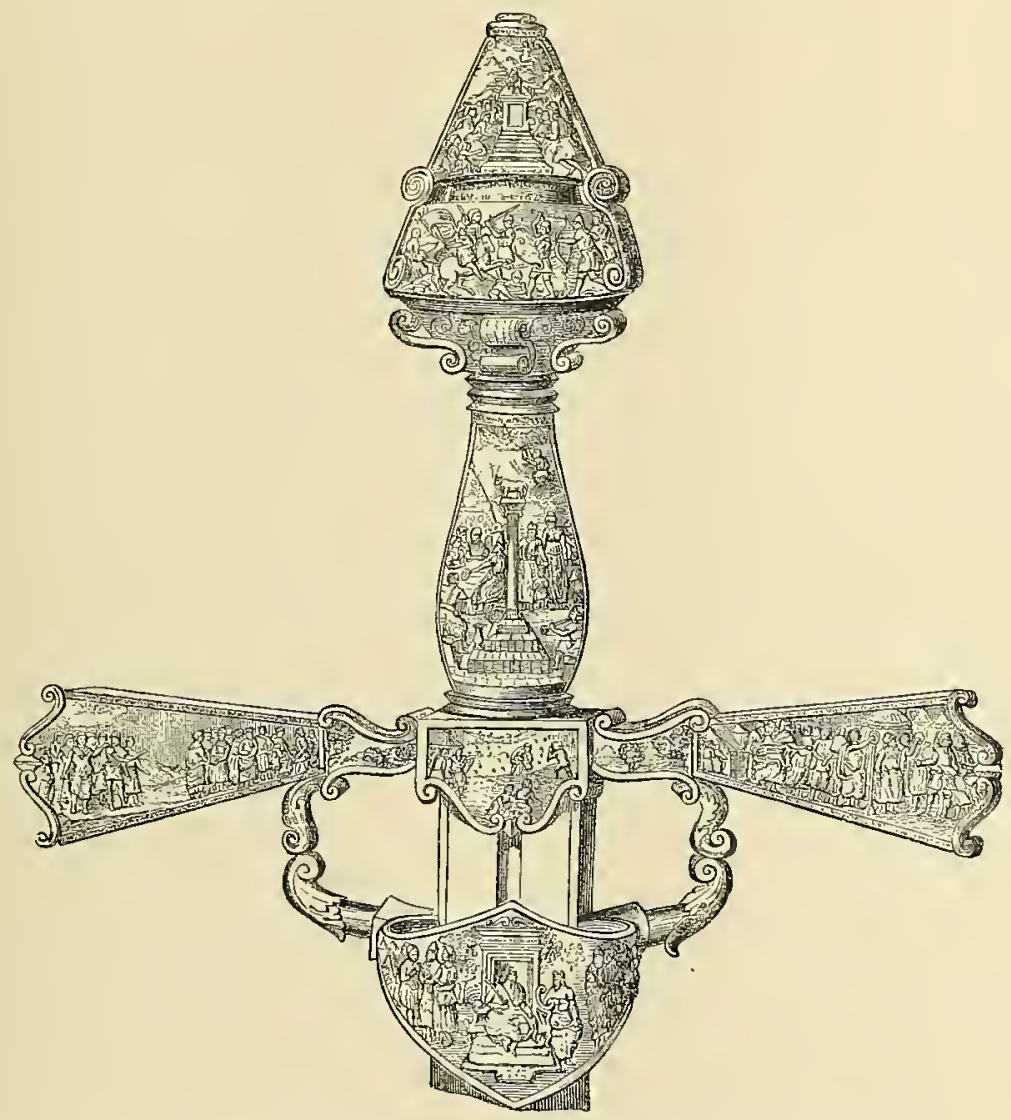

Sword Hilt, XVIIth Century.

From Labarte's Handbok of the Arts of the Middle Ages and Renaissance.

So he hides it. The King knows the deception, and again bids him do his duty, but Sir Lukyn again deceives, and throws in his own sword. At last, stung by the thrice repeated reproaches of Arthur, he flings the magic sword into the river. 
"A hande and an arme did meete the sworde And flourishd three times in the air, Then sunke benethe the renninge streme, And of the duke was seen noe mair."

Yet Richard Cour de Lion claimed to have owned that noted weapon, and gave it to Tancred of Sicily.

"And Richard at that time gaf him a faire juelle,

The good sword Caliburne, which Arthur luffed so well."

Upon the hilt of the sword the word " Jesus" was sometimes engraved, and an oath taken upon the sword was held as sacred as if pledged at the altar. The poets are full of allusions to this. Piers Plowman says that

"David in his daiss dubbed knights, And did him swere on her sword to serve truth for ever."

When Bernardo del Carpio led his troops to the pass of Roncesvalles

"Around his banner flocked in scorn

Of haughty Charlemagne

And thus upon their swords were sworn

The faithful sons of Spain."

Nor would Hamlet be content to part company with his co-witnesses of the ghost of the buried " majesty of Denmark" until they complied with his thrice-reiterated adjuration to swear

$$
\text { "Indeed, upon my sword, indeed." }
$$

And the spiritual visitant leaves them not until he commands them

$$
\text { "Swear by his sword." " }
$$

The solemn use of the Cross-hilt when on the battlefield the dying soldier used the weapon of war as the symbol of the Prince of Peace, has already been alluded to.

An interesting relic was exhibited at a meeting of the English Archæological Association in 1858 . This was the wedding ring with Luther's wed- which Martin Luther married Catharine Bora, or de Boren. ding Ring. It is made of foreign gold. On the inside is engraved the following inscription: " D. Martine Luthero Catherini Boren, I 3 Junii,

\footnotetext{
'Percy, Reliques of Ancient Poetry.
}

${ }^{2}$ Hamlet, act $\mathbf{I}$, scene 5 . 
I 525," the day of his marriage. The ring forms an entire cross, on which is a figure of the Saviour, over whose head a large ruby is set, serving as a nimbus, and above, on a label, are the letters I. N. R. I. Emblems of the Crucifixion are continued round the ring. It belongs to a gentleman of noble family at Wittenberg. ${ }^{1}$

Dr. John Donne bequeathed to his friends, Watton, Herbert, Walton, Hall, and Duppa, seals made of bloodstone, on which was cut a figure of our Saviour extended on an anchor instead of a cross. With one to Herbert he sent the following iines, referring to the change of his old coat of arms from a sheaf of serpents to the cross:

"Adopted in God's Family, and so My old coat lost, into new arms I go. The Cross, my Seal in Baptism, spred below, Does, by that form, into an Anchor grow. Crosses grow Anchors; bear, as thou shouldst do Thy Cross, and that Cross grows an Anchor too. But he that makes our Crosses Anchors thus, Is Christ, who there is crucified for us. Yet with this I may my first Serpents hold ;God gives new blessings, and yet leaves the oldThe Serpent, may, as wise, my pattern be ; My poison, as he feeds on dust, that's me.

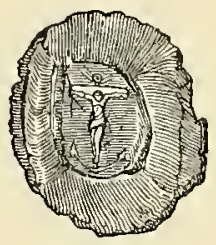

Dr. Donne's Seal. From Walton's Complete Angler. And as he rounds the earth to murder, sure $\mathrm{He}$ is my death ; but on the Cross, my cure, Crucify nature then; and then implore All grace from him, crucified there before. When all is Cross, and that Cross Anchor grown This Seal's a Catechism, not a Seal alone. Under that little Seal great gifts I send, Both works, and prayers, pawns, and fruits of a friend. And may that Saint that rides on our great Seal, To you that bear his name, large bounty deal."

After George Herbert's death, this seal, given to him by Dr. Donne, was found wrapped with the following verse:

"When my dear Friend could write no more,

He gave this Seal and so gave o'er.

When winds and waves rise highest, I am sure, This Anchor keeps my faith, that me secure."

${ }^{1}$ Luther's arms were a cross upon a rose. He placed a crucifix in one of his books, thus showing that he saw no error in the use of the symbol. 


\section{CHAPTER VII}

\section{PROCESSIONAL CROSSES}

$\mathrm{S}$ soon as the Church dared to emerge from the caves and holes of
the earth, wherein she had hid herself during the first three hum dred years of the Christian era, the bride of Christ decked herself with befitting ornaments. Imposing basilicas, rich altars, fragrant incense, glowing lights, emblazoned banners, and jewelled crosses were her accustomed paraphernalia.

It was not merely the dim recollection of the glories of the Jewish Temple which prompted this befitting ornamentation, but we may believe that the same spirit that ordained the ritual of the elder Church moved the hearts of the early Christians and inspired rites, ceremonies, and garniture, which would bear symbolic teaching throughout all time.

The propriety of the Bishop, literally the overseer of

Early Use of Processional Crosses. the flock of Christ, having the symbol of the Cross borne before him, was at once acknowledged.

Among early instances may be cited that of S. Porphyry, Bishop of Gaza, A.D. 396; but even in earlier times processional crosses were used. To one, pre-eminently the standard-bearer of the Cross in his century, does the honor belong of exalting the Cross, like Constantine's Labarum, as the standard of the Church Militant. When S. Chrysostom was Used by s. called upon to battle with the Arians, he resolved to meet chrysostom. them on their own ground. To their magnificent processions with choristers, banners, incense, torches, and crosses, he opposed still more gorgeous pomp and pageantry, and his ritual now is acknowledged as the office of more than sixty millions of Christians. ${ }^{1}$

1 The "Missionary Aspect of Ritualism." by R. F. Littledale, in the Church and the World, 1870, p. 45. The Arians went in procession through the public places of the city on Saturdays and Sundays, chanting hymns expository of their own heresy. S. Chrysostom resolved to countermine them in their own way, "and that the bnsiness might be managed with 


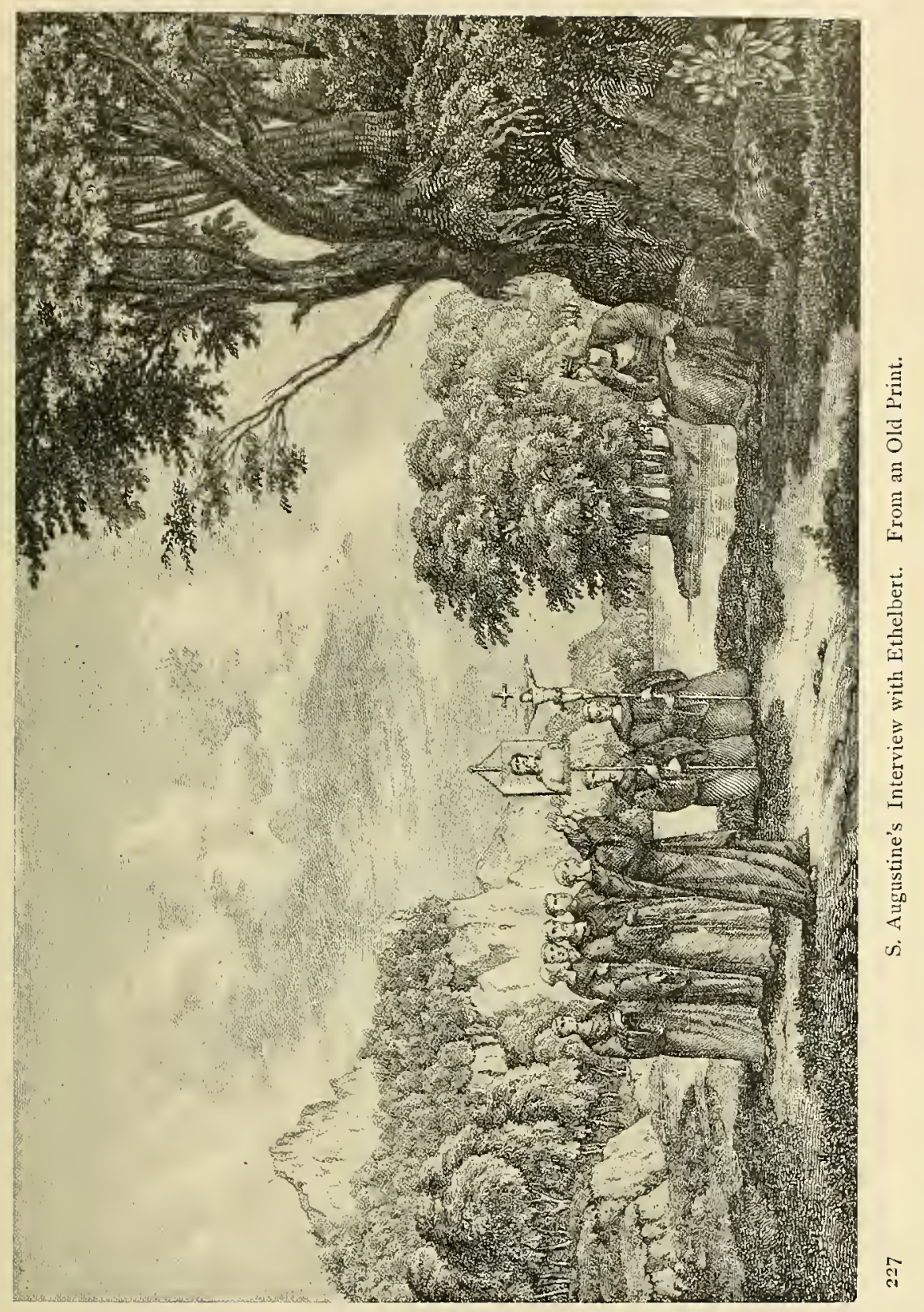




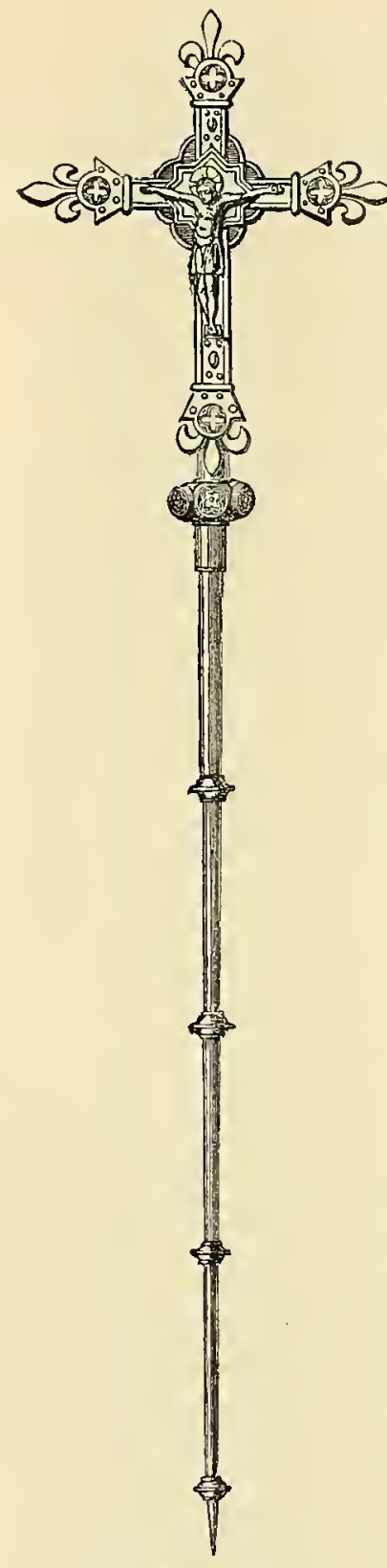

Processional Cross. From Lee's Glossary.

Others profited by the example of the great missionary to the Saxons. When S. Augustine Cross Borne by landed in England, the opportuns. Augustine. ity was not lost of impressing the mind of the Kentish King. A solemn procession, chanting the Litany, was preceded by a silver cross, after which was a painting of the Redeemer, glowing with gold and color. S. Augustine, taking the symbols as his text, preached to Ethelbert of the truths they set forth. In like manner proceeded the Celtic evangelizers of Germany; and the conversion of the great Russian Empire was, at the least, expedited by the gorgeous ceremonial of $\mathrm{S}$. Chrysostom, for when Vladimir sent messengers to Constantinople, the Muscovite envoys, Use in Germany astonished at the vestments, the and Constanti- singing, the lights, the incense, and nople.

processions, reported: "WVhen we stood in the temple [the Church of S. Soplia] we did not know where we were, for there is nothing else like it upon earth; there in truth GoD has His dwelling with men, and we can never forget the beauty we saw there. No one who has once tasted sweets will afterwards take that which is bitter; nor can we now abide any longer in heathenism." ' Still later, in the twelf th century, S. Otto of Bamberg overawed an infuriated heathen mob in Stettin with no carnal weapon, but only the Cross and the litanies of his clergy.

The Cross was taken from the side of the altar, and borne before the procession of clergy Manner of Bear. and laity to certain fixed places, ing the Cross. where it was lowered to receive

greater pomp and ceremony crosses of silver were made at the Empress' charge, and lighted torches were borne before them." Cave, Live's of the Fathers, P. 476, ed. I668.

1 Mooravief, Hist. of the Russian Church, chap. i. 


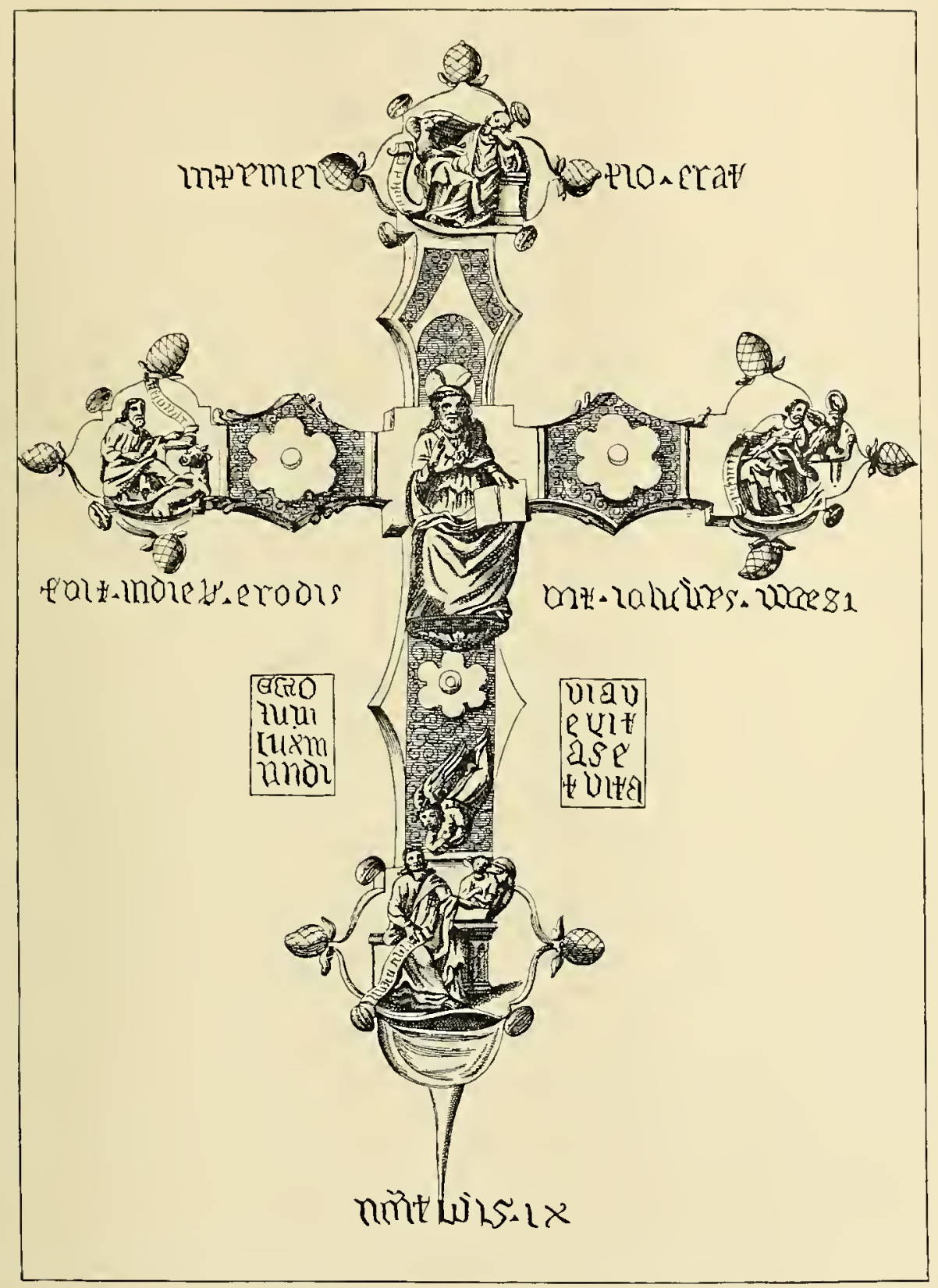

Processional Cross. From Ciampini's Vetera Monimenta. 
the devout kisses of the populace. These places were called stations. Ciampini explains the term, as by their very names reminding the faithful of a military station, that those baptized as soldiers of Origin of the Name Christ composed the Church Militant. Hence the proces"Station." sional cross was at first called the crux stationalis.

Anxious to honor the symbol of their faith, the Christians decked it with their choicest jewels. The frescoes in the subterranean Church of S. Clemente at Rome exhibit gemmed crosses. Charlemagne, following the example of his predecessors, presented a cross covered with hyacinths 'to the Basilica of S. Peter's at Rome. The value incited its theft, and it was replaced by Leo IV., who gave a cross of the purest gold adorned with hyacinths. In after times Innocent II. supplied a cross of silver, one hundred pounds in weight.

Crosses were carried in processions to meet bishops, emperors, kings, and other distinguished persons; also in litanies from a very early period. When Crosses In the course of time the Pope assumed the power of grantwere Carried. ing permission for their use. It had been borne before Apostolic legates since the ninth century. In the eleventh the privilege By Whom. was granted only to such as had received the pallinm. Hence S. Anselm, Archbishop of Canterbury, rebuked Samuel, Bishop of Dublin, for presuming to have the Cross borne before him when not confirmed with the pall. ${ }^{2}$ In the twelfth century the right was obtained from the Metropolitans, and by the thirteenth all the archbishops had the Cross carried before them. The third Council of Lateran, A.D. I2I3, gave to the Patriarchs of Constantinople, Antioch, and Jerusalem authority to carry the Cross everywhere except in the City of Rome, in the presence of the Roman Pontiff, or an Apostolic legate bearing the insignia of his office. The Archbishop of Ravenna bears his Cross not only in his own province, but to within three miles of Rome. The Kings of Hungary also carry the Cross, in memory of King Stephen, to whom the right was granted, in the year Iooo, by Pope Sylvester II. The Archbishop of Nazareth had the right of using the Cross everywhere, and the Archbishop of Toledo, throughout Spain.

${ }^{1}$ Of no ancient gem has there been so much dispnte as the hyacinth. De Boot and De Lact consider it the common amethyst. Niiller says it was a pale, purple stone; Lessing, a reddish brown, fiery, like the jacinth. Considering the strict attention paid to symbolic colors by the early church, it is probable that the color was blue or purple. See King, Precious Stones, Gems, cte., p. I93.

2 S. Anselm, Epist., lib. iii., ep. lxvii., op. p. 393, quoted in Rock, Ch. of Our Fathers, vol. ii., p. 225. 


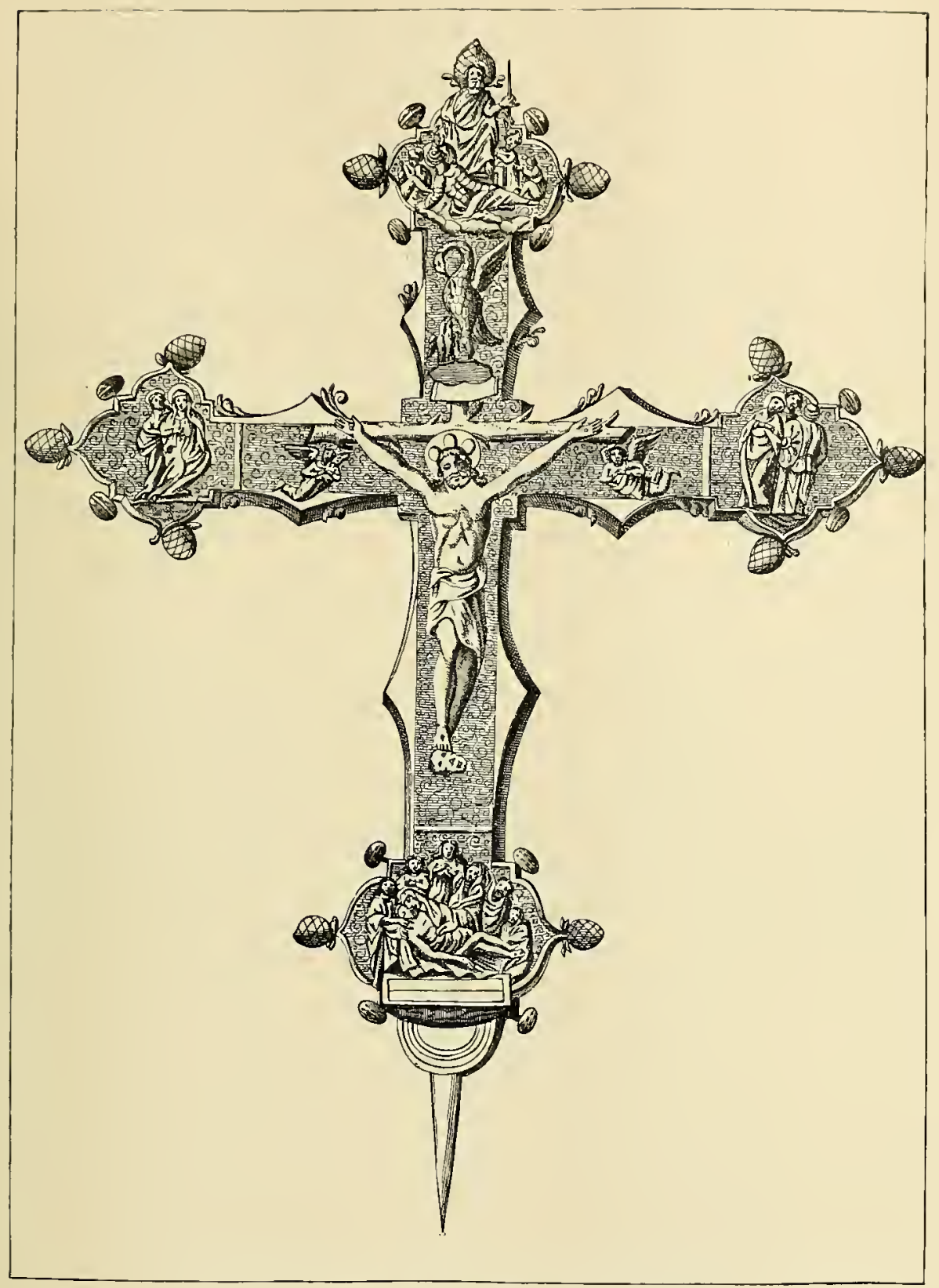

Processional Cross. From Ciampini's Vetera Monimenta. 
The processional cross as an emblem of authority was to be concealed, like the pectoral cross, when a prelate passed through the diocese why concealed. of another. ${ }^{1}$ Disputes frequently arose on this matter. William Wickwane, Archbishop of York, complains to the Pope, that while travelling in the province of Canterbury, A.D. 12SO, having his Cross borne before him according to ancient usage, "Adam de Hales, an officer of my lord of Canterbury, rushed like a madman upon my attendants and scandalously broke my cross in pieces." ?

Archbishop Winchelsey wrote to the Bishop of Lincoln, A.D. I 300 , " commanding him to prevent the Archbishop of York from having his cross borne before him during his progress through that diocese, the laity were not to kneel before him for his blessing, and in all the places which he passed through, divine service and the tolling of bells were immediately to cease." s

About half a century later, A.D. 1354, a compromise was effected between the Archbishops of Canterbury and York. The latter was per-

Compromise between the Archbishops of Canterbury and York. mitted to have his cross borne before him throughout the whole province of Canterbury, on condition of sending to the shrine of $\mathrm{S}$. Thomas à Becket a golden image of the value of forty pounds, representing an archbishop bearing a cross. The image to be sent within two months of his consecration, either by his chancellor, or a doctor of laws, or a knight. The Archbishop of Canterbury was to enjoy the same privilege in the province of York unconditionally. "At this time, or the year previous, it was arranged that when the two Archbishops were in the same procession, their crosses should be borne side by side, if the road were sufficiently wide; that of Canterbury being on the right, and that of York on the left. When the way was too narrow for both to pass on abreast, York yielded the precedence. ${ }^{5}$ Until towards the end of the twelfth century no ecclesiastic, however high his rank, presumed to have a cross borne before him in England except the two Archbishops. About that time the papal legates, though not even bishops, had the Cross carried before them, and wore mitres, by virtue of their office.

\footnotetext{
'Georgius, De ritu Crucis, quoted in Pugin's Glossary.

2 "Constitutions" of John Peckham, Archbishop of Canterbury, quoted in Hart, Eccles. Ricords, p. 103.

${ }^{3}$ Wilkins, Concilia, vol. ii., p, 265.

Ibid., p. 3 I.

${ }^{5}$ Rock, Church of Our Fathers, vol. ii., p. 230. When Thomas a Becket returned from his
} seven years' of exile, he had his cross hoisted high on the ship that brought hin from France. 


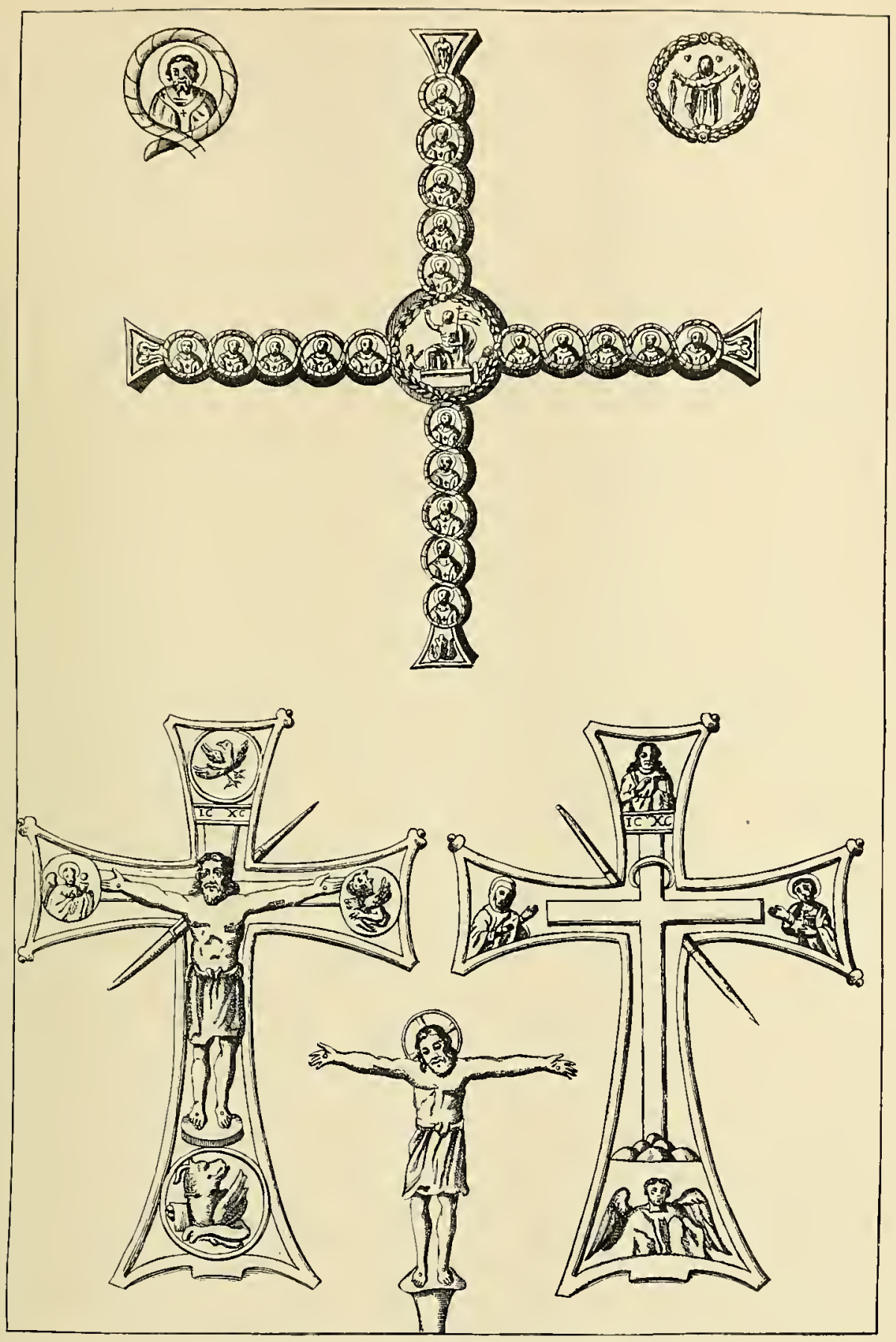

Processional Crosses. From Ciampini's Vetera Monimenta. 
Cardinal Wolsey had " two great crosses of silver whereof one was for his archbishopric, and the other for his legatry." Such crosses were

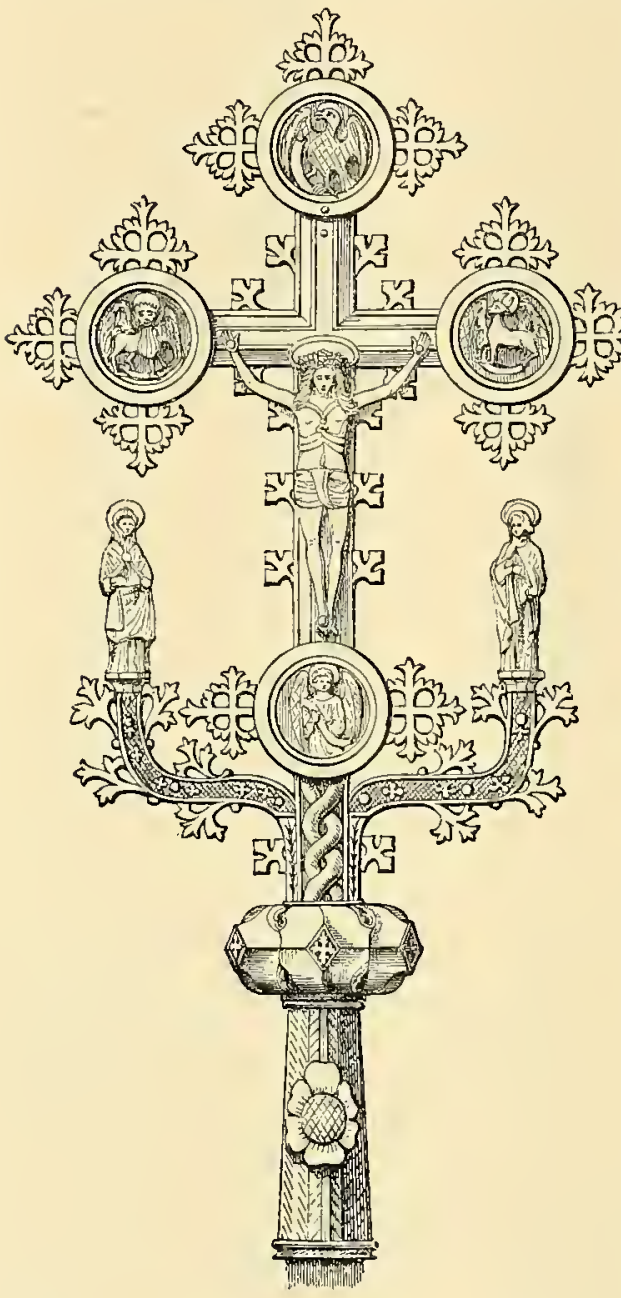

Ancient Processional Cross, Circa 1400.

From Paley's Manual of Gothic Architecture.
Wolsey's Crosses. presumed never to be of less costly metal than silver, sometimes richly wrought of gold and blazing with gems. Sometimes the simple Cross was used without an inage, yet the double Double crucifix appears to have been not un-

Crucifixes.

common; this was to present the image of our Lord both to the people and to the prelate. When the figure was attached only to one side, that was turned towards the Archbishop, as is the present custom when a crucifix is borne before the Pope.

Rock thinks that although it was not according to strict Actual Use of Patriarcha1 ritual usage, yet there are strong grounds for believing that the double-barred, or patriarchal cross, was in a few instances actually used. Anthony Beck, Bishop of Durham, received from Rome the honorary title of the Jerusalem patriarchate. Hence he was en-

titled to an appropriate cross; and among his mortuary gifts to his cathedral is mentioned a silver-gilt patriarchal cross, but whether it was mounted upon a pedestal so that it might be used as an altar cross, or placed upon a staff is not recorded.

In Queen Mary's Psalter, a work of the thirteenth or fourteenth century, which is preserved in the British Museum, a representation is 
given of an archbishop holding a patriarchal cross. Again, on some monastic seals, S. Peter bears this symbol of power.' Cardinal Borgia possessed a Greck double-barred cross of iron, coated with copper, and a reliquary also of this shape is preserved in the Monastery of the Holy Cross, near Avellene. In an old MS. at Lambeth, executed for Archbishop Laud, the arms of the Archbishop of Canterbury are accompanied by a staff patriarchal. ${ }^{2}$

As a double-barred cross was thought to indicate superior dignity above the single, so a triple-barred cross was attributed to the Pope. This seems to be merely an artistic invention. No actual Triple-Barred cross of this fashion is mentioned in the Ordincs Romani, or Papal cross. or in any pontifical ritual; still, as a mark of distinction, the representation has been used, as at S. Denis in the gates of wood brought from Guillon. Gregory the Great is represented as holding in his hand a triple-barred cross, and the typical treatment may be traced even to the Catacombs. ${ }^{3}$

According to the "Sarum use," the processional crosses used in churches in Lent were always of wood painted red, and without the figure of our Lord. From Easter until Ascension the crosses were of crystal or beryl. Such are mentioned in the inventories of the church plate of Lincoln Cathedral.

${ }^{1}$ Rock, Charch of Our Fathers, vol. ii., pp. 2i 7-222.

"Oxford Glossary of Heraldry, art. "Crosier," note.

${ }^{3}$ Bosio, Roma Sottera; Twining, Symbols, pl. viii., fig. 7 . 


\title{
CHAPTER VIII
}

\author{
THE CROSIER AND PASTORAL STAFF
}

DUGIN, in his Glossary", defines "Crosier" " A Cross, or staff, borne by an archbishop . . . this has often been confounded

Confusion of terms Crosier Staff. and Pastoral

by modern writers with the pastoral staff of a bishop, which is quite dissimilar, being made in the form of a crook." The Oxford Glossary of Heraldry says, that " the word [crosier] is properly restricted to the crook of a bishop or abbot." Common usage has applied one name to two articles, which really are distinct, but authority can be cited for the error. "Crosier" may be derived, not from the Latin crut $x$, but the French crosse, which is applied to any thick club-ended article, $c x$. gr., une crosse, a ball bat, le crosse $d$ 'un mousquet, the butt end of a musket. Strictly speaking, the pastoral staff means a staff with a crook head, like that of the shepherd's Definition staff, from which it is derived. The crosier is a staff or rod, of Crosier. with a cruciform termination at the top. Prelates above the rank of bishops had the right of using both crosier and pastoral staff. Bishops and abbots were entitled only to the latter. In Canterbury Cathedral are the tombs of six archbishops. In the hands of three of the effigies are placed the crossed staff, in three the crook. On the seal of S. Thomas à Becket he is represented with the pastoral staff." The Monumental Brass of Francis Halle, Archbishop of Narbonne, 1457, in Paris, bears both the crook and the crosier. The British Archæological Institute, in I848, after investigation, concluded, " that whilst archbishops formerly exhibited the crossed staff as denoting their metropolitan dignity, they also on ordinary occasions used the crooked staff which typified their pastoral charge over their own dioceses, as in the case of other bishops. The carrying of such a cross was a mark that he claimed jurisdiction there."

1 Gentleman's MIag., November, 18.48 . 
It has been supposed that the misapplication of the name crosier to the pastoral staff crept in use from the bearers (croyscrs) of the processional cross, or the bishop's staff. Properly, it belongs to the iusignia of the degree above the bishops, the archbishops. S. Samson. Archbishop of York, in the sixth century, is said to have borne one, as did also S. Casarius, Arclibishop of Arles, a contemporary. In the " Anglo-Saxon period there is nothing positive, although we find that then a procession was often headed by a clerk carrying a golden, or silver, crucifix, in like manner as did S. Augustine when he met King Ethelbert, and the Abbot Ceolfrid when he started from Wearmouth on his pilgrimage to Rome." I Here it is a processional cross or crosier that is spoken of.

By the end of the eleventh century the custom formally began, both in Great Britain and on the Continent, for all archbishops to have carried before them, by one of their chaplains, a staff, terminated, not like that xith Century. of a bishop, with a crook like a shepherd's, but with a small cross richly ornamented with jewels. Romish authorities claim its origin from that See. Afterwards, primates, then archbishops in some parts of Christendom, were allowed its use, and by the beginning of the trvelfth century, it became a general insignia of the latter.

Formerly, the ceremony of the reception of the Cross by the Archbishop of Canterbury was very impressive. As the Primate of all England rode slowly through his See upon the day of his enthronization, he was met by a long procession, in the midst of which

Manner of Reception of the Cross. came one of the monks of Christ's Church, bearing the archiepiscopal cross. When the archbishop caught the first view of this he threw himself from his horse down upon the earth, and in this attitude of reverence and humility awaited with outstretched arms the approach of the sacred symbol. Then aryed in Britthe monk who bore the cross, standing over him, warned the ish Heraldry. prelate of his future duty to love, defend, and govern well the Church entrusted to his pastoral charge. The Cross was then put into the hands

\footnotetext{
${ }^{1}$ Rock, Church of Our Fathers, vol. ii., p. 223.
} 


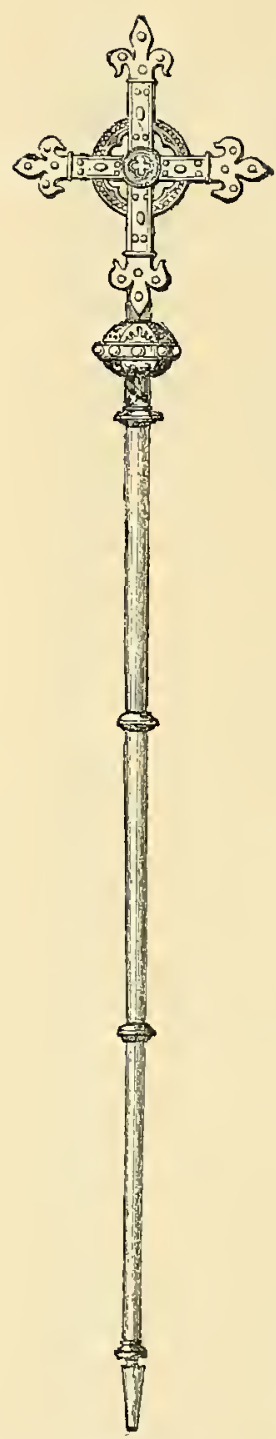

Crosier.

From Lee's Glossary.

of the archbishop, who received it kneeling, and immediately transferred it to that chaplain whom he had chosen for his cross bearer, or croyser. Then arising from the ground the archbishop followed the procession, which, chanting Psalms, brought him to the walls of Canterbury. When the gates were reached, the primate, putting off his shoes, proceeded barefoot, even up to the high altar of his cathedral, where, being robed in his chasuble and wearing his pallium, or pall, for the first time, he consecrated the holy Eucharist, and was in due form installed in his chair.

The first, last, and only time when the archbishop touched his cross, was upon this first primatical visit to his cathedral; ever after it was borne by his croyser. At those parts of the liturgy where the bishop should do so, the archbishop held in his left hand the usual pastoral staff, not his archiepiscopal cross. ${ }^{1}$ Collier says that the archiepiscopal cross was delivered before the pall." Rock, on the contrary, says: "Until he had gotten his pall from the Roman Pontiff, no archbishop might let the cross be carried before him; hence it was that S. Anselm, Archbishop of Canterbury, admonished Samuel, Bishop of Dublin, to leave off doing so." 3

The origin of the pastoral staff has been lost in antiquity. Some have traced it to the Roman Lituus,"

${ }^{1}$ Rock, Church of our Fathers, vol, ii., p. 227. In the Golden Legend we read of Thomas a Becket's martyrdom: "And one Syr Edwarde Gryme that was his croyser put forth his arme with the crosse to bere of the stroke, and the stroke smote the Crosse on sondre, and his arme almoost of." Ed. Wynkyn de Worde, fol. lxvi. Although the archbishops always bad their crosses borme before them by their baguli or croyser, never touching it with their own hands, save on the day of their consecration, yet of S. Thomas a Becket we read that on one occasion he entered Parliament carrying in his own hand his cross and refusing to allow another to do his office, although the Bishop of Hereford proffered his services. Rock gives other instances: Church of Our Fathers, vol, ii., p. $22 \mathrm{~S}$.

Eccles. Hist., iii., p. 450.

${ }^{3}$ Church of Our Fathers, vol. ii., p. 225.

${ }^{4}$ The Liturus was kept in the capital from the time of Romulus, but was lost when the Gauls sacked Rome. Afterwards it was found buried deep in the ashes while everything else was consumed. Plutarch, Life of Numa; see also "Lituus of the Ancient Romans," Archaologia, vol. $x i x$. 
but it has descended from more ancient times. "From the earliest monuments in sacred or profane art - from the most archaic fictile vases of Greece and Sicily, as well as from the oldest frescocs in the Roman Catacombs, we find that during all periods, and among every nation, a wand was considered the emblem of power and command; so luas it continued to be, and still is, under one form or another, from the King's sceptre down to the lowliest staff of office." ' Homer places a royal sceptre in the hand of Achilles. In ancient mythologies the gods are armed with this insignia of power. To Mercury's caduceus, as his symbolic wand, especially when conducting the souls of the departed, reference has already been made. The curved staff of the Egyptian deities might

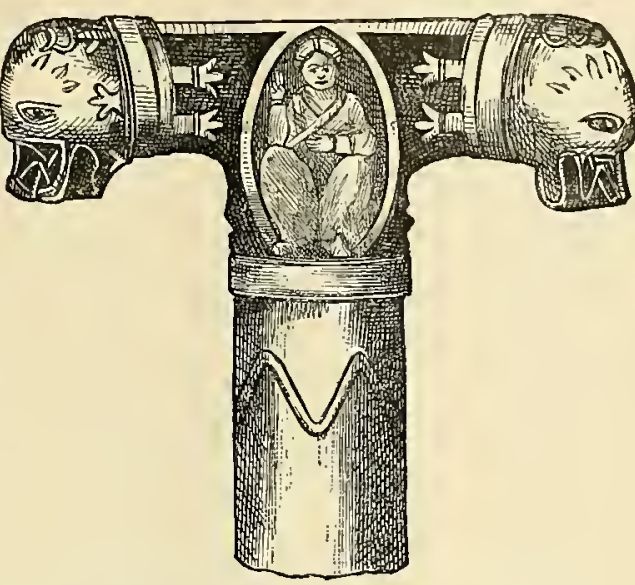

Tau-Shaped Pastoral Staff of Carved Ivory, Limburg. From Lee's Glossary. serve as a pattern for a modern pastoral staff. ${ }^{2}$ When the God of Israel sent Moses to deliver his people, a rod was the instrument of his miracles (Ex. iv., 20); when a token was to be given of a perpetuated delegated authority, Aaron's rod laid up before the Lord budded and brought forth (Numb. xvii., S).

The origin of the pastoral staff was probably to support the feebleness of the aged shepherd of the little flock, but in time it became the acknowledged emblem of the overseeing care of a bishop. In the service, during the reading of the Gospel, the staves were laid down. That there was a practical, as well as a symbolical use of these staves is shown by examples both ancient and modern. Severius. Bishop of Cologne, who died A.D. 400, used his as a walking staff. In the Greek Church at the present day the staves are barely higher than the hand.

The earliest example of a pastoral staff to which we can refer with

${ }^{1}$ Rock, Church of Our Fathers, vol. ii., p. IS3.

2 The Egytian deities, as it will be remembered, bear in one hand the crux ansata, in the other they usually carry a curved staff, the Egyptian symbol of purity. Wilkinson, Ancient Egyptians, vol. ii., p. 266. 


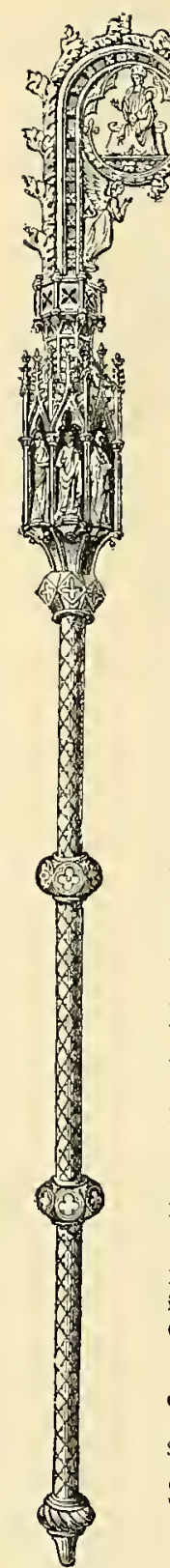

Pastoral Staff.

From Lee's

Glossary.

precision is that of Gaudentius, Bishop of Brescia, cir. A.D. 387. After that time we find that Cæsarius, Bishop of Arles, A.D. 502-542, ${ }^{1}$ who has been claimed

EarIy Example. by some as the inventor, had his staff borne before him by one of his clerks. The fourth Council of Toledo, A.D. 589 , decreed that if a bishop were unjustly deposed, his staff with other insignia shall be returned. Isidore, Bishop of Seville, A.D. 595-636, is our next witness; contemporary with him was S. Remigius, who died about this time, and bequeathed to one of his friends Cambuttam argentam figuratam. "The very word, too," says Rock, "Cambutta, or crook-headed walking-stick, is borrowed by the Church from the Armoric, or rather, our awn British tongue." 2

In Magri's Hicrolcxicon are engravings of the pastoral staves of S. Gregory the Great, A.D. 590, and Gelasius II., A.D. II I8. The former is really a crosier, as it bears a little cross on its top; the latter is terminated with an egg-shaped knob. ${ }^{3}$

In the monastery of Vallombrosa are preserved all the pastoral staves from the time of the founder, Gualbert, in the eleventh century, to the present day. The first is a simple Tau, the next somewhat resembles an adze, and gradually the head bends into a crook. ${ }^{4}$ In the early Anglo-Saxon Church the termination was a knob, as may be seen from the cut given from a consecration service. (Sec page 242.)

The Greek Church has preserved in this matter, as in more important ones, a closer adherence to the customs of the early Pastoral Staff in the Greek Catholic Church, the pateressa, or pastoral staff, Church. being a straight stick used to lean upon, and not much higher than the hand; it was usually made of ebony and ivory, the handle often formed of intertwining serpents. Fig. I is the usual form; Fig. 2 is from the icon of S. Demetrius of Rostoff. ${ }^{5}$ (Sce page 2.12.)

1 Rock, Church of Our Fathers, vol. ii., p. I82, note.

${ }^{2}$ Ibid., p. Is 4 .

"See "Baculus" and "Mitra." Magri, Venice, ed. I735, quoted in Rock, vol. ii., p. 206, note.

${ }^{4}$ Forsyth, Italy, p. 83.

Greek Cluurch in Russia, p. $3^{S}$ and plates vii., ix. 
In the twelfth ccutury pastoral staves were slightly ornamented, perhaps a century carlier. A fan-shaped staff, presumed to be of the eleventh century, is one of the ornaments of the South Kensington Museum, acquired at the cost of $£ 200$. In the Ornamentation. fourteenth and fifteenth centuries ivory, gold, silver, and enamel were freely used, so that the staff, apart from its artistic value, was of great worth and became a temptation even to prelates, for it is recorded that Odo, Bishop of Baycux, stole (" conveyed," as the more courtly Pistol would express the act of such a high dignitary) a staff from Durham Cathedral.'

Sometimes the staves were made of bone and wood, symbolizing the hardness of the Law and the mildness of the Gos-

Symbolism of pel. The crook reminded the bearers of a shepherd's office to restrain and to reclaim the wandering lambs. The lower end is shod with iron, for the motto must be appropriate

\section{"Curva trahit mites}

Pars pungit acuta rebelles."

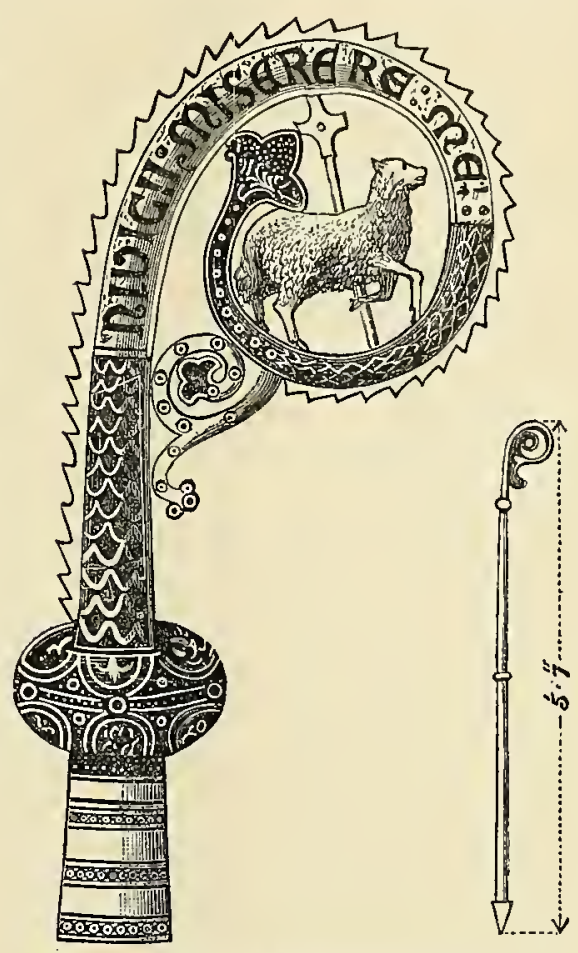

Pastoral Staff. From Lee's Glossary.

Often on the curvature was inscribed "Dum iratus fucris miscricordice recordabcris, ne ob culpam gregis ira turbct in Pastore oculam rationis "$i$. e., "When thou art angry, thou shalt remember mercy, lest wrath for the sin of the people disturb the discernment of judgment in the pastor." Sometimes upon the knob separating the crook, or " cruche-head," as it was anciently called, from the staff, was the word homo, to remind the bishop that he is of like passions with his flock, and near the iron ferule was parce, spare, lest he should forget that to the merciful only mercy is accorded. ${ }^{2}$ Upon the knob of the pastoral staff of Raguefredus, Bishop

'Dugdale, Monasticon, vol. i., p. 516.

${ }^{2}$ Durandus sums up the whole. "At the consecration of a bishop the consecrator says to him, 'Accipe, baculum pastorales offici, ut sis in corrigendis vitiis pie' salvizes.' The apostle says 
of Chartres, who died A.D. 960, were represented six vices overcome by their corresponding virtues.

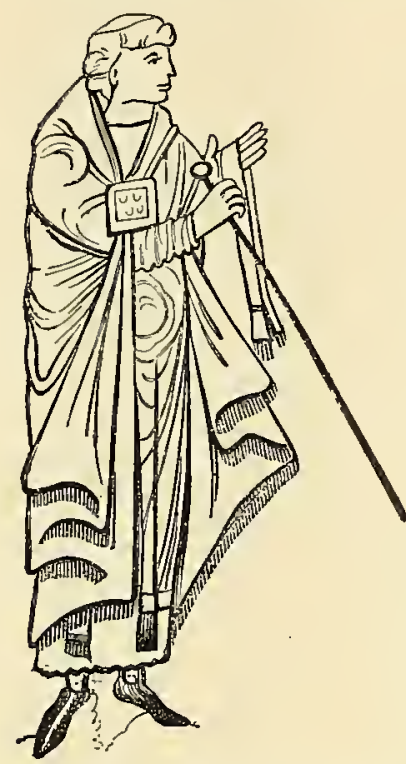

Pastoral Staff with Knob. From Rock's Church of Our Father's.

Faith, Chastity, Charity, Temperance, Bounty, Peace,

Idolatry, Impurity, Envy, Gluttony, Avarice, Strife.'

In the twelfth and thirteenth centuries the head was often ornamented with symbolic figornamentation ures, such as S. Michael slaying the of the Crook. dragon, the serpent being formed by the crook, ${ }^{2}$ an allusion to the rod of Moses, and also the symbol of Prudence and Wisdom.

The unicorn was also appropriately used. It is an early Christian symbol, adopted from remote antiquity; for it appears among the Egyptian hieroglyphics and the allegorical animals in the Persian mythology; it is represented on the walls of Persepolis, sometimes with, at others without, wings, engaged in combat with a lion. The Christians also adopted the pagan significance as a symbol of Purity and Strength, to which they added that of Chastity, as it was believed that if the animal soiled its skin, it pined away and died. The horn of the unicorn was often used by the Fathers as a type of the Cross, ${ }^{3}$ for which it had also a peculiar significance, it being popularly supposed that in cups made from this material poison became innocuous.

(I Cor. iv. 21), 'Shall I come to you with a rod?' By the pastoral rod or staff may be understood the sacerdotal power which Christ conferred when He sent the Apostles to preach, commanding them to take staves. Moses was sent into Egypt with a rod. The staff, therefore, may be viewed as a token both from the Law and the Gospel. For Moses at the command of the Lord had a rod which performed the most stupendous miracles. By the pastoral staff is likewise understood the authority of doctrine. For by it the infirm are supported, the wavering are confirmed, those going astray are drawn to repentance. It resembles, and is called a crook, in allusion to that used by shepherds to draw back and recall the sheep of their flock which have gone astray." Pugin, Glossary, art. "Pastoral Staff."

1 loid.

${ }^{2}$ Pistolesi, Il Vaticano, vol. iii., plate lxxiii.

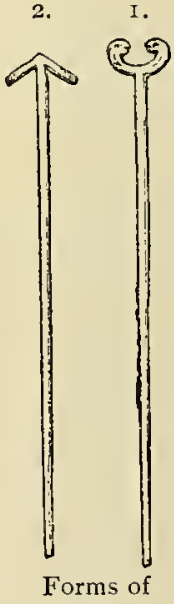

Pateressa.

${ }^{3}$ Justin Martyr on Deut. xxxiii. 17, "Mis horns are like the horns of unicorns; with them he shall push the people together to the ends of the earth."-Dial. with Typho., § $9 \mathrm{I}$. 
In the Middle Ages, the unicorn was an emblen of the Incarnation, for it was supposed that it could be caught and tamed only by a pure virgin; henee in art, the virgin became a type of the blessed Virgin, the unicorn that of her Son. From its love of solitude it was judged to be peculiarly appropriate to the staff of an abbot. An early example is the staff of $\mathrm{S}$. Boniface, which is preserved at Fulda, Germany, and is of the seventh or eighth century. ${ }^{1}$

Bishops were formerly invested with the pastoral staff and ring by the king. S. Anselm was hurried into the presence of William Rufus, and these insignia of office being thrust upon him, he

Bishops Receive the Staff from the King. was forced into the Church while the Te Dcun was chanted, although he objected to his eleva-

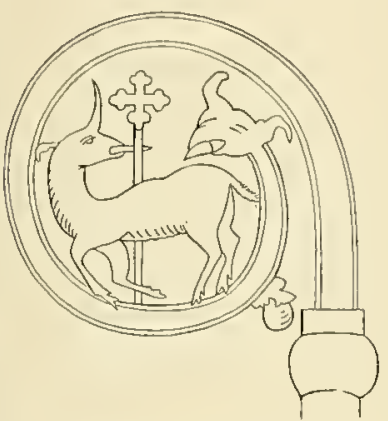

Pastoral Staff of S. Boniface. From Twining's Symbuls. tion to the See of Canterbury on the ground of being a subject of Normandy. ${ }^{2}$

As a reminder of delegated authority the crook was turned toward the consecrator when he delivered the staff into the hand of the ordained prelate. ${ }^{3}$

Crook Turned Toward the Bishop.

In modern times the Pope does not use a pastoral staff except in the diocese of Treves. Two reasons are assigned by Thomas Aquinas and Durandus; one that the Pope's power is not limited (the The Pope's Use
curvature of staff implying jurisdiction over a fold as a of the Staff. curvature of staff implying jurisdiction over a fold as a shepherd, whilst the Pontiff claims unlimited sovereignty, the other, in commemoration of a miracle. S. Eucharius, the first bishop of Treves, raised to life his friend $S$. Maturus by the staff which he received from S. Peter. Honorius, Autun, and Peter of Cluny record this miracle. Egbert, Archbishop of Treves, A.D. 980, obtained this staff from Werinus, Archbishop of Cologne, to which place it had been transferred by the former Archbishop Bruno. This history is engraved on its case.

But that the Bishops of Rome, in early times, used staves is indubitable. The staves of Gregory the Great and Gelasius have been referred to. Paschal II. was consecrated A.D. IO99, and special mention is made of the placing of the staff in his hand. Until the twelth century at least,

${ }^{1}$ Twining, Symbols, pl. lxxxv,, fig. I.

2 Eadmer, Hist. Cantuar, lib. i., p. 16.
${ }^{3}$ Purchas, Directorizm Anglicanum, p. 157.

"Pugin, Glossary, art. "Pope." 
it seems that this symbol of Episcopal jurisdiction was used in the See of S. Peter as well as in others. Luitprand, Bishop of Cremona, A.D. 964, was an eye-witness of the deposition of Pope Benedict V. He says, "After this he put off from him the fallium, which together with the pastoral staff that he carried in his hand he gave up to the Pope, which staff the Pope broke and showed it to the people." '

When a bishop was deposed we have seen that his staff was taken from him and sometimes broken. The Bishop of Dorchester, at the

Staff Taken Away at Deposition.
Synod held by Leo IX., had great difficulty in preventing his staff from being broken, as it was proved that he was ignorant of his duties." According to tradition, when the Archbishop Lanfranc, at the desire of IVilliam the Conqueror, would deprive S. IVulstan, Bishop of Worcester, of his diocese, because the Anglo-Saxon prelate could not speak the language of the Normans, $\mathrm{S}$. Wulstan refused to give up his bishopric to any one save his old sovereign, and proceeding to his grave in the Church of IVestminster, where the council of the bishops was then assembled, thrust his pastoral staff into the marble tomb of the late King, Edward the Confessor, and left it standing. The grave recognized the pious trust, and retained it so firmly fixed that no hand but that of its rightful owner could withdrav it. ${ }^{3}$

The pastoral staff was also given to abbots and abbesses at their consecration. The latter also received a ring, which was not bestowed upon Staff Given to Abbots and Abbesses. the former unless his were a mitred abbey. According to the present Roman Pontifical, the abbots receive the staff, but not the abbesses. In the English convents under the Roman rule, a remembrance of it, according to the " Sarum use," is preserved, a staff being placed by the side of their chair in the choir."

It has been asserted that in monuments, abbots are distinguished from bishops by holding the staff in the right hand while bestowing the benediction with the left, but this rule was not strictly observed. ${ }^{5}$ An

1 Rock, Church of Our Fathers, vol. ii., p. 206, note. According to Mosheim it would seem that Leo was deposed, not Benedict.

${ }^{2}$ Henry of Huntington, Hist., lvi. ; Archaologia, xvii., p. 37.

${ }^{3}$.Ailredus Abbas Rievallis de Iita ct Miraculis Edwardi Conf. Decem Scriptores, col. 406, quoted in Rock, Church of Our Fathers, vol. ii., p. Ig6.

"Ibid., p. I94. "Several church monuments show us abbesses with the pastoral staff." One of Lady Montacute's daughters, who became an abbess, is represented on her tomb in Oxford Cathedral, "having her staff leaning against her left shoulder."

" Oxford Glossary" of Heraldry, art. "Crosier." 
erroneous statement is given by a high authority that " a bishop carried his staff with the crook turned outwards, to denote his jurisdiction over a diocese," an abbot with his inward, i. $c$., " towards him- Manner of Holdself to signify that his jurisdiction reached over the mem- ing the Staff. bers of his own house.' But there is nothing in any ritualistic writer to favor such a view, ${ }^{2}$ and the testimony of the monuments is, that the position of the staff and hand in benediction was common to both. The Brass of John Estney, Abbot of Westminster, A.D. I 498 , represents him with the crook turned outwards and giving his blessing with the right hand. S. Cuthbert is represented holding his staff turned inward. So also is the effigy of a bishop in Temple Church. In the Louterell Psalter an abbess turns her staff outwards. In Litchfield Cathedral there is a statue of a bishop with the crook turned inward. ${ }^{3}$

It has also been asserted that the abbot's staff, by way of distinction from that of a bishop, must have a long linen napkin attached to it below the crook; that this "was generally laid aside by the abbots of exempt abbeys, but is always seen attached to the crosiers of abbesses." "4 The only formal sanction for such a rule came from S. Charles Borromeo, there is no rubrical authority and, whatever may have been the custom in Italy during the time of the archbishops of Milan, no such distinction was made in England."

The wexillum probably was not a mark of difference, but merely a sudarium, or napkin, used to prevent the staff from being tarnished by the warmth of the hand, or the copper beneath the gilding from giving to the hand an unpleasant odor. This veil was

Vexillum as a Sudarium.

1 Maskell, Monumenta Ritualia Ecclesia Anglicana, vol. iii., p. I37.

2 Rock, Church of Our Fathers. vol. ii., p. 2 Io.

${ }^{3}$ For other examples, see Ibid., p. 2os; also Cutts, Slabs and Monuments. In the monumental tomb of Bishop B. T. Onderdonk (the exquisite workmanship of that accomplished architect, Richard Upjohn), in Trinity Church, New York, the crook is turned inward. In future years some wiseacre of an archæologist may, perhaps, discover that it was symbolical of his suspension from the duties of his office.

"Milner, on the "Limerick Crosier," Archaologia, vol. xxii. ; Gloss. of Heraldry, "Crosier."

5 "Baculus pastoralis . . . orario aut sudario non ornatur si episcopalis est quo insigni abbatialis ab illo distinguitur," Acta Fecl. Netiolan. De Baculo Pastorali Instruct. Supell. Eccl., lib. ii., p. 627, quoted in Rock, vol. ii., p. $2 \mathrm{II}$. The vexillum is attached to the staff of Bishop John de Sheppy, of Rochester, Ob. 1360; Bishop Vasey of Exeter, cir. sixteenth cent. : John Estney, Abbot of Westminster, I 498 . The Brass of Bishop Oldbam of Exeter represents his as rolled two or three times around his staff. It is shown also upon the staff of William of Wykeham in Winchester Cathedral.-Rock, vol. ji., p. 2ıx, Gentleman's Mag., Dec., IS63, p. 692. In the Nuremberge Chronicle are many woodcuts of bishops with the napkin fastened by a string to the top, which is capped by a funnel-shaped ornament. 
made either of white silk, or of linen, with a gold fringe at the lower edge, and one or more tassels depending from it.

An interesting relic, a crosier or pastoral staff belonging to the nonCrosier Belonging jurors was, until I $\$ 39$, preserved in the family of John to Non-jurors. Crossley, Esq., of Scaitcliffe, near Todmer, England.

Pastoral staves were borne before the coffin at funerals, and either buried with the deceased prelate, or suspended over the tomb. When represented on the tomb they were sometimes placed on the right, sometimes on the left hand; at other times athwart the effigy. There may have been a symbolical reason which has been lost.

The use of the pastoral staff, crosier, and processional cross has continued almost without intermission from the time that the Church emerged from the Catacombs unto this day. The first Prayer-Book of Present at Holy Edward VI. ordered that " whenever the Bishop shall celeCommunion. brate the Holy Communion in the church or execute any other public ministration, he shall have . . . his pastoral staff in his hand, or else borne or holden before by his chaplain."

Pastoral staves were carried at the coronation of Edward VI. and of Elizabeth, at the latter, by Archbishop Cranmer himself, $i . \epsilon$., probably by his croyser. The Hicrurgia Anglicana gives instances from that time to the present." Among others, "The crosier or pastoral crook of Archbishop Laud with the walking stick, which supported his steps in his ascent to the scaffold . . . have been lately deposited " in S. John's College, Oxford. ${ }^{2}$ At the funeral of that stout anti-Romanist and true Catholic, John Cosin, Bishop of Durham, I67 I, the York herald bore his crosier. The last instance mentioned in the Hicrurgia Anglicana is that of Bishop Mews, I 706.

The Erastian period of the Church intervenes; after the lapse of one hundred and fifty years, the crosier was borne at the funeral of Bishop Doane, and since then, there have been several other instances, both in the Anglican and in the American branches of the Church.

As in other ecclesiastical work, so in the lesser paraphernalia of the Church, the skill of Ireland during the Middle Ages deserves special Irish Pastoral mention. Mitres, bells, vestments of glorious handiwork staves. have been preserved, enough to make us mourn over the treasures lost. Crosiers and pastoral staves, rich in workmanship, and

${ }^{1}$ Hierurgia Anglicana, pp. 8I-89. $\quad{ }^{2}$ Ingraham, Memorials of Oxford, Hierurgia, p. 83. 
hallowed with pious legends, the deligglut of an archæologist, still exist in private collections and in that of the Irish Academy. For example, the pastoral staves of S. Finchue in Brigoun, and of S. Muran in Fahan. These are prized, not so much for their jewels and artistic value, as for their miraculous virtues, affording an oath to the common people, which, as recorded by Giraldus Cambrensis in I 85 , was esteemed much more binding than one upon the holy Gospels. ${ }^{1}$

Pre-eminent among staves is the crosier of S. Patrick, commonly known by the name of the "Staff of Jesus" ; it was held in the greatest reverence, not only on account of the belief that it had once belonged to the Apastle of Ireland, but from the legend

S. Patrick's Crosier. which connects it with our Saviour himself. No mention is made of this by the Saint's most ancient biographers, but such a trifle must not interfere with the antiquarian's enjoyment of the history as delivered by Joceline in $\mathrm{I} 85$.

"S. Patrick, moved by divine instinct or anjelick revelation, visited one Justus, an ascetick, who inhabited an Island in the Tyrrhene Sea, a man of exemplary virtue and most holy life. After mutual salutations and discourse, he presented the Irish apostle with a staff which he averred he received from the hands of Jesus Christ himself. In this island were some men in the bloom of youth, and others who appeared aged and decrepit; S. Patrick conversing with them, found that these aged persons were the sons of the seemingly young. Astonished at this miraculous appearance, he was told that from their infancy they had served God, that they were constantly employed in works of charity, and their doors were open to the traveller and distressed; that one night a stranger came to them with a staff in his hand, and they accommodated him to the best of their power; that in the morning he blessed them and said-' I am Jesus Christ, whom you have always faithfully served, but last night you received me in my proper person.' He then gave his staff to their spiritual father with directions to deliver it to a stranger named Patrick, who would shortly visit them; in saying this He ascended into heaven, and left us in that state of juvenility in which you behold us; and our sons, then young, are the old decrepit persons you now see." Joceline goes on to relate that with this staff our apostle gathered every venomous creature in the island on the top of the mountain of Cruagh

${ }^{1}$ Mant, Hist. of the Ch. in Ireland, vol. i., p. 68. 
Phadraug in the County of Mayo, and then precipitated them into the ocean.

“'When S. Malachy became primate," as related by an author lately cited, "Nigellus, who had usurped the primatial See carried the staff away from Armagh; and such was the importance attached to the possession of it that many persons in consequence adhered to the usurper. But Nigellus did not retain it long; it was again restored to Armagh," where it was made an object of superstitious veneration. In the time of Giraldus Cambrensis, in I 177 , during a pillage of the city and abbey, it was stolen and carried to Dublin. This theft was of such great importance in the estimation of that superstitious age, as to merit a record in the annals of the country, as the breaking of it had been recorded on a former occasion in I027. Being then presented to the Cathedral of the Blessed Trinity, it was there preserved with reverential care, and became the subject of a miracle in $145 \mathbf{I}$. During a great tempest, the chest, containing the Staff of Jesus and other relics, was broken to pieces by the falling in of the east window, but the staff, entirely undamaged, was found lying on the top of the rubbish, although the other relics were entirely buried under it. ${ }^{1}$

An interesting historical relic has been preserved in Canada. At the consecration of the Roman Bishop of Toronto, in 1859 , the crook of the crosier used by Bishop De Carbonel was one which formerly belonged to S. Filiam, and was borne by him at the blessing of the Scottish army at Bannockburn. It was the gift of James III., in 1487 , to John Daire or Dewar. It is of solid silver and contains a relic covered with white stone. ${ }^{2}$

Bishop Doane's staff was a gift from Mr. Beresford Hope of England. It was a simple pastoral staff carved of the ancient oak which had been Bishop Doane's removed in the restoration of $S$. Augustine's, Canterbury. Staff.

It is now in the possession of his son, the Bishop of Albany.

The first pastoral staff ever made in this country, was that given to Bishop Hopkins in 1866 . It is of oak, “ adorned with color, silver, gilt, Bishop Hopkins's and enamel. In the crook is the figure of the Good Shepstaff. herd standing with a lamb in his arms and a sheep on either side, all of silver. Eight enamelled medallions on the knob give the condensed apostolic succession from S. Paul through S. Augustine of

1 Warburton, History of Dublin, vol. i., p. I8I, quoted in Mant's History of the Chuch in Ireland, vol. i., p.68. $\quad 2$ Gentleman's MIag., 1853, p. 420; Nezw York Times, Dec. 7, I859. 
Canterbury, Matthew Parker, and Bishop White." " The cross is of the Celtic pattern, richly carved on its four faces. The upper piece is five feet high and four feet across the arms; the shaft being seven feet; and the steps (three in number) are each one foot in height, making the entire height fifteen feet. The western face has the descending Dove on the heart of the Cross, with the monograms of the sacred names; and fulllength figures of the Twelve Apostles, three in each arm of the Cross. The seven-fold rays of the Dove pass behind the lower three down the whole of the shaft, on which appears the Bishop's pastoral staff grasped by his left hand, and with its crook turned outward. All around are stars which signify 'those who turn many to righteousness.' On the eastern face are the more personal mementos. The other two sides bear the vine, with leaves, tendrils, and bunches of ripe grapes, running up over the ends of the arms and to the gabled top. A circular crown supports the arms relieved by four pierced openings, and marked in each division by seven small knobs showing that the crown is a spiritual crown." Cost about one thousand dollars."

' Life of Bishop Hopkins, p. 358.

${ }^{2}$ Ibid., p. $4+2$, note. 


\title{
CHAPTER IX
}

\author{
PECTORAL CROSSES
}

$\mathrm{L}^{0}$ ONG before the Christian era, Oriental nations made use of pectoral ornaments which would seem to have served some represent-

Ante-Christian ative purpose, from the fact that even after death they Pectoral Cross. accompanied the wearer, and are found in the sepulchres of various ancient peoples. As a symbol of the deity, of sanctity, of eternal life, or of blessing, they were also depicted on the breast of male figures in the mural decoration of Egyptian and Etruscan tombs.

A picture found in Thebes, with the date of the nineteenth dynasty, about 1100 B.C., represents Asiatics bearing tribute, having around their

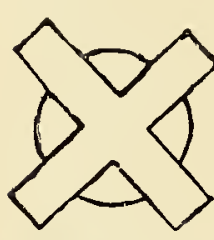

Cross Worn by one of the "Seven Chiefs against Thebes," circa B. C. I 200 .

From Brock's The Cross: Heathen and Christian. necks crosses of equal limb. Wilkinson, in his Ancicnt Egypt, gives the same form on the breast of two warriors, and Rossilini also on the neck of an Asiatic." Another form is portrayed on a warrior, one of the "Seven Chiefs against Thebes," about I 200 B.C., painted on an Etruscan alabaster vase at Volterra, Italy. ${ }^{2}$

In the British Museum, we have a representation of Samsi-Vul IV., King of Assyria, B.C. 835, wearing a pectoral cross quite similar to the Maltese of modern date, and about three times the size of the cut. This is believed to indicate that the wearer was not only a king, but a priest. He flourished before the era of Isaiah, and was a contemporary of Elisha. Another Assyrian monarch, Assur-Nazir-Pal, whose imposing effigy in stone may be seen in the same museum, is also decorated with a similar cross. Dr. Schliemann discovered at Mycenæ and Hissarlik, the supposed site of ancient Troy, necklaces and pendants, in the shape of crosses and stars formed of combined crosses, and others in the form 
of four leaves, wrought in thin gold work with elaborately ornamental detail.

The cross as a sign of Christianity did not at first come into public use in the Church, probably not until the time of Constantine, after persecution had ceased, and when the sacred badge might be regarded with proper respect. Inasmuch as amulets toral Christian appear to have been worn in the most ancient times, the Crosses. adoption of the Christian symbol for this purpose became a matter of course.

The earliest mention that we find of the Christian use of a cross suspended from the neck, is that of Pope Hilarius, A.D. 46I. Gregory the Great wore a cross, but its precise form is not mentioned. The Emperor Justin, A.D. 5 I9, presented to the Pope a pectoral cross. The Agmus Dci stands in the centre, the bust-length figure of our Lord in the act of benediction is placed at the upper end that of S. John below. The Emperor and his wife Flavia Euphemia are at the transverse ends. In the mosaics which adorn the Oratory of S. Venantius at Rome, completed in the seventh century, the blessed Virgin is represented with a Greek pectoral cross on her bosom. ${ }^{2}$

Nicephorus, A.D. SII, sent to Leo III. a golden pectoral cross enclosing some portions of the true Cross. But it was not until the fourteenth century that Pectoral Cross as Cross Worn by Samsi-Vul IV.,

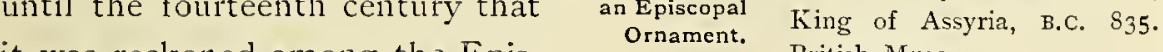
it was reckoned among the Epis-

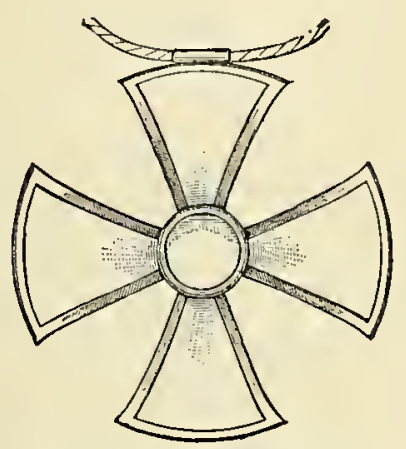
copal ornaments, when special prayers were From Brock's The Cross: Heaused at the time of its bestowal.

When displayed, it was a symbol of jurisdiction, and therefore it was concealed when a bishop entered the dioJurisdiction. cese of another.

The custom of wearing pectoral crosses, or cnkolpia as the Greeks call them, appears to have been more common, among the laics as well as clergy, in the Eastern than in the Western Church, and a relic of no

'Ciampini, Vetera Monimenta, tom. ii., p. Io8, tab. xxxi.

${ }^{2}$ This seems a more reasonable origin than that assigned by Innocent III., who says that the Bishop wears a pectoral cross in imitation of the Jewish High Priest's breast-plate or the gold plate on his brow.-Walcott, Sacred Archaology, art. "Cross, Pectoral." 


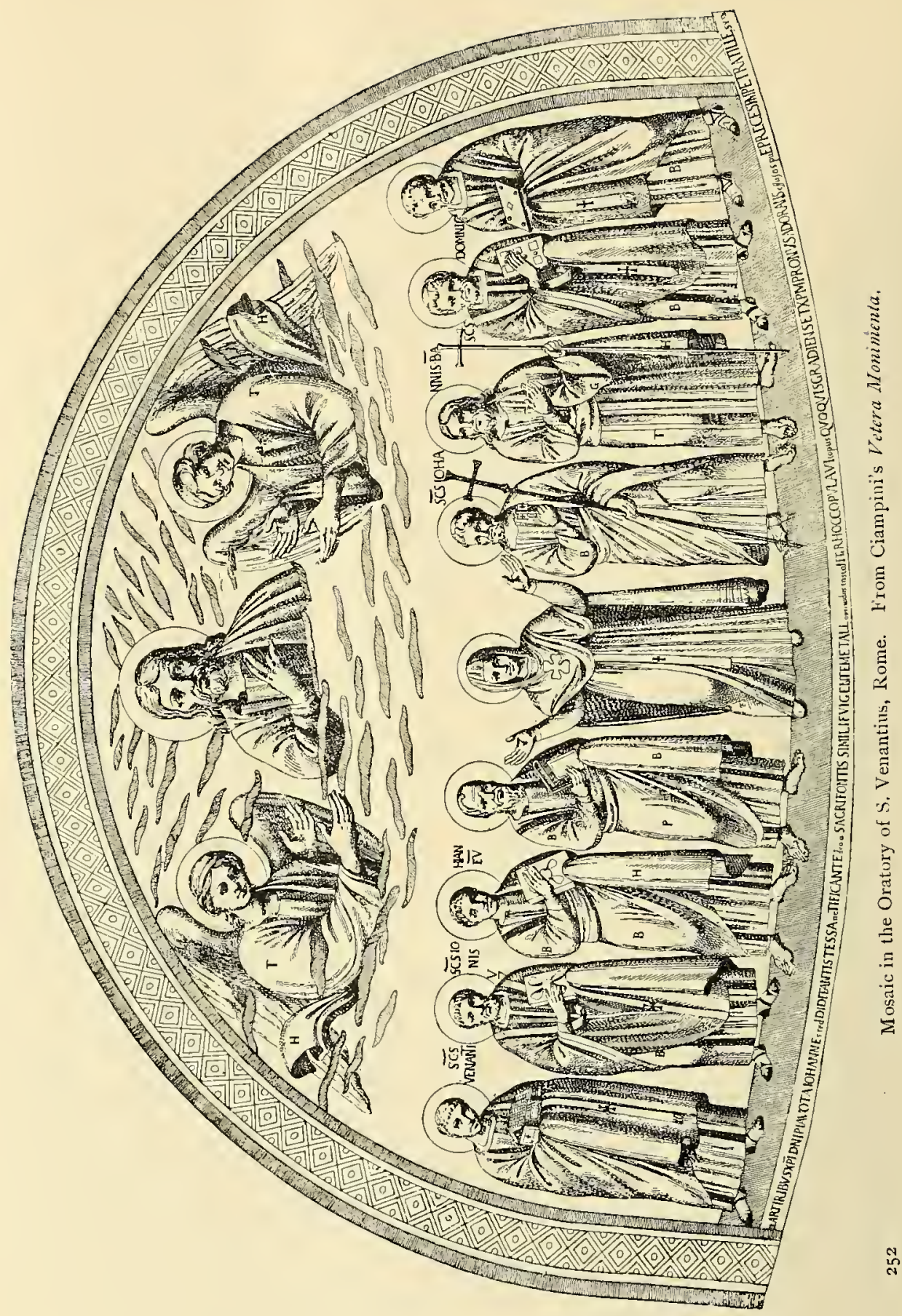


slight value from an historical point of view is preserved in the library of Durham Cathedral, England. It is the Cross of Greek form taken from the breast of $S$. Cuthbert (seventh century) when his tomb was opened in 1827 .

Enkolfia were not always cruciform. The name properly belongs to reliquaries of any shape worn suspended on the breast. Sometimes they were square bearing the monogram $\mathrm{X} \mathrm{P}^{\prime}$ or $A \Omega$, at other times they were in the form of small bottles of gold. Gregory the Great, it is said, first made them cruciform. Walcott mentions an ancient pectoral cross, worn by a bishop, bearing the appropriate motto, " Emmanuel, God with us, the Cross is Life to me, to thee Death, an enemy." '

In Labarte's Handbook of Arts of the Middle Ages and Renaissance is given a curious Byzantine pectoral cross now in the possession of A. B. Hope, Esq. It is formed of two enamelled gold plates, making a reliquary. On the one side is Christ crowned with a cruciform nimbus, his feet on a suppedancum and separated; over his head is the monogram. The presence of the Father is indicated by an initial $\pi(\alpha \tau \eta \rho)$, at the foot of the Cross is the skull of Adam : the blessed Virgin and S. John occupy their respective places, and the words, "Be-
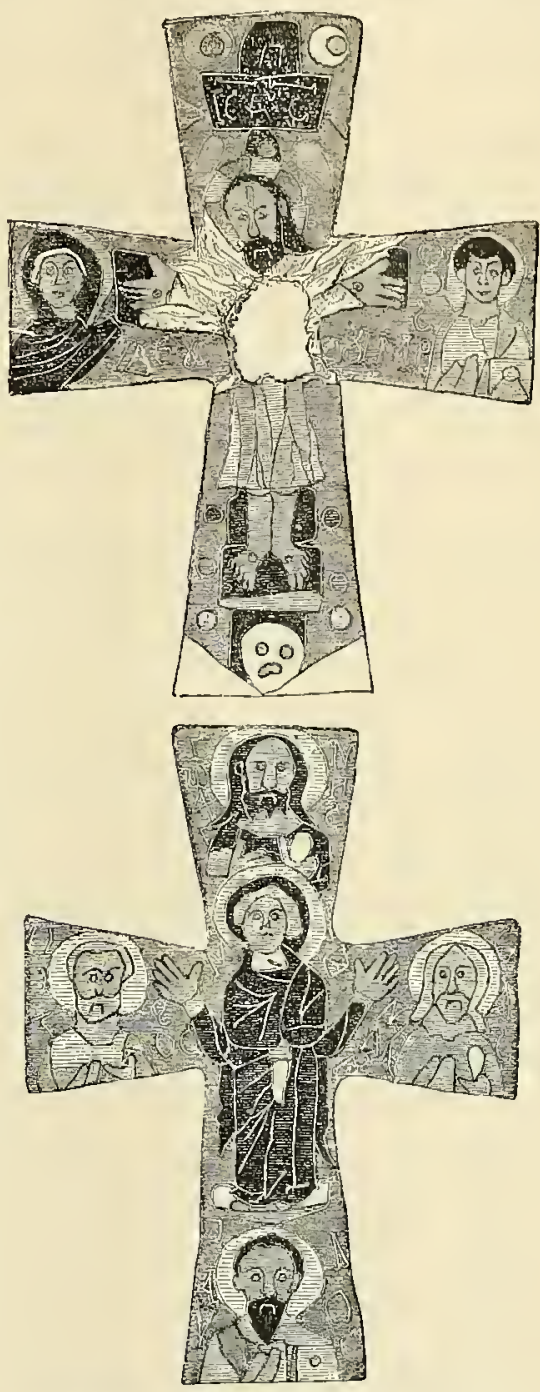

Byzantine Pectoral Cross. From Labarte's Handbook of the Arts of the Middle Ages. hold thy Son" are inscribed. S. John Baptist, S. Paul, S. Peter, and S. Andrew appear. M. Labarte thinks it is of the tenth century, and M. Laborde, of the twelfth century.

1 Walcott, Sacred Archaology, p. 260.

${ }^{2}$ Labarte, Handbook, pp. xxiii., I Io. 
In the Danish Museum of Northern Antiquities is preserved a most exquisite reliquary pectoral cross which once belonged to the celebrated Queen Dagmar's Queen Dagmar. When her tomb was opened about 1690 , cross. it was found lying on her breast. She was the daughter of the King of Bohemia and was wedded, in I205, to Waldemar II. of Denmark. An old ballad tells us that on the morning after her marriage when according to the custom she was entitled to her morning gift,-

\section{Early on the morrow,} Long ere it was day, It was the Lady Dagmar, For her morning-gifts she 'll pray.

They sail' d from the athelest ${ }^{1}$ Beyrland.

"My first bede now I bid, dear, To my lowly prayer inclined,

Let go poor Bishop Waldemar, That long-loved uncle mine!" They sail'd from the athelest Beyrland.

"My second bede eke I bid now, So fain I ask thee it.

Give up, lief lord, all Plough-pennies And all in iron that sit!"

They sail d from the athelest Beyrland.

Of course she became the idol of Denmark. Her name was changed for one of more symbolic meaning. It was originally Dragomir, $i$. $\epsilon$, the dear peace-maker. This meant nothing in her new country. It was altered into Dagmar, i. $\epsilon_{\text {. }}$, the Day-may, the Maiden of the Dawn. But soon, in I212, of the beloved wife and queen we read, her husband was summoned to find the mother a corpse, her child saved by the severe Cæsarean operation. "But at his approach her strong love calls back her soul, and she takes leave of her lord, in that short space having gone through the pains of Purgatory, so venial had been her sins." She again prays for unhappy outlaws, and fettered prisoners, and expires once more with the words,

"Night nor day pain none had I suffer'd,

No fire had come me nigh,

Had I not laced my sleeves one Sunday,

And my gold-cap sticht up high."

Queen Dagmar she resteth there in Ringsted.

1 Noblest.

${ }^{2}$ Bohemia. 
Her eyne she stroketh now once more,

Her cheeks they were so white;

"Hearen's Chimes, they are ringing for me,

No longer can I bide!"

Queen Dagmar she resteth there in Ringsted.

May 24, 1212, her soul departed to its home.

Frederick VII. wishing to give a memento to the Princess Alexandra, the future Queen of England, caused a fac-simile of Queen Dagmar's cross to be made, enclosing a bit of silk, a slip of vellum, and a splinter of wood. " The silken stuff was cut from ouen-simile of the silken cushion on which the head of Holy Cnut, King Cross. and Patron Saint of Denmark, was found resting when his shrine was
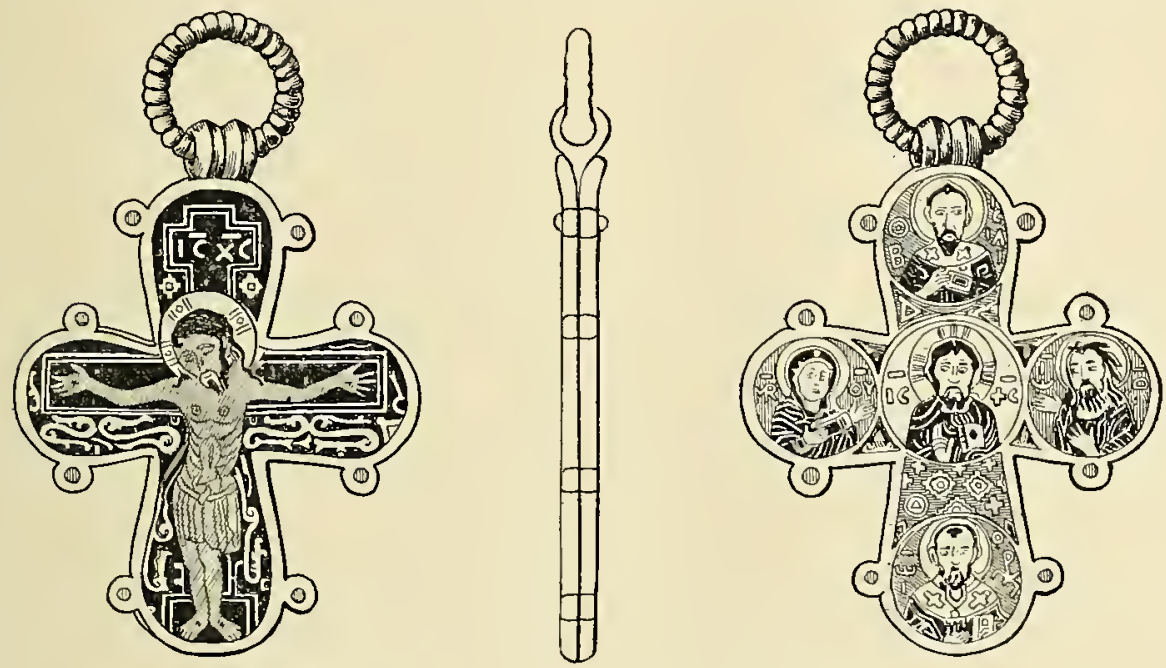

Queen Dagmar's Cross. From Stephens's Queen Dugmar's Cross.

opened in Odense in 1833 . This pillow is now preserved in the OldNorthern Museum. The splint was taken from a reliquary of the Middle Ages, now in the Old-Northern Museum, in which it lay, accompanied by a morsel of vellum, announcing (de ligno de $i$ ) that it was a bit of the Cross of Christ. The slip of parchment bears the words Sericum de pulinari Sti Camti, Regis et Patroni Dania, manu Fridcrici Tll. Regis Danice abscissum " (silk from the pillow of S. Cnut, King and Patron of Denmark, cut off by the hand of Frederick VII., King of Denmark). ${ }^{1}$

Ornamenting this fac-simile cross are two thousand brilliants and rose I Stephens, Queen Dagmar's Cross, IS63. 
diamonds and one hundred and eighteen pearls. The original, like its copy, doubtless contains relics, but that cannot be ascertained without separating it. Upon one side it bears the figure of the Saviour, with figures not unlike swans; upon the other are five medallions, Christ in the centre, the Virgin at his right and S. John at his left; S. Basil above, and S. Chrysostom below, their names, being abbreviated, are given in Greek charactcrs. Its workmanship, and the two latter saints indicate its Byzantine origin.

"The fashion of wearing a cross of gold, merely as an ornament, is of late origin. It may be traced back to the beginning of the sixteenth Cross worn, century. A portrait of Anne of Cleves shows her adorned though Unsuit- with three necklaces, to one of which is attached a jewelled ment. cross. The mode was revived in the beginning of the eighteenth century. The ladies who then went, even to church, in

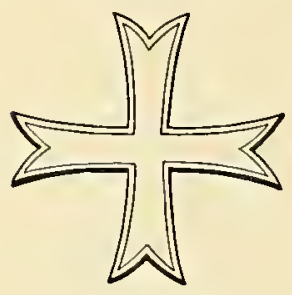

Cross of the Knights

Templars. dresses cut very low, wore, as a throat or bosom ornament, small diamond Saint-Esprits and crosses. Against this profanation of symbols, a zealous preacher thus indignantly exclaimed from the pulpit: 'Alas! can the cross, which represents the mortification of the flesh, and the Holy Ghost, author of all good thoughts, be more unsuitably placed!' " '

Among pectoral crosses should be included the so-called cross of absolution. In the Middle Ages, our forefathers would Absolution extend the virtues and power of the Cross, even beyond life, Crosses. hence we sometimes find in sepulchres, a passport of Papal absolution engraved on metal in the sacred form. In the ancient Church of Butteils, near Dieppe, were exhumed several skeletons bearing upon their breasts rudely cut crosses of sheet lead, on which was a simple form of absolution similar to that used in the tenth century. They have also been found at Meaux, Mayence, Périgueux, Bury S. Edmunds, Chichester, and elsewhere. One of a bishop, about A.D. IOS8, is preserved at Chichester.

Mabillon, in his annals of the Benedictine Order, records that when Abelard died, A.D. I I 42, Heloise applied to the Abbot of Cluny for such an Cross for Abelard instrument, "Ut scpulchro ejus suspendatur." It was granted quest of Heloise. apparently as a matter of course; hence it may be inferred that the custom of using absolution crosses was not unusual.

${ }^{1}$ De Barrera, Gems and Fezels, p. 297. 


\title{
CHAPTER X
}

\author{
CONSECRATION CROSSES
}

“ DY the laws of Justinian (cir. A.D. 528), no church was to be be-

$B$ gun, before the bishop had first made a solemn prayer, and fixed the sign of the Cross in the place where a new church was to be erected. . . . The same custom was observed cration crosses. in purifying the temples of the heathen when they were to be consecrated into Christian churches. . . . And whereas some monks and other orders of men, ${ }^{2}$ would sometimes presume to set up the sign of the Cross in public buildings, and other places erected for the divertisement of the people; which was, in effect, a pretending to make them churches without the bishop's leave; therefore the Emperor Leo made a decree, that nothing of this nature should be done by usurpation for the future, but whether it was to erect a cross, or bring the relics of a martyr into any place, both of these should be done by the direction of the bishops, and not otherwise. And hence it is probably conjectured both by Suicerus and Meur-

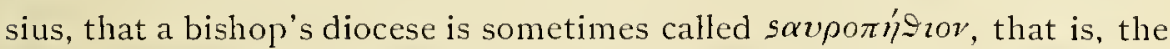
district wherein he had power to fix the Cross within his own bounds for the building of churches. So the word will signify both the act of making a cross, and the limits wherein he had power to make it." "

Before the time of Justinian, Theodosius (A.D. 395-408) commanded that the Cross should be placed within and upon such temples as had been used for pagan worship, to purify them. ${ }^{3}$ Hence, Consecration probably, grew the use of consecration crosses on the walls, manded by Theoalthough the date of their origin is lost in antiquity. ${ }^{4}$ dosius.

1 As the Templars and other ecclesiastical orders did in later times.

${ }^{2}$ Bingham, Christian Antiquities, b. viii., chap. ix., sec. v.

${ }^{3}$ Cod. Theod., lib. i. ; 7 'it de Paganis, leg. 25.-Dingham.

${ }^{4}$ Consecration crosses, with ritual, Walcott thinks may be traced to the fourth century; a form of prayer to the ninth, yet, by a slip of his pen he would unconsciously date them in the eleventh century. See Consecration and Cross of Consecration.

$\mathbf{1} 7$ 
In the Eastern Church at the present time, " although dedication crosses in the Latin use of the term are unknown, exterior crosses in the Use in the East- fabric of the church are more common than in the Western ern Church. and would appear to have been so from very early times. Throughout the ruined churches of Syria, there is one invariable form

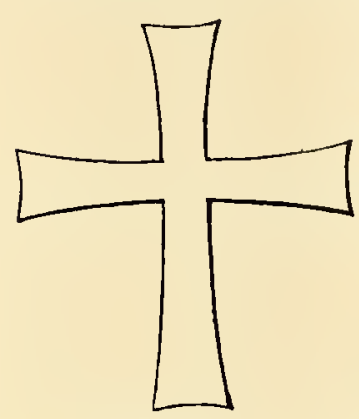

Exterior Cross. From Neale's History of the Holy Eastern Church. of this cross." The Greek, slightly patte, with the lower limb elongated about one fourth. " In like manner, the exterior of Armenian churches are covered with them, and the same thing holds true of Georgia, and, to a certain extent, of Greece." 1

In ancient times, according to Durandus, the bishop carved upon the corner stone, with his Number of own hands, a cross, which might be Crosses. considered one of consecration, although it is not distinctly so stated. Durandus directs that they should be twelve in number, and explains the reason for their use. "First, as a terror to evil spirits; secondly, as a mark of triumph. For crosses be the banners of Christ. - . For even in the pomp of an earthly sovereign it is customary when any city hath been yielded, for the imperial standard to be set up within it. . . . Thirdly, that such as look on them may call to mind the Passion of Christ by which He hath consecrated His Church, and their belief in His Passion. Whence it is said in the Canticles, "Place me as a signet upon thy arm.' (Cant. viii. 6.) The twelve lights placed Lights before the before these crosses signify the twelve apostles who have Crosses. illumined the whole world by the Faith of the Crucified." Anointed with
Chrism. quarters of the world (signified by the four walls) have been lighted up " into love," “ but have been anointed into purity of conscience, which is signified by the oil, and into the savour of a good reputation which is signified by the balsam.",

Consecration crosses were either painted in color, as for example, in How Formed. S. Laurence's Church, Nuremberg, where they are red; on the Cathedral of Rabston, where they are depicted crosses fleury, gold,

1 Neale, Hist. Eastern Church, Introduction, p. 222.

${ }^{2}$ Durandus, Neale's, and Webb's Trans., p. I26. 
on a blue ground within a circle of red; or else carved in the stone, and sometimes inlaid with brass. In Liebfrauenkirche in Treves within circular panels, angels are represented bearing the crosses.

In the south of France there are many instances of the consccration crosses being in the form of the Labarum, i. c., 决. In the formation, the perpendicular stem is placed over the horizontal one, and the latter is sometimes repeated thus, $\neq$, as on one France. jamb at the entrance of Preston Church, Sussex, England. ${ }^{2}$ Another variation is seen in Bar Preston Church, Kent, where the horizontal arm is a double cross crosslet.

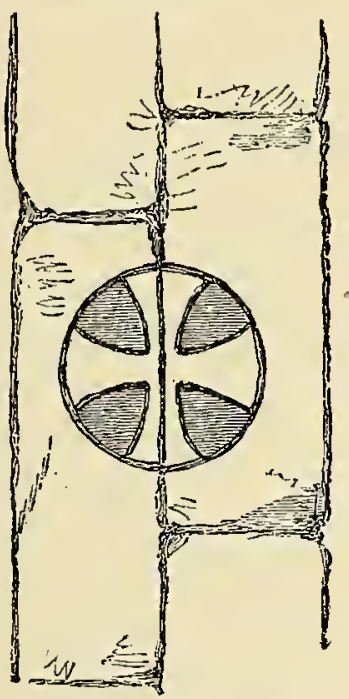

Consecration Cross.

From Lee's Glossary.

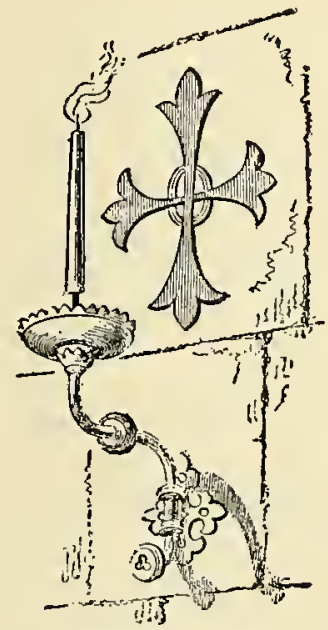

Consecration Cross.

From Lee's Glossary.

There is also another form of consecration cross. According to the Roman Pontificate, after the Litany, a cross of sand and ashes is sprinkled upon the floor upon which the bishop traces with his pastoral staff the Greek and Latin Alphabets. "A thing," Martene observes, "which might appear puerile

Alphabetical Cross in Sand unless it had been instituted by men, great in dignity, spiritual in life, apostolical in discipline." Durandus and Martene thus explain it.

\section{${ }^{1}$ Gentleman's $M$ Mag., r854, p. 56.}

${ }^{2}$ Eng. Ecclesiologist, vol. ii., pp. 47, 80, I7I. The sign and signet of our Lord was the same before and after His coming. See, among other examples, the crosses (consecration ?) in Redcliffe Church, Bristol, and on other Anglo-Norman structures similar to those found in the ruins of Yucatan. The builder's marks on Gloucester Cathedral are ideutical with those found in Carthage and Mlexico. - Notes and Queries, $2 \mathrm{~d}$ ser., xii., p. 425. 
By the alphabet is understood the rudiments of sacred doctrine, as S. Paul said, "Ye have need that one teach you again which be the first principles of the oracles of God." (Heb. v. I2.) The Greek and the Latin are used to represent the (sometime) union in faith of both nations. The Hebrew is omitted because the Jews have rejected the truth. And yet the Cross is to be described athwart the church (i. $\ell$., Saltirewise) beginning at the left corner of the east, for knowledge came from the Jews, to the right corner of the west, and then from the right of the east to the left of the west, for Christ passing from the east, left the Jews on his left hand because of their unbelief, and came to the Gentiles on the west. It is written upon the pavement to remind us of the foundation of our faith, and of mean materials, that we may recall that even Abraham acknowledged "Behold now I have taken upon me to speak unto the Lord, which am but dust and ashes" (Gen. xviii. 27). ${ }^{1}$

There is also probably some reference to the Saviour's stooping down and writing in the dust.

'Durandus, Neale, and Webb's Trans., pp. 122, 239. The alphabet was sometimes written north and south, but, probably, more often as Durandus directs. It is so in the Anglo-Saxon Ceremonial now in the library at Rouen, which Montfancon ascribes to the seventh or eighth century.-Archrologia, vol, xxv., p. 235. 


\section{CHAPTER XI}

\section{SPIRE AND GABLE CROSSES}

$\mathrm{T}$

$\mathrm{HE}$ earliest cross placed upon the summit of a spire was probably about A.D. 568.' The positions which are authorized as proper for a spire, or pinnacle cross, according to the Handbook of English Ecclesiology, are the east end of the chancel, east

Date of first Use. end of the nave, porch, west end where there is no west tower, bell gables, and transepts. There are examples of other positions, $c x g r$, the west end of the south aisle; east and west ends of the chantry; north aisle, east or west end or both; the tower when the roof is gabled; on the central battlement and on the top of a spire or turret.

The varieties of spire crosses are innumerable, from the simple Latin cross, obriously inappropriate, to the most floriated. Some of the most beautiful are found in Spain.

Varieties.

Spire crosses were made of metal bars, wrought in open work to offer the least obstruction to the wind, and yet to produce a rich effect.

The cross was placed upon a globe, Spire Crosses. for its symbolic reason, and surmounted by the ever turning weathercock, to remind Christians of the fall of S. Peter, and of the watchfulness with which they should ever face the Prince of the Powers of the Air.

The cock should be made of copper with a

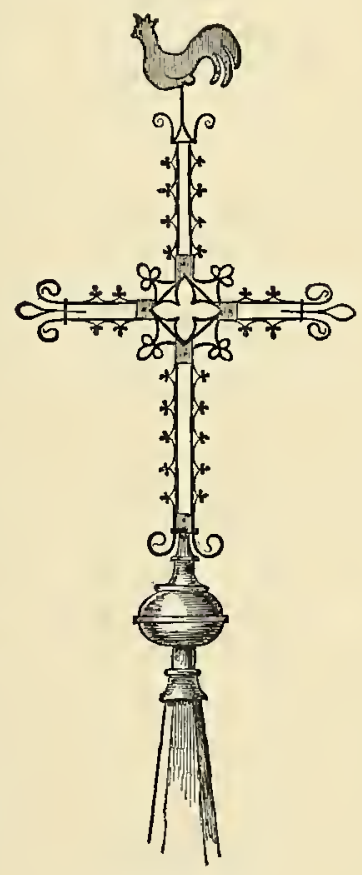

Spire Cross.

From Lee's Glossary. hollow body, and with a tail projecting sufficiently to catch the slightest

1 Haydn's Dictionary of Dates. 

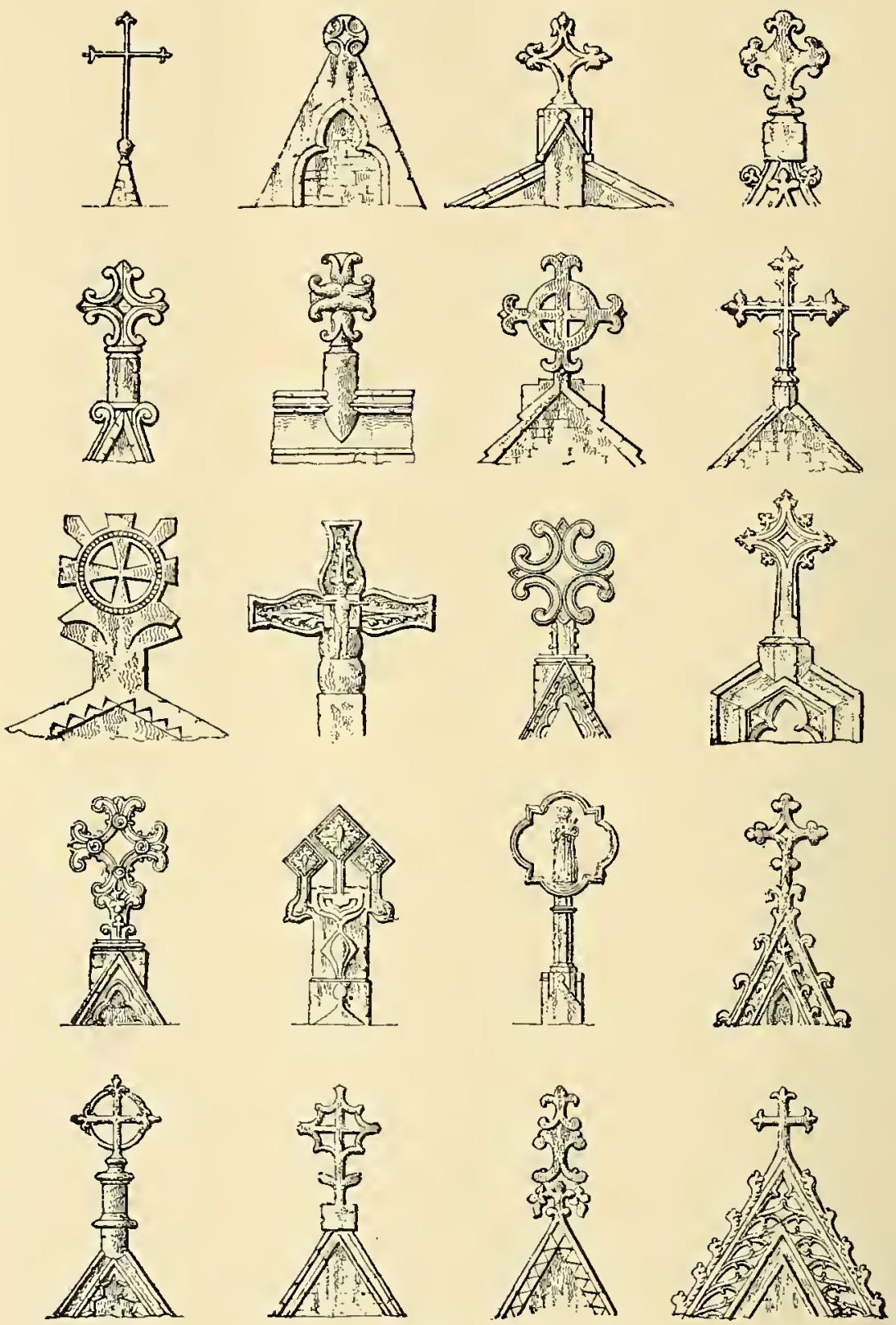

Crosses on Gables.

From Parker's Companion to Glossary of Terms Used in Gothic Architecture. 
vasiation of the wind. Good examples ate found in the cock on the spire of Rouen Cathedral, and that of Amiens, about the date of 1526.

Except the cross erected by Colonel Fremont on one of the highest peaks of the Rocky Mountains, probably the most elevated position to which this sacred symbol has been raised is upon the tops of some of the mountains of the Levant, which are crowned some crosses. by convents. On level ground may be mentioned the cross on the dome of S. Peter's, Rome, or on the spires of Strasburg and Cologne, which are five hundred feet in height.

In the Eastern Church, gable crosses are usually of metal, and differ very materially from those of the Latin Church. In Russia the arms are duplicated, like the pointers under the weather vanes in this country, indicating the four cardinal points of the compass, Eastern crosses. and attached to the main rod by gilt chains. Often the Saltire, or S. Andrew's cross is used. A triple cross is not uncommon, Russian Gable especially in Moscow, in reference to the patriarchal dignity Crosses. in that city, also in the north of Russia and even in Finland. In the triple cross the lower bar usually faces a different point of the compass from that to which the two upper points are directed. ${ }^{1}$ To the peculiar significance of the spire cross with the crescent, which occurs in this country allusion has elsewhere been made.

The cross which crowns the spire at the intersection of the transepts and nave, is called the rood-spire cross.

Rood-Spire cross.

3 Neale, Hist. Eastern Church, Introduction, p. 22 r. 


\title{
CHAPTER XII
}

\author{
STANDARD CROSSES
}

HRISTIANITY may be said to have been publicly acknowledged by the State when the Emperor Constantine set up crosses in the

Official Acknowledgment of Christianity. streets of Rome and Constantinople. But before his time stones had been set up as witnesses, like those by the Israelites of old, in the outermost bounds of the Roman Empire. Among these we find a rude stone pillar in Towyn, Merionethshire, Great Britain, which bears the name of S. Cadvan, who lived in the third century; and a cross is carved on each of its sides with an inscription in Latin, in which occur some British characters that determine its date.

The pillar was the germ of the standard cross: at first it was a rough monolith bearing a small incised cross with an inscription commemorative of the person or event. But, as early as the fifth century, the pillar was developed into a cross proper. After the Norman conquest it has been supposed that they fell into disuse.

Standard crosses were erected for various purposes. Generally the larger are classified as Churchyard, Oratory, Sanctuary, and Memorial crosses, but frequently one structure served all these purposes. The mortuary, or headstone, crosses will be treated of separately, and only a general description will be given of the form and ornamentation of the other crosses and a few of the more notable ones described.

Some features are common to all, not only in Great Britain, but throughout the Continent of Europe. The crosses face east and west. commoncharac- When the image of our blessed Lord is sculptured, interistics. variably it is on the western face, so that the worshipper may turn to the East in his devotions. If a cross is turned in any other 
direction it has been moved since its erection. Often the crosses are elevated upon a calvary of three steps, symbolical of the holy Trinity or the Christian graces. Frequently they are equi-brachial, or of the Greek shape, although at times being set upon a shaft the lower limb is elongated, and hence the appearance of a Latin cross is given. This fact should be noted in regard to others which prove the early connection of the ancient British Church with the Eastern branch of the Catholic Church.

The ancient English, Welsh, and Cornish crosses appear to be of three varieties. The earliest, probably, of Roman work, are monoliths from seven to ten feet high upon which is cut a simple cross, or a cross with a circle, and sometimes the inscription as welsh Crosses. before mentioned. In Cornwall and Wales, the monogram, instead of a cross, is sometimes found. The second class of crosses is pure Saxon work; they are also monoliths, sometimes fourteen feet high, bearing the cross in alto-relief, or carved on the head of a simple shaft. The shaft is entirely plain, without figures, but divided into compartments richly wrought with ribbon, scroll, and chequer work; the arms are connected with the wheel. In the last class, or Dano-Saxon, the scroll work is richly elaborated, and the cross is no longer a single stone, but composed of several. Upon the earlier crosses, but without the figure, the wounds of our Lord are represented by five bosses.

Crosses in Scotland are of two kinds. Pillar crosses of Danish or Norwegian origin, and others which resemble the Irish crosses. The first are from eight to twenty-five feet in height, often with

a Latin cross incised upon the whole western face, and the

Scotch Crosses. arms rarely project beyond the pillar, while those of Ireland and elsewhere are supported by an open circle (usually called the wheel) or a closed disk. The panels are filled with ribbon, chain, net, and diaper work. There are few representations of sacred subjects, and no image of our blessed Lord, but, instead, are carved battle scenes, ships, animals both in natural and conventional shapes, fishes, etc. ${ }^{1}$

1 The interlacing "basket work exists nowhere but in Ireland and Scotland that I am aware of," says Fergusson, "except in Armenia," The "key" ornament in the arm of the Aberlemmo cross "is found in the Sarnath Tope near Benares and elsewhere, but is common to both conntries; as is also the dragon ornament on the side of the cross, though this looks more like a Scandinavian ornament than anything that can claim an origin further East." -Fergusson, Rude Stone Nonuments, p. 270. 
It is almost impossible to decipher the curious sculptures upon these ancient stones. Worn by time and weather, they often present different appearances in the sunshine or when wet with rain. Frequently the

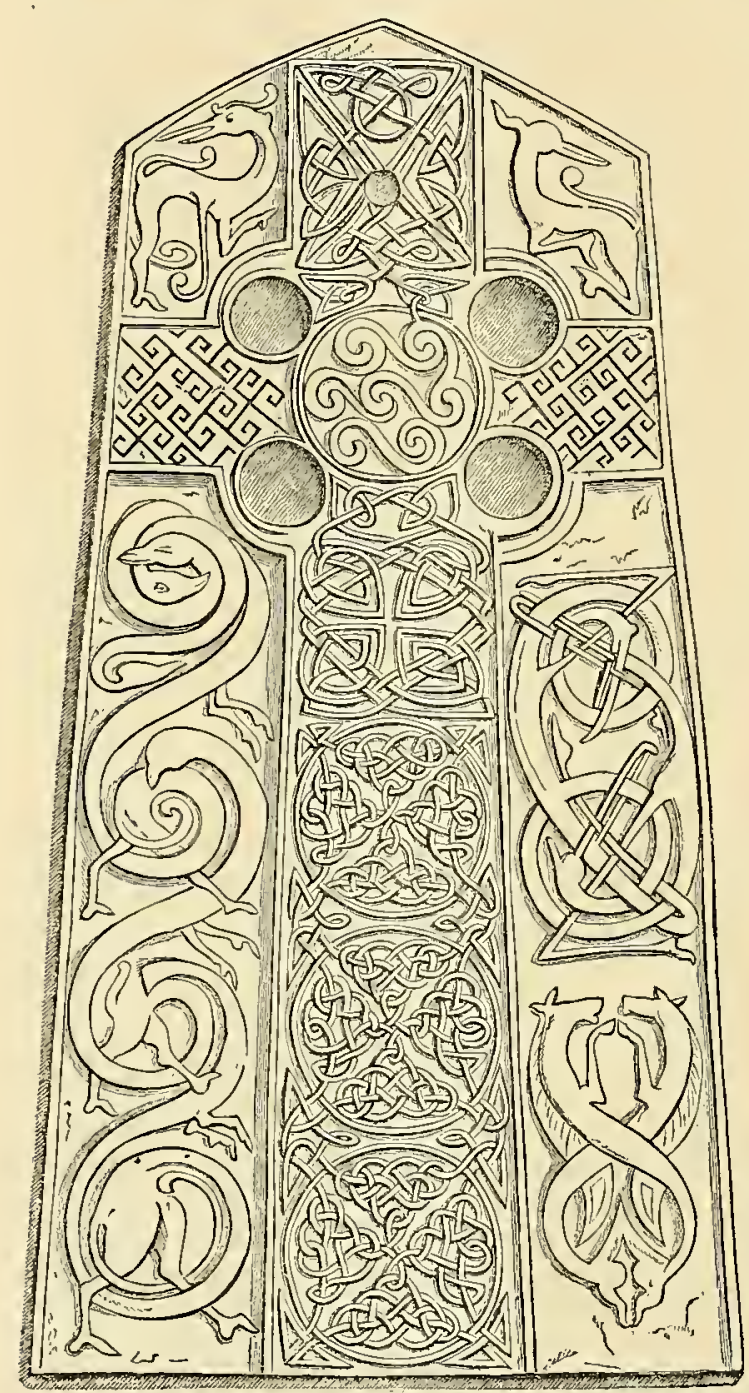

Front of Stone at Aberlemmo, with Cross.

From Fergusson's Rude Stone Monuments. archæologist has to rely more on the sense of touch, tracing the emblems with the finger, than that of sight. For example, on the cross at Aberlemmo, said to have been erected to commemorate a victory over the Danes in the latter part of the tenth century, some have discovered, as they supposed, remains of Hebrew letters, which more fortunate interpreters have decided are the representation of two angels. $^{2}$

A like puzzle is offered upon one of the crosses in the churchyard of Neigle.

Cross of Neigle. Apparently the figure is intended for that of an elephant. Upon others in the same locality, appear a centaur bearing a cross in one paw, a bunch of mistletoe in the other, and a Capricornus, or sea goat. Upon " a cross of S. Vigean (A.D. 729) a grotesque hybrid, half bird, half fish, stalks among fantastic animals and intertwining snakes which decorate the border." Again we find writhing snakes, crocodiles with heads at either end of their bodies, 
fish, part quadruped and part serpent, and such like. Some have thought that they discovered apes, and similar unclean beasts, perhaps these monsters were meant as representations of vices, or of evil spirits like the gargoyles and fantastic figures in Gothic architecture. Conventional figures of aninals, such as elephants with their feet turned up into scrolls, and their trunks thrown in a straight line over their backs, are given, while horses, and other animals with which the artists were familiar are represented correctly, hence it is doubtful whether the portraiture proceeds from ignorance or from a symbolic reason. ${ }^{1}$

Of crosses in honor of special persons, we find instances in the Isle of Man which are identical in character with those of the Scotch. At Kirk Michael there is one bearing the inscription in Runic, " Milbrokli son of Athacan, the smith, raised this cross for his soul

Crosses in the Isle of Man. and that of his faithful friend Gant who made this cross and all [the crosses in Man'](?) Another, at the same church, represents a stag hunt; on one edge, interlaced work, on the other the figure of an armed warrior. Inscription, "Eyolf the son of Thorolf the Red, raised this cross after $[i . \varepsilon$., in memory of $]$ his foster son." At Kirk Andreas is the fragment of a cross which commemorates a crime. "Oskitel betrayed in trust his sworn friend," 2

In the instances of the crosses of which illustrations are given, the first is a token of conjugal affection having an inscription that " Sandulf the Swarthy erected this cross to his wife Arnbjörg." It is evidently of Scandinavian origin. The inscription on the second reads, "Mal Lumkun erected this cross to his foster-father Malmor, or Mal Muru." These names show a Gaelic derivation. ${ }^{3}$

Ireiand presents crosses pre-eminent for grace and beauty. The island

1 Daniel Wilson, Archaology and Prehistoric Annals of Scotland, pp. 501-505. The symbols on the Scandinavian crosses are easily understood by a reference to their nythology which furnished the symbols for the new religion after the Northmen became Christianized. Loki in the beginning of time was the mild, beneficent warmth united to Odin or the $\Lambda / l$ Father, but he descended to Midgard, the middlemost part of the earth, the dwelling-place of man, and became crafty and the cause of evil. One of his offspring by the giantess Angurboda, or boder of sorrow, was Jormundgand, or Midgard's serpent. Thor is the son of Odin and the Earth or Fjorgvin the vivifying. Loki had made for Thor his hammer $M$ jölnir(the Fylfot cross) the crusher, with which he was able to destroy all things and to strike off the head of Mlidgard's serpent. Here we have the Persian theology modified by Northern feeling-the whole system of Christian theology, even to the Devil's supplying the Cross with which the old serpent is slain.-Thorpe, Northern Mythology, vol. i , p. ISo.

"Wilson, Archaology and Prehistoric Annals of Scotland, pp. 540-54I.

${ }^{3}$ Fergusson, Rude Stone Monuments, p. 272, 
abounds with every variety. The simple incised pillar, the plain Latin cross, the circular-headed, the flat disk, and what is commonly, though crosses in incorrectly, called the wheel cross." The highly sculp1reland. tured crosses were generally erected between the ninth and twelfth centuries. The shafts are sometimes of low elevation, but mostly are from eight to twenty-five feet in height, from one foot to two and a half in width, by one third in thickness. The transverse bar is from three to six feet in length, the ends are squared, and, usually,
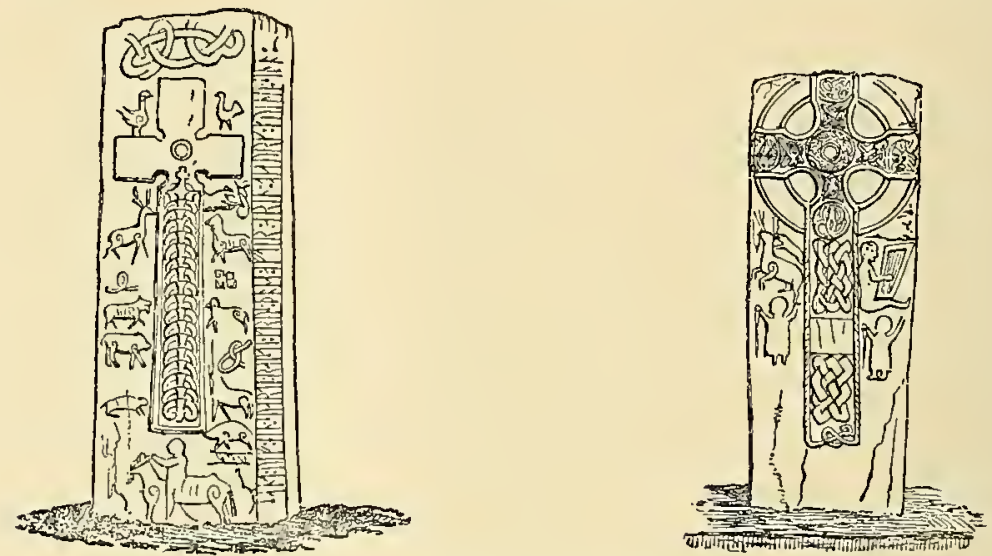

Crosses in Isle of Man, Bearing Runic Inscription. From Fergusson's Rude Stone Monuments.

carved, and the upper arm is crowned with a coping stone. This last is a feature peculiar to Irish crosses. The Crucifixion is placed on the western side, our Lord being sometimes represented with Longinus and Stephaton, or Calpurinus; and other typical and traditional characters and subjects are often introduced. The ornamentation of scroll, ribbon, diaper, net, chequer, and other work is of exquisite perfection. Many examples of similar ornamentation are found in the ancient Irish manuscripts; $c x . g r$. the ribbon pattern is so elaborately wrought in the gospel

'Probably this is meant for the nimbus, glory, or aureole, which is placed around the heads of the Divine Persons and saints in Christian art. It originated, however, before Christianity, and was used by the pagans as an emblem of power and divinity. In a fresco at Pompeii, representing Circe and Ulysses, the head of the former is surrounded by an aureole. Dyer, Pompeiz, p. 3I3. In early Christian art, the whole figure of our Lord, as well as the other persons of the holy Trinity and the Virgin Mary, are enclosed within an aureole. Didron, Christ. Icon. Hence the use of it on a standard cross, especially if it bore the image of the Saviour. Besiles, there is a constructive reason; the arms of the crosses sometimes extended several feet, requiring a support; the aureole, or wheel, afforded this, and by its graceful management, being sunk below the surface of the main parts of the cross, added beauty, by softening the abrupt angles, as well as strength and symbolic meaning. 


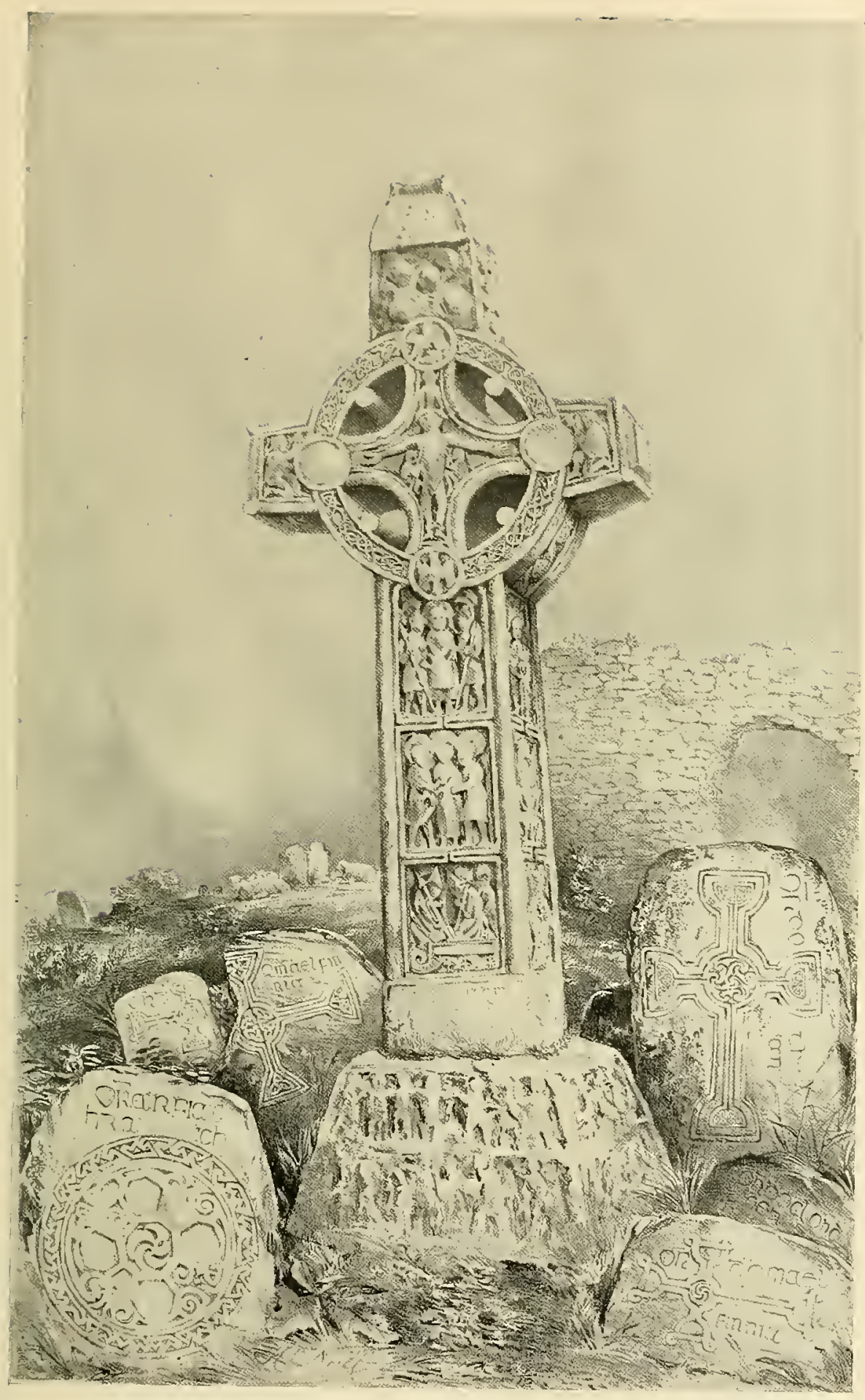

The North Cross, Clonmacnoise. From O'Neill's Crosses of Ancient Iriland. 
known as the Book of Kclls, that tradition ascribes the work to angels. But the various patterns will be seen in the engravings.

It is noteworthy that all ornamentation of standard crosses, whether of simple or elaborate beauty, is apparently derived from that pattern revealed to Solomon in building his temple; cherubim, palm trees, open flowers, bosses, net work, chequer work, chain work, pomegranates, lily work. (I Kings, vi.; a Chron. iii.) From Judea, whether accidentally or providentially, we cannot say, these ornamentations were transported to Italy and thence to the Western Churches. Similar work is found in ancient Italian mosaics, and in the remains of the Roman villas at Woodchester and Woodstock, and in the Temple of Esculapius at Lindsey Park, Monmouthshire, England, and in the Roman basilicas from the fourth to the eleventh century. ${ }^{3}$

There is a tradition that one of the crosses at Monasterboice, that at Ardloc, and others were the gift of the Pope, which gives some reason

Cross at to suppose them of Italian origin. ${ }^{3}$ These crosses are Monasterboice. carved out of stone not found in the neigliborhood, and the workmanship being superior to the other ecclesiastical work of the same period, seems to warrant such a conjecture. In Irish crosses we find the crucifix with the body having outstretched arms, and the long tunic as in early Latin and Greek art. This would seem to bespeak antiquity, as does also the representation of only those personages mentioned in the Gospels as piercing the side and offering the sponge, and the comforting angels.

Among other scenes presented in the sculptures in the panels are the Nativity, the offering of the Magi, the Circumcision, the Baptism, the scenes Repre- Slaughter of the Innocents, Jesus with the doctors in the sented on Crosses. Temple, the overthrow of the money changers, the blessing of the little children, the entry into Jerusalem, the Sermon on the Mount, the Agony in the Garden, the "Ecce Homo" and the attendant soldiers with heads resembling those of birds of prey, Jesus surrounded with dogs tearing him, in reference to the prophecy, "Many dogs are come about me" ; the Crucifixion, and the instruments of the Passion, etc. These occupy the western face : on the eastern is generally repre-

1 Within the past thirty years an eminent artist in Dublin declined tracing this work on reverential grounds. (Eng.) Ecclesiologist, vol. vi., pp. 93, 9..

${ }^{2}$ Ibid., p. 95.

3 Ibid., p. 99 . 


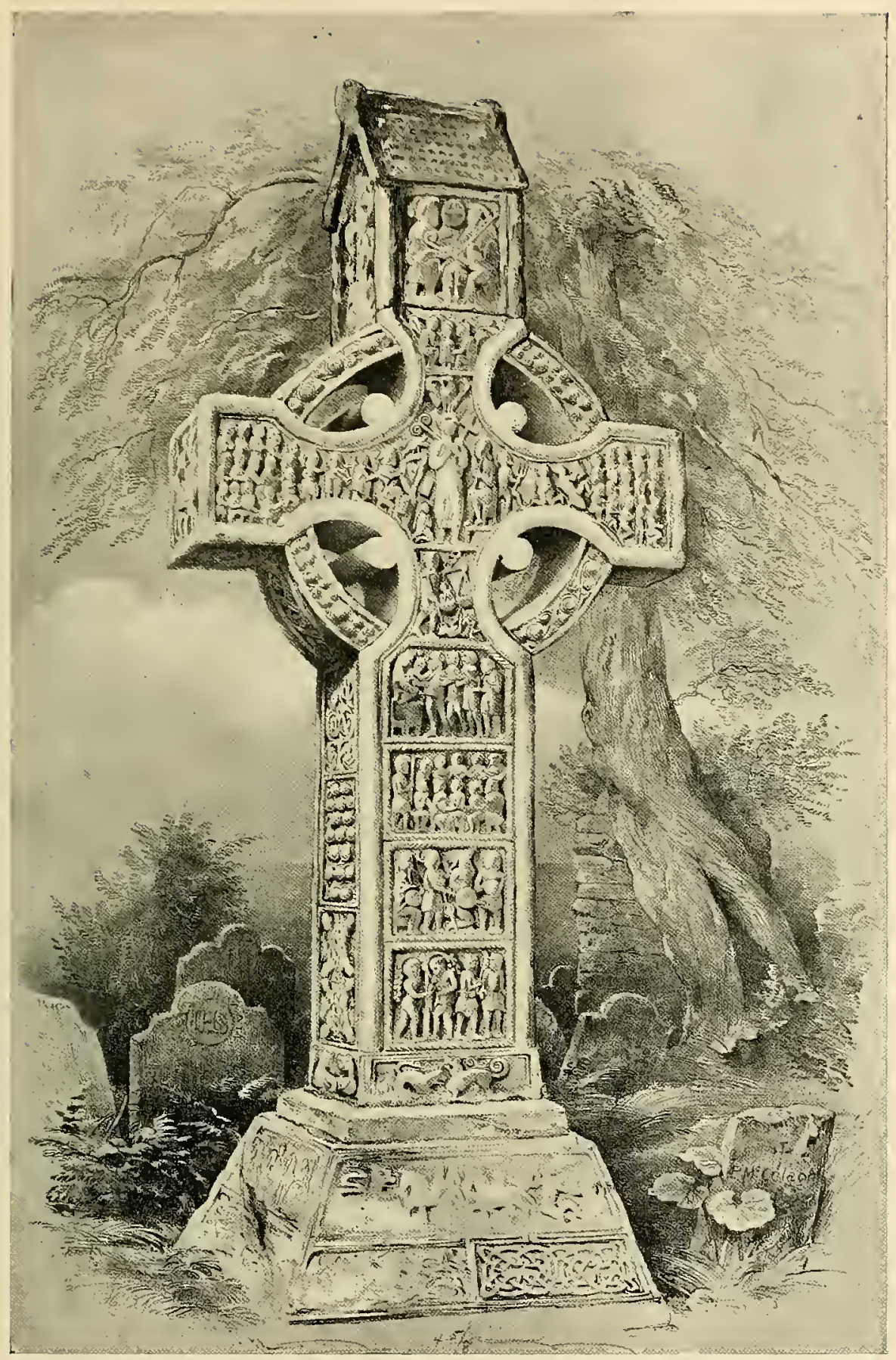

The Southeast Cross, Monasterboice, From O'Neill's Crosses of Ancient Ireland. 
sented the Day of Judgment, in which our Lord often holds a double cross emblematic of his twofold authority, instead of the simple cross of suffering. The most frequent Old Testament subjects are those of Adam and Eve, the Ark, the sacrifice of Isaac, Joseph sold to the Ishmaelites, David playing upon his harp, or rescuing the lamb from the lion, Nebuchadnezzar feeding with the oxen, the erection of the Temple, etc. The crucifixion of S. Peter is common, which fact is easily explained, if we adopt the theory of the Ecclesiologist of the Italian origin of many of the most beautiful crosses. It is significant that the representation of the blessed Virgin and holy Child are not found, it is believed, on many crosses.

The examples of standard crosses have been taken mainly from Great Britain, because there and in Ireland some of the most beautiful, correct, and easily visited specimens exist and also because the events memorialized are of special interest to us of the younger world. Examples might be cited from other parts of Europe. One, no lover of liberty could pass by unnoticed. A pillar bearing four crosses, marks the place of martyrdom of Arnold von Winkelried. At the battle of Sempach, July 9, 1386, the Austrians presented a serried rank of spears, invincible to the poorly armed Swiss. An opening must be made. Arnold von Winkelried rushed forward, and swept all the pikes within his grasp into his own bosom, thus making a way for his countrymen at the sacrifice of his own life. They availed themselves of this offering to liberty and victory was achieved. Two thousand Austrians fell that day and but two hundred Siviss.

"Then lost was banner, spear, and shield, At Sempach in the flight;

The cloister vaults at Konigsfield Hold many an Austrian Knight."

Love and mammon have conquered bigotry in the village of Heemskerk in Holland. The celebrated Dutch painter Martin Heemskerk, crossover known also as Van Veen, who died in 1574, aged seventyHeemskerk. six, for the sake of leaving some memorial of himself, bequeathed a sum sufficient for a dowry annually to one young woman of his village, on condition that the bride and bridegroom should on the day of marriage go and dance on his grave. "Which," saith our author, "I was assured was so religiously observed, that notwithstanding the 


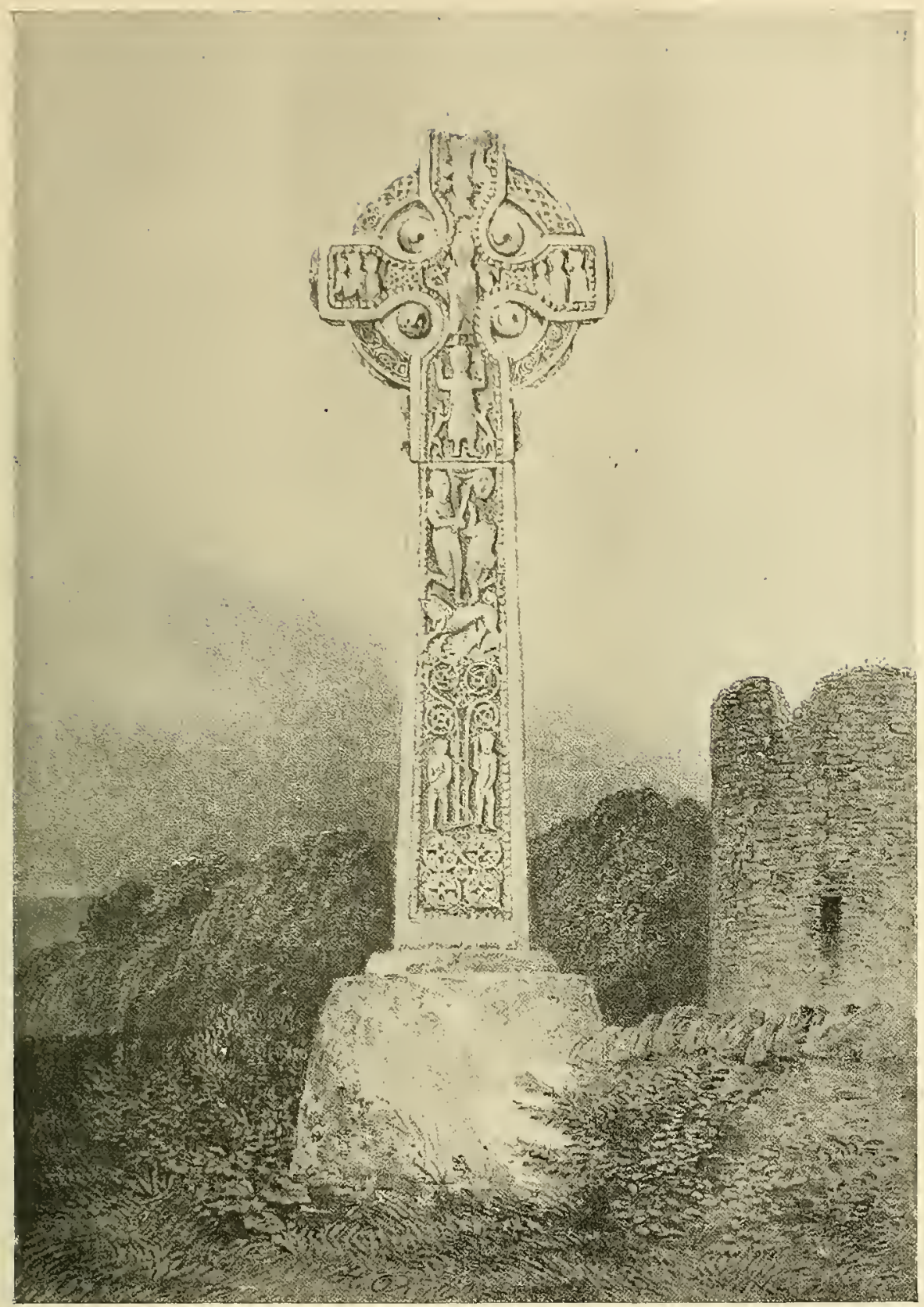

Drumcliff Cross. From O'Neill's Fine Arts of Ancient Ireland. 
change in religion which happened in that country caused all the crosses in cemeteries to be demolished, the inhabitants of Heemskerk would not permit that on the grave of this painter to suffer a like fate. It is of copper, and serves as a deed of settlement of the dowry or ordination made to their daughters." '

The Reverend Dr. Cullen, the Roman Catholic Archbishop of Dublin, during the rage of the rinderpest in I866, urged upon his flock the Restoration of restoration of the early pious uses of the cross. "To all Standard Crosses Catholics I would recommend the use each day, of the
in XIxth Century. prayers against pestilence, which are found in all prayerbooks, or those contained in the missal. I would also recommend them to get their parks and fields blessed with prayers given in the Roman ritual, and also to erect crosses on their lands, and keep them in their dwellings, in the hope that this emblem of the triumph of Christ over his enemies may put to flight the powers of darkness, and preserve us from their wicked influence. Public and private prayers, holy water, and the Cross are looked on by infidelity or heresy as things to be despised, but every pious Catholic knows their virtue and efficacy. Would to God that all these means of obtaining assistance from Heaven were in general use, and especially that the image and Cross of our Redeemer were more commonly erected as objects of veneration, and as memorials of the sufferings of our Lord, in market places, and at cross roads, according to the pious practice of our forefathers ị the faith." 2

'Entreticns sur les Vies et sur les Ouvrages des plus excellents peintres, par M. Félibien, tom. ii., p. 235, Amsterdam, I 706 .

${ }^{2}$ New York Evening Post, March 24, I866. 


\section{CHAPTER XIII}

\section{MEMORIAL CROSSES}

$\mathrm{T}$

$\mathrm{HE}$ Cross is indeed a Catholic emblem. It may sanctify the grave of a slave, or the tomb of an Emperor. It may be a stone of covenant between two private families, or a record of an subjects of meevent decisive of the fate of empires. No other symbol is morial crosses. so universally appropriate. It is never out of place, never offensive to taste, unless maltreated by ignorance or pretension. For instance, in Ely Cathedral, there is preserved the shaft of a cross, in memory of S. Owen, steward of S. Ethelreda, A.D. 679, inscribed " Luccum tuam Orino da Dcus ct Requiam." And in Llandivailog churchyard is a cross, bearing a rude carving of a warrior, commemorative of Broemail, Prince of Powis, who defeated Ethelbred, King of Northumberland, A.D. 6I 7 .

To the archæologist, memorial crosses oftentimes are precious, as giving examples, in their carvings, of garb or implements of the age in which they were erected. For example, at Old Kilcullun, in County Kildare, Ireland, there is a memorial cross to the founder of the church, on which is sculptured a bishop with his attendant deacon, his crosier, his leathern case for the Gospels, his alms purse, and bell.

Sometimes the cross is an expression of family love. A pillar, probably a fragment of a cross, in Wales, is inscribed, "Concewn, great grandson of Elisey, erected this column to his great-grandfather Elisey." Sometimes the sign of our Lord has been erected as an expiatory offering. We read the lines, perhaps inscribed by a heart-broken mother, on a cross near the church of S. Michael in the Isle of Man, "For the sins of Ivalfir, son of Dinal, this stone was erected by his mother Aftride." Baptisms, councils, etc., were often commemorated by a cross, but a greater number of memorial crosses extant tell of stories incongruous 
with the symbol of the Prince of Peace. The result of a war was often memorialized upon a cross. A curious instance may be found near whiteleaf Cross. Whiteleaf, Brockinghamshire, England. Like the celebrated White Horse in Berkshire, it is cut on a high, chalky cliff. The perpendicular is nearly a hundred feet, and the transverse seventy. The trench is from two to three feet in depth, and like the Horse, its scouring is succeeded by a festival. It is supposed to be commemorative of a victory by Edward the Elder, son of Alfred the Great, about the year 905 .

We cannot note the tithe of these monuments interesting to the reader, but those connected with events immortalized by Shakespeare Cross Memoriaicannot be passed by. We hear the "All Hail!" of the ized by Shake- witches in "thunder, lightning, and in rain," as we apspeare.

proach Sweno's stone near Forres. It is a monolith about twenty-five feet high. On one side are represented warriors, both horse and footmen, engaged in a desperate conflict, as is indicated by the number of the fallen, many with their heads dissevered from their bodies. Other carvings represent a procession as if in invasion. On the reverse is inscribed, in its whole length, a cross elaborately ornamented. According to tradition, this cross was erected as a memorial of the treaty between Svend Tveskjaeg and King Malcolm, and also of the expulsion of the Danes from the coasts of Moray ${ }^{1}$ (circa eleventh century).

Another Shakespearian cross may be found in Stainmore. A fragment only remains. It was erected to commemorate the treaty between IVilliam, King of England, and the son of the "gracious stainmore Cross. Duncan," Malcolm Canmore. The latter had refused to give up to the English sovereign the mother and sisters of Edgar Atheling, who had been forced by stress of weather into the Frith of Forth. Malcolm was probably influenced as much by the beauty of Margaret Atheling, for she was one of the fairest women of the time, as by the laws of hospitality. On one side of the cross is sculptured the English king, on the other the Scotch, each facing his own country. ${ }^{2}$ It was called Roi crossc, corrupted into Ree or Rere cross. Scott refers to it in his ballad of Allan- $\alpha-D a l c$ :

1 Worsaae, Danes and Norrvegians in England, p. 215.

${ }^{2}$ Britton, Architectural Antiquities of Great Britain, vol. i, p. 92. 
"And the best of our nobles his bonnet will vail,

Who at Rere cross, in Stainmore, meets Allan-a-Dale."

Another cross, revered because our Shakespeare has consecrated it, is that of Kilnsea, on the coast of Holderness, Yorkshire. It commemorates the landing of Henry Bolingbroke, afterwards Henry IV., at Ravenspurgh in I399. On the west side are repre- Kinsea Cross. sented the blessed Virgin and S. John ; above is a figure being crowned by a female. On the east side are the same figures and two busts, nearly obliterated, and two dogs. As in Irish crosses, these are common, apparently referring to a state of tribulation. "Many dogs came about me" (Ps. xxii. I6), prophetically mourned the royal Psalmist of Israel. In ISIS, in consequence of the encroachments of the sea, this interesting relic was removed to the park of Marmaduke Constable, Esq., in Holderness. ${ }^{3}$

Near Lindores, on the boundary between Fife and Stratham, is a cross dedicated to S. Magider, but it is better known as Macduff's Cross. After the death of Macbeth, King Malcolm granted to the Thane of Fife three requests: first, that he and his Macduff's Cross. successors might place the crown on the King's head at his coronation, second, that they might lead the van in battle, and last, that if any of the kinsmen of Macduff, within the ninth degree, should commit accidental homicide, he should have the privilege of sanctuary at this cross, and total remission of the crime on the payment of a penalty; which, according to some accounts, was that of nine cows and a heifer. This cross was demolished by the fanatic followers of Knox. Its pedestal only remains, around which are tumuli, said to be the graves of those who sought sanctuary but failed to prove the required relationship; their spirits are believed still to haunt the spot, praying for that mercy for their souls which was denied their bodies."

The bloody story of Croyland is memorialized by the remains of its cross. In brief, it reads as follows. During the invasion of the Danes, the Abbey of Croyland received notice of their approach. The younger of the monks were hastily concealed in a neigh-

Cross at Croyland. boring wood with the charters, relics, and jewels. The Abbot Theodore,

${ }^{1}$ Gentleman's Mag., May, I82I. Within the past five hundred years, Ravenspurgh, once the rival of Hull, has been devoured by the sea. Shoals exist where once was a harbor.

"Scott, Minstretsy of the Scottish Border, "Lord Sonles," note B, and "Macduff's Cross." 
- in company with the more aged of the monks and the children, awaited the coming of the enemy, hoping that the venerable appearance of the brethren, some of whom were over a hundred years old, and the youth of the children, might be safeguards. In the solitude of the place, the Danes might have passed the abbey unnoticed, but the distant chant of the matins betrayed it. Just as Theodore had communicated, the Danes forced the gates, and Asketiel, one of the chiefs, smote off the Abbot's head at the steps of the altar. All were slain, save the children and the more aged monks, who were reserved for torture in hopes that their weakness would induce them to disclose the hiding-place of the treasures. But their heroic constancy disappointed the enemy. Only one victim was spared. Turgar, a boy of ten years, would not be separated from his tutor, the sub-prior Lethioins, but when the latter was stabbed to death the child prayed to share his fate. Sidroc, a Danish jarl, struck with the beauty of the boy, tore his cowl from his head, threw his cloak over him, and saved him.

For three days the Danes ransacked S. Guthlake, sparing not even the tombs, knowing that in them were often buried valuable crosiers, chalices, and rings. On the fourth day, after setting the abbey on fire, they proceeded to Medeshamstide, since called Peterborough. Here the tragedy was re-enacted; but the Danes found richer spoil, as that abbey not only contained its own treasures, but those of the neigliborhood, which had been brought within its walls for safe-keeping. The pillage and massacre lasted fifteen days, during which Hubba, a Danish king, slew the Abbot and eighty-three monks with his own hand, to revenge a wound inflicted upon his brother.

Sidroc, anxious to save Turgar, allowed him to escape. He fled by night to the ruins of Croyland, where he found the residue of the monks who had returned. Godric was chosen by them to fill the place of Theodore, and under his direction the half-consumed bodies of their slaughtered brethren were dragged from the ruins, and buried with Christian rites. Scarcely had this sad office been completed, when they performed the same holy office for the corpses of Medeshamstide. Godric raised a pyramid of stones on which was engraved the history, and opposite to this he erected a cross bearing an image of our Lord, not only to rescue the spot from profanation, but also to induce the passers-by to offer a prayer for the repose of the martyrs. During his life he visited 
the spot on each anniversary of the massacre, and spent two days in celebrating masses, and performing the other devotions to which Catholic charity has attributed the power of benefiting the souls of the departed. ${ }^{1}$

A few years ago an interesting cross was discovered at Kirkbradden, Isle of Man. It is a wheel cross about four feet high, and nearly the same in width. In the four compartments of the cross are animals, three of which resemble cats, and the last a mouse. Chainwork surrounds the circle. The figures have a reference to the Isiac mysteries. According to Pliny, Isis, or the moon, is symbolized by the figure of a cat." In the head of the cross are two cats " regardant," with a human face between them. Plutarch in-

forms us that by this is designated the changes of the moon, regulated by wisdom and understanding. ${ }^{3}$ In the first compartment the animal is lean, in the second more plump, in the third not less so. According to Demetrius Phalereus, the cat has sympathy with the moon, increasing and decreasing in size as that luminary waxes or wanes; hence the fable that the moon has brought forth a cat. ${ }^{4}$ In the fourth compartment is a shrew-mouse, which was supposed to exercise a malign influence on animals. This had twenty-eight teeth, equal to the number of days in a revolution of the moon; other of the rat species had sixteen. Reasoning from the mythologic fables of Osiris and Isis, he proceeds to show that the cat is the symbol of Isis, or the moon, and a type of Noah's Ark, especially when the moon is increasing in size. The mygale, or shrewmouse, is also Isis and the ark when the moon is decreasing. The ark was also represented under the figure of a ship called Baris by Egyptians; it was a kind of crescent, hence a symbol of the moon, which, by the Egyptians, was considered as the mother of all things. This nation also used the moon and ark as synonymous terms. As the inhabitants of the Isle of Man came from the East, they are supposed to have brought the Isiac mysteries with them, along with other religious rites."

The most celebrated memorial crosses are those reared, at the instance

1 Lingard, Antiquities of the Anglo-Saxon Church, chap. xi.

${ }^{2}$ Pliny, Natural Hist., lib. xvi., c. 29.

${ }^{3}$ Plutarch, Isis and Osiris, c. 64.

'Demetrius Phalereus, $D_{e}$ Elocution, \& I59.

${ }^{5}$ Condensed from an article by Gco. Dobbs, D.D., on the symbolism of an ancient stone found at Kirkbradden, Isle of Man, in the Gentleman's Mag., November, IS66. 


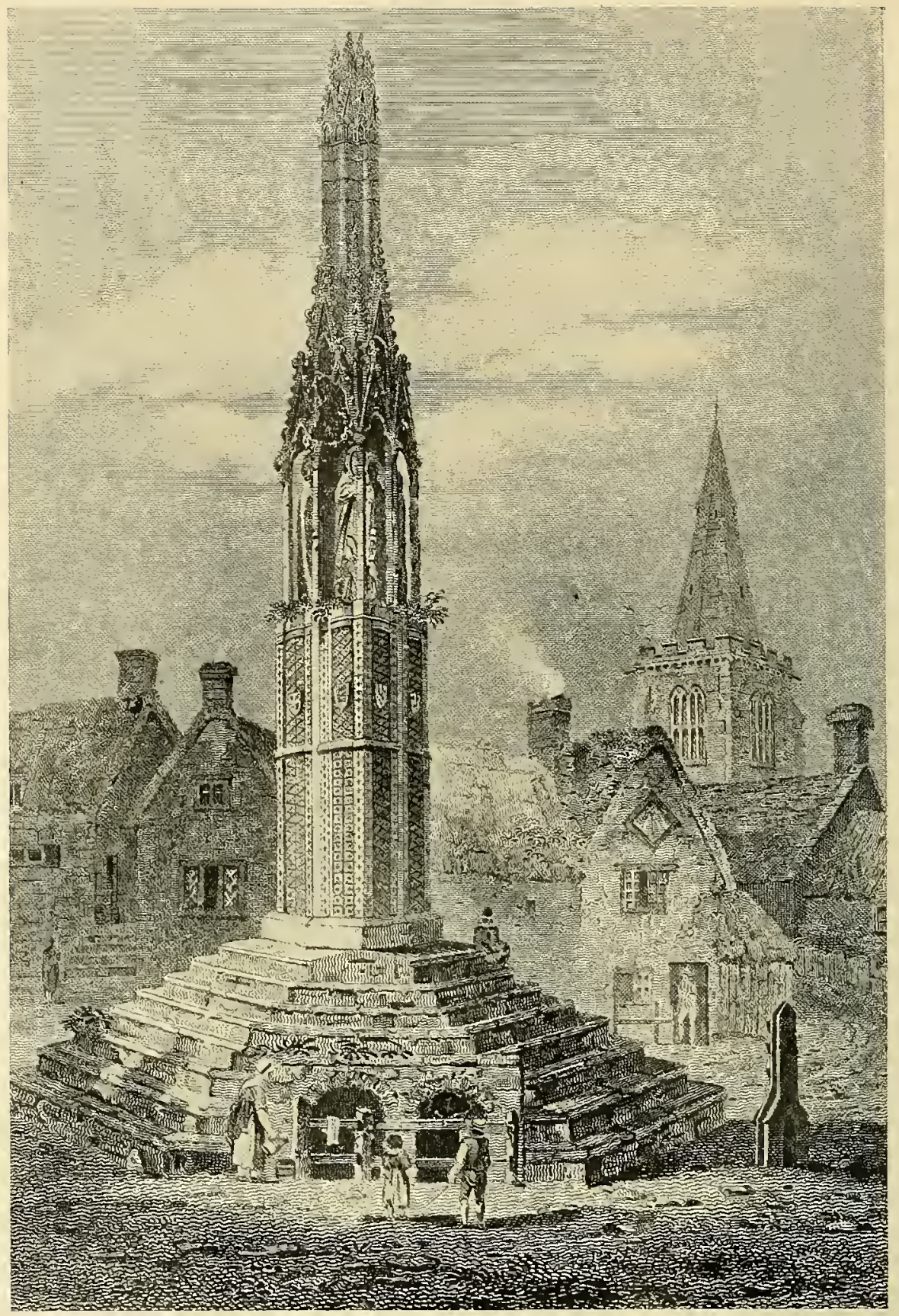

Geddington Cross. From Britton's Architectural Antiquities. 
of royal affection, by Edward I. of England, at the resting-places for a night of the corpse of his queen, Eleanor, during her removal from Hardeby, in Nottinghamshire, to Westminster, from the 4th to the I 7 th of December, I290.' Originally, they were $\begin{gathered}\text { Queen Eleanor } \\ \text { crosses. }\end{gathered}$ fifteen in number," but only three remain; those at Geddington, Northampton, and Waltham. Vertue and Walpole suppose that Pietro Cavallini, ${ }^{3}$ an Italian architect, was the builder, but Pillington and Bromley contest this statement, ${ }^{4}$ yet it is thought that the son of Cavallini built the one at Stamford.

The cross at Geddington, Northampton, is of triangular shape, elevated on eight steps, and of three stages. The first is solid-covered diaper sculpture of six panels, bearing shields charged with the arms of England, Castile, Leon, and Ponthieu; above

Cross of Geddington. rises the canopied tabernacle containing the statue of the Queen. The cross of Northampton is the most perfect of the three. It is octagonal in shape, surmounted on eight steps, and of three stages. Two shields are attached to each panel, charged with the arms of England and Ponthieu singly, and of Castile and Leon quarterly. A carved book is also affixed to four sides. On the western face has been inserted the arms of Great Britain in a garter, under a crown, beneath which is this inscription: "In perpetuam conjugalis amoris memoriam loc Eleanore. Regine monumentum vetustate pene collapsum, restaurari voluit honorabilis justiciariornm cotus comitatus Northamptonice M.DCC.XIII. Anno illo felicissimo, in quo Anna, Grande Britannice suce decus, potentissima oppressorm vindex pascis Bellique arbitra, post Germanian liberatam,

${ }^{1}$ Gough states that such memorials as these are unparalleled in any other kingdom. The nearest approach was the work of Philip III. of France when he brought home the remains of his father, I couis IX., who died at Tunis A.D. I270; those of his wife, Isabella of Aragon, who died at Cozenza in the same year; and those of his brother, the Count of Nevers. The King made a magnificent funeral in honor of them, and also erected moumental towers at certain distances on the road from Paris to S. Denis, containing statues of life size of Lewis the Count of Nevers, of Robert the Count of Clermont, and of himself. These towers, which were forty feet in height, were erected between the years 1270 and 1286 , and were destroyed in the Revolution at the close of the eighteenth century. Bloxam, Ilonzmental Architccture, p. I43; Rimmer, Ancient Stone Crosses of England, p. 44.

2 Some antiquarians limit the number to twelve. But in the Archaologice, vol. xxix., p. I72, etc., fifteen are enumerated: Lincoln, Grantham, Stamford, Geddington, Northampton, StonyStratford, Woburn, Dunstable, St. Albans, Waltham, West Cheap, Charing, Hardley, Newark, Leicester. Rimmer omits the last three.

3 The same who carried the crucifix in "S. Paul's Beyond the Walls" at Rome, famous for having spoken to $S$. Bridget. See infra, part iii., chap. viii.

- Britton, Architect. Antiq., vol. i., p. s. $_{3}$. 


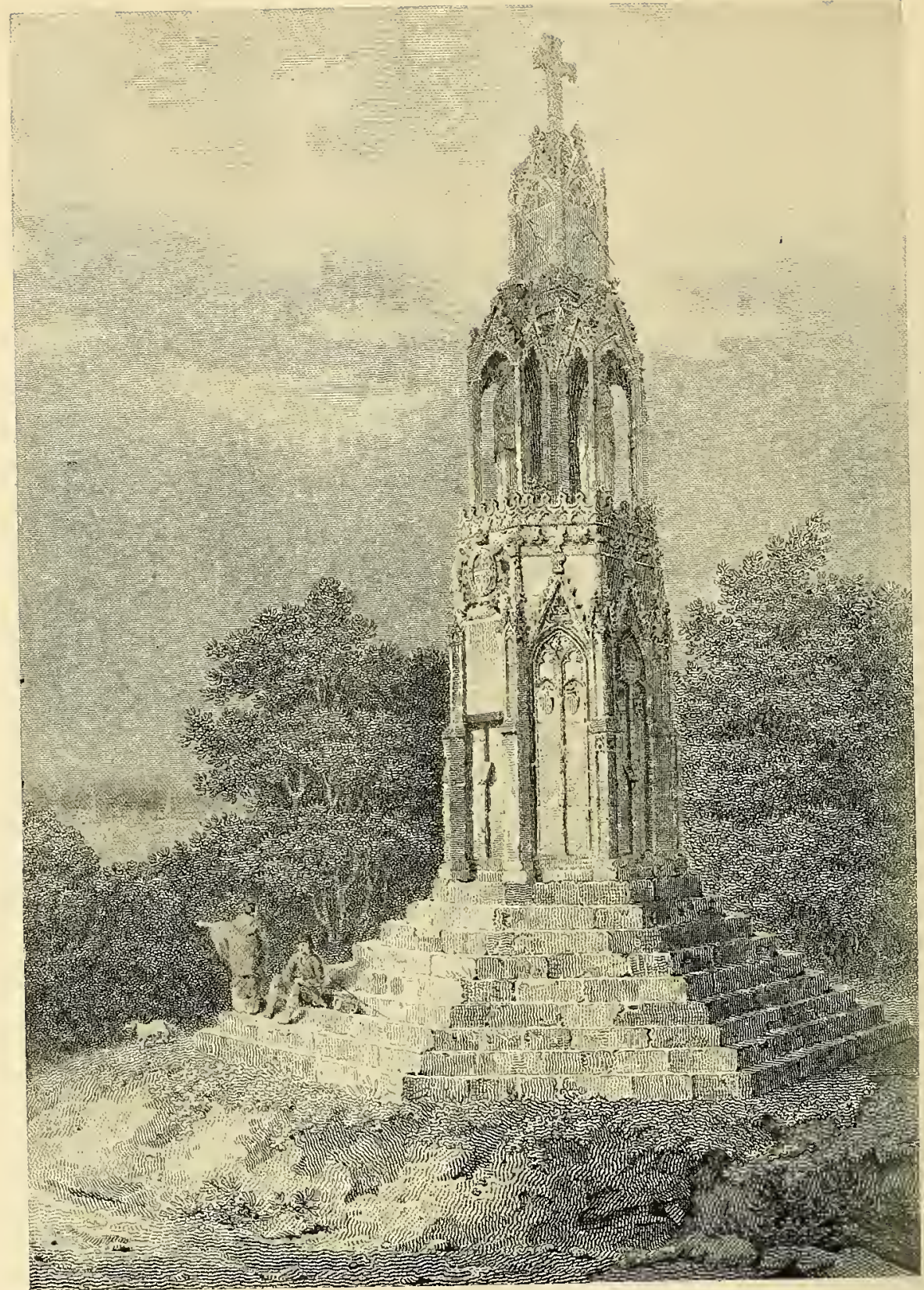

'The Queen's Cross, near Northampton. From Britton's Architectural Antiquities. 
Biggam presidiis munitam, Gallos plus vice dccima profigatos, suis sociorumque armis linccneli modum statuit, st Europe in libcrtatcm vindicate PACE II restituit." On another tablet is the following inscription:

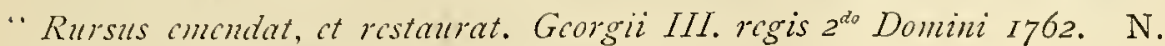
Baylis." "1 The cross at Walthain, Hertfordshire, is more dilapidated than either of the others, but its details are far richer, and show it to be the wreck of a more elaborate and magnificent structure than the others. Its shape was hexagonal.

But the most celebrated, owing to the memory of the historical events which cluster about them, of the Eleanor crosses were those of Cheapside and Charing. The former stood a little west of Bow Church and resembled very closely the cross of Northampton. It was considered the most beautiful in England. Worthy old Peter Heylin gives an interesting account of this cross which is too long to be inserted ; therefore, with regret, we condense. It was originally erected in I 290 , and repaired at

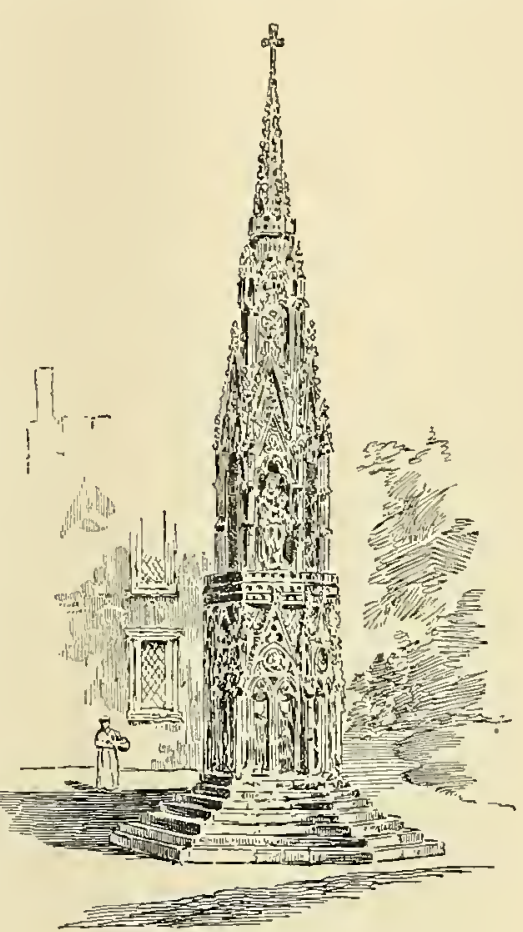

Waltham Cross. the expense of divers worthy citizens in the times of Henry VI. and Henry VII., I 44I and I486, and was regilded in 1522 " for the entertainment of the Emperor Charles the Fifth; new burnished against the coronation of Q. Anne Bullen, Anno I533; as afterwards at the coronation of King Edward the Sixth, and, finally, at the Magnificent charing crosses. Reception of King Philip, I 554. And having for so long time continued an undefaced Monument of Christian Piety, was quarrelled with by the Puritans of the present Reign; who being emulous of the zeal of the French Calvinians whom they found to have demolished all crosses wheresoever they came; they caused this Cross to be presented in several Ward motes, for standing in the High-way to hindering of Carts and other carriages; but finding no remedy in that course, they

${ }^{1}$ Britton, Architectural Antiquities, vol, i., p. 84 . 


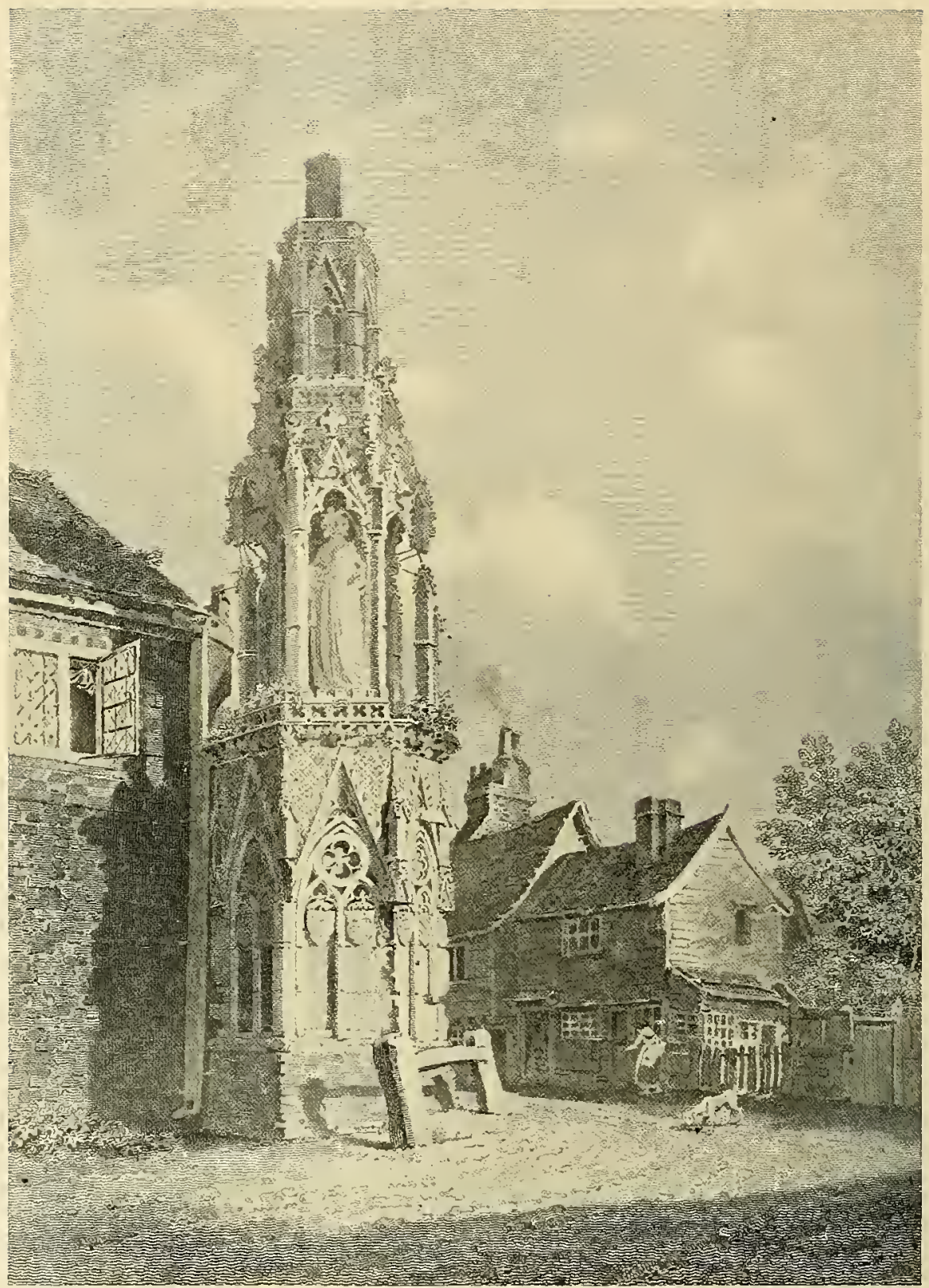

Waltham Cross. From Britton's Architectural Antiquities. 
resolved to apply themsclves to another. In pursuance whereof they first set upon it in the night, June $2 \mathrm{I}$, Anno $15 \mathrm{SI}$, violently breaking and defacing all the lowest Images which were placed round about the same; that is to say, the Images of Christ's Resurrection, of the Virgin Mary, K. Edward the Confessor \&c. But more particularly the Image of the Blessed Virgin was at that tine robbed of her son, and her arms broke by which she held him

Broken. in her lap, and her whole body lialed with ropes and left likely to fall." The cross was partially repaired, the image of Christ being left broken, "And on the East side of the said Cross where the steps had been, was then set up a curious wrought Tabernacle of gray Marble, and in the same an Alabaster Image of Diana, from whose naked breasts there trilled continually some streams of Water conveyed into it from the Thames. But the madness of this Faction could not be so stayed; for the next year (that I may lay all things together which concern this cross) a new misshapen Son, as born out of time, all naked, was put into the arms of the Virgin's Image, to serve as matter of derision to the common people. And in the year 1599 the Figure of the Cross erected on the top of the pile was taken down by Public Order under pretence that otherwise it might have fallen and endangered many, with intent to raise a pyramid or spire in the place thereof." But the Lords of the Council ordered the Cross to be replaced, " which gave such fresh displeasure to some zealous Brethren, that within twelve nights after, the Image of the Blessed Virgin was again defaced by plucking off her crown, and almost her head; dispossessing her of her naked Child, and stabbing her into the breast \&c. Most ridiculous follies." '

Heylin notices the divine retributions on the sacrilegious wretcheswe give the whole paragraph as exhibiting the spirit and spoliations of these sacrilegious " trouble tombs." By an ordinance of their Parliament "they" $-i$. $\boldsymbol{c}_{\text {. }}$, the visitors,- " descend to the taking away all Coaps, surplices, and other Superstitious Vestments, (as they pleased to call them) as also to the taking away all Organs, and the Cases in which they stood, and the defacing of the same, requiring the same course to be taken also in the removing and displacing of Roods, Rood-Lofts, and Holy-water Fonts (as if any such things had been of late erected, or permitted in the Church of England, as indeed they were not) whereupon

${ }^{1}$ Heylin, History of the Presbyterians p. $3+3$. 
followed the defacing of all Glass Windows, and the demolishing of all Organs within the compass of their power; the transposing of the holy table from the place of the altar, into some part of the Church, or Chancel, the tearing and defacing of all Coaps and surplices, or otherwise employing them to domestic uses, finally the breaking down and removing of the Sacred Fonts, anciently used for the Ministration of holy baptism, the name of Holy water fonts being extended and made

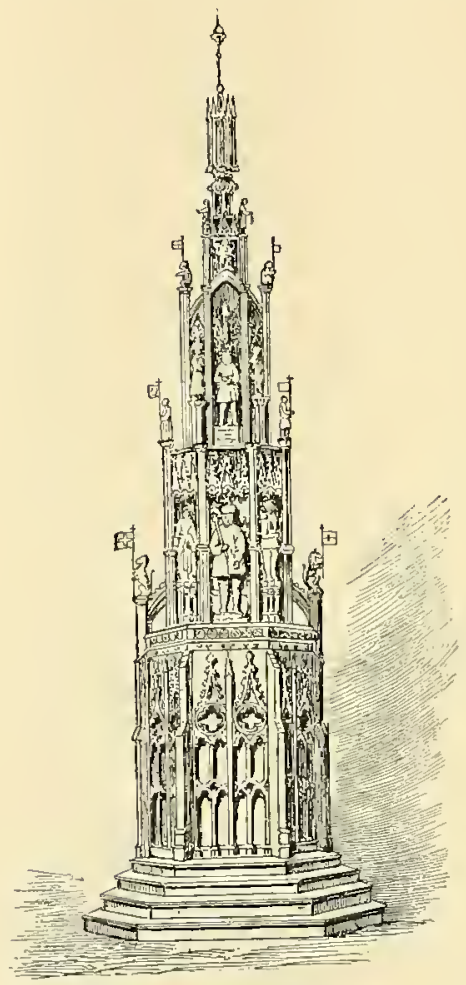

Abingdon Cross.

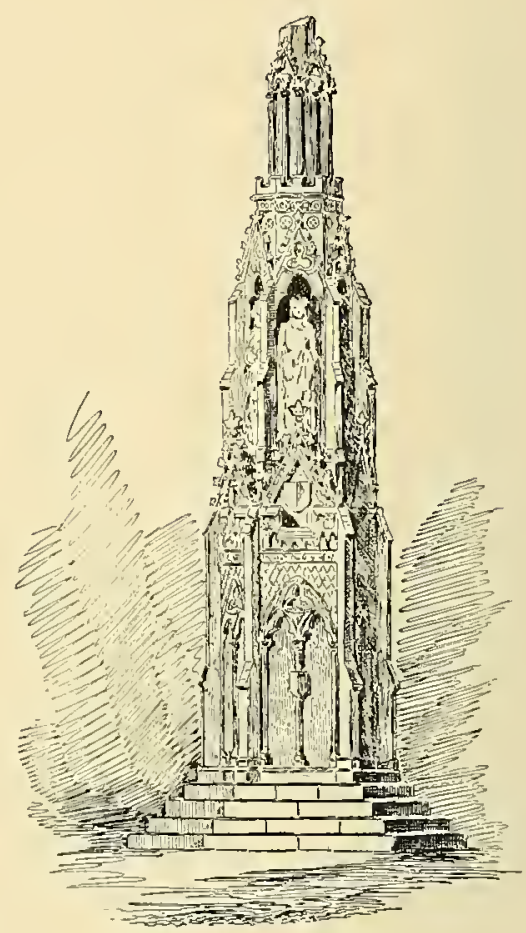

Charing Cross.

use of to comprise them also, hereupon followed also the defacing and demolishing of many Crosses erected as the Monuments of Christianity in Cities, Towns, and most of our Country Villages, none being spared which came within the compass of those enemies of the Cross of Christ.

"Amongst which Crosses none more eminent for cost and Workmanship, than those of Cheapside in London, and Abingdon in the County of Berks, both of them famous for the excellencies of the Statues which were placed in them, more for the richness of the trimming which was. 
used about them. But the Divine Vengeance fell on some of the Executioners, for a terror to others, one of them being lilled in pulling down the Cross of Cheapside, and another hanged at Stow on the Wold, within short time after he had pulled down the first Image of the Cross in Abingdon."

Of Charing Cross, ${ }^{1}$ part remained until the time of Charles I. when it was destroyed as a relic of mediaval popish superstition. In 1633, a brass statue of the king-the first equestrian statue in England-was executed by Le Saur for the Earl of Arundel,

Charing Cross. but was not erected on the site of Charing Cross until I678. The pedestal was the work of Grinling Gibbons. The Puritan Parliament ordered it to be sold and broken into pieces, but the brazier, one John Rives, who purchased it, being a true loyalist, buried the statue unmutilated, and casting a vast number of brazen handles of knives and forks, sold them

1 According to a late writer, Charing Cross is not derived, as has been supposed, from Chire rine, but cer' 'e', Anglo-Saxon for bend, and ins, i.e., meadow-therefore Charing means meadow by the bend, for the river here makes a turn to the south. Nor is it the work of Pietro Cavallini, but of Richard and Roger de Crundale, who received $£_{590} 7 s .9 d$. William Torel modelled the figures, which were executed by Alexander of Abingdon. The one now in Charing Cross Station is the work of E. M. Barry, made from three rude drawings, which are the only extant records of the Monument. - All the Year Round, no. 170, p. 526.

"2 Pennant, London, P. I50. Percy's Reliques preserves a spirited ballad, "The Downfall of Charing Cross," part as follows :

The parliament to vote it down,

Conceived it very fitting,

For fear it should fall, and kill them all, In the house as they were sitting.

They were told, God wot, it had a plot, Which made them so hard-hearted,

To give command, it should not stand, But be taken down and carted.
But neither man, woman, nor child, Will say, I 'm confident,

They ever heard it speak one word Against the parliament.

An informer swore, it letters bore, Or else it had been freed;

I 'll take, in troth, my Bible oath, It could neither write nor read.

The committee said, that verily

To popery it was bent.

For ought I know, it might be so,

For to church it never went.

The bitter feeling of the Puritans towards this cross is exhibited in a tract in the author's possession, entitled: "The Crosses CASE IX CHEAPSIDE; Whether its Malitia the setting of it in a posture of defence, be according to law, THE CONTRARY IS MAINTAINED by one who hath little of that, we commonly call law, against those, who have as little of that, we truly call reason. Notwithstanding. THE Dispute is carried all along in a cool and orderly way, by the Law of Heaven, the line and rule of the Word, and as in God's presence, Who is Iudge Himself, So as the Man in understanding may find strong MEATE here, The Child Milke. 
as true relics of the statue, not only to the loyal adherents of the Martyr King, who cherished them through affection, but also to the rebel roundheads, who were desirous of a token of triumph over their murdered sovereign.

"Jer. x., 15. They'are vanity and the work of errors: in the Time of their Visitation they shall perish.

"Acts. xxvi., 32. This man doth nothing Worthy of death or of bonds. Acts. xix., 32. Wherefore Demetrius and the Craftsmen, have a matter against any MIan the Law is open.

"Printed In the Climacterical Yeare of Crosses and Crosse Men. For T. V. I642."

The title is sufficient. It would be a waste of time to give an abstract of the contents. 


\section{CHAPTER XIV}

\section{SANCTUARY CROSSES}

$\mathrm{M}^{\mathrm{o}}$

OSES set aside certain cities of refuge in which anyone who should unintentionally slay his neighbor might find shelter from the avenger of blood. (Deut. iv. 4I, 42.) The Jews in the reign of Solomon afforded the privilege of sanctuary to sanctuaries. those who laid hold on the horns of the altar (I Kings i. 50-53; ii. 2833); although, as in the case of Joab, the King did not consider it inviolate.

Christians followed the Jewish example. In A.D. 392 Honorius and Theodosius granted the protection of a church and its precincts; probably this is the first legal recognition of the right. The first Council of Orange, A.D. 44I, in its fifth canon ordered the right of asylum in a church to criminals. Boniface V., A.D. 620, gave papal sanction to the right of sanctuary, and, in the same century, King Ina recognized it. Alfred, in 887 , allowed the privilege of sanctuary for seven nights in order to give time for composition. Afterwards the time was extended in some cathedrals. Cologne permitted thirty-seven days. " The Church's Peace," as it was called in 605 , was extended in 965 as the King's Protection, for three miles, three furlongs, and three

Church's Peace. broad acres from the gate of the city in which the royal palace stood. Canute, in IOI7, confirmed the right of sanctuary, and Henry III. of protection, after confession before the local coroner, while the criminal, bearing a white cross or crucifix, went forth to perpetual exile in some Christian land.

While to every church and churchyard belonged the privilege of sanctuary for a short time, unless the criminal was guilty of some special crimes for which the offender might be carried off from the very altar, the protection generally did not extend beyond the burial ground, which 
was often guarded by four crosses at the cardinal points. The AngloSaxons, wishing to show their reverence for the saints, bestowed upon some churches a more extended area of sanctuary. A chair of stone, Frid- or Frith- called the Frid-or Frith-stool ( $i . c_{\text {. }}$, the freed stool, or chair Stool and its of peace) was sometimes set near the shrine of certain Rights. saints, ${ }^{\prime}$ or the high altar; the churches of York, Croyland, Hexham, and Beverley enjoyed this privilege, and in the last two these stools are still preserved.

The rights of the Frithstool overshadowed the region for the distance of a mile, and guarded to the refugee the widest privilege belonging by

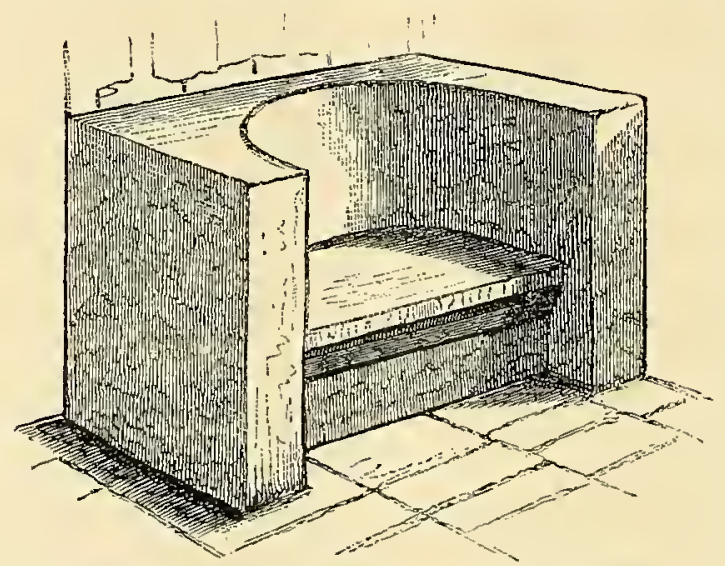

Frithstool, Beverley Minster. From Lee's Glossary. charter to this sanctuary, as long as he chose to remain within bounds. Crosses marked the limits of safety. At Beverley and Hexham, if anyone arrested the fugitive within the crosses he forfeited the two hundredth; if within the town, the four lundredth; if within the courts of the church, the six hundredth; if within the choir, the eighteen hundredth; if from the Stool of Peace, the crime was beyond the power of money to expiate it. The hundredth was eight pounds."

In some cathedrals there was a special door-the north, in Durham. Here was the knocker " hagoday," of which the fugitive laid hold. The Galilee bell was then tolled to give notice that the sanctuary The Hagoday. was gained. He was clothed in a black gown with a yellow cross on his shoulder, and provided with food and lodging in a room near the Galilee for thirty-seven days. The fugitives were bound not to wear weapons, to hear mass, and to assist as bell-ringers. They might go with impunity thirty paces from a church, and forty from a

1 This custom is noticed in the dying wish of S. Cuthbert, who desired to be buried at Farne, lest, if buried at Lindisfarne, his grave might become a place of refuge for runaways. Rock, Church of our Fathers, vol, iii., pp. I, 365.

${ }^{2}$ Ibid., pp. $367-369$. 
cathedral. At the end of the allotted time they were forwarded to the nearest port.

Among persons of note who thus sought safety were Margaret of Anjou, and Perkin WVarbeck, who were sheltered at Beaulieu; the Queen of Edward IV., and Skelton,

Notable Persons who Sought Sanctuary. the poet, at Westminster.

If a person sought sanctuary a third time, he became a servant of the Church. In I26I, all persons who prevented victuals from being brought to the fugitive, or killed him after he had forsworn the kingdom, were excommunicate.

On the Continent the privilege of sanctuary appears to have been still further extended. In the XXIXth and XXXth canons of the Council of Clermont, in France, held in 1095, it was decreed that if any person should flee to a cross in the road, he should remain as free as in the church itself; and by the eighty-

Privileges of Sanctuary at second chapter of the ancient customs of Normandy, anyone being condemned, or having escaped, who could flee to a church, churchyard, or holy place, or "if he take a cross fixed in the earth, lay justice shall leave him in peace, by the privileges of the Church, as if it had not laid hands on him.",

In England no place could enjoy the full rights of sanctuary but by royal grant, because the privilege of the Cross had been abused, as mentioned in the chapter on "Boundary Crosses." Those accused of high treason were declared incapable of sanctuary by Acts 26 and 28 of Henry VIII., and in the twenty-first year of James I. the privilege was abolished. ${ }^{\prime}$

Even to animals was, in one place at least, the privilege of sanctuary allowed. "Basolus, born of a noble race in Lemosia, and founder of the Monastery of Vierge in the hill country of Reims, having Animals Allowed built a cell in the depth of the forest, sheltered by a stone sanctuary. cross, and where his whole furniture consisted of a little lettern, admirably sculptured, to bear the Holy Scriptures, on which he meditated unceasingly, was one day disturbed in his devotions by a great bear, which laid itself at his feet, as if to ask mercy for its life. Following the animal

${ }^{1}$ Walcott, Sacred Archaology, p. 2Sg. Everyone will remember the right of sanctuary enjoyed by Alsatia, White Friars, the last sanctuary, as described by Scott in the Fortunes of Nigel. 
came on horseback one of the most powerful lords of the neighborhood, Attila, whom the mere glance of the hermit brought to a standstill, and rendered motionless. He was a good man at bottom," says the legend, " though a great hunter; he evidenced this by making a gift to the abbot of all he possessed round the cell." Four centuries after, this tradition remained so fresh, that, by an agreement scrupulously observed, the game hunted in the forest of Reims was always spared, both by dogs and hunters, when it reached the little wood over which rose the cross of S. Basle. ${ }^{1}$

'Montalembert, Monks of the West, vol. ii., p. 349. 


\section{CHAPTER XV}

\section{PREACHING CROSSES}

$T^{1}$

$\mathrm{HE}$ origin of the preaching cross must be traced back to the processional cross of the early missionaries. It was an eventful day for England when S. Augustine and his companions, A.D.

597. appeared before Ethelbert, King of Kent, chanting the

Origin.

litany and hymns, and bearing aloft a silver image of our Lord and a crucifix painted upon a board. Meagre as may have been the pomp and ceremonial of the missionary and his attendant monks, the symbolic worship riveted the attention of the pagan king and secured a welcome for Christianity in his dominions. Soon, to the processional cross temporarily set up, structures were added " which supplied the place of an oratory, and around it the Thane and his retainers frequently assembled to perform their devotions." '

Strictly speaking, this was not the earliest missionary meeting in Great Britain, for we believe that S. Paul or his disciples first preached the Gospel in " the extreme isles of the West." " Nor was this the first time that the Cross was known, for it had been carved on stones in Wales two hundred years before, but it may have been the first exhibition of that standard which England proudly boasts, as floating over a dominion upon which the sun never sets.

Such also was the custom of the early Jesuit missionaries in this country. Father Rasles, who labored among the Indians of Canada and the northern part of New England in I689-I723, describing cross Erected by his visit to the Amalingans, says, "I did not lose the least Jesuit Missiontime, but as soon as I arrived, I caused them to plant the America. Cross, and those who accompanied me raised as soon as possible a chapel

\footnotetext{
1 Bede, Eccles. Hist., b. i, c. 25 .
}

S. Clement, I Epistle. 
which they made of bark, in the same way in which they formed their cabins, and within it they erected an altar." "

In England, the preaching cross was used not only for religious instruction, but also for almost every purpose, political or ecclesiastical. At Uses of Preach- its foot, laws were promulgated, and oaths were adminising Cross. $\quad$ tered, which were presumed to be of special sanctity ; papal bulls were solemnly announced, and anathemas fell with crushing weight; penitents grovelled in sackcloth and ashes, and recantations were uttered, with all due pomp and ceremony.

The most celebrated preaching cross in England was that of S. Paul. It would require a volume to contain its history, yet so much has hapS. Paul's Cross. pened under its consecrated shadow which is interesting to everyone who speaks the English tongue, that a few facts must be summarily given. The site was a place of worship long before it was consecrated by the Cross, for the ruins of a temple to Diana were found near the spot, and some relics of the worship of that goddess were preserved even as late as the time of Camden, for he remembered having seen when a boy some remains of the Tauroplia, a festival of Diana, when a stag's head fixed on a spear was borne, with the accompaniment of horns and due solemnity, around the Church of S. Paul's, and a certain family

${ }^{1}$ Kip, Early Fescait Missions in North America, p. 49. Whittier carries us back to the scene in his Mogg Megone, part ii. :

"On the brow of a hill, which slopes to meet

The flowing river and bathe its feet,--

The bare-washed rock, and the drooping grass,

And the creeping vine, as the waters pass,-

A rude and unshapely chapel stands,

Built up in that wild by unskilled hands,

Yet the traveller knows it a place of prayer,

For the holy sign of the Cross is there:

And should he chance at that place to be,

Of a Sabbath morn, or some hallowed day,

When prayers are made and masses are said,

Some for the living and some for the dead,

IVell might the travelier start to see

The tall, dark forms, that take their way

From the birch canoe, on the river-shore,

And the forest paths, to that chapel door;

And marvel to mark the naked knees

And the dusky foreheads bending there,

While in coarse, white vesture, over these

In blessing or in prayer,

Stretching abroad his thin, pale hands.

Like a shrouded ghost, the Jesuit stands." 
by the name of Baud were bound to pay redemption for the stag to the priest, who stood on the steps of the choir, clad in sacerdotal robes and garlands. But long before the time of the worthy chronicler, the friars of S. Martin had usurped the shrine of the goddess of the Ephesians, and had erected a cross which appears to have been used both as a preaching and a market cross. The monks exacted their

Double Use by the Monks. toll, and dispensed the Gospel from the same place, Cheapside. Yet their hand could not have been very heavy; for S. Paul's Cross was ever loved and revered by Londoners from its first foundation until long after " one stone had not been left upon another." It was their common ground for assemblies, civil or religious, their Folke mote; beggar or king had an equal right in it, and it was prized by the citizens accordingly.

To show how dearly the liberty of S. Paul's Cross was held by the citizens of London, we refer to the attempts made, in the reign of Edward II., by the Dean and chapter of the church to gain exclusive possession of the cross and grounds, but the tumult raised by the Londoners was too great. The chapter was vanquished, and the citizens retained the right not only to have free access to the cross, but to the great bell tower, in order to toll the bell and assemble the people for discussion.

The youths also asserted their privilege. The ground around the cross was their playground, whereon mimic wars of the English and French were acted, but with such zeal, that on the feast of S. Ambrose, A.D. I 400, not only many were wounded, but several killed.

S. Paul's Cross preceded by a short time the churcl, which was probably built by King Ethelbert in 6ro. It is

Church of $S$. not known how long this edifice lasted. The old Cathedral of S.

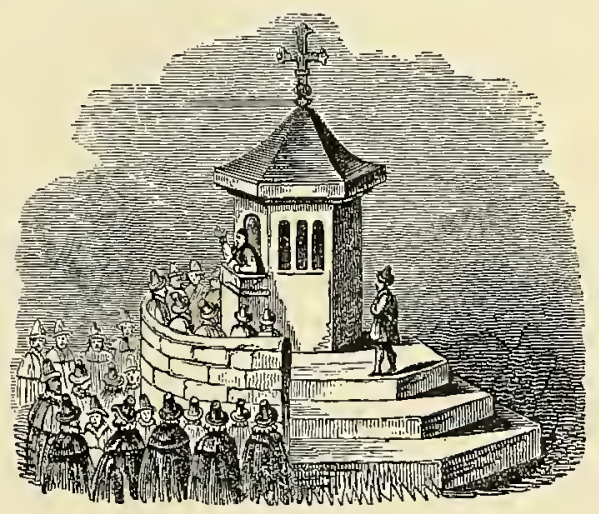

S. Paul's Pulpit Cross. From Holland's Craciana. Paul, which was burned in the Great Fire, was begun in I083. Only incidentally in history do we find mention made of the old cross. About the thirteenth century, proclamations were The old Cross. made from the foot of the cross, civic meetings were held, and the Lord 
Mayor impeached, etc. Henry III., cir. 1259, ordered a general assembly to be held at S. Paul's Cross, where he in person commanded the Lord Mayor to swear in fealty, in the presence of the Aldermen, every person of twelve years old and upward. In A.D. I 260 , or I 262 , in the presence of a splendid gathering of the representatives of both Church and State, the same king caused the bull of Pope Urban IV. to be read, absolving him from the sin of perjury in breaking the oath which he had taken before the "Mad" Parliament in 1238, to rule only under the guidance of a great council. In short, everything was then promulgated from the cross. It seems curious in these days to read the various matters thus published: c.t. $g r$, in I 299, Ralph Baldoe, Dean of S. Paul's, from the cross, cursed all those who had searched for hidden hoards of gold in fields and caves about the Church of S. Martin. ${ }^{1}$

Again, the metropolitan Bishop of Northbury bequeathed one hundred marks to be lent to laymen on pledge, and " directed that if the Money Loaned at pledge was not redeemed within a year, the preacher at $S$. S. Paul's cross. Paul's Cross was to give notice that it would be sold within the ensuing fortnight." Hereby we learn that what was probably the primary purpose of the cross, public worship, exhortation, and preaching, was at that time kept up.

S. Paul's Cross was overthrown by an earthquake in I 382 , and IVilliam Courtney, Archbishop of Canterbury, a prelate powerful enough to

Overthrown by dare to quarrel with old John of Gaunt, " time-honored an Earthquake. Lancaster," collected money for its re-erection. But this Act of Bishop purpose was not carried into effect until the time of Thomas Courtney. Kemp, Bishop of London, in I449. Hence, Dean Nowell, in a sermon preached at the cross, accused the Archbishop of misappropriating the funds to his own use ; perhaps a foul slander,-but at all events, William Courtney was a cool hand, as may be shown in another instance. When Gregory XI, being enraged at the Florentines because they would not acknowledge his temporal power, issued a bull exempting all persons from paying debts due to merchants of Florence, Courtney published the bull at S. Paul's Cross, approving it. The Mayor of London forthwith imprisoned the. Florentine merchants who were in that city. Edward III. not only freed them, but commanded the Archbishop to acknowledge his fault for presuming to publish a papal bull without

\footnotetext{
1 Pennant, London, p. $5 \mathrm{I} 4$.
} 
the royal authority. By special favor, only allowed in rare cases, an attorney appeared for the prelate, and in the presence of the audience, composed of foreign merchants, British nobles, and the common people, coolly denied in the most barefaced manner that the Archbishop had ever uttered a word that was charged to him, adding, " I am astonished

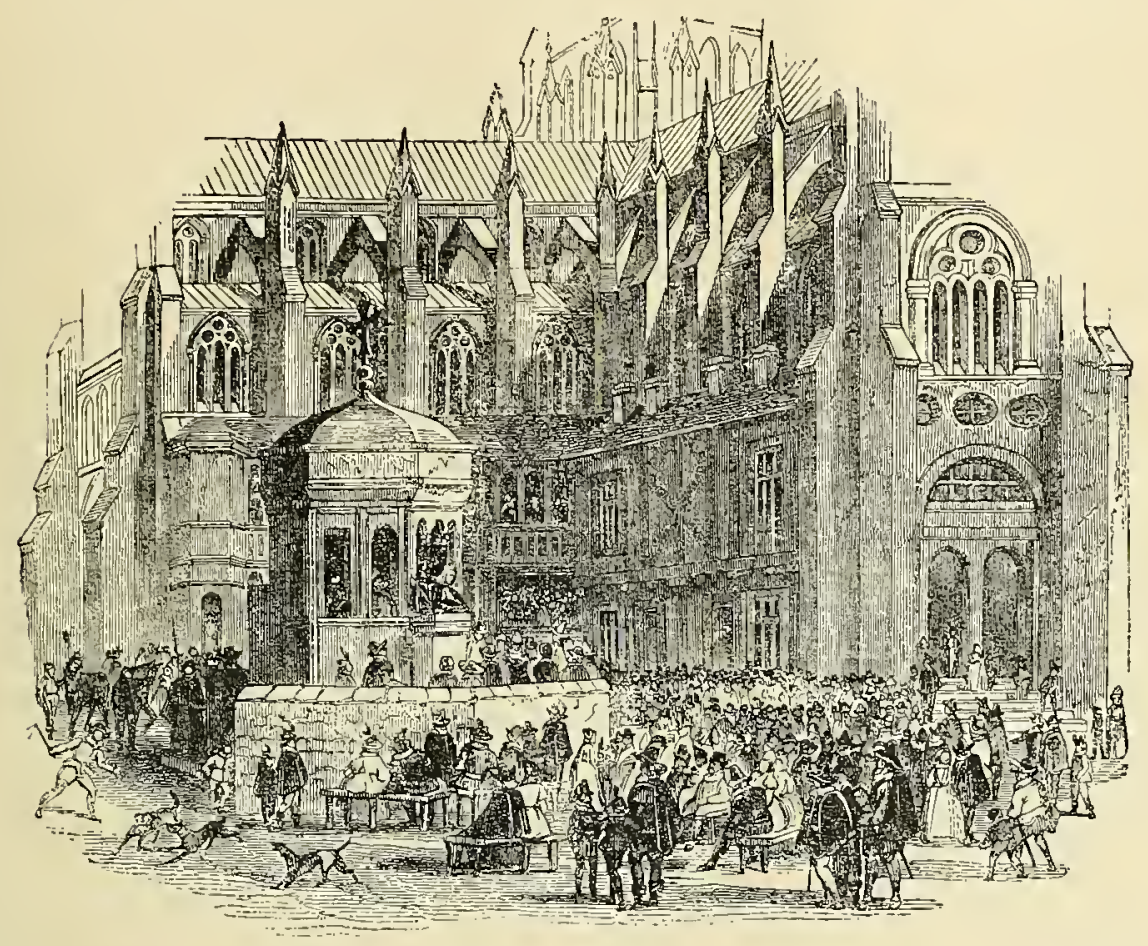

S. Paul's Cross. From an Old Print.

that you who hear so many sermons here should not better understand what is said to you." 1

But to turn to more serious matters. Passing over many curious incidents, such as the anathematizing at the cross of Sir John Oldcastle for maintaining that Richard II. was not dead, after Henry had publicly exposed his corpse, etc., we note that the great Anathematized "King-M Maker," the cross. the steps of S. Paul's Cross, and proclaimed that Edward was not the legitimate son of Henry VI. Afterwards, Warwick's chaplain, Dr. Goddard, preached from the cross on the Sunday after Michaelmas, I470,

1 Doran, Saints and Sinners, vol. i., p. 56. 
and so did he move the audience that not less than six thousand soldiers, who had been levied for King Edward, transferred their allegiance to Henry and Warwick.

But the cross witnessed a simple scene of far more weight than puppet kings and empires could present. In 1474, printing was introduced

\section{Printing}

Denounced at

the Cross.

into England by IVilliam Caxton; and the Vicar of Croydon, at the cross, denounced the new-fangled art, saying, "We must root out printing, or printing will root out us." " All honor to the true prophet, whose vaticinations began to be fulfilled when, in August, 1539, the Bishop of London burned all the copies that could Tyndale's Testa- be bought of Tyndale's New Testament, fined their possessment Burned. ors and compelled them to ride upon their horses, facing their tails, amid the hooting of the rabble. The purchasing of the New Testament was a blessing to Tyndale, for thus he was provided with funds to publish a second and more correct edition. Sir Thomas More asked him how he had obtained means to subsist while abroad. With quiet humor he answered, that "the Bishop of London had been his chief supporter."

A few years later, Coverdale, from the cross, defended Cranmer's Bible. But we have anticipated for the sake of the connection of the Cranmer's Bible subject. To resume chronologically we must go back to a Defended. sad scene.

In I483, Jane Slore began her penance at S. Paul's Cross. Sir Thomas More, in his defence of this poor Magdalen, declares that Richard III.'s persecution of her arose from avarice. After Jane Shore. seizing all her possessions, amounting to " above the value of two or three thousand marks," he sent her to prison, on the cliarge of bewitching him; when unable to sustain that, " then he layd heinously to her charge the thing herself could not deny, that al the world wist was true" ; as More satirically remarks, " as a goodly continent prince, clene and faultless of himself, sent out of heaven into this vicious world for the amendment of men's maners, he caused the Bishop of London to put her to open penance, going before the Crosse in procession upon a Sunday with a taper in her hand. In which she went in countenance and pace demure, so womanly; and albeit she was out of al array save her kyrtle only yet went she so fair and lovely namelye, while the won-

\footnotetext{
${ }^{1}$ Lewis, Hist. of Eng., Translation, p. 55, quoted in Hone's M/y'stcries, p. 228, note.
} 


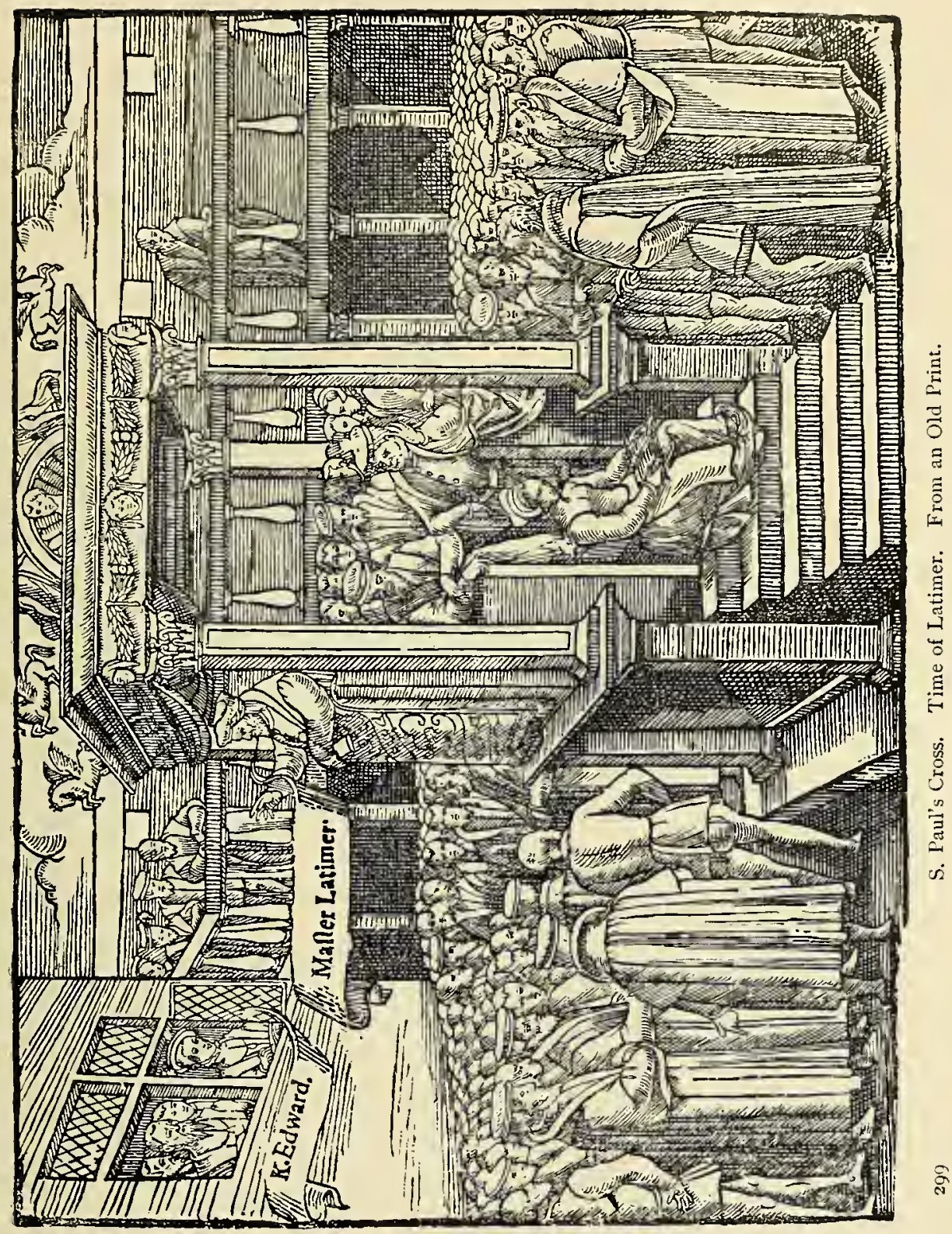


dering of the people caste a comly red in her chekes (of which she before had most misse), that her great shame wan her much praise among those that were more amorous of her body, than curious of her soule. And many good folke also, that hated her living, and glad wer to se sin correted, yet pitted thei more her penance than rejoiced therein, when thei considered that the protector procured it more of a corrupt intent than any virtuous affecion." The testimony of the Lord Chancellor as to Mistress Shore's charity and kindness of heart is emphatic. God grant that it may be of weight at the Last Day! " Whose porver to sai the trouth, (for sinne it were to belie the devil), she never abused to any man's hurt, but to many a man's comfort and relief . . . for at this. daye she beggeth of many living that had begged if she had not bene." Truly the old ballad sings:

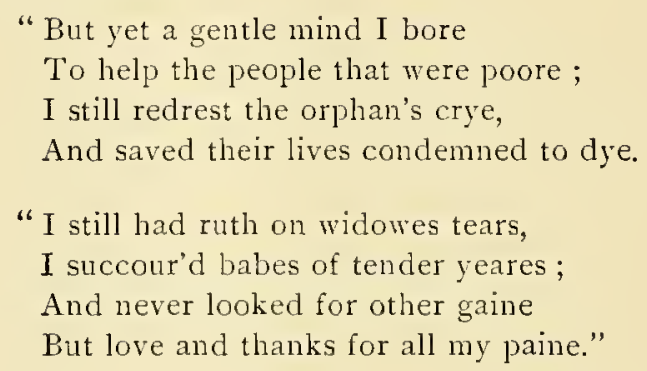

"Her doings were not much lesse, albeit thei be muche lesse remembered because thei were not so evil. For men use, if they have an evil turne, to write it in marble; and who so doeth us a good turne, we write it in duste." ' Probably to these words even Shakespeare was indebted when he wrote, "Men's evil manners live in brass, their virtues we write in water." 2 And again the passage may have floated through his mind when he writes, "The evil that men do lives after them, the good is oft interred with their bones."

This same year witnessed another gathering at the cross, convened by Richard, when he employed Doctors Shaw and Pinke-“"both," says. Stow, "great preachers of more learning than virtue "--to Claims of Richard iIf. Preached at uphold his pretensions to the throne. Not only did Shaw the Cross. (ungrateful wretch, having been chaplain and confessor to Edward IV.) declare the children of the former king illegitimate, on the

1 Percy's Reliques. "Jane Shore." Sir Thos. More's Works, ed. I857, pp. 56, 57.

"Henry VIII., act iv., sc. ii. ; Fulius Ciesar, act iii., sc. 2. 
pretence that Edward's marriage with their mother was illegal, as a precontract had existed between the King and Elizabeth Lucy, but overzealously going still further he maintained that Edward IV. and Clarence, the elder brothers of Richard, were also bastards, but that Richard's likeness to his father, the Duke of York, proved his lineage. According to one tradition, Richard, at this point of the sermon, was to have entered the pulpit, or rather the little room behind the preacher, with the Doctor, so that all might read his likeness, but he failed to appear. Another tradition makes Richard present during the whole time that his mother's fair fame was thus belied. Shaw's eloquence fell on unresponsive ears-in shame he retired, and, it is said, died soon after of mortification. ${ }^{2}$

During the time of Henry VIII. an act was passed decreeing death to all murderers and robbers. The Church party, in the House of Lords, opposed it, but were conciliated by the exception of priests and deacons from the penalty. Yet the act was bene- Benefit of Clergy. ficial, inasmuch as many offenders were punished who else would have escaped on the plea of "benefit of clergy." " The Abbot of Winchester preached at S. Paul's Cross, as the representative of the Old Churchmen, and protested that the act was contrary to the liberties of the Church and the law of God. Dr. Hook, in his Life of Archbishop of Warham, remarks, "The act only so far invaded the liberties of the Church, as to prevent the Church from extending its protection to persons guilty of 'certain offences,' not because they were in Holy Orders, but because, being able to read, they were qualified for Holy Orders."

The cross was put to a more agreeable use in I 501 , when the proclamation of marriage between James IV. of Scotland and Margaret, daughter of Henry VII., was proclaimed from it, but this was only a

1 Doran, Saints and Simers.

${ }^{2}$ In England the exemption of the clergy from civil punishmcnt was based on the text, "Touch not mine anointed, and do my prophets no harm" (I Chron. xvi., 22). The privilege in time was perverted to comprehend, not only all ordained persons, bnt all who, being able to read and write, were capable of entering into Holy Orders. Felons learned to spell out the trial verse of those who claimed the "benefit of clergy," "Have mercy upon me, O God, according to thy loving kindness; according unto the multitnde of thy tender mercies blot ont my transgressions" (Ps. li., I). This was called the " neck verse," and if the convict could read it, the ordinary of Newgate said Legit ut clericus, and the criminal saved his neck, being only burnt in the hand and set at liberty. The law concerning the "benefit of clergy" was repealed in the reign of George IV. 
passing gleam of brightness. Henry VIII. found a vent for his tur-

Marriage of bulence at S. Paul's, for he commanded the preachers James 1V. and from Sunday to Sunday to preach against the Pope's Margaret Proclaimed.

Authority of Pope Denied. authority, and to dispute his claims as universal Bishop, and thus, says Pennant, " his Holiness' bulls were fairly baited out of his kingdom by his own dogs."

On February 24, 1588, Bishop Hilsey of Rochester exposed at the cross the celebrated "Rood of Grace" of Boxley." This image of the Fraud of Rood of Madonna had been made by an English soldier, during his Boxley Exposed. captivity in France, and by its automatical movements of winking and smiling had been a fund of treasure to its possessors. Its mechanism being exhibited, it was burnt. Doubtless a needful sacrifice, yet, still, every lover of mechanism regrets the destruction of an automaton as he would one of the masterpieces of the celebrated Vaucanson three hundred years later.

Before the curtain drops which hides the death-bed of Henry VIII. from the world, we must note his last act; for when in his death throes, struck with remorse, the tyrant ordered the Church of the Grey Friars, which he had desecrated into a storehouse, to be fitted for Divine service for the poor. And this feeble act of retribution was declared from S. Paul's Cross.

During the sixteenth century many persons appeared in penance at the cross. Those who in former and less merciful days would have been Recantation and burnt, were now required only to appear barefooted and Penance. bareheaded and compelled to make public recantation of their religious opinions. The Protestants denied their faith under Mary, and the Romanists under Elizabeth. The former were obliged to carry a fagot as a token of their being brands plucked from the burning, but the latter were exempt from this suggestive symbol. As a punishment for sacrilegious impiety we find that, in I 537 , one Sir Thomas Newman, priest, was ordered to bear a fagot for celebrating mass with ale. Another criminal, one Dolwyn, alias Dynk, had published a book declaring that pastors ought to have meat and drink, but no money. Here, too, was the ludicrous spectacle, on the eighth of March, I555, of a man who having, in Lent, brought two pigs ready dressed for sale, was compelled to stand during the sermon, with one pig upon his head.

${ }^{1}$ Burnet, Hist. of Reformation, part iv., book iii. 
The last person recorded as performing penance was a seminary priest in 1593.

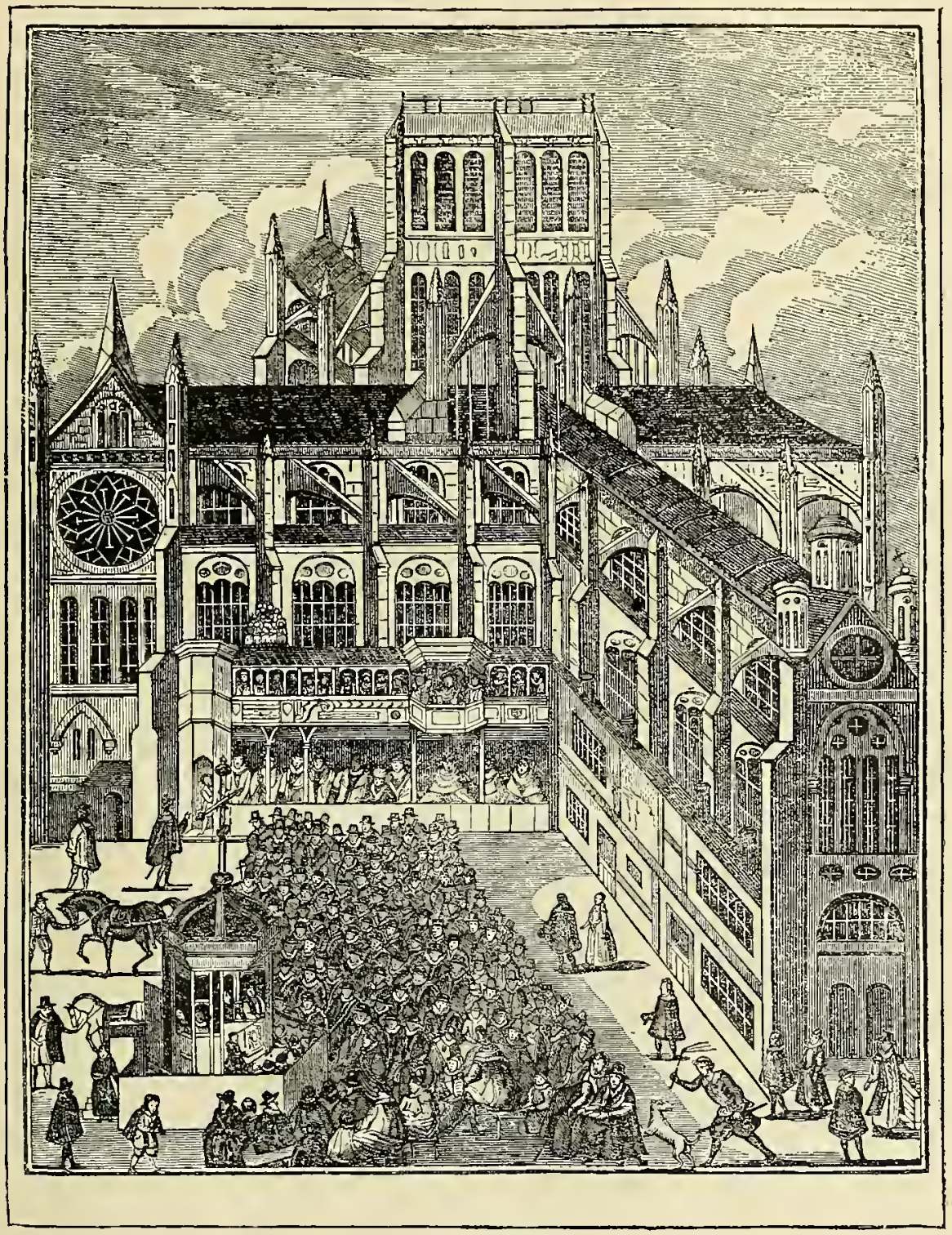

Preaching at S. Paul's Cross. From an Old Print.

It would take too long to catalogue even the noted preachers at the cross, who appeared, sometimes as political advocates for the claims of Lady Jane Grey or Mary Tudor, at others, simply 
as earnest watchmen of the hour. In the record of the latter we find the names of Ridley, Latimer, Jewell, Donne, and other lights of less

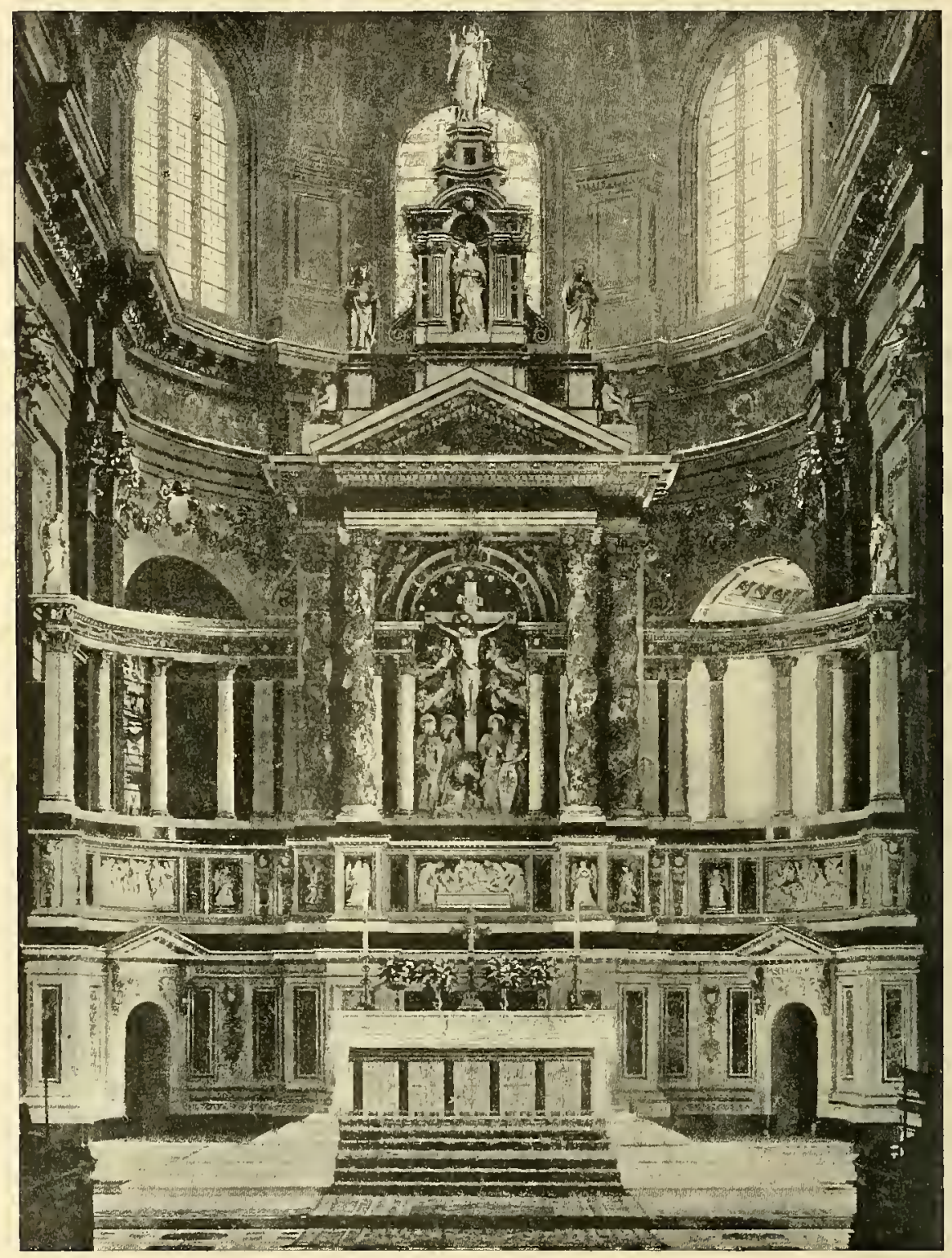

Reredos in S. Paul's. From a Photograph.

brilliancy. Not without care were men selected to fill the popular sensational pulpit of that day. The qualification desired may be judged from 
a letter from Ridley to Parker. "Sir, I pray you refuse not to take a day at the Cross. I may have, if I would call without any choicc, cnow. But in some, alas I desire more learning, in some, a better judgment, in some, more virtue and godly conversation, and some, more soberness and discretion, And he in whom all these do meet, shall not do well to refuse, in my judgment, to serve God in that place." Nor was this post of honor wholly without the " nettle danger." When Bonner, in 1553 , ventured to censure Edward VI., stones were flung against the preacher, and men with drawn daggers rushed to assault him, but a timely flight into the cathedral saved him. The dagger appears again at the cross, once when Bonner's chaplain, Bourn, vexed his audience by his preaching, one hurled a dagger at him which stuck quivering in a post by his side. The preachers of Mary Tudor found equally discourteous treatment. Two hundred halberdiers enforced the pious and attentive hearing of Dr. Watson's sermon, yet a bullet whistled in unpleasant proximity to Dr. Pendleton's ear, giving an emphatic objection to his smooth words. Henceforth the carrying of guns or daggers was forbidden to the peaceful congregation of the cross.

As Mary's most powerful preachers had thundered against Protestantism, so on the accession of Queen E1izabeth's Queen Elizabeth, counter Use of the Cross. fulminations were hurled by the Queen's Almoner, Dr. Bill, followed by Grindal, Horn, Jewell, Sandys, and others. The same sovereign caused the memory of her once-beloved Essex to be blackened in a sermon at the Cross; some sparks

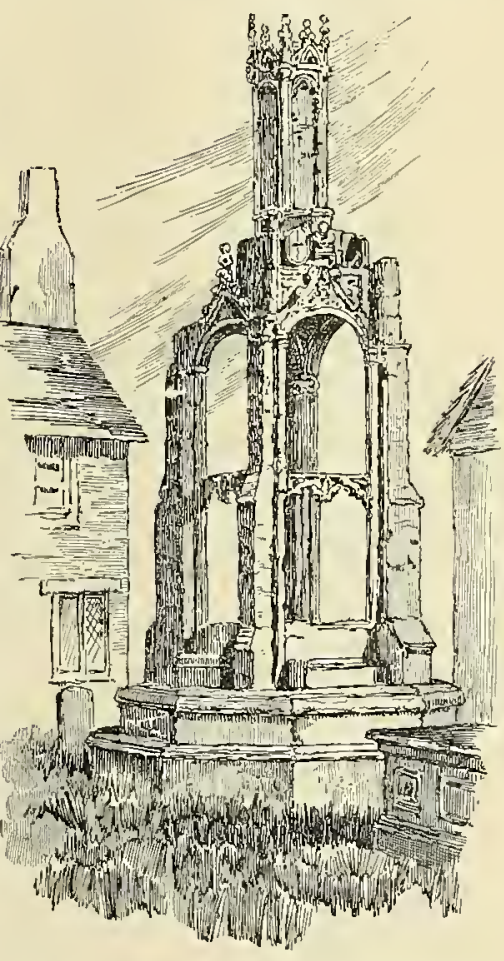

Pulpit Cross at Iron-Acton, Gloucester. of her indignation not being quenched by his blood. The pulpit was

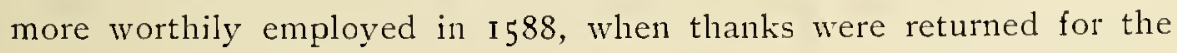
deliverance of Great Britain from the attack of the Invincible Armada of Philip II. Stow likewise relates the account of a splendid memorial 


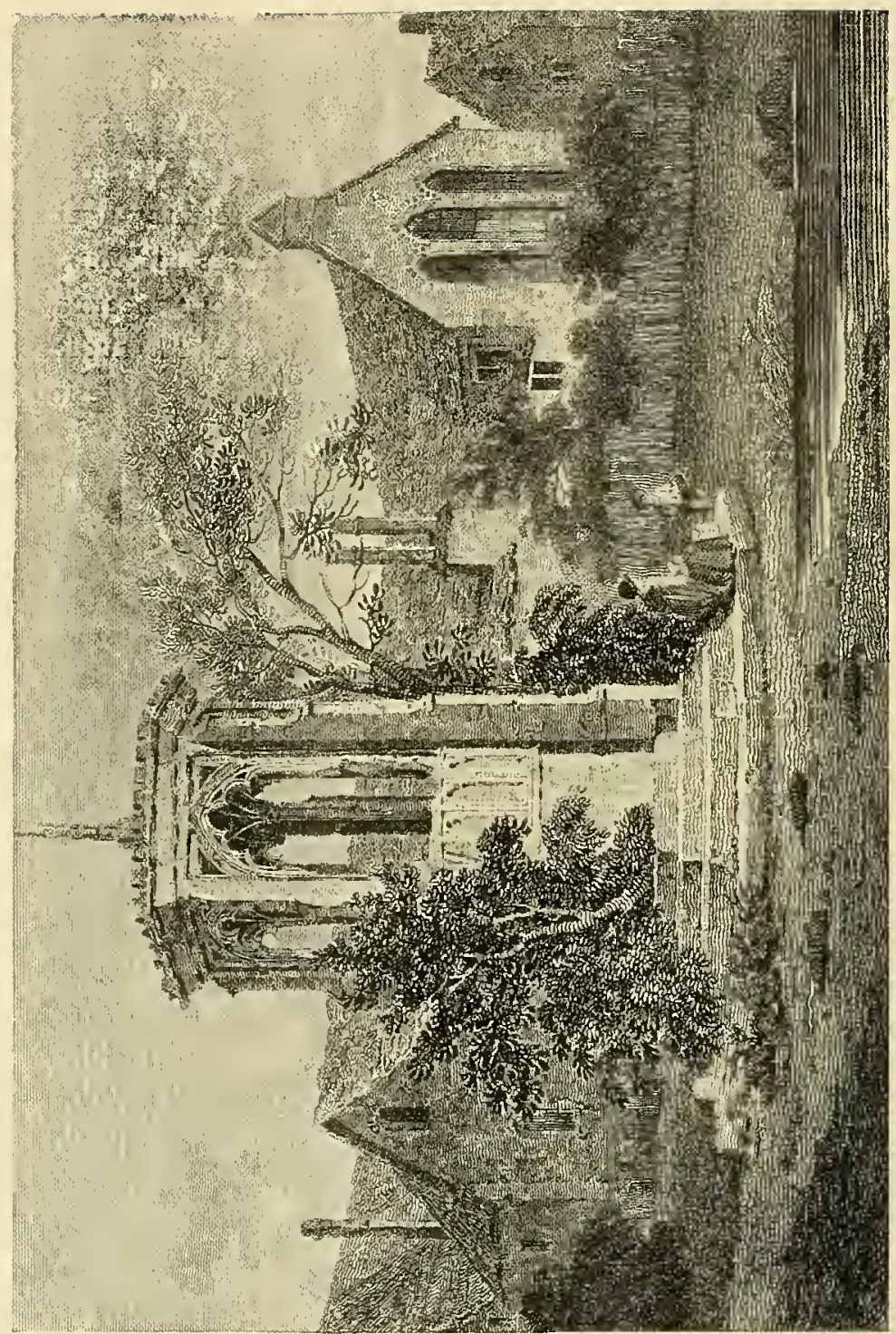

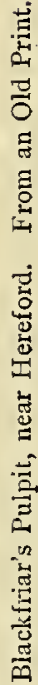


gotten up November 17, 1595, as a day of triumph for her Majesty's long and prosperous i cign.

An example of Queen Elizabeth's wiliness is shown in an occurrence of the following year. Taking advantage of the excitement aroused during a sensational sermon delivered before the Lord Mayor and aldermen, she sent a message requiring a thousand men to be levied to assist the French in raising the siege of Calais, then besieged by the Spaniards. The loyal subjects instantly quitted their devotions, and by eight o'clock that evening the men were enrolled. Their errand was bootless, for on reaching Dover they reccived news of the capture of Calais.

But the glory of the oid cross was departing. James I. listened to a sermon from this pulpit in 1620 . Doubtless the sermon was acceptable, but doubtless still more so was the purse of gold with which he was presented while "organs, cornets, and sackbuts" cross. sounded, and John King, Bishop of London, appealed to the congregation for money to repair S. Paul's. Almost the last time that we hear of S. Paul's Cross was when Charles I. attended divine service and sermon on the 3 oth of May, I63o. The cross was demolished in 1643 , by order of the Parliament, by the fanatical Isaac

Its End. Pennington, Lord Mayor of London, who died in the Tower a convicted regicide. May the malison of all archæologists rest upon him. 


\title{
CHAPTER XVI
}

\author{
MARKET CROSSES
}

$\mathrm{M}$

ARKET crosses, which once were common throughout Europe, naturally originated from the customs of early times. The Markets con- privilege of holding markets was formerly granted to the trolled by Monks. monasteries, and the cross was erected, not only as a sign of their jurisdiction and power to receive tolls, but also as a pulpit for occasional religious exhortation. Again, in former times, markets were Markets Held on Sundays and Holy-days. held on Sundays and on festivals, for the convenience of dealers who were assembled for worship. Hence the churchyard was often selected for this business. In the time of Edward I. an Act of Parliament was passed (in 1285) prohibiting the holding of markets and fairs in churchyards, and in 1677 , in the time of Charles II., the practice of holding the fairs on Sundays was forbidden. ${ }^{2}$ Undoubtedly, also, our forefathers, whose simple ideas of Sunday and religion were not left within the walls of the church when they quitted it, meant to remind men of their Crucified Example, who had recognized and sanctified the necessary business of life, not only by actually laboring with his own hands, but also by paying legal tribute, and directing the toil of his followers. The influence of the Cross was acknowledged by the traders, for they were in the habit of appealing by oath to that sacred image, under whose shadow they stood, that their goods were honestly come by, and perfect. ${ }^{3}$

At first, these market crosses were only single cruciform shafts, elevated on steps similar to those in churchyards, but after a while they became more lofty, and were decorated with pinnacles, niches, etc. ; and

${ }^{1}$ Essay of John Britton, F.S.A., Proceedings of the Archceological Society, I849, p. 304.

${ }^{2}$ I.edwich, Antiquities of Ireland, p. 446. 
still later, projections or arches were erected to shelter the people from the weather. One of the most elegant and appropriate of these structures was the cross at Coventry, Warwickshire. It was built in consequence of a bequest made by Sir William, son of coventry cross. Thomas Hollis, sometime Lord Mayor of London, and was erected on the site of an ancient cross which gave way to its more splendid successor. The foundation was laid by the Mayor in I54I, and three years were occupied in its completion.

By a special act of the town council it was guarded from defacement and injury; and the people were forbidden " at any time to sweepe the pavyments there, excepte they immediately before they sweepe, do caste and sprynkle water upon the saide pavyments upon payne to forfaite for evy defaulte iij s. iiij, d."'

In 1669 , it was repaired at an expense of $£ 2762 s .1 d$. Some idea of its magnificence may be formed from the fact that 15,403 books of gold leaf were used in the gilding, at an expense of $£ 68$ i 5s. This amount does not appear to be included in that before mentioned. This was one of the last efforts of expiring zeal for art and religion in the history of the Cross when sanctifying the daily work in England, for it seems that no further repairs were made, and in $177 \mathrm{I}$, having gradually mouldered and disintegrated by the action of the weather, it was removed. It was hexagonal in shape, elevated on four steps, and was fifty-seven feet in height, by forty-two in circumference. It was divided into four stories,

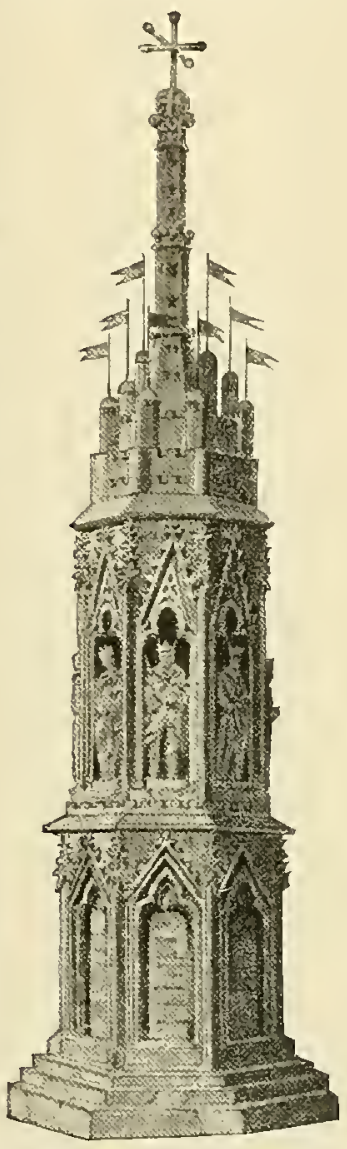

Gloucester High Cross.

From Pooley's Old Crosses of Gloucestershire. each richly decorated with statues, bas-reliefs, heraldic ornaments, etc.

1 The will is dated 25 December, 33. Henry VIIf. The clause referring to the matter runs thus: "I give and bequeath unto the Lord Mayor and Aldermen of the city of Coventre, and to the commons of the same CC. $\delta$ sterling to the intent and purpose hereafter ensuing, that is to say, to make a new cross within the said city, etc.," but differing from most men, who are charitable with their money only when it belongs not to them, $i . e$, after they are dead, it appears that the worthy knight had already advanced $£ 90$ for the purpose. 


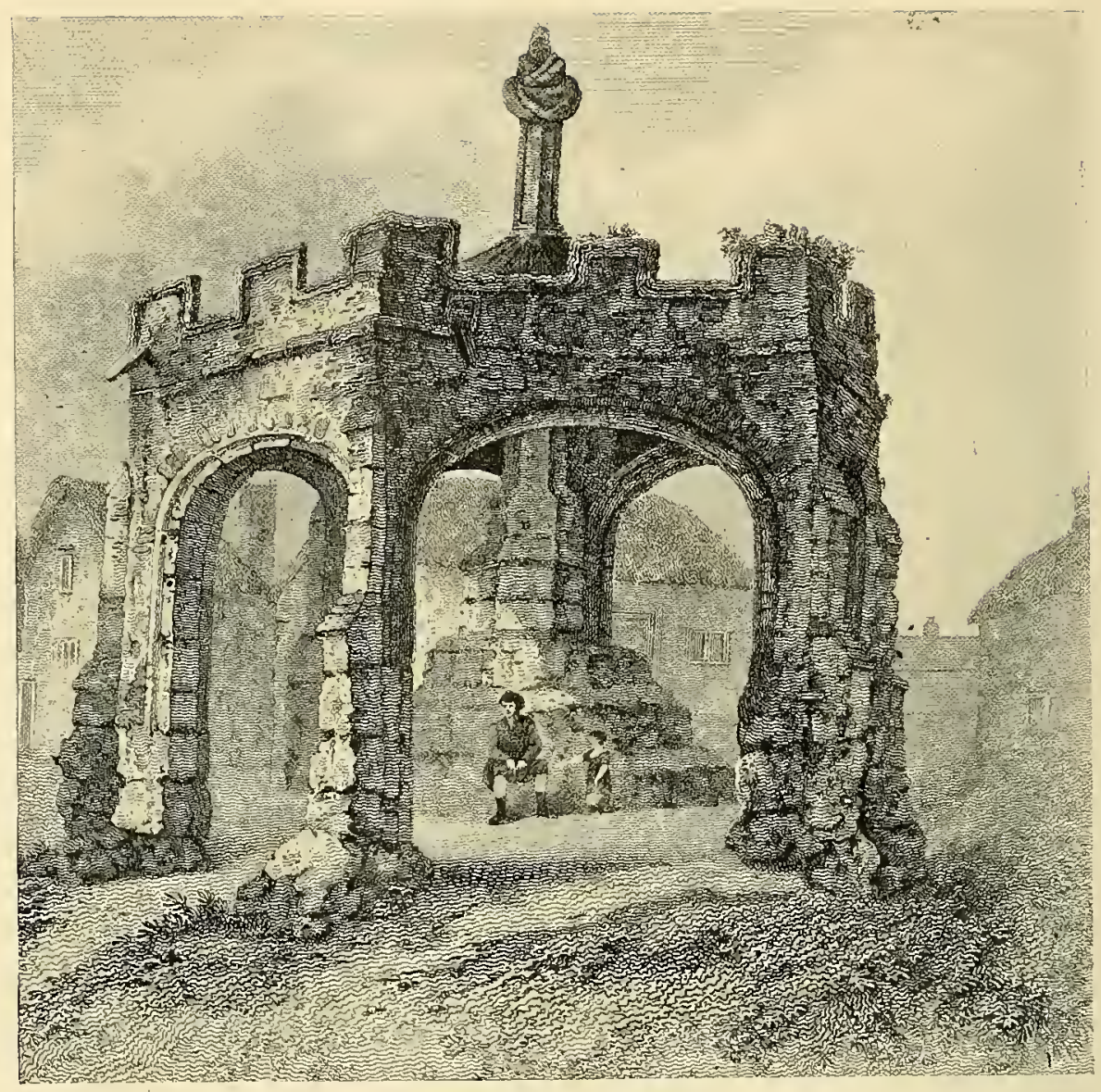

Market Cross at Cheddar.

From Britton's Architectural Antiquities. 
Among the latter the rose and crown, flcur-dc-lis, unicorn, and muzzled bear were prominent.'

The cross at Gloucester is supposed to have been built in the time of Richard III., whose statue occupied a niche in the second stage. The building was octagonal, thirty-four and a half Gloucestercross. feet high, and was taken down in I749."

The cross at Cheddar, Somersetshire, sllows the original structure of the market cross, at first a simple shaft, raised on steps with

1 ateral Cheddar Cross. piers, and a roof erected at a later period. Henry III. granted to Bishop Jocelin a charter for a weekly market, which continued to be held there until the beginning of the present century. ${ }^{3}$ Britton describes likewise the somewhat similar cross at Malmesbury, Wiltshire, built before the time of Henry VIII., and that in Chichester, Sussex, erected by Bishop Story near the end of the fifteenth century. The worthy prelate left an ample estate to keep his practical monument in repair. The clock is a later addition, being the

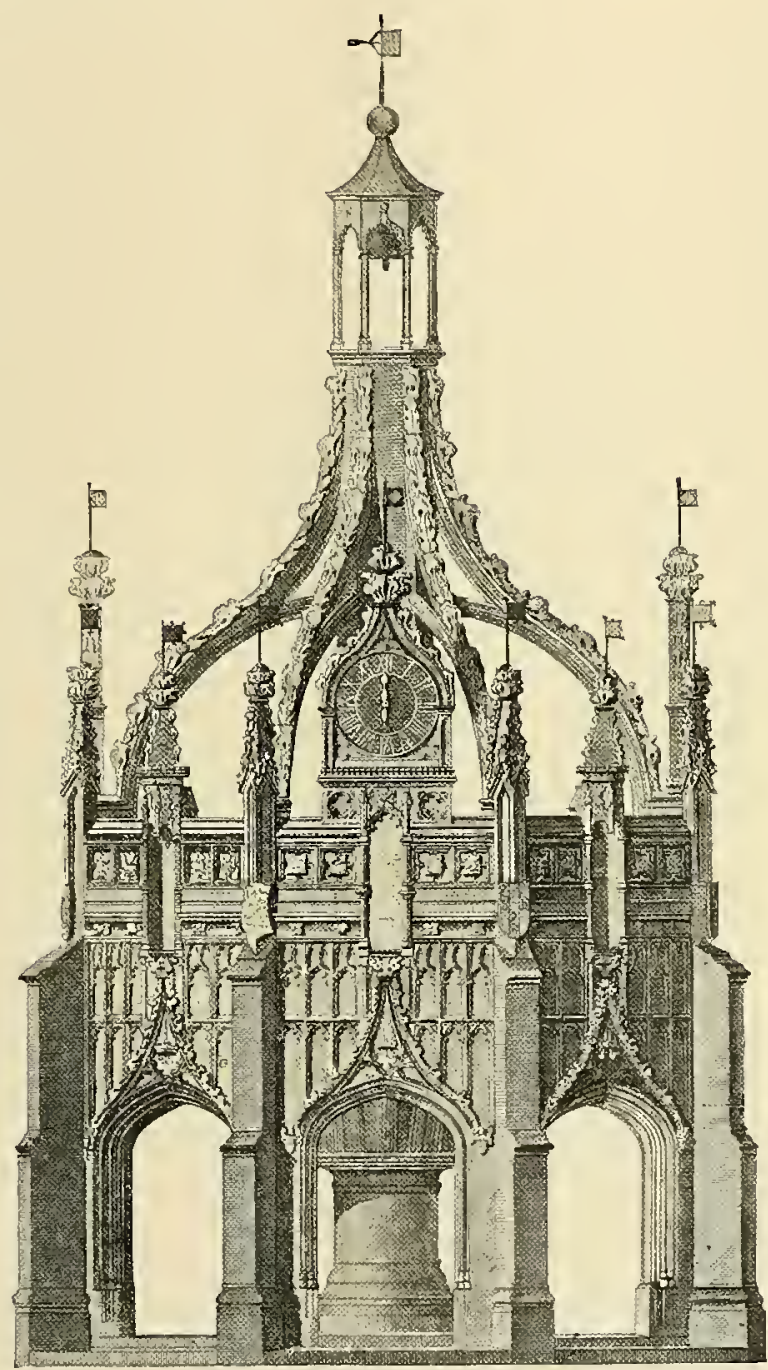

Cross at Chichester, Sussex.

From Britton's Architectural Antiquitits.

\footnotetext{
'Britton, Architectural Antiquities, vol. i., pp. 74-76.
}

Ibid., p. $76 . \quad{ }^{3}$ Ibid., p. 78. 
gift of Dame Elizabeth Farrington in 1724, " as an hourly memento of her good-will."

In some places, as at Winchester, these crosses were called " Butter Crosses." There is still a fine stone cross and fountain at Winchester on the site formerly occupied by the market cross during the plague, just

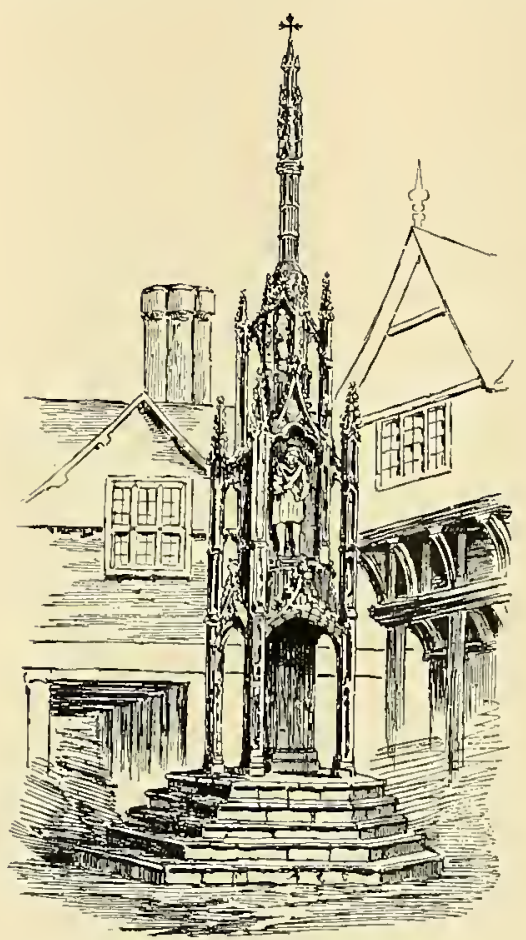

Winchester Butter Cross. without the original walls, to which the surrounding countrymen brought their produce in the early morning for sale, and returned at night to collect their money from the running basin, where it had been left by the purchasers to avoid the risk of spreading the contagion.

Sir Walter Scott has thrown his halo of witching glamourie around the Cross in Edin- Mercat Cross of Edinburgh. burgh :

“Dun-Edin's Cross, a pillared stone, Rose on a turret octagon

(But now is razed that monument, Whence royal edict rang, And voice of Scotland's law was sent

In glorious trumpet-clang. $\mathrm{O}$ ! be his tomb as lead to lead, Upon its dull destroyer's headA minstrel's malison is said.) " 1

In his note to the above, the poet says: "The Cross of Edinburgh was an ancient and curious structure. The lower part was an octagonal tower, sixteen feet in diameter, and about fifteen feet high. At each angle there was a pillar, and between them an arch of Grecian shape. Above these was a projecting battlement, with a turret at each corner, and medallions, of rude but curious workmanship, between them. Above this rose the proper cross, a column of one stone, upwards of twenty feet high, surmounted with a unicorn. This pillar is preserved in the grounds of the property of Drum, near Edinburgh. The magis-

1 Marmion, canto v., xxv. 
trates of Edinburgh, in 1756, with consent of the Lords of Session (proh pudor) destroyed this curious monument, under a wanton pretext that it encumbered the street; while, on the one hand, they left an ugly mass called the Luckenbooths, and on the other, an awkward, long, and low guard-house, which were fifty times more of an encumbrance than the venerable and inoffensive cross."

From the tower of the cross, so long as it remained, the heralds published the Acts of Parliament; and its site, marked by radii, diverging from a stone centre, in the High Street, is still the place where " proclamations are made," in accordance with the custom already alluded to.

Happily the heavy malison of the poet, we trust, has now been removed by the benison of his townsmen on the patriotic restorer of Dun-Edin's Cross. The Hon. William E. Gladstone, the distinguished

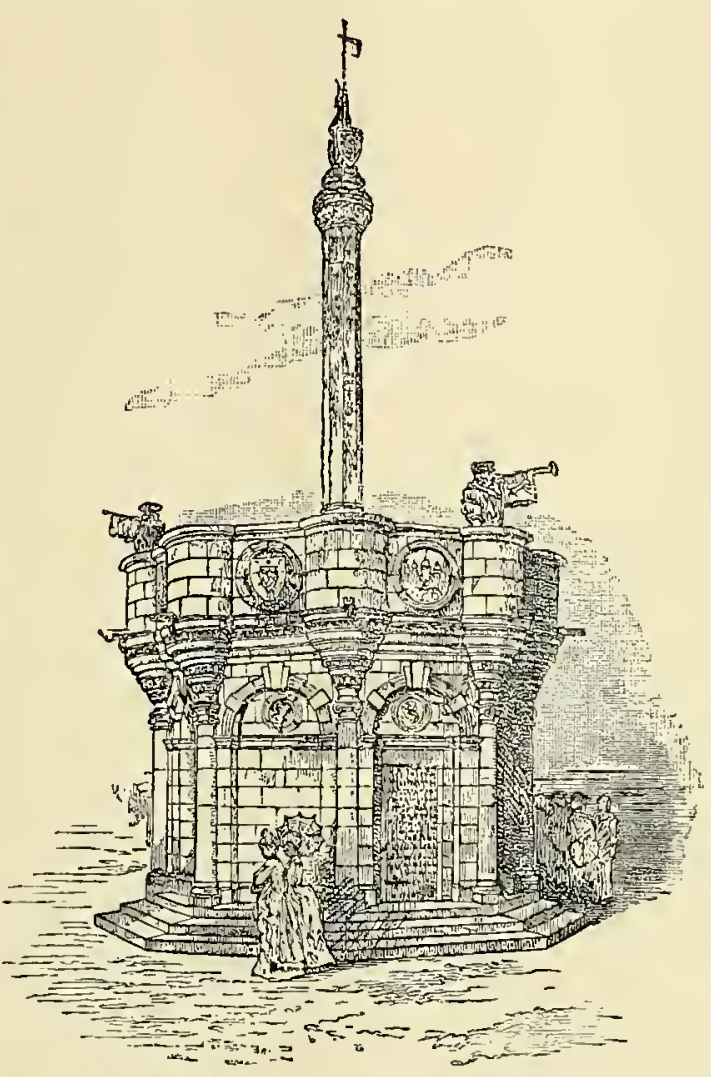

Mercat (Market) Cross as kestored in 1885. From Arnold's History of the Cross of Edinburgh. representative for Midlothian, offered to rebuild the Mercat Cross at his own charges, in 1885 , and the Corporation of Edinburgh accepted the generous proposition, and assigned a spot at the east end of St. Giles's Church, near the original site. The turreted octagon was constructed after a carefully prepared plan of the cross of 1436 ; the old stone pillar, strengthened by a bar of bronze through the centre, was re-erected on its summit. The old medallions, which, in 1814 , fell into the hands of Sir Walter Scott and were inserted in an ornamental garden wall at Abbotsford, were reproduced, bearing heraldic devices of the arms of the United Kingdom of Scotland, England, and Ireland, of the City of 
Edinburgh, of the Burgh of Canongate, of the Town of Leith, and of the University of Edinburgh.

Originally founded, probably, by some Celtic missionary, who set up; according to custom, a cross between the primitive church and the well, still linown as the " Cross WVell " ; rebuilt by " Saint Margaret," Queen of Malcolm Canmore, when she resided in the Castle, and was noted for her devotion to the erection of crosses; alluded to later in the laws of William the Lion, I I 75, as the " Mercat Croce of burghis," at which " it is commandit by the King that merchandises salbe presentit," it is rightly referred to by Calderwood as having stood there "past the memory of man." And so many are the interesting associations that crowd around this ancient monument, that its latest historian ${ }^{2}$ has said that fully to write the history of the "Mercat Cross" would be to write at once the history of Edinburgh and of Scotland; and to trace the influence of events enacted here would involve writing the history of all the great political and religious movements which have shaped the destinies of the Empire. Among a people ever free, and always jealous of anything approaching to interference with their liberties, whether on the part of king or priest, this cross was their civic citadel, and it often proved at Edinburgh stronger than the strong Castle, and able to hold its own against Holyrood itself.

The Scottish crosses of the higher class, which seem to have been limited to the chief burghs, had the peculiar form of the Mercat Cross. A very fine old example, known locally as the Chepman's Cross, is still to be seen, nearly perfect, not farther off than Prestonpans; and a large, handsome specimen adorns the market-place of Aberdeen. The Canongate Cross was smaller, but similar in outline, and the market crosses of Perth and Dundee, now removed, were also of this important class, with a high platform supporting the central pillar with its heraldic termination. In small burghs and villages the market crosses were of the ordinary type-a series of steps, on which is a small base or pedestal supporting a column. At most of these crosses there were arrangements for securing law-breakers, either by " jongs" (iron collars), " branks" (head-pieces), " stocks," or pillory.

In England the crosses are usually of a more monumental character; some resembling the Eleanor crosses, while others, such as the beautiful

\footnotetext{
1 Thomas Arnold, History of the Cross of Edinburgh.
} 
crosses at Salisbury, Chichester, and Malinesbury, have open arcades in their lower portion, surmounted by flying buttresses and other accessories.

At Stourhead, WViltshire, is a most exquisite cross, which, by right of its original design, ought to be classed among memorial crosses, but it was afterwards used as a market cross. It was built in Bristol in I 373, and, as in the case of many others, upon Stourhead, the site of a more ancient cross, and intended in honor of Edward III., who about that time constituted Bristol a town and county in itself. Statues of John, Henry III., Edward III., and Edward IV. were placed in niches around the edifice. In 1633 , it was enlarged and raised, and the statues of Henry VI., Elizabeth, Charles I., and James I. were added, because each of the sovereigns had renewed and confirmed the charter of the city. These improvéments cost £707; its total height was thirty-nine feet six inches. In 1697, it was again repainted and gilded. Less than forty years of Puritanism exhibited it effect. The token of Christ was despised, and a silversmith, ${ }^{1}$ in 1733 , had it removed

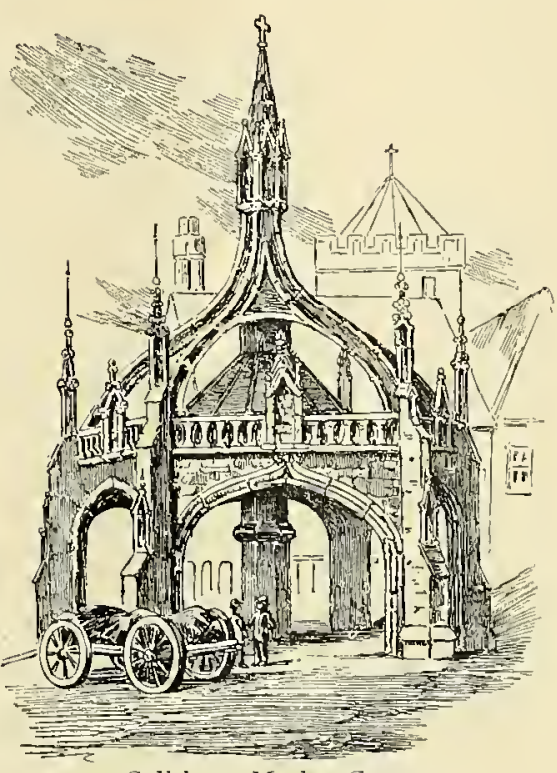

Salisbury Market Cross. and thrown into the Guildhall, where it remained until by private exertion it was erected on the Coliege Green. There it was not long permitted to stand, for, in $17 \sigma_{3}$, it was again levelled to the ground and thrown into an obscure corner, until the Rev. Cutts Barton, Dean of the Cathedral, gave it to Mr. Hoare, of Stourhead, who expended $£ 300$ in its removal to and re-erection in that place, at which time the base, top, and central pier were added. ${ }^{2}$

Another cross, that at Devizes, also in Wiltshire, has served, among

1 Was his name Demetrius?

'Barrett, History of Bristol, p. 494 ; quoted in Britton's Architectural Antiquities, vol. i. p. 79 . 


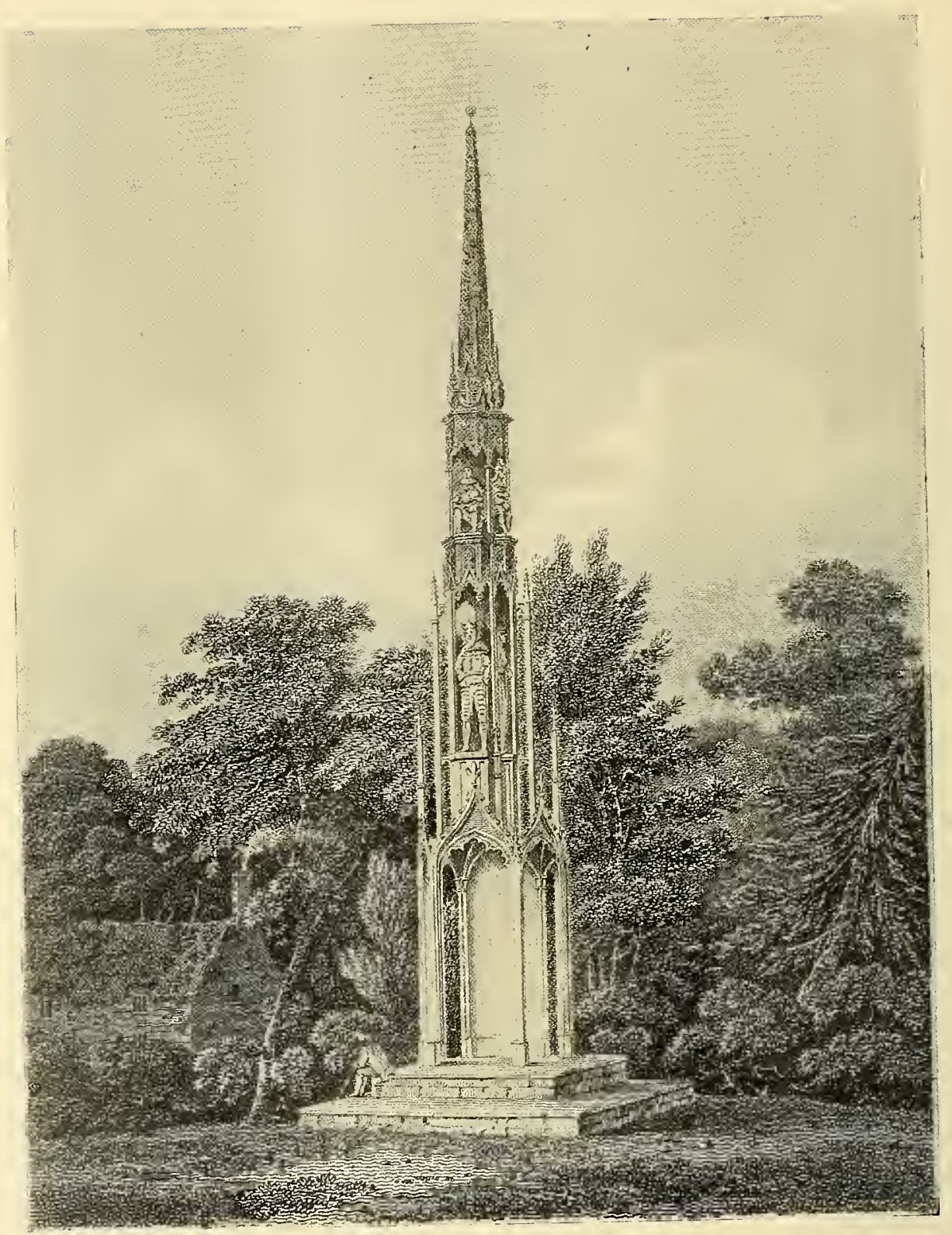

Cross of Stourhead.

From Britton's Architectural Antiquities. 
its other purposes, to perpetuate a notable public event. It is a simple octagonal cross, upon a square pedestal, with the archi- judgment of God tectural faults of the period at which it was repaired, about at Devizes cross. I 820 , by the piety and liberality of the then Lord Sidmouth. On the eastern side is this singular inscription: "The Mayor and Corporation of Devizes avail themselves of the stability of this building, to transmit to future times the record of an awful event, which occurred in this market-place, in the year I 753; hoping that such record may serve as a salutary warning against the danger of impiously invoking Divine vengeance, or of calling on the holy name of God to conceal the devices of falsehood and fraud.

"On Thursday, the 25th of January, I753, Ruth Pierce, of Petterne, in this county, agreed with three other women to buy a sack of wheat in the market, each paying her due proportion towards the same; one of these women, in collecting the several quotas of money, discovered a deficiency, and demanded of Ruth Pierce the sum which was wanting to make good the amount; Ruth Pierce protested that she had paid her share, and said 'Slic wished she might drop down deat, if she had not!' She rashly repeated this awful wish, when, to the conster-

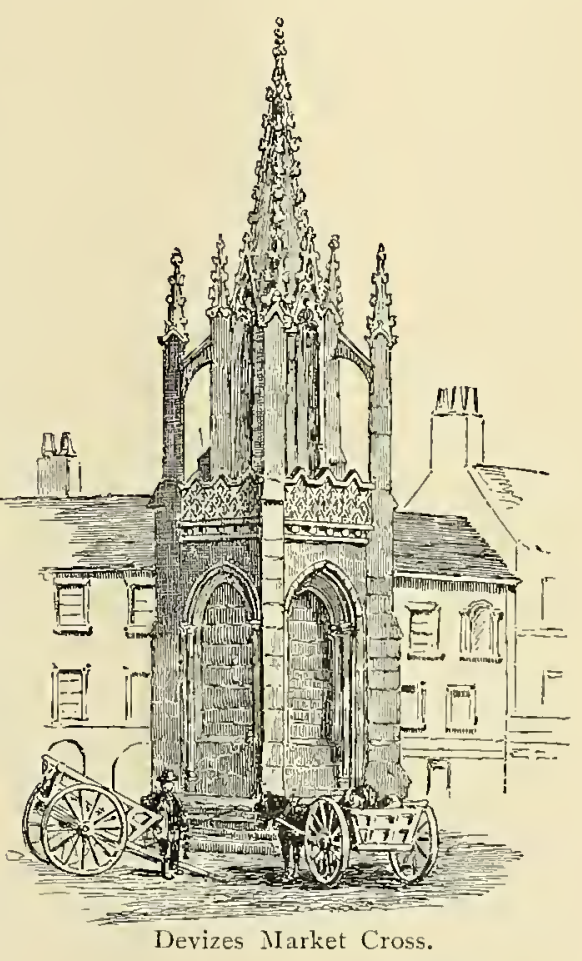
nation and terror of the surrounding multitude, she instantly fell down and expired, having the money concealed in her hand."

In a sermon preached on the subject by Dr. H. Stebbing, Archdeacon of IVilts, and published in 760 , we find a full account of this striking dispensation. "And I submit it to the common sense of mankind," says the preacher, "whether this, and such like instances, many of which occur in history, are not a very strong presumptive evidence from fact, for the truth of a directing Providence.", 


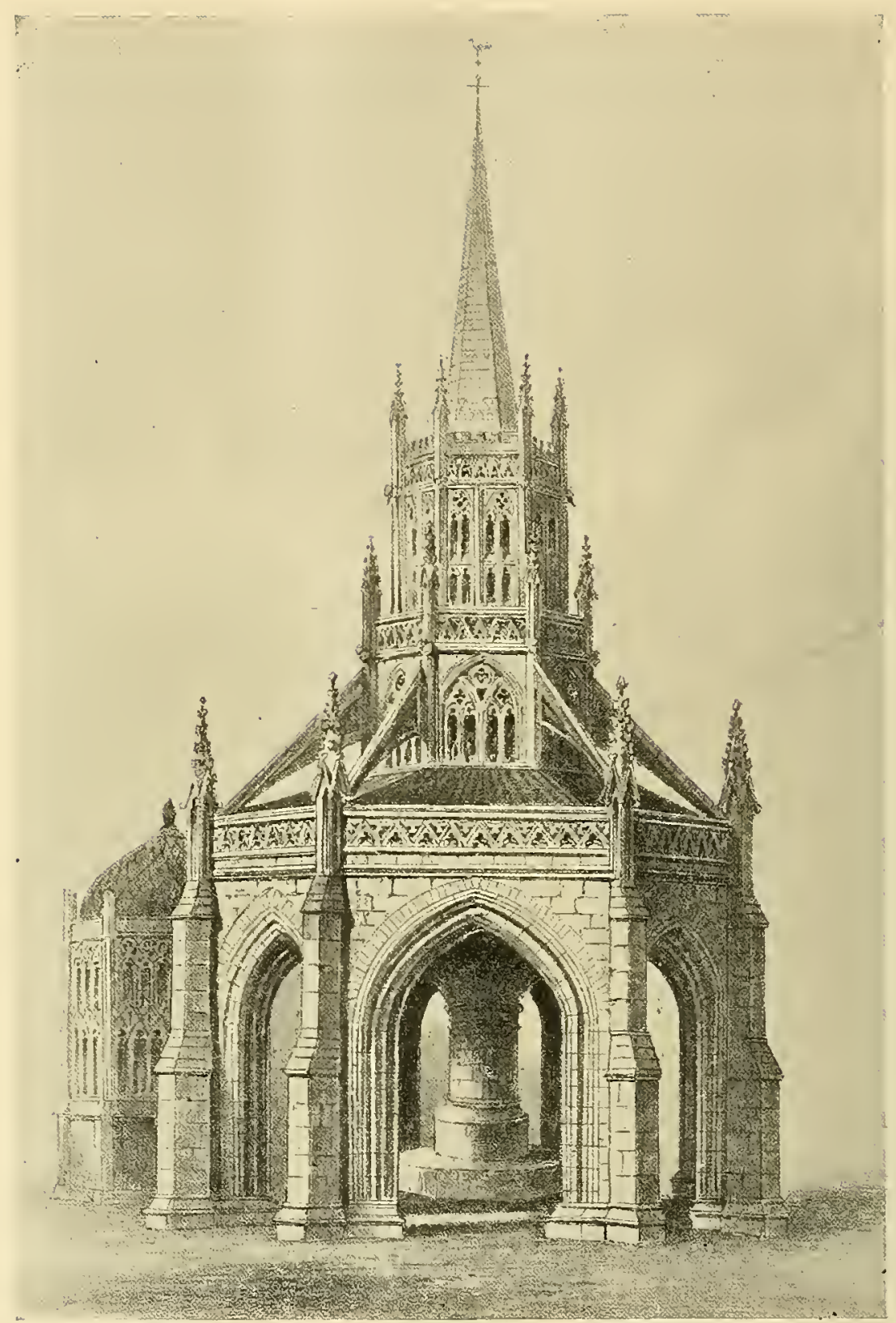

The High Cross, Formerly in the Market-Place at Wells. From Pooley's Old Stone Crosses of Somerset. 
In purity of outline and exquisite symmetry of proportions, scarcely any example can surpass the cross erected in the market-place at Wells, A.D. I542. Leland, who visited this city at the time of its construction, states that " Wyllyam Knight, now Bishop of Bath, buildeth a Crosse in the Market Place, a right sumptuous Peace of Worke: in the Extreme Circumference whereof be vij faire Pillers, and in another Circumference withyn them be vi Pillers and yn the middle of this circumference one Piller. Al these shaul bere a Volte; and over the Volte shaul be Domus Civica." In a marginal note is added: "This work was made by the Legacie of Doctor Wolman, Deane of Welles." The municipal records often notice this old cross as the place where public proclamations were always first read; and in Bishop Knight's will it is provided that the tolls of the Market Cross shall be given "for the use of the Choristers of the Cathedral church for ever."

The ground plan of this cross is hexagonal, rising from its open basement to the second, third, and fourth stages, and to its tapering spire, with the utmost grace and elegance. The exquisitely mullioned windows of the second story, which is strengthened and supported by the flying buttresses, and surrounded by a pierced parapet and crocketed pinnacles, and above this the third story, keeping the same lines, but varying the ornamentation, and surmounted also by its pierced parapet and pinnacles, form together a fitting foundation to be crowned by the slender spire. These features, says Pooley, together with the loftiness of the arches, with their buttressed piers, and the central column piercing the whole, combined to render this cross one of the most harmoniously beautiful in the kingdom. It survived until 1785 , when, a portion having fallen down and the remainder being considered in a ruinous state and dangerous, it was ordered by the Corporation of Wells to be taken down, and "that the place where the cross stood be appropriated for exposing fish and vegetables for sale." 1

These crosses for a long time served the public as Town Halls and Merchants' Exchanges, as well as produce markets. The news of the day was circulated there. Official proclamations were made from them. Henry IV. answers the accusations of Worcester:

"These things, indeed, you have articulate, Proclaimed at market-crosses, read in churches,

' Pooley, Old Stone Crosses of Somerset, pp. 95-100 


\section{History of the Cross}

To face the garment of rebellion

With some fine colour, that may please the eye

Of fick!e changelings, and poor discontents,

Which gape, and rub the elbow, at the news

Of hurly-burly innovation." "

Even Puritans paid some deference to the once sacred ground, for, during the Protectorate, banns of marriage were published from the crosses.

\footnotetext{
1 Shakespeare, Ist part Henry $I V^{\prime}$, act v., sc. I.
} 


\section{CHAPTER XVII}

\section{LANDMARK CROSSES}

T ANDMARK crosses are mentioned about the year 528, and soon 1. became common, not only as tokens of dominion and bounds of ecclesiastical grounds, and of those belonging to such ecclesiastical societies as the Knights Templars and Knights Hospitallers, but of those belonging to royalty and the nobility. mark Crosses.

Frequent mention of them occurs in history. Louis le Débonnaire, in A.D. 887 , mentions crosses engraved on boundary stones. Ingulphus tells us that in the tenth century the chancellor Turketiel renewed the stone crosses which had been erected by Kenulph, first Abbot of Croyland, where they had been destroyed. At Edmundsbury the monks erected four crosses, one at each extremity of the town, to define the limits of their jurisdiction, within which the Abbot exercised episcopal authority."

Bishop Losinga also erected a cross at Norwich, bearing, among other images, probably that of S. Michael, as a boundary between the church-lands and the borough. ${ }^{2}$

The cross was used so that no man for conscience' sake would dare to remove the landmark. Among the Irish canons of the eighth century we find one directing that a cross should be set up on all consecrated grounds, not only to mark the bounds, but also Reasons for Use. to sanctify the spot. A few centuries later we find a law in England forbidding men falsely to set up a cross on their lands, thus, by pretending that they belonged to the Churcl, defrauding the state of the taxes.

Like many other customs, the perambulation of boundaries was part

${ }^{3}$ Dugdale, Monasticon, vol. iii., p. 99.

2 Ibid.

21 
of the wisdom of the Church in Christianizing festivals and customs Antiquity of common among the pagans. From early Roman times we Perambulations. Find the celebration of the festivals called Terminalia, in honor of Terminus, who was the guardian of fields and landmarks, and the preserver of peace and good-will among men. ${ }^{1}$

This usage was retained long after Puritan outrage had destroyed the crosses, leaving often only fragments, hence they were sometimes called Stump Crosses. Stump crosses. Rogations occur as early as A.D. 550, when they were first observed by Marnertius, Bishop of Vienna, on account of the frequent earthquakes that happened, and the incursions of wild beasts. ${ }^{2}$

In the fourth century public supplications for God's favor and deprecation of his wrath were observed. Part of these services were processions with crosses, candles, and hymns. The major litanies. Litanies. were made through the streets, the minor within the close, cloister, and interior of the church. Some say that the major were made on the Festival of S. Mark, and the minor on Rogation Days. S. Gregory instituted the greater procession on April 25th, enjoining a procession of seven orders, the clergy, abbots, and monks; abbesses and nuns; boys ; laity, widows, and married women. These were called black crosses, because they originated during a pestilence Black Crosses.

in Rome, and the altars and crosses were veiled in black, and the processions draped in mourning. In France, bare feet, ashes, and sackcloth were prescribed. Mills tells us that the same name in that country was also applied to the processions in honor of the great multitude who perished in the Crusades. ${ }^{3}$

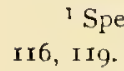

${ }^{2}$ By the Canons of S. Cuthbert, Archbishop of Canterbury, made at Cloveshoo, in the year 747 , it was ordered that " Litanies, that is, Rogations, should be observed by the clergy and all the people, with great reverence, on the seventh of the calends of May, according to the rites of the Church of Rome, which terms this the greater Litany, and also, according to the custom of our forefathers, on the three days before the Ascension of our Lord, with fastings," etc.

In the Injunctions also made in the reign of Queen Elizabeth, it is ordered " that the Curate, at certain and convenient places, shall admonish the people . . . saying the ro3rd and rotth Psalms, the Litany and Sufferages, together with the Homily set forth for that purpose. Thanks were given to God for hopes of plenty, and a prayer for mercy if scarcity seemed impending, and the wardens were admonished to assist the Rector. At which time the minister shall inculcate these, or such sentences- 'Cursed be he which translateth the bounds and doles of his neighbours." "-Brand, Antiquities, vol. i., pp. Ir6-122.

${ }^{3}$ Holland, Cruciana, p. 124; Mills, History of the Crusades, chap. i. 
Rogation Days, inroking God's blessing on the harvest, are mentioned in the Councils of Orleans, A.D. 5I5, and Mayence, A.D. 813 . In England, on the three Rogation Days before Ascension Day, the dragon was carried; on the first two days before Perambulations. the Cross, on the last day behind it, to typify the victory over the devil. Earth and grass were placed on the boundary crosses, and prayers offered to avert pestilence.

How these customs were esteemed may be learned from the practice of the " judicious" Hooker and the advice of " holy" George Herbert. Of the first we read that, "He would by no ineans omit the Perambulations customary time of Procession, persuading all, both rich and Recommended by poor, if they desired the preservation of love, and their Divines. parish rights and liberties, to accompany him in his Perambulation; and most did so; in which Perambulation he would usually express more pleasant discourse than at other times, and would then always drop some loving and facetious observations, to be remembered against the next year, especially by the boys and young people; still inclining them, and all his present parishioners, to meekness and mutual kindness and love, because love thinks no evil, but covers a multitude of infirmitics."

Herbert says, "The Country Parson is a Lover of old Customs, if they be good and harmless; and the rather, because Country people are much addicted to them, so that to favour them therein is to win their hearts, and to oppose them therein is to deject them. If there be any ill in the custom that may be severed from the good, he pares the apple, and gives them the clean to feed on. Particularly he loves Procession, and maintains it because there are contained therein four manifest advantages: First, A blessing of God for the fruits of the field; Secondly, Justice in the Preservation of bounds; Thirdly, Charity in loving walking, and neighbourly accompanying one another, with reconciling of differences at that time, if there be any; Fourthly, Mercy in relieving the poor by a liberal distribution and largess, which at that time is, or ought to be used. Wherefore he exacts of all to be present at the Perambulation, and those that withdraw, and sever themselves from it, he mislikes, and reproves as uncharitable and unneighbourly; and if they will not reform, presents them.",

1 Walton, Lives, p. 239.

"Herbert, Country Parson, chap. xxxv. 


\title{
CHAPTER XVIII
}

\author{
WAYSIDE, STREET, AND WEEPING CROSSES
}

$\mathrm{T}$ origin of way- toms endeared to their converts; so also they respected side Crosses. their Hermes, or statues of Mercury, set by the roadside, and especially where three paths met, and did not abolish them, but sanctified them by changing them to wayside crosses. S. Chrysostom refers to the usage in his day, ${ }^{1}$ and the Book of Homilies brings the fashion almost to our own time. ${ }^{2}$

Wayside crosses are almost a peculiar feature of the Western Church, yet they are found in the Eastern. They are met with in Circassia, Wallachia, and even as far west as the Alps. The Western peculiar to the form of the cross is used, but the inscription, IC.XC. Western Church. NIKA, "Jesus Christ Conquers," shows as thoroughly the footprints of the Greek Church as the I.H.S. the Latin. This monogram is almost the last symbol adopted by the crusaders.

In Circassia are found small iron crosses chained to the branches of the oak trees. In Wallachia the crosses are from ten to twelve feet in In Circassia and height, either of stone or of wood, bearing inscriptions. Wallachia. They extend along the Danube to the Carpathian Mountains, and sometimes occur in groups of ten or twelve. In the southern districts is seen the monogram IC. XC., but in the northern, the Latin I.H.S.

${ }^{1}$ Chrysostom, Quod Christus Set Deus.

2 "They used in times past, to set in highwaysides, the pictures (statues) of Mercury pointing with his finger which was the right way to the town. And we use in crossways to set up a wooden, or stone, cross to admonish the travelling man which way he must turn when he cometh thither to direct his journey aright."-Homily of Almsdeeds, p. 3+3, Oxford ed., I86 I. 


\section{Wayside, Street, and Weeping Crosses}

But, to come nearer home, Shakespeare reminds us of onc of the uses of the wayside crosses, when, in the Mcrchant of wayside Crosses I cuice, he makes Stephano apologize to Lorenzo for the Referred to by absence of Portia:

\section{"She doth stray about}

By holy crosses where she kneels and prays

For happy wediock hours."

Again, in the Mcrry Doil of Edmonton, the father accounts for the delay in a wedding:

"But there are crosses, wife; here 's one in Waltham.

Another at the Abbey, and the third

At Chestor, and ' $t$ is om.. inous to pass

Any of these without a pater noster."

One wayside cross will recur to the memory of the reader whose youthful love for poetry and honor owes its training to the magic of Scott. How many a breast

has heaved when they read Clara de Clare's ministration to the $\mathrm{d} y$ ing Marmion, when:

"-half he murnur'd,'Is there none

Of all my halls have nurst,

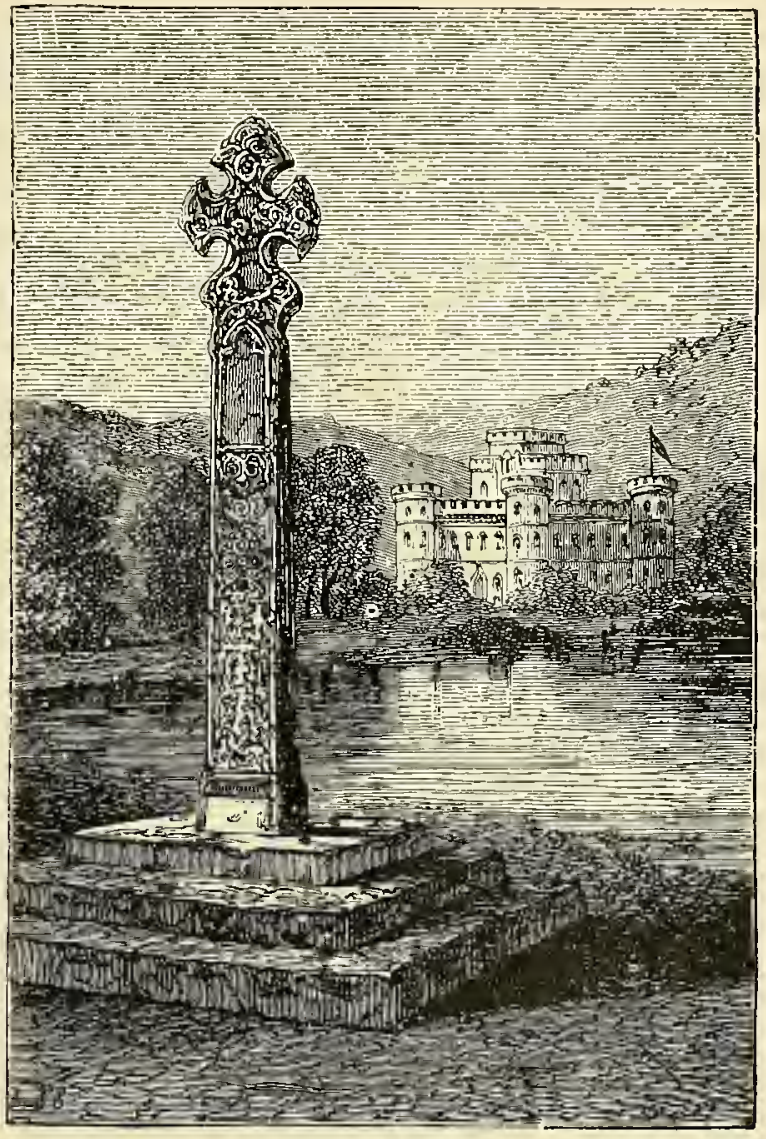

Cross at Inverary. From Bishop's Pictorial Architecture.

Page, squire, or groom, one cup to bring

Of blessed water from the spring,

To slake my dying thirst?" "' 
Clara forgets her wrongs, but-

"Where shall she turn? behold her mark

A little fountain cell,

Where water clear as diamond-spark,

In a stone basin fell.

Above, some half-worn letters say,

'Drink . weary . pilgrim . drink . and pray,

For , the . kind . soul . of . Sybil . Grey,

Who . built . this . cross . and . well.","1

With feelings nearly akin we read the lines over a cross, traced by a hand dear to every Churchman. At Ampfield, England, the water By Keble. gushes from a spring above which are the lines by the author of the Christian Year:

"While cooling waters here you drink,

Rest not your thoughts below,

Look at the sacred sign and think,

Whence living waters flow.

Then fearlessly advance by night or day,

The Holy Cross stands guardian of our way."

A wayside cross was set up by the Fitz William family, which was Cross Erected by standing until about 1520 , on which was engraved the

the Fitz William following:
Family.

"Whoso is hungry, and lists to ate

Let him come to Sprodburgh to his meate;

And for a night, and for a day

His horse shall have both corn and hay,

And no man shall ask him where he goes away." 2

Some idea may be formed of the immense number of crosses, wayside, market, etc., formerly in Great Britain from noticing the number Great Number of "of places which retain the name of the cross although the wayside Crosses structure itself has disappeared. In Devonshire alone in Ancient Times. there are one hundred and thirty-five places so designated. ${ }^{3}$

Nor was France behind, either in the number of crosses or the Gothic vandalism of their destroyers. On the return of the Bourbons, the restoration of the wayside crosses, which had been destroyed in the Revolution, was proposed. It was found in Finistère alone it would cost

I Marmion, canto v., stanzas xxiv., xxx.

"Stanford and Townsend, The Great Governing Families of England, vol. i., p. I25.

${ }^{3}$ Walcott, Sacred Archaology, "Wayside Cross." 
no less than $I, 500,000$ francs. Hence the project was dropped as being too expensive. ${ }^{1}$

Street crosses, once common in European towns, were used, like others of more pretentious proportions, for sermons, publication of royal proclamations, and laws, and sometimes they pointed out the place where malefactors were hanged. In funeral pro-

Street Crosses. cessions the corpse, while being conveyed to church, was set down by these crosses, in order that the attendants might pray for the repose of the soul of the deceased. Beggars stationed themselves at them to implore alms, for the sake of Him of whose sufferings they were reminded by the symbol. Hence the old proverb, "He begs like a cripple at the cross." Our forefathers, following the early Church, recognized the fact that there was scarcely any locality in which the Cross was out of place. A MS. of about 1312, written probably by one Adam Davy, entitled The Pylgrymages of the holi land, begins thus, "Quevesoever a cros standyth, thir is a forgivenes of payne."

Mounds on the highway, often, probably, sepulchral tumuli over the remains of an earlier people, were frequently surmounted with a cross, and used

Montjoy. as wayside crosses, both for the direction of travellers, and as affording an opportunity

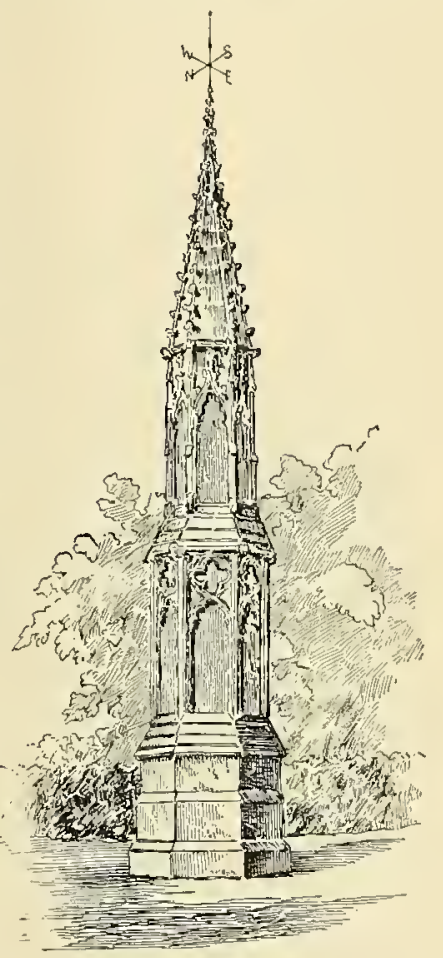

Tottenham Cross. for offering petitions for themselves and for the repose of those whose bodies were there entombed. The names of these graves were taken up as war-cries in former times; and Montjoic S. Dcnis was adopted as that of France; Montjoic Notre Dame, that of the Dukes of Bourbon; and Montjoie S. Georgi, that of England.

Wayside crosses are common in Switzerland and in the South of Europe. Among the passes of the Alps, the tourist not infrequently pauses to note an humble cross, bearing only some initials, and a date, preceded by P. I., or, when written at length, Périt ici.

\footnotetext{
1 Robert Bell, Wayside Pictures, p. I98.
} 
Throughout Italy and Spain, and transplanted Spain-South America - the, emblem of life records death; not, as in Switzerland, death by accident, but in the latter countries upon the rough block of stone, or simple

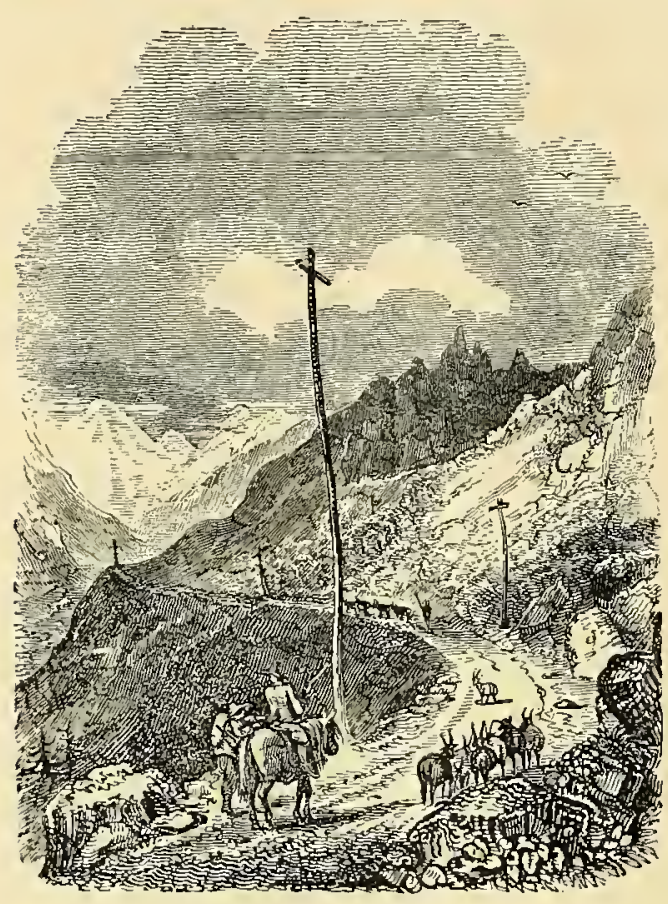

Wayside Cross in the Alps.

From Holland's Cruciana.

"lath," rudely formed into a cross, the traveller reads Aqui mataron (here they killed) such an one.

"And here and there, as up the crag you spring,

Mark many rude-carved crosses near the path;

Yet deem not these devotion's offering-

These are memorials frail of murderous wrath ;

For whereso'er the shrieking victim hath

Poured forth his blood beneath the assassin's knife,

Some hand erects a cross of mouldering lath;

And grove and glen with thousand such are rife,

Throughout this purple land, where law secures not life."

Penances were very commonly performed at wayside and other crosses, and, as they were attended with manifestations of contrition, Penance at hence arose the name of IVeeping Crosses. ${ }^{1}$ The memory Weeping Crosses of this pious custom is preserved in an old English proverb: Proverbs. "The way to Heaven is by Weeping Cross." Another homely distich is:

"He that goeth out with often loss,

At last comes home by Weeping Cross."

The early dramatists often allude to the course of some one of the dramatis personce as likely to end at the "Weeping Cross," that is, in sorrow and repentance. Thus in the old comedy of Eastward Hoe ${ }^{2}$ :

1 Near Stafford stood a cross commonly called "Weeping Cross," from its being a place often designated for the expiation of $\sin$. T. Astle on Crosses, etc., London Anliquities Society, 1798, p. 216.

"The slang expression for being hanged at New Gate was to go "Westward Ho." Doran, Annals of the Stage. 
"My daughter, his ladie, was sent Eastward by land to a castle of his i' the aire, (in what region I know not), and as I heare, was glad to take up her lodging in her coach, she and her two waiting women, her maide, and her mother, like three snails in a shell. . . . I think since they have all found the way backe again by ' IVeeping Cross.',

A noted weeping cross at Shrewsbury was used as a station, which on Corpus Christi Day was visited by various guilds, corporate and religious bodies, to offer prayers for an Rogations. abundant harvest.

Sometimes crosses known as weeping crosses were erected as memorials of private grief, such as that raised by Queen Matilda at Caen in memory of her sorrows caused by the cruelty of her husband, William of Normandy. The example given in the Personal Grief. illustration is that of "Ampney Crucis," on the Fairford road, about two miles from Cirencester. The shaft rises octagonally and very boldly from two large square step sand a set-off, and is crowned by a sort of tabernacle, with an inclined roof. This custom of resorting to a spot set apart for penitence or lamentation has early authority in the custorn of the Jews, who, down to the present day, go every week to the walls of the Temple, and lament over its destruction.'

Formerly, in England, the bodies of suicides were buried at cross-roads, and were pierced with a suicides Buried stake. This custom was at Cross-Hoads. abolished by an Act of Parliament, July 8, I 823. It has been suggested, and the suggestion deserves consideration, that, originally, this place of

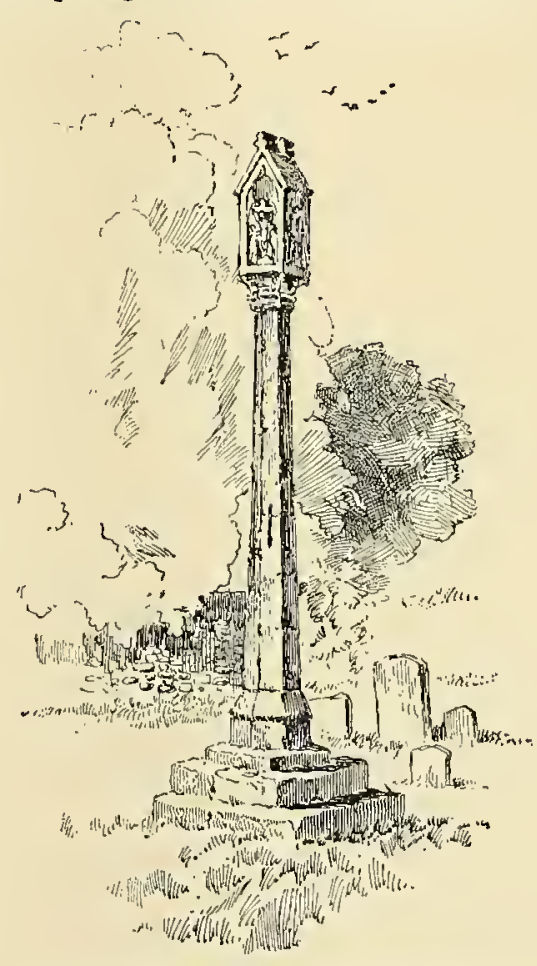

“Ampney Crucis, " near Cirencester. sepulture was not selected as an indignity, but because there was a wayside cross in old times at the intersection of roads, and so in a

${ }^{1}$ Alfred Rimmer, Ancient Stone Crosses of England, p. I27. 
certain sense their unblessed graves were hallowed, and the wayfarer was reminded of his devotions, especially that some prayer might be offered for the poor soul, who, a beggar by the wayside, craved the alms of a supplication for mercy. The stake also was meant not for a punishment, but for a protection against the removal of the bodies.

The Jews placed a cross on the graves of those who had died an unfortunate death, but with a different signification from that of our forefathers. The post-Christian Church used the Cross as the badge of mercy, the ante-Christian, that of shame. 


\section{CHAPTER XIX}

\section{MORTUARY AND BURIAL CROSSES}

$\mathrm{T}$

HE Cross was not only the sign whereby the early saints lived, but when the Angel of Death was about to close the record of their earthly lives, the prayer of the weary ones, breathed with fluttering breath, was: "Sign me with the sign of Christ, Crossat Death. and pour out your prayers for me."

Nicephorus records the tradition that the Apostle S. John, when he knew the hour was approaching that he should pass to his God, "fortified himself with the sign of the Cross, and descended into the tomb." " The instance of $S$. Ambrose has been already alluded to.

Sometimes, while strength lasted, the departing stretched forth his arms in acknowledgment of Him in whose service he had labored, or commanded a "bed of penitence" to be made of ashes, or of the dust to which he was so soon to return, spread in a cruciform shape, and thus met the last enemy. Upon

Cruciform Bed of Ashes or "Penitence." such a couch did Ludovicus, Louis VI., and Louis IX. render up their souls; the latter monarch with his arms composed in the form of a cross. Upon such a "bed of penitence" expired Henry III. of England. Louis le Gros breathed his last in the act of signing himself with the Cross, imitating Charlemagne, who, in his last hour, impressed his forehead, breast, and body with the holy sign. And in later times the good Bishop Jolly, of Scotland, following the example of S. Ambrose, thus extending his arms, gave up his spirit. Did space allow, many other examples might be given ${ }^{2}$; yet one more must not be passed by.

Among the illustrious persons who died on the " bed of penitence," no one is more worthy of mention than S. Hugo of Avalon, monk of the

1 Nicephorus, lib. ii., cap. 42.

2 For which see Gretser, De Cruece, tom. i., lib. iv., cap. 26. 
Grand Chartreuse, who was invited to England by Henry II., became Bishop of Lincoln, and in this position defended the Church most nobly, even when he had to oppose Henry II. and Richard I. When the time of his death drew near, he gave directions as to his grave in Lincoln Cathedral, and bade his Chaplain make a cross of ashes on the floor of his cell. It was a November afternoon. The choristers of $\mathrm{S}$. Paul's were chanting the compline service around him; before it was finished he motioned that he should be laid on the ashes. The choir sang on, and as they began the Nunc Dimittis, the servant of God departed in peace. ${ }^{1}$

From very early times it was the custom to hold the Cross before the dying, that their last gaze might rest upon it, and in that fearful

Cross at the moment they might be reminded of their purchased salvaHour of Death. tion, and of the staff which was to be their support in passing through the Valley of the Shadow of Death to the Paradise beyond. " Hold the Cross before me that I may see it in dying," entreated Joan of Arc when at the stake. An English soldier hastily broke Joan of Arc.

a branch and tied the two pieces together in the form of a cross, and gave them to the patriot martyr. A priest forced his way through the crowd and endeavored to reach a crucifix to her, till she, perceiving that his life was endangered by the flames, begged him to desist. A blast of wind, as if heaven-directed, drove away for a moment the smoke and flames. Joan was seen clasping her rude cross to her heart. Above the crackling and roar of the fire was heard her last word, " Jesus," as it ascended to mingle with the prayers of those under the altar, who cry day and night, "How long, O Lord!" Tradition says, that at the last moment a white dove was seen flying to heaven."

Sir Thomas More.

Sir Thomas More walked to the scaffold carrying in his hands a red cross.

Just before the execution of Mary Queen of Scots, the Earl of Kent, seeing that her contemplation was riveted upon the crucifix in her hand, Mary Queen rudely taunted her, " Madam, the Cross will avail you little of Scots. if it is not imprinted upon your heart." “"Ah," replied Mary, " there is nothing more becoming a dying Christian than to carry

'Froude, Short Studies on Great Subjicts,_-" A Bishop of the Twelfth Century."

${ }^{2}$ Etty's description of his painting of Joan of Arc; Leslie, Hand Book for Young Painters, p. 209. 
in his hands that remembrance of his redemption. How is it possible to have such an object in our hands, and keep our heart unmoved?" ' Then, having lissed it, she prayed, with her eyes still fixed upon the image of her crucified Saviour,-“"Even as thy arms, O Jesus! were sprede here upon the Crosse, so receive me into thy arms of mercy, and forgive me all my sinnes."

Upon the battlefield the dying soldier pressed his lips to the crosshilt of his sword in token of his reliance on Him who, on the Cross of Calvary, became his armor-bearer, against whose sword and buckler the attacks of the enemy of souls availed naught. In this act of devotion expired Don Rodrigo Trogoz, the noble Chevalier Bayard, and many others less known on earth, but, doubtless, whose faith and deeds have written their names as fairly in the Book of Life.

\section{"The sword had conquered kings,} And the spear through realms had passed, But the Cross alone of all seen things Could avail them at the last."

An instance of the ruling passion strong in death was exhibited by the celebrated Spanish painter, Alonzo Cano. In his last moments a crucifix, of indifferent execution, was put into his hands by his confessor. Cano desired him to take it away. HorrorCrucifix. struck, the priest thought him possessed of a devil, and proceeded to exorcise him. "My son," said the holy man, " what dost thou mean ? This is the Lord who redeemed thee, and who must save thee." “ I know that well," replied the painter, " but do you want to provoke me with this wretched thing so as to give me over to the devil? Let me have a simple cross, for with that I can reverence Christ in faith. I can worship Him as he is in Himself, and as I contemplate Him in my own mind." This was brought, " and Alonzo Cano died in the most exemplary manner, edifying the bystanders with his piety." a

An equally celebrated artist, whose name has escaped our memory, turned with abhorrence from a rude crucifix presented at his last hour, and demanded that one of Donatello's should be brought, that his dying moments might not be disturbed by the sight of such revolting ugliness.

1 Tyler, Hist. of Englant, vol. viii., p. 403. The crucifix used by Mary on the scaffold is still preserved by a titled family in Winchester. The image is of ivory, the cross of ebony. Notes and Queries, Ist ser., vol. iii., p. 517. " Head, Handbook of Spanish Paintings, p. гz2. 
After death, a cross was laid upon the corpse to guard it against evil Use of the Cross spirits. The Anglo-Saxons placed on it a book of the after Death. Gospels, the code of belief of the departed, and the Cross, the emblem of his hope. ${ }^{1}$

Frail, but significant, was a similar cross laid upon the breast of the Duke of Guise, renowned as Le Balafré, who was assassinated by the Duke of Guise. order, and in the presence of Henry III. The story is too long to be recounted in detail. Briefly, it reads thus: The King and the Duke were reconciled in 1588 , and partook of the holy Sacrament at the same altar in token of amity; but even then Henry was plotting his rival's destruction. An opportunity was soon afforded when the King was at the Castle of Blois. The Duke was summoned at an early hour to the King's cabinet under pretence of meeting the Council. As he entered he was attacked by the hired ruffians, and after a manful resistance, fell at the foot of the royal couch. Henry, who had remained concealed behind the tapestry till all was over, drew the curtain aside. The noble form of the Duke barred his entrance. Kicking aside the head that he might pass, he brutally exclaimed, "How big he was!" An old carpet was flung over the corpse, and one of the attendant lords, either in derision, or from a pious desire to perform every sacred duty possible, made a cross of some straw which chanced to be lying by, and laid it upon the ignoble pall. The next Cross of Straw. day the bodies of the Duke and his brother, the Cardinal of Lorraine, who was also assassinated in the same castle, were burned, and their ashes scattered, lest any relic should be preserved. Frail was the material of the Cross, yet significant of the brittle tenure of power held by Henry of Guise, and equally so of the lives of his enemies. Twelve days after this double murder, Catherine de Medicis expired in delirium under the same roof, and within eight months Henry of Valois himself fell beneath the assassin's knife.

The cross was often buried with the corpse. When the tomb of John of Gaunt, " time-honored Lancaster," was broken into by some laborCross in Tombs. ers, a rich crucifix was stolen from the grave. The arms of the body, after undergoing some strange fortunes in the hands of an itinerant showman, were rescued, and are now preserved in the Hunterian Museum.

' Lingard, Antiq. Anglo-Saxon Church, p. 158. 
The crosses thus found were of different matcrials. A small silver cross was found in the tomb of S. Vinciana; also, in I635, a wooden cross was found with the remains of S. Martina. Absolution crosses, as in the instance of the one elsewhere alluded Crosses. to, discovered in the tomb of Abelard and Heloise, appear to have been often of lead.

The earliest use of the incised cross over a tomb was, of course, in the Catacombs, but one of the earliest canons inculcating reverence, strange to say, we find among those whom the Romans would have called Northern barbarians. Kenneth of Scotland, in the ninth century, commanded: "Let every sepulchre be esteemed sacred, and let it be marked with the sign of the Cross, and take care lest any one tread on it with their feet."

The primitive Romans buried the dead entire. ${ }^{2}$ From Greece, probably, they derived the custom of cremation. Britain, as a province of Rome, adopted the custom, but as Christianity prevailed and respect for the body as the temple of the Holy Ghost gradually increased, the corpse was reverently committed to the grave,

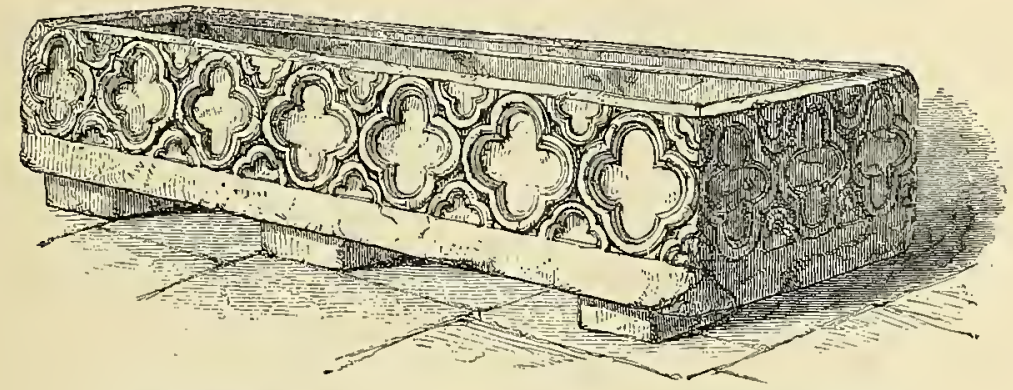

Stone Coffin of Llewellyn, Prince of Wales. In Llanrwst Church. From Boutell's Christian Monuments in England and Wales.

and by the fourth century, burning, although not altogether abolished, was rarely used. ${ }^{3}$ Nearer mediæval times we find that the bodies were swathed, like the ancient mummies, in cloth, leather, or lead, the last more especially in the eleventh and twelfth centuries. The use of leather was discontinued, probably, about the beginning of the thirteenth.

1 “'Kennethi Leges Religiosæ," Spelman, Concilia, p. 342.

2 Pliny, Nat. Hist, lib. vii.

${ }^{3}$ Bloxam, Monumental Architcture, p. 22. 
century ${ }^{1}$; coffins of wood and stone were also used, especially for the nobility and higher classes.

The lids of stone coffins were raised a few inches, and were of an angular shape in the form known as en dos $d$ 'asne, the ridges marking the stone coffins. length and breadth of the body forming a cross. Coped coffins were used until after the Puritan troubles. Examples are found as late as 1650 , without the cross, however. The custom of using stone coffins is one of the few old usages which Time has left unchanged. Two thousand years before Christ, the Pharaohs were fashionably laid in their stone beds. A similar sepulchre is not unknown in these days.
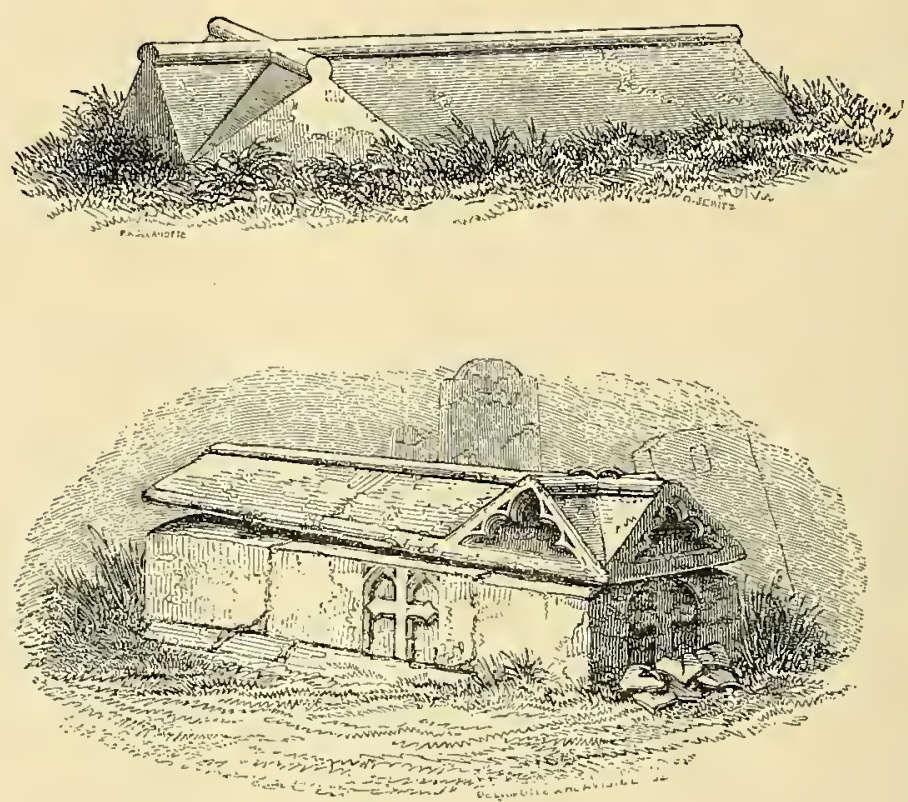

Stone Coffins with Cross on Lid.

From Cutts's Manual of Sepulchral Slabs and Crosses.

Headstone crosses were used about A.D. 950, and continued until the Reformation, ${ }^{2}$ when, with many churchyard crosses in England, they Head-stone were destroyed by the wanton sacrilege of the Puritans. In Crosses. the island of Iona there were formerly three hundred and sixty, of which only three remain, two of which are churchyard, or

1 The remains of the Empress Maud, who died 1167 and was buried at the Abbey of Bec, were found in 1282, wrapped in an ox-hicle. Bloxam, Monumental Architecture, p. 55.

"Cutts, Manual of Sepulchral Slabs and Crosses, p. 48. 
memorial, crosses, respectively called Maclean's and S. Martin's crosses. They are twelve or fourteen feet high, and the first is said to be the one referred to by Adamnanus in his life of S. Columba. This saint visited the island in the sixth century, but the date of the monument is unknown.' The earliest crosses which have been preserved are of stone,
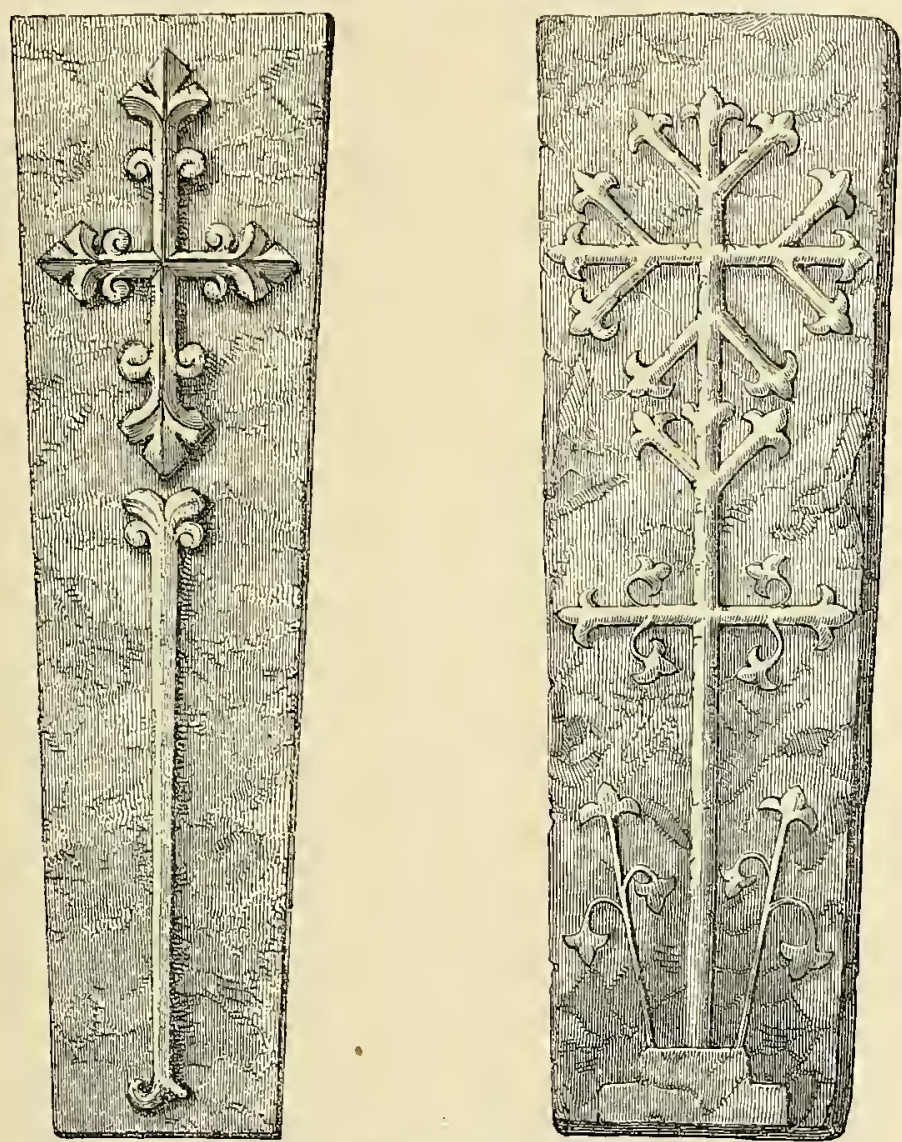

Stone Coffin-Lids.

From Boutell's Christian Monuments in England and Wales.

but wood has been used from the time of their first erection. Some old wooden ones are yet standing in Normandy, and that material is still used by Russians. In the latter country the crosses are of wooden Crosses the Greek crenulated form. On one side is the name of the in Russia. deceased, who is styled " a servant of God"; the inscription, "In the name of the Father, and of the Son, and of the Holy Ghost," followed

${ }^{1}$ Billings, Antiq. of Scotland, "Iona"; Montalembert, Monks of the West, vol. iii., p. 464. 
by some pious expression, such as " Eternal memory to thee," " Peace to thy remains," " The eternal kingdom to thee," " Salvation to thy soul," etc., while some conspicuous part of the monument bears the petition, "Good Christians are entreated to pray for the soul of ___." " When the Russians quitted the Island of Guernsey, in 1800 , they left more than fifty such crosses in their burial-ground, which the islanders, with a spirit worthy of Cromwell's soldiers, irreverently used for firewood. ${ }^{2}$
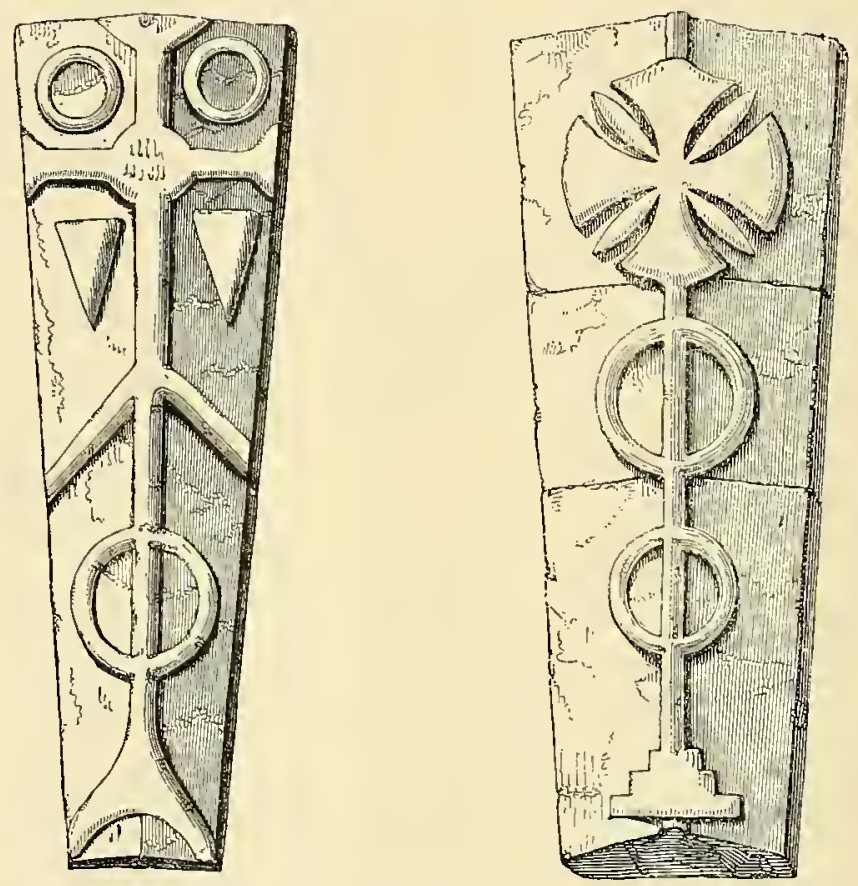

Stone Coffin-Lids.

From Boutell's Christian Monuments in England and Wales.

In the west of Greece crosses are frequently of the form represented in In Greece. the engraving ( $\sec$ page $3 \neq 0$ ). In the middle is a square hollow, with a door, in which on festivals a lamp is placed. ${ }^{3}$

In Sils in the Tyrol, the crosses are usually of metal, tall and floriated, with holy-water stoups suspended from them."

Monumental

Among the most beautiful of mortuary crosses are Mon-

Brasses. umental Brasses.

'Neale, Hist. of Eastern Church, "Alexandria," vol, i., p. 223.

${ }^{2}$ Britton, Architectural Antiquities, vol, i., p. 9r, note.

${ }^{3}$ Neale, Hist. Eastern Church, vol. i., p. 223.

"Webb, Continental Ecclesiology, p. 180. 
Long previous to the use of metal, the cross was graven upon the tombs in the Catacombs, from the first to the fifth century, as may be seen on the slabs preserved in the Lapidarian Incised crosses. Gallery at Rome. Ireland probably affords the next oldest instance, S. Brecan's stone being of the early part of the sixth century. In the course of time the incised work was filled in with lead, or composition; but as these materials were not durable, and the raised copestones were inconvenient in churches, at length was originated the slab inlaid with brass or latten (a mixed metal resembling that used for faucets), sometimes called Cologne, or, by contraction, cullen plate, although it appears to have been brought first from Flanders. The earliest form was

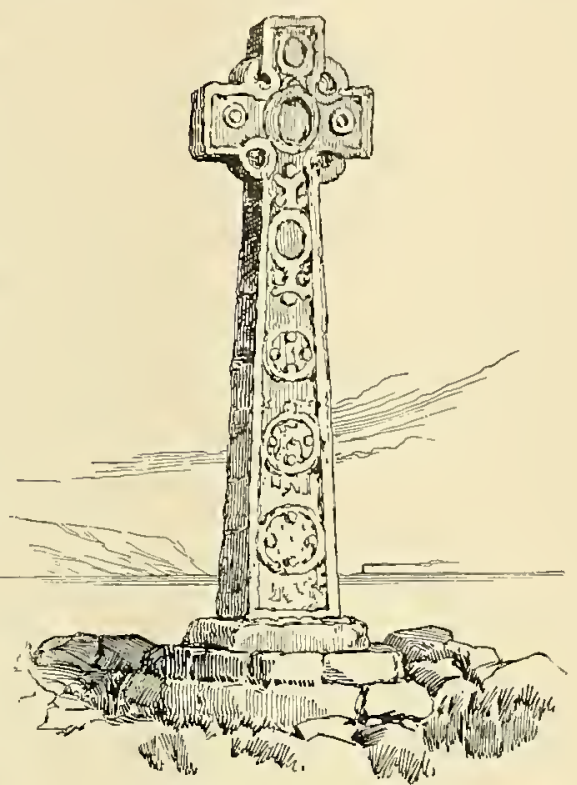

Headstone Cross in Iona. the enamelled work of Limoges, about the middle of the twelfth century. The simplest form was the old Lombardic slab, a flat stone with an incised marginal legend. The Cross was usually depicted with floriated
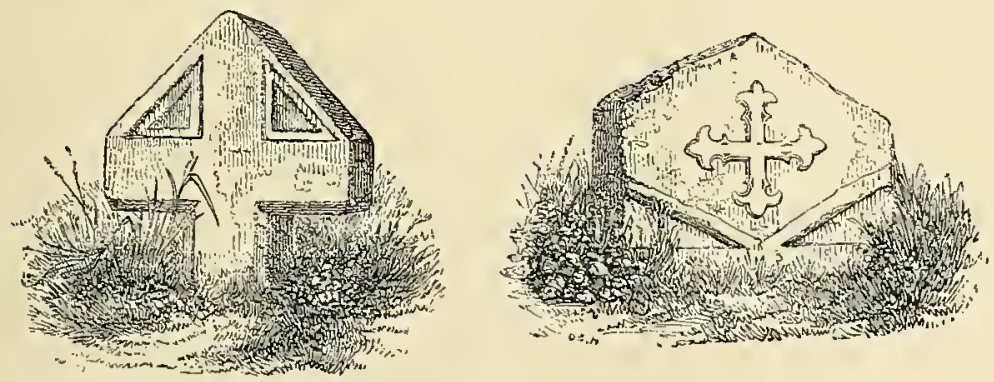

Cross on Headstones.

From Cutts's Manual.

arms, the stem resting upon a calvary, or inserted in the mouth of a dragon, emblematizing the power of the Cross over Satan. The ornamentation of the crosses increased with the development of architecture. Above the Cross was placed the head, or part-length figure, of the 
deceased, enclosed in a quatrefoil ; this finally became a full-length figure, clad in sacerdotal robes, or armor, according to the profession of the

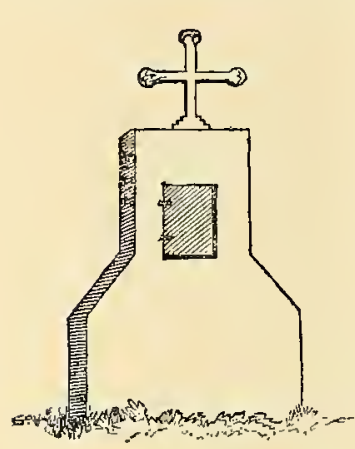

Grecian Headstones. deceased, and finally usurped the place of the Cross. When the cross was used, it exhibited the fertility of the invention of the oid masters. No two devices were alike, and some were so richly loaded with ornament as almost to conceal the cross, except to the eye of mediaval faith.

The earliest recorded example of a Brass in England is that of Simon de Beauchamp, Earl From Neale's Histury of the Latest Examples. earliest cross was that of Bishop Holy Eastern Church.

Bingham, who died 1247 , and was buried on the north side of Salisbury Cathedral. The latest example known is at $\mathrm{S}$. Mary's, Croy, Kent, I 776 . From the early part of the fifteenth century the art declined, and became utterly degenerate in the sixteenth.

The value of the brass tempted the Puritans during the Reformation and the Rebellion; hence the number destroyed and irrevocably lost to Christian art is immense. As late as 1612 , York Minster contained one hundred and twenty brasses, of which only one now exists. Still, there are more than four thousand remaining ${ }^{1}$ to attest the skill and piety born in the so-called Dark Ages. Previous to the Revolution many ex-

In France, amples existed in France, but even the indents, or matrices, North Germany, of them cannot now be found. North Germany and Beland Belgium. gium still possess some beautiful examples, but in other parts of Europe they have been destroyed, or are hidden in a few private chapels of the higher classes.

Connected with the subject of monumental crosses is that of monumental effigies, which are represented with the legs crossed. It has been conjectured that this attitude was intended to distinguish the actual

Cross-legged Monumental Efigies. crusader and those who vowed to engage in the holy wars, but had been prevented by death from fulfilling their vows. The former are represented with the sword sheathed; the

Walcott, Sacred Archaology. About four thousand are preserved in England, more than exist in any other country; and these examples are most common on the east coast, from Kent to Norfolk, and in the adjoining counties, Surrey, Sussex, Middlesex, and Berks; but are rare in the north and west, being chiefly confined to the cathedral and conventional churches, as in Herefordshire. In Ireland, Wales, and Scotland they were also far from common. 

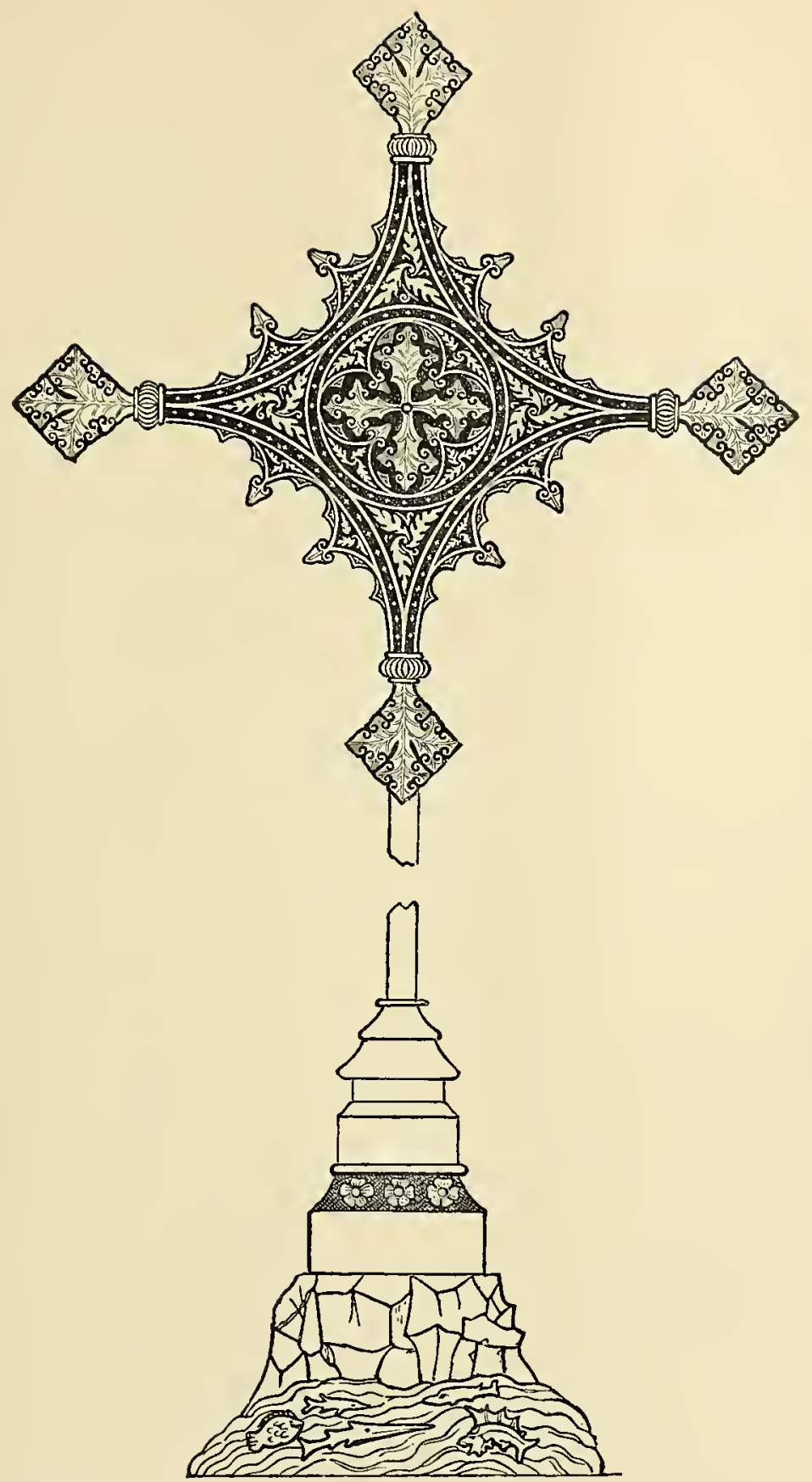

Head and Base of a Monumental Brass Cross. Grainthorpe Church, Lincolnshire. From Boutell's Monumental Brasses of England. 
latter with it partly drawn from the scabbard. This is the popular opinion, and is strongly defended by Fosbroke, the Rev. J. M. Neale,

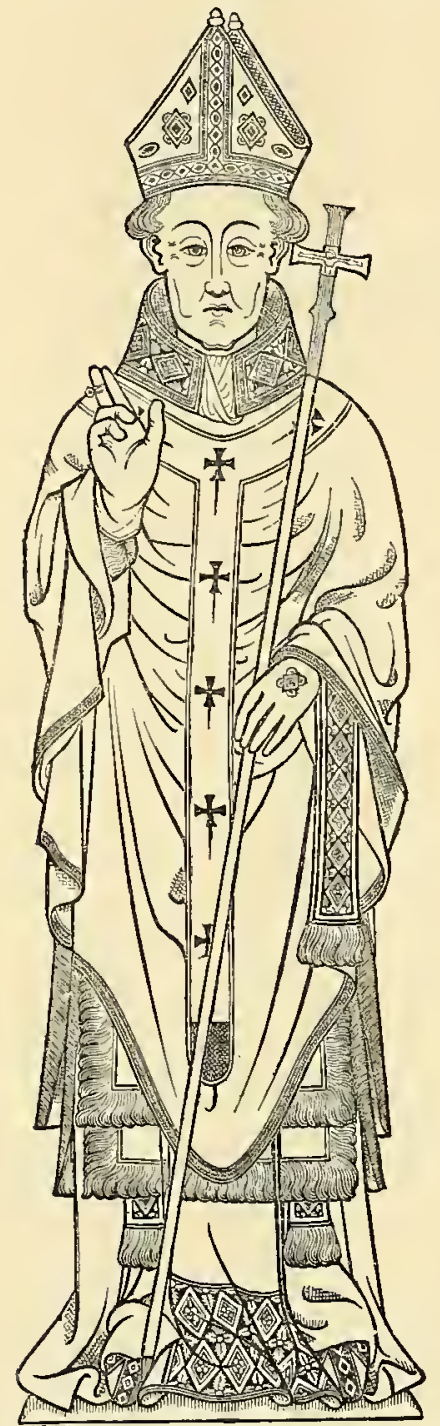

Brass Effigy of Thomas Cranley, Archbishop of Dublin, and Warden of New College Chapel, Oxford.

From Boutell's Monumental Brasses of England.

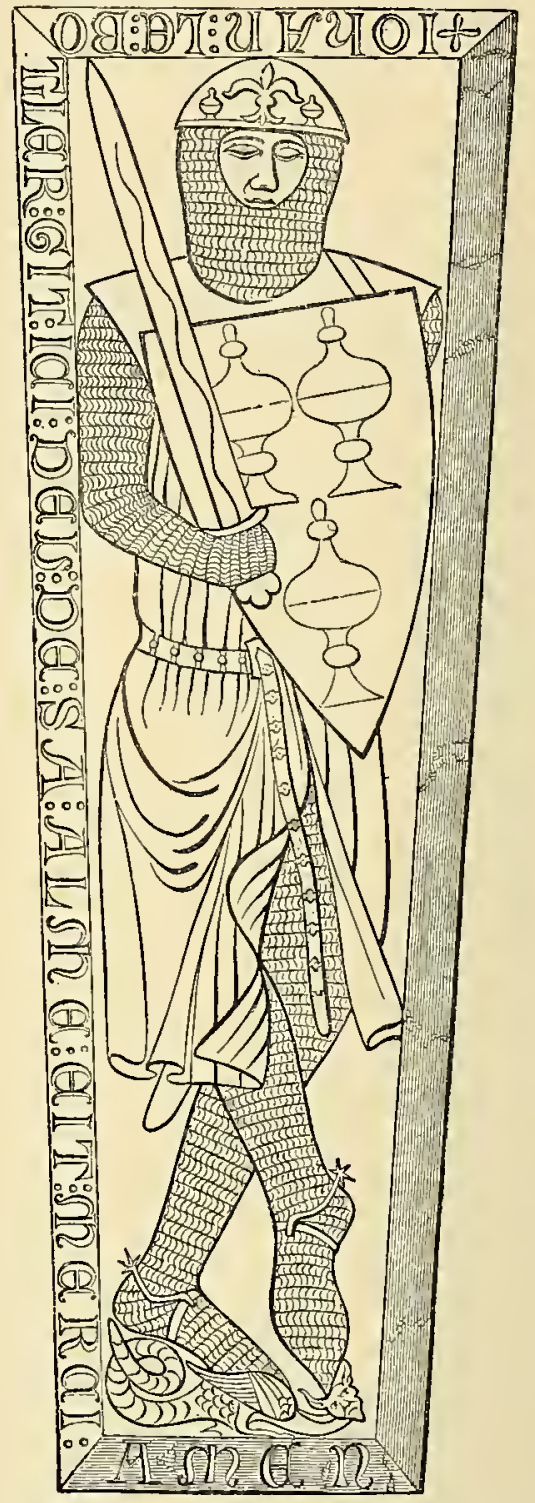

Monumental Effigy of a Crusader.

From Cutts's Manuol for the Study of Sepulchral Slabs and Crosses.

and others. Bloxam maintains that the " notion is, however, but conjectural, and can be traced to no sufficient authority; and, besides this, 
the cross-legged attitude was retained for more than half a century after the cessation of the last Crusade, though it may be remarked that subsequent to the thirteenth century the instances of such attitude are not very numerous. The sculptors of these early effigies certainly seem to have been more intent upon giving freedom and general breadth of effect to their compositions than elaborate exccution or high finish of detail, although they were by no means deficient in the latter; and on refering to the effigies of this era, it will be observed that where the legs appear crossed, the surcoat opens in front, and the drapery falls on each side in free and graceful, flowing lines; and by such disposition a degree of lightness and elegance was often attained, which the heary and constrained folds of the surcoat, when the legs were straight, did not admit of. In the early part of the fourteenth century, when the cyclas, a shorter and closer-bodied surcoat, was worn, this attitude became less frequent; and the final discontinuance of the cross-legged attitudes may be traced to about the period that the cyclas was discarded, and the defensive armor was chiefly composed of plate." '

Ve have but glanced at this part of the subject, which would occupy too much space to treat of fully; but those who are interested will find no difficulty in consulting many able and elaborate treatises which have appeared during the last half-century. ${ }^{2}$

'Bloxam, Monumental Architecture, p. I37.

2 The most easy of reference are: E. L. Cutts, Manual of Monumental Slabs and Brasses; Chas. Boutell, Christian Monuments, and his Monumental Brasses of England, etc. 


\section{CHAPTER XX}

\section{CHURCHYARD CROSSES}

" THERE is one emblem, perfectly unobjectionable, perfectly appropriate, full of solemnity, full of consolation, which raises hope, and dries the tear, and turns mourning into gratiReasons for the Churchyard tude; which while it reminds us that we are sinners, reCross. minds us of the means of pardon; which, while it shows us the penalty of sin, and thereby humbles us to the dust, at the same time cheers with the thought of Him who paid the penalty; Who rose triumphant from the grave, Who is the Resurrection and the Life, Who will change our vile bodies, and raise them from the dust, Who hath hallowed the grave and gate of death into the passage of immortality; and Who having Himself overcome the sharpness of death, hath opened the Kingdom of Heaven to all believers. That emblem, I need scarcely say, is the Cross." :

Thus writes a true-hearted son of the Church in our mother-land. And one of our noble band of Fathers in God, speaking of those by whom this blessed symbol was early used in sepulture, of those who were driven to worship God in the holes and caves of the earth, the persecuted Christians of Rome who met together in the Catacombs to celebrate the sacrifice of their crucified Lord, says: "By far the larger proportion [of sepulchral memorials] refer to the profession of Christianity and those hopes which had so lately dawned upon them, and lived beyond the narrow grave which they had deprived of its terrors. Of these we naturally turn first to the Cross, the primal symbol of Christianity, because it is the one most generally used. This emblem of our common faith is everywhere to be seen. Although so lately invested with the most humiliating associations, to the early Christians it became

' Paget, A Tract upon Tombstones, p. 22. 
at once a mark of dignity and honor. Unlike but too many who, in this day, bear that holy name which was first assumed at Antioch, thicy gloried in the Cross. They used it as an cmblem on all occasions during life-for with them the Cross explained everything-and it consecrated their tombs when the conflict of life was over, and they had exchanged it for the crown."

But to the saints of those days, trembling with fear lest their worship should be discovered, obliged to conceal under symbolic representations the portraiture of truths so precious

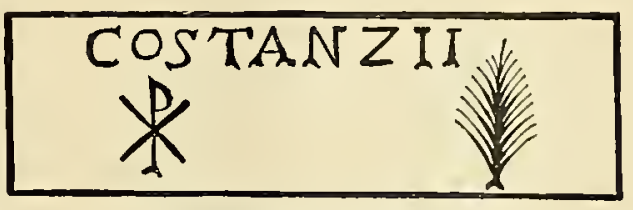

Inscription in Catacombs. From Kip's Catacombs of Rome. to those downtrodden ones-to them the Cross was a token of triumpl and of joy. The inscription which startled the Roman Emperor Constantine was an old familiar truth to them. Their life here was one of constant care and watchfulness;

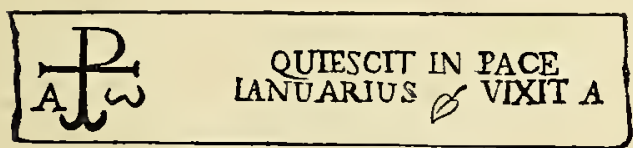

Inscription in Catacombs.

From Kip's Catacombs of Rome. their death the ushering of them. into a new life of peace and triumpli: so even the bitter instrument of torture bore as clearly to their eyes as to those of Constantine the Divine assurance, "By this we conquer."

Hence we cannot wonder to find the Cross in the graveyard, hallowing the rest of all who slept beneath its shadow, and a token of victory over the last enemy.

Churchyard crosses have, necessarily, already been touched upon when treating of Preaching, Memorial, Sanctuary, and other standard crosses. As the Cross was erected to be a gathering point for the congregation, so it was retained for divers sacred reasons after the building was in course of time erected. Puritanism in England, and infidelity on the Continent of Europe have destroyed most of them; still some few remain. How the pious generations of by-gone ages re- Every church to garded them may be learned, not only from their uses have achurchalready noticed, but by the carefulness with which each yard Cross. church was provided with one. In the constitution of William Bleys, A.D. I229, it is directed that a handsome cross be erected in every church-

\footnotetext{
${ }^{1}$ Bishop Kip, Catacombs of Rome, p. 107.
} 


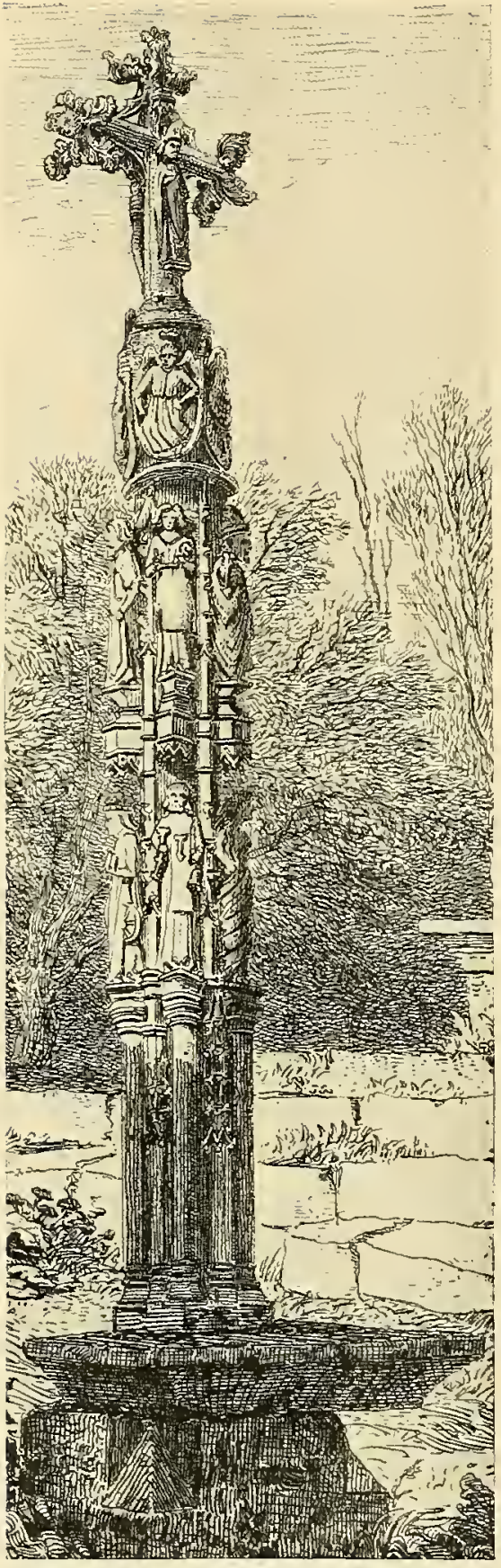

Cemetery Cross at Saillans (XVI Century).

From Drouyn's Croix de Procession, de Cimetières et de Carrefours. yard, to which a procession shall be made every Palm Sunday, on Palm Cross. which festival it was decorated with palms, and hence it is sometimes called the Palm Cross. It was usually placed near the south entrance.

As some of the principal churchyard crosses in Great Britain have been already noticed under other heads, a description of a few of the less known in France are given. ${ }^{1}$ Other examples might be cited, but many are of the Renaissance, or debased order of architecture, and are of but little interest except to local historians.

The cross of the cemetery of Saillans, Canton of Fronsac, sixteenth century, is, of all those of the Department of the Gironde, the best cross at preserved. It is dividSaillans. ed into three distinct parts. I. A square base sunk in the herbage of the cemetery, and in which is the table of the altar. 2. A round shaft, against which are statuettes and ornaments. 3. A cross ornamented with floriations and statuettes. The shaft is divided into four horizontal stages, separated virtually by four pilasters with clochctons mounting to the height of the fourth stage, separated from the rest by a saillante moulding. Between

1 Condensed from Leo Dronyn. His language has been preserved in an almost literal translation. 
these pilasters stand in the inferior stage four columns, whose capitals serve as consoles to four statuettes, which form the second stage. They are surmounted by canopies; on these still rise, in the third stage, four other statuettes. The lower represent, Ist, to the northeast (the Cross is oriented towards the summer solstice), S. Magdalene, holding in the left hand the vase of perfumes, and in the right her long hair, as prepared to perfume the feet of Jesus Christ. 2d, to the southeast, S. Antony, holding a hammer (Tau cross?) in the right hand, and a small bell in the left. $3 \mathrm{~d}$, to the southwest, S. Catharine ; a crown fleurdelisée ornaments her head, her right hand is armed with a sword, and her left hand holds a book. The wheel of torture is at her feet. $4^{\text {th }}$, to the northwest, S. John the Baptist, covered with his costume of camel's hair; he holds a lamb in his right hand. The superior statuettes represent: Ist, to the northeast, S. Peter, whose head is coifed with the tiara; he bears the keys. $2 \mathrm{~d}$, to the southeast, the angel Gabriel, holding a flower in his left hand, and blessing with his right. $3 \mathrm{~d}$, to the southwest, S. Paul, the right hand armed with a sword.

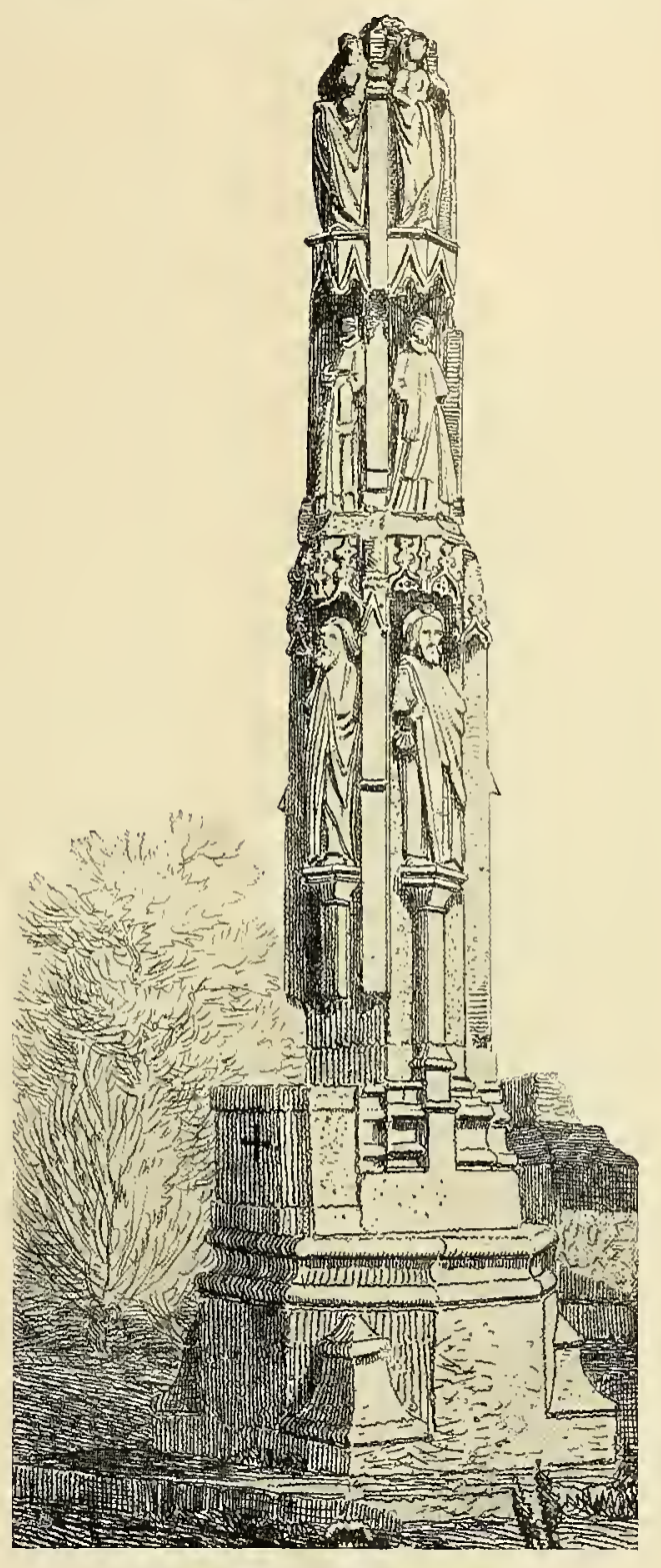

Cemetery Cross at Marcillac.

From Drouyn's Croix de Procession, de Cimetiéres et de Carrefours. 


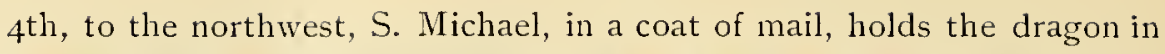
chains. Between S. Michael and S. Paul is an escutcheon, on which we read the date of the monument, I 543 ; and this proves that in the middle of the sixteenth century monuments in France were still made in the style of the fifteenth century.

These eight statuettes are almost completely detached from the shaft of the cross. The symbols of the Evangelists which cover the fourth stage are only sculptured in bas-relief. Above rises the cross properly speaking. It is very elegant, and covered with

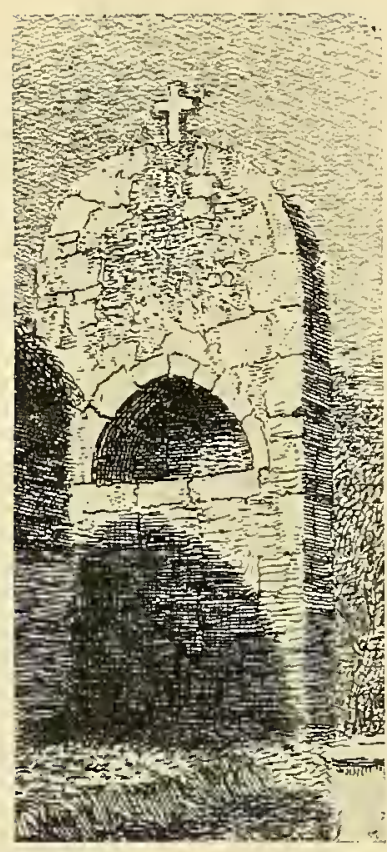

Cross at Georget.

From Drouyn's Croix de Procession, de Cimetieres et de Carrefours. rich ornaments of the Gothic decadence. The extremities of the branches were ornamented with large floriations in curled leaves forming an angel's head; one only of the motives is complete, the others have been in part broken. To the west is a crucifix, the figure having around the waist a simple band of cloth; its feet are attached with a single nail, and a death's-head is beneath the feet. To the east is S. Seurin, the patron of the parish; he holds a cross in the left hand, and blesses with the right. If the cross had more breadth, this monument, which is but slightly injured, would be a masterpiece of composition; but the statuettes, which form the principal decoration, are designed in the most deplorable manner, and in this respect it is much inferior to the crosses of S. Projet and of Marcillac.

We have only room to notice briefly the latter of these crosses, which, although mutilated, yet, owing to its happy proportions and to cross of the number and beauty of its sculptures, is regarded by $M$. Marcillac. Leo Drouyn as the most notable in the Department of the Gironde. The base need not be described. A modern altar will be seen on the pedestal, to which some of the statues have been sacrificed. Canopies shelter the images, and support them on the next stage. The four in the lower series are S. Peter, S. James, S. John, and S. Andrew. In the next above, one is so mutilated that it cannot be determined who 


\section{Churchyard Crosses}

is represented; the others are S. Laurence, S. Vincent, and an unknown bishop. Above are statuettes of female saints, only one of whom, S. Catharine, still retains her symbol. The drapery of all has been exquisite, and probably all carried their distinctive symbols. The hcight of the cross above the modern base is fourteen and a half feet.'

'Drouyn's paper on Processional, Cemctery, and IVaysid' Crosses. Read before the Im. perial Academy of Bordeaux, I 858 . Pl. viii., fig. 3 ; x., fig. I. 

PART III 



\section{CHAPTER I}

\section{VARIETIES OF THE CROSS}

THE writers on the Cross in the seventeenth century, Lipsius, 1 Gretser, Bosius, Salmasius, etc., recognized three varieties from which all the others have sprung. The crux commissa, Three Primary so called from the transverse being on the top of the upCrosses. right, $\mathrm{T}$, the form already described as the Tau cross; the crutx decussa, divided like the letter X, familiarly known as the S. Andrew's cross; and the crux immissa, + , the Latin or long cross. A fourth form, where the arms are equal, is the Greek cross, +. The first three, together with the Pall or yoked cross, $Y$, resembling a tree with branches, to which the arms of the sufferer were attached, were used as the actual instruments of suffering.

The earliest form of the cross is the Tau, the anticipatory cross, the typical cross, the cross of the Old Testament; that with four branches is the true Cross, the Cross of Christ, the Cross of the Gospel. "The virtue of the cross in Tau was derived solely from the cross with four branches; it was like a planet having no light in itself, but receiving all its splendor from the Sun of the Gospel." " And observe," says Durandus, "that the Cross is divided into four parts; whether on account of the four elements, polluted through our sin and healed by the passion of Christ; or by reason of men; whom Christ draws to Himself from the four parts of the world, according to His own prophecy, 'And I, if I be lifted up from the earth, will draw all men unto me' (S. John, xii. 32). These four parts may relate to the human soul; the Cross is lofty, long, large, and deep. The depth is in the foot which is buried in the earth; the length is from the root to the arms; the breadth extends with the arms; the height is from the arms to the head. The

\footnotetext{
1 Didron, Christ. Icon., vol. i., p. 374.
} 
depth signifies faith planted on a sure foundation; the height is hope, having its resting-place in heaven; the breadth, charity, extending even to the left, or our enemies; the length, perseverance, which continues, or is without limit." "

All varieties of the Cross with four limbs spring from the two principal types, the Latin and the Greek. The realistic Romans preferred an Greek and Latin. transformed the instrument of punishment into a symbol. These forms were not at first confined respectively to the two Churches from which they now derive their names. The most ancient Greek Christian sculptures contain crosses with arms of unequal length. Goar's Rituale presents the icons of SS. Methodius, Germanus, and Cyrillus,"

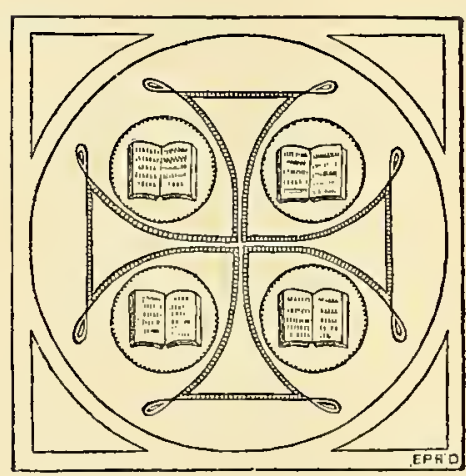

Cross Quartered with the Four Gospels.

From a fresco in the Catacombs. From Didron's Christian Iconography. whose garments are adorned with Latin crosses. The Church of the Holy Apostles of Constantinople was built with a nave longer than the transepts, according to Procopius, that it might give more exactly the form of a cross. On the other hand, in Italy, Greek crosses upon sarcophagi, pillars, altars, even in the Catacombs, testify to the use by the Western Church of the symbol of the East. In time, however, influenced probably by the bitter feelings resulting from the separation between these two branches of the Church, the Greek Church, actuated

${ }^{1}$ Durandus, Rationale d'Off., lib. v., cap. 2. The imagery is derived from S. Augustine, whose language is still more beautiful. "And yet we rightly understand to be required by it (i. $c_{\text {. }}$, the Cross) that which the apostle saith, "What is the breadth and length, and height and depth. It is broad namely in the Cross on which the hands of the suspended are stretched forth, and signifies good works in the breadth of charity ; it is long, from the cross-beam to the ground, where the back and feet are fixed, and signifies perseverance in length of time even unto the end; it is high in the top part, which rises upward from the cross-beam, and signifies the supernal end to which all works are referred; because all that in breadth and length are well and perseveringly done, are to be done with a regard to the height of the Divine rewards; it is deep in that part which is fixed in the earth, for there it is hidden and cannot be seen, howbeit all that is apparent and eminent arises thence, just as onr good things do one and all proceed from the depth of the grace of God, which cannot be comprehended and judged."-Hom., cxviii. in S. John, sec. 5. Bishop Hall uses the same similes, but compares the foot of the Cross to the faith rooted upon grace and mercy (ser, xxx).

${ }^{2}$ Goar, Rituale Gracorum, Pp. II4, II5, I26. 
somewhat by the conservative principlc which has characterized her, confined herself more exclusively to that form now considered peculiarly her own, while the Latin Church has become equally exclusive. That this feeling did not belong to the early Christians of Rome may be seen from the accompanying cngraving taken from the Catacombs. Didron interprets the Cross as symbolizing Christ, the books, the four Evangelists. ${ }^{1}$

A form rarely seen except in heraldry is that in which the foot and head are of equal length, and longer than the transverse arms. It is sometimes called the Armenian cross, but is only a variation of the Greek.

Armenian Cross.

The simple Latin cross, free from floriation or ornament, is known as the Cross of Suffering or Passion. It represents the actual gibbet altar upon which the atonement was offered and ought never to be used except when the special direct reference is to the Passion. sacrifice. Hence in architecture it is strictly appropriate (in our humble opinion) only over the rood screen, because, as the nave symbolizes the Church Militant, and the chancel the Church Triumphant, so the chancel arch (over which the Doom was formerly painted) or roodgate, typifies death. Hence the appropriateness of the severe, simple symbol of our trust, in passing that portal.

The Resurrection or Triumphal cross is a simple shaft crossed at the top, the crux longa, or hasta longa, from

he Resurrection or Triumphal which floats a banner.

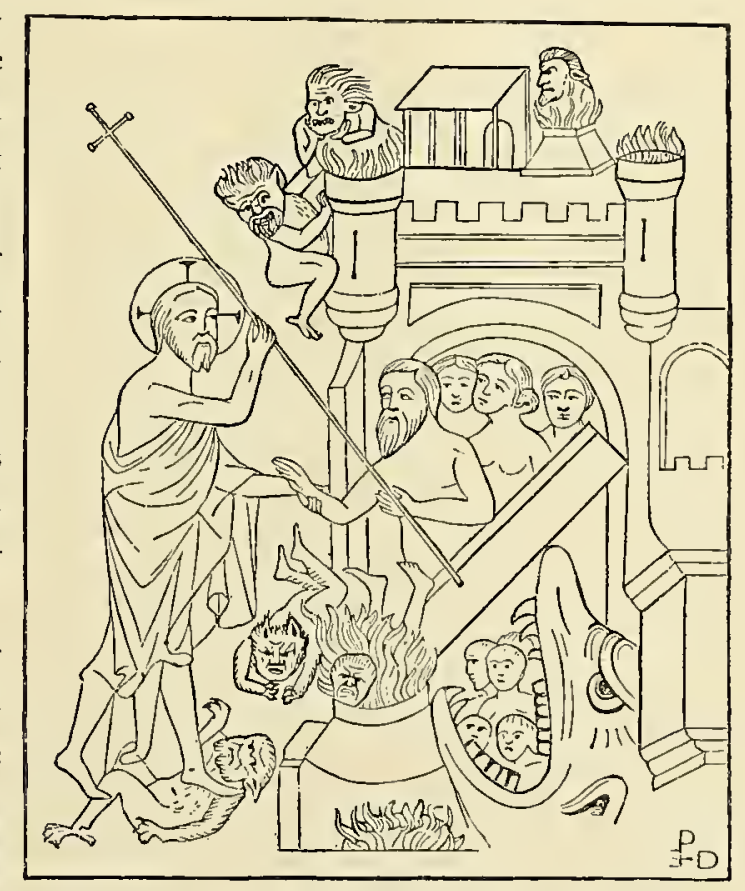

Christ, Armed with the Cross of Resurreciion, Descending into Limbo. From Didron's Christian Iconography.

${ }^{1}$ Didron, Christ. Icon. vol. i., p. 39 I. 
Christ bears it in his hand, his standard of power, when represented as the conqueror over death and Hell. Hence in the first instance when descending into Hades, he opens the gates of woe with a touch of the Cross, and our first parents and the saints are delivered while the devils howl and gnash their teeth in impotent rage. In the last instance, when rising from the tomb, our Lord bears aloft histriumphant banner towards heaven.

There is a beautiful tradition concerning the Cross of Triumph, recorded by S. Ambrose as extant in his day. The blessed Virgin was Legend of the alone with her grief in her chamber. Open before her was Triumphal cross. the volume of the prophecies, some of which she had seen fulfilled, hence, not hopeless or unbelieving, she prayed,-“ Thou didst promise, O my most dear Son, that Thou wouldst rise again on the third day. Before yesterday was the day of darkness and bitterness, and, bchold, this is the third day. Return then to me, Thy Mother; O my Son, tarry not, but come." And lo! there appeared a company of angels singing Regina Coli latare, Allchia! and the patriarchs and prophets released from Hades, and Christ bearing his standard of victory over $\operatorname{Sin}$ and Death. ${ }^{1}$

This banner cross is that properly borne by the Paschal lamb, or by the woman, symbolical of the Church in art, and must be distinguished Crosses Borne by from that carried by S. John Baptist. This last is a reed the Lamb, and the banner is attached not to the staff but to the transWoman, and
$\mathrm{S}$ John.

Upon the gold coins of the elder and younger Theodosius, and of several other Greek emperors, appears a cross with two transoms; and Double-barred there are ancient crosses of this fashion. The upper bar is

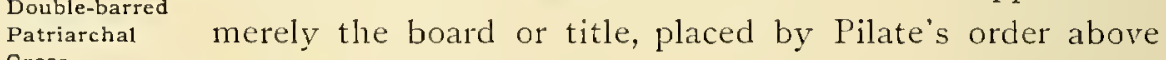
Cross.

the head of our Saviour. It was a common form of the Eastern Church, and may be seen on some Byzantine monuments. In one of the illuminations in a Greek manuscript in the Vatican, the Redeemer, uprising from the tomb, bears the double-barred cross."

Godfrey de Bouillon. Duke of Lorraine, being chosen, by the Crusaders, the first Christian King of Jerusalem, adopted this Cross; hence it is sometimes called the Lorraine, or Jerusalem cross $^{3}$; it was adopted

1 Jameson, Legends of the MIadonna, p. 299.

" D'Agincourt, Pinture, pl. Ivii.

${ }^{3}$ This must not be confounded with the proper Jerusalem cross, for which see infra, Part iii., chap. ii. 
also by the Order of the Knights Templars, which was established in III 9 .

Sometimes the foot of the Lorraine cross terminates in acanthus leaves, as may be seen in the convent of S. Laura on Mount Athos. Some have erroneously supposed that the Cross of Christ is here represented as triumphant over the crescent of Mahomct. But crosses of this shape existed long before the time of the false prophet, even in the reign of Justinian. Sometimes it is called the rooted cross, but it appears to be only a development or ornamentation of the cross and anchor, which symbol is often met with in the Catacombs.

Another variety of the Cross is the triplebarred, or with three transverse beams, which

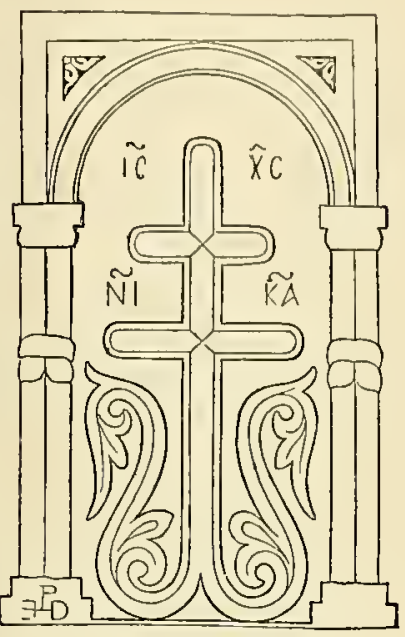

Lorraine or Jerusalem Cross. was adopted as a mark of special distinction above the single or

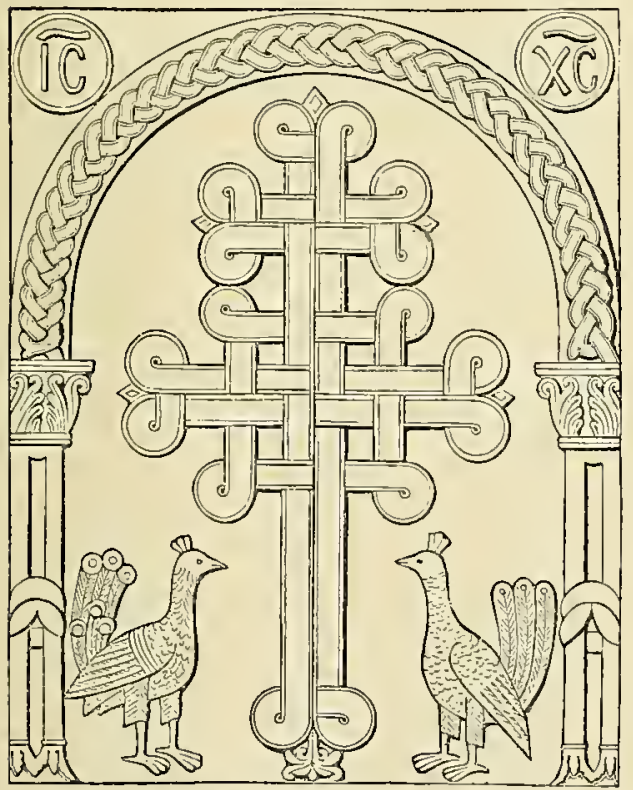

Greek Cross, with Double Cross Arms (XIth Cen-

double- barred. While the double crosses are used by cardinals and archbishops as a medium of hierarchi- Triple-barred or cal distinction, the Papal cross. Pope alone is entitled to the triple cross. ${ }^{1}$

$A$ form of the Cross peculiar to the Greek and Russian Churches presents an oblique suppedancum. The reason assioned Greek or Russian reason assigned is, Cross with that one foot of Suppedaneum. the Saviour, when suffering, was drawn higher than the other. It is natural to suppose that in the agony of the nailing to the cross, one limb should be retracted, while the other was being fastened. But as we have seen in the actual Crucifixion no footstool was used.

\footnotetext{
1 See Part ii., chap. vii.
} 
The inhabited cross is an ancient variety of this symbol, described by Dante in his Divina Commedia, printed in Florence in I49I." This cross The Inhabited is resplendent with a glory far more radiant than the suns Cross of Dante. and constellations of every kind which blaze around it. Arriving with Beatrice in the planet Mars, the poet exclaims:

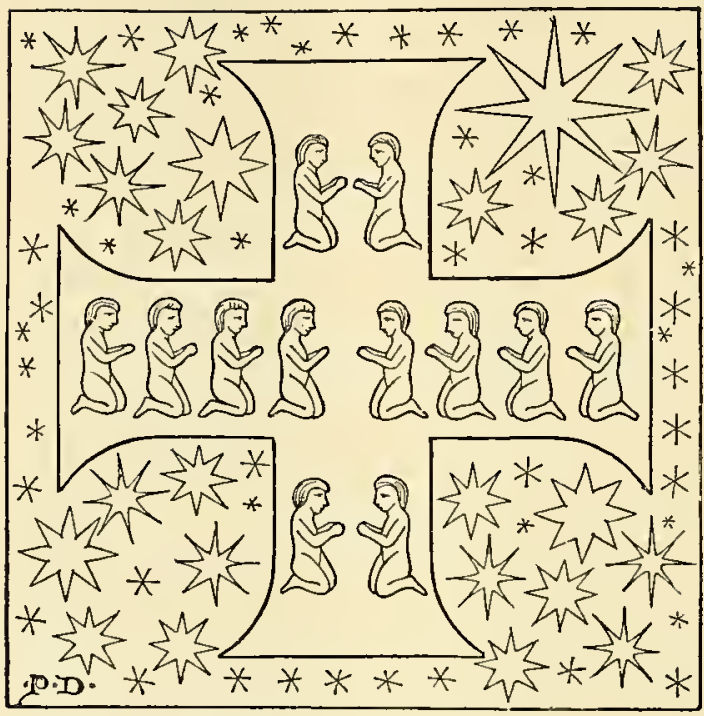

Inhabited Cross, Florentine, I49I.

From Didron's Christian Iconography.
"For with so great a lustre and so red

Splendors appeared to me in twofold rays,

I said: 'O Helios who dost so adorn them!'

Even as distinct with less and greater lights

Glimmers between the two poles of the world

The Galaxy that maketh wise men doubt,

Thus constellated in the depths of Mars,

Those rays described the venerable sign

That quadrants joining in a circle make.

Here doth my memory overcome my genius ;

For on that cross as levin gleamed forth Christ,

So that I cannot find ensample worthy ;

But he who takes his cross and follows Christ,

Again will pardon me what I omit,

Seeing in that aurora lighten Christ.

From horn to horn, and 'twixt the top and base,

Lights were in motion, brightly scintillating

As they together met and passed each other" " ;

Among the twelve little figures inhabiting the cross, representing the souls of valiant warriors, Dante gives the names of eight who occupy the arms of the cross, beginning from left to right. These are Joshua, Judas Maccabæus, Charlemagne, and Roland in the left arm; and in the right, William the Conqueror, Richard Cœur de Lion, Godfrey de Bouillon, and Robert Guiscard. ${ }^{3}$ Cacciaguida, an ancestor of the poet, is one of the four souls, not named, who are kneeling in the

'Paradiso, canto xiv., 1. 94.

${ }^{2}$ Longfellow's trans., Far, canto xiv., 1. 94-I I I.

${ }^{3}$ Ibid., canto xviii., 1. 37-48. 
stem, and upper part of the cross. "This cross does not contain the Crucified in person, and yet Dante declares that there Christ shone resplendent; in fact, as has been said, the Cross is the symbol of Christ. Iconographically considered, the Son of God is in the Cross, as He is in the Lamb, and in the Lion; He is there hidden under the semblance of the instrument of punishment on which He died. The second Person of the Trinity is figured by an infinite number of different objects; three alone, the Lamb, the Lion, and the Cross, are symbols of our Lord. Even the Fish does not rise to the dignity of a divine symbol.",

Most of the varieties of the cross originated in the fertile imaginations of the medirval heralds, and will be mentioned under their proper head, Heraldic Crosses; and yet other modifications seem to be rather more correctly varieties of the monogram than of the cross.

'Didron, Christ. Icon., vol. i., p. 405. 


\section{CHAPTER II}

\section{THE CROSS IN HERALDRY}

TO ordinary symbol occupies so large a space in heraldry as the 1 Cross, and most appropriately, when we consider that the science originated from the command of that God of order who marshalled the enormous multitude of the children of Israel, each under his own banner, during their long journey from Egypt to the Promised Land. For we read: "And the Lord spake unto MIoses and unto Aaron saying, Every man of the children of Israel shall pitch by his own standard with the ensign of their father's house " (Num. ii. I, 2).

It is not in our province to look further in to the antiquity of a science which carries us back to the earliest epoch to which the annals of history extend, and in whispers, faint with age, still speaks to us, although in a tongue scarcely understood by the people. " Heraldry," says Lord Lindsay, "is, in fact, the last remnant of the ancient Symbolism, and a legitimate branch of Christian Art; the griffins and unicorns, fesses and chevrons, the very tinctures or colors, are all symbolical,--each has its mystic meaning, singly and in combination, and thus every genuine old coat of arms preaches a lesson of chivalric honor and Christian principle to those that inherit it,- - truths little suspected now-a-days in our Heralds' Offices!" '

"A cross," says Guillim, " is an ordinary composed of four-fold Lines whereof two are Perpendicular and the other two Transverse, for Definition of so we must conceive of them, though they are not drawn a cross. throughout, but meet by couples in four right angles, near about the Fess-Point of the Escutcheon. This ordinary is in Latin

${ }^{1}$ According to Aben Ezra, the standard of Judah was that of a lion; of Reuben that of a man ; of Ephraim that of an ox ; and of Dan that of an eagle.

${ }^{2}$ Lindsay, Letters on Christian Art, vol. ii., p. 49. 
call d Crux a cruciando, or a cruciatec, from the Torture of those who undergo this Death. The Content of a cross is not the same always; for when it is not charg'd, it has only the fifth Part of the Field; but if it be charg'd, then it must contain the third Part thereof. In the ancientest Constitution of the Bearing of the Cross, without all Controversy it had this Form, and this Bearing was bestowed on such as had perform'd, or at least undertaken, some service for Christ and the Christian Profession, and therefore being duly consider'd I hold it the most honourable Charge to be found in Heraldry."

Upton agrees with Guillim in his estimation of the Cross, and adduces the following from S. Chrysostom, as authority: "The Cross is to us the cause of all blessedness. It has delivered us from the blindness of error; it has given us peace after being vanquished; it has united us to God after having been estranged from him; it makes us that were pilgrims, settled citizens. The Cross is the hope of the Christian, the resurrection of the dead; the guide of the blind, the life of those that were given over; the staff of the lame; the comfort of the poor; the pilot of sailors; the harbor from danger, and the wall of the besieged. The Cross has been translated from places of execution to the foreheads of Emperors."

It is usual to trace the bearing of the ordinary of the cross to the time of the Crusades, because about, or rather immediately after their time, according to Camden, "we received the hereditary use of arms, but which was not fully established until the the cross. time of Henry III." ; tradition, however, claims greater antiquity. It is said that Lucius, the first Christian king of the Britons, in the second century assumed the Cross, and that the Cross Saltire (S. Andrew's) was the device of Scotland as early as the fourth century. ${ }^{1}$ The arms of King Arthur are enveloped in as much mystery as is that royal personage himself, but getting on firmer ground we find the English sovereign,

1 "King Arthur . . . toke hys armys a Crosse of silver in a shelde of veste, . . . and with that signe of the Cross, he dyd many marvels." Third part of the Boke of S. Albans, I+86. The same author, Juliana Berners, refers to a tradition to which she gives pious credence, which places the assumption of the Cross far earlier: "Also I have red thys signe of the Cross to be sende from God to that blessed man Macuri, with a shelde of asure and a cross fluri with iiij roses of golde, as here in thus, and I soude never that ever any armys woar sende from heuvyn but in them was the sygne of the Cros." Ibid., quoted in Dollaway, Inquiries in Heraldry, p. 79 . Arthur himself bore three different devices. Two dragons addorsed, $i, e$, back to back, three crowns; and vert a cross argent having in chief the Virgin and Child. Millington, Heraldry in Hist., Poet., and Romance, p. 35. 
Egbert, about the year Soo, bearing for his arms the Cross. His coat of arms is supposed to have been the same as that of Edward the Confessor (1040), now, we believe, appropriated by Westminster Abbey, i. $\varepsilon$., " azure, a cross patonce, between five martlets, or." Edmund Ironside also bore these arms at the battle of Ashdown, or Assendon, in Essex. They were afterwards assumed by Margaret, his granddaughter, who married Malcolm Canmore, King of Scotland.

That most of the crosses used in heraldry originated in the Crusades

Eastern Origin of Heraldic Crosses.

is probable from their form; the generality of them being Greek seems to indicate their Eastern origin, although it may have been chosen as best adapted to the shield. ${ }^{2}$

A badge was necessary in the Holy Wars to enable those who were strangers in person and language to recognize each other as allies. The Badge of the different nations were distinguished by crosses of various Crusaders. the French the cross argent; the English the cross or; the Germans the cross sable; the Italians the cross azure, and the Spaniards the cross gules. In the third Crusade the French appropriated the cross gules, the English the cross argent, and the Flemings the cross vert. ${ }^{3}$ These crosses were generally of cloth interwoven with gold or silk at first, afterwards of any cloth. In an expedition against Mansfield of Sicily, when he was denounced by Urban IV. and Clement IV. as a heretic, the Cross was divided in two colors, red and white. On other expeditions, in distinction from those to Jerusalem, the Cross was worn on the breast, not on the right shoulder.

Among the stratagems resorted to in recruiting for the Crusades, that of Philip II. of France may be noted. At Christmas it was customary to distribute gifts of garments among the courtiers. The Trick in Recruit- King ordered a large number of robes of precious cloth, and
ing for the Crusades.

had crosses of fine goldsmith's work sewed upon them privately at night. The next morning at Mass, the recipients of the royal

'Such is the story. Millington, Heraldry in History, Poetry, and Romance, p. 36. Grose and Astle say: "The ancient arms of [Westminster] Abbey were partie per fesse intente, or, and azure a crosier erect, and a mitre in chief. The new arms are partly those of Edward the Confessor, and partly those of England in chief, or between two red roses." - Antiquarian Repertory, vol. ii., p. $17 \mathrm{I}$.

${ }^{2}$ To the Crusades may be referred the origin of many heraldic terms: Gules, from Persian gul, crimson. The furs ermine and vair were probably brought home by the Crusaders.

${ }^{3}$ Natthew Paris, p. 146. 
bounty were astonished to sec the Cross upon each other's shoulder, but, perceiving the King's object, were ashamed to remove them.'

When the Cross was repeated upon the armor or dress it denoted a resolution to do some great deed of arms. Iteration of arms always had this significance; thus Froissart, speaking of Sir John Chandos, describes him as dressed in a large robe which

Repetition of the Cross. fell to the ground, blazoned with his arms in sarcenet; argent, a pile, gules, one upon his breast, another on his back. " Thus he appeared resolved on some adventurous undertaking. " 2

The ingenuity of the heralds was taxed to supply the demand for variations of the Cross, and there were "Crossis innumerabull born dayli," says Juliana Berners. Guillim describes thirty-nine, Colombière ninety-six, Edmondson and Berry four hundred and thirty-three. About fifty are in common use.

"The plain or S. George's cross," s saith worthy old Fuller, " I take to be the mother of all the rest; as plain song is much the senior to any running division. Now s. George's Cross as by transposition of a few letters, a world the Original. of words are made, so by the varying of this Cross in form and colour and metal (ringing as it were the changes,) are made infinite several coats." " The Cross of S. George has been the badge of England, of both king and nation, at least from the time of Edward III.

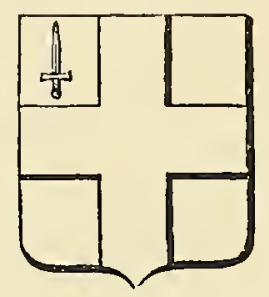

Cross of S. George.

During the wars of York and Lancaster, the red or white rose nearly superseded it, but it revived upon the termination of the civil contest. The king's badge was formerly worn only by his own retainers, and by free corporations, hence the city of London bears the red cross and the sword, the latter probably as the symbol of S. Paul, the patron saint of the city. ${ }^{5}$ Stow believes the sword to have been granted as an honorable augmentation to Walworth, for the service done by him to Richard II. when he smote down Wat Tyler. Others say that the

${ }^{1}$ Matthew Paris, p. 60.4. Upon the stained glass of the time of the first Crusade, the warriors are represented "carrying a cross upon their banners; their helmets, mail jackets, sleeves, and hoods, and their bucklers, are still without heraldic distinctions."-Maillot, Costumes, vol. iii., p. $7 \mathrm{I}$, pl, xxiii.

2 Froissart, vol. jii., p. I05.

3 The heraldic shields in this chapter are taken from Newton's Display of Heraldry.

${ }^{4}$ Fuller's Supplement to Hist. of Holy Warre, bk. v., chap. iv.

${ }^{5}$ Glossarv of Heraldry, "Badge." 
arms granted at that time were those of Sir John Philpot, who killed the rebel after he was stricken down. ${ }^{1}$

In heraldry every charge and tincture had its symbolical meaning, as well understood in the age of chivalry as is the alphabet in this "; so symbolism of doubtless every variety of the sacred sign of our salvation Heraldic Crosses. lhad its mystical interpretation, which reminded the wearer of some virtue with which he himself, or his ancestor, was graced, and which it was his duty to keep bright. The signification of many of the crosses has been lost, but some have been preserved. A few instances are given.

The Cross Potent. ing Elde, says :

Potent (enabling) was the ancient name of a crutch, or walking-staff. Chaucer in the Romaunt of the Rose, describ-

\section{A foot, but it were by potente."}

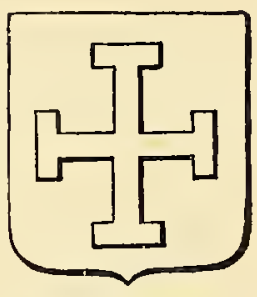

Cross Potent.

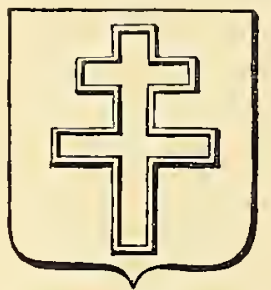

Jerusalem Cross.

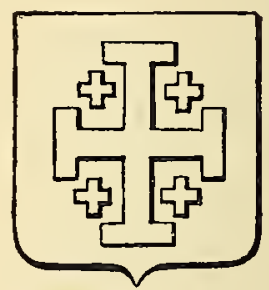

Jerusalem Cross.

Again in Somnour's tale:

"And leyde adoun his potente and hat."

Hence the cross potent implies support. It is not a symbol of a decrepit Christian, but of one who trusts in the virtue and power of the Cross. Sometimes it is pointed or pitched, for thus the pilgrims' staves were made, that they might plant them in the ground when they wished to perform their devotions. Both forms are appropriate bearings of an aged Christian. Hence also the fitness of its adoption by the Knights of the Holy Sepulchre, who guarded that sacred place and aided the pilgrims.

1 Millington, Heraldry in Hist., etc., p. I94.

${ }^{2}$ In the legend of King Arthur and the Ermine in the arms of Bretagne, Nlessire Yves, etc., Kerskao is described as pre-eminent in knightly prowess and accomplishments. "But in the noble science of heraldry he was indeed a master. No king-of-arms, nor herald, understood better than he the value of armorial bearings blazoned upon a warrior's shield. He could tell at a glance to what nation he belonged, could trace the origin of his race, and name the exploits by which his ancestors had distinguished themselves."-Ibid., p. I67. 
This form also is sometimes called the Jerusalem cross, but it was only part of the armorial bcarings of the holy city. The arms of Jerusalem are argent, a cross potent between four plain crosslets or. The five crosses symbolize the five wounds of our blessed Lord; or Christ and the four quarters of the earth, for which $\mathrm{He}$ Cross. suffered ${ }^{1}$; or as some say, equally inaccurately, Christ and the four Evangelists. The false blazonry-metal upon metal-was purposely used in allusion to Ps. lxviii., v. 13: " Though ye have lien among the pots, yet shall ye be as the wings of a dove covered with silver, and her feathers with yellow gold." “ Another cause why Godfrey bare that coat was this: after his conquest of the Holy Land, it was concluded that he should forever use the most strange and unaccustomed coate of arms that ever was borne, which for thereon manner of bearing might move question to all that should behold the same to demaund if it were not a false coat." Godfrey de Bouillon may have been influenced by the

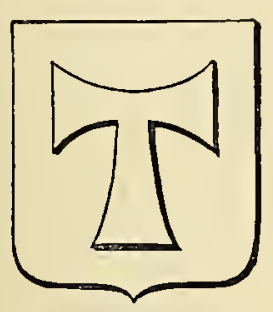

Tau Cross.

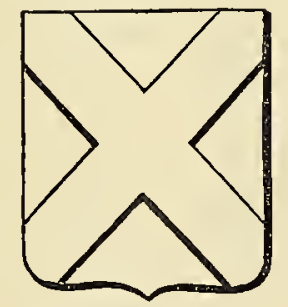

Saltire Cross.

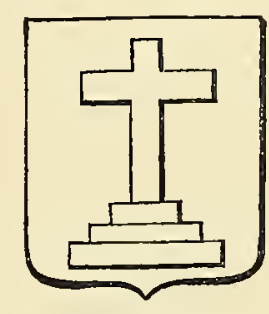

Calvary Cross.

same feeling of humility which led him to refuse to wear a crown of gold when his Master had worn a crown of thorns," and hence he would put aside all tokens of human honor and bear those of humiliation.

The Tau cross is oftentimes called the Cross of S. Antony, because that saint is represented as bearing it upon his habit. It resembles the cross potent, but the extremities are enlarged like the cross pattec. It is the old symbol of security, as already exTau Cross. plained, from the command given to the angel as recorded in Ezek. ix., 6. Yet in Europe, the crouch, or cruch, is recognized, and some ancient families, like that of Bette in Flanders, bear this ordinary to signify that they have been great supporters of their prince and of the Christian faith. As has been elsewhere mentioned, forms of absolution were formerly inscribed on a crass of this form,

${ }^{1}$ Stephen Borgia, De Cruce I'aticana. $\quad{ }^{2}$ Millington, Heraldry in Hist., etc., p. 201. 
hence it was sometimes called, according to Berry, the Cross of Absolution.

The Saltire, or S. Andrew's cross, has been derived from an instrument used in scaling walls. Leigh says that " this, in the old time, was Cross Saltire. of the hight of a man and was borne of such as used to scale the walls (saltare in muros) of towns," which were then very low, as evidenced by the walls of Rome, which "were such that Remus easelye leaped over them; witnesseth also the same, the citie of Winchester, chieftaine of the Danes, who was sleyne by Guy, Erle of WVarwick." But the Christian herald cannot give up the hallowed associations identifying the Saltire with the cross upon which S. Andrew ascended to the crown of martyrdom. In the days of chivalry it was held in honor as that Apostle's cross, and was assumed by " many

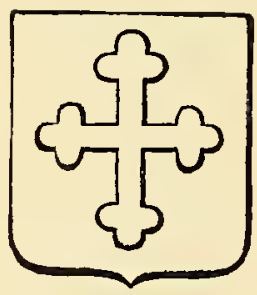

Cross Botoné

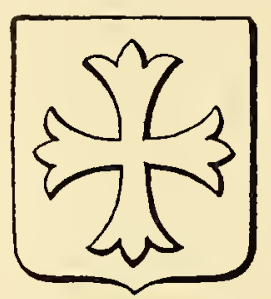

Cross Patonce.

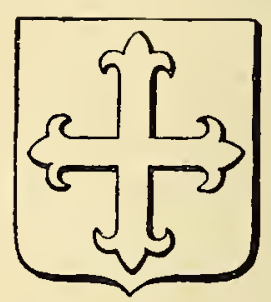

Cross Fleury.

knights and martyrs, some bearing it sharp to show their sufferings, some plaine to denote their willingness to suffer, and some flory in token of their triumpl." S. Alban, the first Christian martyr in Ancient Britain, is said to have borne, azure, a Saltire or. The symbolism of the Saltire cross is, therefore, readiness to suffer for the faith. This cross, crossletted, is called by the French heralds the Cross of S. Julian.

cross of Calvary. The Cross of Passion, when erected upon three steps, is known as the Cross of Calvary. The steps allude to the three Christian virtues, Faith, Hope, and Charity.

All crosses whose ornamentation is derived from the vegetable kingdom have a symbolic reference to the growing and developing virtues of the Christian bearer. The cross botone, formed with trefoil or three Cross Botoné. buds at the end, is specially applicable to the budding or promising virtues of a young champion of Christ, and may properly be used in reference to children or youths. If the terminations 
be considered as trcfoils, there is an allusion to the Holy Trinity, but some think them incomplete trefoils.

In the cross patonce the bud has expanded into an opening blossom, denoting the progressive stage of the graces

Cross Patonce. developing in the Christian warrior.

The cross feury is the earliest variation of the cross. It appears on the coins of the Emperor Justinian. The extremities are expanded, the petals being open and curled over in volutes, - the flower in full bloom, implying that the bearer was a matured soldier

Cross Fleury or Flory. of the Cross, whose noble achievements had been recognized as flourishing in the field of Christian chivalry. It is strange that while frequent on Monumental Brasses in England, it is never found on them on the Continent.

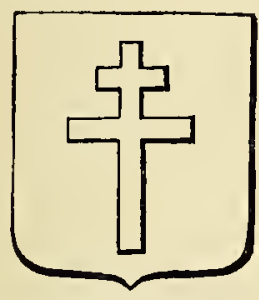

Patriarchal Cross.

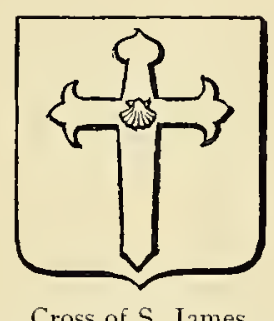

Cross of S. James.

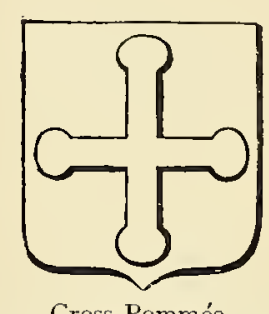

Cross Pommée.

The Patriarchal cross, called by the French the Cross of Lorraine, should be specially noted, not only on account of the doubt cast upon its ever having been actually used as a processional cross, but for its pregnant symbolism. It is recognized as an ordinary Cross. in heraldry. Its pale crossed by two transverse bars, says Nisbet, represents the work of Redemption, performed both for the Jews and the Gentiles. "The ancient Patriarchs of Jerusalem bore on their banners this form of the cross, upon a white sheet between four stars gules, and the Patriarch of Constantinople had a similar cross of gold upon a blue sheet, between two stars in chief and a crescent in base argent." ' This cross was the badge of the Knights Templars. Upon a white cloak they wore a Patriarchal cross gules, fimbriated with gold. The red cross indicated their readiness to shed blood in defence of Christ and His religion, and the white garments, emblems of the purity of the lives and conversation of the Order.

We are compelled to omit a most important part of our subject,- the

${ }^{1}$ Newton, Display of Heraldry, p. I64. 
cross connected with the various orders of knighthood,-but to treat this as it deserves would require a volume in itself. One cross we note becross of cause of its frequent occurrence in heraldry. The Spanish s. James. Order of S. James or S. Iago commemorates the miraculous appearance, according to tradition, of the Apostle at the battle of Clavijo, A.D. 846 . Their badge is not so much a cross as a sword-liilt, for the upper limb is terminated with a heart, the lower limb pointed like a sword, and the transverse terminations are like those of the cross patonce. Knights of noble birth bore the pilgrim's scallop shell of S. James at the intersection of the arms. ${ }^{\text {. }}$

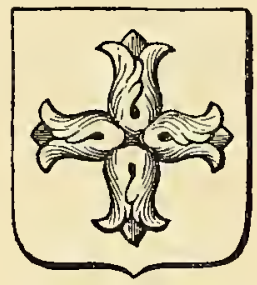

Cross Avellane.

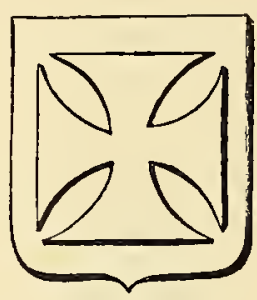

Cross Pattée.

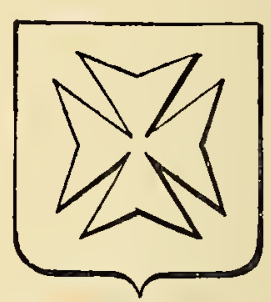

Maltese Cross.

Cross Pommée, Pomelle, or Pommettée.

The cross pommé bears at its terminations balls intended to represent apples. This device is applicable to a fruitful champion of the Cross.

The cross avellane represents four filberts. Its significance is the same as the cross pomméc. "This form of the Cross," says Nisbet, " is Cross Avellane. placed" (sometimes) " at the top of the mound of kings and emperors, as an ensign of sovereignty."

The cross pattéc symbolizes the open wings of a bird as covering her young, hence it intimates the protecting power of the Cross, and appercross Patté tains to the Christian soldier who has shielded the weak. or Formée. It was fitly adopted by the Knights Hospitallers.

The Maltese cross is the cross pattec indented, thus forming eight points symbolical of the eight beatitudes. It is an approMaItese Cross. priate badge for charitable societies.

The cross moline is the form of the iron upon the nether stone of a mill, " which beareth and guideth the upper stone equally in its course and," Cross Moline. saith Boswell in his Armorics of Honour, " is a fit bearing for judges and magistrates, who should carry themselves

${ }^{1}$ For a brief compendium of Orders of English Knights, see Millington, Heraldry in Hist., etc. For a full account of European Orders, see Favine, Theatre of Honour. 
equally to all men in giving justice." Sometimes the pale, or single shaft, only is used, when it is termed the cross milrinc. In allusion to the allegory of equal justice just mentioned, the

Cross Milrine. arms of the Honorable Society of Lincoln's Inn, London, are blazoned, according to Guillim, fifteen terdemoulines or, on a canton of the second a lion rampant purpure.

The cross corcille, sometimes called rccercllee, is perhaps one of the richest of heraldic crosses in symbolism, and most pregnant with meaning. The ends are curled like rams' horns, a symbol of crosscercellée strength frequently used in the Bible. To the bearer this or Ancree.

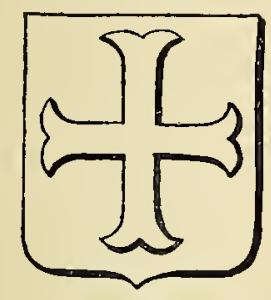

Cross Moline.

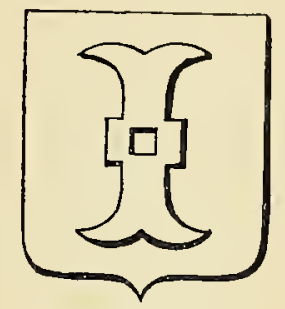

Cross Milrine.

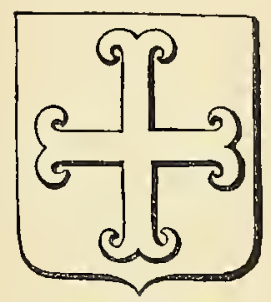

Cross Ancrée.

form of the Cross implies confiding strength in the Cross. When the terminations are less curled, some heralds distinguish it as the cross ancrée, signifying hope anchored in Christ.

The cross barbée derives its name from its arrow-like, or barbed, terminations. It alludes to the firmness with which the doctrine of the Cross is fixed in the heart of the bearer. It is sometimes known as the nail-head cross, because of the resemblance to the quadrangular-headed nails of the Passion when represented in art. No herald of note, however, has sanctioned this application.

There are instances of the cross humette (i. e., a plain cross couped, or cut off), having the heads of animals issuing from its extremities; usually these are denominated from the animals represented, but by some heralds such crosses have the generic appella- nating with Anition of ancetté (handled): ex. $g r$., a family of the name of mals' Heads. Kaer in France bear gules, a cross ermine gringole (snake-headed). Such terminations of the cross ancettée as the heads of lions, eagles, reptiles, etc., are met with, although they are not common. The same interpretation must be used as when the entire animal is employed in heraldry. The noble, and not the ignoble, qualities are implied. Thus the lion 
signifies nobility, courage, magnanimity; the eagle, authority, power, jurisdiction; the serpent, subtlety and wisdom.

Parts of ferocious animals, with crosses and other Christian symbols, occur in arms. They indicate the invincible courage, comparable only to that of the animals depicted upon the shield, with which the bearer fought in the Holy Land, in the cause of the Cross.

These examples of crosses, either borne alone or associated with escallop shells, martlets, mullets, and crescents, unequivocally tell the story of their origin when found on old coats of arms, the devices of those enlisted in the Crusades in the twofold capacity of pilgrims and champions.

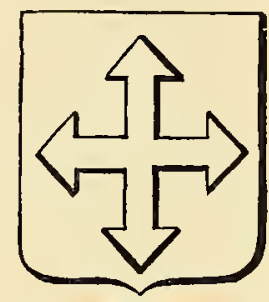

Cross Barbée.

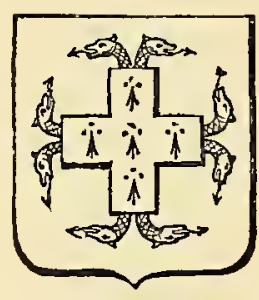

Cross Ancettée.

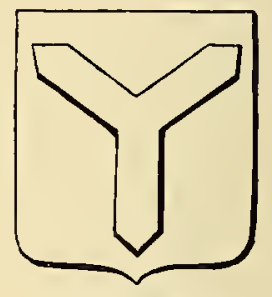

Pall Cross.

The Pall or forked cross, resembling the branches of the tree upon which the sufferer was suspended, demands special attention. AccordThe Pall cross ing to heraldry it may be described as the upper half of a Saltire, conjoined to the lower half of a pale. It is sometimes called the cross furchee, but that is frequently represented with four forked pointed arms; even when three are used, the devices differ in form and meaning. The cross furchee might be called the Pall cross couped fitched.

The ancient family of Cunningham, in Scotland, bear, argent, a cross furclié, sable, in honor of the loyalty and subtlety of their ancestor. cunningham When Malcolm Canmore escaped from the usurper Macbeth, Arms.

a Cunningham concealed the fugitive prince by covering him with straw. After Malcolm was established upon the throne, he granted large domains to his protector, and the arms, a cross furchee, representing the wooden fork used in spreading the straw.

The Pall cross proper extends to the edge of the shield and repreThe Pall or sents the well-known ecclesiastical vestment also called Pallium. superhumerale, hiera, stole, and omophorion. Although hardly in place here, some description of this vestment may not be un- 
necessary. It has been used in the Church since the time of S. Chrysostom, who was charged with accusing three deacons of taking his omophorion. Some archeologists claim that it was first worn by Sylvester I. in the reign of Constantine. In the prescnt time it is worn, by all bishops of the Greek Church, above the pliclonion, or vestment, during the service of the Eucharist, and, as used by them, it resembles the ancient pall much more nearly than that used by the Western ecclesiastics. According to Rock, it originated in the ancient Roman toga, which was permitted to dwindle, for the sake of convenience, till it became a broad band, the badge of authority.

In the time of Gregory the Great it was made of white linen without seam or needlework, and the earliest adornment was either a Good Shepherd, or a cross. In later times, the pall was woven of white lamb's wool. In the Roman Church it purports to be made of the wool shorn from the lambs which are blessed on S. Agnes's Day upon the altar of the venerable Church of S. Agnes at Rome. The vestment was placed for a night upon the altar (some say, tomb) of S. Peter, and the next day was consecrated with papal benediction. For a thousand years it has scarcely varied in shape, an ovoid, bearing, before the eighth century, two, or four, red or purple crosses, since then, eight black crosses. Pelagius either the I. or II. required all metropolitans to present themselves to receive their pall within three months of their consecration, but the custom afterwards became more lax. Isidore of Seville says it was once common to all bishops, but in time it was restricted to archbishops. Gregory the Great forbade the payment of fees, on the reception of the pall, but his successors became wiser in their generation, and the journey and fees became a grievous tax. One archbishop of Mayence paid thirty thousand gold pieces.

Mystically, the pall is taken either for the lost sheep, or for the Cross as borne by our Lord. Like the stole, it would seem to symbolize Christ's yoke (Matt. xi., 29), hence it is interpreted to teach humility, zeal, etc. Walcott interprets the "pendants to the Pall. represent the double burden of the Pope" ; of course this symbolism could only be applicable to the Pontiff's use of the vestment.

The very pins with which the Pall was fastened were pressed into service. Bosio, after speaking of the manner in which all Christians, but especially prelates, ought to bear their cross spiritually, in self-denial, 
self-discipline, and love to their neighbor and fear of God, tells the bishops that they are reminded of their virtues by their pall upon their shoulsymbolism of ders, and quotes from Pope Innocent III., I I98, as follows: the Pins. " "The pall is fastened with three pins. One on the breast, another on the left shoulder and the third upon the right shoulder (behind, says innocent). The first alludes to compassion for our neighbor, the second to the administration of the office, and the third to the execution of justice. The first pricks the mind by pity, the second by labor, and the third by terror. The first, the apostle reminds us of when he says, "Who is weak, and I am not weak? who is scandalized, and I burn not ?' The second, 'Besides all that which is without, which is instant daily with me, The care of all the Churches.' The third, 'If the just scarcely be saved, where shall the sinner and impious appear ?" "'

" By the way," saith old Fuller, " the pall is a pontifical vestment, considerable for the matter, making, and mysteries thereof. For the Fuller's Explana- matter, it is made of lamb's wool and superstition, the tion of the Pall. making, the wool being without artificial color, and spun by S. Agnes's nuns, and first cast into the tomb of S. Peter, taken from his body, say others. Three mysteries are couched therein. First, Humility, which beautifieth the Clergy above all their costly copes. Secondly, Industry to follow Him who fetched his wandering sheep home on his shoulders. But to speak plainly, the mystourie of mysteries in the pall was the archbishops receiving it showed their dependence on Rome, and . . . was a sufficient acknowledgment of their subjection: and as it owned Roman power, so in after ages it increased their profit. For though once such palls were freely given to archbishops whose places in Britain were rather cumbersome than commodious, having little more than their pains for their labor; yet in after ages the Archbishop of Canterbury's pall was sold for five thousand florins: so that the Pope might well have the golden fleece if he could sell all his lamb's wool at that rate. Only let me add, that the author of Canterbury's book styles this pall tanquam grande Christe sacramentum. It is well tanquam came to help it, or else there had been eight sacraments."

Many wealthy mechants in the Middle Ages both in England and on the continent of Europe, having no armorial bearings, used as their

${ }^{1}$ Innocentius Papa Tertizes Lysterizem Nussa, lib. i., cap. 63 ; Bosio, La Trionfante Croce, lib. ii., cap. 3 .

${ }^{2}$ Fuller. Church Hist., p. 71 . 
signet, or marks of cognizance, certain monograms. These are invariably of the Cross in combination with some other merely mundane emblem, such as the circle referring to the globe, the pennon or flag mllustrations from of a ship, or the vane of a weathercock, alluding to the Heraldry. prosperous gales upon which depended the success of their navigation.
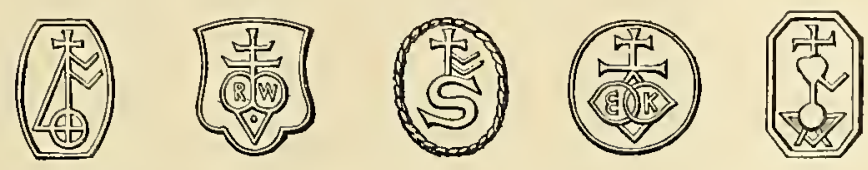

Merchants' Seals, From Newton's Display of Heraldry.

The engravings are from seals on ancient MSS. in the Rolls Chapel, London, and are given of the original size; they are supposed to be the signets of merchants or of wealthy commoners generally, anterior to the
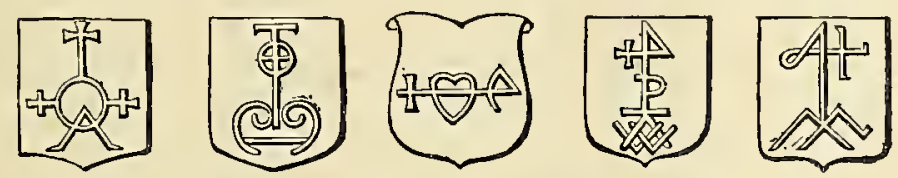

Sculptured Monograms. From Newton's Display of Heraldry.

time of Richard III. As armorial bearings are affixed to some of the instruments, it is to be presumed that some were gentlemen; others secm not to have been entitled to bear arms.
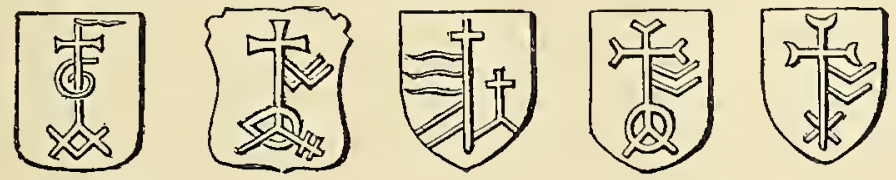

Sculptured MIonograms. From Newton's Display of Hiralary.

In the fourteenth and fifteenth centuries the wool merchants appear to have contributed largely both in England and on the Continent to the
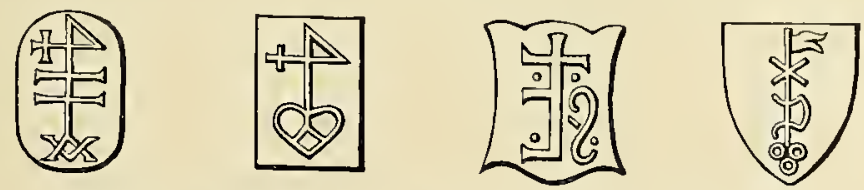

Sculptured Monograms. From Newton's Display of Heraldry.

erecting and repairing of churches; hence, especially in seaports, we find their monograms, sometimes in the ceiling or walls, at other times in the glass. 
The first of this series of monograms appertained to John Jay, a merchant of Bristol; it is found in Redcliffe Church, and bears the date of I451. Others belonged to merchants of the reigns of Henry VI. and Edward IV.

In the next series will be found devices taken from the Church of S. Andrew-under-shaft, London, the church at Doncaster, and from Bristol Cathedral. Similar monograms were in use on the Continent, particularly in Germany, and in the Netherlands, where the woollen manufactories formerly abounded. The engravings in the third series are from Malines in Belgium, with the exception of the last one, which is on the wall of the ruined monastic Church of S. Clement at Tours in France.'

' Newton, Display of Heraldry, pp. 396-399. 


\section{CHAPTER III}

THE CROSS ON COINS

T

HE mystic sign of the Lord of Life' hallowed the symbol of property from the beginning of coinage. Numismatics have of late become one of the fashionable studies, hence the barest Antiquity of the reference to a few facts only is needed in illustration of this Cross on Coins. part of our subject.

The place of the origin of coinage is a matter of dispute. Ionia, Miletus near Ephesus, and Egina are rival claimants for the honor. But the doubt appears to be respecting gold; the first silver coins, it is presumed, belong to Egina, about B.C. 870; or, according to some authorities, they were struck by Phidon, B.C. 750. Upon one side they bear a tortoise, upon the other, an indented square, or cross, considered a certain mark of antiquity; it seems probable that the latter was merely the stamp of the coiner.

The use of a cross before the Christian era, on early Sidonian and Phœnician coins has been previously noticed. Coinage attained a high degree of excellence in the reign of Alexander I. of Macedon, B.C. 497-454; a cross appears upon the coins of that period and continued to be used

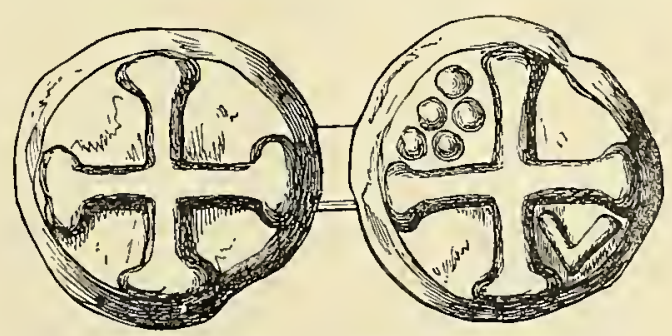

Roman Quincunx. From The Art Fournal. until the time of Amyntas, 37 I B.C. The Roman quincunx also bears a cross on each side.

I It seems fitting that the sign of the Lord of Life should consecrate money, for the first mention of it is in connection with death: Abraham's purchasing the cave of Machpelah to "bury his dead out of his sight." Gen. xxiii., 5, 9, 15, 16. 
Although the early Christians, especially the various heretical sects, introduced the head of Christ and even the Cross upon their medals, yet Cross on Christ. the first current coins of the Christian era which bore the ian Coins. token of our Lord were those of Constantine. This emperor naturally preferred the represcntation of the Labarm to that of the Cross, as attesting the reality of his vision.

Gretser, commenting on the stamping of coins with the Cross, indulges in what reads like grim satire. In substance, he says: "Truly it pleased the rulers of Christian nations to place on money the most sacred sign of the Cross, that those who loved not the Cross on account of Christ, might love it for the sake of the coin; and as Christians place their heart on money, they might not tear it away from the Cross, lest
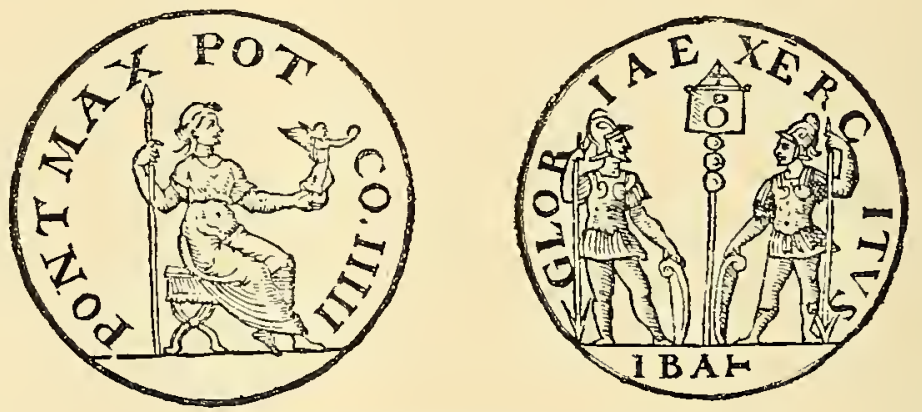

Coin of Constantine. From Gretser's De Suncta Cruce.

in gathering that treasure on which alone their heart was placed they might be submerged and drowned. Thus, while they beleld the price for all things in this world, they might recall the great price paid for their redemption; and that not in corruptible gold and silver, but the precious blood of the immaculate Lamb, immolated upon the Cross for us. And since those who covet wealth fall into the snares of the Devil and various temptations, therefore to the incitement of avarice the Cross was added as an antidote and shield against the evil arts of the malign enemy. Hencc Nicolaus Oresimus, Bishop of Lexoviensis, says, that to the name of God the Cross was added as testimony to the genuineness of the coin in weight and material, which if princes violate in either respect they are tacitly guilty of lying and breaking that commandment, 'Thou shalt not take God's name in vain., ', '

${ }^{1}$ Gretser, De Cruce, tom. i., lib. ii., cap. 56. 
Constantine was content with the Labarum. His son Constantius added the legend, "In this conquer," not precisely as it has been transmitted to us by historians, " In hoc signo imec," but "Hoc Coins of consigno aictor cris." " On one of his coins, Victory is crown-

stantius. ing the Emperor, who holds the Labarum, and the exergue may be read,

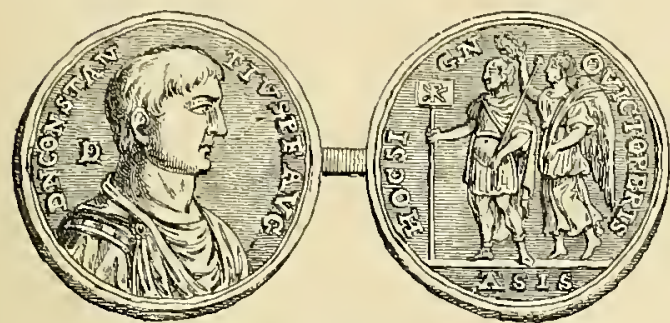

Coin of Constantius.

From Walsh's Ancient Coins, Whedals and Gens.

A for Primin, SIS for Sisconsiom, i.c., "the first tribute of Siscia," a town in Croatia.

In spite of the Emperor's Arianism, he was overruled to testify to the faith. His coins bear the monogram $\mathbb{R}$ between $A$ and $\Omega$, Christ the beginning and the end. ${ }^{2}$ To this Emperor is usually given the credit of being the first who adopted Christian emblems, but Gretser gives an engraving of a coin of Crispus on which our Lord is represented holding a long Latin cross between two figures presumed to be those of Constantine and Crispus. ${ }^{3}$ The authenticity of this coin is disputed by some numismatists, although Baronius describes it."

Allusion has already been made to the difference of opinion as to whom belongs cross and Orb. the honor of inventing that most significant symbol, the Cross surmounting the globe or orb, which is used in the coronation of Christian sov-

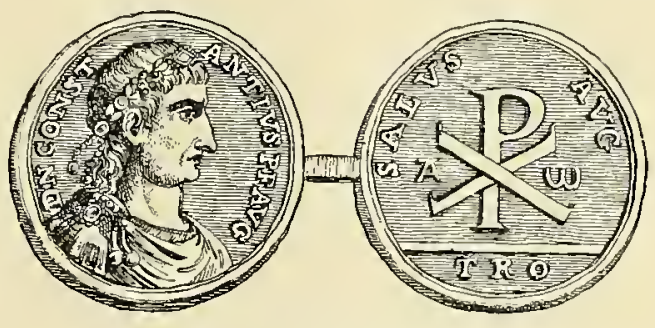

Coin of Constantius.

From Walsh's Ancient Coins, Medals and Gems. ereigns to this day. The orb was the ancient insignia of dominionGretser gives an illustration of a coin of Nerva (A.D. 96-98); three pila, or balls, arranged in a pyramidal form, marked with the parts of the then known world, Asi. Evr. Afr., Asia being placed on top of the others, instead of Europe, as would seem more in accordance with Roman feel-

1 Walsh, Essay on Coins, p. 98.

?Ibid., p. I00.

${ }^{3}$ Gretser, De Cruce, tom. iii., lib. i., cap. 8. Crispus was born A.D. 300; created Cæsar, 317 ; slain by order of his father, 326 (see page ${ }_{5} 6$ ).

4 Baronius, Anno 324 . 
ing.' Constantine placed the three perpendicularly under the Labarum. The change, the substitution of the Cross in place of the figure of Victory

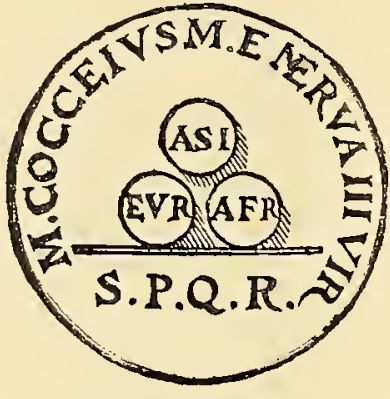

Coin of Nerva.

on the globe held in the hand, was natural; as we have seen, it has been claimed for Jovian, A.D. 363. Gretser gives a coin of Valentinian, A.D. 364 , on which it appears, ${ }^{2}$ but at all events it became established as part of the royal paraphernalia from the time of Theodosius.

Gratianus, A.D. 367-379, we believe was the Cross Made Prin- first who honared the Cross by cipal Charge on maling it, with a wreath, the only From Gretser's De Sancta Cruce. charge on the reverse of a coin.

On another coin of the same Emperor, he holds in his right hand a long Latin cross, and in his left a globe surmounted by Victory, while he is trampling upon a serpent. ${ }^{3}$

Theodosius, A.D. 379-408, according to tradition, was favored in a vision at night by the appearance of two men on white horses whom he recognized as S. John and S. Philip. It is supposed that this event is commemorated on his coins, which bear two figures with a nimbus, throned, holding in their right hands a roll, in their left a long cross as a sceptre, the first time it is so used. ${ }^{4}$

But little cllange worth noting appears in the coinage of the several succeeding emperors. Honorius (A.D. 395-408) has sometimes a long cross formed by the monogram. Valentinianus III. (A.D. 424-450) often used the Greek cross on the reverse of his coins, and on the obverse the double-

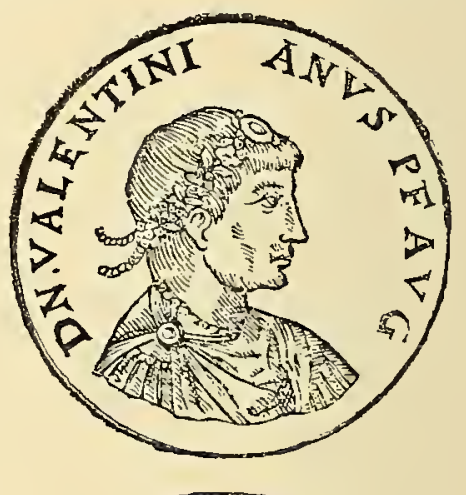

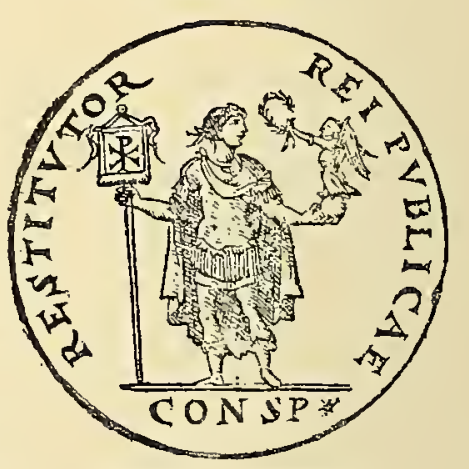

Coin of Valentinian.

From Gretser's De Sancta Cruce. barred cross first appears. To Justinian belongs more credit than is

1 Gretser, De Cruce, tom. i., lib. ii., cap. 54. Lipsius says, "Malis (hoc est pomis) figrtran orbis ostenderet." Query : Has this apple, or globe, any reference to the fatal fruit which figured in the Fall of Adam? $\quad{ }^{2}$ Gretser, De Cruce, tom. iii., lib. i., cap. I2. ${ }^{3}$ Ibid., cap. I3.

4 Theodoret, Hist. Eccles., lib. v., cap. 24 ; Gretser, tom. iii., lib. i., cap. I4. 
usually given. On his mind the perception seems to have dawned of the symbolical teaching of the Cross. Heretofore the "great ones of the earth" had been contented in doing homage to Justinian Introtion of the Cross.
tented the Cross by presenting a

literal figure of the instrument of death, but Justinian saw in it the Tree of Life, and hence ventured on the first development of the Cross by stamping his coins

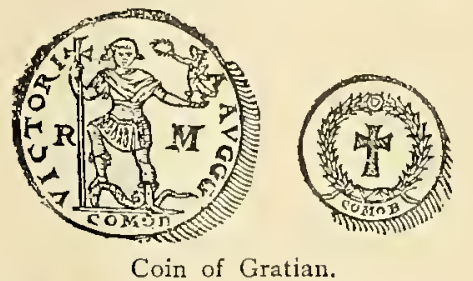

From Gretser's De Sancta Cruce. with a cross flory, the earliest variation of the Cross, A.D. 527-565. Some authorities have claimed that he was the first who placed the Cross upon the crown, and was the originator of cruci-

Cross Ftory. Originator of Cruciform Churches. form ground plans for churches. He also used the monogram, with the chi transformed into a Latin cross, the upright of which

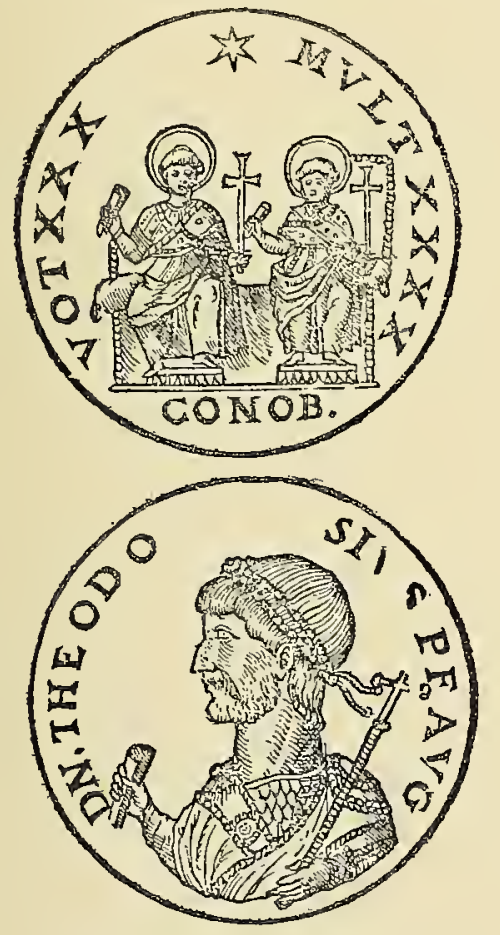

Coin of Theodosius.

From Gretser's De Sancta Cruce.

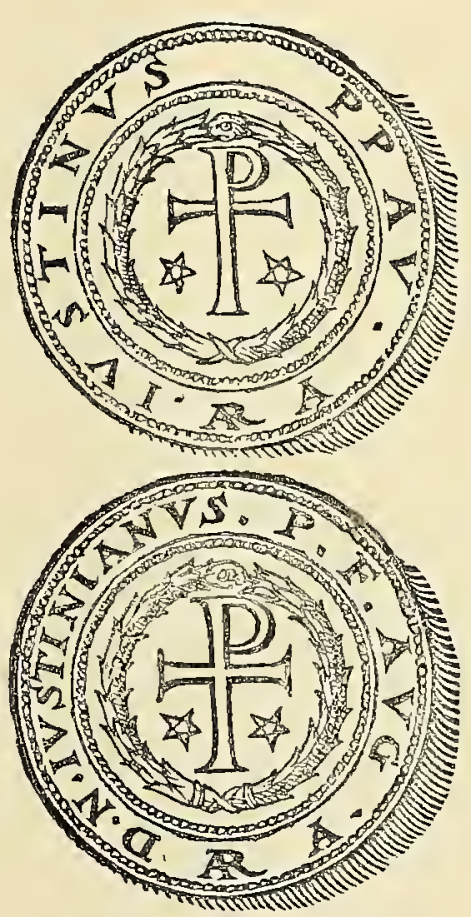

Coin of Justinian.

From Gretser's De Sancta Cruce.

formed part of the rho, and he likewise elevated the cross upon a calvary. 
The detestable Phocas (A.D. 602-6IO) introduced other changes. Not phocas. satisfied with one orb and cross, his coins bear one in each hand, and a cross-surmounted diadem.

Heraclius (A.D. 6IO-64I) formed a cross Heraclius. of four taus (cross rebated), and placed a Greek cross molinc, or cercelléc, over a small globe mounted on a calvary.

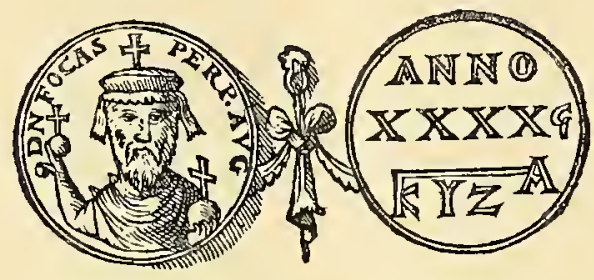

Coin of Phocas. From Gretser's De Sancta Cruce.

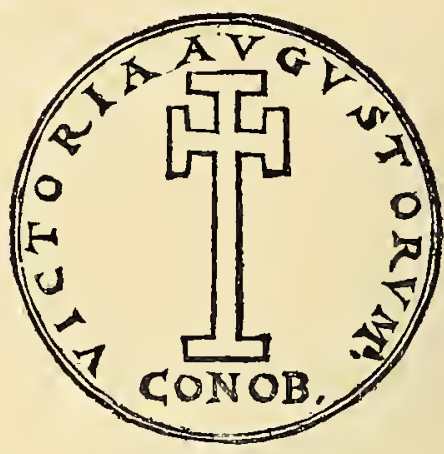

Coin of Heraclius.

From Gretser's De Sancta Cruce.

Justinianus II. (A.D. 685-7II), son of Constantine Pogonatus, ascended the throne in 685. Although of a cruel disposition, he affected Justinianus 11. piety, and was the first who introduced on his coins the image of the Saviour, copied, it is supposed, from a brazen statue in one of the cliurches.

The eighth century witnessed the rise of the Iconoclasts, or imagebreakers. They erased, as impious, all impressions of the blessed Virlconoclasts. gin, and even of our Lord, but retained everywhere the sign of the Cross.

Henceforth history on this head presents little of interest.

Upon the coins of Great Britain the Cross first appears on the sceata of Egbert, King of Kent, A.D. 665-674. Although probably at first cross on coins of merely the mark of the stamp, yet it continued in various Great Britain. forms on the coins of the Saxon, Norman, and English kings and archbishops, until the thirty-second year of Henry III., when a uniform type was aciopted. Until the reign of Henry I. the Cross was deeply impressed on copper pence so that they could easily be broken into halves and quarters. Armorial bearings appear on the money of Edward III., and the Cross gradually gave ground, but did not disappear cross on Jewish before the time of James I. On the coinage of the conCoins. tinent of Europe it holds its place to this day. It is rather strange that the very shekel of the Jews bears this sign. 
In America, or rather in Mexico and the colonies, about the middle of the last century, silver coins were scarce. The most common was a rudely cut and stamped Mexican (or Spanish) piece, still occasionally to be found in brokers' windows, known among numismatists as cob money.
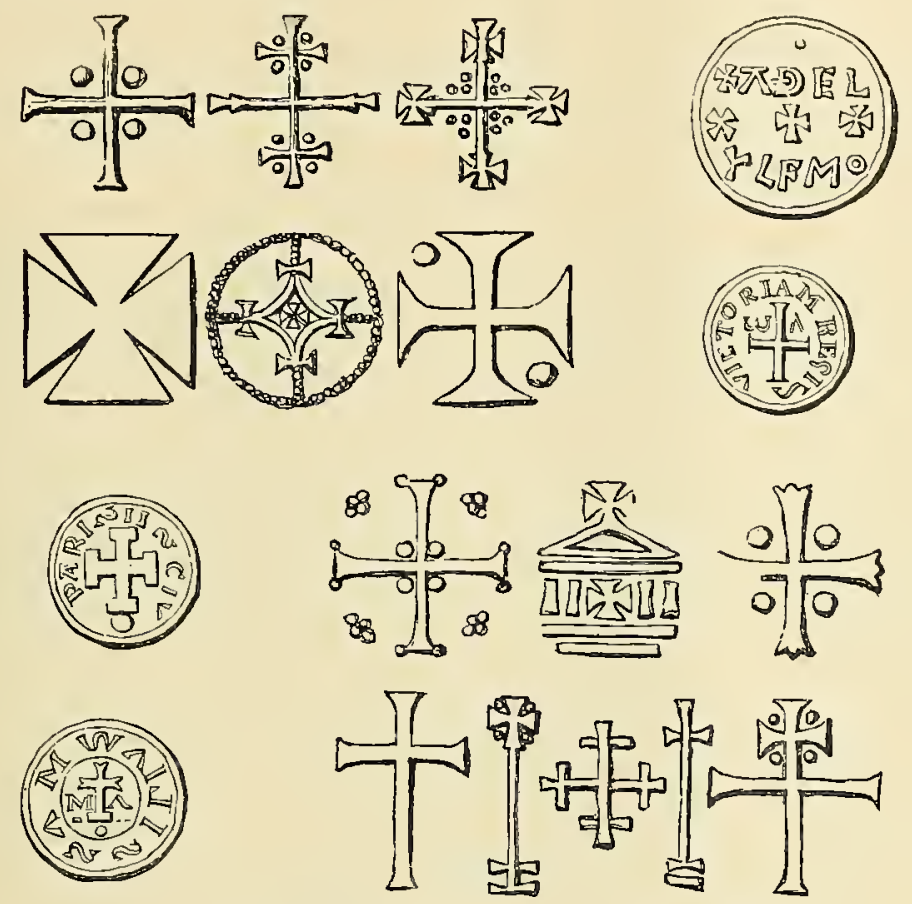

Crosses from Anglo-Saxon Coins. From The Art Foumal.

The Cross being placed on coins naturally gave rise to many proverbs and allusions in the drama and poems of bygone days. A man confessing his poverty would exclaim, "I have never a cross in pocket to keep the Devil away." Priests were presumed Coins. to be armed in proof against his Satanic majesty, for in those happy days "they being never without money, of course had always a cross in their pockets." 1

Pierce Penniless, in the Supplication to the Devil (by Nash), addresses the Father of Evil thus: "Whereas your impious excellence hath had the poor tenement of my purse any time this half year for your dancing schole, and yet notwithstanding hath received no penye, nor crosse," etc.

${ }^{1}$ Gilpin, Beehive of the Romish Church, p. $25 \mathrm{I}$. 
Skelton sings:

\section{"And in his pouche}

The Devil might dance therein for any crouche."

" Rare Ben Jonson" puns on the word several times in his Every Man in his Humour, and of course our beloved Shakespeare plays with it as none other could. What pictures are presented to our mind's eye, when we conjure up the interview between Falstaff, who would his "waist were less," and the Chief Justice, when the latter replies to the request of the Knight for a loan of a thousand pounds :
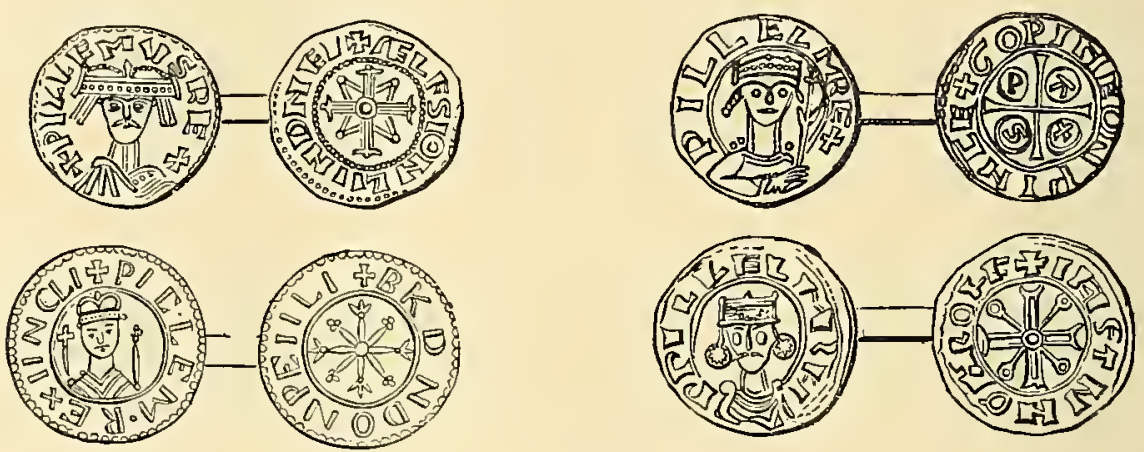

Pennies of William the Conqueror and William Rufus. From The Art foumal.

"Not a penny, not a penny; you are too impatient to bear crosses." : And again, Touchstone:

"For my part I had rather bear with you, than bear you; yet I should bear no cross if I did bear you; for I think you have no money in your purse." ?

So also Massinger:

"What would you have? The devil sleeps in my pocket. I have no cross to drive him out."

${ }^{1} 2 \mathrm{~d}$ part, Henry $I V$., act i., sc. 2.

${ }^{2}$ As You Like It, act.ii., sc. 4.

${ }^{3}$ Bashful Lover's, act iii,, sc. I. 


\section{CHAPTER IV}

\section{THE BANNER OF THE CROSS}

W ROM the day that the miraculous Labarmm led the army of the great Christian emperor to victory, the Cross was no longer the badge of shame, but the standard of glory; and the succeeding Roman emperors followed the example of Constantine. Julian, the

le exception, replaced the Roman Eagle, but the Apos- Julian Displaces sole exception, replaced the Roman Eagle, but the Apos- the Cross by the tate soon fell before the just vengeance of the "Galilean." ' Julian was the last of the family of Constantine. The first had recognized Christianity, the last attempted to extinguish it.

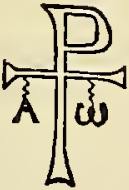

Labarum from the Catacombs.

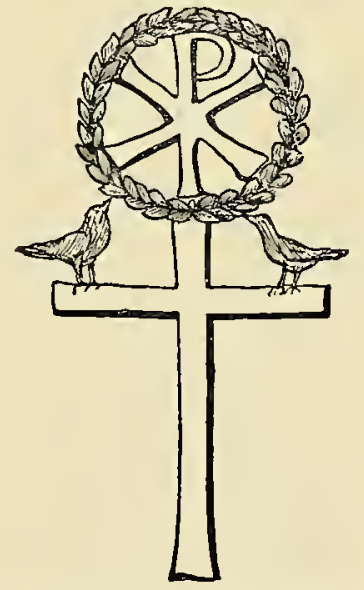

Labarum from the Catacombs.

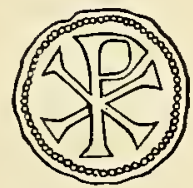

Labarum from a Coin.

From Lee's Glossary of Liturgical and Ecclesiastical Terms.

His successor, Jovian, who was with Julian at the time of his death, was a Christian, and on his return to Constantinople he displayed the

1 When Julian received his death-wound in a skirmish, Jnne 27, A.D. 363 , he caught some of his blood in his hand and threw it towards heaven, exclaiming, "Galilean ! thou hast conquered." Theod., Eccles. Hist., iii., 25. 
Labarum, which had been prohibited in the former reign. Theodosius ascended the throne in A.D. 379, and issued a decree that none should Labarum dare to worship an idol by sacrifice in the Roman Empire. Resumed. It was on this occasion that he surmounted the globe with a cross, as may be seen on his coins. Previously, the orb had been

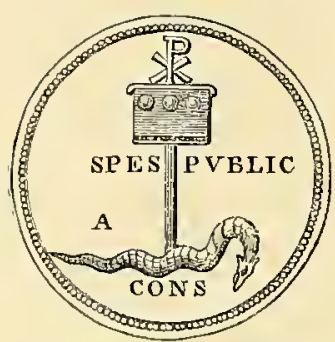

Coin of Constantine. Orb and cross. crowned by the figure of Victory or by an eagle. After doing its duty for two hundred years, the Labarum was deposited, a venerable relic, at Constantinople. ${ }^{2}$

Justinian succeeded to the imperial purple in A.D. 527. He erected a statue in the Augusteion, and placed in its hand the orb and cross, which heretofore had been confined to coins. Justinian From Holland's Craciana. seemed ambitious of distinction in little things. He modified the form of the cross, changing it to that which is known Greek Cross. as the Greek cross, and also bent down the points of the tiara, forming the crown surmounted by the cross, which became, with slight alterations, the standard shape to this day. ${ }^{2}$ One hundred years later Heraclius gave the banner of the Cross to the breeze, to arouse the valor of the Roman Christians against Chosroes, and from that time the Cross has become the standard of Christendom. Sometimes it was

\section{" a natural cross}

Of rudest form, unpeeled, e'en as it grew

On the near oak that morn ";

at others it was richly ornamented with gems and precious metals.

It was natural that the renown, derived from a divine origin, like that of the Labarum, should lead many to claim for their standards a similar miracle. Spain preserves in the Camera Santa at Ovie-

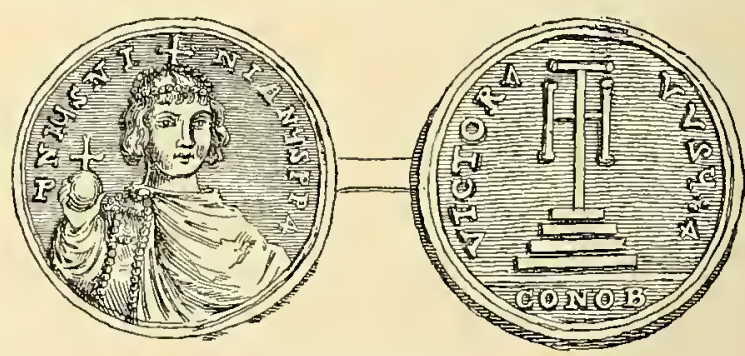

Coin of Justinian.

From Walsh's Ancient Coins, Medals and Gems. do two crosses; the one made, it is said, by angels for Alfonso the 
Great, the other, of like supernatural workmanship, for Pelayo, in the eighth century.'

Pisa also claims angelic parentage for her flag. It is a cross upon a crimson field. The story runs that S. Ephesus, a Roman officer in the service of Diocletian, was commanded to persecute the Christians in Sardinia. On his way to execute the Em-

Flag of Pisa. peror's mandate, he was warned by God not to hurt His servants, and he and his companion in arms, Politus, became converted and turned their arms against the heathen, being encouraged by the gift from $S$. Michael of a banner woven by angelic hands. After marvellous successes, S. Ephesus was taken prisoner, and cast into a furnace of fire, from which he escaped uninjured, while the executioners were consumed by the flames. At length both Ephesus and Politus suffered martyrdom and were buried in Sardinia. Winen that island was taken by the forces of Pisa in the eleventh century, the relics of the two martyrs were conveyed in solemn pomp to the Duomo of Pisa, and the banner of Ephesus was adopted as the ensign of Pisa. ${ }^{2} \quad$ The legend is painted in the Campo Santo of the city by Spinelio Aretino.

Denmark likewise asserts supernatural aid in the origin of her standard. Her ancient banner, consecrated to Odin, was a raven, termed Landeyda, " the desolation of the country," blazoned on a light ground in time of peace, on a red ground in time of Dlag of

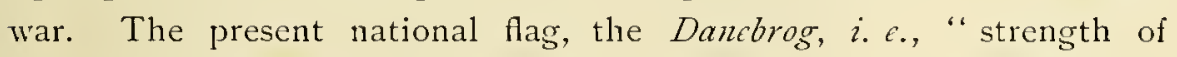
the Danes," bears a white cross on a red field. One tradition is that it was assumed soon after the introduction of Christianity. Another, that it fell from Heaven among the Danish army during one of the crusades of Waldemar the Victorious, in Livonia, 12I9. The battle had been desperate, and well-nigh lost, but the miraculous gift nerved the soldiers to victory.

The supernatural origin of the Cross of Scotland is given in another place.

Flag of Scotland.

I It was covered with gold and enamel in A.D. 908. The top bears this inscription: "Susceptum placide naneat hoc in honore Dei quod offerunt famuli Christi Adefonsus Princeps et Scemena Regina." On the right arm, "Quisquis auferre hue donaria nostra presumpserit fulmine dizino intereat ipse." On the left, "Hoc opus perfectum est, concessum est Sancto Salvatoic Ovetensis Sedis. Hoc Signo tuetur pius, hoc signo aincitui inimicus." On the foot, "Et cperatune est in Castello Gauzon anno Regni nostri XVII discuerenti Era DCCCCXLVI."Southey, Don Roderick, xxv., p. 738, note.

2 Millington, Heraldry in History, etc., p. 25. 
Among the standards of the Middle Ages the most celebrated was the Carroccio. It is said to have been first used by Eribert, Archbishop of Milan, in I035; he did not originate, but only revived an The Carroccio. ancient practice of mounting a standard upon wheels. The Carroccio was used in all the Italian states, but the most noted was that of Florence, said to have been used first in 1228, when Florence was at war with Pistoia. Upon a massive car on four low wheels were two masts bearing the great red and white banners of the commonwealth. The whole machine was painted vermilion and was drawn by a pair of the largest oxen that could be procured, covered with housings. Those who have seen Italian cattle know what elcphantine animals they must have been. The oxen were kept at the public expense for the exclusive use of the Carroccio. As soon as war was proclaimed the nobles and captains of the city proceeded in solemn state to the storehouse of the Church of S. John, where the velicle was kept, and brought it forth to the market-place, now known as the Mercato Nuovo, and placed it upon a stone on which was engraved a wheel.

The Carroccio was given in charge of a band of youths, with a solemn admonition to defend it at all hazards. It was accompanied by a second car bearing a lofty belfry in which was the Martello, or great war bell, which usually hung in the tower of a small church near the station of

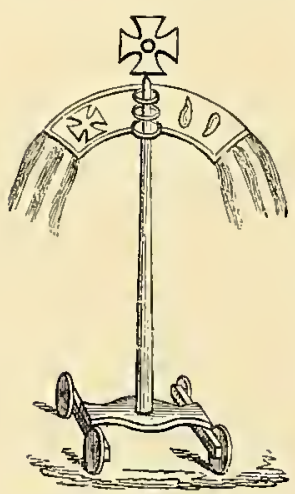

The Carroccio. From Holland's Cruciana. the Carrocio, and one month previous to the time of the army's taking the field it was rung day and night, from a chivalric idea that the enemy should have due notice of the intent of the Florentines. Although often the standard of triumph, yet fortune deserted it, and it fell into the hands of the enemy in the battle of Montaperto, September 4, I260, between Siena and Florence. Many of the captive trophies of the once rival cities of Italy have been restored to their former owners, but this was too dear to the Sienese, and to this day the masts are retained in their Duomo. Another Carroccio was made, which fell into the hands of the army at Lucca, in the battle of Altopascia, September 23, I $325 .^{1}$

Among modern Italian banners the most significant is that of Venice.

1 Trollope, Hist. of Florence, vol. i., pp. I13, I55, 410. 
It bears the Lion of S. Mark, holding in his right paw a cross in the time of peace, a sword in that of war.

Flag of Venice.

In Great Britain the earliest instance of the use of the Cross as a standard was at the battle between Oswald the Saxon and Cadwalla the Briton, in the neighborhood of Hexam, A.D. 635. A rude cross was hastily erected by the Saxons, the King himself

Cross in Great Britain. assisting, and almighty aid was implored. A church was afterwards erected on this spot, known as Havenfelth, or Heavenfield.'

There is a tradition that the Britons were converted to Christianity by Joseph of Arimathea, and that one of his earliest disciples was King Arviragus, or Arvirigus. The latter is known to have died in Gloucestershire, and the ruins of a bath of Romano-British construction have of late been discovered in that shire, the bricks being stamped ARVIRI, agreeing with the inscription on the coins of that monarch. Near this bath are the remains of a villa of similar work; and upon the foundationstone is the monogram $x_{.}{ }^{2}$ John Harding, whom Southey called " the worse of all our old poets," says :

"Joseph converted this king Arviragus

By his prechying to know ye lawe devine,

And baptized hym as write hath Nenius

The Chronicles in Britain tongue full fyne,

And to Christe lawe made hym enclyne,

And gave hym then a shelde of silver whte,

A cross end long and overthwart full perfect.

These arms were used through all Britain

For a common signe, eche mane to know his name

(And thus this armes by Joseph's creacion)

Full long afore Sainct George was generate

Were worship't here of mykell elder date."

According to Thierry, England owes her cross to Pope Alexander II., who delivered the banner to William of Normandy as a warrant to invade the island. The Pope also presented him with one of S. Peter's hairs under a diamond. The standard was not Alexander 11 . original, but was the same as that which had some years before been planted on the towns of Campania in Italy, by the Norman chiefs. ${ }^{3}$

${ }^{1}$ Bede, Eccles. Hist., b. iii., chap. ii.

${ }^{2}$ Lysons, Our British Ancestors, p. 77.

3 'Thierry, Norman Conquest, b. iii. Among other traditions abont S. George, too numerous to be mentioned here, we read that he rendered miraculous assistance to Godfrey de Bonillon. Richard Cœur-de-lion placed himself and his kingdom under the protection of the saint, but the $\mathrm{S}$. George's cross was of much earlier date. 
William bore this flag at his masthead, till he reached his " land of promise," when it was committed to the care of Foustain le Blanc. After the battle of Hastings, I066, the Conqueror placed the standard on the spot which had been occupied by that of the defeated Harold, and in commemoration erected Battle Abbey.'

The most famous local banner in England was that consecrated to $\mathrm{S}$. Cuthbert, tutelar saint of Durham. It owed its sanctity to the corporax The Banner of cloth used by the saint, which was enclosed between its s. Cuthbert. folds. It was always deposited in the cathedral, and a monk of Durham had the honor of being its bearer in the field. A minute description of it as renewed, by John Fosser, Prior of Durham in 1346 , has been preserved. The staff was five yards long, surmounted by a cross, the transverse was terminated with wrought knobs and bells, all, except the staff, of silver. The banner-cloth was of red velvet, indented in five parts, at the bottom of which were fastened three silver bells; both sides were embroidered with flowers of green silk and gold. In the midst, a square half-yard of white velvet, bearing on both sides a cross of red velvet; within this was the precious relic. This banner was considered invincible. One of the early kings of Scotland, resting at Durham on his way to expel a usurper from his throne, was warned by a vision that if he took the banner of S. Cuthbert he should be victorious. He obeyed the supernatural admonition, and was rewarded for his faith. When David of Scotland took up arms for his niece Matilda, and invaded England, the Norman barons, to incite the English, brought out the banners of the Saxon saints from the Saxon churches. S. Cuthbert's, S. Wilfrid's of Ripon, S. John's of Beverley, and some say S. Peter's of York, were united upon a rude car, somewhat like the Carroccio. The armies met at Northallerton. The victory was ascribed specially to the favor of S. Cuthbert.

1 The ancient national flag of England, the Cross of S. George (a cross gules), received the augmentation of the Cross of S. Andrew (azure, a Saltire argent), which was united with it, instead of being quartered upon it according to ancient custom, by royal proclamation, April i2, 1606. To avoid contention, it was ordered that all ships should carry the red cross joined with the white at their maintop, but that the South Britons should carry at their foretop the red cross and the North Britons the white. Upon the union with Ireland, January, I8or, the Cross of S. Patrick (argent, a Saltire gules) was combined with those of S. George and S. Andrew. Thus, rather awkwardly, was formed the Union Jack. The white edging borders the red, that the heraldic canon may not be violated which forbids the placing of one color upon anuther.-Glossary of Heraldry, "Union Jack." 
"E'en Scotland's dauntless king and heir Before his banner fled "

Hence the battle is known as that of THE STANDARD. The banner was used by Queen Philippa in the battle of Neville's Cross in I346; and it was again displayed at Flodden in I5 3 3, when the Earl of Surrey, halting at Durham Hall, informs us, " herde masse and appoynted with the Prior for Sainct Cuthbert's banner." But alas! it lost power before that of the arch-robber Henry VIII., and at the dissolution of the monastery it was burnt by Catherine, wife of VVilliam Whittingham, Dean of Durham.

In connection with the legendary part of our subject may be mentioned the banner of Prester John. This myth is of the eleventh century, and Prester John is mentioned as a real personage by Maimonides and Benjamin of Tudela, who travelled in the East between the years I I59-II73. About this time a letter appeared in Europe from this mysterious personage addressed to Manuel Comnenus, Emperor of Constantinople, and similar communications were sent to Alexander III., Louis VII. of France, and other monarchs. After describing the extent of his territory and his wealth and magnificence, he says, "when we go to war we have fourteen golden and bejewelled crosses borne before us instead of banners. Each of these crosses is followed by 10,00o horsemen and 100,000 foot-soldiers, without reckoning those in charge of the luggage and provisions. When we ride abroad

Prester John. plainly, we have a wooden, unadorned cross, without gold or gem about it, borne before us, in order that ive may meditate on the sufferings of our Lord Jesus Christ; also a golden bowl filled with earth, to remind us of that whence we sprung, and that to which we must return; but besides these there is borne a silver bowl full of gold, as a token to all that we are the Lord of Lords." Prester John is borne on the arms of the See of Chichester, England.

From old England the transition is easy to New England. The ancient standard of the colonies was a red banner with a red cross upon a white chief. But it became an offence to the Puritans. Roger Williams was probably the first whose weak conscience was troubled about it as " a badge of superstition," and John

Cross on the Banner of New England. Endicott declared that it was idolatrous to allow that relic of Antichrist to remain, which had been given by the Pope to the King of England.

${ }^{1}$ Millingen, Heraldry, p. 39 ; Holland, Cruciana, p. I45; Thierry, Norman Conquest, bk. iii. 


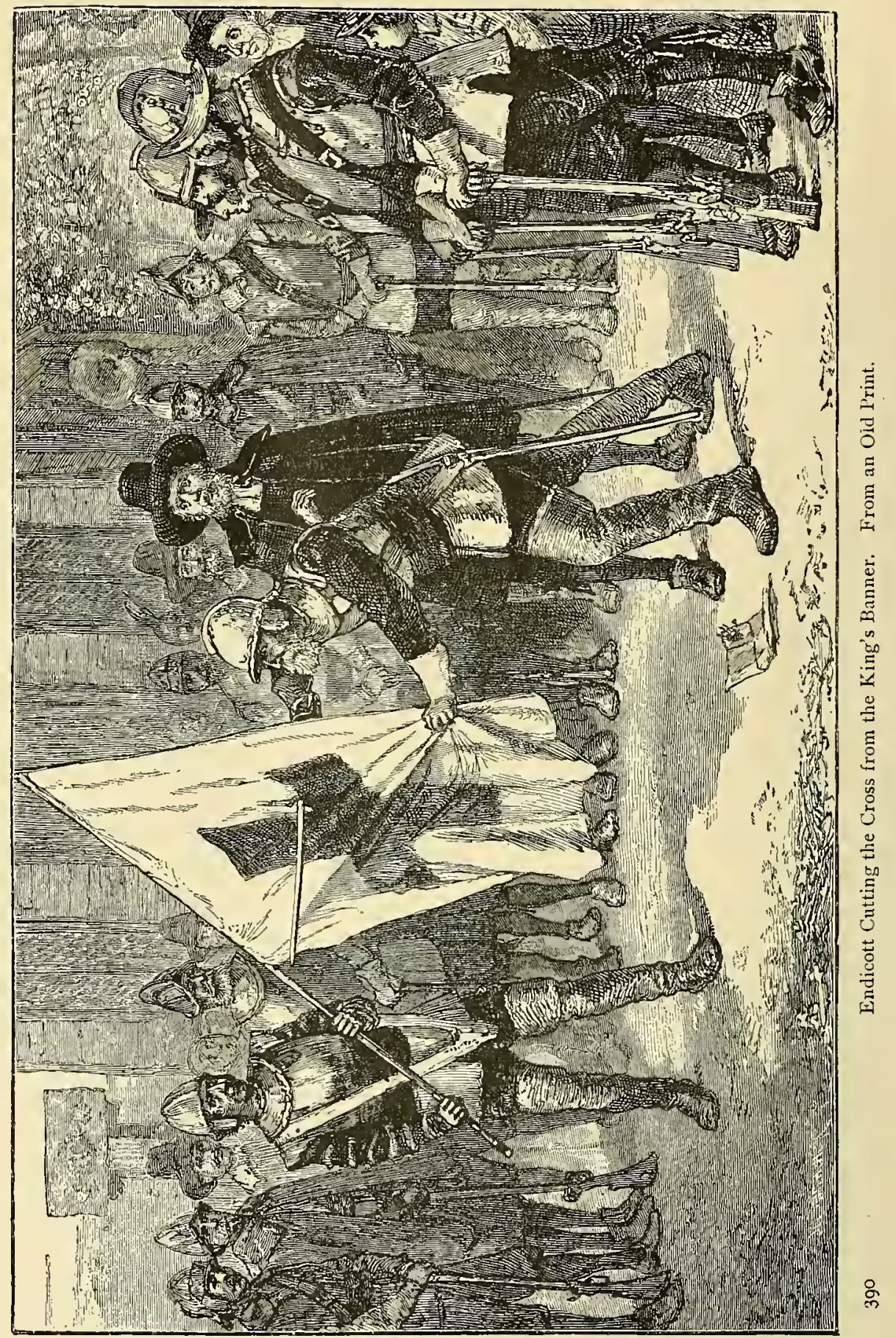


Being supported by Governor IVinthrop and John Cotton, Endicott, in I634, publicly cut out with his sword the Cross from the flag. His act, however, was not generally approved, for Richard Browne, ruling elder of the congregation at Watertown, complained of the deed, fearing lest it might be construed as an act of rebellion by the mother country. Richard Davenport, ensign-bearer at Salem, for imitating Endicott, was declared by the Court as "worthy of admonition, and disabled from bearing any public office for one year." ' Yet proceedings were delayed, the authorities being doubtful of the lawful use of the cross on any ensign. It was proposed that red and white roses be substituted, but the suggestion was not adopted, and the colonies continued to use the English flag under protest. Sometimes a red flag with a blaze of white merely was displayed.

In December, I686, Sir Edmund Andros brought over a new standard: a square white field with a red cross of S. George; inscribed upon the latter was the royal cypher surmounted by a crown of gold. ${ }^{2}$ In I 704 , we find the colonial flag bearing upon a red field a white canton with a red S. George's cross. In the first quarter is a green tree, probably a pine, which had been adopted in 1652 upon the coinage." In I705, according to another authority, the standard was a blue field with a white canton and a S. George's cross, with a globe in the first quarter. Probably there were no other changes till the time of the Revolution, when, in I775, a pine-tree was substituted for the globe. This was the flag borne at Bunker Hill."

When the colonies revolted against the op-

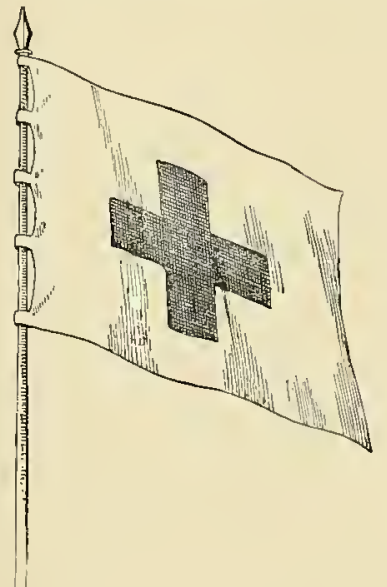

S. George's Flag. pression of Great Britain some standald was needed. January 3, 1776, the Continental army raised a banner bearing thirteen Flag of the stripes in the field, the crosses of S. George and S. Andrew American in a canton. Under this flag the first fleet left Philadelphia on February

I Drake, History and Antiquities of Boston, pp. I07, I68; The American Cyclopadia, vol. vii., p. 250 .

${ }^{2}$ New England State Papers, vol, iv., p. 223, in British State Paper Office ; Arnold, Hist. of Rhode Island.

3 Beaumont, State of the Universe.

${ }^{4}$ Allard, Niezve Hollandre Schups-Bon; Notes and Queries, vol. iii., pp. 72-74; Lossing, Pictorial Fielt Book of the Revolution, vol. i., p. 54 I. 
$9^{\text {th }}$ of the same year. Yet this was not adopted as the standard, for on February $\mathrm{I} 7 \mathrm{th}$ a fleet left the Delaware capes bearing a rattlesnake on a yellow field, the striped Jack and ensign, also a S. George's ensign, United States etc. On the I4th of June, I777, Congress resolved that Flag.

the national standard should be thirteen stripes, alternately red and white, and thirteen stars, white on a blue canton. This design is said to have been originated by Washington.

A star and stripe was added on the admission of each new State until ISIS, when a return was ordered to the original number of stripes, that of the stars only to be increased.

There are about thirty nations, provinces, and cities which bear a cross, Nations who Bear in some form or other, as their standard, ' yet, with a few exthe Cross as

their Standard. ceptions, they possess but little of general interest.

The banner of the Shah of Persia flutters in the breeze, a page of history in itself, or rather like a string of wampum of the North AmeriFlag of Persia. can Indians, recording in symbolic language the annals of the nation. It is composed of five horizontal bars, the upper and lower one being blue; the second and fourth yellow; and the middle one green. The blue bars are charged with three stars of six rays, and the crescents of yellow; the green bears a naked sword, the handle towards the staff; beyond are two crescents with a white star between them; the yellow are charged with two crosses, red. It seems as if the history of the Ancient, Middle, and Modern Ages were here inscribed, the stars being symbolic of the old Sabæanism, the sword, crescents and the captive crosses telling of some bygone victory of Mohammedanism over Christianity.

The flag of the Pasha of Turkey tells a somewhat similar story. In the middle of a blue field is a yellow cross placed horizontally, with the Flag in Turkey. transverse beam next to the staff. Upon the middle of the main limb, enclosed within a circle, are three crescents, white; the convex side turned towards the foot of the Cross. The whole is probably emblematic of the conquests of the Moslem over the soldiers of the Cross in the Crusades. ${ }^{2}$

\footnotetext{
${ }^{1}$ Norway, Sweden, Poland, Hanover, Holland, Calais, Dunkirk, Spain, Portugal, Biscay, Prussia, Oldenburgh, Riga, Malta, Sardinia, Genoa, Leghorn, Marseilles, etc. In America, Venezuela and Brazil.

2 The crescent, it may be noted, is not contemporaneous with Moslemism. True, it now crowns the great mosques at Constantinople, but it is not found in early work. It is simply the
} 
As an offset to this, it may be noted that the spires in many of the cities in Russia bear a cross surmounting the crescent, indicating that the city had been retaken from the Tartars; but in Novgorod the Cross alone is exhibited, showing that that city never was ruled but by Christians. ${ }^{1}$

Cross over the Crescent in Russia.

The Crimean War gave birth to a singular banner. In the frontier provinces of Turkey, Bosnia, Servia, and Bulgaria, the people being composed of Christ- In the Crimea. ians and Mohammedans, the banners bore the emblems of both religions, one half being red, charged with the crescent, the other half bearing a red cross."

There is one standard too pregnant with meaning to be passed by without notice. It is that of the Spanish Inquisition, Standard of the a banner bearing a cross, rough with knots, having a sword on one side, and

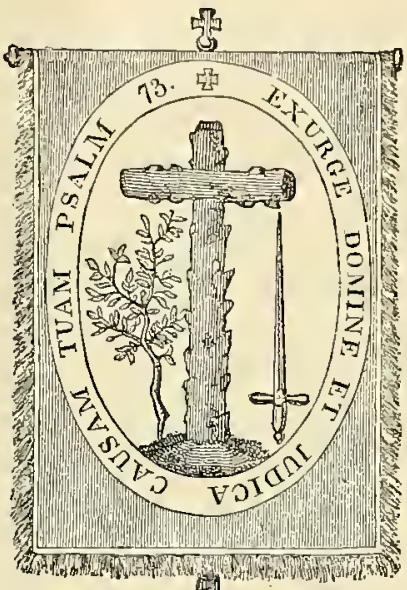
an olive branch on the other, with the inscrip- Banner of the Spanish Inquisition. tion "Exurge, Domine, et judica causam tuan." From Holland's Crucianc. It is significant that the olive, the symbol of peace, is only a branch cut off; it has no root, and the sword is unsheathed.

trophy of the conquest of the ancient Byzantium, of which it was the symbol, that town having been saved from a surprise one night by the timely appearance of the new moon. Constantinople was not captured by the Turks until 1473 .

'Stephens, Travels in Greece, Turkey, Russia, and Poland, vol. ii., p. 94.

¿ London Globe, Jan. 19, I854. 


\section{CHAPTER V}

THE COLOR OF THE CROSS IN ART

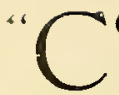

all

Symbolism of Colors among the Ancients. common origin, which extends to the earliest state of humanity, and develops its highest energies in the religion of Persia; the dualism of light and darkness presents, in effect, the two types of colors which become the symbols of two principles, benevolence and malevolence. The ancients admitted but two primitive colors, white and black, whence all others were derived; the divinities of Paganism were likewise emanations of the good and evil principles.

"The language of colors, intimately connected with religion, passed into India, China, Egypt, Greece, Rome, reappeared in the Middle Ages, and the windows of Gothic cathedrals found their explanation in the books of the Zends, the Vedas, and the paintings of Egyptian temples." '

Early Christians were scrupulously mindful of the mystic signification of colors. The earliest crosses were usually red; the primary symbolism Color of Early of that color being love, strictly speaking the love of man to Crosses.

God; hence its appropriateness in the Cross of the incarnate God when paying the penalty due by man to his Maker.

"The Cross blushes, and is dyed in the blood of the Lord," writes S. Paulinus, Bishop of Nola, to his friend Sulpicius Severus, and he placed these words beside two crimson crosses:

\section{"Ardua florifera CRUX cingitur orbe corona, Et Domini fuso tincta cruore ruhet."}

Even among pagan nations love was symbolized by red. Jupiter or Zeus, and Life, Heat, and Fire, when deified, are robed in red.

In later art, the Cross is painted green, symbolical of regeneration,

1 De I'ortal on Symbolic Colors, p. I. 
charity, and hope. In the windows of S. Denis, and of S. Chapelle, in Paris, and in those of the cathedrals of Bourges, Chartres, and Rheims, and in many manuscripts, " the Cross is a tree with the branches lopped and covered with a greenish bark.",

Even when no longer a tree, but squared by the carpenter, in glass and elsewhere, the Cross is green sometimes edged with yellow. At times the cross appears almost a mere trellis supporting the symbolic vine which overspreads it with its mystic branches and clusters of grapes, as may be seen in the Abbey of S. Denis.

Occasionally the cruciform nimbus of our Lord is tinged with green, especially when represented, as at Bourges, in the washing of the Apostles' feet, the Last Supper, His arrest in the garden, His descent into Hell, etc. The color is particularly appro-

Green Nimbi. priate in the last instance, speaking of hope and of the final resurrection which would welcome those Saints, then absent from the Lord, to the green pastures of the great Shepherd.

Sometimes the green cross is bordered with red, exhibiting charity and love, as in the large windows of the cathedral at Chartres.

Other colors were used, though not commonly, except in heraldry : blue, because that symbolizes divine truth, divine eternity, and human immortality; white, because it is the symbol of divine wisdom, the color of light, whose visible source is the image

Other Colors. of the invisible Creator. " It is to make the Cross a centre of light that it is represented loaded with diamonds and flashing stones; it is to envelop it with flashing fire that it is surrounded with stars as [in the Church of S. Apollinare in Classe] at Ravenna; but even then, the Cross itself is more radiant than the constellations around it, and the Church exclaims, "O Crux splendidior astris.' " '

A white cross was formerly placed in the hands of those banished by the Church, which they retained until they

Cross for the Banished. reached the nearest seaport. ${ }^{3}$

${ }^{1}$ Labarte, Handbook of the Middle Ages, p. xviii. At an exhibition of specimens of mediæval art in London, in I86I, there was a crimson velvet chasuble of the sixteenth century. Upon it was represented Christ suspended, not from a cross, but a veritable tree, leafless and lopped of its branches. Nezu York Post, May, r 661 . "It must be remarked that in paintings, chnrch windows, and enaniels of the Middle Ages, the body of the Cross is almost always green." Dronyn, Cross of Processions, etc., p. 2. In the windows of Bourges, the Cross in the hands of Isaac, and of the son of the Widow of Sarepta, are green.

${ }^{2}$ Didron, Christ. Icon., vol. i., p. 4โ3. ${ }^{3}$ Palgrave, Merchant and Friar, p. 189. 


\section{CHAPTER VI}

\section{THE ORDEAL OF THE CROSS}

$\mathrm{S}$ God had promised to take cognizance of the violation of one of
the most sacred of earthly duties and obligations, by appoint-

Water of ing to His own people the trial by the water of jealousy Jealousy. (Num. v., I 7-3I), an ordeal so fearful that we have no record of its ever being employed, ${ }^{1}$ it is not strange that in the ages of superstition an appeal to the Omnipotent Judge was often invoked in matters which seem to us of later times too trivial for such awful solemnity. Hence the ordeals of hot or cold water, red-hot ploughshares, etc., in all of which faith or fraud played their parts as aptly as when the Vestal virgin, Tucca ${ }^{2}$ of Rome, washed her chastity pure from stain by bearing a sieve of water from the Tiber to the Temple.

The Ordeal of the Cross was, apart from miraculous aid, one of mere physical strength. The accused and the accuser stood with arms either Ordeal of the uplifted, as in supplication, or extended, like the suffering cross. victim upon the cross, while the appropriate portions of divine service were being performed. Victory in such a case was a matter either of muscle or miracle.

The earliest allusion to this form of trial that we can find occurs in a Capitulary of Pépin le Bref, in $752,{ }^{3}$ where it is ordered in case of an application by a wife for dissolution of marriage. Charlemagne recognized its validity; even decreeing in the division of his empire, A.D. 806, that territorial disputes should be thus settled. ${ }^{2}$ The extremest charity was shown in this ordeal, for by the Capitulary of 816 , in cases of debility,

${ }^{1}$ Unless we receive as fact the account in the Apocryphal Gospel of Nicodemus, where the blessed Virgin clears herself before the eyes of the priest by this test.

2 Brewster, Letters of Natural Magic.

${ }^{3}$ Henry C. Lea, Superstition and Force, p. 231.

${ }^{4}$ Lea gives a number of references to capitularies of this monarch, p. 230. 
a stronger champion might be selected." By this ordeal S. Lioba, Abbess of Bischoffsheim, vindicated the innocence and honor of her convent, which had been charged with crime, owing to the discovery of an infant drowned in a neighboring lake.

Louis le Débonnaire, considering this ordeal as tending to bring the Cross into contempt, at the Council of Aix-la-Chapelle, A.D. 8I6, prohibited it. His son Lothaire repeated his order, but the regulation appears to have been respected only in the Rhenish Provinces and in Italy, and Louis himself retracted it on the division of his succession between his sons, and allowed its use in the settlements of disputed boundaries. ${ }^{3}$

Gretser included among the varieties of Ordeal by the Cross, one which is, strictly speaking, a judgment by lot. By the ancient Frisian laws, when a man was killed in a sedition, or a popular tumult, and the homicide could not be discovered, seven

Cross in Lots. men were taken, combatants, who individually took the oath of denial with twelve conjurators. Two twigs, precisely alike, except that one was marked with a cross, were wrapped in white wool and reverently placed upon the altar, or, if there were no neighboring church, upon the relic of some saint. God was invoked to declare the truth. The priest, or an innocent boy, drew the lot. If it was the rod marked with the Cross, the defendants were pronounced innocent, if the unmarked one, then the criminal was supposed to be among them. Each then chose a similar rod, and having marked it, they were rolled up and placed as before upon the altar and drawn. The one to whom the last lot fell was pronounced guilty and compelled to pay the weltr-geld."

According to Brady, the Ordeal of the Cross was instituted for the test of truth between freemen, or persons of condition, and was superintended by the clergy; while the Ordeals by Fire, or Water, were for people in the lower ranks of life, whose offences were to be punished by the secular powers."

${ }^{1}$ Lea, Superstition and Force, p. $23 \mathbf{1}$.

${ }^{2}$ Rudolph, Vite S. Lioba, cap. I5; Gretser, De Cruce, lib. ii., cap. 2 I ; Ducange, Crucis Fudicum.

${ }^{3}$ Longobard, lib. ii., tit. v., $\$ 32$.

${ }^{4}$ Gretser, De Cruce, lib. ii., cap. 21.

${ }^{5}$ Clavis Calendaria, vol. ii., p. 259. 


\section{CHAPTER VII}

THE ADORATION OF THE CROSS

$\mathrm{T}$

HE early Christians were charged with idolatrous adoration of the Cross by the Apostate Julian, but they replied that the homage Early Christians Charged with Idolatry. was paid to Him who was hanged upon the Cross, and not to the instrument of torture itself. With this explanation even John Huss allowed the use of the phrase adoration.

It is asserted that the custom is as old as the finding of the Cross, and originated from the exhibition of a piece of it, which was exposed for

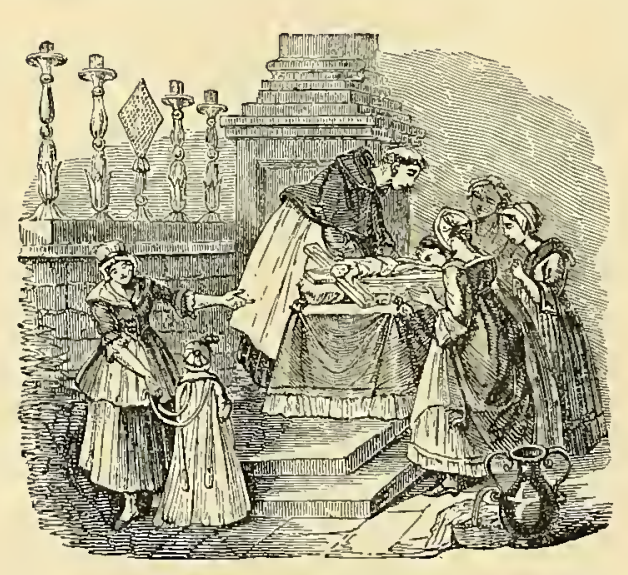

The Adoration of the Cross.

From Holland's Cruciana.
Antiquity of the veneration of the the Custom. faithful at Jerusalem every Good Friday. "The wise Helena," says S. Ambrose, “ worshipped not the wood of the Cross, but Him who was crucified on the wood; that would be a heathenish error, a vanity of impious men, but she worshipped Him who hung upon the Cross." Yet, by the time of Sophronius, Patriarch of Jerusalem, who died after the taking of that city, A.D. 639 , the rite of salutation of the Cross on the anniversary of our Lord's death was lost in that Church.

In the $\stackrel{C}{C}$ urch of Constantinople it continued until the eighth century, after which we find no mention of it, except an incidental reference to the transferring of the ceremony from Good Friday to the third Sunday in Lent. A letter of $\mathrm{S}$. Ambrose shows that the custom was extant in 
his day, and this is confrimed by the Sacramentary of S. Gelasius, and the Antiplouny of S. Gregory.

S. Aldhelm, who lived in the seventh century, styled the Christians Crucicole, or worshippers of the Cross. Alcuin, a few years later, was always accustomed to bow to the Cross, and repeat his prayer, "Tuam irucin adoramus, Dominc, tuam gloriosam.

Crucicola. recolimus passioncm ; miscreri nostri." ' Yet that the worship or respect paid to the Cross was not idolatrous is plain, from the prayer composed by Alcuin, and from a passage in the Saxon Homilics: " We bow ourselves to the Cross, not indeed to the wood, but to the Almighty Lord who liung on it for us." "

It is declared by some that the Romish Church commands that latria, or the highest worship, paid only to God, should be offered to the Cross. We must allow the credit of the denial of Lingard, and also the benefit of the decree of the second Council of Nice.

Latria.

In the seventh session of the above Council, held October 13, 787, it was declared that "Salutation and the adoration of honor ought to be paid to images, but not the worship of latria, which be-

longs to God alone; nevertheless, it is lavful to burn lights council of Nicæa. before them, and to incense them, as it is usually done with the Cross, the books of the Gospels, and other sacred things, according to the pious use of the ancients. For the honor so paid is transmitted to the original, which it represents. Such is the doctrine of the holy Fathers, and the tradition of the Catholic Church; and we order that they who dare to think or teach otherwise, if bishops, or other clerks, shall be deposed; if monks or laymen, shall be excommunicated." 3

Martiall, quoting from Athanasius, not only answers the silly objection to the use of the Cross as liable to the charge of senseless idolatry, but also refutes those who demand, "why not worship the speare, reede, and sponge being holy as the crosse ? answereth and saith, we may easily separate and dissolve those ii pieces of wood, and defacinge the forme and figure of the crosse by accomptinge them but mere wood, but the figure and sign of the Crosse, persuade the same inthe Sign fidel, that we worship not the wood, but the figure and sign of the cross; of the speare, reede, and sponge we cannot do, nor shewe the same." "

\footnotetext{
1 Lingard, Antiquities of the Anglo-Saxon Church, p. I74, note.

${ }^{3}$ Landon, Manual of Councils, "Nicæa, Second Council."

4 Martiall, Treatise of the Crosse, p. 84. 
Jonas, Bishop of Orleans, in the ninth century, defends the adoration of the cross, "of recordationem passionis domini," but explains the act to mean no more than "Salutare."

It appears, however, that some prelates did suppose that latria was paid to this symbol, for we find Claudius, Bishop of Turin, A.D 82I-839, not only excluding from churches invocations of saints, but all images, pictures, and crosses, which could possibly give rise to adoration.

In the Roman Pontifical the rubric commands, that in the procession, or receiving of an emperor, if the Apostolic legate receive him, or enter the city with him, or go with him elsewhere, either on horseback or otherwise, he who bears the sword before the emperor, and he who carries the legate's cross ought to go together. The Cross shall be carried in the right hand, because latria is due to it, and the sword of the emperor in the left hand.

The Council of Trent declined to give a clear decision in this matter, only desiring that due worship should be given to images, but did not council of Trent. define what that "due worship" was. It confirmed the decrees of the second Nicene Council, and, in particular, made use of its maxim that the honor of the Type goes to the Prototype. Cruci debctur latria, says the Pontifical."

In the prayer in the Consecration of a Cross, the Roman Church implores " that the blessing of that Cross on which Christ hung, may be in it, that it may be a healthful remedy to mankind, a strengthener of faith, an increase of good works, the redemption of souls, and a comfort, protection, and defence against the crueity of our enemies." " It would seem that latria is given to all those images to the originals of which it is due; and in like proportion dulia and hyperdulia to other images."

That the majority of Roman Catholics supposed latria to be the proper worship of the Cross we can also judge from the story of Imbert, Prior of Gascony, who was severely prosecuted in 1683 for telling the people that, in the ceremony of adoring the Cross practised in that clurch on Good Friday, they were not to adore the wood, but Christ who was crucified upon it. The curate of the parish told them the contrary; it was the wood that they were to adore! Imbert was cited be-

'De Cultu Imaginum in Bibl. Patrum (ed. Lugdun.), vol. xiv., fol. 183.

${ }^{2}$ Burnet, on the XXXIX articles, art. XXII, p. 2 S2.

${ }^{3}$ Ibid. 
fore the Archbishop of Bordcaux, suspended from his functions, and even threatened with chains and perpetual imprisonment.

By Elfric's Canons, A.D. 957, the faithful were required to pay their adoration, and greet God's rood with a kiss. "We humble ourselves to Christ herein," Cranmer says, " offering unto Him, and kissing the Cross in memory of our redemption by Christ on the Cross." The practice was forbidden in I 549, but was observed at Dunbar, in I 568 , by the congregation, barelegged and barefooted. During the ceremonial the hymns Pange lingua and Vexilla regis prodeunt were sung, followed by the Improperia, or reproaches, an expansion of Malachi iii., 3, 4 .

Charles Clarke ${ }^{1}$ considers that the Saxons meant by worshipping the Cross only the payment of respect and reverence. The wise men among that nation were called worshipworthy. Again it is said that the Lady Eadgith, or Editha, Queen of Edward the Confes- Word Worship. sor, in I075, was brought to Westminster "with great worship." 2 The English retain the meaning of worship in the address of mayors and magistrates as "Your worship," and corporations are termed "right worshipful companies." Yet again the Bridegroom in the Order of Matrimony in the English Church declares to the Bride, " with my body I thee worship." That our ancestors only paid due veneration seems clear from the very wording of the following extract from an instrument dated November 25, I449, concerning the churchyard of S. Mary Magdalene in Milk Street, London, in which it is stated that on a piece of "voidegrounde " on the west side of the street, there " stode a crosse of the height of a man or more; and that the same crosse was worshipped by the parishioners there, as crosses be commonly worshipped in other churchyards." " This may imply a greater or less degree of " worship," but there is good reason for thinking it is the latter.

Dr. Grant, when travelling among the Nestorians, on one occasion was led by one of their bishops to a plain stone cross which lay upon the altar, supposing that he would manifest his reverence and devotion after their own custom, by pressing his lips upon Cross among the
Nestorians. it. " There is something," he adds, " very affecting in this simple outward expression, as practised by the Nestorians, who mingle with it none of the image worship, or other corrupt observances of the

${ }^{1}$ Britton, Architectural Antiquities, vol. i., p. 93.

2 Saxon Chronicle, p. I83.

3 Achaologia, vol. xiii., p. 199. 26 
Roman Catholic Church. May it not be that the abuse of such symbols by the votaries of the Roman See has carried us Protestants to the other extreme, when we utterly condemn the simple memento of the Cross?"

Ve cannot better sum up than in the words of Ruskin: "It is utterly impossible for one man to judge of the feeling with which another bows Ruskin on Rever- down before an image. From that pure reverence in which ence to the Cross. Sir Thomas Browne wrote, 'I can dispense with my hat at the siglit of a cross, but not with a thought of my Redeemer,' to the worst superstition of the most ignorant Romanist, there is an infinite series of subtle transitions; and the point where simple reverence and the use of the image merely to render conception more vivid, and feeling more intense, change into definite idolatry by the attribution of Power to the image itself, is so difficultly determinable that we cannot be too cautious in asserting that such a change has actually taken place in the case of any individual. Even when it is definite and certain, we shall oftener find it the consequence of dulness of intellect than of real alienation of heart from God; and I have no manner of doubt that half of the poor and untaught Christians who are this day lying prostrate before crucifixes, Bambinos, and Volto Santos, are finding more acceptance with God than many Protestants who idolize nothing but their own opinions, or their own interests. I believe that those who have worshipped the thorns of Christ's crown will be found at last to have been holier and wiser than those who worship the thorns of the world's service, and that to adore the nails of the Cross is less a sin than to adore the hammer of the workman." " What lover of art or of Christianity but responds from his heart, Amen!

The custom of creeping to the Cross on Good Friday is clearly a token Creeping to the of profound reverence rather than adoration of the Cross. cross. It seems to have been peculiar to the Church in England.

In an original proclamation dated the 26 th of February, 1530 , Henry VIII., we read: " On Good Friday it shall be declared howe creepinge to the Crosse signifieth an humblinge of ourselfe to Criste, before the Crosse, and the kissinge of it in memorie of our redemption made upon the Crosse." Wealso find noted in A Short Dcscription of Anti-Christ, etc., " a custom of creeping to the Cross with eggs and apples." We are at a loss to understand the meaning of the last, unless it was to put people

\footnotetext{
1 Grant, Nestorians, vol. i., p. 32.
}

'Ruskin, Stones of Venice, vol. ii., p. 387. 
in mind of the fall of man by the forbidden fruit, and the assurance of his salvation by the Resurrection, of which the egg was used in early times as an emblem.

At the sale of the MSS. belonging to Mr. Anstis, Garter King-ofarms, the Duchess of Northumberland bought an ancient ceremonial of the Kings of England in which occurs " The order of the Kinge on Good Friday touching the evening service, Hallowing of the Crampe Rings, and offerings, and Crosse.

"Firste, the King to come to the Chappell, or Closset, with the Lords and noblemen, waytinge upon him, without any sword borne before on that day; And there to tarrie in his travers until the Byshope and the Deane have brought in the crucifix out of the vestrie, and layd it upon the cushion before the high altar. And then the Usher to lay a carpet for the Kinge to creepe to the Crosse upon. And that done, there shall be a forme sett upon the carpet before the crucifix, and a cushion laed upon it for the King to kneale upon. And the master of the Jewell House then to be ready with the Crampe Rings in a bason of silver, and the Kinge to kneale upon the Cushion before the form. And then the Clerke of the Closett be redie with the Books concerning the Hallowing of the Crampe Rings and the Ainner [i. $\varepsilon$., Almoner] was to kneale on the right hand of the Kinge holding the sayd book. When that is done, the Kinge shall rise and goe to the Altar where a Gent: Usher shall be redie with a cushion for the Kinge to kneale upon-And then the greatest Lords that shall be there to take the bason with the Rings, and beare them after the Kinge to offer. And this done the Queene shall come down out of her Closset, or Traverse, into the Chappell with Ladies and Gentlewomen waytinge upon her and Creepe to the Crosse, and then goe again to her clossett or Traverse, and the Ladies to creepe to the Crosse likewise. And the Lords and Noblemen likewise." '

In i 536, when the convocation under Henry VIII. abolished some practises as superstitious, that of creeping to the cross on Good Friday was retained as a laudable and edifying custom. It was, Abolished by however, forbidden by Henry in $\mathbf{I} 545 .^{2}$

${ }^{1}$ Grose and Astle, Antiquarian Repository, vol. iv., p. 3 rg.

${ }^{2}$ Collier, Eccles. Hist. vol. v., p. 137. 


\section{CHAPTER VIII}

\section{SUPERSTITIONS CONCERNING THE CROSS}

ADLY we turn to a darker page in the history of the Cross - that $\rightarrow$ clouded at times by superstition, or, what is worse, by fraud. Only a few instances of the more notable are given, without regard to chronology or place.

In the Irish annals of the Four Masters, we read that, in 1397, " Hugh Mathews by fasting and prayers in honor of the miraculous Cross of 1reland. Raphoe and of the image of the blessed Virgin of Trim recovered his eyesight. In the year $14 \mathrm{II}$, from the five wounds of the image flowed a stream of blood, whereby various kinds of infirmities were healed." '

But what was in this instance an occasional miracle was permanent in the crucifix in the Church of S. Thomas at Malabar. "At the time of Mass," says Ribadeneira, “ the holy Cross begins little by little, to change its natural color (which is white), turning into yellow, and afterwards into black, and from black into azure; until that the sacrifice of Mass being ended, it returns to its own natural color. And that which augments both admiration and devotion is, that as the holy Cross changes its color, it distils certain little drops of blood, and, little by little, as they grow thicker they fall in so great abundance, that the cloths with which they wipe it are dyed with the same blood, and if any year this miracle fail, it is held as a certain sign of some great calamity that is to come upon them, as experience has showed them." 2 Perhaps this miracle may be akin to that of the liquefaction of the blood of $\mathrm{S}$. Januarius.

Some crucifixes manifested their displeasure in a miraculous manner.

1 Mant, History of the Ch. in Ireland, vol. i., p. 74.

' Ribadeneira, Flos Sanctorum, P, 992. 
"When Comyn, Archbishop of Dublin, in the early part of the thirtecuth century, visited an offence committed against him by the Lord Justice with the extremest ecclesiastical vengeance, he caused the crucifixes and images in the Cathedral to be taken down and laid upon thorns, as if the Passion of the Redeemer were

Displeasure Manifested by Crucifixes. renewed in the person of the minister; and his sufferings were supposed to be repeated in one of the figures which was exhibited to the beholders with the face inflamed, the eyes shedding tears, the body bathed in sweat, and the side pouring forth blood and water."

In Ireland, childbed linen is drawn through the holes of the crosses to insure easy delivery.

Scotland was specially favored supernaturally. David I. was hunting in the forest of Drumsheuch, now part of the town of Edinburgh, when in the ardor of the chase having outstripped his followers, he was attacked and thrown down by a stag. At the very

Holy Rood Abbey. instant when the enraged stag was about to gore him to death, a cross was miraculously slipped into the monarch's hand, and the angry animal, at the sight of it, instantly took flight.

Accounts vary as to details. One chronicler says that the chase took place on the Festival of the Exaltation of the Cross, when the King, in stead of following the advice of his confessor, and devoting the day to his devotions, preferred following his pastime with his profligate young nobles.

In commemoration of his miraculous escape, about A.D. I 28 , David founded the Abbey of Holy Rood in honor of the Cross. The miraculous Cross which had saved the founder's life was placed in the reliquary, and possessed the remarkable quality that no one could tell of what it consisted, or even whether it was of animal, vegetable, or mineral material. ${ }^{2}$

David I. reminds us of S. Hubert, a nobleman of Aquitaine, "who lived for some years in the Court of Pepin d'Héristal. . . . One day in Holy Week, when all good Christians were at their devotions, as he was hunting in the forest of Ardennes, he encountered a milk-white stag bearing the crucifix between his horns." Of course he was converted, and in after years exhibited an example of

${ }^{1}$ Hoveden, quoted in Mant, Hist. of the Ch. in Kreland, vol. i., p. 75.

2 Billings, Baronial and Ecclesiastical Antiquities of Scotland, "Holy Rood Abbey." 
most edifying piety. “S. Hubert appears to have been one . . who carried not only religious discipline, but social civilization into the

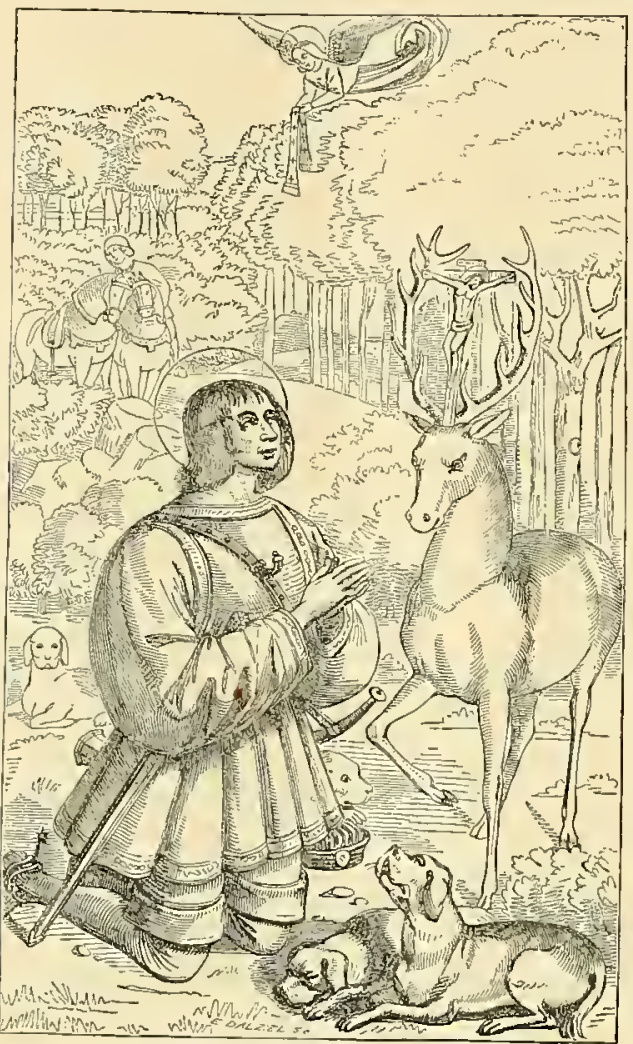

The Conversion of S. Hubert.

From Jameson's Sacred and Legendary Art. depths of the forests; his effigies were anciently represented, sometimes with wild animals, - . sometimes with the stag bearing the crucifix, which among the antique symbols expressed either piety . . . or the conversion of some reckless lover of the chase, who like the wild huntsman of the ballad, had pursued his sport in defiance of the sacred ordinances and the claims of humanity." Anciently, the allegory was understood by the people, but finally, like many an old saint story, it was assumed to be real. In art the saint carries a book bearing the miraculous stag, or the stag stands by his side.'

Care must be taken not to confound, in works of art, S. s. Eustace. Hubert with $\mathrm{S}$. Eustace, who was a Roman soldier and captain of the guards of the Emperor Trajan. To him also appeared a stag bearing a crucifix of radiant light, from which the Saviour revealed himself and the huntsman was converted. In art, S. Eustace is represented in the armor of a knight, while S. Hubert is vested either as a huntsman or as a bishop. ${ }^{2}$

Among the peasantry of Northern Europe the belief in the virtue of the cross is still retained. In Norway the housewife carefully crosses her Sign of the Cross pies and cakes between Christmas and Twelfth Day, and puts in Northern a cross over her door that the Wild Huntsman may not
Europe. enter. The Danes believe that the Trolls cannot pronounce the sacred

1 Mrs. Jameson, Sacred and Legendary Art, vol. ii., pp. 732-737.

2 Ibid., pp. 792-794. 
word, but call it "here and there." ${ }^{1}$ They also believe that a bride must not enter her new home except under two drawn swords placed saltire-wise.

To return to Great Britain. Within the last century, every bride, in " Holy Isle"

-doubly consecrated by Scott's

verse-was obliged to stride across the "Petting stone," part of the foundation of a churchyard cross, else the marriage would prove unfortunate. ${ }^{2}$

Stow also tells us, that when Cardinal Wolsey was at dinner on All Hallows day, his cross fell, and wounded Dr. Bonner's head. " Hath it drawn any bloude?" inquired the Cardinal. "Yea, forsooth, my Lord," they replied. IVith that he cast his hood aside and shaking his head said grace, and muttering, "Malum oncn," arose from the table and went to his chamber. Within a few days Wolsey had fallen.

Innumerable instances of miraculous crucifixes might be told. We give, however, but a few.

Miraculous

In the Church of S. Domenico at Ravenna is preserved a crucifix said to have shed blood during the battle which occurred on Easter Sunday, 1512, between the French

Crucifix at and the Spanish, in which battle Gaston de Foix

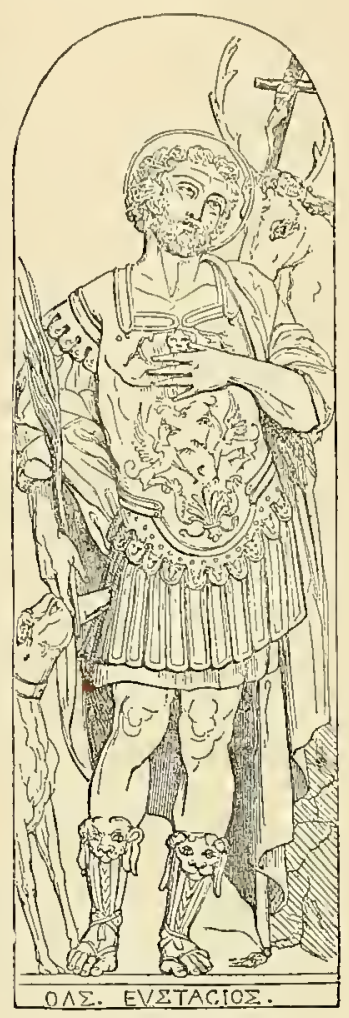

S. Eustace.

From Jameson's Sacred and Legendary Art. was killed. In commemoration, two tapers have been burnt before it ever since. ${ }^{3}$

In the plague of Malaga, in I649, a certain statue of Christ at the column, carved for the Cathedral by Giuseppe Micael, an Italian, performed prodigies of healing, and bade fair to rival that holy crucifix sculptured at Jerusalem by Nicodemus, and pos-

The Lord of Health. sessed by the Capuchins of Burgos, which sweated on Fridays, and wrought miracles all the week. While the pestilence was yet raging, the sculptor stood, one evening, musing near the door of the sanctuary

1 Thorpe, Northern AYythology', vol. ii., p. I75.

${ }^{2}$ Brand, Popular Antiquities, vol. ii., p. 105. $\quad 3$ Webb, Continental Ecclesiology, P. 442. 
where his work was enshrined, but with so sorrowful a countenance that a friend hailing him from afar, according to the usages of plague-stricken society, inquired the cause of his sadness. "Think you," said the artist, " that I have anything more to look for on earth after seeing and hearing the prodigies and marvels of this sovereign image which my unworthy hands have made? It is an old tradition amongst the masters of our craft, that he shall soon die to whom it is given to make a miraculous image." And the good Giuseppe erred not in his presentiment; his chisel's work was done; he was to return no more, nor see his native country; and within eight days the dead-cart had carried him to the gorged cemetery of Malaga. His name, if not his life, was preserved by the statue, which was long revered for its Esculapian powers, under the title (profanely usurped) of the " Lord of Health." '

In the Church of the Madonna del Carmine, in Naples, is a crucifix which in former times is said to have exhibited miraculous vitality, the hair of the head growing after being cut every year. It is held in great veneration, and is exhibited on the first and last days of the year. Perhaps, latterly, the faith of the Neapolitans is so strong as not to need a repetition of the miracle, for the festa is now only commemorated by a mass celebrated with extraordinary pomp, during which the image is lowered to be kissed on the feet by the priests and congregation. From the right side of the head a long lock of hair hangs down, which is now permitted to grow unshorn. ${ }^{2}$ This may be the same figure which is said to have bowed its head to avoid a cannon-ball which passed through the church in the siege of $1435 .^{3}$

Naples is especially favored, for in another church, that of S. Domenico Maggiore, is preserved the picture of the crucifix which is Speaking said to have congratulated S. Thomas Aquinas with the crucifixes. $\quad$ words, "Bene scripsisti de me, Thoma, quam ergo mercedem recipies?" To which the saint replied, "Non aliam nisi te." "

1 Stirling, Annals of the Artists in Spain, vol. i., p. 28.

${ }^{2}$ Correspondent of London Times, December 27, 1857 .

${ }^{3}$ Murray, Handbook of Southern Italy, p. I2I.

* In Pisa there is another painting of the same subject by Francesco Vanni. It shonld be noted, as Mrs. Jameson reminds us (Monastic Orders, p. 379), that this is related by the biographers of S. Thomas, not by himself. Ribadeneira, not content with this story, multiplies it, and tells us of three revelations to this saint: once when writing on the Eucharist, a second time when composing an Office for the Festival of Corpus Christi, and a third as above when finishing his Summa Theologia. 
When S. Francis of Assisi was praying in the Church of S. Damian, a voice issued from the crucifix, "Go, Francis, and repair my house." Supposing the command to refer to the ruinous condition of the church, he took some of his father's cloth and having Assisi. sold it, brought the money to the priest, who refused to receive it, for fear of the saint's father. S. Francis threw it in a corner and retired. At length, being instructed as to the meaning of the revelation, he renounced his father and wealth, and assumed Orders. ${ }^{2}$ This crucifix is at present preserved in the Church of S. Chiara at Assisi.

In the Church of S. Paolo Fuori delle Mura at Rome, which Webb terms a "treasure-house of Christian antiquities," ${ }^{2}$ is preserved the crucifix which spoke to S. Bridget. This saint must not be confounded with the patroness of Ireland, but was a widow of high rank in Roman hagiology because of her " Revelations" of the Passion of our Lord.

S. Dunstan also was admonished by a crucifix to expel the married priests from his diocese, ${ }^{3}$ which command the gentle(?) saint was not slow to obey.

S. Dunstan .

Mrs. Jameson has resuscitated for the benefit of modern times the most Christian legend of S. John Gualberto, who spared the murderer of his brother, because, when he met him unarmed upon Good

S. John GualFriday, the assassin threw himself upon his linees, and ex-berto of Florence. tending his arms in the form of a cross, implored mercy in the name of Him who suffered that day. S. John hastened to the Church of San Miniato, and prostrating himself before the crucifix begged that the measure he had meted to another should be measured to himself. The image bowed its head. This completed the conversion, and the sometime soldier became the founder of the Order of Vallombrosa.

This crucifix is one of the oldest extant, circa 1020 , and is painted on cloth stretched on a wooden cross. It is now over the altar of S. Trinita, Florence, and is exposed on the evening of Good Friday.

It is related of S. Margaret of Cortona that " as she knelt one day before the image of the crucified Redeemer, He bent His s. Margaret. head in compassion and forgiveness. She was regarded from that day

${ }^{1}$ Lindsay, Christzan Art, vol. ii., p. 204.

${ }^{2}$ Webb, Continental Eccles., p. 538.

${ }^{3}$ Camden, Britannia, p. I 42.

4 Hemans, Hist. of Mediceval Christianity and Sacred Art, p. I38. 
with religious reverence by the people of Cortona, and became the local Magdalene." '

In I602, when the city of Cortona was visited by the plague, the image of S. Nicolas of Tolentino was borne in solemn procession to the s. Nicolas of Lazaretto. The procession was met by another carrying a zolentino. large crucifix. "Thereupon the saint stretched forth his arms, and the figure of Christ stooping from the Cross embraced $\mathrm{S}$. Nicolas, and from that moment the pestilence was stayed." 2

While not meaning to be uncharitable, and making all due allowance for overwrought imagination, we think that some light may be thrown on these, and similar miracles, by the story of the "gaping rood " or " bearded crucifix" of Boxley in Kent, England. This was commonly called the " Rood of Grace," s to which many pilgrimages had been made, because it was observed sometimes to bow, and to lift itself up, to shake and stir its head, hands, and feet, to roll the eyes, move the lips, and bend the brows, all of which were looked on by the abused multitude as the effects of a divine power. These were now publicly discovered to have been cheats; for the springs were showed by which all these motions were made. Upon which John Hilsey, then Bishop of Rochester, made a sermon, and broke the rood in pieces, ${ }^{4}$ at $\mathrm{S}$. Paul's Cross, London.

When the Litany was sung in English in Christ Church, Dublin, at the arrival of the Earl of Sussex, the Lord Lieutenant under Queen Elizabeth, the Archbishop and the rest of the Privy Council Crucifix. being present, drops of blood trickled from the thorns of the crown upon the face of the marble image upon the Cross, and the people were told by one privy to the contrivance, " that our Saviour could not choose but sweat blood when heresy was come into the Church."

By command of the Archbishop, the image was examined, and a sponge soaked in blood was discovered within the hollow of the head, which had been placed there by one Lee, formerly a monk of the Cathedral. He and his assistants were exposed for three Sundays upon a

${ }^{1}$ Mrs. Jameson, Monastic Orders, p. 329.

2 Ibid., p. 199.

3 " Rood of Grace," a term usually applied to a cross of which it has been certified, under seal and sign-manual of a Bishop or Pope, that it has exhibited the prerogative of miraculous or intercessory powers. Pooley, Churchyard Crosses of Gloucestershire, p. 26.

${ }^{4}$ Burnet, Fistory of the Reformation, part i., bk. iii., p. I78. 
table before the pulpit, with their crime placarded upon their breasts. Parker, then elect-l'rimate of Canterbury, made use of this detected fraud to induce Queen Elizabeth to consent to the removal of images from the churches, but " all his learning and zeal could not persuade the Queen to part with the crucifix and tapers from her own closet; she thought, 't is likely, that the arguing against the use, from the abuse, was short of exact reasoning." "

The Rood of Beccles, which sweat, bled, and emitted a sweet perfume, was doubtless contrived in a similar manner. ${ }^{2}$ Rood of Beccles.

In connection with this head of the subject, may be noted some of the instances of the stigmata, the most celebrated of which is afforded in the history of S. Francis of Assisi.

Stig mata.

This saint was living on Monte Alverno in the Apennines, when upon the Festival of the Exaltation of the Cross, a seraph appeared bearing a cru-

S. Francis of Assisi. cifix. Two wings of the angel were above the head of the figure, two covered the body, and two were stretched forth to fly. " Pity passed through the [saint's] heart like a sivord, and a supernatural sympathy visibly and indelibly imprinted the wounds of the crucified upon his person." " In the holes remained, as it were, nails of hard flesh, the heads whereof were round and black. The points were long and went beyond the skin, and were turned back as if they had been clenched with a hammer. The wound of his right

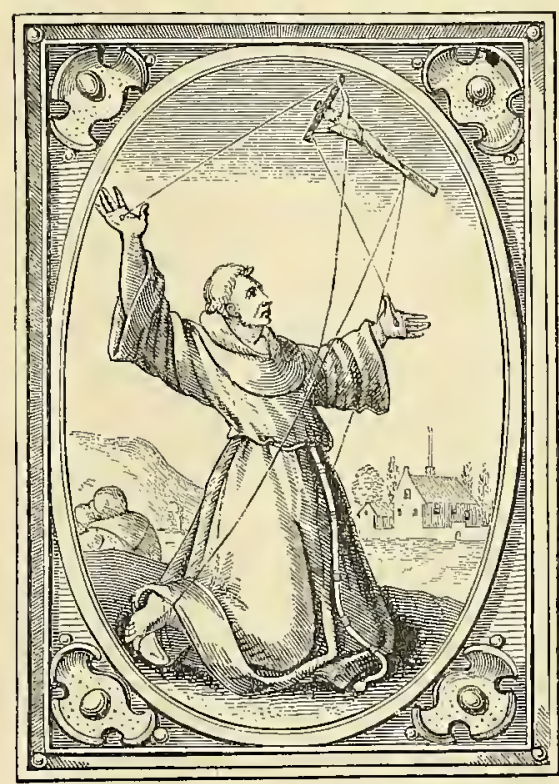

Stigmata of S. Francis of Assisi. From Holland's Cruciana. side was a red scar, out of which flowed so much blood that it colored the habit of the saint." "That the wounds actually existed during S. Francis's life there can be no question," writes Lord Lindsay, "although"

${ }^{1}$ Cecil's Memoirs; Collier, Eccles. Hist., vol. ii., pp. 434, 435.

2 Walcott, Sacred Archaoiogy, p. 447.

${ }^{3}$ Lindsay, Christian Art, vol. ii., p. 217.

- Ribadeneira, Flos Sanctorum, p. 767. 
(Roman) "Catholics and Protestants, and such as view the Christianity of the Middle Ages with Oriental eyes, will account for their infliction very differently." '

According to the legend, after the death of S. Francis, when the populace of Assisi were permitted to view his body, one Jerome, being skeptical, touched and moved the nails, whereupon the hands, feet, and side shrank as with pain. This subject forms one of the series of frescoes illustrating the life of the saint by Giotto at Assisi. ${ }^{2}$

It is a little curious that in I222, a few years before the miracle exhibited by S. Francis, " two naughty fellows," as Holinshed calls them,

Men Crucified for Assuming the Stigmata. were crucified by order of a council held in Oxford, because they were found to be false dissemblers, showing the signs of the wounds of our Saviour. ${ }^{3}$

Concerning stigmata, Ennemoser says that medical history affords many instances of the power of thought to produce wounds on the surMedical Theory face of the body in parts to which it is intently directed. of the Stigmata. The explanation he finds in the plastic force of phantasy, the essence of which, as poetic shaping power, consists in the realizing of ideal representations, wherein the soul of man can do much even to his own body. In confirmation of this, De Boismont gives the following account, which cannot be doubted:

Marie de Moerl was born in 1812. In her infancy she was subject to Marie de Moerl. severe nervous attacks, and when about twenty years old she became affected with ecstasy on the reception of the Eucharist, on one occasion remaining on her knees for thirty hours after par-

1 Lindsay, Christian Art, vol. ii., p. 218. This author refers to a work then $(\mathrm{r} 8+7)$ in preparation by Alfred Maury, author of Essai sur les Légendes Pieuses du Moyen-age, on stigmatation. The Quarterly Reviezo also adds its weight: S. Francis "was no deceiver. He never spoke of his wounds during his life, and his followers remembered, after his death, that by the length of his robes, he had seemed studiously to conceal his hands and his feet. It is likely that the five wounds were really discerned on his person, when he was no more. Towards the close of his life, in an excess of ascetic fervor, it is very possible that he might have made the attempt, which so many enthusiasts have made, to realize to himself the pains of the Passion, and that in his debilitaled state his wounds never closed." April, is5s, p. 366.

S. Francis receiving the stigmata was a favorite subject with medireval artists, but few think, when they gaze upon the picture by Cigoli in the Acarlemy of Florence, of the incident which enabled the painter to portray the marvellous pallor and wanness which are there expressed. A poor pilgrim, worn out with hunger and fatigue, presented himself one day at the studio and begged an alms. Cigoli wished to sketch his figure, before he extended his charity. Forgetful of his model's need, the poor wretch fainted. At once the painter seized the happy moment, and the wasted features were transferred to the canvas.

'southey, Omniana, vol. i., p. 274. 
taking of the Communion. In the autumn of 1833 , the paims of her hands sank in as if under pressure, became painful, and frequently cramped. On the Feast of the Purification in 1834 she was observed to wipe her hands and exhibit a childlike alarm at the appearance of blood. Soon marks appeared on ixer feet, and on her heart. On Thursday and Friday the wounds shed blood; on other evenings they were covered with a crust of dried blood. After some time she was visited by Dr. Goerres. She had then been four years almost continually in a state of ecstasy, and when aroused from it, as she was daily, appeared rational and collected, and gave directions about the household affairs. On arousing from trance her first movement always was to hide her marked hands beneath the bedclothes, as a clild would conceal them when soiled from its mother. Her meditations usually were of the Passion of our Lord, and on Friday her sympathies were so intense that she appeared to agonize with Him to the last extremity. "If Marie de Moerl actually died," says Dr. Goerres, " her death could not appear more real." '

Another instance noted by Ennemoser is that of the nun Enrich; from youth sickly and devout, before she entered the cloister she had a vision in which she was offered a crown of thorns, or a wreath of flowers. She chose the crown, pressed it upon her

Enrich. brow, and felt upon her head a violent pain accompanied with bleeding.

A later case is that of Louisa Lateau, of Belgium. The stigmata were manifested every Friday. When the sufferer was not in a state of ecstasy, she was afflicted with catalepsy. Her arms remained rigidly extended as upon a cross and she would fall Louisa Lateau. even upon the stones without injury. From this peculiar condition she could only be awakened by one of the Order of the Passion.

Thirty-two other instances of similar stigmata, or in which wounds have appeared upon the body, are cited by the authors referred to, one of which is remarkable enough to be repeated.

Upon the entry of the French into Moscow the terror of a citizen who witnessed a conflict between a Frenchman and a Cossack was so great that, although actually untouched, bleeding gashes appeared upon his person. ${ }^{2}$

1 De Boismont, Hist. of Hallucinations, p. 225.

${ }^{2}$ Mountford says there have been sixty instances of stignata since the days of $\mathrm{S}$. Francis, perhaps ten within the past year (1867). MFiractes, Past and Present, p. I55. 
Ennemoser insists that the stigmata are not scientifically produced deceptions, nor yet are they to be explained by the mere physical circumstances of the body. We will hardly ascribe them to spirits or to any immediate divine apparition. Far from being miraculous, they are due in every case to a purely psychical cause. ${ }^{2}$

Cruciform birth-marks occasionally occur. S. Roch is said to have had the figure of a small red cross upon his breast. ${ }^{2}$ Frederick, the

\section{Cruciform} eldest son of John the Constant, of the House of Saxony, Birth-marks. had a similar one upon his back. ${ }^{3}$

1 Ennemoser, Hist, of Magic, Pp. 497-409.

${ }^{2}$ Jameson, Sacred and Leg. Art, vol. ii, p. 33.

${ }^{3}$ Shobel, Prince Albert and the House of Saxony, p. 94. It is not necessary to multiply instances of stigmata known in art. Two principal ones doubtless will occur to the reader, e.g., S. Catharine of Siena (Mrs. Jameson, Monastic Orders, p. $38 \mathrm{r}$ ), and S. Clare of Montefalco. The latter is said to have had the crucifix and instruments of Christ's Passion imprinted upon her heart. Such was the testimony of her sister nuns, before whom, after her death, she was dissected. Holland, Craciana, p. 66. 


\title{
CHAPTER IX
}

\author{
THE SIGN OF THE CROSS
}

Section 1.-Personal Use of the Sign. Section 2.-In Baptism. Section 3.-In Confirmation. Section 4.-In the Holy Eucharist. Section 5.-In Benediction. Section 6.-In Ordination. Section 7.-In Prayer. Scction 8.-In Signatures. Section 9.-In Touching for the King's Evil. Section IO.-Power of the Sign over Devils.

$\mathrm{W}^{\mathrm{B}}$

have seen that the cross was used among the heathen, who, in traditional prophecy derived from their forefathers, declared that it signified " eternal life." Nowonder then that when men's eyes were opened, and their hearts cheered by the tidings of an accomplished redemption, they expressed

Use of the Sign of the Cross by the Early Christians. their feelings by employing the same sign, now doubly dear, because it was no longer a dumb emblem, but one which they hailed as their anchor, their armor, and the symbol and assurance of eternal life, once promised and dimly discerned through ages of spiritual darkness, now blazing with the effulgence of the Sun of Righteousness bearing the cheering words to the humblest as well as the highest among God's saints, " By this conquer."

The use of the Cross was with the early Christians no superstitious custom. Their "heart was in the Cross, and the Cross was in their heart." " It was not unaccompanied by practical faith and fervent

1 "Cor in Cruce, Crux in Corce." This idea is beautifully embodied in some lines on a marble slab inserted in the wall of a church at Sorrento. They begin and end alternately with the words Croce and Cuore. The following is as nearly as possible a literal translation :

" Cross, most adored! to thee I give my heart ;

Heart I have not, except to love the cross.

Cross, thou hast won my wayward, alien heart ;

Heart, thou hast owned the triumph of the cross.

Cross, tree of life! to thee I nail my heart ;

Heart cannot live that lives without the cross.

Cross, be thy blood the cleansing of my heart ; 
prayer. Their dependence was placed not upon the mere sign, but on the power of the Lord of the Cross. Thus testifies S. Chrysostom, Testimony of exhorting his hearers: "Let no man therefore be ashamed s. Chrysostom. of the honored symbol of our salvation, and of the chiefest of all good things, whereby we even live, and whereby we are, but as a crown so let us bear about the Cross of Christ. Yea, for by it all things are wrought, that are wrought among us. Whether one is to be newborn, the Cross is there, or to be nourished with the Mystical Food, or to be ordained, or to do anything else, everywhere our symbol of victory is present. Therefore both on our houses, and walls, and windows, and upon our foreheads, and upon our mind, we inscribe it with much care.

" For the salvation wrought for us, and of our common freedom, and of the goodness of our Lord, this is the sign. . . . When, therefore, thou signest thyself, think of the purpose of the Cross, and quench anger, and all other passions. IVhen thou signest thyself, fill thy forehead with all courage, make thy soul free. And ye know assuredly what are the things that give freedom. Wherefore also Paul leading us there, I mean unto the freedom that beseems us, did on this wise lead us unto it, having reminded us of the Cross and Blood of our Lord. For ye are bonght, saith he, with a price, be not ye the serrants of men. Consider, saith he, the Price that hath been paid for thee, and then wilt thou be a slave to no man; by the Price meaning the Cross.

\section{" Since not merely by the fingers ought one to engrave it, but before this} by the purpose of the heart with much faith. And if in this way thou hast marked it on thy face, none of the unclean spirits will be able to stand near thee, seeing the blade whereby he received his wound, seeing the sword which gave him his mortal stroke. For if we, on seeing the places in which the criminals are beheaded, shudder, think what the devil must endure, seeing the weapon whereby Christ put an end to all his power, and cut off the head of the Dragon.

"Be not ashamed of so great a blessing, lest Christ be ashamed of thee, when He comes with His glory, and the Sign appears before Him,

Heart, be thy blood an offering to the cross.

Cross, thou shalt have the homage of my heart;

Heart, thou shait be the temple of the cross.

Cross, blest is he who yields to thee his heart ;

Heart, rest secure, who cleavest to the cross.

Cross, key of Heaven, open every heart;

Heart, every heart, receive the holy cross." 
shining beyond the very sunbeam. For indeed the Cross cometh then, uttering a voice by its appearance, and pleading with the whole world for our Lord, and signifying that no part hath failed of what pertained to him.

" This Sign, both in the days of our forefathers and now, hath opened doors that were shut up; this hath quenched poisonous drugs; this hath taken away the power of hemlock; this hath healed bites of venomous beasts. For if it opened the gates of hell, and threw wide the archways of Heaven, and made a new entrance into Paradise, and cut away the nerves of the devil, what marvel, if it prevailed over poisonous drugs, and venomous beasts, and all other such things.

"This therefore do thou cngrawe upon thy mind, and embrace the salvation of our souls. For this Cross saved the converted world, drove away error, brought back truth, made earth Heaven, fashioned men into angels. Because of this, the devils are no longer terrible, but contemptible; neither is death, death, but sleep; because of this, all that warreth against us is cast to the ground, and trodden under foot." '

The sign of the Cross was among Christians the password among friends, the confession of faith before enemies, the tangible expression of fervent prayer at all times and in any circumstances. To this Tertullian testifies:

"In all our travels and movements, in all our coming in and going out, in putting on our shoes, at the bath, at the table, in lighting our candles, in lying down, in sitting down, whatever employment occupieth us, we mark our forehead with the sign of the Cross.

"For these and such-like rules, if thou requirest a law in the Scriptures thou shalt find none. Tradition will be pleaded to thee as originating them, custom as confirming them, and faith as observing them. That reason will support tradition, and custom, and faith, thou wilt either thyself perceive, or learn from some one who hath perceived it. Meanwhile thou wilt believe that some reason there is, to which due submission is due.",

We can scarcely open a volume of the Fathers without lighting upon some passage expressive of the love and veneration in which the symbol of hope to the lost world was held. S. Ephrem's exhortation is so full

1 S. Chrysostom on S. Matt. Hom., liv., pp. 735-737, Oxf. Trans.

2 Tertullian, of the Crown, p. I65, Oxf. Trans. 
of holy faith that we cannot pass it by. In his sermon on the holy Cross he urges this precept: "Let us point and imprint upon our doors, on our foreheads, and upon all our members this life-giving Cross. Let us arm ourselves with this invincible armor of Christians, " the vanquisher of death, the hope of the faithful, the downfall of heresies, the bulwark of true faith.' Thus defended, no evil will hurt us. By this sign have all nations been united in one Church, in one Faith, in one Baptism, and knit together in charity." 1

The ancient writers reverently collected much curious matter concerning the sign of the Cross. It would occupy too much space to give the tithe of it in full, therefore we condense, explaining the symbolism. Symbolism of the They tell us when we use five fingers we are reminded of Sign of the Cross. the five wounds of Christ, when three are employed, we represent the holy Trinity, with two we denote the twofold natures of Christ, in opposition to the Monophysites."

By the passing from the left to the right, remission of sins, and life to come, are indicated; from the goats to the sheep; from misery we pass to glory as Christ passed from death to life; from Hades to Paradise; we are reminded that Christ's mission passed from the Jews to the Gentiles.

When the finger alone was used we are told it ought to be bent to the thumb. Some in reverence bring the finger to the mouth and kiss it-the forehead first is touched, " in the name of the Father," He is the head and beginning of all things; descending to below the breast, we call to mind the eternal generation of the Son, and his abiding in the womb of the blessed Virgin, while passing from the left to the right we pronounce " and the holy Ghost," love in the heart at the left, possession with honor and power at the right, or, as S. Ambrose says, we touch the forehead for profession, the heart for love, the arm for work. Another form is perpendicularly used; three crosses, beginning the cross upon the brow because it is the head of all, on the mouth whence issues the word, on the heart for love.

In modern days, in both the Greek and Latin branches of the Church, when an individual makes the sign of the Cross upon his own person, he uses the right hand, having the first and second fingers open, while

${ }^{1} \mathrm{~S}$. Ephrem, quoted in Haslam's The Cross and the Serpent, p. $21 \mathrm{I}$.

${ }^{2}$ Before their time the ancients used but one finger, ex. gr.., Sozomen says with his finger he signeth the Cross. S. Gregory, "By virtue of the Cross which the man of God signed with his finger." 
the third and fourth are closed. Durandus says, that the sign of the Cross is made with the three fingers to invole the Trinity. The Greeks have the same opinion, but add that each finger symbolizes one of the Divinc Persons. The Archbishop Modern Mode of Nistra, whom Didron Mistra, whom Didron interrogated on that subject, told him, "that the thumb, from its strength, indicated the Creator, the Father Eternal, the Almighty; that the middle finger was consecrated to jesus Christ, who has redeemed $u s$, and is therefore, in respect of men, the chief person of the Trinity; that the forcfinger, standing between the middle finger and thumb, figured the Holy Ghost, who unites the Father and Son, and in representations of the Trinity is placed between those two persons.

" With the three fingers open, the body is marked with the form of the Cross, beginning at the brow, and descending thence to the breast, crossing that vertical line by another or horizontal one, drawn from the left shoulder to the right. The Greeks go from the right to the left, and it appears that with us also in the thirteenth century, at the time when Durandus wrote, the line was traced indifferently from either shoulder. The following extract from Durandus comprehends everything that remains to be said concerning the sign of the Cross:

"The sign of the Cross should be made with three fingers, because while tracing it we invoke the Trinity. Hence the prophet exclaims, Quis appendit tribus digitis molcm terra (Isaiah xl., 12, Editio Vulgate). Still the thumb has the pre-eminence, because we fix our whole faith upon God, one and three. Immediately after the invocation of the Trinity the following verse may be said: 'Shew me a token for good; that they which hate me may see it, and be ashamed; because Thou, Lord, hast holpen me, and comforted me' (Psalm lxxxvi., i7). But Jacobites and Eutychians, affirming that there was in Christ one single nature only, the divine nature; and at the same time, one single person only in the Godhead, make " the sign of the Cross, as we are told, with one finger only. This error has been eradicated by the decision of the canon.'

"Some persons sign themselves from the head even to the feet, to signify mystically that God, having bowed the heavens, descended upon earth. He did, indeed, descend to raise us from earth to heaven. They next sign from right to left; first, to show that they prefer things eternal, 
- signified by the right hand, to things temporal, signified by the left; secondly, to remind us that Christ passed from the Jews to the Gentiles; and thirdly, because Christ, coming from the right hand, that is to say, from the Father, conquered on the Cross the Devil, typified by the left, whence the words, "I came forth from the Father, and am come into the world' (John xvi., 2S). But others signing themselves from left to right justify that formula by the text, "He came from the Father, he descended into hell, and returned to the throne of God.' In fact, they commence by making the sign in the upper part, which designates the Father; then they descend below, meaning earth; then they go to the left, which marks hell, and so re-ascend to the right, signifying to heaven, for Christ thus descended from heaven to earth, and afterwards reascended from hell to heaven, where he sits at the right hand of God the Father. Secondly, by doing thus they intimate that we pass from misery to glory, and from vice, signified by the left, to virtue, whose place is on the right, as we read in the Gospel of $\mathrm{S}$. Matthew. Christ, in fact, has passed from death unto life. Thirdly, because Christ raises us through faith in his Cross from things which pass away to things which endure forever.

" In the present day, however, an individual making on his body the sign of the Cross employs the right hand entirely open, instead of the three fingers only ${ }^{1}$; but, on the contrary, he uses one finger only, the thumb, to trace the sign of the Cross on the forehead, the mouth, and the heart, when (before reading the Gospel, and as a response to the deacon who appears to chant it) homage is rendered to God by inclining the body and saying, Gloria tibi, Domine!

" These three little signs are made in the form of a Greek cross, and on three different parts of the body, to signify that we believe with the heart and the mind, and are ready to confess with the lips our faith in that divine word about to be spoken.

"The thumb is also used by the bishop and priest in tracing the little Greek cross with which the faithful are signed upon the forehead, and other parts of the body, previous to the administration of the Holy

1 The early Christians, says MI. Cyprien Robert (Cours d' Hicrogl. Chr't.), did not sign themselves, as at the present time, with the entire hand, and in such a manner as to embrace half of the body, but simply with the first finger of the right hand, and (as is now done by the Greeks and Russians) they traced that sign three times following, in the name of each of the three Divine Persons. 
Sicrament. And it is with the thumb more especially, and making the sign of the Cross, that the priest places on our brow at the commencement of Lent, the ashes which are to remind us, that from dust we came, and to dust we shall return."

The Nestorian usage is similar to the Greek. The Armenians employ the three fingers, but touch the left before the right breast. The Syrians use only the thumb and forefinger, but sign themselves in the same order as the Armenians.

That the English Reformers intended to leave the use of this sign optional, appears from the " certain notes for the more plain Explication and decent ministration of Things contained in this Book (Ist Common Prayer-Book of King Edward VI.) as touching, kneeling, crossing, holding up of hands, knocking upon the breast, and other gestures, they may be used, or left, as every man's devotion serveth without blame."

It seems needless to waste time in refuting the charge, formerly made against the Church, of idolatry in the use of the sign of the Cross. If any weak conscience is still troubled, let Dr. Hammond answer him :

"For the sign of the Cross, used by our Church in Bap-

Charge of Idolatry in the Use of Sign of the Cross. tism, which hath been by some cryed down under the title of Idolatry, two things it will not be amiss briefly to have observed; I. That the same ground of zeal or passion that hath incited some men lately to charge it of a breach of the second commandment, hath long since moved " one of the same spirit to accuse it as a sin against the other nine, and entitle his several chapters, of the Swearing, Sabbath-breaking, Murthur, Adultery, Stealing, False-witness, etc., and at last of the concupiscence of the Cross, as well as the Idolatry of it, the reasons being much alike for the whole charge. 2. That the signing with the sign of the Cross in that sacrament, is somewhat distant from that which the Papists use, and an act of departure from them in King Edward's second liturgy, more than had been in the first Reformation. The former custom was to cross the child at the church door, when it was brought to Baptism, but this of ours as a mark of initiation or reception into Christ's flock immediately following Baptism, in a kind of tessere, or military sign that the person thus consigned into Christ's Militia, shall forever after think himself obliged manfully to fight, etc. A change made merely

'Didron, Christ. Icon., vol. i., pp. 4os-4tI.

2 Parker, Of the Cross. 
out of compliance with them which were jealous of too great an inclination to Popery, and yet now charged with the guilt of that which it was on purpose designed to decline." 1

The opinion of the Church of England as to the sign of the Cross, is clearly expressed in her XXXth canon, in which she declares, it is no part of the sacrament, which is perfect and complete without it, but that in using a sign " for the remembrance of the Cross, which is very precious to all them that rightly believe in Jesus Christ, she both followed the primitive and Apostolical Churches."

In a MS. account of the Knights of Bath, written about the time of Henry VI, we find that a sort of baptism formed part of the ceremony Baptism of the of initiation. The knight who gave the "Charge" to the Knights of Bath. squire about to be elevated to higher rank, put his hand in the bath in which the candidate was seated, and taking up water, made the sign of the Cross upon the squire's left shoulder, both before and behind, and then having kissed it, said, In nomine Patris, etc., adding "God send you as much worship as any of your kin." "From this rebaptism some philologists have derived the word " dub " from the AngloSaxon $d y$ pon, to dip. Dub is still used in some some parts of the north of England to signify a pool.",

Section 2. In Baptism.-At the very threshold of the Church, the very beginning of Christian life was sanctified with the sign of the Crucified. Bingham shows that four several times during the preparation for consummation of Baptism, the sign was used.

"First, at the admission of catechumens to the state of catechumenship, and the general name of Christian. Second, in the time of exorcism and imposition of hands, while they were passing through the several stages of catechumens. Third, at the time of unction before Baptism. Fourth, at the unction of Confirmation, which was then usually the conclusion of Baptism both in adult persons, and infants." 3

In most, if not all, of the liturgies of the Eastern Church, these four times of consecration are observed, with the slight change of the first, the child being sealed with the holy sign on the eighth day, when he receives his name. In the liturgy of Constantinople, the child accom-

\footnotetext{
1 Hammond, Works, vol. i., p. 254 (ed. I684).

2 Millington, Heraldry in History, etc., p. 78 .

${ }^{3}$ Bingham, Antiquities of the Christian Church, bk. xi., chap. ix., sec. 4.
} 
panies the mother on the fortieth day, and is again signed with the sign of the Cross. ${ }^{1}$

Bingham gives full quotations from the Fathers and early writers, so that it is needless to repeat them here, showing that it was no new ceremony, even as early as the fourth century. Yet a few examples may be cited.

S. Augustine says, "the Cross is always joined with Baptism." 2 The author of the Apostolic Constitutions is express in explaining the various ceremonies of Baptism. The water is to represent Christ's burial, the oil to represent the Holy Ghost, the sign of the Cross to represent the Cross, and the anointing or chrism, Constitutions." S. Augustine. "A postolic Constitutions." the confirmation of men's promises. ${ }^{3}$ S. Jerome writes, "I am a Christian, born of Christian parents, and carry the banner of the Cross on my forehead." 4

S. Jerome.

In the time of Tertullian there was no unction before Baptism, but there was one immediately after it, which, together with the imposition of hands, was properly a ceremony belonging to confirmation, and not to be confounded with those of Baptism. He says,

Tertullian. "The flesh is washed, that the soul may be cleansed; the flesh is anointed, that the soul may be consecrated; the flesh is signed [i. $\epsilon$., with the Cross] that the soul may be guarded; the flesh is overshadowed by imposition of hands, that the soul may be illuminated by the Spirit; the flesh is fed by the body and blood of Christ, that the soul may receive nourishment from God." s

Even in the consecration of the water, S. Augustine says, "the water itself was signed with the Cross of Christ." "And the author who writes under the name of Dionysius records, "that in his time while the priests were finishing the unction, the Bishop

Dionysius. by invocation sanctified the water in the font, thrice pouring in some of the holy chrism, tracing the form of a Cross." "

"Many sacraments we receive," says the same saint, " one in one

I Neale, Hist. Eastern Church, Introduct., chaps. v., vi. The modern Eastern Church nearly follows the ancient, for in the fourth century, according to Palmer, candidates for baptism were thrice signed on the forehead before the water was consecrated and the sacrament administered. Origines Liturgica, vol. ii., chap. v., sec. 8.

${ }^{2} \mathrm{~S}$. Augnstine, ser. ror ; $D_{e}$ Tempore, p. 290.

${ }^{3}$ Apostolic Constitutions, bk. iii., chap. I7.

4 S. Jerome, Epist. Ir3; Prafat. on Job, chap. iii.

'Tertullian, De Resurrctione, cap. 8.

${ }^{6} \mathrm{~S}$. Augustine, Hom. 27 , ex. 50.

${ }^{7}$ Dionysius, De Hierach., Eccles., chap. ii., p. 253. 
way, another in another, some ye know we receive with the mouth, and some we receive over the whole body. But because the forehead is

S. Augustine. the seat of the blush of shame, He, who said "Whosoever shall be ashamed of me before men, of him will I be ashamed before my Father which is in Heaven,' set, so to speak, that very ignominy $[i . \epsilon$., the Cross, the badge of infamy] which the pagans mock at, in the seat of our shame." '

Yet another exquisite quotation from the same Father: " His sign we bear on our forehead, whereof we are not ashamed if we bear it, because in our hearts $\mathrm{His} \operatorname{sign}^{-}$is that of His humiliation. By a star the wise men knew Him, and thus was a sign given of the Lord, heavenly and glorious. He would not have a star to be on the forehead of $\mathrm{His}$ believers as His sign, but the Cross, whereby humbled, by the same glorified. He lifteth up the humble even by the same to which being humbled, He himself depended," a

Hence the reason why, when the priest takes the child in his arms in Baptism, he signs the Cross on his brow and says, " WV receive this child Sign of the Cross into the congregation of Christ's flock, and do sign him with in Baptism. the sign of the Cross, in token that he may not be ashamed to confess the faith of Christ Crucified," etc.

It does not seem, however, that any of the most ancient rituals appointed the sign of the Cross to be made exactly at the same time that the English and American branches of the Church direct. The position of the consignation in the service which was appointed in $1552^{3}$ is peIn the Eastern culiar to Great Britain and to the Churches derived from it. church. In the Eastern Church, about the fourth century, candidates were signed three times before the water was consecrated, and Baptism administered.

In the Prayer-Book of Edward VI. we find the old custom still retained of crossing before Baptism. The first crossing was placed upon

In the PrayerBook of Edward VI. both the forehead and breast, the ministrant saying, " $N$., receive this sign of the holy Cross both on thy forehead and on thy breast, in token that thou shalt not be ashamed to confess thy faith in Christ crucified."

IS. Augustine on Psalms, vol, vi., p. 270, Oxf. Trans..

2 S. Augustine on S. John. Hom., vol. iii., p. 33, Oxf. Trans.

s Procter on the Book of Common Prayer, p. 313.

* Palmer, Origines Liturgica, vol. ii., chap. v., sec. 8. 
Wheatley tells us, that it was an ancient custom for masters and generals to mark the forehead or hands of their servants and soldiers with their names or marks, that it might be known to whom they did belong; and to this custom the angel in the Revelation is thought to allude, "Hurt not the earth . . . till we have sealed the servants of our God in their foreheads " (Rev. vii., 3) and again the redeemed of the Lamb are said to have "His Father's name written in their foreheads" (Rev. xiv., I), and lastly in the same chapter (verse 9) the great adversary shall sign lis servants also. "If any man . . . receive the mark of the beast in his forehead."

This custom of marking different parts of the body, appears to have been common among the heathen. Among the Hindoos, the different sects who worshipped more especially Vishnu or Siva are distinguished, the first by a longitudinal mark of vermilion on the forehead, the latter by a parallel line of turmeric or

Hindoo Custom of Marking the Body. saffron. This mark was called the tiluk and can only be performed by a Brahmin, and is indispensable before entering a temple. ${ }^{2}$

Among the Egyptians, if any slave fled to the temple of Hercules and had the sacred marks impressed upon him, he was placed under the immediate protection of that deity, and was privi-

Egyptians. leged from all harsh treatment. ${ }^{3}$

The Greeks also branded their soldiers, so that they could not desert in time of war. ${ }^{4}$ S. Paul appears to allude to this custom, when he says, "I bear in my body the marks of the Lord Jesus"' (Gal. vi., 17). The Jacobite, so called, rite of Baptism by fire, in which the Cross was imprinted with a red-hot iron upon the foreheads of the neophytes, has been elsewhere described.

A writer in Notes and Queries" gives the simple explanation that the S. Andrew's cross in the Greek Church represents the initials of Christ, the symbolical affixing of which (sealing) before and after baptism, indicates that the name of Christ is imCross. posed on the believer, who takes his new, or Christian, name at baptism. This mark on the forehead refers to Rev. vii., 3 ; xiv., I ; xx., 4.

1 Wheatley on Common Prayer, Baptism of Infants, sec. 7.

2 Maurice, Indian Antiquities, vol. v., p. 82.

${ }^{3}$ Blackwell, Sacred Classics, vol. ii., p. 66.

${ }^{4}$ Potter, Archaologia Graca, vol. ii., p. 7 ; see also Deane, Serpent IVorship, p. I42.

${ }^{5}$ Notes and Queries, vol. viii., p. $46 \mathrm{I}$. 
The longer Catechism of the Greek Church, in answer to the question, What force has the sign of the Cross used on this and other occasions? says, " The name of Jesus Christ crucified can not only be pronounced with faith by the motion of the lips, but it can be represented as well by the sign of the Cross, when made with faith by the motion of the hand, or in any other way." " In the "Sarum ritual " the Cross is made at the words, " sanctify this water," etc.

The spiritual significance of the rite is well expressed in the aspiration of the Rev. John Marriott, written on his son Charles's christening-day:

"Grant to this child the inward grace

While we the outward sign impart.

The Cross we mark upon his face,

Do Thou engrave upon his heart.

May it his pride and glory be

Beneath Thy banner fair unfurl'd

To march to certain victory,

O'er sin, o'er Satan, o'er the world." 2

Section 3. In Confirmation.-Anciently, Confirmation was often called Consignation (o Usage in the the Cross with the unction. Neale cites the following inEastern Church. stances from early liturgies:

The Gelasian is this: "The sign of Christ for eternal life." The present Roman: “ N., I sign thee with the sign of the Cross, +, and Gelasian Sacra- Confirm thee with the chrism of salvation. In the name of mentary. the Father, and of the Son, and of the Holy Ghost. Roman. Amen."

The Pontifical of Egbert of York, circa A.D. 750: " Receive the sign of the holy Cross in the Chrism of Salvation in Christ Jesus Egbert of York. for life eternal."

The Pontifical of Cadurces, tenth century: “ I confirm and sign thee Cadurces. with the sign of the Cross, + , in the Name of the Father, and of the Son, and of the Holy Ghost."

The Ritual of Moisac, tenth century: "I confirm thee with the sign Moisac. of the Cross, + . In the Name of the Father, and of the Son, and of the Holy Ghost for life eternal. Amen."

1 S. Cyril, Catechet. Lectures, vol. xiii., p. 36, to which reference has already been made.

: Burgon, Lives of Twelve Good Men, p. I 55 . 
The Pontifical of Poitiers, twelfth century: "God signs thee with the seal of His faith, in consignation of faith, in the name of the Father, and of the Son, and of the Holy Ghost. Amen."

The Pontifical of Vienna: "I confirm thee in the Name of the Father, and of the Son, and of the Holy Ghost. Amen. Peace be with thee and with thy spirit. The sign of Christ for life

Vienna. eternal. Amen."

The Pontifical of Paris, fourteenth century: "N., I sign thee with the sign of the holy Cross, and confirm thee with the chrism of Salvation. In the name of the Father, and of the Son, and of the Holy Ghost; that thou mayest be filled with the same Holy

Paris. Ghost, and mayest have life eternal."

Proceeding to the East, we find in the present Ritual of Constantinople that the priest " Anoints the baptized person with holy oil, making the sign of the Cross on his forehead, and eyes, and nostrils, and mouth, and both ears, and breast, and hands, and feet, saying, 'The seal of the gift of the Holy Ghost. Amen.' ,'

In the Arabic ritual the sign of the Cross is used upon the forehead, temples, eyes, ears, nostrils, and mouth, liands, breast, knees, and feet, shoulders, shoulder-blades, and arm-joints. The Armenian is the same; except that the anointing mentioned in the last clause is between the shoulders; no further symbolized. The Coptic also is very nearly similar, except that the rubric directs, "Here breathe upon the forehead, in the form of the glori-

Coptic. ous Cross, and say, Receive the Holy Ghost, and be a pure vessel, through Jesus Christ our Lord, to Whom, etc."

The Ethiopic rite is nearly the same. In the Nestorian, each of the candidates is signed, with the thumb, on the forehead. In the Syrio-Jacobite both the foreheads and the throats of the candidates are signed thrice. ${ }^{1}$

The Anglo-Saxons followed the custom of the Church from which they derived their orders, ${ }^{2}$ and the Scotch still retain the sign of the Cross; but the Church of England has omitted it since A.D. 1552.

In the first Prayer-Book of Edward VI., in the Order of Confirma-

1 Neale, Hist. Eastern Church, Alexandria, part i., General Introduction, pp. Io0I-1006.

${ }^{2}$ Lingard, Antiquities of the Anglow Saxon Church, note. 
tion, the minister prays: "Sign them, O Lord, and mark them to be Thine forever, by virtue of thy holy Cross and Passion Confirm and strengthen them with the inward Unction of Thy Holy Ghost First PrayerBook of Edward mercifully unto everlasting life. Amen." The rubric furVI.

ther directs, "Then the Bishop shall cross them in the forehead, saying, " I sign thee with the sign of the Cross, and lay my hand upon thee. In the name of the Father, and of the Son, and of the Holy Ghost. Amen."

It will be seen that confirmation was expected immediately to follaw baptism.

It will be noticed that above, the minister prays " Sign them, etc.," but the bishop is directed to give the sign. This arose from the ancient Chrism. custom of administering chrism after Baptism. As Tertullian says, " as soon as we come out from the bath, we are anointed thoroughly with the consecrated unguent according to the ancient rule, . . . next to this, the hand is laid upon us, calling and inviting the Holy Spirit througl the blessing." '

Easter and Whitsunday were formerly set apart for this ordinance. But as Christianity increased and numbers of persons wishing Baptism, Times Set Apart especially when sick, or those in cxtrcmis, could not resort for Confirmation. to the bishop at convenient times, in order that they might not be totally deprived of the spiritual strength and defence which confirmation afforded, it was allowed that the presbyter, or minister, who baptized should have the liberty to anoint the neophyte, but with these two cautions-First, that the chrism should be first consecrated by the bishop; secondly, that he should anoint without the imposition of hands. By this course the bishop parted with the shell, but retained the kernel, reserving to himself the apostolical rite of imposition of hands, and also the sole power of consecrating the chrism. The sixth canon of the Council of Carthage, and the first canon of the Arausican synod declared " that no minister who hath taken the office of Baptism, ought to go abroad without the chrism, for we have agreed it should be used at once" ; but in case one was brought to confirmation without having been anointed, ${ }^{2}$ the bishop, according to the canon just quoted of the

1 Tertuilian on Baptism, secs, 7, 8, p. I64, Oxf. Trans.

${ }^{2}$ L'Estrange, Alliance of Divine Offices, p. 405. Burnet on the Articles, Art. XXV.; Neale, list. Eastern Chzrch, Intro., p. IOOI, gives quotations from numerous liturgies in which the holy sign is used. 
Council of Carthage, was to be put in mind of it, in order that it might then be administered.

Section 4. In the Holy Eucharist.-In the sacrament of the Lord's Supper, Wheatley says, "I do not know that there is a single ancient liturgy in being, but what shows that this sign was always mign of the Cross made use of in some part or other of the office of the Com-" in Ancient munion." ' S. Augustine says, "which sign, unless it be Liturgies. applied whether to the brows of the believing, or to the very water out of which they are regenerated, or to the oil wherewith they are anointed with the chrism, or to the sacrifice whercby they are fed, none of these are duly performed." 3 S. Chrysostom says expressly, that it was not only used by Christians every Sacramental day, but particularly at the holy table, and in the ordination of priests; and that its glory shined with the body of Christ in the mystical supper. ${ }^{3}$

The synod in Trullo ordered that those coming to the Holy Communion should form with their hands the sign of the Cross. ${ }^{4}$ It has been doubied whether it meant that the arms should be crossed upon the breast (cancellatis brachiis) or that one hand should be placed upon the other; both customs are ancient. S. Cyril of Jerusalem directs: "Approaching therefore, come not with thy wrists extended, or thy fingers open; but

Decree of Council " in Trullo."

S. Cyril's Direction. make thy left hand as if a throne for thy right, which is on the eve of receiving the King. And having hollowed thy palm, receive the Body of Christ, saying after it, Amen." " The reception of the elements in little vessels of gold or other material was prohibited.

In the First Prayer-Book of Edward VI. the sign of the Cross was ordered at the words "Ble+ss and sanc+tify the gifts, etc."

First PrayerBook of

Edward VI.

1 Wheatley on Com. Prayer, Lord's Supper, sec. 2.

${ }^{2} \mathrm{~S}$. Aug, on S. John. Hom., p. II 8 , sec. 5. S. Aug. had no fear lest his words should be misunderstood, and the mere action unduly exalted. The context explains: "What is the sign of Christ save the Cross of Christ ? . . The Cross of Christ signifies . . . 'But they that are Jesus Christ's have crucified the flesh with its passions and lusts,' Gal. v., 2f."

${ }^{3}$ S. Chrysos., Demonstrat. Quod Christus sit Duts, tom. v., cap. 9, p. 840.

${ }^{4}$ Canon ior.

${ }^{5} \mathrm{~S}$. Cyril, Catec. Lec, xxiii., 2I. In the Oxf. Trans, there is an error that reads, "hallowed thy palm "instead of "hollowed," concava manu. 
Section 5. In Benediction.-The sign of the Cross in benediction Manner of Giving ${ }^{i n}$ both the Greek and Latin branches of the Church is the Benediction. always given with the right hand, the hand of power. The mode, however, differs between them. In the Greek Church the foreThe Gresk Form. finger is open to form an $I$ (iot $\alpha$ ), the middle finger is curved like a $C$ (the ancient sigma), the thumb and annular finger are crossed forming a $I$ (chi), and the little finger is bent to shape a $C$ (sigma). Thus they obtain $I C, I C$, the Greek monogram of Inoov $C$ X

The Latin benediction is given with the thumb and first two fingers open, the annular and little fingers being closed. Durandus and Beleth The Latin.

affirm that this manner of blessing is symbolical, the three open fingers signifying the Holy Trinity, while the two closed represent the twofold nature, Divine and human, of the Second Person." Anciently, the bishops gave the benediction after the Lord's Prayer, just before the Communion. It was not until the eleventh century that the custom became general for the priest to give the blessing at the end of the Mass. In the same century it was granted to some abbots to sign with the sign of the Cross, even out of the Mass, a form of blessing previously confined to the bishops.

Formerly, both bishops and priests gave the benediction alike, but latterly, a distinction has been made; the Episcopal blessing being be-

Benediction of Bishops and Priests. stowed with three fingers open, while the presbyters were obliged to use the full open hand. The bishop also faces the congregation, but the priest stands in profile with his hand turned edgewise." Again, in the performance of ecclesiastical ceremonies in which the bishop gives three successive benedictions, and three times makes the sign of the Cross, the priest gives only one blessing, and makes a single sign.

Benediction by It is worthy of note to those who, like us, have endeavJews and Pagans. ored to trace Christian rites and usages to pre-Christian times, that both the Hebrews and pagans gave their benediction with three

1 Gaide for Painting, a Byzantine MS. quoted by Didron, Christ. Icon., vol. i., p. 407 ; Labarte, Handbook of Art of the Middle Ages, p. I4t.

${ }^{2}$ Durandus, Rationale Divin. Offi., lib. v., cap. ii. ; J. Beleth, Explicatio Divin. Offi., cap. xxxix., de Evangelio; Didron, Christ. Icon., p. 408.

${ }^{3}$ Stephen Borgia, De Cruce Veliterna, chap, xv., quoted in Pugin's Gloss. " Cross."

${ }^{4}$ The symbolism preserved in heraldry; on a crest a helmet turned full face belongs to one in authority, side face, to an inferior rank, who received the command. See Newton. 
fingers extended, and uttered a malediction with the hand closed.' Count Caylus gives a representation of an Egyptian amulet, a forearm and hand with the fingers arranged as in the Latin bendiction.

"S. Joln the Baptist is usually represented by the Greeks in the act of blessing with the right hand, holding in the left, his head the reed cross, or the scroll, and calling men to repentance. S. John is a man, a minister of God, the precursor of Christ. To s. John Baptist. him all the power and prerogatives of the priesthood were delegated by God. He therefore gives the blessing by good authority. Yet, amongst us, S. John the Baptist is always represented holding the Lamb of God in his left arm, the index of the right hand being engaged in pointing to it : that hand points but does not bless." 2

In the consecration of a bishop, or an archbishop, in the Russian branch of the Greek Church, the archbishop crosses his hands in giving the benediction." This subject is treated most elaborately in Gretser, to whom we refer those who desire further information.

In the Russian Church.

Section 6. In Ordination.-S. Chrysostom, as has been already stated, "refers to the use of the sign of the Cross in the office of Holy Orders. Suicer quotes from the author who writes as Dionysius, that the imposition of hands in ordination was called $\sigma \rho \rho \alpha y i s$, consignation, and $\sigma \tau \alpha v \rho \circ \varepsilon \sigma \eta \nu \sigma \varphi \rho \alpha \gamma i$, consignation in the form of a cross, because of the sign traced on the brow of the candidate by the bishop. ${ }^{5}$

The sign was used in ancient forms of ordination in the Greek Church, ${ }^{6}$ and is still preserved in Russia, a single consignation being used for the lower orders, but a triple one at the consecration of a bishop or an archbishop."

In the Greek Church.

J ike many other rites in the Christian Church, it had been foreshadowed in the Jewish. The High Priest upon his installation was anointed with holy oil upon the forehead in the shape of a S. Andrew's or Saltire cross. ${ }^{8}$

1 M. Cyprien Robert (Cours d'Hierogl. Chrét.), quoted by Didron, Christ. Icon., vol. i., p. 4 II, note.

"Didron, Christ. Icon., vol. i., p. 407.

${ }^{3} \mathrm{King}$, Greek C'r. in Russia, "Rites of Consecrating Bishops," p. 294.

4 S. Chrysostom, Hom., liv., S. Matt., p. 735, 'Oxf. Trans.

${ }^{5}$ Suicer, Thesaur., бфрху25 ; Dionysius, De Hierarch. Eccles., cap. 5, pp. 3I2, 3I4, 364 ; Bingham, Antiq., bk. iv., chap. vii., sec. I2, and bk. ii., chap. xix., sec. 17.

${ }^{6}$ Goar, Eucologium., etc., pp. 247-250.

' King, Greek Ch. in Russia, pp. 275, 279, 281, 285, 299.

${ }^{8}$ Selden, lib. ii., De Success, in Pontif., cap. v. ; Bosio, bk. iii., chap. ii. 
The form is still preserved in the rite of Benediction and Coronation of the English sovereigns. The directions in the service are that, after the hing has been disrobed of his crimson gown and his cap of state, and taken his place before the altar, the Dean of Westminster shall take the ampulla and pour some of the holy oil into the anointing spoon and with it the archbishop shall anoint the king, in the form of a cross, on the crown of the head, and on the palms of both the hands, saying, "Be thou anointed with holy oil, as kings, priests, and prophets were anointed." '

Section 7. In Prayer.-As might be expected, from early ages the suppliant has used the mute but expressive appeal to the Sign of the Cross Judge, by exhibiting the sign of the sacrifice. Tertullian in Prayer. Says, that Christians usually prayed with their arms elevated Tertullian. to represent Christ's Passion. ${ }^{2}$ So, also, Minucius: "They Minucius. worshipped God with a pure mind and their hands stretched Paulinus. forth in the form of a cross." ${ }^{3}$ Paulinus describes S. Ambrose, while breathing his last breath, as praying with his hands extended in the form of a cross, ${ }^{4}$ and Prudentius, relating the martyrdom of Fructuosus, a Spanish bishop, says, the bands which tied his arms were first burnt off without touching his skin ; for they durst not restrain those arms which were to be lifted to the Father in the manner of a cross. Examples of this posture in prayer are found in the Catacombs. Eusebius informs us that the Emperor Constantine ordered his own image to be stamped on his coins, representing him as a suppliant with eyes and arms stretched upward to his Creator.

Bosio, in his Trimmph of the Cross, calls our attention to the fact that the arms naturally are raised so as to form a cross-in surprise, in giving thanks, or entreating for pardon or aid in danger.

We find that the ancient Egyptians used this posture in prayer, as is figured in the hieroglyphics on the obelisk before the Church of S. John Lateran at Rome. This also was the custom of the Romans, The Cross as a Posture in Prayer. "tendcns ad sidera palmas." The Hebrews spread forth their hands before the Lord; in short, this posture in devotion we believe may be traced the world over, even almost to our day, for

${ }^{1}$ Palmer, Origines Liturgica, vol, ii., pp. 33S, 339.

${ }^{2}$ Tertulhian, Apology, p. 7o, Oxf. Trans.

3 Minucius, Dial, p. go.

\footnotetext{
${ }^{4}$ Paulinus, Vit. Ambros., p. 12.

${ }^{5}$ Bosio, La Trionfante Croce, p. 146.
} 
Jeremy Taylor recommends as discipline in overcoming lust and inordinate desires, "painful postures in prayer, reciting our devotions with our arms extended at full length, like Moses praying against Amalek, or our blessed Saviour hanging upon his painful bed of sorrows, the Cross." "

Besides the primary meaning of the cruciform posture, there was also another intimated.

Origen. Origen says the lifting up of the arms was to represent the lifting up of their hearts to God; and Chrysostom makes use of the same idea in expounding Psalm cxli., 2, " Let the lifting up of my hands be as the evening sacrifice." "What means," says he, "the stretching forth

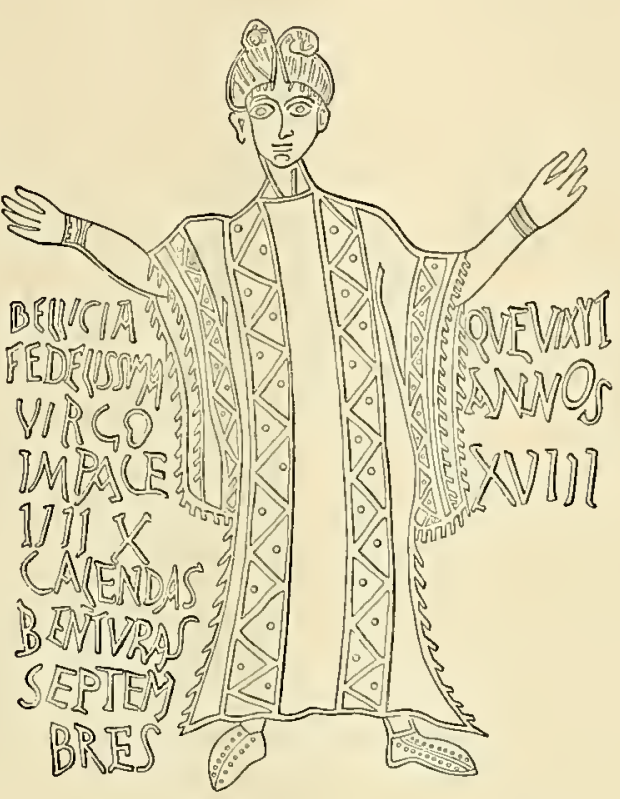

The Cross as a Posture in Prayer.

From Maitland's Church in the Catacombs. our hands in prayer? Because they are instrumental in all sorts of wickedness . . . so external symbols should put men in mind of internal purity.",

Section 8. In Signatures.-The sign of the Cross in signature was used for various reasons. First, because of the inability of the parties to write. The clerkly accomplishment of penmanship was lacking in the education of many noblemen. As late as of the Cross in the fourteenth century even, we find that the celebrated Du signatures. Guesclin, Constable of France, could neither read nor write. ${ }^{2}$ The charter of William the Conqueror, preserved in the museum of Rouen, bears his mark. Second, on account of physical disability arising from age or infirmity; as in the case of Eugenius at the Council of Constantinople, A.D. 553, who subscribed by the hand of Paul his deacon. ${ }^{3}$ Third,

'Taylor, Holy' Living, "Of Chastity."

${ }^{2} \mathrm{~S}$. Palaye, Mémoires sur l'Ancienne Chevalerie, lib. ii., p. 82.

${ }^{3}$ Naitland, Dark Ages, p. I3. 
an affectation of dignity, because persons of high official rank chose oftentimes to have their names written by their notaries.

Even as late as the days of Shakespeare most of the great men, according to Blackstone, wrote very badly. Shakespeare makes Hamlet give the reason:

"I once did hold it, as our statists do, A baseness to write fair, and labor'd much How to forget that learning." :

" But the sign of the Cross," says Maitland, was " usual for those who could write," being, " in fact, the confirmation and signature, and the subscriber, in thus inaking the sign of his holy religion, was considered as taking an oath. He was, in fact, said manu jurare, ${ }^{2}$ and for greater

\section{Wine of the} Eucharist $\mathrm{Min}$ gled with Ink. solemnity the Cross was made with the consecrated wine" mingled with the ink. The Patriarch Ignatius thus subscribed to the acts of the eighth Council of Constantinople, A.D. S70; an earlier example was given by Pope Theodore $1 .{ }^{9}$ and it is said the same profanity was practised in signing the false peace between Charles the Bold and Bernard, Count of Toulouse, in the ninth century.

In early Saxon legal instruments, sigillum is used to signify the sign of the Cross. In their charters the words occur, "sigmum s' $a$ " or " sancSigillum, i.e., the tissime crucis ct acxillum," as synonymous with sigillum, Sign of the Cross. and the sign alone was frequently used."

So little regard was had for a simple promise, or oath, that the presence of sacred relics or the Cross, was necessary to ensure the Oath upon Reli- fidelity of the contracting parties. In the seventh century, quary Crosses. when Elwin of Burgundy desired to entrap Martin, Duke of Austrasia, two bishops were sent bearing the royal reliquaries; upon them they swore that his life should be safe. But the relic had been removed from the caskets, hence the murder of the Duke was held to be only a venial sin. ${ }^{5}$ About 680, Theodore was Archbishop of Canterbury,

1 Hamlet, act, v., sc. 2.

2 Ducange, Glossary, "Crux" ; Maitland, Dark Ages, p. I4.

${ }^{3}$ Flenry, Eccles. Hist., lib. 51, sec. 45 . Fleury reverently says he trembled while recording the fact.

4. Archaologia, vol. x., pp. 232, 234. So in the charter of King Eadred, Wulfstan, Archbishop of York, nses the words, "Sigillum Sanctissima Crucis impressi," meaning, not the impression in wax, but the sign in ink. Ibid.

${ }^{5}$ Lea, Superstition and Force, p. 23. 


\section{The Sign of the Cross}

whose Pcnitintial is one of the oldest that has reached us, and this venerable code of morality assumes that a perjury committed on a consecrated cross, requires for absolution three times the penance needful in cases in which the oath had been administered on an unconsecrated one.

When Andronicus II. of Constantinople, in I333, resigned in favor of his grandson Andronicus III., he pledged himself never to reassume his power. He was blind through infirmity, and for that, or some other reason, used the sign of the Cross. In his double capacity Double crosses as Emperor and monk, he made a red cross for the first for Two Digdignity, and a black one for the second. ${ }^{2}$

Among the ancient forms of conveyance in England was that by the gift of a knife, chalice, ring, walking staff, or a cross. William de Albini, on founding the Priory of Wymondham in Norfolk, gave the whole town of Happisburgh, confirming the grant at the burial of his wife, Maud, by delivering a reliquary cross

Gift of a Cross in Conveying Property. of silver. ${ }^{3}$ King Edgar confirmed a grant to a monastery by cutting asunder a crosier of ivory and gold, and depositing it upon the altar.

Many of the Puritans who had occasion to " make their mark" in consequence of their " ignorance of letters," were scrupulous in making the sign in a defective manner, thus, $\vdash$, or $T$, to show their abhorrence of popery.

Puritan Malformation of the Cross.

\section{Section 9. In Touching for the King's Evil.-French and Eng-} lish mediæval historians claim for their respective sovereigns the supernatural power of healing scrofula by the touch. its Origin. Thomas Aquinas asserts that Clovis I., A.D. $48 \mathrm{I},{ }^{5}$ was the first that

1 Theodori Cantuar Panit., cap. xxiv., sec. 2, quoted in Lea, Superstition and Force, p. 23. Theodore also ordered that if the ministration of a priest had not been employed, the oath was void and no penalty was to be inflicted for its violation.

"Doran, Monarchs Retired from Business, vol. ii., p. 88.

3 Archceologia, vol, xvii., p. 317. Many of the tenures of property in England are dependent upon the performance of ceremonies which appear strange in this age, but conveyed their lesson in ruder yet more pious times. At Caistor, on Palm Sunday, a man holds over the priest's hear a whip with a leathern purse at the end containing thirty pieces of silver, signifying the price of blood paid to Judas, and four pieces of witch-elm tied upon the Cross to typify the Gospel. During the reading of the first lesson the whip is cracked three times in the porch to commemorate S. Peter's denial, and during the second lesson it is waved thrice over the head of the reader in honor of the Holy Trinity. Upon the performance of this ceremony the tenure of Hundon Manse depends, Walcott, Sacred Archaology, "Palm Sunday."

"Brady, Clavis Calendaria, vol. j., p. 334.

${ }^{5}$ S. Favoul, Du Pouvoir que les Rois de France ont de guérir ces Écrouelles, 1633. 
exercised this miraculous virtue. So also does Andrew Favine," and Laurentius, ${ }^{2}$ first physician to Henry IV. of France. The last, however, says that S. Louis, A.D. BI4, added to the words in use from the time of Clovis, "The King toucheth thee, but God healeth thee," the sign of Edward the the Cross. Stow says that the practice originated in the Confessor. kindness of Edward the Confessor, IO4I, who complied with the request of a young woman, who dreamed that she was healed by the laying on of royal hands. The King bathed the tumors with warm water till they broke and then signed the Cross, and the cure was effected within a week. Some antiquaries think that tactual healing came in Plantagenets first
Cured King's with the Plantagenets who confined their pretensions to curEvil. ing only the cramp, and that the Stuarts were the first who Elizabeth. claimed to heal the King's Evil. ${ }^{3}$ Elizabeth seldom used the ceremony, although William Tooker, a doctor of Theology, wrote a work, which was dedicated to the Queen, maintaining the sanitary power of the royal touch." Laurentius states that he had tried to see Tooker's book, but in vain. He had heard that there were many absurd things in it, among others, that the French kings had received the power of healing from the English, etc. The contrary was maintained by others, who asserted that the sovereign of England never possessed this power, but as a king of France, who ever had such a gift from God. The kings of England first ventured to exercise this power when they, upwards of two centuries and a half ago, had possession of nearly the whole of France, and when Henry VI. was crowned at Paris as Henry Vi. and James 1 . Claimed $\mathrm{King}$ of France, December I7, I 431.

the Power. To James I. the ceremony of healing was distasteful, Shakespeare's yet perhaps in compliment to him Shakespeare inserted the compliment.

Malcolm. Comes the king forth, I pray you?

Doctor. Ay, sir; there are a crew of wretched souls

That stay his cure: their malady convinces

The great assay of art ; but at his touch-

${ }^{1}$ Favine, Theatre of Honour, vol. i., pp. $153,1623$.

- Laurentius, De Mirabile Strumas Sanandi vi, Salis Gallia Regibeis Christianissimis divinitus coucessa, Paris, 1609. An engraving in this volume represents Henry IV. touching the patients, who are kneeling in the open air.

${ }^{3}$ Grose and Astle, Antiq. Repertory, vol. iv., p. 320.

+ It was entitled, Charisma sive donum sanctorious seu explicatis totius quastionis de curatione struma cui Reges Anglie rite inaugrati divinitus medicato sunt, etc, 1597. 
Such sanctity hath heaven given his handThey presently amend.

Macduff. What 's the disease he means? Malcolm. $\quad T$ is called the evil;

A most miraculous work in this good king: Which often, since my here remain in England, I have seen him do. How he solicits heaven, Himself best knows: but strangely-visited people, All swol'n and ulcerous, pitiful to the eye, The mere despair of surgery, he cures, Hanging a golden stamp about their necks, Put on with holy prayers: and 't is spoken To the succeeding royalty he leaves

The healing benediction.

- Macbeth, act. iv., sc. 3 .

The usurper Cromwell tried to exercise this royal power, but in vain. ${ }^{1}$

Advocates for the divine rights of kings will probably

Cromwell Wanting in the Miraculous Power. class this supernatural power among them. Certainly, it cannot owe its virtue to any personal holiness in the royal leech, for Charles II. exceeded his predecessors in the number of his patients. During the period from his restoration to his death, he touched nearly one hundred thousand persons, and the royal physician, Dr. Wiseman, certifies that nearly all were cured " ; and in ten years $£ 6000$ were expended in " touch pieces," or medals. Evelyn, in 1684 , mentions that the concourse was so great on one occasion that six or seven persons were crushed to death. In the same year Thomas Mousewell was tried for high treason because he spoke with contempt of the pretensions of King Charles to cure.

William III. refused to touch, and when solicited, bade his chamberlain "Give the poor creatures some money and send them away." Once he yielded to the supplications of a poor wretch and laid his hand upon him, saying, "God give thee better health and fused to Touch. more sense." The practice, however, was not laid aside even as late as

'Forsyth, Antiquarian's Portfolio, vol. ii., pp. I79, I8I.

${ }^{2}$ A public record was kept at Whitehall. The actual number "stroked" was 92,107. N. A. Rev., July, I84i, p. 276 . J. C. Jeafferson, Book about the Clergy, vol. i., p. I64, note. In 1662 a proclamation was set forth "For the better ordering of those who repair to the Court for cure of the disease called the King's Evil, wherein his Majesty, being as ready and willing to relieve the necessities and diseases of his good subjects by his sacred touch, which shall come for care, as any of his royal predecessors, in which, by the grace and blessing of God, he hath in an extraordinary measure had good success," etc. 
the time of Queen Anne, for Dr. Johnson relates that, in 1712, when he was three years old, he was brought before her Majesty, and the "touch piece" which she suspended from his neck is said Queen Anne Touched Dr. to be still preserved in the British Museum. ${ }^{1}$ There also may Johnson.

be seen the first form of service, said to be that drawn up in the time of Henry VII. It is also in the Books of Common Prayer in the reign of Charles I., Charles II., James II., and Anne. Form of Service. As these vary, it would seem that a new form was composed for each sovereign. The Gospel read was S. Mark xvi., beginning at verse I4. At the words, " They shall lay their hands on the sick, and they shall recover," the rubric directs, "Here the infirm persons are presented to the King on their knees, and the King lays his hand upon them." Instead of the epistle, another Gospel is read, S. John i., 2, and at the words, " that light was the true light," they are again presented, and the King puts about their necks a piece of gold, or a medal bearing S. Michael. ${ }^{2}$

The times appointed were from the Feast of All Saints to a week before Christmas, and in the month before Easter; but they were not strictly adhered to, for there were quarterly, monthly, and probably other opportunities afforded the sufferers to come and be healed.

Section I0. Power of the Sign over Devils.-It is recorded of Julian the Apostate, that when he flung aside the fear of the true God, Use of the Sign by Julian the he sought out magicians, but being frightened at the sight of the devils evoked, the Emperor made the sign of the Apostate.

Cross. The demons, recognizing the sign of their victor, and acknowledging its power, vanished; but it was long before the flatteries and sophistry of the magicians calmed the agitation and fears of Julian. ${ }^{3}$ The story is told in simple faith by the historian of the Church, but it was doubtless long before his day that, in the treatment sign of the Cross of demoniacs in the early Church, prayer was esteemed of Used over De- great efficacy together with the sign of the Cross. True, as moniacs.

Hagenbach remarks, that which " was at first nothing more than a symbol of the power of faith itself, became afterwards a mechanical opus operatum," but not such was the opinion of S. Cyril, who

1 Rye, England as Seen by Foreigners, p. 277.

${ }^{2}$ Kennel, Register, p. 73I, quoted in Fierurgia Anglicana, p. 203.

3 Theodoret, Eccles. Hist., bk. iii., chap. iii. 
ascribed all power to Christ, not to the Cross," " since," he says, "its grace is from God," adding: "It is the sign of the faithful, and the dread of devils: for He has triumphed over them in it, having made a show of them openly; for when they see the Cross,

S. Cyri1. they are reminded of the Crucified, they are afraid of Him who hath bruised the head of the dragon. Despise not the seal, because of the freeness of the gift; but for this the rather honor thy Benefactor." a

Tradition also gives the power of casting out demons by this sign to S. Gregory

Nazianzen, ${ }^{3}$ and

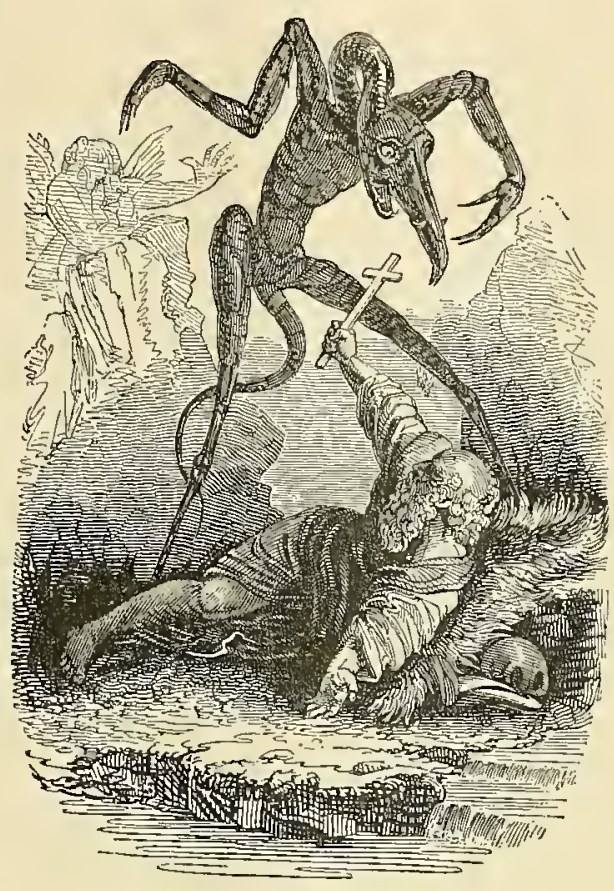

Power of the Cross over Devils.

From Holland's Cruciana. of the incantation of devils, let only the sign of the Cross, which the Gentiles ridicule, be used; let Christ be merely named, and the devils will instantly be put to flight, the oracles be silent, and all the arts of magic be reduced to nothing." "s

Lactantius declares, "As Christ whilst he lived among men put devils to flight by His word, restored those to their right mind whom these evil spirits possessed, so now his followers, in the name of their Master, and by the sign of His Passion, exercise the

Lactantius. same dominion over them. The proof is evident: when the idolators

1 Hagenbach, History of Doctrines, vol. i., p. I50. "The poem of Severus, Sanctus Endelechius, de mortibus bonum, contains a lively description of the supernatural efficacy of the sign of the Cross against demoniacal infuences, even in references to the animal kingdom." rbid., p. 375 .

"Cyril, Catechetical Lectures, xiii., 39. p. I62.

${ }^{3}$ Fleury, Eccles. Hist., p. 578 , xiii., ix.

+ L'Estrange, Alliance, p. 372.

${ }^{5} \mathrm{~S}$. Athanasius, quoted in Haslam, The Cross and the Serpent, p. 210. 
sacrifice to their gods, they cannot proceed if a Christian, being present, make the sign of the Cross, nor can the diviner give his responses. This often has been the cause of persecutions which we have undergone." 1

The ancient Church in her form of Exorcism in the Office of Baptism recognized the power of the sign over the devil. The liturgies of the Eastern Church still remind us of this : $e x . g r$, in that of

Exorcism with the Sign of the Cross.

Constantinople, Satan is bid to "Depart, and retreat from this newly chosen, and cross signed, soldier of Christ our

God.", 2

${ }^{1}$ Lactantius, quoted in Haslam, The Cross and the Serpent, p. 2 1o.

2 Neale, Hist. of the Eastern Church, Introduction, p. 959. The Northern mythological traditions abound in tales of the belief of the simple people in the power of the Cross ever over the beings which they believed were intermediate between the supernatural world and ours. There is not room to introduce such stories in the text, besides, such mere superstition ought not to be brought in connection with the earnest faith of our forefathers. As a specimen we quote the following Danish tradition. Even the elfish world is fettered by the Cross, if only accidentally made. Near Arnhuus, in Denmark, as a smith was going to church, he saw a Troll sitting on a heap of coals by the wayside, and busied with two straws which by chance had fallen across the heap. The Troll begged the smith to take them away, but he, suspecting the truth of the case, took possession, paying no attention to the outcries of the poor little defrauded elf. Of course, when he reached home, the dishonest Christian was rewarded with a heap of treasure instead of cinders. Trolls cannot pronounce the word Cross, but call it "here and there." Thorpe, Northern Nythology, pp. I 52, 275. 


\section{CHAPTER X}

\section{PURITAN OPPOSITION TO THE CROSS}

" NORE in sorrow than in anger," is this part of the subject 1 treated. Yet the history of the Cross, without it, would be incomplete. Like many errors recorded in the history of Christianity, this arose from men's being " righteous over Opponents of the much," the opponents of the Cross being among those who Cross. in all ages of the Church have claimed to be more holy, more pure, than their fellow-Christians; hence we are compelled for the sake of truth and uniformity to class all objectors to the use of the Cross under the title adopted by their later followers as Puritans.

It is not worth while noting all the sects who have erred in this matter; most of them are now forgotten, but it is significant that those especially distinguished for their opposition in the seventh, tenth, and twelfth centuries, were doctrinal descendants of the Manichæans, hence it is not surprising that those who were heretical in their belief in the blessed Saviour Himself, should despise His Cross. Prob-

ably the first who rejected the Cross were the Ascodrutes, First who Rejectan obscure sect of heretics in the second century, who rejected sacraments and symbols under the pretence of a purely spiritual religion, and held that perfect knowledge was their redemption.'

In the middle of the seventh century arose the sect of the Paulicians, who amongst other errors, held that the Creator of the Vorld was not the Supreme God; that the soul of man, " originally vilth Century; wedded to Divinity itself, had been seduced into union the Paulicians. with the body where she dwelt in doleful prison." Her deliverance was the work of the Redeemer, who brought His body from Heaven, hence

${ }^{1}$ Bingham, Antiquities, bk. xi., chap. ii., sec. I. 
His suffering and Passion were only in appearance, and they loaded the Cross with contumely, considering it only a sign of malediction. Yet some of them made use of a wooden cross with superstitious intent. They also held that Baptism was only of the spirit, and rejected the Lord's Supper and the Old Testament. ${ }^{1}$

Passing over the intervening time we find that by the ninth century the ceremonies of the Church had greatly increased. Then Claudius, IXth Century. Bishop of Turin from 82 i to 839 , in his zeal for reformation, excluded from the churches ali symbols, whether pictures, images, or crosses, which could possibly give rise to adoration. ${ }^{2}$

About a hundred years before, Leo the Isaurian, influenced, it is said, by the invectives of the Jews and Mohammedans, had proscribed all images and pictures, with the sole exception of the Cross. He even erected one in his own palace in place of a figure of our Lord which he removed. ${ }^{3}$

In the eleventh century there lived one Gundulf, who denied the cross to be more holy than any other wood, and refused it any honor.

X1th Century.

His followers treated churches with irreverence, rejected altars, holy sacraments, and holy orders, and would not tolerate bells or chanting. In the early part of the twelfth century a Bogomiles. Sect arose in Bulgaria, known as the Bogomiles, or the Masxilth Century. silians. The leading tenets are given to show in what category to class the haters of the Cross. Their theological system, which was quasi-dualistic, centred, so to speak, in the person of a superhuman being, the first-born Son of God, holding a second place in the government of the world, a distorted image of the Prince of Evil called Sataneal. He seduced the mother of the human race, and became the father of Cain. He also deluded Moses, and through him the Jews, hence the ii., $v$.

${ }^{1}$ Hardwick, Hist. of the Christian Church in the Middle Ages, p. 80; Mosheim, iii., ix.,

"Hardwick, Hist. of the Christ. Church in the Middle Ages, p. I7o. The iconoclastic controversy was commenced by Philippicus Bardanes, Emperor of the Greeks, A.D. 7I2. Masheim, iii., viii., ii., iii., 9. Although Leo, from the prominence of the controversy in his time, is generally considered as its originator. Four centuries before, Epiphanins, Bishop of Constantia in Cyprus, when passing through Anablatha, a village in Palestine, tore down a veil on which was painted a figure of Christ, or some saint, he did not recollect which, and bade the guardians of the church to make a shroud of it for some poor man. Bingham, Antiquities, bk. viii., chap. viii., sec. 6 .

${ }^{3}$ Hardwick, Hist. of the Christ. Charch, etc., p. 78.

4 Mosheim, iii., xi., ii., v., 4. Their doctrines resembled those revived by the modern Quakers. 
Bogomiles had no reverence for the Pentateuch. Their views of the second and third Persons of the Holy Trinity were heretical.

They considered the Church as anti-Christian, and as ruled by fallen angels, and that none save those who professed their own creed and communion could attain salvation as true followers of Christ. Hating the Mosaic code and ritual, they of course despised the ceremonies of the Church, and rejected Baptism, save that which they pretended to be of the Holy Ghost. They refused the title of Thcotakos to the blessed Virgin, assuming the ground that it properly belonged to every holy soul, and not peculiarly to her who, they say, was unconscious even of the Saviour's birth; they abhorrcd the symbol of the Cross, and held in high admiration Constantine Copronymus, whose impiety and cruelty were only equalled by his hatred of art, and his support of the Iconoclasts. ${ }^{\prime}$

The Western sects of Bulgri, Cathari (i. $\epsilon$., pure), Boni Homines (good men), and Albigenses stood in relations, more or less immediate, with the Bogomiles, and holding certain points in common with Paulianus and the Manichaans proper, among others that

Sects in XIIth Century. of hating the Cross. The Petrobrusiani appear to have been of a better character. They confessed the main truths of Christianity, and sought to raise the tone of morals, yet they rejected Infant Baptism, undervalued the Eucharist, denounced Church music and ritual, and burned the crosses. ${ }^{2}$

Of course the Cross could not escape the ill-directed zeal of the Reformation. Luther himself saw no evil in the Cross. In his translation of the Bible, published in 1524 , there is Luther's Use of the Crass. a cross with an angel adoring it. On the title-page of his works edited by Melanchthon, Luther is represented on his knees before a crucifix. His adopted coat of arms was a cross upon a heart upon a rose; the holiest

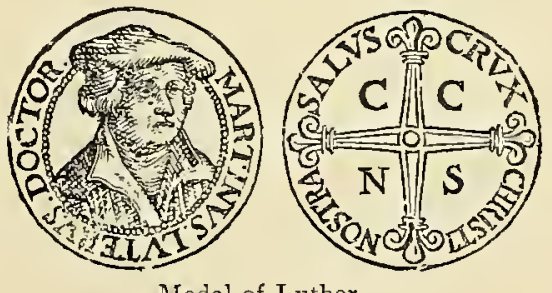

Medal of Luther.

From Gretser's De Sancta Cruce. of symbols and the most beautiful of flowers enshrined in the human sanctuary. And the ring with which he wedded Catharine Bora (or de

${ }^{1}$ Hardwick, Hist. of the Christ. Church, etc., p. 306.

${ }^{2}$ Ibid. p. 3 Io. 
Boren) was adorned with a crucifix and the instruments of our Lord's Passion. He rebuked Carlstadt's intemperate zeal in demolishing altars and crucifixes. And yet to the fanaticism of those who claim to be

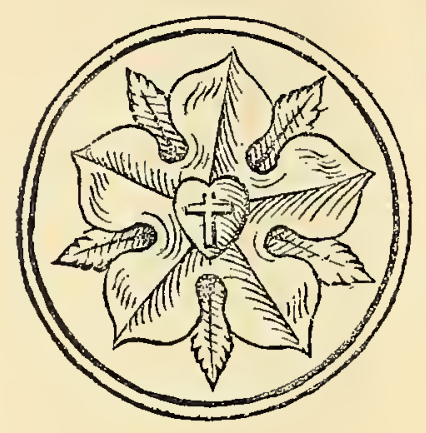

Coat of Arms of Luther.

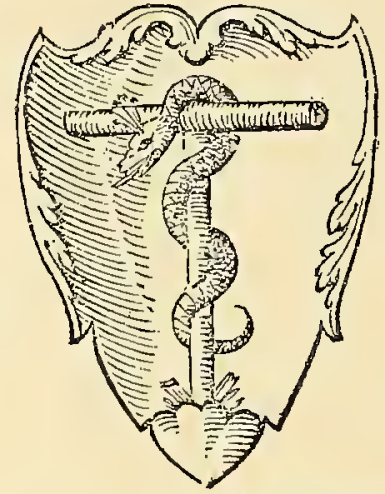

Coat of Arms of Melanchthon.

his followers we owe much of the destruction of crosses, wayside and sanctuary, churchyard, memorial, and altar, and even the precious gems of manuscript art.

It was reserved, however, for the $\mathrm{Pu}$ ritans in England to "out-Herod Herod" in impiety and sacrilege. In the time of King Puritans in England. James they objected to the use of the sign of the Cross in Holy Baptism. Yet at the Hampton Court Conference, Dr. Reynolds, one of their chiefest representatives, overcome by arguments for its antiquity and fitness, acknowledged that he would nevermore gainsay the ceremony. ${ }^{1}$

The English reformers were in correspondence with the Continental, and Bucer confessed that he could find nothing indecent in the sign of Bucer's Opinion. the Cross in Baptism " if it were used with a pure mind." He disapproved of directing the form that was used in imposing it on the child itself, who could not understand it. For which

'L'Estrange, Alliance, p 373. Although everyone knows what were the things objected to by the Puritans, still it is well, in this country where they are, if not literally canonized, yet worshipped as saints, to rehearse a few of them. They objected to kneeling at the Lord's Supper, to bowing at the name of Jesus, to the observance of saints' days and of Lent, to the use of sponsors at baptism, nnless the parents were dead or in a distant country; to the answers of sponsors in the name of the child instead of their own ; to the use of the surplice, of the ring in marriage; to the churching of women, the frequency of the Lord's Prayer, etc. Some objected to the Lord's Prayer because it was Fewish. True, every word is from Jewish liturgies; see authorities elsewhere. These are only some of the ghosts of stumbling-blocks conjured up by the Puritans. As a slight specimen of "Puritan Insolence" (the words are Southey's, not ours) we quote the following: "I629. The Lady Laurence, for turning up the buttocks of a child at the font, when the Plaintiff would and should have signed it with the sign of the Cross, which was proved, but not charged by the Bill, was recommended to the High Commission Court."-Rushworth, part ii., vol. ii., appendix, p. 27 ; quoted in Southey, Common Place Book, ser. i., p. 2 r. 


\section{Puritan Opposition to the Cross}

reason he wished it might be turned into a praycr. " In my opinion," saith he, "the use of it is neither unseemly nor unprofitable." "

But what weight the objections of the Continental reformers had upon the British, we can judge from the following:

In I 559, Bishop Cox writes to Peter Martyr: " Respecting our affairs what shall I write? All those heads of religion are restored to us which we maintained in the time of King Edward. We are only constrained to great distress of mind to tolerate in our

Bishop Cox's Opposition. churches the image ${ }^{2}$ of Him, who was crucified. The Lord must be entreated that this stumbling-block may be removed."

Again in the same year Bishop Jewell, a holy man whose amiability led him to look too kindly on the Puritans, writes to the same Peter Martyr: "That little silver cross " of ill-omened Bishop Jewell. origin, still maintains itself in the Queen's [Elizabeth's] Chapel. Wretched me! this thing will soon be drawn into a pre- cross in Queen's cedent. There was at one time some hope of its being chapel. removed, and we all of us diligently exerted ourselves and still continue that it might be so. But as far as I can perceive, it is now a hopeless case." 4

During the next eleven years the Cross was several times removed from, and restored to, this altar. ${ }^{5}$

Archbishop Laud placed a cross upon the altar of Westminster, at the coronation of Charles I., I625. When that was removed, we know not. Its fate may be judged from that placed years before upon the altar at Whitehall, which was at last broken by Pach, the court fool, " when no wiser man," says Heylin, " could be got to do it." "

No country has shown its enmity to the Cross more persistently than Scotland. In May, I559, an attack was made by a Protestant mob against a Carthusian monastery in Perth, during which a Aversion to the large cross was torn up, and used as a battering-ram against crossin Scotland. the gates. ${ }^{7}$ The same spirit was shown in 1850 , when a building com-

1 Bucer, Opus ang., p. 479 ; Wheatley on Common Prayer, chap. vii., sec, I, P. I I I.

2 Zürich Litters, Ist ser., xxviii., p. 66.

It was not simply a cross, but a crucifix, and was objected to by Archbishop Parker. Life of Parker, p. 49 .

4 Zïrich Letters, 1 st ser., xxiv., p. 55.

5 See Appendix for account of dispute of Parker and Cox, and Grindal and Jewell.

- Heylin, Life of Archbishop Laud, p. It (ed. 1638).

"Lawson, Hist. of the Reformation, p. 195. 
mittee to whom was entrusted the care of erecting a place of worship as a memorial of John Knox, objected to the plan presented because a cross appeared; which symbol, they said, the pious reformer would have abhorred.

To illustrate the bitter hatred of the Puritans to the Church, and everything tending to glorify and symbolize the divine truths of her worship, would carry us beyond our limits. A few specimens will suffice, and we have not patience to give more.

William Dowsing of Stratford was Parliamentary visitor appointed, under a warrant from the Earl of Manchester, to demolish the superExtracts from William Dow. sing's Journal.

stitious pictures and ornaments of churches, etc., within the county of Suffolk in the years $1643-1644$. Selecting at random from over one hundred and fifty instances in his journal, we read: "At Clare the 6 th We brake down one thousand pictures superstitious; I brake down two hundred; three of God the Father, and three of Christ, and the Holy Lamb; and three of the Holy Ghost like a dove with wings; and the twelve apostles were carved in wood on the top of the roof, which we gave order to take down; and twenty cherubims to be taken down, and the sun and moon in the east window by the king's arms, to be taken down.

"Barham Jan the 22nd. We brake down the twelve apostles in the chancel, and six superstitious more there; and eight in the church, one a lamb with a cross $X$ on the back; and digged down the steps; and took up four superstitious inscriptions of brass one of them 7 esu, Fili, Dci, miserere mei, and $O$ mater Dci, memcnto mci, $O$ mother of God, have mercy on me!'

"Copdock 29th. I brake down one hundred and fifty superstitious pictures; two of God the Father, and two crucifixes; did deface a cross on the font, and gave order to take down a stoneing cross on the chancel, and to levell the steps; and took up a brass inscription, with ora pro nobis and cujus anima propitictur Dcus.

"Woolpit Feb 29th. My Deputy. Eighty superstitious pictures; some he brake down, and the rest he gave order to take down; and eight crosses to be taken down in twenty days.

“ Beccles, April 5th. He destroyed by the altar, " My meat is flesh indeed, and my blood is drink indeed," and thirteen crosses in all, and Jesus and Mary in letters and the twelve apostles. 
"Ofton Aug. 22nd. There was a holy water font in the chancel, and the steps, and some crosses on the outside of the church and chancel; and we gave order to deface them. We gave order to have them all defaced, and two more in a window of the church, and two stone crosses on the top of the steeple: all which we gave order to mend all the defaults by Saturday come se'nnight. At Ipswich at Mr. Coley's."

The very name of JEsus as well as His symbol was an offence unto them, for at Benacre, April the 6th, among other superstitious things " eighteen JEsuses written in capital letters on the roof" were ordered to be defaced. On the same day at Cochie, Jesus Destroyed. "There were many inscriptions of JEsus in capital letters on the roof of the church, and cherubims, with crosses on their breasts, and a cross in the chancel, all which with divers pictures in the windows, which we could not reach, neither would they help us raise the ladders, all which we left a warrant with the constable to do in fourteen days."

Upford, January $27^{t h}$, was visited, and thirty superstitious pictures and six brasses were broken and directions given that thirty-seven more and forty cherubim were to be destroyed. On August 3ist, the vandals again visited the church, and described in pitiable words the misery they suffered by the perverse churchwardens, who would not find the key and kept them two hours waiting. But Puritan patience was rewarded; twelve more cherubim and above a hundred representations of Jesus and Mary, and a crosier staff in glass, and a font cover, which these barbarians described as "glorious," with a pelican picking its breast on the top, " all gilt with gold," were destroyed, besides an angel and the Trinity. The organ case was broken and given to the poor.

No opportunity for showing their hatred of the sacred symbol was ever allowed to pass unimproved by the Puritans, as may be seen in the literature of the time.

The Cross was formerly placed at the beginning of the horn-books, hence the line of alphabet was called Christ's

Cross in HornBooks. Cross row.

"The very children ere they scarce can say

Their pater noster, or their Christ's Cross A,"

were taught to speak of it as a spot. Sir John Birkenhead likewise banters these Precisians. "An act for removing the alphabet Cross

${ }^{1}$ Poem in Praise of Sack, Tatham Francis Theatre, I6 40. 
from the children's primer, and the Cross from off the Speaker's Mace, and for adding S. Andrew's cross to S. George's in the State's Arms." objections Ridi- Again, "Resolved, etc., that all crosses were due to the culed by Birken- state, and therefore all coin that is stamped with superhead.

stitious kind of idolatry is confiscated by modern laws to the devil's melting pans." '

Richard Flecknoe, in his Enigmatical Characters, ${ }^{2}$ speaking of " your fanatick reformers," says, " Had they their wills, a bird would not fly in the air, with its wings across, a ship with its cross-yard sail upon the sea, nor prophane taylor sit cross-legged on his shop-board, or have crossbuttons to wind his thread upon." Again he gives us the following:

\section{"On Fanaticks or Cross Haters.}

"Who will not be baptized, onely because

In Baptism they make the sign o' th' Cross, Shewing, the whilst, how well the Devil and he, In loving of the signe o' th' Cross, agree.

Seeing how every one in swimming does

Stretch forth their arms, and make the sign o' th' Cross, Were he to swim, rather than make (I think)

The signe o' th' Cross, he 'd sooner chuse to sink."

These foolish whims are still further exhibited by Dr. Grey, the worthy annotator of Hudibras. He quotes from several works of the time. ${ }^{3}$ The hypocritical preciseness of those times is humorously cnough bantered by an anonymous writer or two, who were contemporary. The first is a dialogue between the Cross in Chcap and Charing Cross. "Cheap. I must tell you sister, I am accused for a Papist, and not thought fit to have any abiding in the Heart of the City; I am called and preached against by the name of the City Idol. The Brownists spit at me as they come along; the Fanilists hide their eyes with their fingers, the Anabaptists wishes me knocked in a thousand Pieces. The Sisters of the Fraternity will not come near me, but get about by walling street, and come in again by Bow Lane, to buy their Markets of the Country Women. They so extremely hate the cross, that they hate everything

${ }^{1}$ Grey's Notes to Hudibras on his famons lines,

"And some against all idolizing

The Cross in shop-hooks, or baptizing."

28 vo, London, I 665, p. $\varsigma_{3}$

Pt. iii., canto 2, bk. 3I5.

${ }^{3}$ Grey, Examination of the third vol. of Neal's History of the Puritans pp. 80-52. 
that maketh a show or carrieth the resemblance of a cross. This last Week a Broker's wife of Hounditch beat her Maid pitifully for laying, as she made her master's Bed, by chance, two bed-staves across. And another, a Parish Clark, a petty School-master, would not suffer a Christ's-Cross in any Hornbook, but cut them all out, and rubbed over the place with Chalk and Butter."

Again (p. 5), "Some think it very fit that we and our Children should be again baptized because we were signed with the Sign of the Cross.

"There is one Cross in London, a very honest man a Taylor, who very much fears that he must change his Name, and so malie himself no better than a Rogue by the Statute.

" Two Broanists as they came along, were overheard by the Drawer at the Thrce Tuns to affirm, that the very name of Cross ought utterly to be abolished, and not so much as to be named in or about any Thing. As if your Maid be bid to mend the fire, you must not say to her Lay those Sticks across, nor may a Dancer once name a Cross caper, nor if any misfortune befal you, must you say, I an crosscd in mind, nor must a Tradesman say to his Prentice, Cross the Book, nor must a Country Taylor be said to sit cross-legged, but Andrew wise, nor must say I will cross the street, but overthwart it."' 1

And another about the same time says, " If we break down sorry half headed Croslets, in our Church-Yards and High-ways, for fear of the worst, with what courage should we (with the valiant and zealous Don Quixote) set upon these Giantly Champions of superstition ? Since we may boldly say, That no old Pimmer or Horn Book, no Book of Popish Massing or Conjuring, hath in it a more exact Form of that great Idol than the common Windmill hath.

"Well fare a good sister of ours who would not suffer the little ones to name that Idol in her first lesson, but taught them to say Black Spot,

${ }^{1}$ In a merry pamphlet, entitled, New Ordios New, agreed upon by the Parliament of Roundheads, confirmed by the Brethren of the new Separation, assembled at Roundhead-Hall without Cripplegate, with the great Direction of Master Long Breath an upright new inspired Cobler Speaker of the House. Avowed by Ananias Dulman, alias Prick-ears cler parl. Round London, printed for T. V., 1642 (penes me), are the following words: "5. That we have no crosses, for they are meer Popery, and tend to the confusion and opposition of Scripture. Especially let the sight of Cheap-side Cross be a detestation unto you all, and let these streets, that are called crosses as Red Cross Street and IVhite Cross, S.c., be turned otherwise, and called after the name of some of our own family, as Green Spencer, \&c., and call it rather Green Street, than Red Cros's Street, \&c. That thus all Profaneness being rooted out and extirpated from our Conventions, nothing but holiness may remain amongst us." 
instead of Christ-Cross. And our Brother U. L. the Baker, in detestation of this figure, would not so much as prick his Loaves with a headless Cross, but contented himself with one single motion of his Knife." ,

The "headless cross" $-i$. $e$., a Tau cross-spoken of, refers to the fact that even the use of the Cross by the illiterate in place of their Mutilated Cross signature was rejected; the ignorant signing their mark with in Signature. one of the arms deficient, thus $T$ or 1 instead of $X$, as in earlier times. The Puritans brought their hatred of the Cross to this country, as was shown by the act of Endicott, already alluded to, in publicly cutting out the Cross from the Colonial standard.

${ }^{1}$ A new Wind-Mill a nea', Printed at Oxford, 1643 , penes me, p. 5. A defence of our Ancient and Modern Historians, p. I34. 


\section{CHAPTER XI}

\section{THE SOUTHERN CROSS}

THIS constellation is composed of five stars : one of the first mag1 nitude, two of the second, one of the third, and one of the fourth. They are nearly cruciform in their position, and as the most southerly and most northerly are in line with the south pole, they serve as pointers to the Antarctic, as the pointers in the Great Bear do to the Arctic pole.'

Besides these principal stars, the surrounding parts of the constellation are bright with nebulous clusters, one of which, intermixed with the four stars, occupies one forty-eighth part of a square degree and consists of about one hundred stars, from the seventh magnitude downwards, and the telescope discloses eight of the more conspicuous to be colored with various shades of red, green, and blue, so as to give the whole the appearance of a piece of rich jewelry. But no words can describe it like Humboldt's:

" IVe saw distinctly for the first time the Cross of the South only on the night of the $4^{\text {th }}$ and $5^{\text {th }}$ of July (I799) in the sixteenth degree of lati-

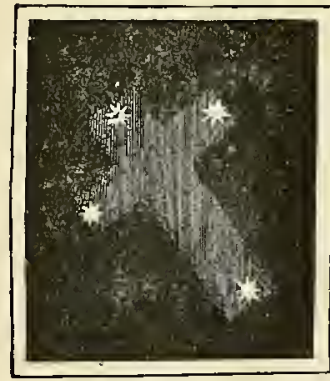

The Southern Cross. From Crowther's The Staryy Cross tude; it was strongly inclined, and appeared from time to time between the clouds, the centre of which, furrowed by uncondensed lightnings, reflected a silver light. If a traveller may be permitted to speak of his personal emotions I shall add, that on this night I saw one of the reveries of my earliest youth accomplished.

"When we begin to fix our eyes on geographical maps, and read the

${ }^{1}$ Herschel, Outlines of Astronomy, p. 597. 
, narratives of navigators, we feel for certain countries and climates a sort of predilection, for which we know not how to account at a more advanced period of life. These impressions, however, exercise a considerable influence over determinations, and from a sort of instinct we endeavor to connect ourselves with objects, on which the mind has long been fixed as by a secret charm. At the period at which I studied the heavens, not with the intention of devoting myself to astronomy, but only to acquire a knowledge of the stars, I was agitated by a fear unknown to those who love a sedentary life. It seemed painful to me to renounce the hope of beholding those beautiful constellations, which border the Southern pole. Impatient to rove in the equinoctial regions, I could not raise my eyes without thinking of the Cross of the South, and without recalling the sublime passage of Dante which the most celebrated commentators have applied to this constellation:

\section{'Io mi iolsi a man destra e poré mente All' Altro polo e vide quatro stelle Non viste mai fuor alla prima gente. \\ ' Godar pariar, lo ciel di lor feammelle; $O$ setten trionel vedoz'o sito Poi prinato se' di mirar quclle!'}

"The pleasure we felt on discovering the Southern Cross was warmly shared by such of the crew as had lived in the colonies. In the solitude of the seas, we hail a star as a friend, from whom we have been long separated. Among the Portuguese and the Spaniards peculiar motives seem to increase this feeling; a religious sentiment attaches them to a constellation the form of which recalls the sign of the faith planted by their ancestors in the deserts of the new world. The two great stars which mark the summit and foot of the Cross having nearly the same right ascension it follows hence, that the constellation is almost perpendicular at the moment when it passes the meridian. This circumstance is known to every nation that lives beyond the tropics, or in the

1 "To the right hand I turned, and fixed my mind Upon the other pole, and saw four stars Ne'er seen before save by the primal people. Rejoicing in their flamelets seemed the heaven, $\mathrm{O}$ thou septentrional and widowed site Because thou art deprived of seeing these."

Longfellow's trans., Purg., canto i., 1. 22. 
Southern Hemisphere. It has been observed at what hour of the night, in different seasons, the Cross of the South is erect, or inclined. It is a time-piece that advances very regularly nearly four minutes a day, and no other group of stars exhibits to the naked eye, an observation of time so easily made. How often have we heard our guides exclaim in the savannahs of Venezuela, or in the desert extending from Lima to Truxillo, 'Midnight is past, the Cross begins to bend!' How often these words remind us of that affecting scene, where Paul and Virginia, seated near the source of the river of Lataniers, conversed together for the last time, and where the old man at the sight of the Southern Cross, warns them that it is time to separate."

"In consequence of the precession of the equinoxes, the starry heavens are continually changing their aspect from every portion of the earth's surface. The early races of mankind beheld in the far North the glorious constellation of our Southern Hemisphere rise before them, which, after remaining long invisible, will again appear in those latitudes after the lapse of thousands of years. . . . The Southern Cross began to become invisible in $52^{\circ} 2 \mathrm{O}^{\prime}$ north latitude 2900 years before our era, since, according to Galle, this constellation might previously have reached an altitude of more than $10^{\circ}$. When it disappeared from the horizon of the countries on the Baltic, the great pyramid of Cheops had already been erected more than five hundred years. The pastoral tribe of Hyksos made their incursion seven hundred years earlier. The past seems to be visibly nearer to us when we connect its measurement with great and memorable events."

"In the fourth century the Christian anchorites in the Thebaid desert might have seen the Cross at an altitude of ten degrees. I doubt, however, whether its designation is due to them. Dante in the celebrated passage of the Purgatorio:

'Io mi volsi a man destra', etc.,

and Amerigo Vespucci, who at the aspect of the starry skies of the South first called to mind this passage on his third voyage, and even boasted that he now 'looked on the four stars never seen till then by any save the first human pair,' were both unacquainted with the denomination of the Southern Cross. Amerigo simply observes, that the four stars form

1 Humboldt, Personal Narrative, vol. ii., p. 20. 
a rhomboidal figure (una mandorla), and this remark was made in the year 1501 . The more frequently the maritime expeditions on the routes opened by Gama and Magellan, round the Cape of Good Hope and through the Pacific, were multiplied, and as Christian missionaries penetrated into the newly discovered tropical land of America, the fame of this constellation continually increased. I find it mentioned first by the Florentine, Andrea Cossali, in 1517, and subsequently, in 1620, by Pigafetta, as a wonderful cross (croce maravigliosa) more glorious than all the constellations in the heavens. The learned Florentine extols Dante's 'prophetic spirit,' as if the great poet had not as much erudition as creative imagination, and as if he had not seen Arabian celestial globes, and conversed with many learned Oriental travellers in Pisa."

Admirably also does this great philosopher expound the teaching of the Italian poet, ${ }^{1}$ so that by the celestial light of the stars we read the interpretation of the luminaries of the Cross and its attendant heralds, Canopus, Achernar, and Fomalhaut, which set when the four stars of the Cross arise. "I have endeavored," he says, "to solve these difficulties " (those of the commentators on Dante respecting the quattro stelle) "by the following considerations. The philosophical and religious mysticism which penetrates and vivifies the grand composition of Dante, assigns to all objects, besides their real or material existence, an ideal one. It seems almost as if we beheld two worlds reflected in one another. The four stars represent in their moral order, the cardinal virtues, Prudence, Justice, Strength and Temperance; and they, therefore, merit the name of the holy lights, luci sante. The three stars which light the pole, represent the theological virtues, Faith, Hope, and Charity. The first of these beings, themselves reveal their double nature, 'We here are Nymphs, and in the Heaven are stars.' Noi sem qui ninfe, e nel cielo sem stelle." "In the land of truth, in the terrestrial paradise there are seven nymphs.' In cerchio faceran di se claustro le sette ninfe. This is the union of all the cardinal and theological virtues. Under these mystic forms, we can scarcely recognize the real objects of the firmament, separated from each other, according to the eternal laws of the celestial mechanism. The product of poetic inspiration."

That Humboldt has interpreted truly, no one can doubt who will

1 The passages which refer to the Cross and the three facelle are Purg., i., 22-24, 37 ; viii., 85-93; xxix., I2I; xxx., 97 ; xxxi., I06; and Infer., xxvi., I17, r27. 2 Purg., xxxi., 106. 
compare the passages to which reference has been made. How beautifully are the three who " here are nymphs but in heaven are stars" set forth in their mystic symbolic colors.

"'Three maidens at the right wheel in a circle

Came onward dancing; one so very red

That in the fire she hardly had been noted.

The second was as if her flesh and bones

Had all been fashioned out of emerald;

The third appeared as snow but newly fallen." 1

There is an old tradition that the Southern Cross was the Advent banner of the old-world explorers. A writer in Blackwood thus alludes to it :

"The rainbow at the flood was not then first created, 'but it was then first selected by preference amongst a multitude of natural signs as yet unappointed, and then first charged with the new function of a message and a ratification to man. Pretty much the same theory, that is, the same way of accounting for the natural existence without disturbing the supernatural functions, may be applied to the great constellation of the other hemisphere, called the Southern Cross. It is viewed popularly in South America, and the southern parts of our Northern Hemisphere, as the great banner or gonfanon held aloft by heaven before the Spanish heralds of the true faith in 1492 . To that superstitious and ignorant race it cost not an effort to suppose that by some synchronizing miracle, the constellation had been then specially called into existence at the very moment when the first Christian procession, bearing a cross in their arms, solemnly stepped on shore from the vessels of christendom.' True we know it was not so, yet "as the glorious cross does really glitter through the silent hours of a vast hemisphere, even they who are not superstitious, may willingly yield to the belief that, as the rainbow was laid in the very elements and necessities of nature, yet still bearing a pre-dedication to a service whicli would not be called for until many ages had passed, so also the mysterious cypher of man's imperishable hopes may have been entwined and enwreathed with the starry heavens from their earliest creation, as a prefiguration, as a silent heraldry of hope through one period, and as a heraidry of gratitude through the other.'" =

${ }^{1}$ Purg., xxix., I2I.

2Blackwood's Magazine, vol. xlvii., p. 555. 


\section{CHAPTER XII}

\section{MISCELLANEOUS}

Section I.-Noteworthy Crosses in History and Nature. Section 2.-Ingenious Crosses. Section 3.-The Cross and Pile. Scction 4.-Good Friday Cross-Buns. Scction 5.-The Crown of Thorns.

T W HEN Margaret, granddaughter of Edmund Ironside, and wife of Malcolm, fled to Scotland, she carried with her among other The Black Rood treasures the celebrated Black Rood. According to Hailes, of Scotland. it was about a palm's length, the figure of ebony, studded with gold, and containing a fragment of the true Cross. Upon her death-bed Margaret embraced and kissed it as long as life remained. Afterwards it is said to have been deposited upon the altar of Dunfermline, where the queen was buried in I093, but it was removed from its shrine to be a consolation to David I. in his last illness in I I 53 .

Frequent mention is made of the relic in after-times. Upon the Black Rood, James Steward of Scotland swore fealty to Edward I. of England, ${ }^{1}$ who brought from Scotland the great charter called the "Ragman Roll," the Black Rood, and the coronation stone, ${ }^{2}$ which, according to tradition, was used as Jacob's pillow and is still placed under the seat of the Coronation Throne of England. It is supposed to have been restored with the Nigh cross. Miss Strickland says it was restored to Scotland in 1327 by Edward III. ${ }^{3}$ They used to be kept with

1 " By his corporal oath taken upon the consecrated body of Christ, and upon the two holy crosses, to wit, the Cross Neytz and the Black Rood and other holy reliques,"-Baronia Anglica, p. 26s.

${ }^{2}$ For a full account of the travels of this stone, see Brady, Clavis Calendaria, vol. ii., p. I63, and Dean Stanley, Hist. of Westminster Abbey.

${ }^{3}$ Query, is this Cross the same as that of S. Neot, upon which Sir Francis Palgrave says the nobles of Scotland swore allegiance? Merchant and Friar, p. I87. S. Neot was the brother of Alfred; his lay name was Athelstan. 
other relics in the treasury of Westminster. We next read of it as being in the possession of David Bruce, who lost both it and his life at the battle of Neville's Cross, Durham, October $18,1346 .^{1}$ It is difficult to keep trace of it longer; perhaps two crosses have been confounded by historians. At Durham a cross was preserved claiming to be the original; but the description differs. This was " a most faire roode, or picture, of our Saviour in silver, called the Black Roode of Scotland, brought out of Holy Rood House by King David Bruce with the picture of Our Lady on the one side, and of our Sariour and S. John on the other side, very richly overwrought in silver, all three having crowns of pure beaten gold of goldsmith's work, with a device to take them off or on." ' Sanderson's description, while agreeing in some points, would make the Cross much too large for the original sacred relic. "Which rood and pictures," he writes, " were richly wrought in silver, and were all smoked black all over, being large pictures of a yard, or five quarters long, and on every one of their heads a crown of pure beaten gold."

There is but little probability of this precious relic being in existence. If it had not disappeared in intestine warfare, the sacrilegious church robbers of Henry VIII. and the Puritans would not have spared what they would have considered a "Nehushtan " of such value. Its sacred repute is alluded to by Sir Walter Scott. Halbert Glendinning, warning Henry Warden against Julian Avenel, says: " Take this advice for your safety, and believe that it is founded upon the usage of this country and its inhabitants. If you can better shift for yourself, go not to the Castle of Avenel, - if you do risk going thither, obtain from him, if possible, his safc-conduct, and beware that he swears it by the Black Rood." 3

There was also another cross, bearing a similar name, the Black Rood of S. Helen's in Abingdon. Popular tradition invests it, like the former, with supernatural power. It was believed that God specially punished perjury when this cross was sworn by. It was made of iron, and buried upon the breast of Cissa,

Black Rood of S. Helen's in Abingdon. uncle to the founder, Herne, of the abbey of Abingdon, and found by the Abbot of Athewold when excavating for the walls of S. Helen's. The

1 Anderson, Scotland in Early Christian Times, ist ser., p. $24 \mathrm{~T}$.

${ }^{2}$ Description of the Ancient Monuments, Rites, and Customs of the Abbey Church at Durham, written in 1593 .

${ }^{3}$ The Monastery, chap. xxiv. 
token upon this sacred symbol was in words nearly similar to the following :

"Among the ornaments of which Phildebert, the son of Clovis, robbed the Church of Toledo when he ravaged Spain in 542, was a

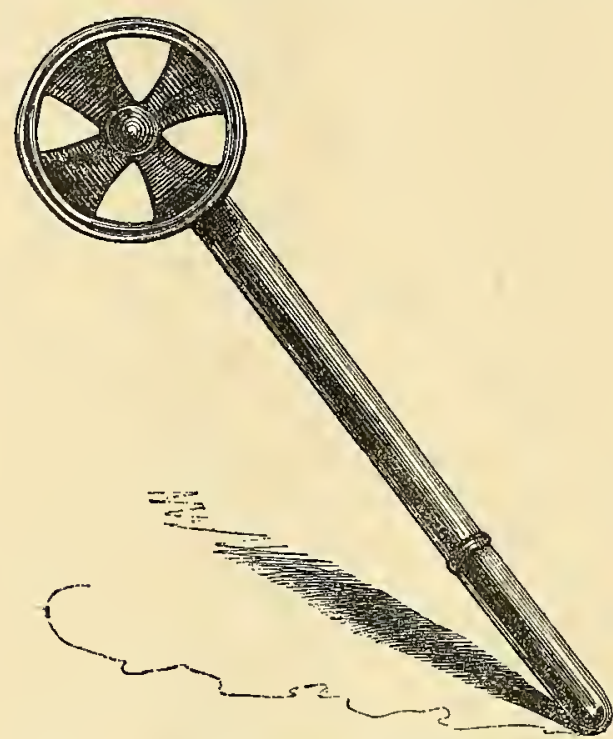

Black Cross of Abingdon. From Palmer and Crowquill's Wanderings of a Pen and Pencil. magnificent cross enriched with Cross of Toledo. wrought gems, which," so said the tradition, " had belonged to King Solomon." As the cross was consecrated to Astarte, whose worshipper the King of Jerusalem became, there may have been some ground for the story.

More modern, but a valued relic is the cross given by the crose of Richard Archbishop of CyCour de Lion. prus to Sir Sidney Smith. It was given as the offering of a grateful people to the " hero of Acre," and held by them to be the same which Richard Cœur de Lion bestowed upon the Patriarch when he went to the third Crusade. Sir Sidney Smith bequeathed this valuable relic to the convent of the Order of S. John in Jerusalem, in Paris, as being the successors of the Templars, with the direction that it should be worn by the Grand Master in perpetuity.

William the Conqueror swore Per Vultum Lucca, i. e., the crucifix said to have been made by Nicodemus. Louis XI. of France regarded his word as binding only when sworn by the Cross of S. Lo Other Crosses. d'Angers, which he supposed contained a fragment of the true Cross. The king refused to pledge safe conduct to the Constable of S. Paul's on this relic, though he was ready to take any other oath. He believed that should he forswear himself on this cross he would die within a year.

Black Marble

Sir Walter Scott, in his Eve of S. Fohn, refers to a cruciCross at Melrose. fix of black marble at Melrose, which was celebrated for its superior sanctity. The Lady of Smaylho'me Tower meets the spirit 
of her lover, who appears as when he lived, and she, not knowing that he had been slain by her husband, urges an interview on the following night :

"And I 'll chain the blood-hound, and the warder shall not sound, And rushes shall be strew'd on the stair ;

So, by the black rood-stone, and by holy S. John, I conjure thee, my love, to be there!"

The power of the adjuration is shown by her ghostly lover's confessing when he appears in " the chamber fair,"

\section{"But I had not power to come to thy bower} Had'st thou not conjured me so." 1

One of the attributes of S. Bernardius of Siena is the Monte-di-Pieta, a little green hill composed of three mounds, and on the top either a cross, or a standard on which is the figure of the dead Saviour, usually called in Italy, a Pieta. It has been sup- Monte-di-Pieta. posed that to S. Bernardius belongs the honor of founding, in every city in which he preached in France and Italy, charitable societies for lending money to the poor upon pledges. Another

Origin of Pawnbrokers. brother of the same order, "Il Bernardino da Feltri," who preached in the Church of Santo Cruce, I488, against Jews and usury, and the need of a Monte-di-Picta at Florence, is also supposed by some to be the true founder of these banks for the poor, and to claim this symbol. These Monte-di-Pieta were not perverted into mere usury-shops, like modern pawnbrokers. Interest was reasonable, and many placed their little possessions in these institutions for the summer season when employment was scarce, and withdrew them when autumn brought travellers and work.

Jesuni is the name given by the Japanese to the ceremony of trampling upon the Cross and the picture of the Virgin. It is said to have

1 Minstrelsy of the Scottish Border, vol. iv., pp. I88, I93. The superstition that some evil spirits cannot cross the threshold of a home, unless aided by human power, is referred to by Coleridge, where Christabel brings in Geraldine :

"The lady sank, belike through pain, And Christabel wilh might and main Lifted her up, a weary weight, Over the threshold of the gate:

Then the lady rose again,

And moved, as she were not in pain." 
been suggested to the government by the Dutch, who, impelled by the " sacred lust of gold" into compliance with this custom, retained the Jesuni. trade of Japan for several hundred years. The images were Jesuni. carried from house to house and even infants at the breast were compelled to comply with it. ${ }^{1}$

Not alone have history and art in various ways and from immemorial times represented the symbol of life, and told the story of the Divine Natural Crucifix. nature, often remind us of the humiliation of their Creator.

One of the apartments in the grotto of Adelsberg, in Austria, is called the Cathedral, not only on account of its church-like appearance, but also because it contains a most singular group of stalactites resembling the Crucifixion. The floor of the apartment " resembles a plain dotted with

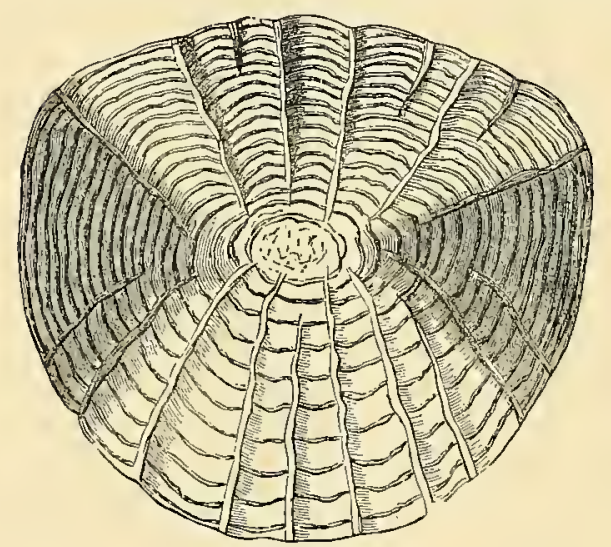

Magnified Scales of the Minnow.

From The Art Foumal.

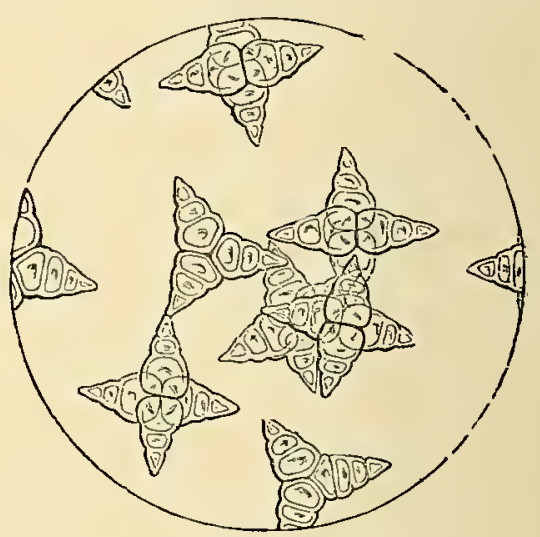

Cross- or Star-spored Fungus.

From The Art Fournal.

hills; and upon the summit of one of these elevations, against the side of the cavern, stand three crosses, the central one taller than the others, and each supporting what strangely resembles a human figure. The surface of the hill sloping from the foot of the crosses down to the plain, as also the opposite hill sloping upward, are covered with spiculæ, or accretions, standing thick, and of proportionate height, representing with wonderful fidelity the appearance of a vast crowd gazing at the spectacle." "

Among the minerals belonging to the order of hyalinea, so rich in gems, several bear the sacred sign in their crystals. The andalusite,

${ }^{1}$ Mercier, Fragments, vol. i., p. 204.

2 The Century, May, I889. 

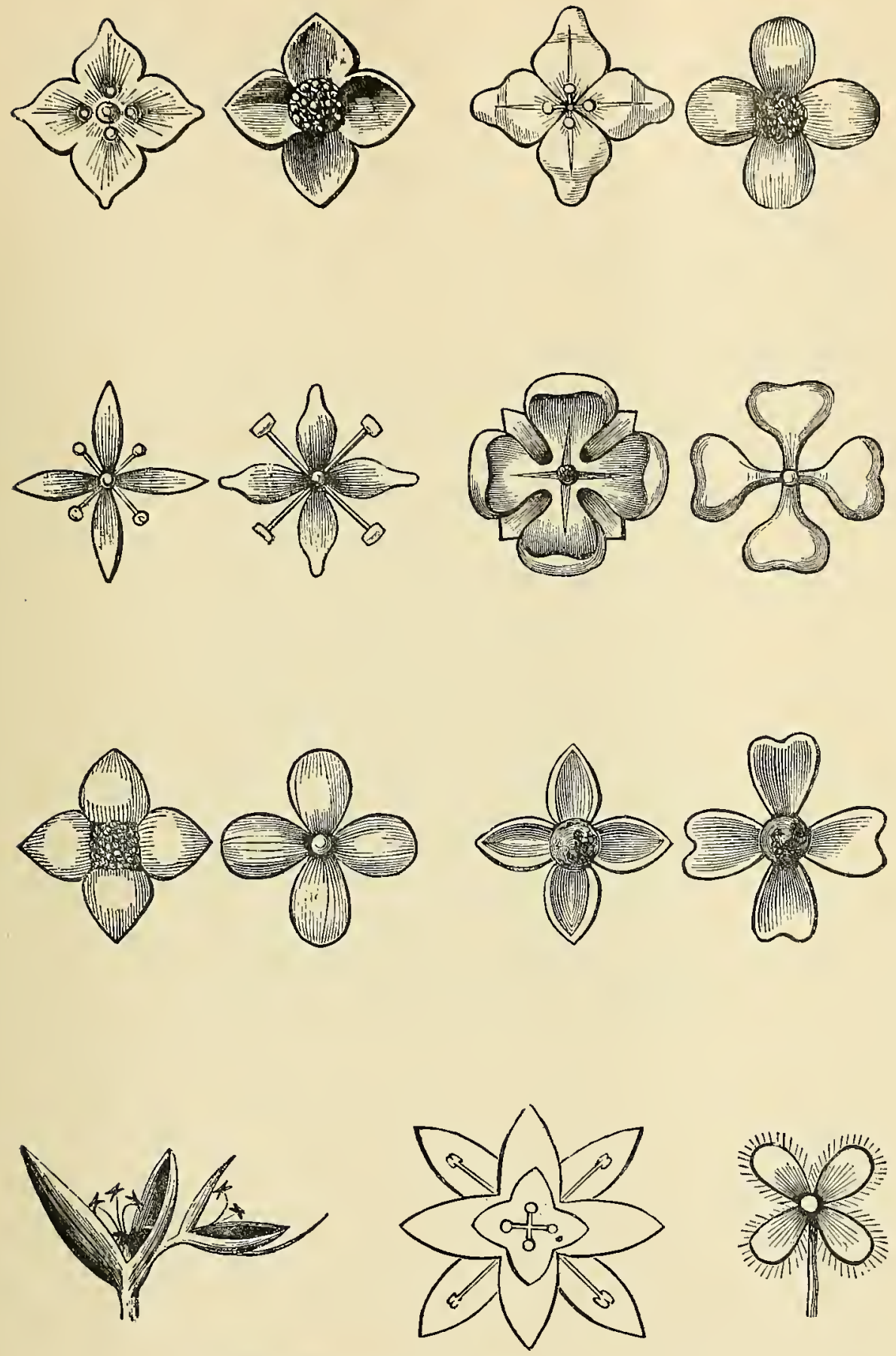

The Cross in Flowers. From The Art fournal. 
known also as the chiastolite, or crucite, often presents the appearances shown in the plate. The crystals of the staurotide or staurolite are still more beautiful and perfect. Even so low in the scale of created beings as the medusa, the Pilmograda Lymmorca exhibit on the disk a most exquisitely formed Greek cross. ${ }^{1}$ This is also to be seen in the Eudora undulosa, though perhaps it is not always so distinctly traced; in fact, we may find it in all the kingdoms of nature. Even among

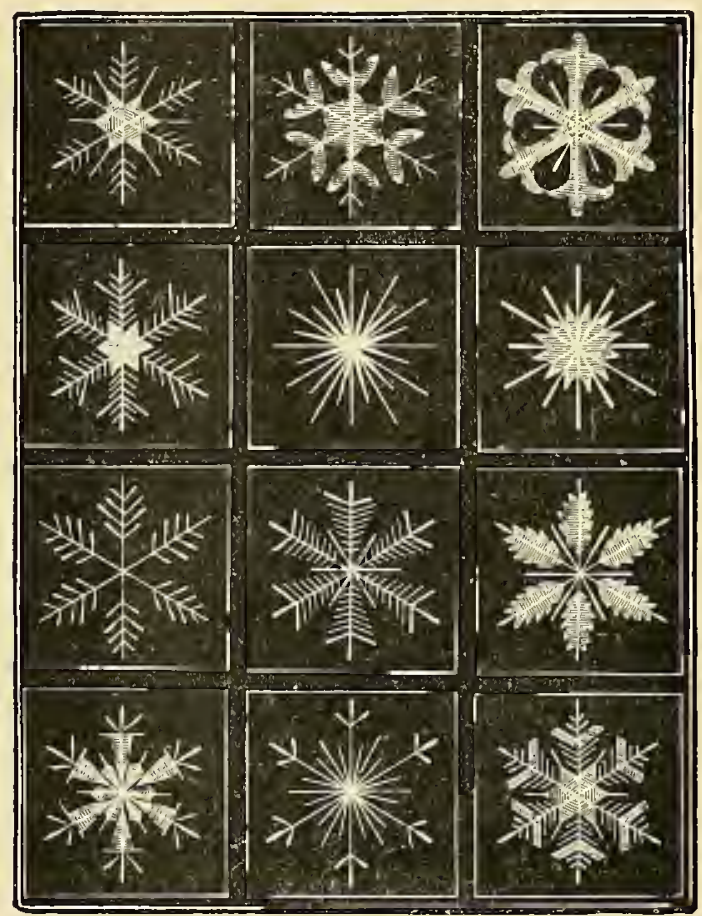

Snow Crystals. From Crowther's The Starry Cross.

microscopic objects we note especially the members of the stauromedusan family. ${ }^{2}$

Vegetable life abounds with curious and suggestive forms, of which a few illustrations will suffice. It is remarked by naturalists that most of cruciform the specimens represented are innocuous. And the query Flowers. arises, is it a mere accident of nature that cruciferous plants bearing fruit are not only not poisonous, but are often nutritious ? ${ }^{3}$

' See plate in Penny' Cyclopadia.

${ }^{2}$ Quarterly Fournal, Microscopic Science, October, 1867.

3 The Unseen World, p. 16. 
Sir David Brewster calls our attention to the fact that if sand is sprinkled on a thin metal plate, and the key-note of that plate is sounded upon a stringed instrument, the sand will arrange its grains in the form of a cross. ${ }^{1}$

The falling flakes of snow exhibit an infinite variety of cruciform crystals, reproducing in beautiful shapes the Crosses in Snow. sign of the Cross."

A tear-drop is full of minute crosses, and, when it has evaporated, leaves in unmistakable characters its cruciform record of sorrow.

A Tear.

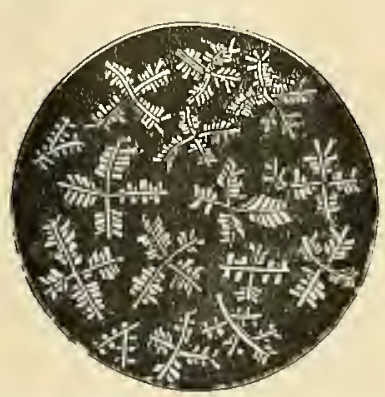

Crystallization of a Tear-Drop. From Crowther's The Starry Cross.

Section 2. Ingenious Crosses.-The cruciform arrangement of words of prayer and praise in the form presented below, Holland says,

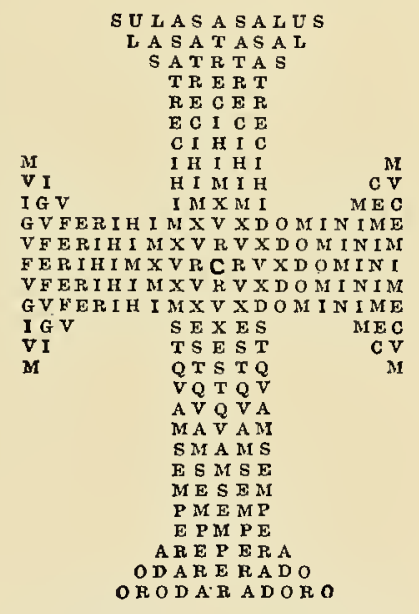

Croce Angelica di S. Tomasa de

Aquinæ. From Holland's Cruciana.

is called " Croce Angelica di S. Tomasa de Aquina," and was originally used as a charm, having been found behind every window-shutter in a house at Frascati, to preserve it from lightning.

It consists of four Latin sentences, each beginning from the word

I Brewster, Letters on Natural Magic, letter viii.

${ }^{2}$ Crowther, Stary Cross, p. 21. 
"Crux" in the centre. The following has been given as an English translation :

"The Cross I ever adore,

The Cross of the Lord is with me;

The Cross doth my safety ensure,

The Cross still my refuge shall be." 1

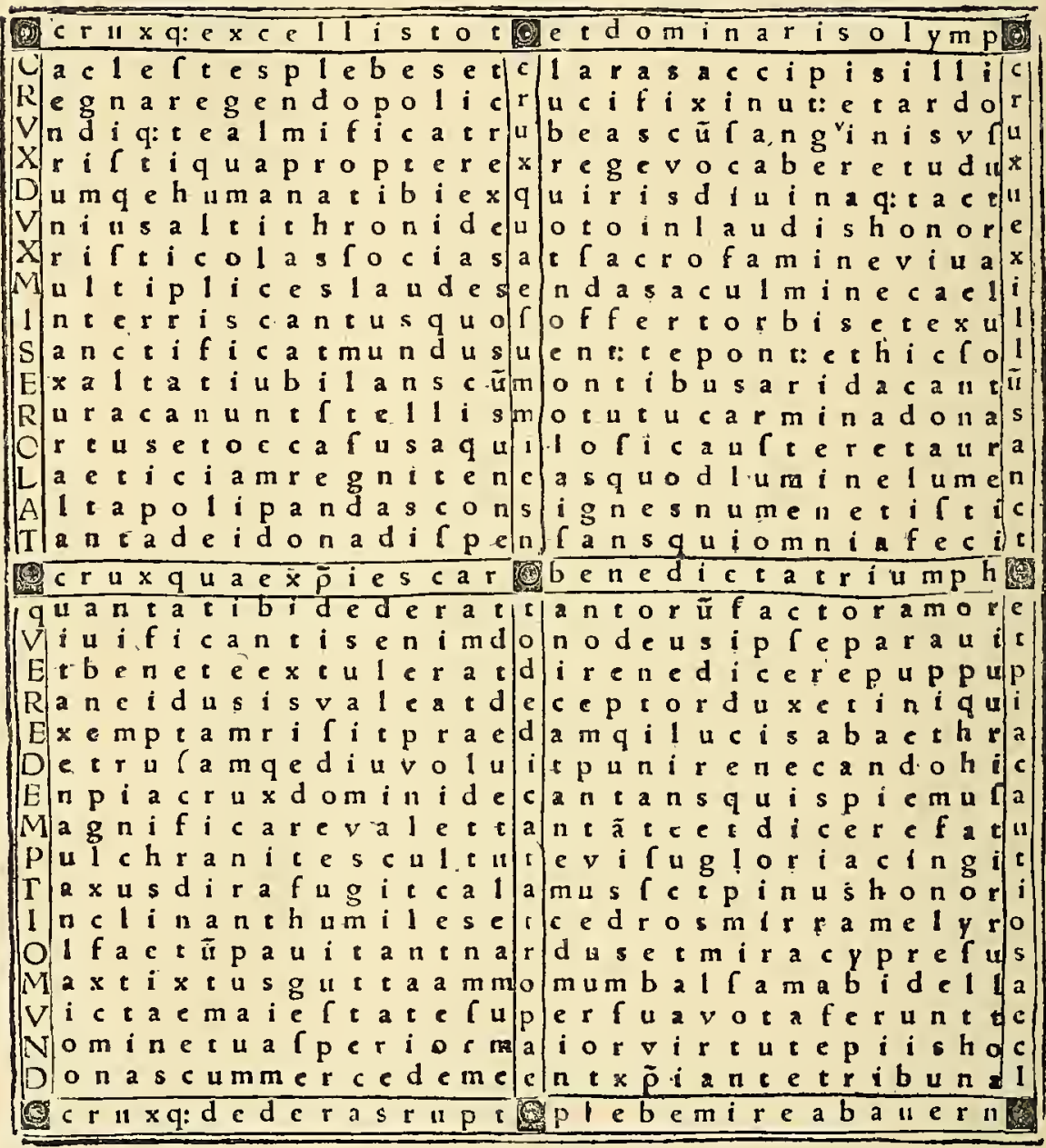

Acrostic of Raban Maur, From Maur's De Laudibus Sanctet Crucis.

A curious work of ingenuity is given on the following page. Its author is unknown, but it excels any of Raban Maur, Archbishop of Mayence, who, in A.D. 847 , wrote an elaborate poem in praise and honor

${ }^{1}$ Holland, Cruciana, p. 279. 
Danie], traditionary tomb of, 15

Dante, Divina Commadia, cited, $181,1 \$_{4}, 358$, $359,452-455$

Danube River, 324

Davemport, Rev. James R., II I

Richard, 39i

David I., of Scotland, legencl of, and the miraculous crucifix, 405; at Battle of the Stanclard, 388 ; death of, 456

Davy, Adam, The Pylgrymages of the holi land, cited, 327

De Carbonel, Bishop, crosier of, 248

Decius, Emperor, igo

Demetrius, Phalereus, 279

- Saint, of Rostoff, 240

Denmark, the cross in, 28 ; kings of, 254 255 ; miraculous standards of, 385

De Portal, cited, 394

Devizes, market cross at, 3I5, 3I6

Didron, A. N., cited, 419

Dieppe, 256

Diocletian, Emperor, 155, 385

Diogenes Laertius, 467

Dionysius, cited, $423,43 \mathrm{I}$

- of Syracuse, 22

Dismas, see Thieves

Doane, Bishop, of Albany, pastoral staff of, 246,248

Docetæ, the, I 8

Doddridge, Dr., cited, III

Domitian, Emperor, Igo

Donatello, story of the crucifix of, I $87 ; 333$

Donne, Dr. John, hymn of, I00; seal of, 225 ; 304

Dorchester, Bishop of, 244

Dowsing, Wi]liam, journal of, cited, 446,447

Dresden Codex, the, 36

Drontheim, 29

Drouyn, M. Leo, cited, $34^{8}$

Druids, the, $30-32$

Discange, C., I56

Du Guesclin, Constable of France, 433

Dulia, the worship of, 400

Dumachas, see Thieves

Dundee, market cross at, $3 I_{4}$

Dun-Edin's Cross, 3I 3 , 3 I 3

Dunfermline, 456

Dunstan, Saint, 409

Du Paix, - - 37

Duppa, Bishop, 225

Durandus, Gulielmus, cited, 203, 243, 258 et passim

Eastlake, Lady, cited, I53, I54, I72

Eastwarn Hoe, cited, 328, 329

Edgar, Saxon King of England, 435

Edinburgh, Mercat cross of, 3I 2-3I4; 405

Editha, wife of Edward the Confessor, 218, 401

Edmondson, Joseph, 363

Edmund Ironside, Saxon King of England, 362,456

Edmundsbury, landmark crosses at, $32 \mathrm{I}$

Edward the Confessor, the crown of, 21 7, 218; the sword of, 222 ; the tomb of, 244,284 ; coat-of-arms of, 362; 40I ; and the "ling's Evil," 436

the Elder, 276

I. of England, 281-288, 308, 456, 466

II. of England, 295, 466

III, of England, 296, 3i5, 363,380, 456

IV. of England, 29I, 298, 300, 30I, 3 I 5 .

374

VI. of England, 202, 246, 283, 305 ;

prayer-bonk of, 246, 421, 424, $427+429$

Eghert, Archbishop of Treves, 243

- King of England, 362

King of Kent, 380

of York, the Pontifical of, $\downarrow 26$

Egypt, the cross in, $2 f f, 39+$

Egyptian triad, the, 3

Elder-tree, legend of the, 94

Eleanor Crosses, the, 28I-288, $3 \mathrm{I} 4$

Elizabeth, Queen of England, 246, 302, 305.

$307,315,322,410,4$ I I, 436, 445

Queen of Hungary, 219

Endicott, John, cuts the cross from banner, $389,391,450$

England, rog-rIr, 2 I7, 218, 388, 422, 427, 444

Enkolpia, or pectora] crosses, 25I, 253

Ennemoser, Joseph, cited, 4I2-4I4

Enrich, the nun, 413

Ephesus, Council of, I57, 205:375

Eaint, 385

Ephraim, Saint, 49, 55, 60

Ephrem, Saint, cited, 418

Epiphanius, cited, I82, 189

Erasmus, cited, I24

Eribert, Archbishop of Milan, 386

Estney, John, Ablot of Westminster, 245

Ethelbert, King of Kent, and S. Augustine, 228, 237, 293; prohable builder of S. Paul's Church, 295

Ethelbred, King of Northumberland, 275

Ethelreda, Saint, 275

Ethiopic ritual, the, 427

Etruria, the cross in, 26

Eucharius, Saint, Bishop of Treves, 243

Eugenius (IV.), Pope, I 39

Saint, 433

Europe, the cross in, 22 ff

Eusebius, cited, 105, 1 16, 156, I 58, 205

Eustace, Saint, the legend of, $4 \mathrm{c} 6$

Evagrius, 207

Evangelists, symbols of, in early art, 174

Evangelium, or Evangeliarium, 47, 170, 172

Evelyn, Join, cited, IIo, 437

Excalibar, Excalberd, or Caliburn, the sword of King Arthur, 221-224

\section{F}

Farno, King of Media, 64

Farrington, Dame Elizabeth, 3I 2

Fausta, wife of Constantine, I56

Favine, Andrew, 436

Fejérváry, Herr, 36

Felicite, Sister, voluntary crucifixion of, 80

Feroher, the, or winged globe, I 8

Fiery cross, the, see Cross 
Filliam, Saint, crosier of, 248

Finchue, Saint, 247

Flavia Euphemia, Empress, 251

Flecknoe, Richard, cited, Diarum, 94, 95 ; Enigmatical Characters, 448

Fleury cross, ses Cross

Florence, I10, 131, I44, I70, I76, IS1, 207, $386,409,459$

Foix, Gaston de, 407

Fomalhaut (star), 454

Forres, cross at, 276

Foshroke, Thomas, $3+2$

Fosser, John, Prior of Durham, 388

Fossors, the early Christian, 26

Foustain le Blanc, 388

Fra Angelico da Fiesole, $14 t^{-147,208}$

France, the cross in, 27; $326,340,346$

Francesca, Pietro della, 96

Francis, Saint, of Assisi, legend of, 409, 4II, 412

Frascati, 463

Frederick, of Saxony, 4It

- Barbarossa, Emperor, 120

- IV., Emperor, 219

— V11., of Denmark, 255

Fremont, Colonel, 263

Frithstool, the, 290

Froissart, Jean, cited, 363

Fructuosus, the martyrdom of, 432

Fuente di Guerrazzar, 219

Fuller, Thomas, cited, I25, I86, 363, 372

Furchée cross, see Cross

Fusberta Joyosa, sword of Charlemagne, 22I

Fylfot cross, see Cross

\section{G}

Gaddi, Agnolo, 96

Galilee bell, the, 290

Galla Placidia, story of, 156,157 ; coins of, 154,157

Galla tribes, 9

Galle, Johann Gottfried, 453

Gama, Vasco da, 454

Gamaliel, 185

Gardiner, Colonel James, story of conversion of, III

Galty, Rev. Alfred, I I

Gaudentius, Bishop of Brescia, 240

Gauls, coins of the, 27

Geabritas, King of the Turks, 2I8

Geddington Cross, $281-283$

Gelasius II., Pope, 240

- Saint, the Sacramentary of, 399, 426

George, Saint, cross of, see Cross

Germanus, Patriarch of Constantinople, 35t, 473

Gestas, see Thieves

Gibbon, Decline and Fall of the Roman Empire, cited, 103,105

Gibbons, Grinling, 287

Gideon, number of his men, 60

Gilead, the Balm of, 470

Giotto, - I8I, 20S, 4 I2

Giovanni, Cardinal, I47

- da Pisa, 207

Giraldus Cambrensis, 247,248
Gitche River, 9

Gladstone, Hon. William E., 313

Gloucester, market cross at, 31 I

Gnossos, 22

Goar, Jacques, Rituale Gracortum by, 354

Goddard, Dr., 297, 298

Godefroi, -, IO5

Godfrey de Bouillon, King of Jerusalem, 356 , $358,365,387$

Godric, Abbot of Croyland, 273

Goerres, Dr., cited, 4 I3

Golasecca, cemetery at, 25

Golden Legend, the, I28, 238; see also J.egenda Aurea

Golden Rose, consecration of the, I 39

Golgotha, legendary origin of name, 85

Gonzaga, Anne de, Princess Palatine, I22

Granadilla, the, IOI-IO3

Grant, Dr., cited, 401

Gratianus, coins of, 156,378

Great Britain, 293, 305, 326, 346, 387, 38s, 424

Greece, the cross in, 22 ; burial customs in, $335 ; 394$

Greek, art, 173, I77 ; Church, the, 324, 354 . $357,37 \mathrm{I}, 4 \mathrm{I} 8,4 \mathrm{I9}, 425,426,431$; cross, see Cross

Gregory the Great, Pope, I70, 235, 240, 243 , $25 \mathrm{I}, 253,37 \mathrm{I}$

- 11., Pope, 136, 184, 399

XI., Pope, 296

Nazianzen, Saint, 439

_ Saint, cited, 55, 322, 4I8 ; the Autiphony of, 399

— of Tours (Bishop), I70, I 76

Gretser, Jac., cited, $156,165,353,376-378$ et passim

Grey, Lady Jane, 303 Dr. cited, 448

Grindal, Edmund, 305

Gualberto (Gualbert), S. John, the legend of, 409

Guernsey, Island of, 338

Guevara, Bishop of Mondonedo, 73

Guillim, John, cited, 360, 361, 363, 369

Guiscard, Robert, $35^{8}$

Guise, Henry, Duke of, 334

Gundulf, $4+2$

\section{$\mathrm{H}$}

Habibus, 76

Hacon, King, 29

Hadrian, Emperor, II $4,157,181,190$

Hädur, Scandinavian deity, 94

Hagenbach, K., 438

"Hagoday," the knocker, 290

Hailes, Lord, $45^{6}$

Hales, Adam de, 232

Hall, Bishop, 74, 225

Halle, Francis, Archbishop of Narbonne, 236

Hammond, Dr., cited, 42 I, 422

Handbook of English Ecclesiology', 202, 26I

Harding, John, cited, 387

Harold, Saxon King of England, 388

Hastings, the batile of, 358

Hea, Assyrian deity, 16 
Headstone crosses, scc Cross

Heemskerk, Martin, the cross of, 272, 274

Ilelen, Saint, the Black Rood of, 457

Helena, (Saint), Empress, legend of discovery of The Cross by, 87-93, I14, I I9, I 22, 123 -126, I $76,205,39^{8}$

Heliogabalus, Emperor, 136

Héloise, 256, 335

Hemans, Mrs., Wood Walk, cited, Ior, I03

Henry I., of England, 380

II., of England, IO9, 332

- III., of England, 289, 296, 3II, 3I I, 33I,

$36 \mathrm{I}, 380,468$

IIf., (Valois), of France, 334

IV., (Boliugbroke), of England, 277,

297,319

IV., of France, 436

- VI., of England, 1 22, 283, 297, 298, 315, $374,422,436$

VTI. of England, I 23, 283, 438

- VIII. of England, 29I, 30I, 302, 389, $402,403,457$

Hera, the Assyrian Venus, 16

Heraclius, Emperor, 92, 93, 120, 121, 380 , $38+, 47 \mathrm{I}$

Heraldry, the cross in, 360 ff

Herbert, George, cited, 225, 323

Herculaneum, 467

Hermes, 6, 7, I8I, 182, 239 ; statues of, changed to wayside crosses, 324

Herne, 457

Herod the Great, I 89

Hesus, one of the Druidical triad, 30

Hesychius, 467

Hexam, the battle of, 387

Heylin, Peter, cited, $28_{3}-287,445$

Hiera, the, 370

Hierurgia Anglicana, 2.66

Hilarius, Pope, $25 \mathrm{I}$

Hilary, Saint, 52

Hilsey, John, Bishop of Rochester, 302, 410

Hindoo triad, the, I3

Hipparchus, 76

Hohenlohe Siegmaringen crucifix, the, 173

Holbein, Hans, 133

Holinshed, Raphael, 4I 2

Holland, John, 462

Hollis, Thomas, 309

Sir William, Lord Mayor of London, 309

Holy Family, Jegend of the, I3o, I 31

Holy Rood Abbey, legend of founding of, 405

Homilies, the Saxon, 399

Honorius, Emperor, I57, 2.43, 289, 378

Hook, Dr., cited, $30 \mathrm{I}$

Hooker, Richard, cited, I95, 323

Hope, Beresford, 248, 253

Hopkins, Bishop, pastoral staff of, 2.48

Horn, - 305

Hortense, Queen, 123

Houbigant, Charles François, cited, 20 -

Hubert, Saint, the legend of, 405, 406

Hugh, of France, I23

- Saint, of Lincoln, 8I, 82

Hugo, of Avalon, Bishop of Lincoln, 331, 332

Humboldt, Baron, cited, 45I-454

Humettée cross, see Cross

Hungary, 218, 219, 230
Huss, John, 398

Iyperdulia, the worship of, 400$$
\text { I }
$$

Iceland, the cross in, 29

I conoclasm, of the eighth century, 380 ; Puritan, 446,447

Iconostasis, rood-screen of the Eastern Church 195

Ignatius, Patriarch of Constantinople, 434

Imbert, Prior of Gascony, 400,401

Ina, King, 289

India, the cross in, 9 ff; 394

Indians, North American, customs of, 45

Ingulphus, $32 \mathrm{I}$

Inhabited cross, see Cross

Innocent II., Pope, 230

- IIl., Pope, I $76,37^{2}$

V., Pope, I47

Inquisition, the standard of the Spanish, 393

Iona, headstone crosses in island of, 336,337

Ionia, 375

Ireland, the cross in, 32, 267, 268, 339; miraculous crucifixes in, 404,405

Irenæus, cited, 72

Irene, Empress, 123

Isiac mysteries, the, 279

Isidore, Saint, Bishop of Seville, 240, 371

Isis, Egyptian deity, 6, 190, 279, 474

Italy, the cross in, $22 f f, 328,387$

Itzexes, tribe in Yucatan, 4 I

\section{$\mathrm{J}$}

Jacobites, rites of the, I5I, I 52, 425

Jainas, the, IO, II

Jama, Io

James 1., of England, 291, 307, 315, 380, 436 II., of England, 438

III., of Scotland, 248

IV., of Scotland, 30I

Saint, crucifixion of, 76 ; cross of, 367 , 368 ; Order of, 368

Jameson, Anna, cited, 82

Jantiarius, Saint, 404

Japan, the cross in, I4

Jarrow, monastery of S. Paul at, 55

Java, the cross in, $x_{3}$

Jay, John, merchant, 374

Jericho, 470

Jerome, Saint, cited, 50, 99, II3, I3I, 423

Jerusalem, I09, II I, I16, I17, I20, I80, I85, $230,356,365,398,407,429,470,471$

Jerusalem cross, the, see Cross

'Jesuni, Tapanese ceremony, 459, 460

Jewell, Bishop, cited, $185,304,305,445$

Jews, the, customs of, $67-70$; I I 7,135 ; accused of crucifying children, 81,82

Joan of Arc, 332

Jocelin, Bishop, 3II

John, Saint, I 79-181, I83, 186, 331, 348, 378

_- Baptist, Saint, banner of, 356 ; in Greek art, 43 I Saint, of Beverley, standard of, 388

- Casimir, King of Poland, I 22 the Constant, of Saxony, 4I4 of England, 315 
John, of Gaunt, Duke of Lancaster, 296, 334 VII., Pope, I83

- de Sheppy, Bishop of Rochester, 245

Johnson, Dr. Samuel, tonched for the "Iring's Evil," 438

Jolly, Bishop, of Scotland, $33 x$

Jonas, Bishop of Orleans, 400

Jonson, Ben, Every Man in his Humour, cited, 94,382

Jordanus of Germany, 147

Jormundgand, the serpent of Midgard, 267

Joseph of Arimathea, as represented in art, I29; traclitionary mission of, to Britain, 387

Jovian, Emperor, $\mathbf{I}_{56} 6,378,383,38+$

Joyeuse, sword of Charlemagne, I 23

Fubé, or rood-loft, I99

Julian the Apostate, Emperor, 90, 165,383 , 398,438

- Pope, ${ }^{2} 8_{3}$

- Saint, cross of, 366

Juliana, the Anchoress of Norwich, I 79

Julius II., Pope, I 39

Saint, I 72

Jupiter Ammon, I 88

Justin, 76

- Emperor, 25 I

Justinian, Emperor, 189, 197, 207, 257, 357. $378,379,384$

Justinianus II., 380

Justinus, see Thieves

K

Kalinski, cited, 77

Kamchatka, the cross in, I5

Keble, John, Christian 1'ear, cited, 326

Kelmainham, priory of, I.24

Kemp, Thomas, Bishop of London, 296

Kenneth, of Scotland, 335

Kent, Earl of, 332

Kenulph, Abbot of Croyland, $32 \mathrm{I}$

Khorsabad, 7, 6

Kilcullem, Old, memorial cross in, 527

Kilnsea, cross of, 277

King, Dr., I 53

- John, Bishop of London, 307

" King's Evil," touching for the, origin of, 435,436 ; ceremony of, 438

Kirkbradden, memorial cross at, 279

Knight, Wyllyam, Bishop of Bath, 3 ro

Knights of Bath, $\$ 22$

Hospitaliers, the, 32 I, 368

of S. John, 472

Templars, the, I21, 257,321, 356, 357, 367,458

Knox, John, $277,44^{6}$

Krishna, Io

\section{L}

Labarte, Handbook of Arts of the Middle Ages and Renaissance, by, 253

Labarum, the, Constantine's vision of, ro4; description of, IO4; adopted by the Roman army, I02, I06; 107, I56, I89, 226, 259, $383 ;$ final disposition of, 384
Laborde, Count de, 253

Lactantins, De Mortibus Persecutorum, cited, $107 ; 156,439$

Landcyd $a$, the, ancient standard of Denmark, 385

Landmark crosses, see Cross

Lanfranc, Archbishop, 244

Lao $T$ se, the, Io

Lao-tseu, the, 13

Lateau, Louisa, of Belgium, 4I 3

Lateran, Council of, 230

Latimer, Bishop, 304

Latin Church, the, $324,354,355,418$

Latria, the worship of, 399,400

Laud, Archbishop, 235, 445

Laurentius, 436

Legenda A urea (Golden Legend), by Jacobus de Voragine, 83, 98, 128

Leland, John, cited, 3 I 9

Lenni Lenape, the, of North America, 45

Leo, Emperor, 257

- the Great, Pope, I85, 186

- III., Pope, I72, 25 I

- IV., Pope, 207, 230

- IX., Pope, synod of, 244

- X., Pope, 139

- the Isaurian, Emperor, 442

I Leonidas, 66

Lepsius, Dr. KarI, 47

Le Saur, - - 287

L'Estrange, - cited, 439

Leuci, the, 27

Iilly, Alexander and Campaspe, cited, 95

Lincoln, Bishop of, 232

Lindsay, Lord, cited, I53, 4 I I, 4I 2

Lingard, John, 399

Lioba, Saint, 397

Lipsius, Justus, 66, 353

Limus, the, 238

Loki, Scandinavian deity, 94, 267

Lollianus, 76

London, $294 f f, 298,307,374,410$

Longfellow, H. W., cited, 29 , IOI

Longinus, Saint, story of, I28

- 268

Lorraine, Cardinal of, 334

- cross, see Cross

Losinga, Bishop, $32 \mathrm{I}$

Lothaire, 397

Lothario, cross of, I 74, I 75, I77

Lotharius, signet of, 220

Louis VI., of France, 33I

- VII., of France, 389

- IX., Saint, of France, I2I, 33I, 436, 471

XI., of France, 458

e Débonnaire, of France, 32I, 397

le Gros, of France, 331

Louterell Psalter, the, 245

Lovat, Matthew, self-crucifixion of, $80,8 \mathrm{I}$

Lowry, Robert, II I

Lucca, I 84, 386

lucius, King of Britain, $36 \mathrm{r}$

Lucy, Elizabeth, 30I

Ludovicus, $33 \mathrm{I}$

Luitprand, Bishop of Cremona, 244

Luther, Martin, 224, 225, 443 
M

Mabillon, Jean, 256

Macarius, Bishop of Jerusalem, go, I I6, I 8

Macduff's Cross, 277

Maclean's Cross, 337

Mlagellan, Fernando, 454

Mlagider, Saint, 277

Magri, Hierolexicon of, 2 to

Mahon, Lord, 138

Maimonides, $66,77,389$

Maitland, C., cited, I 55,434

Malachy, Saint, 248

Nalaga, 407,408

Malcolm Canmore, King of Scotland, 276, 277 $362,370,456$

Malik-el-Camel, Sultan, I20

Malmesbury, market cross at, 3II, 3I5 ; Abbey, I23

Maltese cross, see Cross

Mamertins, Bishop of Vienna, 322

Man, Isle of, crosses in, 267, 275, 279

Nanchester, Earl of, $44^{6}$

Mandeville, Sir John, cited, 94, 469

Manichæans, the, 443

Mansfield of Sicily, 362

Mantegna, Carlo, 180

Manual of York, I 2 I

Manuel Comnenus, Emperor, 389

Marceus and Marcellainus, crucifixion of, 76

Marcillac, churchyard cross at, 348

Margaret of Anjou. 20I danghter of Henry VII., $30 \mathrm{I}$

Saint, of Cortona, $409,4 \mathrm{IO}$

Saint, wife of Malcolm Canmore, 3I4, 362,456

Margaritone, $I 76$

Mark, Saint, festival of, 322

Market crosses, see Cross

Marriott, Rev. John, cited, 426

Mlartene, E., 259

Martiall, J., cited, 399

Martin, Saint, the friars of, 295

- II., Pope, 123

Martina, Saint, 335

Martyr, Justin, 46,48, 52, 58, 72 et passim

- Peter, 445

Mary, Queen of England, 234, 302, 303, 305 Queen of Scots, 332, 333

Massinger, P., Bashful Lovers, cited, 382

Mathew's, Hugh, 404

Mlatilda, of Scotland, 388

- wife of William of Normandy, 329

Maturus, Saint, 243

Maud, wife of William de Albini, 435

Maur, Raban, acrostic of, 464

Maury, Alfred, 412

Maxentius, $\mathrm{IC}_{4}, 205$

Maximian, Emperor, 76

Maximianus, Bishop, 207

Mayence, Conncil of, 256, 323, 371, 464

Mazois, C. F., cited, I 55

Medici, the, arms of, 466

Médicis, Catherine de, 334

Melanchthon, Philip, 443

Memorial crosses, see Cross

Mendoza, Cardinal, 136
Mercury, see Hermes

Merry Deril of Edmonton, the, cited, 325

Mesopotamia, the cross in, I9

Nlethodius, Saint, 354

Meursius, Jan, 257

Mews, Bishop, 246

Mexico, the cross in, $34-4 \pi ; 381$

Micael, Giuseppe, 407,408

Michael, Saint, 385

Ducas, Emperor of Constantinople, 218

Michaelis, Johann, 468

Midas, King of Phrygia, 2 I

Midgard, 267

Mill, Jacob de, 473

Mills, Charles, 322

Milrine cross, see Cross

Mimung, the sword of Siegfried, 222

Minucius, 432

Mishna, the, 67,68

Mistletoe, legends of the, $3 I, 94$

Mistra, Archlishop of, cited, 479

Mixtecas, the, of Mexico, 36

Mjölnir, the hammer of Thor, 28, 267

Moerl, Marie de, 4I2, 4I3

Moisac, the ritual of, 426

Molanus (Vermenlen, Jan), 177

Moline cross, see Cross

Monasterboice, crosses at, 270

Mondonedo, Bishop of, 73

Monograms, heathen and Christian, I88-190, $324,373,374,385$

Monophysites, the, 418

Monstrance, forms of the, 212

Montagne, Bishop, I95

- J. A., 466

Montaperto, the battle of, 386

Monte-di-Pieta, the, 459

Monza, I 72, I79

More, Sir Thomas, 298, 332, 473

Morglay, sword of Sir Bevis, 221

Mosaics, I $38,158,159, I 61, I 63, I 66, I 72, I 8_{3}$, I $89,25 \mathrm{I}, 270$

Mosen, Julins, poem of, Ior

Mound temples, in Great Britain, 32, 34, 45 ;

in North America, 43-45

Mousewell, Thomas, 437

Mnllooly, the Rev. Dr., I 83

Muran, Saint, 247

Murtogh, King of Ireland, I24

Mnyscas, the, South American tribe, 4 I

Mycenæ, 250

\section{$\mathrm{N}$}

Nash, Thomas, Supplication to the Devil, cited, 381

Neale, the Rev. J. M., 342

Neigle, cross of, 266

Neot, Saint, 456

Nero, Emperor, I 27, I 72

Nerva, coins of, 377

Nestorians, the, 2IO, 2II, 4OI, 42I ; ritual of, 427

Neville's Cross, the battle of, 457

New England, the banner of, 389-39I

Newman, Sir Thomas, 302

Nicæa, Councils of, $185,399,400$ 
Nicaragua, the cross in, 36

Nicephorus, Patriarch of Constantinople, 25 I, $33 \mathrm{I}$

Nicetas, cited, 52

Nicholas IV., Pope, I6r Saint, of Tolentino, 4 ro

Nicodemus, as represented in Greek art, 129; traditionary crucitixes made by, IS $4, I S 5$, $407.45^{8}$; the Gospel of, $83 \not f, 39^{6}$

Nicquetus, 98

Nigellus, 245

Ninus, 64

Nishet, Alexander, cited, 367,368

Nisroch, 16, 34, 40

Nixon, Strange Footpost, cited, 94

Normandy, 29I, 337

North America, the cross in, 42

Northallerton, Battle of the Standard at, 388

Northampton Cross, 28 I

Northbury, Bishop of, 296

Northern Europe, the cross in, 28 ff

Norwich, cross at, 81,321

Notes and Queries, 425, 467

Nowell, Alexander, Dean of S. Paul's, 296

$\mathrm{O}$

Oak, tradition of the, 95,96

Odenheimer, Bishop, I I 9

Odin, Scandinarian deity, 28, 29, 267

Odo, Bishop of Bayeux, $24 \mathrm{I}$

Oge, Barry, I2+

Ogham characters, 32

Oldcastle, Sir John, 297

Oldham, Bishop, of Exeter, 245

Omophorion, the, 370,37 I

Orange, Councii of, 289

Oresimus, Nicolaus, Bishop of Lexoriensis, 376

Origen, cited, 5O, 52, I I 3, I S9, 433

Orlando, the sword of, 222

Orleans, Council of, 323

Orœetes, a commander of Darius, 66

Osiris, Egyptian deity, 6, 187, 190, 279

Ossuaries, 25

Oswald, the Saxon, 387

Otto of Bamberg, Saint, 228

Ourique, battle of, 109 , I 10

Oviedo, 384

Owen, Saint, 275

Ox ford Glossary of Heraldry, the, 236

Oxia, island of, 2 I 5

\section{$\mathrm{P}$}

Pacific Islands, the cross in, 45

Palestine, the cross in, :9, 109

Pall cross, the, see Cross

Pall, or pallium, the, 238,370 of

Panniculam, the, 133

Pansa, house of, I5

Papal cross, see Cross

Paragrus, 76

Paraguay, the cross in, 42

P'aris, $17,27,121,122,395,45 S, 471$

- Abbé, 80
Paris, Matthew, 8I, 1 20, 130

Part the Pontifical of, 427

Parker, Matthew, Archbishop of Canterbury, I95, 249, 305, 4I I

Parliament, the "Mad," 296 ; acts of, 307 , $305,313,329$

Paschal I., Pope, 184

- II., Pope, I24

Pastoral staff, the, 236-249

Patagonia, the cross in, 42

Pattée cross, see Cross

Pateressa, the, $24^{\circ}$

Patonce cross, see Cross

Patriarchal cross, see Cross

Patrick, Saint, crosier of, 247,248 ; cross of, 389

Paul, Saint, 74, 185, 260, 293, 425

V., Pope, 36

Paulianus, $4+3$

Paulicians, sect of the, 441

Paulinus, Saint, Bishop of Nola, cited, 6o, I I6, 124. 168, I01, 394, 432

- Bishop of Tyre, I93

Pearce, Bishop, 468

Pearson, Bishop, 59

Pectoral cross, see Cross

Pehlevi characters, 14,19

Pelagius I., Pope, I 70, $37 \mathrm{I}$

Pelayo, of Spain, 385

Pendleton, Dr., 305

"Penitence, bed of," 33 I

Pennant, - - 302

Pennington, Isaac, Lord Mayor, 307

Pépin le Bref, Cafitulary of, 396

d'Héristal, 405

Perambulation of boundaries, 322,323

Perdiccas, Persian commander, 66

Perizonizm, the, 176

Persia, I 5, 120, 392

Perth, market cross at, 3 I 4

Peru, the cross in, 4 I

Perugino (Pietro Vanucci), I 39

Peter, Saint, 74, 75, 235, 261,272, 37 I, 372, 387,473

- of Cliny, $2+3$

Martyr, Saint, $1+6$

Saint, of York, standard of, 388

Peterborough, Abbey of, 278

Petrobrusiani, sect of the, 443

Phelonion, the, $37 \mathrm{I}$

Phidon, of Argos, 375

Phildebert, son of Clovis, 458

Philip, Saint, 378

the Fair, of France, I2I

II., of France, 362

I1., of Spain, 283, 305

Philippa, Queen, of England, 389

Philotheus. 76

Philpot, Sir John, 364

Phocas, Flavius, Emperor, 21 5,380

Phœnicia, the cross in, 20, 21

Pierce, Ruth, story of, 317

Pietro della Pallude, Patriarch of Jerusalem, I 47

Pigafetta, 454

Pinke, Dr., 300

Pinturicchio, I39 


\section{Index}

Pionius, 72

Pisa, $385,408,454$

Pius V., Pope, 139

Plato., Pope, 139

Plato, 22

Pliny, 279

Plowman, Piers, 224

Plutarch, 279

Poitiers, the Yontifical of, 427

Politus, 385

Pollux, Julins, 467

Polycrates, ling of Samos, 65, 66

Pommée cross, sce Cross

Pooley, C.. cited, 3 I 9

Porphyry, Bishop of Gaza, I Iq, 226

Porter, Sir Robert Kier, I5

Potent cross, se' Cross

Preaching crosses, see Cross

Prescott, W. H., cited, 34

Prester John, 389

Prestonpans, 3It

Prime, Dr. WVilliam C., cited, I 26

Probus, Sextus Petronius, I58

Processional crosses, sie Cross

Procopius, 354

Prudentins, 432

Ptolemy, coins of, ro8, IS8

Epiphanius, 8

Soter, 4

Puritans, the, $444,445,457$

\section{Q}

Querini, Nicolas, of Venice, $47 \mathrm{I}$

Quetzalcoatl, 37, 4I

Quiateot, Nexican god of rain, 40

Quiriacns, Bishop of Jerusalem, 90

R

Ra, Egyptian and Assyrian deity, 3, 6, I6

Raffles, Sir Stamford, I3

"Ragman Roll," the, 456

Ragnefredus, Bishop of Chartres, 241, 242

Rameses, 19

Rafhael, 208

Rasles, Father, 293

Rebo, the, Asiatic tribe, is

Reccesvinthus, crown of King, 219, 220

Regulus, 66

Remigius, Saint, 240

Resurrection cross, see Cross

Reynolds, Dr., 444

Ribadeneira, Pedro, cited, I 24, 404

Richard of Pontoise, Saint, 81

- Cour-de-Lion, 224, 332, 35\&, $387,45^{8}$

II., of England, 297, 363

III., of England, 209, 298, 300, 30r 3I I, 373

Richter, G., Dissertation on the Saviour's Crucifixion, by, 78, 79

Ridley, Bishop, 30.4, 305

Rives, John, 287

Robin-redbreast, legend of the, Ioo

Robinson, Dr., Researches, I 16 , I 18
Roch, Saint, +14

Rochette, Raoul, I 72

Rock, Dr. Daniel, cited, I24, 238, 37 I

Rogation Days, 322, 323

Romanus, 76

Rome, 26, I I 9, I 36, I59, I6I, I66, 181, I83. I9I, 230, 263, 264, 335, 339, 344, 39t, 409. $+32,470,471$

Roncesvalles, the pass of, 224

Rood, the black, of Scotland, 456,457 ; of S. Ilelen's, in Abingdon, 457; of Melrose, I 86,458

Rood-screens, I93-204

Rosenmüller, 470

Rosetta Stone, the, 8

Rndolph, of Hapsburg, Iog

Rufinus, cited, II6, I 57

Runic characters, 28

Ruskin, John, cited, 402

Russia, the cross in, 263, 337, 357, 393, 43I

S

Sabbaoth, the gnostic, 182

Sabinus, King of Bulgaria, 184

Saillans, churchyard cross at, $34^{6}$

S. Albans, I99

S. Andrew's cross, see Cross, Saltire

S. Denis, the Abbey of, 395

S. Germain, I 22

S. Guthlake, Abbey of, 278

S. John's College, Oxford, 246

S. Laura, Convent ot, 357

S. Paul's Cross, see Cross, Preaching, 4io

S. Projet, churchyard cross at, $34^{8}$

Saladin, I 20

Salamis, coins of, 15

Salisbury, market cross at, 315

Salmasius, 353

Saltire cross, see Cross

Samaria, coins of, 59

Sammosata, crucifixions at, 76

Samsi-Vul IV., King of Assyria, 250

Samson, Saint, Archbishop of York, 237

Samuel, Bishop of Dublin, 230, 238

Sanctuary crosses, see Cross

Sanctuary, the right of, $2 S 9 f f$

Sanderson, Robert, 457

Sandys, Edwin, 305

Sarto, Andrea del, 208

"Sarum use," the, $235,244,426$

Sataneal, the Prince of Evil, $4+2$

Sawastika, the, I I

Scandinavia, deities of, 28 ff

Schliemann, Dr. Heinrich, 250

Scotch ritnal, the, 427

Scotland, $30,186,265,361,362,385,388$, $405,445,456$

Scott, Sir Walter, cited, Marmion, 3I2, 3I 3 , 325,326 ; The Eve of $S$. Fohn, 186, 458, 459; The Alonastery, 457

Scourging, Iaws concerning, 68

Scythia, Queen of, crucified, 65

Seals of merchants in the Middle Ages, 372, 373

Semiramis, Queen of Assyria, 64

Sempach, battle of, 272 
Septimus Severus, Emperor, I8I

Serapis, Egyptian deity, 4, 2I4, 474

Sergius I., Pope, 186

Severius, Bishop of Cologne, 239

Shakespeare, cited, As You Like It, 382 ; Cymbeline, Hamlet, 224, 434; Henry IV., 3I9-320, 382; Love's Labour 's Lost, 92 ; Macbeth, 276, 436,437 ; Merchant of Venice, 325

Shalmaneser, I7

Shari, Assyrian tribe, I 8

Shaw, Dr., $300,30 x$

Shelton, John, cited, 291, 382

Shore, Jane, 298, 300

Shrewsbury, weeping cross at, 320

Sibylla, prophecy of, 87

Sicily, the cross in, 27

Siegfried, the swords of, 222

Sigillum, or the sign of the cross, 434

Simon, Saint, of Trent, 81, 82

Sindone, the, I33

Siva, the Destroyer, 9, 10, 13,425

Sixtus Ill., Pope, I 59

Smith, Sir Sidney, 458

Socrates, I I6

Sophronicus, Patriarch of Jerusalem, ISo, 395

South America, the cross in, 41 ff, 328

Southey, cited, 79, 82,387

Sozomen, I I6, 205, 418

Spain, $185,261,328,384,385,392,45^{8}$, $47^{\circ}$

Spire and Gable crosses, see Cross

Standard crosses, see Cross

Standard, of Great Britain, 388 ; of New England, 389-39r; of the American Colonies, 30I; of the United States, 392; of the Spanish Inquisition, 393; Battle of the, see Northallerton

Standards of the cross, miraculous, 384-386

Stebbing, Dr. H., Archdeacon of Wilts, 3 I 7

Stephaton, or Calpurinus, I 29, 268

Stephen, King of Hungary, 230

Steward, James, of Scotland, 456

Stewart, John, $47^{\circ}$

Stigmata, the, instances of, $4 \mathrm{II}-4 \mathrm{I} 4$

Story, Bishop, 3 II

Stourbead, market cross at, 3 \ 5

Stow, John, cited, 202, 305, 363, 407, 436

Street crosses, see Cross

Strickland, Agnes, 456

Sudarium, the, 127, 133, 245

Suicer, Johann, 257, 431

Sulpicins Severus, 116, 394

Superhumerale, the, 370

Srippedanewn, the, 73, 98, I73, 209, 357

Sussex, Earl of, 4Io, 4 II

Sweden, the cross in, 28

Swilt, Dean, 124

Switzerland, wayside crosses in, 326

Swords, famous, 123, 22I-224; nse of crossbilted, 333

Sylvester I., Pope, $37 \mathrm{I}$

II., Pope, 230

Symbolism in art, 47-56; in architecture. 355 ; of colors, 394; in heraldry, 364-371; of sign of the cross, 418 ; of the thorns, $471-$
472 ; of the unicorn, $242,2.33$; of vestments, $370-372$

Symmachus, Pope, 207

Syracuse, coins of, 27

Syria, consecration crosses in, 258; manner of signing the cross in, 427

Syrio-Jacobite ritual, the, 427

\section{T}

Tancred, of Sicily, 224

Tarlati, Guido, tomb of, 207

Tarquin, 66

Tau cross, the, see Cross

Tauroplia, the, 294

Tavernier, Jean Baptiste, I 2

Taylor, Jeremy, cited, 433

Terminalia, the, 322

Terramares, the, 23,26

Tertullian, cited, $58,72,189,423,428,432$, 468

Tharnis, one of the Druidical triad, 30

Theodora, Empress, I \&9, 197

Theodore, Abbot of Croyland, 277

- Archbishop of Canterbury, the Penitential of, 434

- I., Pope, 434

Theodoret, cited, I I 6

Theodosius, Emperor, I56, I57, 214, 219,257 , $289,356,378,384$

Theophylact, Saint, I I 3

Thierry, J. N., 387

Thieves, the two, legend of, $130-132$

Thomas, Saint, 37,73

- Aquinas, Saint, 146, 243, 408, 435, 463 à Becket, Saint, 232, 236, 238 of Malabar, Saint, I65, 404

Thor, Scandinavian deity, 28,267

Thorns, the crown of, $468-474$

Thoth, 8

Tiber, the river, 396

Tiberias, battle of, 120

Tiberins, Emperor, 127

Tiglath Pileser, I6

Timotheus and Maura, crucified, 76

Title, the, of the Cross, see Cross

Titus, see Thieves

Tizona, the sword of the Cid, $22 x$

Toledo, 2I9, 230, 240, 458

Toltecs, the, of Nexico, 39, 4 I

Tonsure, forms of, 473,474

Tooker, Dr. IVilliam, 436

Toulouse, Bernard, Count of, 434

Tours, Council of, 193, 205, 208, 209

Trajan, Emperor of Rome, 406

Tree of Life, legend of, $85-87$

Trent, Council of, 400

Triad, the Druidical, 30

Tripoli, 120

Trogoz, Don Rodrigo, 333

Troy, 2I, 250

"Trullo," Council in, I 7o, x 72,429

Trypho, the Jew, 46, 52

Tucca, a vestal virgin, 396

Turkey, I 34, 392, 393

Tvashtri, Io

Tyler, Wat, 363 
Tyndale, William, 298

Types of Christ, see Christ

Tyre, 20, I 20, I 21,193

$\mathrm{U}$

Unicorn, the, symbolism of, $2+2,2+3$

Upton, - $36 \mathrm{r}$

Urban IV., Pope, 296, 362

\section{V}

Valens, Emperor, 157

Valentinian, Emperor, 156,378

- III., Emperor, I 38

Valentinianus, Emperor, I 56

- III., Emperor, 15i, $37^{8}$

Vallancy, Charles, 32

Vallombrosa, the Order of, 240, 409

Vanni, Francesco, 408

Varus, 66

Vasey, Bishop, of Exeter, 245

Vatican, the, I9I, 207, 208, 356, 467

Velletri, I 70

Venantius Fortunatus, I 70

Venice, $80,81,386,387,47 \mathrm{I}$

Venus, temples of, II 4. $\simeq 36,138$

Vera icon, the, I27

Veronica, Saint, legend of, I27, 128, I84

Vertot, René de, cited, I2 I

Vertue, George, 28 I

Vespasian, Emperor, I9o

Vespucci, Amerigo, 453

Vestments, ecclesiastical, 370-372

I'exilla Regis, 36

$V$ exillum, the, $2+5$

Vibius Pansa, 26

Victor, Bishop of Amaterna, 76

Vieimns, see Thieves

Vienna, the Pontifical of, 427

Vigean, Saint, 266

Vigilius, Pope, I 70

Vinciana, Saint, 335

Vishnu, IO, 425

Vladimir, Russian Emperor, 228

Volcæ Tectosages, the, 27

Voltaire, 124

I'olto Santo, the, of Lucca, I84, I85

Voragine, Jacobus de, Legenda Aurea, by, 83 , I 76

\section{IV}

Wagram, battle of, 123

Walcott, M. E. C., cited, 37 I

Waldeck, - , to

Waldemar, the Victorius, of Denmark, 385 II., of Denmark, 254

Wales, crosses in, 265, 275 ; coronet of Prince of, 2 I8

Wallachia, wayside crosses in, 324

Walpole, Horace, 97,281

Waltham Cross, $28 \mathrm{I}-283$

Walton, Izaak, 225

Walworth, Sir William, 363
Wandering Jew, legend of the, I 30

Warbeck, Perkin, 29I

Warham, Archbishop, 301

Warton, Thomas, 97

Warwick, Earl of, 297, 298 Guy, Erle of, 366

Washington, George, 392

Watson, Dr., 305

Wayside crosses, se $e^{3}$ Cross

Wearmouth, 55, 237

Webb, Benjamin, cited, 409

Weeping crosses, see Cross

Wells, market cross at, 319

Werinus, Archbishop of Cologne, 243

Westminster Abbey, $217,245,281,291,362$. $+32,+57$

Wheatley, Charles, cited, 425,429

White, Bishop, 249

Whitehall, fate of cross at, 445

Whittier, John G., cited, IoI, 294

Whittingham, Catherine, 359

- - William, Dean of Durham, 380

Wickwane, William, Archbishop of York, 232

Wieland, 222

Wilfrid, Saint, of Ripon, 388

Wilkinson, Sir Gardner, cited, 18,250

William the Conqueror, $244,276,329,358$, $387,388,433,458,467$

- III., of England, refuses to touch for the

"King's Evil," 437

- the Lion, of Scotland, 3I4

— of Norwich, Saint, $8 \mathrm{t}, 82$

- Rufus, King of England, $2+3$

- of Wykeham, staff of, 245

Winchelsey, Archbishop, 232

Winchester Butter Cross, 3 I 2

Winkelried, Arnold von, 272

Winthrop, Governor, $39 \mathrm{I}$

Wiseman, Dr., 437

Wittich, 222

Wolman, Dr., Dean of Wells, 3 I9

Wolsey, Cardinal, 234, 407

WTren, Sir Christopher, 202

Wnlstan, Bishop of Worcester, 244

Wymondham, Priory of, 435

\section{$\mathrm{X}$}

Xaca Japonicus, Japanese sect, 14

Xavier, Saint, History of Christ, by, I3I

Xerxes, 66

\section{$\mathrm{Y}$}

York, Duke of, 30 I : Manual of, I 2 I

Yuaricks, kingdoms of the, 9

Yucatan, native hymns of, 39

\section{Z}

Zaccheus, 185

Zacharias, the Patriarch of Jerusalem, I20

Zapotecas, the, of Mexico, 36 





19 
SMITHSONIAN INSTITUTION LIBRARIES

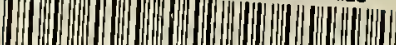

3908800424189

chm BV160.S4X 4 a9

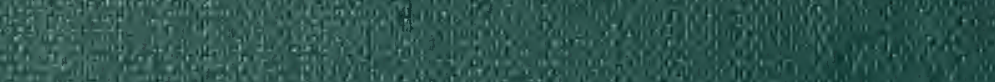

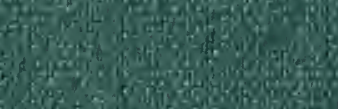

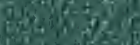

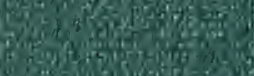

ancos

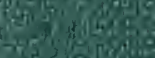

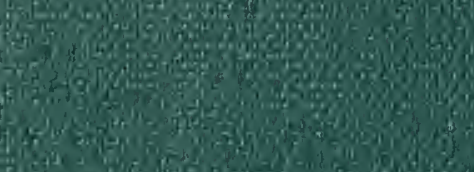

Son

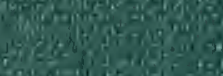

